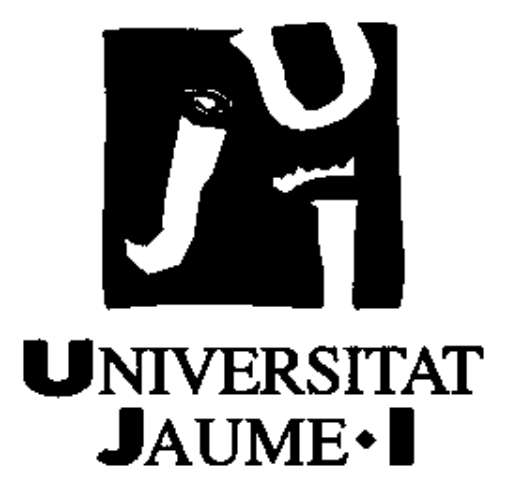

La prueba en el proceso de consumidores y usuarios español

Presentada por:

Lcda. María Pilar Mollar Piquer

Dirigida por:

Prof. Dra. Andrea Planchadell Gargallo

Profesora titular (acreditada catedrática) de Derecho Procesal

Castellón de la Plana, Marzo 2017 



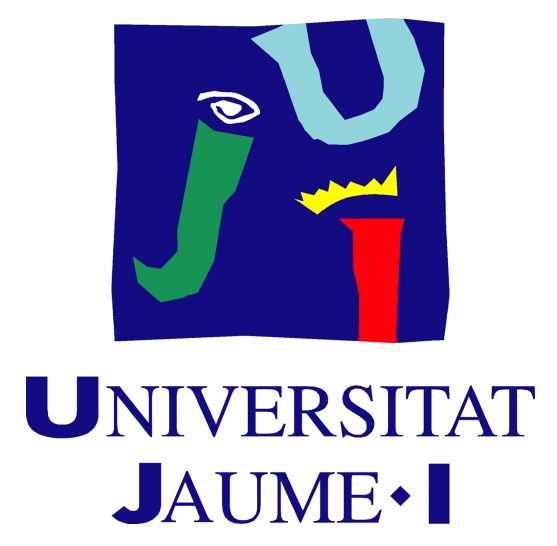

La prueba en el proceso de consumidores y usuarios español

Presentada por:

Lcda. María Pilar Mollar Piquer

Dirigida por:

Prof. Dra. Andrea Planchadell Gargallo

Profesora titular (acreditada catedrática) de Derecho Procesal 



\title{
La prueba en el proceso de consumidores y usuarios español
}

\section{Lda. María Pilar Mollar Piquer}

\author{
Área de Derecho Procesal \\ Departamento de Derecho Público
}

Facultad de Ciencias Jurídicas y Económicas

Universitat J aume I 

La prueba en el proceso de consumidores y usuarios español 

Í NDI CE SI STEMÁTI CO 



\section{PRI MERA PARTE}

CAPÍTULO I. EL DERECHO DE CONSUMO ................................................ 33

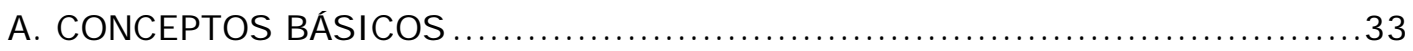

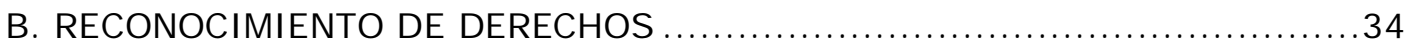

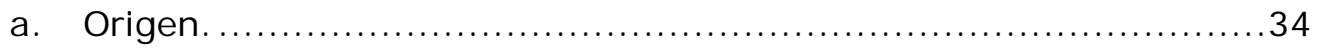

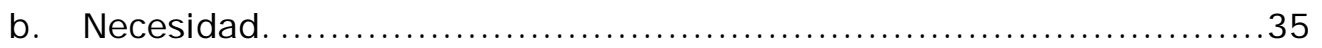

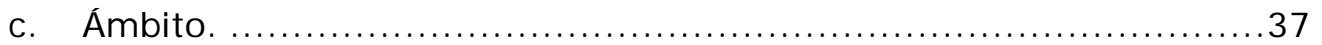

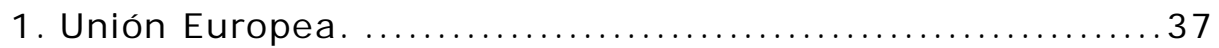

2. Constitución Española.................................... 39

3. Legislación Estatal. ................................... 40

4. Legislación Autonómica.................................40

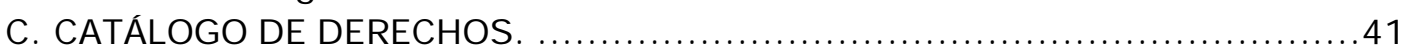

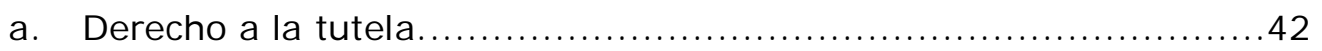

b. Derecho de información. ............................................ 43

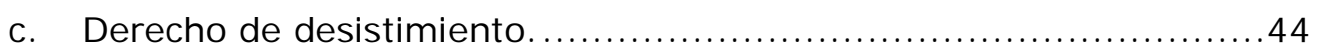

d. Derecho de representación y asociación..............................44

e. Derecho de integración. ............................................... 45

f. Obligaciones de los fabricantes o empresarios. .......................46

g. Derechos sectoriales. ..........................................46

CAPÍ TULO II. LA TUTELA DE LOS CONSUMI DORES Y USUARIOS.............. 47

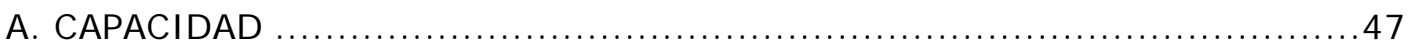

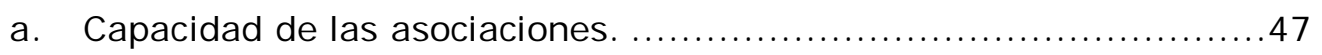

b. Capacidad de los grupos de afectados. ............................48

c. Capacidad de las entidades habilitadas .............................. 48

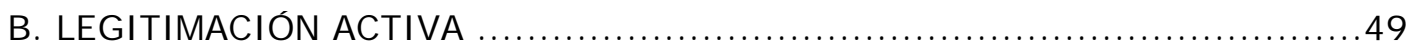

a. Legitimación ordinaria de los consumidores afectados ................50

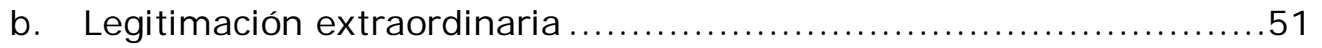

1. De las asociaciones de Consumidores .................... 51

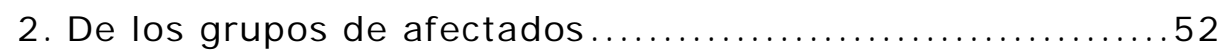

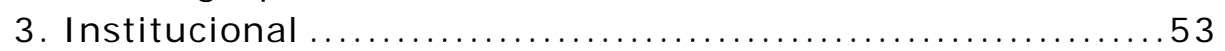

4. Del ministerio Fiscal .................................... 54

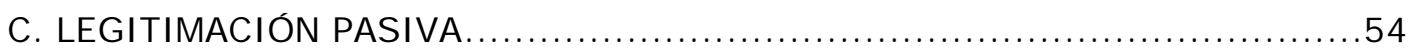

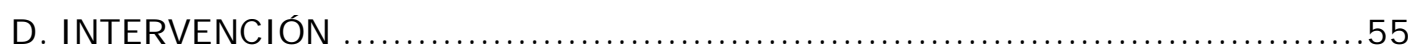

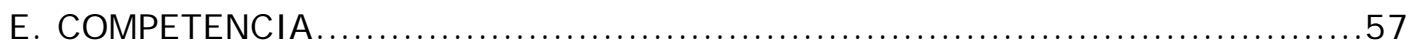

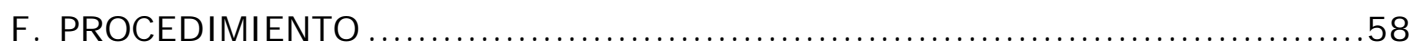




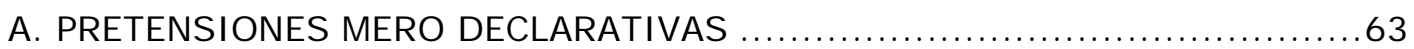

a. Acción de resolución del contrato ..................................63

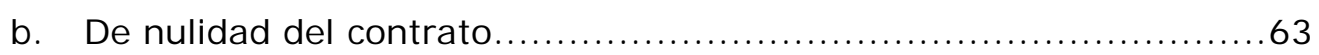

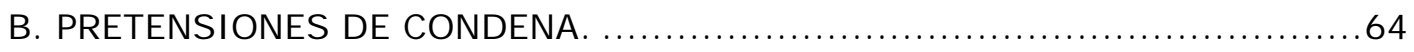

a. La pretensión de condena a la indemnización de daños y perjuicios.

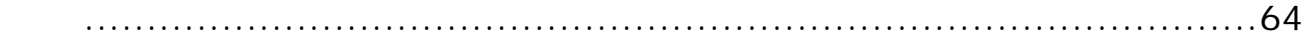

b. Pretensiones de condena dineraria de carácter colectivo. ............66

c. Pretensiones de condena inspiradas en las acciones reguladas en el

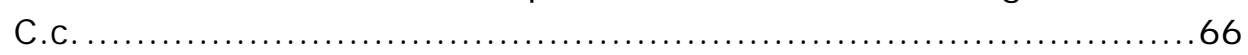

d. Por vicios o defectos en la construcción de vivienda. .................67

e. Acciones por vicios o defectos en la compraventa internacional. ....667

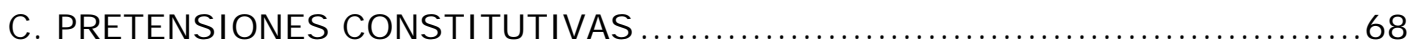

D. ACCIONES CONTEMPLADAS EN LA LEY DE CONDICIONES GENERALES DE

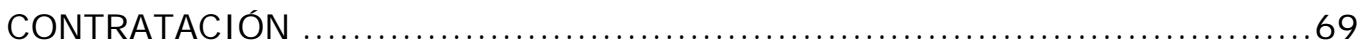

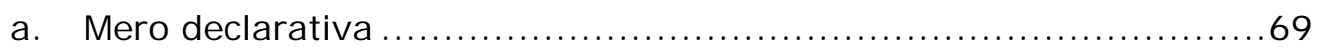

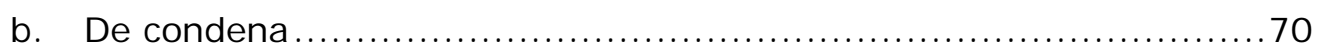

1. Acción de cesación........................................ 70

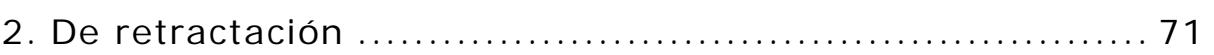

3. De restitución e indemnización de daños y perjuicios...... 71

E. ACCIONES EN MATERIA DE COMPETENCIA DESLEAL $\ldots \ldots \ldots \ldots \ldots \ldots \ldots \ldots 71$

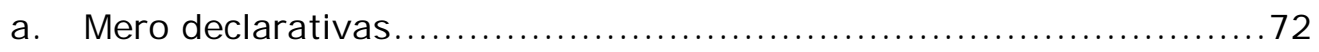

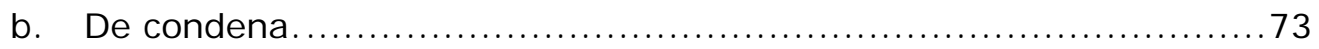

1. Acción de cesación........................................ 73

2. La acción de prohibición.................................. 73

3. La acción de remoción y rectificación. ...................... 73

4. La acción de resarcimiento de los daños y perjuicios ......73 73

5. La acción de enriquecimiento injusto del art. 32.16 a ..... 74

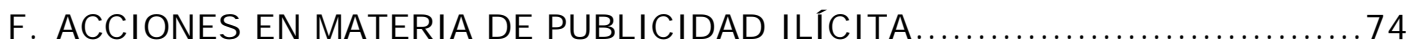

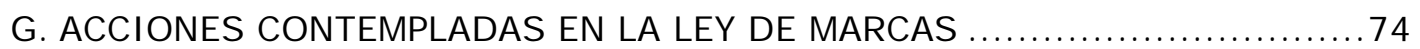

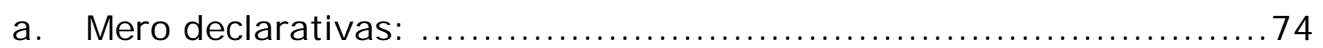

b. De condena, recogidas en el art. 41 LM: ............................. 75

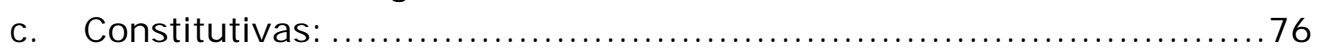

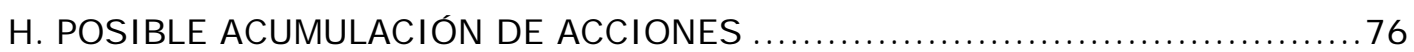




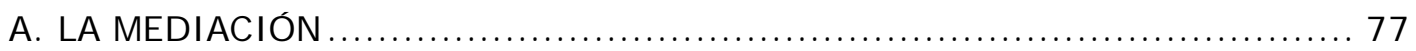

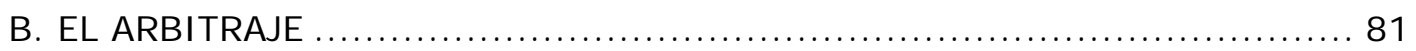

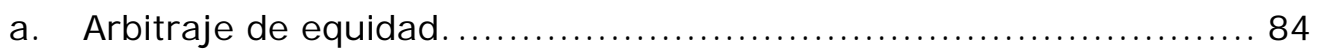

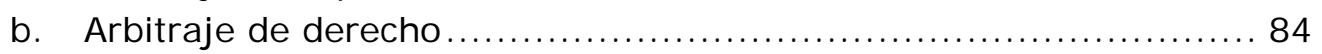

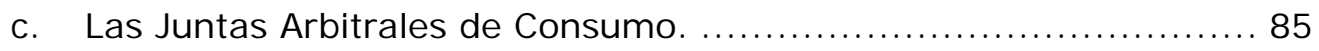

d. Colegios arbitrales................................................... 86

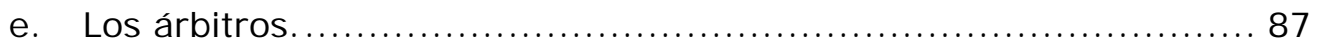

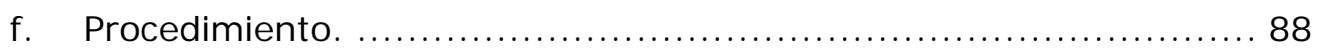

g. Acumulación de procedimientos ............................... 89

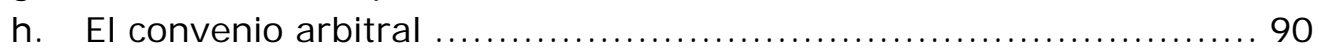

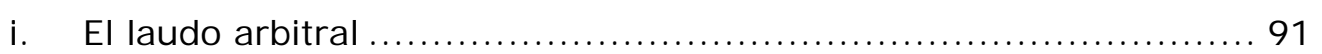

j. Acciones que caben frente a los laudos ......................... 91

SEGUNDA PARTE

CAPÍ TULO V. LA PRUEBA EN GENERAL............................................ 96

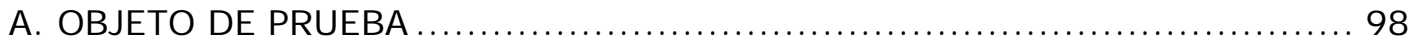

B. OBJETO DE LA PRUEBA EN PROCESOS DE CONSUMO ..................... 102

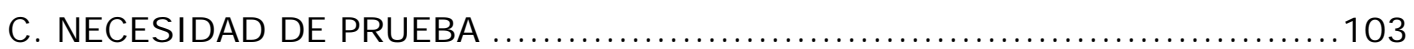

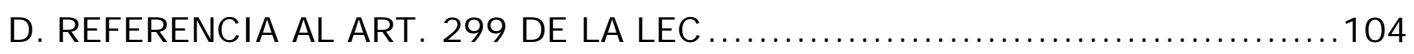

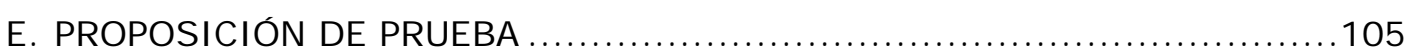

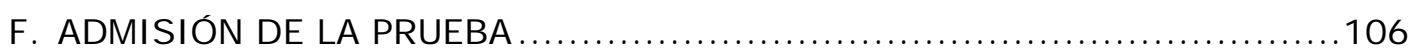

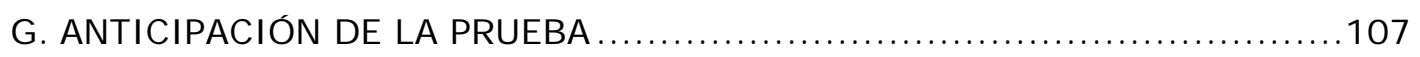

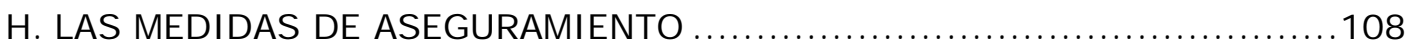

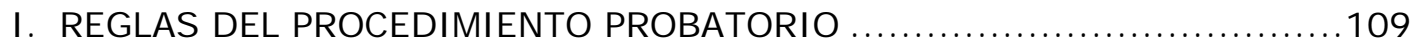

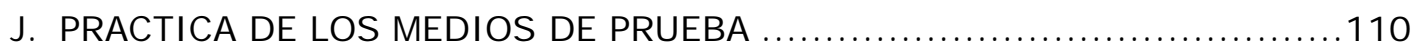

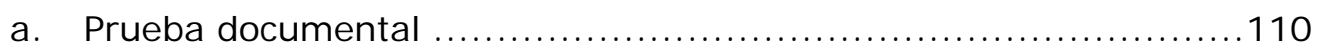

b. Instrumentos de reproducción de palabras, imágenes y sonidos....114

c. El interrogatorio de parte (art. 301 a 316) .........................116

d. Interrogatorio de testigos (arts. 360 a 381 ) . ......................118

e. Prueba pericial (arts. 335 a 352 ) ................................. 121

1. En relación a los aportados por las partes. ............... 122

2. La designación judicial del perito....................... 124

3. Breve puntualización sobre el desarrollo de la pericial informática. ...................................... 125

a. Reconocimiento judicial.......................... 125

b. Las presunciones. ................................. 126

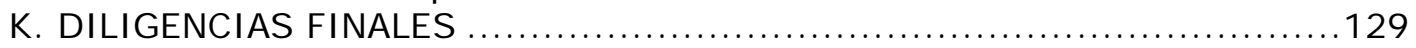

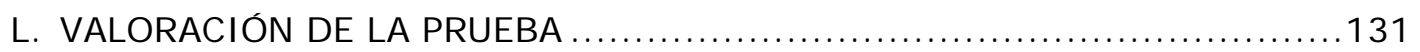

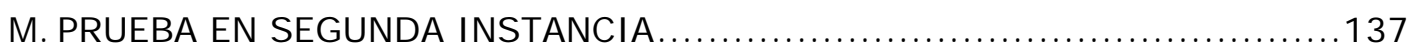




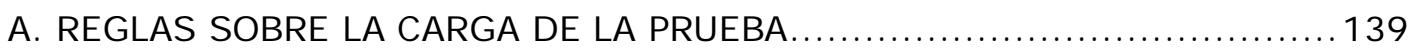

a. En relación a la carga de la prueba del defecto de los productos ... 141

1. Carga de la prueba de la relación de causalidad entre el defecto y el daño................................... 147

2. Carga de la prueba de la culpa del perjudicado.......... 148

b. Carga de la prueba de la exoneración de la responsabilidad por daños ocasionados por productos defectuosos. ........................... 150

c. Sobre la carga de la prueba de la falta de conformidad del producto con el contrato. .................................................. 151

d. Carga de la prueba del carácter individual de una cláusula ..........153

e. Carga de la prueba en la ley 15/2003, de 20 de noviembre, de firma electrónica. .................................................... 154

f. Carga de la prueba en otros supuestos ............................ 154

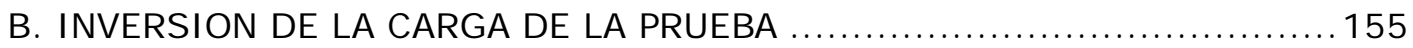

C. LA ADMISIÓN DE LA PRUEBA INDIRECTA O INDICIARIA .................... 160

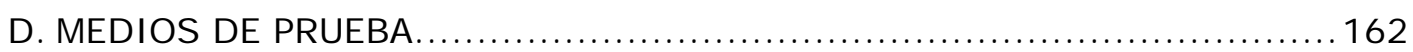

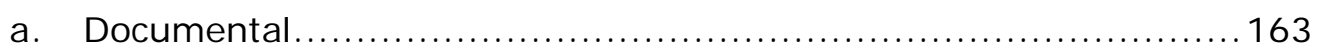

b. Los medios audiovisuales y soportes informáticos .................. 164

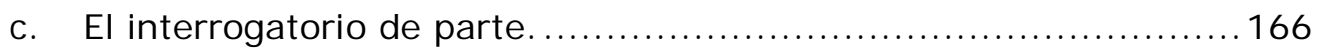

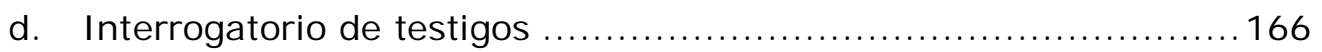

e. La prueba pericial ................................................ 167

f. El reconocimiento judicial ante las especialidades de los procesos de consumo........................................................... 169

CAPÍ TULO VII. ESPECIALI DADES DE LA PRUEBA EN EL PROCESO DE

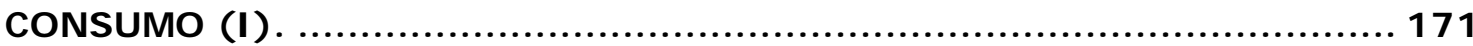

A. IMPORTANCIA DE LA PRUEBA PERICIAL EN LOS PROCESOS DE CONSUMO. .

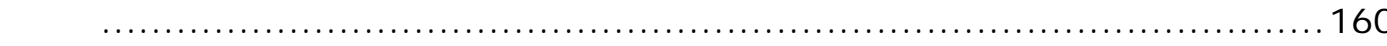

B. REFERENCIA A LOS SONDEOS DEMOSCÓPICOS ......................... 174

C. PRUEBA EN LOS CONCRETOS PROCESOS DE CONSUMO .................... 177

a. En relación a las prácticas comerciales desleales......... 177

b. Prueba en el proceso sobre publicidad ilícita. ............ 182

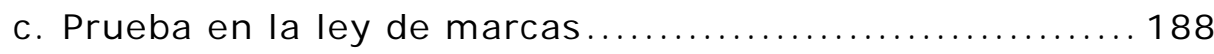

d. Prueba sobre cláusulas abusivas........................ 193

e. Prueba en los procesos sobre productos defectuosos.... 209

1. En relación a la prueba del defecto.................. 210

2. La Prueba de la relación de causalidad.............. 213

3. Prueba de la responsabilidad de productor.......... 219

4. Prueba de la responsabilidad del perjudicado y su exoneración...................................... 220

5. Prueba de daños causados en el uso de tecnologías.

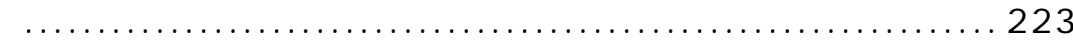

6. Las presunciones. ............................. 224

7. Reclamación de daños y perjuicios y su cuantificación.

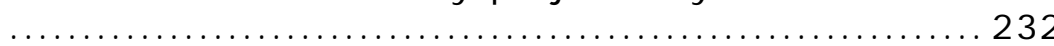

8. La concreción del daño moral. ....................... 235

9. Prueba en supuestos concretos de daños por productos defectuosos.................................... 236 
A. PRUEBA DE LA FALTA DE CONFORMIDAD DEL PRODUCTO CON EL

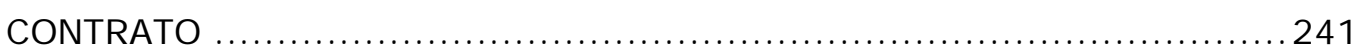

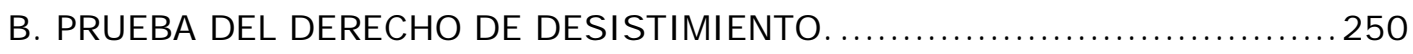

C. ESPECIAL REFERENCIA A LOS CONTRATOS VINCULADOS $\ldots \ldots \ldots \ldots \ldots \ldots \ldots . \ldots \ldots$

a. En relación a la prueba del derecho de desistimiento ................253

b. Sobre la prueba de la exclusividad de los contratos vinculados .....256

c. Prueba de la defectuosa prestación del servicio en los contratos

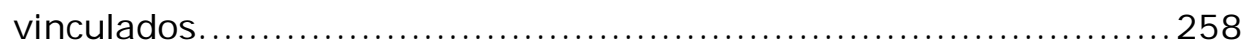

d. Falta de prestación efectiva del servicio o de entrega del producto

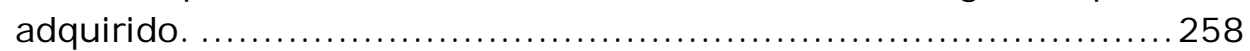

D. LEY 43/2007, DE 13 DE DICIEMBRE, DE PROTECCIÓN DE LOS CONSUMIDORES EN LA CONTRATACIÓN DE BIENES CON OFERTA DE

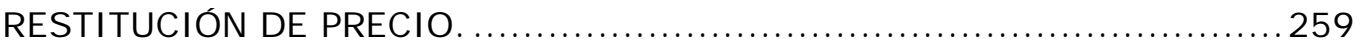

E. PRUEBA EN LOS PROCESOS SOBRE RECLAMACIONES DE TELEFONÍ A. ....260

F. LA PRUEBA EN LOS CONTRATOS CELEBRADOS FUERA DE LOS

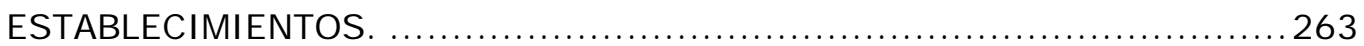

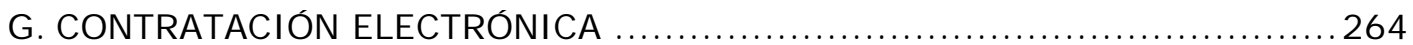

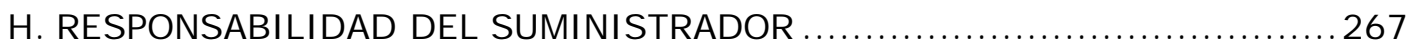

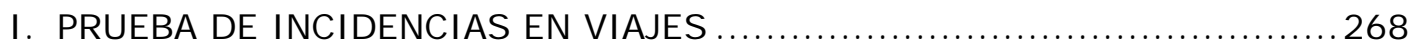

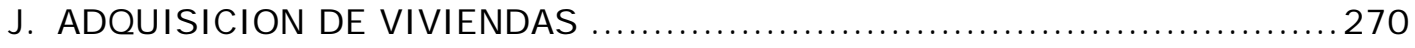

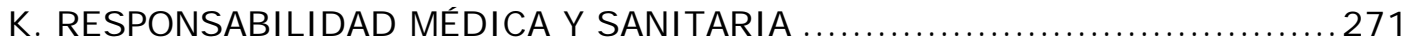

L. MEDICAMENTOS O PRODUCTOS SANITARIOS DEFECTUOSOS ..............274 
A. CUESTIONES EN RELACIÓN A CONTRATOS DE SERVICIOS BANCARIOS .. 278

B. PARTICIPACIONES PREFERENTES, SWAPS, OBLIGACIONES, DEUDA

SUBORDINADA Y ACCIONES DE BANKIA ................................ 283

a. La acción de nulidad contemplada en el art. 1261 C.c., basada en error del consentimiento. ......................................... 295

b. Nulidad por dolo civil del art. 1269 C.c. ............................ 298

c. Anulabilidad por defecto de capacidad. ............................. 298

d. Nulidad por incumplimiento de normativa MIFID .................... 299

e. Nulidad por incumplimiento de la legislación sobre consumo. .......299

f. Acción subsidiaria por negligencia en el cumplimiento de las

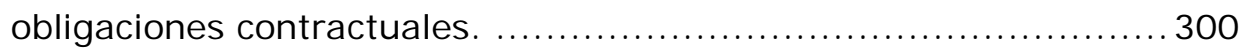

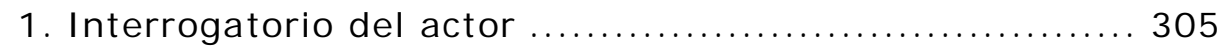

2. Documental, consistente en ........................... 305

a. La orden de compra ............................. 305

b. La certificación de la entidad bancaria............... 305

c. Aporte de los test de idoneidad por parte de la entidad bancaria......................................... 306

d. Certificación de los estudios del cliente .............. 306

e. Certificación del estado de salud del cliente........ 306

f. Certificación acreditativa del representante de la entidad que realizó la operación.................... 306

g. Aportación del tríptico de información entregado al cliente.......................................... 307

h. Informe elaborado por el Defensor del Pueblo...... 307

i. Aportacion de documentos electronicos ............. 307

3. Testifical. ............................................. 308

4. Pericial .............................................. 309

5. Reconocimiento judicial ........................... 310

CAPÍTULO X. PRUEBA EN EL ARBITRAJE DE CONSUMO: ESPECI AL REFERENCI A A LA PRUEBA EN EL ARBITRAJ E DE TELEFONI A ................ 313

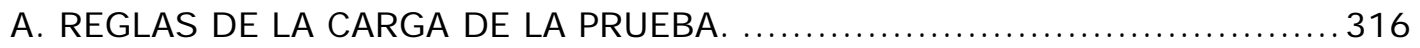

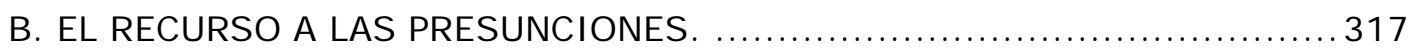

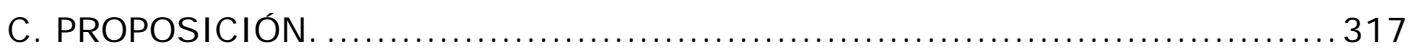

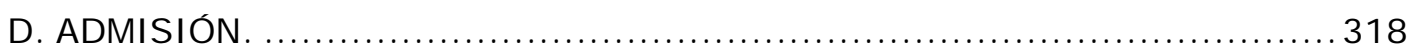

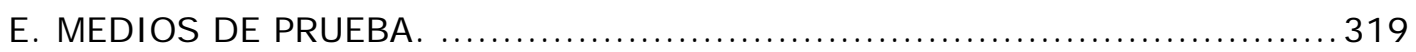

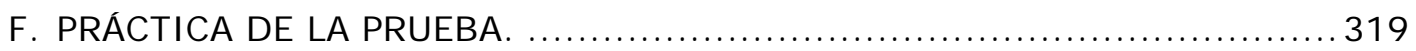

G. ESPECIAL REFERENCIA A LA PRUEBA PERICIAL. .......................... 320

H. COSTE DE LA ACTIVIDAD PROBATORIA ................................... 322

I. VALORACIÓN DE LA PRUEBA EN EL ARBITRAJE. .......................... 322

J. ESPECIAL REFERENCIA A LA PRUEBA EN EL ARBITRAJE DE TELEFONÍA. . . 323

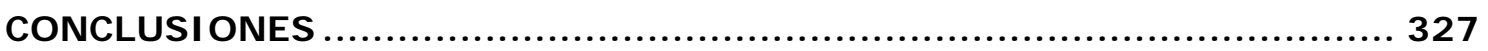

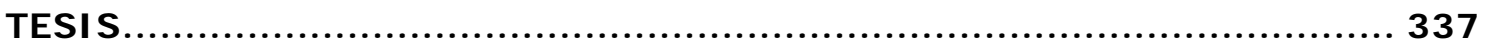

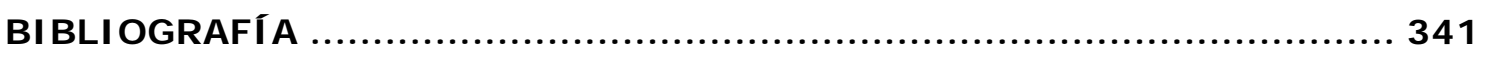

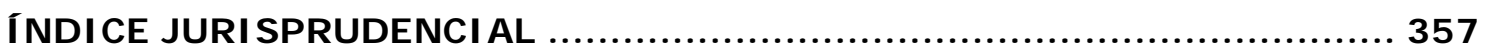


I NTRODUCCI ÓN 

El presente trabajo, cuyo objeto es analizar la prueba en el proceso de consumidores, sintetiza algunas especialidades del proceso de consumo que, por la gran cantidad de supuestos diversos existentes y su regulación a través de distintas normas, ofrecen una numerosa y distinta casuística.

Por ello, entendemos de gran importancia y tratamos de analizar cuestiones como la utilización de los concretos medios de prueba, sobre quién recae la obligación de aportar la prueba en el proceso o qué es lo que debe probarse para alcanzar una sentencia favorable al consumidor.

En una Primera Parte del trabajo introducimos los conceptos básicos de Derecho de Consumo, así como el origen y necesidad de su reconocimiento, haciendo alusión a su regulación desde la Unión Europea a través de las Directivas que se han dictado en la materia.

Esta normativa resulta de vital importancia para el reconocimiento de derechos tan básicos como el de desistimiento, la regulación de las prácticas comerciales desleales o la publicidad engañosa, y para el impulso de medidas específicas de garantías de los consumidores y empresas de los estados miembros, desarrolladas a través de las denominadas "collective redress", acciones colectivas de indemnización, y las "small claims", reclamaciones de escasa cuantía, como alternativas a la solución de litigios, de manera rápida en reclamaciones transfronterizas de hasta dos mil euros.

A nivel estatal, el reconocimiento de derechos de consumo se desarrolló a partir de la Constitución de 1978, cuyo art. 51 sentó las bases de la protección a los consumidores, siendo objeto de regulación a través de la primera ley de consumo española.

A esa primera regulación mediante la Ley 26/1984, de 19 de julio, General para la Defensa de Consumidores y Usuarios, le siguió el actual Texto Refundido de la Ley General para la Defensa de los Consumidores y Usuarios, aprobado por Real Decreto legislativo $1 / 2007$, de 16 de noviembre, modificado a su vez por la Ley 3/2014, de 27 de marzo, que establece los derechos básicos de los consumidores.

Además, la normativa nacional se complementa con legislación autonómica, siendo únicamente referida la de la Comunidad Valenciana, cuyo desarrollo se encuentra en la Ley 1/2011, de 22 de 
marzo, reguladora de derechos de básicos de los consumidores, que recoge la indemnización de daños, la reparación de los perjuicios sufridos, la información sobre la promoción, oferta, adquisición, utilización y disfrute de bienes y servicios, la actuación de las administraciones públicas, el derecho a la educación y formación, así como el derecho de representación, audiencia y participación.

Una vez sintetizada la normativa de aplicación, se realiza una apreciación sobre lo que podríamos considerar un "Catálogo de Derechos", que incluye derechos "básicos e irrenunciables de los consumidores" protegidos por los poderes públicos.

Entre ellos, hacemos una breve referencia al derecho a la tutela judicial efectiva, de origen constitucional, al derecho de información, de desistimiento o de integración, así como a las obligaciones de los fabricantes y empresarios, todos ellos recogidos en el Texto Refundido de la Ley General para la defensa de los consumidores y usuarios.

También nos referimos al derecho de representación y asociación, de reconocimiento constitucional cuyo marco general viene definido por la Ley Orgánica 1/2002, de 22 de marzo, con una simple mención, sin adentrarnos en ellos, y a otros derechos recogidos en la normativa sectorial, como los de transporte aéreo, de viajeros de autobús, transporte público de viajeros por carretera, telecomunicaciones o seguros.

De las consideraciones previas sobre la regulación de los derechos de los consumidores enlazamos con su concreta tutela y con algunas cuestiones procesales, como la capacidad para ser parte en el proceso, o ciertas peculiaridades que surgen en relación a la posible representación de los intereses de los consumidores por asociaciones - grupos de afectados. También analizamos la posible legitimación activa, bien individual de los afectados, o colectiva de asociaciones, instituciones o grupos, así como la legitimación pasiva y las distintas formas de intervención en el proceso, tanto la adhesiva, como la voluntaria y la provocada. 
Tras realizar una breve mención sobre los órganos competentes y el procedimiento adecuado, nos referimos brevemente a los posibles objetos de la pretensión y nos adentramos en las vías de interposición de las acciones que los textos legales aludidos ponen a disposición del consumidor.

Analizamos su objeto y tipos de pretensiones, en primer lugar las acciones reguladas en el Código Civil y en el Texto Refundido de la Ley General Defensa de Consumidores y Usuarios, pretensiones mero declarativas como la resolución o nulidad del contrato, las de condena dineraria de carácter colectivo, las de condena a la indemnización de daños y perjuicios, las pretensiones de responsabilidad del fabricante por productos defectuosos, también aquellas otras reclamaciones en que se aducen vicios o defectos constructivos en la compraventa de vivienda, y las acciones por defectos en la compraventa internacional.

Además de a las acciones expresadas se añade también una mención en relación a aquellas pretensiones constitutivas que se encuentran en el TRLGDCU y que derivan de la falta de conformidad del producto con el contrato.

Encontramos otras acciones que puede ejercitar el consumidor en defensa de sus derechos en la Ley de Condiciones Generales de Contratación, como son la mero declarativa, dirigida a obtener la devolución de cantidades cobradas con ocasión de las cláusulas nulas e indemnización de daños y perjuicios, o de condena al demandado a eliminar de sus condiciones generales aquellas que se reputen nulas y a abstenerse de utilizarlas en lo sucesivo, así como su cesación, retractación e indemnización.

A estas acciones aún debemos añadir todas las contempladas en leyes especiales, como la Ley de Competencia Desleal, que regula la mero declarativa y las acciones de condena, tanto a la cesación de la y prohibición de reiteración futura, a la retractación de los actos de competencia desleal así como su restitución e indemnización. También son objeto de mención las acciones recogidas en la Ley de Publicidad I lícita o las contempladas en la Ley de Marcas. 
A los procesos judiciales se une la posible sumisión de las cuestiones de consumo a las vías alternativas de solución de conflictos, como la mediación, con su regulación europea y la creación de la plataforma "Online Dispute Resolution", así como la regulación nacional y el arbitraje de consumo, bien de derecho o de equidad, a los que también aludimos de forma breve.

La segunda parte del trabajo se inicia con una referencia a la prueba en el proceso civil, a lo que es el objeto de la prueba, tanto en los procesos civiles en general, como en los procesos de consumo en particular, con una alusión al procedimiento probatorio desde su proposición, admisión, anticipación, medidas para asegurar su práctica, reglas del procedimiento y la práctica de los distintos medios de prueba con las peculiaridades de cada uno, aludiendo también a las presunciones por la importancia que estas tienen, como veremos, en materia de prueba en los procesos de consumo.

También en relación al procedimiento probatorio tratamos someramente las diligencias finales, así como su valoración y los casos en que procede la prueba en segunda instancia.

El Capítulo VI detalla el desarrollo del procedimiento probatorio en materia de consumo, por las peculiaridades que presenta en relación a los demás procesos civiles, tratando la importancia de la prueba, su necesidad y las reglas que rigen en relación a cuál de las partes debe acreditar las afirmaciones que realiza así como los medios de prueba utilizados.

Aunque el concreto análisis sobre los elementos de la prueba en cuestiones de productos defectuosos se realiza en el capítulo siguiente, hemos considerado conveniente tratar en este las reglas sobre la carga de la prueba en varias cuestiones sobre productos defectuosos como son en relación a la prueba del defecto, a la relación de causalidad entre el defecto y el daño, la carga de la prueba de la culpa del perjudicado, también de la exoneración de la responsabilidad, y sobre otras cuestiones como la falta de conformidad del producto con el contrato, el carácter individual de una cláusula, la consideración de la carga de la prueba en la Ley de Firma Electrónica, en los contratos celebrados fuera de establecimiento, y en la Ley del Contrato de Seguro.

El análisis sobre la carga de la prueba en los distintos procesos continúa con aquellos en que se observa una falta de conformidad del 
producto con el contrato, la prueba del carácter individual de una cláusula, o la prueba según la ley de firma electrónica, también la prueba de los contratos celebrados fuera de establecimiento, en que debe ser el consumidor quien acredite su derecho de revocación, o la prueba en la Ley del contrato de seguro.

El Capítulo VI nos introduce también en la inversión de la carga de la prueba que tanta importancia tiene en estos procesos por ser un recurso establecido tanto en la normativa europea, como estatal y haberse acogido ampliamente por la jurisprudencia, así como el recurso a la prueba indiciaria o de presunciones.

Además, hacemos referencia a los medios más utilizados en los procesos de consumo, como el interrogatorio de parte, por las cuestiones técnicas que en el mismo se pueden plantear o la prueba de medios audiovisuales y soportes informáticos, como acreditación de determinado registro de una concreta transacción comercial tan común en estos procesos.

Son de gran importancia también otros medios de prueba, como la documental $o$ el interrogatorio de testigos, que resulta determinante en los casos en que se carece de la documental necesaria, y la también trascendente prueba pericial, que introduce al proceso información relevante al objeto de verificar las alegaciones de hecho de las partes.

El reconocimiento judicial es objeto de mención, aunque sus especialidades son las propias de los demás procesos civiles, y en la práctica se observa la reticencia de los jueces a su realización, aunque podría permitir evaluar las consecuencias sobre el uso de determinado bien de consumo, siendo la forma más útil de llevarse a cabo junto al dictamen de peritos.

Al hilo de las especialidades referidas, debemos adentrarnos en el siguiente capítulo, en la prueba pericial y sus peculiaridades, las exigencias que debe reunir, la posible solicitud de ampliación por el órgano jurisdiccional, tratando además la eficacia probatoria del dictamen pericial emitido, tanto en relación a la acreditación de la responsabilidad, como a su exoneración y la posible intervención del Centro de Investigación y control de Calidad.

En relación al referido dictamen pericial, es particularmente utilizado el sistema de aportación de datos al proceso a través de los 
denominados "sondeos demoscópicos", que realizan una medición estadística de la opinión pública sobre determinada cuestión de consumo, y que como veremos, puede ser introducida en el proceso bien como pericial si se trata de un verdadero dictamen, o como documental, mediante la declaración en juicio del experto que lo ha elaborado.

A continuación, y dentro del mismo capítulo VII, analizamos la prueba en los procesos sobre prácticas comerciales desleales, publicidad ilícita y de la Ley de Marcas, para continuar con la prueba sobre cláusulas abusivas y productos defectuosos.

Es de gran importancia en todos los procesos referidos, determinar a quién corresponde la carga de la prueba, debido a la dificultad de prueba por parte del consumidor, y al establecimiento expreso en la LEC de la inversión de la carga de la prueba en los concretos procesos sobre competencia desleal y publicidad ilícita.

Esta regla ha sufrido matizaciones en su aplicación jurisprudencial, de ahí que analicemos sentencias sobre supuestos y cuestiones específicas que entendemos deben ser tratados por su importancia o su especialidad. Nos referimos a supuestos sobre competencia desleal, en cuya materia se ha considerado necesaria la inversión, pero en la que también existen otros casos excepcionales en los que se ha exonerado de prueba a la parte actora por presumirse el daño.

Otros casos a los que también aludimos son los de publicidad ilícita, donde analizamos situaciones concretas y lo que debe ser objeto de prueba según el Código de Conducta Publicitaria de la Asociación para la Autorregulación Comercial.

Por lo que respecta al estudio de las acciones contempladas en la Ley de Marcas entramos en cuestiones sobre el uso de los signos distintivos como palabras clave en un contrato de publicidad a través de internet aludiendo además a la prueba en cuestiones sobre marcas comunitarias.

Un tema de gran preocupación que ha ocupado a los juzgados con multitud de demandas es el análisis de las cláusulas abusivas existentes en los contratos, que incluso ocasionó una reforma de la LEC, facultando el control de oficio por parte del órgano jurisdiccional. 
En este sentido, partiendo del impulso llevado a cabo por el propio Tribunal de Justicia de la Unión Europea, se analiza la posición jurisprudencial respecto a cláusulas abusivas en diferentes tipos de contratos y la prueba que debe practicarse para llevar al tribunal a la convicción sobre tal carácter, siendo motivo de mención específica la prueba de las referidas cláusulas en los contratos de hipoteca, entendiendo que el consumidor no precisa aportar prueba sobre su abusividad, así como las que podamos encontrar en contratos de transporte aéreo.

Nos referimos concretamente a procesos sobre defectos de los productos, donde la prueba resulta imprescindible tanto en relación al defecto, como sobre la relación de causalidad o la exoneración de responsabilidad, en que será el fabricante quien deba probar la culpa del perjudicado, aludiendo además a la reclamación de daños y perjuicios y a su cuantificación, haciendo mención también al daño moral.

Por ello, y debido a que son muchos los supuestos que observamos en la jurisprudencia sobre productos defectuosos, no podemos pasar por alto una mención a alguno de ellos según se precise prueba del defecto, o este se presuma, y tratamos la prueba de daños causados en el uso de medios tecnológicos, aludiendo a las distintas presunciones que observamos en la jurisprudencia en estas materias concretas.

En relación a las aludidas presunciones, en el estudio jurisprudencial sobre productos defectuosos hemos encontrado siete tipos diferentes, donde, dependiendo de los concretos hechos resueltos, es posible presumir la falta de conformidad del producto, el correcto uso del producto, el origen del defecto, la culpa del fabricante, la existencia del defecto e incluso la existencia del nexo causal o en su caso, la conformidad del producto.

Continuando el capítulo VIII con las especialidades en la prueba en los procesos de consumo que iniciaba el Capítulo VII, analizamos la prueba en los casos de falta de conformidad del producto con el contrato y las presunciones que pueden darse sobre ella, así como a la necesaria advertencia del consumidor dentro del plazo establecido.

También encontramos en relación a la referida falta de conformidad, la prueba del derecho de desistimiento donde es relevante tanto la prueba sobre la entrega del documento para poder 
ejercer este derecho, como la del incumplimiento por el empresario y el ejercicio en plazo por el consumidor.

Se realiza además una referencia a la prueba en los contratos vinculados en los que analizamos cuestiones de prueba sobre el derecho de desistimiento, la exclusividad de los contratos vinculados, la defectuosa o falta de prestación efectiva del servicio o de entrega del producto adquirido.

Aludimos brevemente también a otros supuestos regulados también por ley especial como los que recoge la Ley 43/2007, de protección de los consumidores en la contratación de bienes con oferta de restitución de precio, para a continuación, dada la importancia de las cuestiones sobre telefonía, analizar la prueba en estos procesos, que correrá a cargo de la compañía prestadora del servicio, continuando con una mención a la prueba en los contratos celebrados fuera de establecimiento y la contratación electrónica, en cuyo caso será el empresario el que deberá practicar prueba sobre la validez de la firma electrónica utilizada en la contratación.

Merecen también nuestra atención cuestiones como la responsabilidad del suministrador, de la cual puede ser exonerado si prueba el cumplimiento de la reglamentación administrativa en la manipulación del producto; las incidencias en viajes, cuya prueba depende del supuesto concreto; la adquisición de viviendas, donde no existe una regla única sobre la carga de la prueba; la responsabilidad médica y sanitaria, donde es de vital importancia la acreditación de la existencia del consentimiento informado, siendo el demandado quien lo deberá acreditar y para finalizar el capítulo, la prueba en relación a los medicamentos o productos sanitarios defectuosos, que corresponderá al perjudicado.

En último lugar se trata la prueba en ciertas cuestiones de servicios bancarios como la comisión de errores administrativos o de gestión, la prestación de servicios financieros a distancia, la contratación de préstamos hipotecarios o servicios de intermediación, reclamaciones sobre cuotas impagadas y cuestiones sobre tarjetas de crédito, cuya prueba corresponde en todos estos casos a la entidad bancaria.

En este mismo Capítulo IX se trata de forma específica la contratación bancaria y se abordan temas que han originado multitud de demandas judiciales y colapsado los juzgados de todo el país. Nos 
referimos a la contratación de determinados productos financieros como las participaciones y obligaciones preferentes, la deuda subordinada o los swaps y a la compra de acciones de Bankia, así como la prueba que se practica en este tipo de procesos.

En estas cuestiones la jurisprudencia se muestra unánime en la necesidad de realizar un examen completo al cliente minorista a través de la realización de dos tests, uno de conveniencia, y otro de idoneidad para determinar el tipo de cliente de que se trata y si está en condiciones de entender el producto que adquiere.

En este apartado hemos considerado conveniente analizar en primer lugar la legislación aplicable, los tipos de acciones distintos que se pueden plantear en relación a estos productos, realizando un estudio jurisprudencial de forma distinta al de los apartados anteriores, debido a que la línea jurisprudencial es única y lo especialmente relevante para que el juez adopte su decisión es la prueba aportada, documental, testifical o pericial. De ahí que hayamos analizado la documentación utilizada en la práctica, tanto por la parte actora, como por la parte demandada, y los resultados que del aporte de cada uno de estos medios se pueden obtener.

Por último, dada la importancia que en la resolución de cuestiones de consumo tiene la vía del arbitraje, hacemos mención a la prueba en este tipo de procesos, a su desarrollo y particularidades, tratando además de forma especial el arbitraje de telefonía por ser la principal vía de solución de estos conflictos, siendo especialmente relevante la amplitud de los medios de prueba que se pueden aportar, aunque los habitualmente empleados sean la documental y la pericial. 

ABREVI ATURAS: 

ADR: Alternative Disputes Resolutions.

AP: Audiencia Provincial.

Apdo.: apartado.

Art.: artículo.

CE: Constitución Española de 1978.

CEE: Comunidad Económica Europea.

C.c.: Real Decreto de 24 de julio de 1889 que aprueba el Código Civil.

C.Co: Real Decreto de 22 de agosto de 1985 por el que se publica el Código de Comercio.

Cit.: citado.

Coord.: Coordinador.

D.O.U.E.: Diario Oficial de la Unión Europea.

J M: Juzgado de lo Mercantil.

JI: Juzgado de Primera Instancia

LA: Ley 60/2003, de 23 de diciembre, de arbitraje.

LCC: Ley 7/1995 de 23 de diciembre de crédito al consumo.

LCD: La Ley 29/2009, de 30 de diciembre, de competencia desleal.

LCFEM: Ley 26/1991, de 21 de noviembre, de contratos celebrados fuera de establecimientos mercantiles.

LCGC: Ley 7/1998, de 13 de abril, de Condiciones Generales de Contratación.

LCU: Ley 3/2014, de 27 de marzo, por la que se modifica el Texto Refundido de la Ley General para la Defensa de los Consumidores y Usuarios.

LCS: Ley 50/1980, de 8 de octubre, de contrato de seguro.

LEC: Ley 1/2000, de 7 de enero, de Enjuiciamiento Civil. 
LFE: Ley 59/2003, de 19 de diciembre, de Firma Electrónica.

LGDCU: Ley 26/1984, de 19 de julio, General para la Defensa de Consumidores y Usuarios.

LGVBC: La Ley 23/2003, de 10 de julio, de garantías en la venta de bienes de consumo.

LM: Ley 17/2001, de 7 de diciembre, de Marcas.

LMACM: Ley 5/2012, de 26 de julio, de mediación en asuntos civiles y mercantiles.

LMV: Ley 47/2007 que modifica la Ley 24/1988, de 28 de julio, del Mercado de Valores.

LOPJ : Ley Orgánica 6/1985, de 1 de julio, del Poder Judicial.

LOE: Ley 38/1999, de 5 de noviembre, de Ordenación de la Edificación.

LPD: Ley 22/1994, de 6 de julio, de responsabilidad civil por los daños causados por productos defectuosos.

LSSICE: Ley 34/2002, de 11 de julio, de servicios de la Sociedad de la Información y el Comercio Electrónico.

MiFID: Directiva 2004/39/CE sobre mercados de instrumentos financieros.

OCDE: Organización para la Cooperación y el Desarrollo Económicos.

Pág.: página.

RDAC: Real Decreto 231/2008, de 15 de febrero, por el que se regula el Sistema Arbitral de Consumo.

S.: Sentencia.

Sec.: Sección.

ss: Siguientes.

STS: Sentencia del Tribunal Supremo.

TJUE: Tribunal Superior de Justicia. 
TRLGDCU: Real Decreto Legislativo 1/2007, Texto Refundido de la Ley General para la Defensa de los Consumidores y Usuarios.

TS: Tribunal Supremo.

UE: Unión Europea. 

PRI MERA PARTE 



\section{CAPÍ TULO I. EL DERECHO DE CONSUMO}

En cualquier estudio que se afronte sobre el derecho de consumo debemos partir de la problemática que genera la gran cantidad de fuentes normativas que lo regulan.

En contra de lo que tal detalle de regulación podría parecer, lo cierto es que, en lugar de repercutir en una mejor y más efectiva tutela de los consumidores, acaba teniendo un efecto negativo en la misma, en tanto que lo complica excesivamente.

En este sentido, vemos reconocidos derechos de los consumidores en la normativa europea, también en diversas normas del derecho estatal, atendiendo a la materia, así como en la legislación autonómica. Concretamente en la Comunidad Valenciana la regulación sobre los derechos de especial protección de los consumidores, el sistema para llevarla a cabo, los agentes intervinientes en ese sistema, y el régimen sancionador, se regulan mediante Ley 1/2011, de 22 de marzo, de la Generalitat, por la que se aprueba el Estatuto de los Consumidores y Usuarios de la Comunidad Valenciana.

Puesto que el tema de la prueba está íntimamente ligado a los fundamentos de derecho de consumo, haremos una breve alusión a los conceptos básicos más habitualmente tratados en derecho de consumo, al origen y evolución del reconocimiento de los derechos de consumo, a la necesidad que desde la Unión Europea se transmite de desarrollar la normativa de protección al consumidor y a la normativa nacional básica que existe en la materia.

\section{A. CONCEPTOS BÁSI COS}

El derecho de consumo, orientado a proteger al consumidor en su relación con el empresario o productor, se configura mediante conceptos básicos como el de consumidor, empresario, productor, producto y proveedor.

La definición de consumidor que aparece en el art. 3 del Texto Refundido de la Ley General para la Defensa de los Consumidores y Usuarios (en adelante TRLGDCU), así como la definición que se encuentra en las Directivas comunitarias, coinciden en señalar como nota característica la ajenidad respecto a toda actividad en relación al 
producto ${ }^{1}$, distinguiéndolo de esta forma del profesional y del empresario.

La figura del empresario que ofrece el art. 4 del mismo cuerpo legal es opuesta a la de consumidor, encontrándose en clara relación con el producto por ser el proveedor o fabricante del mismo, que actúa en el marco de su actividad empresarial o profesional, ya sea pública o privada.

Quien actúa como fabricante o productor del bien, prestador del servicio o intermediario (art. 5), interviene, al igual que el empresario, de forma directa en el proceso de puesta a disposición o de fabricación del producto, pudiendo incluso considerarse en esta posición al importador del bien o servicio en el territorio de la Unión Europea, o también a cualquier persona que se mencione como tal, ya sea en el envase, el envoltorio o cualquier otro elemento de protección o presentación, servicio, marca u otro signo distintivo.

En cambio, otro concepto que también aparece, el de proveedor, (art. 7) es distinto a los anteriores, puesto que al contrario que el de productor, se limita a la figura del empresario que suministra o distribuye productos en el mercado, cualquiera que sea el título o contrato en virtud del cual realice dicha distribución.

A los agentes personales intervinientes descritos, se suma el propio producto, siendo este el elemento que inicia cualquier cuestión de consumo (art. 6) y entendiéndose por tal todo bien mueble conforme a lo previsto en el art. 335 del Código Civil (en adelante C.c.).

\section{B. RECONOCI MI ENTO DE DERECHOS}

\section{a. Origen.}

Si bien es en la 106 Sesión Plenaria de la Asamblea General de la ONU celebrada el 9 de abril de 1985 donde se inicia el reconocimiento de los derechos de los consumidores, ya en el Programa Preliminar de la CEE, mediante Resolución de 14 de abril de $1975^{2}$ y reiterado por la de 19 de abril de 1981, se enunciaban cinco derechos fundamentales del consumidor ${ }^{3}$, siendo en el Acta Única Europea de

\footnotetext{
${ }^{1}$ Cabanillas Sánchez, A.: "El concepto de consumidor en el Texto Refundido de la Ley General para la Defensa de los Consumidores y Usuarios”. Ed.: Tirant lo Blanch, Valencia 2011, págs. 377 a 400.

${ }^{2}$ Paños Pérez, A: "Derechos y garantías del consumidor en el ámbito contractual”, Ed.: Universidad de Almería, Almería 2010, pág. 26.

${ }^{3}$ De León de Arce A., en García García, L. M. (coord.), “Derechos de los Consumidores y Usuarios”, Ed.: Tirant lo Blanch, Valencia 2007, pág. 59.
} 
1986, que reforma el Tratado de Roma, firmado el 25 de marzo de 1957, donde aparece la primera alusión expresa a la protección de los consumidores ${ }^{4}$.

A estos primeros textos legales les han sucedido diversas Resoluciones, Decisiones y Directivas reguladoras del derecho de consumo en el ámbito de la Unión Europea, entre las que podemos hacer alusión a la Resolución del Consejo, de 9 de noviembre de 1989, sobre futuras prioridades para el relanzamiento de la política de protección al consumidor (entre las que se incluían la integración de la política y fomento de los intereses de los consumidores, la mejora de la representación de los consumidores en el plano comunitario o el fomento de la seguridad general de los productos), o la Decisión de la Comisión de 17 de noviembre de 1989, por la que se crea el Consejo Consultivo de Consumidores ${ }^{5}$.

Ya dentro del panorama nacional fue la promulgación de la Constitución de 1978 (en adelante CE) la que marcó un hito en la historia del derecho de consumo, introduciendo una modalidad de principio general del Derecho, denominado por la doctrina «principio pro-consumidor» 6 , y estableciendo como obligación del Estado la protección del consumidor.

\section{b. Necesidad.}

A lo largo de los años desde la Unión Europea se ha incidido en la necesidad de proteger íntegramente al consumidor, como mencionaremos al aludir a los antecedentes de la Constitución Española, actuando esta idea como motor de acciones legislativas que han consagrado valores y principios en los que se apoya su protección, convirtiendo en realidad jurídica la realidad socio-

\footnotetext{
${ }^{4}$ Reyes López, M.J.: “Manual de Derecho Privado de Consumo”. Ed.: La Ley Actualidad, Madrid 2009, pág. 64.

${ }^{5}$ De León de Arce A., en García García, L. M. (coord.), “Derechos de los Consumidores y Usuarios”, cit., págs. 59 a 61.

6 “El principio pro consumidor", consiste en una modalidad de principio general del Derecho, inspirado en la Resolución del Consejo de la CEE de 14 de abril de 1975, por la que se establece el Programa Preliminar para llevar a cabo una política de protección y de información a los consumidores, que enumera los derechos fundamentales de éstos y los clasifica en las cinco categorías: salud y seguridad, intereses económicos, información, educación y representación, exigiendo además que estos sean debidamente asegurados. Este principio es tratado por numerosos autores, entre los que podemos referirnos a De León de Arce A., en García García, L.M. (coord.), "Derechos de los Consumidores y Usuarios”, cit., pág. 58 y ss; Iboleón Salmerón, B., García-Villanova Zurita, G.: "Una aproximación jurídica al estudio del principio "in dubio pro consumidor". Revista de estudios jurídicos nº 14/2014, Ed.: Universidad de Jaén.
} 
económica, debido sobre todo al desarrollo del mercado, la competencia, la competitividad, la productividad empresarial, el valor de la adecuación del derecho a la realidad económica y social así como a la actividad empresarial, promocionando además valores de la sociedad moderna como la solidaridad, la igualdad material y la justicia social.

Por ello, las instituciones europeas, desde su Tratado constitutivo, mostraron gran interés en eliminar los obstáculos existentes para garantizar un alto nivel de protección mediante el establecimiento de normas uniformes a escala comunitaria ${ }^{7}$.

El texto constitucional, continuando la idea de protección de la Comunidad Europea, fue el antecedente en España de la regulación del derecho de consumo.

El primer texto legal que regula en España el derecho de consumo es la Ley 26/1984, de 19 de julio, General para la Defensa de Consumidores y Usuarios (BOE de 24 de julio de 1984, en adelante $\operatorname{LGDCU})^{8}$, que se fue complementando con un amplio conjunto normativo, cuya promulgación se debió a un trágico suceso, conocido como "Enfermedad de la colza" o "síndrome del aceite tóxico" causado por el consumo entre un sector de la población de aceite de colza desnaturalizado, que produjo un importante número de muertes y lesiones.

La actual regulación estatal sobre derecho de consumo se encuentra en el Texto Refundido de la Ley General para la Defensa de los Consumidores y Usuarios aprobado por Real Decreto legislativo 1/2007, de 16 de noviembre, modificado por la Ley 3/2014, de 27 de marzo, que establece los derechos básicos de los consumidores.

En síntesis, la normativa referida regula la protección de sus legítimos intereses así como la protección de la salud y la seguridad, crea el Registro Estatal de asociaciones de consumidores, los órganos de representación y consulta de los consumidores, el sistema de cooperación institucional, a la vez que establece la potestad sancionadora de la administración, el régimen de infracciones y

\footnotetext{
${ }^{7}$ De León de Arce A., en García García, L. M. (coord.), “Derechos de los Consumidores y Usuarios”, cit., pág. 58 y ss.

${ }^{8}$ De León de Arce A., en García García, L.M. (coord.) "Derechos de los Consumidores y Usuarios “, cit., pág. 130.
} 
sanciones, los procesos judiciales y extrajudiciales de protección, regulando también los contratos y garantías de consumo, incluido el servicio postventa.

\section{c. Ámbito:}

\section{Unión Europea.}

El primer programa de acción relativo a la protección de los consumidores fue presentado en la Cumbre de Paris en febrero de 1961. En él se recogían las cinco categorías de derechos fundamentales que constituyen la base de la legislación comunitaria; nos referimos al derecho a la protección tanto de la seguridad como de los intereses económicos de los consumidores, al derecho a la representación, información y educación, así como a la posible indemnización de daños sufridos.

En la práctica, las líneas de actuación de la UE se han concentrado en los ámbitos del derecho de información y protección de la salud y de los intereses económicos ${ }^{9}$.

El esfuerzo de la Unión Europea se ha visto concretado en la regulación de derechos sectoriales, más que en una regulación genérica de los derechos de los consumidores, lo cual se traduce en los numerosos textos legales aprobados ${ }^{10}$, de los que destacamos la

\footnotetext{
${ }^{9}$ Busto Lago, J.M., (coord.) en Álvarez Lata, N. y Peña López, J.: "Reclamaciones de consumo. Derecho de consumo desde la perspectiva del Consumidor”, Ed.: Aranzadi, S.A., Pamplona 2010, pág. 345.

${ }^{10}$ A las líneas básicas que contiene la normativa europea aludida, le siguen otros muchos textos legales que concretan medidas para la cooperación de las autoridades nacionales encargadas de su aplicación, como el Reglamento (CE) no 2006/2004 del Parlamento Europeo y del Consejo, de 27 de octubre de 2004, sobre la cooperación entre las autoridades nacionales encargadas de la aplicación de la legislación de protección de los consumidores, el Reglamento (CE) n ${ }^{0}$ 593/2008 del Parlamento Europeo y del Consejo, de 17 de junio de 2008, sobre Ley aplicable a las obligaciones contractuales.
}

Como normativa europea de consumo existen Directivas en todos los ámbitos, siendo las más representativas la Directiva 98/27/CE, de 19 de mayo de 1998, reguladora de la acción de cesación, que ha sido el marco de nuestra Ley 39/2002, de 28 de octubre, la Directiva 98/6/CE, de 16 de febrero de 1998, relativa a la indicación de precios de los productos ofrecidos a los consumidores; la Directiva 87/102/CEE, modificada por la Directiva 90/88/CEE de 22 de febrero de 1990, relativa a la aproximación de las disposiciones legales, reglamentarias y administrativas de los Estados Miembros en materia de crédito al consumo, y por la Directiva 98/7/CEE del Parlamento Europeo y del Consejo de 16 de febrero de 1998, relativa a la aproximación de las disposiciones legales, reglamentarias y administrativas de los Estados Miembros en materia de crédito al consumo, así como la Directiva 97/55/CEE, , que modifica la Directiva 84/450/CEE sobre publicidad engañosa a fin de incluir en la misma la publicidad comparativa. Existen otras, como la Directiva 2005/29/CE del Parlamento Europeo y del Consejo, de 11 de mayo de 2005, relativa a las prácticas comerciales desleales de las empresas en sus relaciones con los consumidores en el mercado interior, que modifica la Directiva 84/450/CEE del Consejo; la Directiva 98/27/CE, relativa a la acción de cesación en materia de protección de los intereses de los consumidores, la Directiva 2002/65/CE del Parlamento Europeo y del Consejo, sobre contratos a distancia. 
regulación del derecho de desistimiento, las prácticas comerciales desleales y la publicidad engañosa ${ }^{11}$.

La Comisión también propuso un "Libro Blanco"12, publicado el 2 de abril de 2008, que contiene un conjunto de medidas específicas para garantizar que los consumidores y las empresas de los estados miembros de la U.E. puedan obtener una compensación efectiva de los perjuicios sufridos como consecuencia de los incumplimientos de la normativa europea sobre competencia.

En los últimos años han sido numerosas las reclamaciones de consumo, para cuya resolución, desde la Unión Europea, se han establecido mecanismos supra individuales que las atiendan de forma colectiva a través de las denominadas "collective redress"13, es decir, las acciones colectivas de indemnización en materia de consumo como forma de acción judicial.

Las Ilamadas "small claims" (reclamaciones de escasa cuantía), han sido impulsadas también desde la Unión Europea como alternativa a la solución de litigios de manera rápida en reclamaciones transfronterizas de hasta 2000 euros. Este procedimiento se regula a través del Reglamento (CE) № 861/2007, del Parlamento Europeo y del Consejo, de 11 de julio de 2007, y del Reglamento (UE) no 524/2013, del Parlamento Europeo y del Consejo, de 21 de mayo de 2013, sobre resolución de litigios en materia de consumo.

Este último establece la creación de una plataforma de resolución de litigios en línea, al objeto de evitar procesos largos y costosos para resolver cuestiones sobre ventas online. Se encuentra disponible en la dirección htt://ec.europa.eu/consumers/odr/, y ofrece a consumidores y comerciantes una ventanilla única para la resolución extrajudicial en

\footnotetext{
Además de las Directivas enumeradas, existen muchas otras que regulan materias específicas de derecho de consumo, como la Directiva 93/13/CEE del Consejo, de 5 de abril de 1993, sobre cláusulas abusivas en los contratos celebrados con consumidores; la Directiva 97/7/CEE del Parlamento y del Consejo de 20 de mayo de 1997, relativa a la protección de los consumidores en materia de contratos a distancia, la Directiva 2007/64/CEE, de 13 de noviembre de 2007, sobre servicios del mercado interior, o la Directiva 2009/22/CE del Parlamento y el Consejo de 23 de abril de 2009, relativa a las acciones de cesación en materia de protección de los intereses de los consumidores.

${ }^{11}$ También se regula la publicidad engañosa mediante la Directiva 2006/114/CE del Parlamento Europeo y del Consejo, de 12 de diciembre de 2006.

${ }^{12}$ http://www.europa.eu/documentation/official-docs/white-papers/index_es.htm.

${ }^{13}$ http://ec.europa.eu/consumers/solving_consumer_disputes/judicial_redress/index_en.htm.
} 
línea, a través de procedimientos de calidad mediante entidades de resolución alternativa de conflictos vinculadas a ella.

\section{Constitución Española.}

El art. 51, marca un hito histórico en la regulación de los derechos de los consumidores, debido a que no existen precedentes del referido artículo en las constituciones europeas ni españolas anteriores, salvo en la Constitución portuguesa de 1876, aunque en alguna pueden encontrarse medidas que suponen una defensa de los consumidores.

Pese a ello, sí que existen documentos de organismos supranacionales referidos a la protección de los consumidores a través del reconocimiento de derechos básicos ${ }^{14}$, concretamente en la OCDE, la CEE y el Consejo de Europa. Podemos aludir a la Resolución 543/73 de la Asamblea Consultiva del Consejo de Europa que aprobó el texto de la Carta Europea de Protección de los Consumidores y al Programa Preliminar de la CEE para una política de Protección e información a los consumidores, aprobado mediante Resolución de 14 de abril de 1975.

Debido al desarrollo referido por parte de la UE, en España la protección de los consumidores y usuarios se convierte en un principio constitucional básico encuadrado dentro del ámbito del estado social de Derecho (art. 1.1 CE), contemplando la vertiente social de la acción de los poderes públicos.

Su importancia radica en la esencia de la propia CE y en el entorno que la misma pretende crear sentando las bases de la protección de los consumidores y usuarios, y asegurando a los ciudadanos la protección de sus derechos y libertades, estableciendo lo siguiente:

"1. Los poderes públicos garantizarán la defensa de los consumidores y usuarios, protegiendo, mediante procedimientos eficaces, la seguridad, la salud y los legítimos intereses económicos de los mismos.

\footnotetext{
${ }^{14}$ De León de Arce, A. (Dir.), García García, L.M.:” Derechos de los consumidores y usuarios”. Epígrafe 2: "La protección legal de los consumidores y usuarios en España” (TOL 1.190.307), pág. 60.
} 
2. Los poderes públicos promoverán la información y la educación de los consumidores y usuarios, fomentarán sus organizaciones y oirán a estas en las cuestiones que puedan afectar a aquellos, en los términos que la ley establezca.

3. En el marco de lo dispuesto por los apartados anteriores, la ley regulará el comercio interior y el régimen de autorización de productos comerciales."

Lo dispuesto en este artículo supone la introducción del derecho de protección de los consumidores como principio rector de la política social y económica.

\section{Legislación Estatal.}

La actual regulación española de los derechos de los consumidores y usuarios la encontramos en el Texto Refundido de la Ley General para la Defensa de los Consumidores y Usuarios que establece un marco de protección general, y cuya reforma llevada a cabo por la Ley 3/2014, de 27 de marzo, incorpora al ordenamiento interno la Directiva 2011/83/UE del Parlamento Europeo y del Consejo, de 25 de octubre de 2011.

Existe además una extensa normativa sectorial, a la que haremos mención a lo largo de estas páginas, como la Ley 7/2001 de 17 de diciembre, de Marcas, la Ley 29/2009, de 30 de diciembre, por la que se modifica el régimen legal de la Competencia Desleal y de la publicidad para la mejor protección de los derechos de los consumidores y usuarios. Podemos también aludir a la regulación de la Propiedad Intelectual mediante Real Decreto Legislativo 1/1996, de 13 de abril, por el que se aprueba el Texto Refundido de la Ley de Propiedad Intelectual, y a la Ley 34/1988, de 11 de noviembre, General de Publicidad.

También existe regulación sobre transportes públicos, telecomunicaciones o seguros, a cuyo conjunto normativo hemos de añadir la propia Ley de Enjuiciamiento Civil, a la cual tan solo haremos alusión a lo largo de estas páginas.

\section{Legislación Autonómica.}

Las Comunidades Autónomas gozan de competencia en materia de consumo, si bien la forma en que han desarrollado esta facultad 
difiere entre ellas, estableciendo sobre todo un conjunto de disposiciones de protección de los consumidores generalmente de carácter administrativo.

En algunas Comunidades las normas de consumo son estatutos básicos, en otras se trata de normas generales, pero en ninguna de las regulaciones actuales se aportan novedades a las normas existentes en los demás ámbitos descritos ${ }^{15}$.

Por su parte, la competencia de la Comunidad Valenciana en materia de consumidores y usuarios se concreta en el art. 49.135 a del Estatuto de Autonomía Valenciano aprobado mediante Ley Orgánica 5/1982, de 1 de julio, cuyo desarrollo se ha llevado a cabo mediante la ley $1 / 2011$, de 22 de marzo, por la que se aprueba el Estatuto de los Consumidores y Usuarios de la Comunidad Valenciana, vertebrada sobre los siguientes puntos fundamentales:

- Los derechos básicos de los consumidores, regulando además estos derechos en relación a la indemnización de daños y a la reparación de perjuicios sufridos.

- La información en la promoción, oferta, adquisición, utilización y disfrute de bienes y servicios y la actuación en esta materia de las administraciones públicas; a la educación y formación en materia de consumo y la actuación de las administraciones públicas en este sentido. participación ${ }^{16}$.

El derecho de representación, audiencia y

\section{Catálogo de derechos.}

Uno de los objetivos fundamentales del Derecho de Consumo, siguiendo las directrices marcadas por la CE, es el establecimiento de un "Catálogo de Derechos del consumidor" recogido tanto en el TRLGDCU como en la legislación sectorial.

\footnotetext{
${ }^{15}$ De León de Arce A., en García García, L.M. (coord.) "Derechos de los Consumidores y Usuarios “, cit., pág. 119.

${ }^{16}$ Reyes López, M.J.: “Manual de Derecho Privado de Consumo”, cit., pág. 95 a 131.
} 
Concretamente, el art. 8 del TRLGDCU establece unos derechos básicos e irrenunciables de los consumidores, los cuales deben estar protegidos por los poderes públicos ${ }^{17}$.

Siguiendo a De León de Arce, el contenido básico de los derechos de consumo abarca diversos campos, entre los que destacamos los siguientes ${ }^{18}$ :

1. La seguridad, la salubridad, la prevención del consumidor, la sanción de daños que puedan derivarse del mismo, así como la indemnización de los mismos, con la regulación de la responsabilidad civil ${ }^{19}$.

2. Un sistema eficaz de información al consumidor ${ }^{20}$.

3. Control de la publicidad, los precios, la promoción de ventas en los contratos de adhesión.

4. El fomento del desarrollo de las asociaciones de consumidores al objeto de dotarlas de legitimación para el ejercicio de acciones sobre intereses colectivos.

Estos campos desarrollan las directrices básicas que concretan tanto los principales derechos básicos de los consumidores, como una serie de obligaciones que afectan a los empresarios o fabricantes en aras a la consecución de los derechos de los consumidores, entre los que se encuentran los siguientes:

\section{a. Derecho a la tutela.}

La Constitución, en el referido artículo 51 aludido, recoge la defensa de los consumidores y usuarios, protegiendo la seguridad, la salud y los intereses económicos de estos ${ }^{21}$.

\footnotetext{
${ }^{17}$ Vázquez Barros, S. “Memento Practico de consumo 2010-2011”. Ed.: Francis Lefebvre, Madrid 2010, pág. 52.

${ }^{18}$ De León de Arce A., en García García, L. M. y Fuente Noriega, M. (coord.), "Derechos de los Consumidores y Usuarios”, cit., pág. 99.

${ }^{19}$ Reyes López, M.J.: “Manual de Derecho Privado de Consumo”, cit., pág. 177 a 200.

${ }^{20}$ Busto Lago, J.M., (coord.) en Álvarez Lata, N. y Peña López, J.: "Reclamaciones de consumo. Derecho de consumo desde la perspectiva del Consumidor”, cit., pág. 96.

${ }^{21}$ Barona Vilar, S. (coord.), Calderón Cuadrado, M.P., Sanchís Crespo, C., Jiménez Forte, J., Martínez García, E., Pardo Iranzo, V., Pascual Serrats, R., Andrés Ciurana, B., García Vila, M., González Malabia, S.: "Tutela de los consumidores y usuarios en la nueva Ley de Enjuiciamiento Civil", Ed.: Tirant lo Blanch, Valencia 2002, pág. 24.
} 
Por su parte, el art. 24 de la $\mathrm{CE}$, reconoce el derecho de toda persona a obtener la tutela efectiva de jueces y tribunales en el ejercicio de sus derechos e intereses legítimos.

Existe también referencia al derecho a la tutela en el art. 9.2응 $\mathrm{CE}$, tanto de forma individual como colectiva cuando haya una pluralidad de consumidores afectados.

En este sentido, encontramos mención expresa en el art. 11 de la LEC sobre la posible acción conjunta de todos los consumidores perjudicados, como veremos al tratar la legitimación colectiva, aunque como entiende Planchadell Gargallo, su regulación es pobre, siendo necesario su desarrollo para lograr la satisfacción de la pretendida tutela, tanto en el ámbito individual como colectivo ${ }^{22}$.

\section{b. Derecho de información.}

El Derecho de información tiene una enorme trascendencia debido a que a través del mismo se ve condicionado el consentimiento contractual, de ahí que se exija una información veraz, exacta, suficiente y completa.

El obligado a informar es el empresario o productor con quien contrata el consumidor, entendiendo incumplida la obligación de informar cuando sea falsa o inexacta ${ }^{23}$, pudiendo acudir a la acción de nulidad, argumentando que la falta de información generó un error en el consumidor.

El contenido mínimo del derecho de información sobre los bienes y servicios se regula en el art 60.2 del TRLGDCU, que contempla el deber de entrega de la información relativa a los mismos, especificando el nombre, razón social y domicilio completo, incluidos impuestos o un presupuesto, la fecha de entrega, la ejecución del contrato y su duración, el procedimiento de que dispone el consumidor para poner fin al contrato, las garantías ofrecidas, así como las lenguas en que debe formalizarse el mismo y la existencia del derecho de desistimiento ${ }^{24}$.

\footnotetext{
${ }^{22}$ Planchadell Gargallo, A.: "La consecución de la tutela judicial efectiva en la litigación colectiva", Revista InDret, núm. 4/2015, pág. 24.

${ }^{23}$ Reyes López, M.J.: “Manual de Derecho Privado de Consumo”, cit., pág. 434.

${ }^{24}$ Busto Lago, J.M., (coord.) en Álvarez Lata, N y Peña López, J.: "Reclamaciones de consumo. Derecho de consumo desde la perspectiva del Consumidor”, cit., pág. 105 a 111.
} 
De omitirse la información exigida por la Ley, el consumidor podrá resolver el contrato con la indemnización correspondiente y los efectos que establece el art. 1124 C.c., entendiendo que interviene dolo o culpa del empresario.

\section{c. Derecho de desistimiento.}

Regulado en los arts. 68 a 79 del TRLGDCU es, junto con el derecho de información, uno de los derechos más importantes de que goza el consumidor, ya que le permite rescindir la relación comercial por incumplimiento de las condiciones de la oferta del empresario o comerciante ${ }^{25}$. Los efectos del derecho de desistimiento se regulan en el art. 74.1 TRLGDCU.

EI TRLGDCU reconoce además el derecho de desistimiento en los contratos celebrados a distancia (art. 101 y 102), en los celebrados fuera de establecimiento mercantil (art. 110 y 111), y en los contratos de viajes combinados (art. 160).

Aunque será objeto de estudio con mayor detalle a lo largo del presente trabajo, el consumidor deberá probar que ejerció su derecho de desistimiento dentro de plazo, pudiendo realizarse por cualquier medio, incluso electrónico que permita tener constancia de la recepción por el empresario, cuyo efecto es el de dejar extinguido el contrato de consumo concertado, estando el contrato inicialmente suscrito válidamente celebrado, siendo obligatorio para ambas partes $^{26}$.

\section{d. Derecho de representación y asociación.}

También reconocido por la $\mathrm{CE}$, su marco general queda definido en la Ley Orgánica 1/2002, de 22 de marzo, reguladora del Derecho de Asociación ${ }^{27}$.

\footnotetext{
${ }^{25}$ Álvarez Lata, N.: "Invalidez e Ineficacia en el Derecho Contractual de Consumo Español. Análisis de los supuestos típicos de ineficacia en los contratos con consumidores". Ed.: Aranzadi, S.A., Pamplona 2004, pág. 83; Busto Lago, J.M., (coord.) en Álvarez Lata, N. y Peña López, J.: "Reclamaciones de consumo. Derecho de consumo desde la perspectiva del Consumidor”, cit., pág. 263.

${ }^{26}$ Beluche Rincón, I.: "El derecho de desistimiento del consumidor", Ed.: Tirant lo Blanch, Valencia 2009, págs. 37 a 100.

${ }^{27}$ Ruiz González, J.G.: “Las asociaciones de consumidores. Configuración y Régimen jurídico”. Ed.: Tirant lo Blanch, Valencia 2010, pág. 5 y ss.
} 
Este derecho resulta de especial trascendencia puesto que en derecho de consumo se produce un auténtico fenómeno asociativo a través de asociaciones de consumidores; de hecho, estas han sido el verdadero motor para que el derecho de los consumidores se vea desarrollado, atendido y aplicado por el legislador.

Desde las asociaciones de consumidores se ha dado el empuje preciso para que toda la normativa de consumo se desarrolle en pro de la defensa del consumidor, con el consiguiente interés y medidas que por parte de la industria, el comercio y los profesionales han tenido que desarrollar al objeto de salvaguardar los intereses de los consumidores, que se han visto protegidos en gran medida por el asociacionismo creciente en su defensa ${ }^{28}$.

Actualmente estas asociaciones se encuentran integradas en el Consejo de Consumidores y Usuarios, que es oído en consulta en el procedimiento de elaboración de disposiciones de carácter general de ámbito estatal relativas a materias que afecten directamente a los consumidores y usuarios.

El Consejo está adscrito al Ministerio de Sanidad y Política Social a través del Instituto Nacional de Consumo, cuya función es la de lograr una colaboración eficaz con las asociaciones de consumidores que lo integran.

\section{e. Derecho de integración.}

La consagración del derecho a la integración viene de la ya derogada Ley 26/1984, de 19 de julio, General para la Defensa de los Consumidores y Usuarios, y supone la integración de la oferta, su contenido, promoción o publicidad. Este derecho se sigue recogiendo en el TRLGDCU con el objeto de evitar la información engañosa y que se induzca a error al consumidor ${ }^{29}$.

El contenido de la oferta, la promoción y publicidad del producto deben ser siempre conformes con el contrato celebrado, es más, si el contrato tuviese alguna cláusula más beneficiosa que las de la oferta, prevalecerá el contrato.

\footnotetext{
${ }^{28}$ Busto Lago, J.M., (coord.) en Álvarez Lata, N. y Peña López, J.: “Reclamaciones de consumo. Derecho de consumo desde la perspectiva del Consumidor”, cit., pág. 81 a 94.

${ }^{29}$ Llobet i Aguado, J.: "El Derecho de información en la formación de los contratos", pág. 33. Ed.: Marcial Pons, Madrid 1996.
} 
Esta integración se observará siempre en beneficio del consumidor, conforme al principio de buena fe objetiva, en los casos en que haya existido una omisión de información precontractual relevante.

\section{f. Obligaciones de los fabricantes o empresarios.}

Junto a los referidos derechos, el art. 19 del TRLGDCU establece los principios generales de las prácticas comerciales que deben ser cumplidos por los empresarios o fabricantes, basadas en el respeto a los intereses económicos y sociales de los consumidores, y concretando el marco de protección por remisión a la normativa contenida en la Ley 29/2009, de 30 de diciembre, de Competencia Desleal y en la Ley 7/1996, de 15 de enero, de Ordenación del Comercio Minorista, siendo el art. 13 del mismo cuerpo legal, el que establece una enumeración de las obligaciones de los empresarios en la puesta a disposición de los bienes y servicios ${ }^{30}$.

\section{g. Derechos sectoriales.}

Junto a los derechos básicos de los consumidores y usuarios que se aplican con carácter general, existe una regulación específica en relación con determinados sectores de servicios que concretan o amplían aquellos.

Nos referimos a derechos de grupos concretos de usuarios, aunque no vamos a entrar en su estudio, entre los que podemos aludir a los derechos de los pasajeros del transporte aéreo, regulados en la Ley 48/1960, de 21 de julio, sobre navegación aérea, o de los viajeros de autobús, regulados en la Ley $9 / 2013$, de 4 de junio, por la que se modifica la Ley 16/1987, de 30 de julio, de ordenación de transporte terrestre; los derechos de los usuarios de los Servicios de Telecomunicaciones, establecidos en la Ley 9/2014, de 9 de mayo, General de telecomunicaciones; 0 de los usuarios de seguros, establecidos en la Ley 50/80, de 8 de octubre, de Contrato de Seguro con sus modificaciones.

\footnotetext{
${ }^{30}$ Parra Lucán, M.A.: “La Protección del Consumidor frente a los daños. Responsabilidad del fabricante y del prestador de servicios”, págs. 10 a 14. Colección D. del Consumo, Universidad de Zaragoza, Madrid 2011. Ed.: Reus, S.A.
} 


\section{CAPÍTULO II. LA TUTELA DE LOS CONSUMI DORES Y USUARIOS}

La tutela judicial efectiva de los jueces y tribunales reconocida en el art. 24.1 de la CE a todas las personas ${ }^{31}$, presenta no obstante particularidades cuando se refiere a los consumidores. Vamos a referirnos brevemente a los presupuestos procesales de los procesos de consumo, concretamente a la capacidad, a la legitimación, así como a la intervención en sus distintas modalidades.

\section{A. CAPACI DAD}

La capacidad para ser parte, regulada en los arts. 6 de la LEC ${ }^{32}$, muestra peculiaridades en el proceso de consumo donde se otorga tanto al consumidor individualmente considerado, como a un grupo de personas afectadas por una reclamación concreta, de forma que puedan comparecer conjuntamente en el proceso, o a través de las asociaciones y corporaciones que representan intereses de los consumidores ${ }^{33}$.

\section{a. Capacidad de las asociaciones.}

De los posibles interesados en los procesos en defensa de los consumidores y usuarios, los que aparecen con mayor frecuencia como demandantes son las asociaciones de consumidores, siendo en estos casos necesaria la notificación a los afectados previa a la formalización de la demanda, tal como establece el art. 15.2 de la LEC.

Sobre la capacidad de las asociaciones de consumidores y usuarios se exige que se encuentren legalmente constituidas para defender los derechos e intereses de sus asociados y los propios de la

\footnotetext{
${ }^{31}$ De la Oliva Santos, A., Peiteado Mariscal, P.: "Sistema de tutela judicial efectiva", Ed.: CEF Ediciones, Madrid, 2014, pág. 225 a 228; De la Oliva Santos, A.: "Sobre la protección jurisdiccional a los consumidores y usuarios”. Revista sobre Consumo, n 16/1989, pág. 157 a 164.

${ }^{32}$ Montero Aroca, J.: “De la legitimación en el proceso civil”, Ed.: Bosch, S.A., Barcelona 2006, pág. 62. Martínez García, E.: “Algunas reflexiones sobre la legitimación en el proceso civil”. Ed.: La Ley Revista Jurídica nº 2 de 1996, págs. 1498 y 1499.

${ }^{33}$ De León de Arce, A. en García García, L.M. (artículo de Bujosa Vadell, L.M.): "Derechos de los Consumidores y Usuarios", cit., tomo II, pág. 1734; Bujosa Badell, L.M.: "La protección jurisdiccional de los intereses de grupo”, Ed.: J.M. Bosch Editor, Barcelona, 1995, pág.107.
} 
asociación, así como los intereses generales de los consumidores y usuarios recogida en el art. 6-70 34 .

En relación a los concretos intereses que pueden representar las asociaciones de consumidores y usuarios, el art. 24.1 del TRLGDCU establece que podrán actuar en nombre y representación de los intereses generales de los consumidores y usuarios.

\section{b. Capacidad de los grupos de afectados.}

La capacidad para ser parte del grupo de afectados 0 perjudicados por un mismo hecho regulada el art. 6.1-70 de la LEC, depende de la existencia de un interés afectante a una pluralidad de personas, siempre que concurra el hecho dañoso y que el grupo esté constituido por una mayoría de afectados, debiendo además estar determinados o ser fácilmente determinables ${ }^{35}$.

En base al artículo referido se ha reconocido capacidad para ser parte incluso a entes sin capacidad jurídica, como las comunidades de bienes, las de propietarios, la comunidad hereditaria ${ }^{36}$ o las uniones sin personalidad ${ }^{37}$.

\section{c. Capacidad de las entidades habilitadas}

El punto $8^{\circ}$ del mismo artículo regula la capacidad de las entidades habilitadas conforme a la normativa comunitaria europea para el ejercicio de la acción de cesación en defensa de los intereses

\footnotetext{
${ }^{34}$ S. no 65/2012, Sec. 21 $2{ }^{\text {a }}$ Bis AP Madrid, de 20-12-2012, (TOL 5.360.202), hace alusión al art. 11.2 de la LEC que reconoce legitimación procesal a las asociaciones, a las entidades legalmente constituidas, y a los propios grupos afectados, matizando que será de aplicación este art. cuando sean personas determinadas o fácilmente determinables, los perjudicados por un hecho dañoso relacionado con la defensa de derechos e intereses de consumidores y usuarios.

Entiende además la sentencia que si se trata de una pluralidad de consumidores y usuarios indeterminada o de difícil determinación, la defensa de estos intereses difusos corresponderá, exclusivamente, a las asociaciones de consumidores y usuarios, que, conforme a la ley, sean representativas.

${ }^{35}$ Bujosa Badell, L.M.: "La protección jurisdiccional de los intereses de grupo", pág. 169. Ed.: J.M. Bosch Editor, S.A., Barcelona 1995; González Cano, M.I.: "La tutela colectiva de consumidores y usuarios en el proceso civil". Ed.: Tirant lo Blanch, Valencia 2002, pág. 143; Cabañas García, J.C.: "Los procesos civiles sobre consumidores y usuarios y de control de las cláusulas generales de los contratos", Ed.: Tecnos, Madrid, 2005, pág. 197; Planchadell Gargallo, A.: "Las acciones colectivas en el ordenamiento jurídico español”,Ed.: Tirant lo Blanch, Valencia 2013, pág. 95.

${ }^{36}$ Bujosa Vadell, L.M.: “La protección jurisdiccional de los intereses de grupo, cit., pág. 156.

${ }^{37}$ Cabañas García, J.C.: "Los procesos civiles sobre consumidores y usuarios y de control de las cláusulas generales de los contratos”, cit., pág. 193.
} 
colectivos y difusos de los consumidores y usuarios en procesos que se sigan ante tribunales españoles ${ }^{38}$.

\section{B. LEGI TI MACIÓN ACTI VA}

Es destacable en este punto la existencia de diversas formas de acceder a la tutela: por un lado tenemos la forma habitual, cuya legitimación se concreta en el art. 11.1 de la LEC; por otro lado, la acción colectiva, reconocida en el art. 11.2 de la LEC.

El art. 11 de la LEC regula la legitimación para la defensa de los derechos e intereses de los consumidores y usuarios, estableciendo su apdo. 1 tanto la legitimación individual de cada uno de los consumidores afectados como colectiva de las asociaciones legalmente constituidas para defender sus propios intereses, los de sus asociados ${ }^{39}$ y los generales de los consumidores y usuarios ya aludidos al tratar su capacidad.

El apdo. 2 o del mismo artículo especifica otros supuestos de legitimación de las asociaciones cuando los perjudicados por un hecho dañoso sean un grupo determinado o de fácil determinación de consumidores.

Siguiendo el mismo artículo, su apdo. 3o regula la legitimación de las asociaciones que sean representativas en defensa de los afectados por un hecho dañoso cuando no estén determinados o su determinación resulte difícil, introduciendo el concepto de "intereses difusos" 40 .

Aún existen otros legitimados, según el apdo. 4, las entidades habilitadas para el ejercicio de la acción de cesación en defensa de los intereses colectivos y difusos de los consumidores; y por último, el apdo. 5 otorga legitimación al Ministerio Fiscal para ejercer cualquier acción en defensa de los intereses de los consumidores.

\footnotetext{
${ }^{38}$ González Cano, M.I.: "La tutela colectiva de consumidores y usuarios en el proceso civil”, cit., pág. 110. Martínez García, E. en Gómez Colomer, J.L., Barona Vilar, S, Calderón Cuadrado, M.P., Montero Aroca, J.:” El Derecho procesal del S. XX a golpe de tango. Las acciones colectivas de consumo en la Unión Europea”. Ed.: Tirant lo Blanch, Valencia 2012, págs. 1317 a 1336

${ }^{39}$ Cabañas García, J.C.: "Los procesos civiles sobre consumidores y usuarios y de control de las cláusulas generales de los contratos", cit., pág. 182; García Gil, F.J.: "Suma de la Protección y defensa de los derechos de los consumidores”, Ed.: Bosch, S.A., Barcelona 2009, pág. 690.

${ }^{40}$ Barona Vilar, S.: "Competencia Desleal. Tutela jurisdiccional (especialmente proceso civil) y extra jurisdiccional. Doctrina legislación y jurisprudencia”. Tomo I. Consideraciones generales y objeto del proceso civil. Ed.: Tirant lo Blanch, Valencia 2008, pág. 1158.
} 


\section{a. Legitimación ordinaria de los consumidores afectados}

Este tipo de legitimación, establecida en el art. 10 párrafo 1ำ de la LEC expresa que serán consideradas partes legítimas quienes comparezcan y actúen en juicio como titulares de la relación jurídica u objeto litigioso ${ }^{41}$.

Concretando la legitimación de los consumidores, el art. 21.1 del TRLGDCU, es el que establece la posibilidad de interponer la acción individual ${ }^{42}$, actuando el demandante como persona física afectada.

También la LCGC en su art. 9.1 hace mención a esta legitimación individual en las acciones de nulidad de cláusulas que incorporen condiciones generales, expresando que «La declaración judicial de no incorporación al contrato o de nulidad de las cláusulas de condiciones generales podrá ser instada por el adherente de acuerdo con las reglas generales reguladoras de la nulidad contractual».

Por su parte, la legislación específica en materia de consumo también establece reglas en cuanto a la legitimación. En relación a la legitimación activa ${ }^{43}$, el art. 33 de la Ley de Competencia Desleal (en adelante LCD), expresa que la ostenta cualquier persona física o jurídica que participe en el mercado, cuyos intereses económicos resulten directamente perjudicados o amenazados por la conducta desleal, y se encuentre legitimada para el ejercicio de las acciones previstas en el artículo 32.1, 1aㅡ a $5^{a} \mathbf{4 4}$.

Por último, referirnos La Ley 17/2001, de 7 de diciembre, de Marcas, cuyo art. 59 hace mención a la legitimación activa de cualquier persona física o jurídica.

\footnotetext{
${ }^{41}$ Monsalve del Castillo, R.: "Legitimación activa de las asociaciones de consumidores y usuarios para el ejercicio de las acciones colectivas en defensa del interés general”. Revista Aranzadi Doctrinal núm. 9/2011 (comentario). Editorial Aranzadi, S.A., Pamplona 2011; Montero Aroca, J.: "De la legitimación en el proceso civil", cit., pág. 166.

${ }^{42}$ Busto Lago, J.M., (coord.) en Álvarez Lata, N. y Peña López, J.: "Reclamaciones de consumo. Derecho de consumo desde la perspectiva del Consumidor”, cit., pág. 298.

${ }^{43}$ Pipaón Pulido, J.G.: Acciones en materia de prácticas desleales y códigos de conducta en relación con los consumidores y usuarios". Actualidad Jurídica Aranzadi n $n^{\circ}$ 799/2010 (Comentario). Editorial Aranzadi, S.A., Pamplona 2010, pág. 2.

${ }^{44}$ Barona Vilar, S.: "Competencia desleal. Tutela jurisdiccional (especialmente proceso civil) y extra jurisdiccional: Doctrina y jurisprudencia". Petitum o Petición. "Tutela de condena al resarcimiento de daños y perjuicios”, cit., pág. 19.
} 


\section{b. Legitimación extraordinaria}

La legitimación extraordinaria surge cuando comparece en juicio persona distinta del titular de la relación jurídica, en cuyo caso, nos encontramos ante lo que Montero Aroca califica como una "ampliación de la legitimación"45.

Este tipo de legitimación se concreta en los apdos. 2, 3, 4 y 5 del art. 11 ya referidos de la LEC, y se otorga a las asociaciones de consumidores, a los grupos de afectados, a algunas instituciones y al Ministerio Fiscal.

Además de la LEC, otros textos legales como la Ley de Marcas prevé en el referido art. 59 la posible legitimación activa de cualquier agrupación legalmente constituida para la representación de los intereses de los fabricantes, productores, prestadores de servicios, comerciantes o consumidores afectados que ostenten un derecho subjetivo o interés legítimo en los casos de nulidad absoluta o caducidad por los motivos establecidos en los pactos c), d), e) y f) del art $55^{46}$.

\section{De las asociaciones de Consumidores}

Como ya hemos referido, las asociaciones de consumidores, reconocidas por el art. 51.2 de la $\mathrm{CE}$, tienen atribuidas funciones específicas en relación a la defensa de los intereses legítimos de los consumidores y usuarios, consagrándolas como instrumentos a través de los cuales los consumidores podrán participar en las cuestiones que pudieran afectarles.

Concretamente, el art. 7.3 de la LOPJ regula una legitimación para la defensa de intereses colectivos a favor de las corporaciones o asociaciones de consumidores que se encuentren legalmente habilitadas para la defensa de los intereses de sus asociados y para la protección de sus derechos ${ }^{47}$.

\footnotetext{
${ }^{45}$ Montero Aroca, J.: "De la legitimación en el proceso civil", cit., pág. 321; Cordón Moreno, F.: "El acceso a la justicia de los derechos de los consumidores”. Estudios Sobre Consumo, n 16/1989, pág. 123.

${ }^{46}$ De León de Arce, A., en García García, L.M., y Bujosa Badell, L.M. (coord.): "Derechos de los consumidores y usuarios”, cit., pág. 17.

${ }^{47}$ Así lo ha entendido la S. de la Sec. $9^{\text {a }}$ de la AP de Madrid de 15-09-2005 (TOL 1.034.661).
} 
Estas han ido adquiriendo un importante reconocimiento social como instituciones garantizadoras de los derechos e intereses de los consumidores desarrollándose una regulación específica tanto a nivel estatal como autonómico, así como en legislaciones sectoriales.

Su principal regulación se establece en el art. 23 del TRLGDCU, concretando el art. 24 del mismo cuerpo legal su legitimación para actuar en varios ámbitos, tanto en defensa de los intereses de sus asociados ${ }^{48}$, como en nombre y representación de los intereses generales de los consumidores y usuarios ${ }^{49}$, y en su propio nombre, protegiendo sus propios intereses ${ }^{50}$.

Para que puedan actuar en defensa de los intereses de grupo es condición indispensable que los propios Estatutos incluyan tal defensa entre sus fines ${ }^{51}$.

Existe otro condicionante en relación a la defensa de los denominados intereses difusos ${ }^{52}$ (aquellos en que los consumidores afectados sean una pluralidad indeterminada 0 de difícil determinación), en cuyo caso, legitimadas activamente sólo lo estarán aquellas asociaciones que, conforme a la ley, sean representativas ${ }^{53}$.

\section{De los grupos de afectados}

La defensa de los intereses de grupo se regula ${ }^{54}$ en el art. 11 de la LEC en su apdo. 2 y 3 ya referidos.

\footnotetext{
${ }^{48}$ González Cano, M.I.: "La tutela colectiva de consumidores y usuarios en el proceso civil”, cit., pág. 145.

${ }^{49}$ S. $n^{0}$ 44/2012, Sec. $8^{\text {a }}$ de la AP de Alicante de 2-02-2012 (TOL 2.526.728), considera que, para ser "asociación de consumidores y usuarios" es preciso, por un lado, que se haya constituido conforme a lo previsto en la ley de asociaciones teniendo como finalidad la defensa de los derechos e intereses legítimos de los consumidores, y por otro, que reúna los requisitos específicos que exige la propia LCU. Las asociaciones, deberán indicar, tras su denominación, el no de inscripción registral. Sin el cumplimiento de los requisitos establecidos en el TRLGDCU no podrán ejercer las funciones de representación. Línea mantenida por otras sentencias como $n^{\circ}$ 4/2005 la del Juzgado de lo Mercantil $n^{\circ} 1$ de Oviedo de 1-2-2005 (AC 2005/1195), el Auto $n^{\circ}$ 211/2011 Sec. $15^{\text {a }}$ de la AP Barcelona de 23-12-2011 (TOL 5.350.137) o la S. no 88/2012, Sec. $1^{\text {a }}$ AP León de 2-03-2012 (TOL 2.491.861).

${ }^{50}$ Planchadell Gargallo, A.: “Las acciones colectivas en el ordenamiento jurídico español”, cit., pág. 129.

${ }^{51}$ Bujosa Badell, L.M.: “La protección jurisdiccional de los intereses de grupo”, cit. pág. 161.

${ }^{52}$ Bujosa Badell, L.M.: “La protección jurisdiccional de los intereses de grupo”, cit., pág. 260.

${ }^{53}$ S. no 339/2006, Sec. $12^{\text {a }}$ de la AP de Madrid de 17-05-2006 (JUR 2006\187882).

${ }^{54}$ Díez Picazo, L y Guillón A.:”Sistema de Derecho Civil”, Vol. I. Ed.: Tecnos, Madrid 1990, pág. 85;
} 
Es un requisito necesario para que el grupo de afectados pueda demandar en juicio, que esté determinado, reúna a la mayoría de los afectados, defienda un interés coincidente y se establezcan unos criterios de representatividad en alguno de ellos con respecto a la totalidad ${ }^{55}$. El tribunal procederá al control de tal representatividad, puesto que, debe existir un representante que ejerza una función preventiva de protección de los intereses de los afectados ${ }^{56}$.

Cuando el grupo de afectados no esté determinado al inicio del proceso, el tribunal adoptará, a petición de la propia parte, las medidas oportunas al objeto de proceder a la averiguación de los integrantes del grupo, de acuerdo con las circunstancias del caso y conforme a los datos suministrados por el solicitante, incluyendo el requerimiento al demandado para que colabore en dichas diligencias ${ }^{57}$.

\section{Institucional}

Además de los casos de representación expuestos, existe la representación institucional, regulada en el apdo. 4ㅇ del art. 11 referido, mediante la cual es posible conferir la defensa y gestión de los derechos e intereses de determinados grupos de personas, a un ente representativo personalizado, como los Colegios Profesionales, las corporaciones locales o el Instituto Nacional de Consumo, así como los órganos y entidades correspondientes de las Comunidades Autónomas.

Existe por tanto una representación institucional explícita, que deriva de la Ley y que se produce cuando de modo voluntario un interesado se adhiere a una institución, lo cual comporta la aceptación de su sistema jurídico y representativo ${ }^{58}$.

Martínez García, E.: “Tutela de los Consumidores y Usuarios en la nueva Ley de Enjuiciamiento Civil”, Ed.: Tirant lo Blanch, Valencia 2003, pág. 97.

${ }^{56}$ S. Sec. $14^{\text {a }}$ AP Madrid de 29-01-2002 (AC 20021860) entiende que la acción de grupo se caracteriza por la presencia del interés propio y específico de cada uno de los integrantes de un determinado colectivo, cuyos miembros individuales en principio indeterminados, son fácilmente determinables e identificables, carácter que la distingue de la acción por intereses difusos, en la que se defiende un interés genérico, homogéneo y concurrente de una masa invertebrada y sin rostro, en el que la identificación personal y la idea de perjuicio patrimonial están muy diluidos. En el primer caso el esquema es el de actuación de una parte "pluri-subjetiva", un litisconsorcio puramente voluntario de varios unidos bajo una misma dirección y representación, y que como tales deben estar plenamente identificados.

\footnotetext{
${ }^{57}$ S. no 33/2004, Sec. $5^{\text {a }}$ AP Sevilla de 22-01-2004 (TOL 351.596).

${ }^{58}$ Planchadell Gargallo, A.: “Las acciones colectivas en el ordenamiento jurídico español”, cit., pág. 166.
} 
También encontramos alusión a la legitimación activa colectiva o institucional en la LCD, cuyo art. 32 establece que corresponde a los mismos entes que la ostentan en materia de consumo, y también al Instituto Nacional de Consumo, así como a las entidades de otros estados miembros de la Comunidad Europea constituidas para la protección de los intereses de los consumidores.

\section{Del Ministerio Fiscal}

El Ministerio Fiscal también se encuentra legitimado para el ejercicio de la acción de cesación para la defensa de los intereses colectivos y de los intereses difusos de los consumidores y usuarios. Así viene reconocido en el art 16 de la LCGC, en art. 32 de la LCD y en el art 11.4 de la LEC.

\section{LEGITIMACIÓN PASI VA}

El art. 10 de la LEC contempla la previsión legal en relación a quien puede comparecer en el proceso como legitimado pasivo, al margen de lo que la realidad exija en cada caso, concretándolo en el obligado a respetar el interés legítimo, que coincide con la persona que el actor llama al proceso como demandado ${ }^{59}$.

Merece especial mención la legitimación pasiva en supuestos de competencia desleal que, en virtud de lo dispuesto en el art.10 de la LEC, corresponde a cualquier persona que haya realizado un acto de competencia desleal, lo haya ordenado o intervenido junto con otros en su realización ${ }^{60}$.

Por su parte, la legitimación pasiva para el ejercicio de las acciones de cesación, retractación y declarativa viene establecida en el art. 17 de la LCGC, y la puede ostentar cualquier profesional que utilice condiciones generales que se reputen nulas, tanto en contratos con consumidores, como con otros profesionales, siendo bastante que estas hayan sido incorporadas al contrato, correspondiendo la prueba al demandante, tal como establece el art. 1214 del C.c. ${ }^{61}$.

\footnotetext{
${ }^{59}$ Montero Aroca, J.: “De la legitimación en el proceso civil”, cit., pág. 490.

${ }^{60}$ Barona Vilar, S.: “Competencia Desleal. Tutela jurisdiccional (especialmente proceso civil) y extra jurisdiccional. Doctrina legislación y jurisprudencia. Tomo II. Consideraciones generales y objeto del proceso civil”, cit., pág. 1175.

${ }^{61}$ Rebolledo Varela, A.L.: "Legitimación pasiva”. Publicación Grandes Tratados, Ed.: Aranzadi, S.A., Pamplona 2000, pág. 15 y ss.
} 


\section{INTERVENCIÓN}

La intervención supone la introducción en un proceso ya iniciado de una persona que hasta ese momento no era parte y que formula una pretensión. Los derechos que defiende ese tercero con su intervención pueden ser propios o en defensa de alguna de las partes $^{62}$.

A su vez la intervención se puede clasificar dependiendo de su forma de acceso al proceso, como voluntaria o provocada ${ }^{63}$. Se trata de intervención voluntaria cuando se produce a iniciativa del interviniente, y provocada cuando surge de alguna de las partes, normalmente de la parte demandada ${ }^{64}$.

Desde la perspectiva de la relación que tenga con la parte principal, puede existir otra distinción entre intervención principal y adhesiva. Será principal cuando el que interviene puede introducir una pretensión contradictoria con el objeto del proceso, y adhesiva, cuando la pretensión sea compatible con el mismo ${ }^{65}$.

Dentro de la intervención adhesiva distinguimos la simple de la litisconsorcial, siendo la diferencia entre ambas la posición en que se encuentran los intervinientes respecto del objeto y efectos del proceso, dado que el interviniente litisconsorcial debió ser parte en el proceso y defiende sus propios derechos; por el contrario, el adhesivo simple tan solo tiene interés en el resultado del mismo ${ }^{66}$.

En el ámbito de consumo, la posibilidad de intervención puede tener lugar tanto por el consumidor individual, titular de un derecho digno de protección, que viene reconocida en el art. 13 de la LEC

\footnotetext{
${ }^{62}$ Serra Domínguez: “Estudios de Derecho Procesal”. Ed.: Ariel, Barcelona 1969, pág. 208 a 250; Ariza Colmenarejo, M.J.: "La intervención procesal en el ámbito de los consumidores”. El Derecho, 2 de octubre de 2016.

${ }^{63}$ Carreras Maraña, M.A.: "La intervención adhesiva en el proceso civil”. Ed.: El Derecho Editores, Madrid, 2006, págs. 1 y 2.

${ }^{64}$ Martínez García, E.: “Tutela de los Consumidores y Usuarios en la nueva Ley de Enjuiciamiento Civil”, Ed.: Tirant Lo Blanch, Valencia 2003, pág. 43.

${ }^{65}$ Martínez García, E.: "Tutela de los Consumidores y Usuarios en la nueva Ley de Enjuiciamiento Civil”, cit., pág. 161.

${ }^{66}$ Montero Aroca, J.: "La intervención adhesiva simple. Contribución al estudio de la pluralidad de partes en el proceso civil”. Ed.: Biblioteca Hispano Europea, Barcelona, 1972, pág.159; Serra Domínguez. M.: "Intervención de terceros en el proceso", art. publicado en la Revista de Derecho Procesal, Barcelona, 1969, pág. 249 a 250.
} 
apdo. 2 ㅇ del párrafo 10 , estableciendo que el consumidor podrá intervenir en los procesos instados por las entidades legalmente reconocidas para la defensa de los intereses de aquellos, pudiendo incluso intervenir las entidades, asociaciones o grupos que acrediten tener un interés individual, colectivo o difuso, como ya hemos manifestado al tratar la legitimación.

La forma de intervención descrita permite a los consumidores ser parte en el proceso en calidad de adherentes afectados, cuya solicitud de adhesión no suspenderá el curso del procedimiento, debiendo el tribunal resolver sobre ella mediante auto, previo traslado a las partes personadas en el plazo de 3 días ${ }^{67}$.

Esta intervención voluntaria litisconsorcial también se trata en el art. 18 apdo. 1 y 2 de la LCGC, al establecer la posible personación en el proceso de las Cámaras de Comercio, Industria y Navegación, las asociaciones de consumidores y usuarios, el Instituto Nacional de Consumo, los órganos correspondientes de las Comunidades Autónomas y de las Corporaciones locales competentes en materia de defensa de los consumidores, los colegios profesionales legalmente constituidos y Ministerio Fiscal ${ }^{68}$.

La regulación sobre la intervención de los consumidores en el proceso, continúa en el art. 15 de la LEC, que concreta la forma en que esta debe producirse, mediante la publicidad y posible intervención de los consumidores y usuarios en los procesos planteados para la defensa de derechos e intereses colectivos y difusos de los consumidores ${ }^{69}$.

La publicidad aludida se lleva a cabo mediante un llamamiento al proceso que practicará el Letrado de la Administración de Justicia ${ }^{70}$ del propio órgano jurisdiccional, mediante la publicación de la admisión de la demanda, exceptuando del llamamiento a los

\footnotetext{
${ }^{67}$ De León de Arce, A. en García García, L.M. (coord.): “Derechos de los Consumidores y Usuarios”, cit., tomo II, pág. 1797.

${ }^{68}$ Martínez García, E.: "Tutela de los Consumidores y Usuarios en la nueva Ley de Enjuiciamiento Civil”, cit., pág. 155.

${ }^{69}$ Planchadell Gargallo, A.: "La intervención de los consumidores afectados en los procesos colectivos", en Gómez Colomer, J.L., Barona Vilar, S., Calderón Cuadrado, M.P. (coord.): "El Derecho Procesal Español del Siglo XX a golpe de tango, Juan Montero Aroca (Liber Amicorum, en homenaje y para celebrar su LXX cumpleaños)”. Ed.: Tirant lo Blanch, Valencia 2013.
}

${ }^{70}$ S. no 33/2004, Sec. $5^{\text {a }}$ de la AP Sevilla de 22-01-2004 (TOL 351.596). 
afectados en los procesos iniciados mediante el ejercicio de una acción de cesación ${ }^{71}$.

Existe además en los procesos de consumo una intervención excepcional del Ministerio Fiscal, regulada en el mismo art. 15 de la LEC, que se producirá en concretos supuestos en que aparezca un interés social. Esta intervención se producirá cuando el propio órgano jurisdiccional considere que debe comunicar al Ministerio Fiscal la existencia del proceso al objeto de que valore su posible personación en el mismo ${ }^{72}$.

\section{E. COMPETENCI A}

Tal como establece el art. 52.3 de la LEC, el fuero territorial aplicable en los litigios derivados de acciones individuales de los consumidores procesos de consumo será a elección del consumidor, el tribunal de su domicilio o el tribunal correspondiente conforme a los arts. 50 y 51 .

En relación a la competencia territorial, la prohibición de sumisión expresa que establece el art. 54.1 de la LEC afecta a buena parte de las pretensiones que se pueden plantear, tal como desarrollamos en el punto siguiente.

En los procesos en que se ejercita una acción de cesación en defensa de los intereses, tanto colectivos como difusos de los consumidores y usuarios, se establece una regla específica en el art. $52.16^{a}$ de la LEC, entendiéndose competente el tribunal del lugar donde el demandado tenga un establecimiento y a falta de este, el de su domicilio; si careciere de domicilio en España, entrará en juego el criterio del lugar del domicilio del actor.

\footnotetext{
${ }^{71}$ Para el ejercicio de la acción de cesación en defensa de los intereses colectivos de los consumidores y usuarios, no resulta necesario efectuar el llamamiento a los perjudicados por el hecho dañoso, en tanto que el apartado 4 del citado artículo 15 de la Ley de Enjuiciamiento Civil señala: "Quedan exceptuados de lo dispuesto en los apartado anteriores los procesos iniciados mediante el ejercicio de una acción de cesación para la defensa de los intereses colectivos (llamamiento previo por el futuro demandante) y de los intereses difusos (llamamiento tras la admisión de la demanda por el secretario) de los consumidores y usuarios". Claro ejemplo de la postura jurisprudencial es el Auto no 13/2011 de la Sec. $28^{a}$ de la AP Madrid de 4-02-2011(TOL 5.316.564).

${ }^{72}$ Martínez García, E.: “Tutela de los Consumidores y Usuarios en la nueva Ley de Enjuiciamiento Civil, cit., pág. 146.
} 


\section{F. PROCEDI MI ENTO}

Los procesos de consumo, aunque su tramitación se realizará por los cauces del juicio verbal o del procedimiento ordinario dependiendo de la cuantía, tienen muchas peculiaridades procedimentales.

Se tramitarán por el juicio verbal, las demandas en que se ejercite la acción de cesación en defensa de los intereses colectivos y difusos de los consumidores y usuarios, tal como establece el art. 250.1 punto $12^{\circ}$, mientras que las demandas en que se ejerciten acciones relativas a condiciones generales de contratación se tramitarán por el juicio ordinario tal como establece el art. 249.1.5ㅇ.

La demanda de juicio verbal se puede presentar incluso por el propio consumidor, sin necesidad de abogado y procurador ${ }^{73}$, tal como establece el art. 23.2 de la LEC, si la cuantía que se reclama es inferior a 2.000 euros.

En estos casos, la presentación de la demanda, según el art.437.2 de la LEC podrá formular demanda sucinta que podrá realizarse mediante uno de los impresos normalizados que se encuentran a disposición de los ciudadanos en el decanato de los juzgados.

Por su parte, se tramitan por el juicio ordinario las demandas sobre competencia desleal, tal como prevé el art 249.1. 4으 de la LEC, salvo si se ejercita la acción de publicidad ilícita del art.18 de la $\mathrm{LCD}^{74}$, que deberá tramitarse en el procedimiento correspondiente en relación a la cuantía. También serán objeto de tramitación a través del juicio ordinario las demandas en que se ejerciten acciones sobre condiciones generales de contratación (art. 249.1 5o de la LEC).

En la práctica, el proceso que puede ser más beneficioso para tramitar una demanda de consumo de un consumidor individual es el juicio verbal, que puede permitir ver satisfechos sus intereses en menor tiempo, estando en ambos procesos igualmente garantizada la práctica y desarrollo de la prueba, de forma que en la contestación a la demanda, el consumidor puede aportar prueba pericial, solicitar

\footnotetext{
${ }^{73}$ Larrosa Amante, M.A.: “¿Es necesario un nuevo proceso específico para la protección de los intereses individuales de los consumidores?”. Revista de Jurisprudencia el Derecho nº 5, marzo 2006.

${ }^{74}$ De la LCD puede ejercitarse la acción de cesación, la declarativa de deslealtad, la de enriquecimiento injusto y la de resarcimiento.
} 
que sea el empresario o profesional demandado quien la aporte, o pedir la designación de un perito judicial.

Por el contrario, en los procesos en que se resuelven acciones colectivas, donde se puede ver reducido el coste al aportar una única prueba del defecto $o$ el daño de forma conjunta, es más recomendable el proceso ordinario por la existencia de la vista previa para entrar a valorar sobre la necesidad de prueba y argumentar sobre el particular, pudiendo incluso ser mayores las posibilidades de éxito.

Del análisis de las peculiaridades que encontramos en estos procesos, como desarrollaremos a lo largo de este trabajo, vemos que resulta necesaria la regulación de un procedimiento especial y exclusivo para tratar todas las cuestiones sobre consumidores, basado precisamente en sus especialidades y en las reglas específicas sobre la prueba que tratamos en los capítulos siguientes, de forma que ofrezcan solución a los problemas que se plantean en la práctica. 



\section{CAPÍtulo III. OBJeto DEL PROCESO: TIPOS DE PRETENSIONES}

Partiendo del art. 24 de la $\mathrm{CE}$, que reconoce la tutela judicial efectiva, tanto el TRLGDCU, como la Ley 7/1998, de 13 de abril, de Condiciones Generales de Contratación (en adelante LCGC) y la Ley 39/2002, de 28 de octubre, de transposición al ordenamiento jurídico español de diversas directivas comunitarias en materia de protección de los intereses de los consumidores y usuarios, ponen a disposición de los consumidores un elenco de lo que denominamos legalmente como "acciones" 75 dirigidas a obtener una tutela colectiva a través del ejercicio de una acción conjunta, como ya hemos indicado, que agrupa intereses de una serie de afectados y que se lleva a cabo sobre todo por las asociaciones de consumidores, además de otras acciones dirigidas a obtener una tutela individual ${ }^{76}$.

En realidad, la expresión que aparece en los textos legales como equiparada al concepto de pretensión, es el concepto de "acción", más concreto que el primero, puesto que define la petición sobre la cual la sentencia deberá resolver.

Entendemos por tanto que la pretensión es un concepto más amplio que abarca tanto la petición de inicio de la actividad jurisdiccional y su continuación, como la concreta acción que se ejercita.

Las pretensiones constituyen por tanto el objeto propio del proceso, entendiendo que se trata de la petición dirigida al órgano jurisdiccional, que a su vez comporta dos peticiones; una mediata de actuación de los órganos jurisdiccionales; $y$, otra inmediata, de obtener el derecho a la tutela.

Partiendo de las distintas formas de manifestación de la tutela jurisdiccional establecidas en el art. 5 de la LEC, son tres los tipos de pretensiones que los consumidores podrán plantear ante los

\footnotetext{
${ }^{75}$ De la Oliva Santos, A., en De la Oliva Santos, A., Díez Picazo, I., Vegas Torres, J.: Curso de Derecho Procesal Civil I. Parte General: "La acción y los Derechos Básicos de los justiciables”. Ed.: Universitaria Ramón Areces, Madrid 2012, pág. 126 a 131; Montero Aroca, J., en Montero Aroca, J, Montón Redondo, A., Gómez Colomer, J.L., Barona Vilar, S.: "Derecho Jurisdiccional II. Proceso Civil”, Ed.: Tirant lo Blanch, Valencia 2010, pág. 122 y 123.

${ }^{76}$ De León de Arce, A. en García García, L.M.: “Derechos de los consumidores y usuarios”, cit., Tomo II pág. 1219.
} 
tribunales: pretensiones de condena, mero declarativas, 0 de constitución, modificación o extinción de una relación jurídica.

Estas pretensiones pueden ser objeto de planteamiento conjunto por los afectados de un concreto acto; de hecho, tanto el TRLGDCU (art. 53), como la LCGC (art. 12), también la Ley 29/2009, de 30 de diciembre, de Competencia Desleal y de la publicidad para la mejora de la protección de los consumidores y usuarios (art. $32.12^{\text {a }}$ ), el Real Decreto Legislativo 1/2015, de 24 de julio, por el que se aprueba el Texto Refundido de la Ley de garantías y uso racional de los medicamentos y productos sanitarios (arts. 117 y 118) o el Real Decreto 8/2012, de 16 de marzo, de contratos de aprovechamiento por turno de bienes de uso turístico, de adquisición de productos vacacionales de larga duración, de reventa y de intercambio (art. 21), regulan una posible acción de cesación, que puede comportar la existencia de una pluralidad de pretensiones acumuladas en una misma demanda mediante un proceso colectivo que favorece tanto a los afectados como a la parte demandada ${ }^{77}$.

La posible acción colectiva prevista en el art. 11 de la LEC, a nuestro entender es el mecanismo procesal que mayor protección concede al consumidor, debido a que posibilita su acceso a la justicia, que por su elevado coste, de forma individual podría verse obstaculizado en muchas reclamaciones de reducida cuantía.

A su vez, es un mecanismo que abarata y agiliza la posición del demandado al ver acumuladas todas las pretensiones que se dirigen contra él, en un único proceso ${ }^{78}$.

Debido a las numerosas pretensiones que las leyes sectoriales contemplan y tratando de enfocar los tipos de acción de una forma práctica, los vamos a analizar de forma breve partiendo de los distintos ámbitos de derecho de consumo y de las distintas normas legales que los regulan.

\footnotetext{
${ }^{77}$ Gimeno Sendra, V.: "Derecho Procesal Civil. II. Los procesos especiales”. Ed.: Colex, Madrid 2014, pág. 473.

${ }^{78}$ García Gil, F.J.: "Suma de la Protección y defensa de los derechos de los consumidores”, Ed.: Tirant lo Blanch, Valencia 2007, pág. 749.
} 


\section{A. PRETENSI ONES MERO DECLARATI VAS}

Son aquellas reguladas en el C.c. y en el TRLGDCU en las que se pide la mera declaración de la existencia o inexistencia de un derecho o situación jurídica, de forma que la sentencia estimatoria agota su fuerza al producir la cosa juzgada sin que llegue a crearse el título ejecutivo ${ }^{79}$. Entre ellas, podemos aludir a las siguientes:

\section{a. Acción de resolución del contrato}

El consumidor tiene derecho a la reparación del producto, su sustitución, rebaja del precio o resolución del contrato.

Como norma general, procederá la reparación o sustitución, salvo que una de estas opciones sea imposible o desproporcionada, siendo la rebaja del precio o la resolución del contrato peticiones secundarias en caso de resultar desproporcionada la reparación o sustitución en un plazo razonable o esta produzca inconvenientes mayores para el consumidor, tal como establece el art. 121 TRLGDCU ${ }^{80}$.

Por ello, el derecho a resolver el contrato no procede cuando la falta de conformidad es de escasa importancia (art. 121 citado), debiendo ser el propio consumidor el que inste la rescisión del contrato según el art. 1124 del C.c., en todos los casos en que el incumplimiento pueda dar lugar a su resolución.

\section{b. De nulidad del contrato}

Se podrá instar la acción de nulidad del contrato regulada en el art. 83.2 del TRLGDCU, en los casos en que exista una cláusula que, por abusiva, pueda ser considerada nula y su anulación no permita la continuación del contrato con el resto del clausulado.

Serán consideradas abusivas las cláusulas que no reúnan las condiciones expresadas y causen perjuicio al consumidor por existir un desequilibrio importante en los derechos y obligaciones de las partes que deriven del contrato ${ }^{81}$.

\footnotetext{
${ }^{79}$ Montero Aroca, J., Gómez Colomer, J.L., Barona Vilar, S., Calderón Cuadrado, M.P.: "Derecho Jurisdiccional II”, cit., pág. 152.

${ }^{80}$ Busto Lago, J.M., (coord.) en Álvarez Lata, N. y Peña López, J.: “Reclamaciones de consumo. Derecho de consumo desde la perspectiva del Consumidor”, cit., pág. 777.

${ }^{81}$ Pipaón Pulido, J.G.: “Derechos de los consumidores y usuarios”, cit., pág. 174.
} 
En general, son abusivas las cláusulas que vinculen el contrato a la voluntad del empresario, las que limiten los derechos del consumidor y usuario, las que determinen falta de reciprocidad, las que exijan al consumidor garantías excesivas o le impongan la carga de la prueba, las que sean desproporcionadas en relación al perfeccionamiento del contrato y su ejecución y, las que contravengan las reglas de competencia y derecho aplicable ${ }^{82}$.

\section{B. PRETENSI ONES DE CONDENA.}

Entendemos como acciones de condena aquellas en que la satisfacción del actor no se produce con la mera declaración de nulidad de las condiciones generales, ni con la condena al demandado a que cese en su utilización o recomendación, sino que se pretende la condena a realizar determinada prestación, consistente en la devolución de las cantidades cobradas y la indemnización ${ }^{83}$.

Analizando las pretensiones de condena recogidas tanto en el TRLGDCU como en el C.c., podemos hacer alusión a las siguientes:

\section{a. La pretensión de condena a la indemnización de daños y perjuicios.}

El derecho a la indemnización encuentra su regulación en los arts. 114 a 124 del TRLGDCU, cuyo fundamento se encuentra en los arts. 1101 a 1107 del C.c., que establecen los criterios de imputación de la responsabilidad, estando su ejercicio condicionado a la producción de un incumplimiento por parte del vendedor, siendo su finalidad compensar la lesión patrimonial producida al consumidor ${ }^{84}$. Los sujetos protegidos lo son todos en general, y así lo establece el art. 128 del TRLGDCU, distinguiendo, tanto este artículo, como el 129 , entre daños personales o materiales.

Concretamente, el art. 128 apdo. 20 del TRLGDCU regula la reparación del daño, estableciendo el derecho a la indemnización de daños y perjuicios, incluidos los daños morales como consecuencia de la responsabilidad contractual. Los daños resarcibles son los que

\footnotetext{
${ }^{82}$ Reyes López, M.J.: “Manual de Derecho Privado de Consumo”, cit., pág. 316 a 348.

${ }^{83}$ Montero Aroca, J., Gómez Colomer, J.L., Barona Vilar, S., Calderón Cuadrado, M.P.: "Derecho Jurisdiccional II”. Ed.: Tirant lo Blanch, ed. 23a, Valencia 2015, pág. 160; Martínez García, E.: “Tutela de los Consumidores y Usuarios en la nueva Ley de Enjuiciamiento Civil”, cit., pág. 286.

${ }^{84}$ García Gil, F.J.: “Suma de la Protección y defensa de los derechos de los consumidores”, cit., pág. 131.
} 
provoque al consumidor el incumplimiento imputable al productor, incluyendo tanto el daño emergente como el lucro cesante, y en algunos supuestos puntuales muy concretos incluso es posible obtener el resarcimiento del daño moral ${ }^{85}$.

Respecto a daños personales, pueden ser objeto de la acción de indemnización tanto la muerte, como el dolor físico, las secuelas, incluso los perjuicios estéticos, así como los daños patrimoniales derivados de los gastos de asistencia médica, sanitaria, farmacéutica y de entierro, pudiendo incluso dar lugar a indemnizar el lucro cesante, todo ello en los términos establecidos en los artículos referidos.

Existe un límite establecido como indemnización de los daños personales en el art. 141 del TRLGDCU de 63.106.270,96 euros, debiendo el sujeto responsable aportar como elementos probatorios los datos de hecho que permitan presumir que no ha participado en la producción del defecto ${ }^{86}$.

En relación a los daños materiales, serán indemnizados siempre que afecten a bienes o servicios destinados al uso o consumo privados y hayan sido utilizados de esta forma por el perjudicado, no siendo indemnizables los daños materiales del propio producto.

Existen unos daños excluidos del ámbito de protección del TRLGDCU, son aquellos causados por accidentes nucleares, la muerte o lesiones corporales ${ }^{87}$, así como los daños materiales que no se hallen sujetos a consumo privado.

El fabricante, de acreditarse la existencia del daño y el origen de la producción del mismo, siempre deberá responder, puesto que el propio TRLGDCU en su art. 130 establece que cualquier pacto de exoneración de responsabilidad, carecerá de eficacia.

\footnotetext{
85 Busto Lago, J.M., (coord.) en Álvarez Lata, N. y Peña López, J.: “Reclamaciones de consumo. Derecho de consumo desde la perspectiva del Consumidor”, cit., pág. 777.

${ }^{86}$ Lasarte Álvarez, C.: “Manual Sobre Protección de los Consumidores y Usuarios”. Ed.: Dykinson, Madrid 2010, pág. 293.

${ }^{87}$ Deben ser resarcidos a cualquier persona, independientemente de que sea consumidor o no.
} 


\section{b. Pretensiones de condena dineraria de carácter colectivo.}

Su presupuesto de prosperabilidad, al igual que en las pretensiones individuales, se basa en la existencia de un perjuicio patrimonial, y en la concurrencia de un elemento intencional que comporta la existencia de dolo, culpa o mala fe en la conducta ilícita que ha ocasionado los daños y perjuicios que se pretenden reclamar.

\section{c. Pretensiones de condena inspiradas en las acciones reguladas en el C.c.}

Se trata de acciones como la de responsabilidad del fabricante por daños causados por responsabilidad del productor, que en el supuesto de los productos defectuosos se encuentran recogidas tanto en el TRLGDCU como en Real Decreto Legislativo 1/2015, de 24 de julio, por el que se aprueba el Texto Refundido de la Ley de garantías y uso racional de los medicamentos y productos sanitarios.

Tienen su fuente de inspiración en los preceptos relativos a la responsabilidad extracontractual (art. 1902 y ss.), y en los arts. 1101 y ss sobre la responsabilidad en materia contractual ${ }^{88}$.

La regulación de la responsabilidad del productor o fabricante establecida en el TRLGDCU en sentido amplio se complementa con el sistema más restrictivo del C.c. que establece la responsabilidad del vendedor siempre que exista culpa, debiendo probar que su actuación fue diligente o bien que intervino el caso fortuito o la fuerza mayor.

Existen muchos supuestos de pretensiones de condena en cuestiones sobre productos defectuosos, según el concepto desarrollado por el TRLGDCU en su art. 136, que define el producto como cualquier bien mueble, aun cuando se encuentre incorporado a un bien inmueble, y también en el art. 137, que entiende como defectuoso cualquier producto que no ofrezca la seguridad que cabría esperar, teniendo en cuenta todas las circunstancias ${ }^{89}$.

Por su parte, en relación a los productos defectuosos, las acciones que regula el C.c. son la edilicia (redhibitoria y estimatoria y quanti minoris), la de responsabilidad por dolo del vendedor, la de resolución y resarcimiento en caso de incumplimiento del vendedor

\footnotetext{
${ }^{88}$ Vázquez Barros, S.: “Memento Practico de consumo 2010-2011”, cit., pág. 148; Lasarte Álvarez, C.: “Manual Sobre Protección de los Consumidores y Usuario, cit., pág. 285.

${ }^{89}$ Vázquez Barros, S.: “Memento Practico de consumo 2010-2011”, cit., pág. 150.
} 
por inadecuación absoluta del objeto ( por infracción de los arts. 1101 y 1124 C.c.) ${ }^{90}$, la de resarcimiento por el defectuoso o parcial cumplimiento de la obligación, al producirse la entrega en condiciones distintas de las debidas y exigibles ( arts. 1091, 1101, 1124 y 1258 C.c.), la establecida en el art. 1484 C.c. sobre la obligación de saneamiento del vendedor, la que nace de los vicios y defectos constructivos que se ejercita en base al art. 1591 C.C. ${ }^{91}$ (también regulada en el art. 17 de la Ley 38/1999, de 5 de noviembre, de Ordenación de la Edificación, en adelante LOE), por vicios o defectos en la construcción ${ }^{92}$.

\section{d. Por vicios o defectos en la construcción de vivienda.}

Los defectos constructivos se regulan tanto en el TRLGDCU, como en el propio C.c., estableciendo su art. 1591 la obligación del contratista y arquitecto de responder de los vicios de la construcción.

Por lo que respecta a la regulación en el TRLGDCU de la acción por defectos en la construcción (art. 149), se somete al régimen especial de responsabilidad del art. 148 a los que construyan o comercialicen viviendas en el marco de una actividad empresarial por los daños causados por defectos en las mismas no cubiertos por el régimen legal específico.

\section{e. Acciones por vicios o defectos en la compraventa internacional.}

Además de la normativa estatal de aplicación a los contratos nacionales, existen disposiciones de aplicación en las compraventas internacionales, cuya regulación se encuentra en el Convención de Naciones Unidas sobre contratos de compraventa internacional de mercaderías de 1974, enmendada mediante Protocolo de 1980.

La Sección III del Convenio regula Derechos y acciones en caso de incumplimiento del contrato por el vendedor, estando concretadas aquellas que corresponden al comprador en el artículo 45, 46 y 47,

\footnotetext{
${ }^{90}$ De León de Arce, A., en García García, L.M. (coord.): “Derechos de los consumidores y usuarios”. Editorial Tirant lo Blanch 2006, cit., pág. 1271.

${ }^{91}$ López Hernández, C.V.: “La protección frente a los gravámenes ocultos”, Epígrafe I, pág. 42 a 46. Ed.: Tirant lo Blanch, Valencia 2003.

92 Puche Ramos, A.: “La Acción por incumplimiento contractual en reclamación de vicios o defectos en la construcción”. Ed.: El Derecho Editores, Revista de Jurisprudencia, pág. 2.
} 
tratándose todas ellas de pretensiones de condena tanto por el incumplimiento con la consiguiente reparación e indemnización.

\section{PRETENSI ONES CONSTITUTIVAS}

Pertenecen a este grupo todas las acciones derivadas de la falta de conformidad del consumidor con el producto o servicio, debida a cualquier cuestión. En estas pretensiones la petición se dirige a obtener la creación, modificación o extinción de la relación jurídica, es decir, a lograr un cambio respecto de la situación existente.

En este ámbito nos encontramos con uno de los conceptos fundamentales de este trabajo, objeto de desarrollo en los capítulos siguientes, como es el establecimiento de presunciones. Nos referimos en este apartado a la que establece el art. 116 del TRLGDCU, se trata de una presunción "iuris tantum" sobre la conformidad de los productos con el contrato, expresando, que salvo prueba en contrario, se entenderá que los productos reúnen las condiciones pactadas, siempre que se ajusten a la descripción realizada, sean aptos para el uso al que se destinen, y presenten la calidad y prestaciones habituales de un producto de esas características.

Los requisitos que deben darse para que se produzca una falta de conformidad son similares a los que exige el C.C., aunque el criterio del TRLGDCU sobre las exigencias necesarias es menor, no siendo imprescindible que se vea afectada la utilidad del bien de consumo ni que el defecto tenga una determinada entidad. Por ello, el vendedor responde por la falta de adecuación del contenido al contrato sin ser necesaria la existencia de defecto en el producto.

De este modo, el vendedor será responsable ante el consumidor de cualquier falta de conformidad del producto que exista en el momento de la entrega en relación con el contrato, teniendo un plazo de dos años para denunciar la falta ${ }^{93}$.

Dentro de las posibles acciones que puede ejercer el consumidor se encuentra la de reparación o sustitución del producto, recogida tanto en el art. 119.1 del TRLGDCU, si se dirige contra el vendedor, como en el art. 124 del mismo cuerpo legal donde se prevé la posibilidad de dirigirla directamente contra el productor, siendo

\footnotetext{
${ }^{93}$ López Hernández, C.V.: “La protección frente a los gravámenes ocultos”, cit., pág. 40.
} 
condición indispensable haber informado al vendedor de la falta de conformidad en el plazo de dos meses desde que tuvo conocimiento de ella, y comunicarle además la opción de reparación o sustitución elegida, siempre y cuando sea proporcionada y de posible ejecución.

Los plazos y condiciones de ejercicio serán los mismos que para la acción que hubiera ejercitado contra el vendedor, siendo responsable el productor cuando la falta de conformidad se refiera al origen, identidad o idoneidad del producto según su finalidad.

Dentro de este tipo de procesos encontraremos, como analizaremos a lo largo de este trabajo, cuestiones en relación a la prueba sobre las advertencias realizadas por el vendedor sobre determinadas carencias del producto, la efectividad de las mismas, y otras cuestiones que pueden afectar a la conformidad. Todo ello ha sido interpretado de forma restrictiva por la jurisprudencia, que como regla general, no ha concedido valor probatorio a la declaración de conformidad emitida por el fabricante, entendiendo que el consumidor desconocía el estado del producto y sus posibles defectos.

\section{ACCIONES CONTEMPLADAS EN LA LEY DE CONDI CI ONES GENERALES DE CONTRATACI ÓN}

Adentrándonos en el estudio de las acciones contempladas en el art. 12 de la LCGC, son también de varios tipos: la mero declarativa, la acción de cesación, dirigida a impedir la utilización de las condiciones generales ${ }^{94}$ y la de retractación. Todas ellas se reconocen tanto al consumidor individual, como a las entidades legitimadas para ello.

\section{a. Mero declarativa}

Regulada en el apdo. 4 del art. 12, se dirige a obtener una sentencia que reconozca la existencia o inexistencia de una relación jurídica, o bien su nulidad, si reúne los condicionantes previstos para

\footnotetext{
${ }^{94}$ En la S. no 71/2006, Sec. $11^{\text {a }}$ de la AP Madrid de 21-02-2006 (TOL 949.772) se ejercita la acción de cesación de las condiciones generales de contratación, interesando la declaración de nulidad de ciertas cláusulas, al amparo del artículo 12 de la LCGC, siendo su presupuesto necesario el de encontrarse la parte demandante en alguno de los supuestos del artículo 16 del mismo cuerpo legal, en cuyo apartado 3 prevé como accionantes a las asociaciones de consumidores y usuarios legalmente constituidas que tengan estatutariamente encomendada la defensa de éstos.
} 
que esta se produzca en relación a cualquier negocio jurídico ${ }^{95}$. Su principal característica es la imprescriptibilidad.

Esta acción es la única utilizada por parte de las asociaciones profesionales y las Cámaras de Comercio y procede (art 12.4) contra cualquier profesional que utilice condiciones generales de contratación.

El objetivo de esta acción se dirige a obtener una sentencia que reconozca la nulidad de alguna de sus cláusulas que a su vez ordene su inscripción en el Registro de Condiciones Generales de Contratación regulado mediante Real Decreto 1828/1999, de 3 de diciembre, cuando esta proceda conforme al art $11.2^{96}$.

\section{b. De condena}

\section{Acción de cesación.}

La acción de cesación se integra dentro de las acciones declarativas de condena a hacer, no hacer o dar; es la más importante en derecho de consumo, regulada tanto en la LCGC referida (art. 12), como en la Ley 39/2002 (art. 16 bis), en el TRLGDCU (art 53) y también en la LCD (art. 32.1) ${ }^{97}$.

Esta acción tiene como finalidad obtener un pronunciamiento judicial por el que se condene al demandado a eliminar las cláusulas que se reputen nulas de sus condiciones generales, y a abstenerse de utilizarlas en lo sucesivo ${ }^{98}$.

Junto a la cesación, tal como establece el art. 12.1 de la LCGC, es necesario que el tribunal se pronuncie expresamente sobre su nulidad, aunque no lo pida el actor, condenando además a abstenerse

\footnotetext{
${ }^{95}$ Martínez García, E.: "Tutela de los Consumidores y Usuarios en la nueva Ley de Enjuiciamiento Civil”, cit., pág. 279; Gimeno Sendra, V., Morenilla Allard, P.: "Derecho Procesal Civil II. Los procesos especiales”, cit., pág. 401.

${ }^{96}$ De León de Arce, A. en García García, L.M. (artículo de Bujosa Vadell, L.M.): "Derechos de los Consumidores y Usuarios”, cit. tomo II pág. 1793.

${ }^{97}$ Cabañas García, J.C.: "Los procesos civiles sobre consumidores y usuarios y de control de las cláusulas generales de los contratos”. Ed.: Tecnos, Madrid, pág. 111.

${ }^{98}$ Álvarez Lata, N.: "Invalidez e Ineficacia en el Derecho Contractual de Consumo Español. Análisis de los supuestos típicos de ineficacia en los contratos con consumidores”, cit., pág. 139.
} 
de utilizar las condiciones generales en el futuro y concretando la parte del contrato que debe mantenerse como válida y eficaz ${ }^{99}$.

\section{De retractación}

Es una acción que procede contra cualquier profesional que recomiende cláusulas nulas. Se regula también en el art 12.1 de la LCGC, y tiene por objeto una sentencia que imponga al demandado el deber de retractarse de la recomendación de utilizar condiciones generales que se consideren nulas, y se abstenga de su uso o recomendación en el futuro ${ }^{100}$.

Puede ocurrir que la misma persona que ha recomendado la utilización de condiciones generales nulas sea quien las ha incorporado a alguno de sus contratos o también, que aquel que haya realizado la recomendación sea persona distinta del que las ha utilizado $^{101}$. En ese caso podemos encontrarnos ante una pluralidad de partes con condenas concretas.

\section{De restitución e indemnización de daños y perjuicios.}

La acción de restitución se podrá acumular como accesoria a la acción de cesación, tal como establece el art. 12.2 párrafo 2o de la LCGC ${ }^{102}$. En cuanto a la acción de indemnización está implícita cuando se haya producido un daño y se podrá instar cuando exista una declaración de la cesación mediante sentencia, debiendo concretarse su importe en ejecución de sentencia ${ }^{103}$.

\section{E. ACCI ONES EN MATERI A DE COMPETENCI A DESLEAL}

La Directiva 2005/29/CE del Parlamento Europeo y del Consejo, de 11 de mayo de 2005, relativa a las prácticas desleales, extiende al control de todas las fases de las prácticas comerciales que se producen en la relación entre el empresario y el consumidor, incluido

\footnotetext{
99 García Gil, F.J.: “Suma de la Protección y defensa de los derechos de los consumidores”, cit., pág. 489.

${ }^{100}$ García Vila, M: “Las condiciones generales de la contratación: aspectos procesales”, pág. 111. Ed.: práctica de derecho, Valencia 2006; Gascón Inchausti, F.: “Tutela Judicial de los Consumidores y Transacciones Colectivas”, cit., pág. 103.

${ }^{101}$ De León de Arce, A. en García García, L.M. (art. de Bujosa Vadell, L.M.): “Derechos de los Consumidores y Usuarios”, cit., tomo II pág. 1793.

102 Gimeno Sendra, V.: “Derecho Procesal Civil II. Los procesos especiales”, cit., pág. 407.

103 Martínez García, E.: “Tutela de los Consumidores y Usuarios en la nueva Ley de Enjuiciamiento Civil”, cit., pág. 276.
} 
el primer contacto, pudiendo los estados miembros introducir disposiciones más estrictas para garantizar un mayor nivel de protección de los derechos contractuales individuales de los consumidores ${ }^{104}$.

El objetivo de la Directiva, según el Considerando 23, es eliminar los obstáculos de funcionamiento del mercado interior que constituyen las diferentes leyes nacionales sobre prácticas comerciales ${ }^{105}$.

La transposición al ordenamiento jurídico español de la Directiva aludida se produce de forma extemporánea a través de La Ley $29 / 2009$, de 30 de diciembre, de competencia desleal ${ }^{106}$, puesto que debía haberse realizado antes del 12 de junio de 2007. Su finalidad es la protección a los consumidores y el funcionamiento del mercado.

Las acciones que se regulan en la LCD se contemplan también con carácter general en el art. 60.2 TRLGDCU del Libro II de «Contratos y Garantías» ${ }^{107}$.

Son varias las acciones que se pueden interponer en materia de competencia desleal ${ }^{108}$ :

\section{a. Mero declarativas}

Como mero declarativa encontramos la enumerada en primer lugar en el art. 32, la acción declarativa de deslealtad (art. 32.1 1aㅡ), que requiere la existencia de una perturbación y que esta persista 0 , en el caso de que no continuara, existiera la necesidad de que no se repita.

\footnotetext{
${ }^{104}$ Camacho Pereira, C.: "La Protección del Consumidor frente al mensaje publicitario. Integración de la publicidad en el contrato”. Ed.: Aranzadi, S.A., Pamplona 2012, pág. 83.

${ }^{105}$ Barona Vilar, S.: “Competencia Desleal. Tutela jurisdiccional (especialmente proceso civil) y extra jurisdiccional. Doctrina legislación y jurisprudencia”. Tomo I. Consideraciones generales y objeto del proceso civil, cit., pág. 125; Gimeno Sendra, V.: "Derecho Procesal Civil II. Los procesos especiales", cit., pág. 384 a 390.

${ }^{106}$ Pérez Mosteiro, A.M. en Boyano Adánez, U.C. (coord.): "La reforma de la Ley de Competencia Desleal”, Ed.: Difusión Jurídica y Temas de Actualidad, S.A. Madrid 2011, pág. 89.

${ }^{107}$ Camacho Pereira, C.: "La Protección del Consumidor frente al mensaje publicitario. Integración de la publicidad en el contrato”, cit. pág. 117.

${ }^{108} \mathrm{El}$ art. 32 de la Ley 29/2009, de 30 de diciembre, de competencia desleal y publicidad regula las acciones a disposición del perjudicado.
} 


\section{b. De condena.}

\section{Acción de cesación.}

Contemplada en el art. $32.122^{a}$, sus presupuestos son la necesidad de protección de los intereses, tanto el general, como el de aquellos que se ven afectados por actos de confusión en la utilización de una marca, o por la realización de prácticas anticompetitivas ${ }^{109}$.

Se excluye del ejercicio de esta acción la existencia del daño real debido a negligencia.

\section{La acción de prohibición}

Junto a la acción de cesación se contempla el posible ejercicio de la acción de prohibición, dirigida a eliminar los efectos de la conducta y de la perturbación que origina el acto, y también a prohibir la puesta en práctica la conducta desleal, en caso de que todavía no se haya iniciado.

\section{La acción de remoción y rectificación.}

Regulada en el art. 32.1 4a , exige concretar lo que se pide y las medidas necesarias a adoptar para su eliminación.

\section{La acción de resarcimiento de los daños y perjuicios}

Pretende la reparación de los perjuicios ocasionados por la conducta desleal (art. $32.15^{a}$ ), cuando haya intervenido dolo o culpa del agente.

Concretamente, la acción resarcitoria tiene un carácter autónomo respecto al resto de pretensiones ejercitables, aunque se insta junto a otras acciones, como la que debe solicitarse en primer lugar, que es la declaración, utilizando además la acción de cesación, incluso la de remoción o rectificación, o también la mero declarativa ${ }^{110}$.

\footnotetext{
${ }^{109}$ Camacho Pereira, C.: "La Protección del Consumidor frente al mensaje publicitario. Integración de la publicidad en el contrato”, cit., pág. 193; Gimeno Sendra, V.: "Derecho Procesal Civil II. Los procesos especiales", cit., pág. 352 a 354; Gimeno Sendra, V.: "Derecho Procesal Civil II. Los procesos especiales”, cit., pág. 395.

${ }^{110}$ Vilata Menadas, S. en Ruiz Peris, J.I. (Dir.): “La nueva ley de competencia desleal. Modificaciones en materia de legitimación y procedimiento”. Ed.: Tirant lo Blanch, Valencia 2010, pág. 177 a 192.
} 


\section{La acción de enriquecimiento injusto del art. 32.16 a.}

Procedente cuando se lesione la posición jurídica de un derecho de exclusiva u otro de análogo contenido económico, pudiendo ejercitarse por el titular de la posición jurídica violada.

\section{F. ACCI ONES EN MATERI A DE PUBLI CI DAD I LÍ CI TA}

Las acciones que anteriormente recogía el art. 6 apdo. 1o de la LGP se encuentran ahora incluidas en la LCD, ampliando algunos supuestos de protección de determinados derechos concretos ${ }^{111}$ y extendiendo su ámbito de protección tanto a la vía civil como penal.

La actual regulación incluye acciones de publicidad en cuestiones sobre publicidad discriminatoria o vejatoria de la imagen de la mujer, bien mediante una imagen asociada a comportamientos estereotipados que vulneren nuestro ordenamiento jurídico, también en cuestiones sobre publicidad dirigida a menores, publicidad subliminal, si se infringe la normativa reguladora de determinados productos, bienes o actividades así como en los supuestos en que la publicidad resulte engañosa, agresiva o desleal.

\section{G. ACCI ONES CONTEMPLADAS EN LA LEY DE MARCAS}

Por su parte la Ley $17 / 2001$, de 7 de diciembre, de Marcas regula los signos distintivos que puede utilizar un empresario en el mercado para que los consumidores conozcan sus productos ${ }^{112}$.

En ella existen también varios tipos de acciones ${ }^{113}$ :

\section{a. Mero declarativas:}

Se trata de acciones entabladas por el titular de la marca frente a la conducta de un tercero que perjudica su derecho. Entre ellas encontramos las siguientes:

Corresponde al Epígrafe Cap. VIII- La Nueva Ley de Competencia Desleal. Modificaciones en materia de legitimación y procedimiento.

${ }^{111}$ Camacho Pereira, C.: "La Protección del Consumidor frente al mensaje publicitario. Integración de la publicidad en el contrato”, cit. pág. 92 y ss; Vázquez Barros,S: “Memento Práctico Francis Lefebvre”, Consumo 2010-2011, cit., pág. 572.

112 El art. 25 de la Ley 17/2001, de 7 de diciembre, de marcas regula el restablecimiento del derecho.

${ }^{113}$ Gimeno Sendra, V.: “Derecho Procesal Civil II. Los procesos especiales”, cit., pág. 352 a 354. 
La acción de nulidad de una marca y la cancelación del asiento registral (art. 51 LM), en los casos en que se haya visto infringida una de las normas imperativas que establece el art. 3 apdo. 1 y 2 , y el art. 5 LM.

La reivindicatoria de la propiedad de una marca (art. 2.2 LM), que comporta una pretensión positiva en aras a reivindicar el dominio de una marca.

\section{b. De condena, recogidas en el art. $41 \mathrm{LM}$ :}

Este tipo de pretensión tiene como finalidad principal proteger el derecho de una marca registrada frente a su infracción (art. 34 LM). violen su derecho.

1. De cesación (art. 41.1 a) LM) de los actos que

2. La adopción de medidas para que no prosiga su violación (art. 41.1 c) LM).

3. La destrucción o cesión con fines humanitarios de los productos identificados con la marca (art. 41.1 d) LM).

4. La publicación de la sentencia a costa del condenado (art. 41.1 e) LM).

5. La acción de responsabilidad objetiva (art. 43.5 LM) en base a la cual, el titular de una marca que haya visto reconocida judicialmente su violación tendrá derecho a la indemnización de daños y perjuicios concretados sobre el $1 \%$ de su cifra de negocios, sin que sea necesario practicar prueba en este sentido y sin que por tanto el tribunal tenga que razonar prueba alguna para alcanzar su decisión condenatoria.

6. La indemnización de daños y perjuicios (art. 41.1 b) LM), que alcanza tanto al lucro cesante como al daño emergente (art. 43 LM), concretando incluso el propio artículo, en su apdo. 2 los criterios de cuantificación.

Esta acción difiere de la responsabilidad objetiva en la concreción de la cuantía a solicitar como indemnización de daños y perjuicios, puesto que el perjudicado podrá optar por la acción de responsabilidad objetiva, cuya cuantificación se encuentra determinada, o bien, instar la acción de indemnización, donde el 
importe reclamado puede haberse obtenido en base a criterios distintos.

\section{c. Constitutivas:}

Reguladas en el art. 34.2 y 3 LM se dirigen a obtener la anulación o la prohibición del uso de una marca, fundamentando la pretensión en el propio derecho que se ve perturbado, y concretando el motivo de la pretensión en los signos distintivos de la marca y en sus semejanzas, cuya valoración debe producirse por el propio juzgador ${ }^{114}$.

\section{H. POSI BLE ACUMULACIÓN DE ACCIONES}

En derecho de consumo nos encontramos en supuestos de acumulación de todas las acciones que pueda ejercitar el consumidor contra el demandado, siempre que se respeten los requisitos establecidos en el art. 73.1.2 LEC, es decir, que no sean incompatibles entre sí, y se den los presupuestos procesales de jurisdicción y de competencia del tribunal, así como de unidad de procedimiento ${ }^{115}$.

Además, cabe también la acumulación de acciones por pluralidad de partes, es decir, acciones que provengan de diferentes títulos cuya única conexión sea la coincidencia del demandado. Estas se pueden ejercitar de forma conjunta por todos los afectados, por una asociación que les represente y también, como hemos visto al analizar la legitimación, por un grupo que represente intereses difusos de una pluralidad de actores no determinada.

La condición para que la acumulación sea admitida se basa en la concurrencia de los presupuestos procesales de admisibilidad del art. 73 de la LEC, salvo que fueran incompatibles entre sí.

También el art. 12.2 LCGC establece la posible acumulación de la acción de cesación, la acción accesoria de devolución de lo indebidamente cobrado y de indemnización de daños y perjuicios ${ }^{116}$.

\footnotetext{
${ }^{114}$ Gimeno Sendra, V.: “Derecho Procesal Civil II. Los procesos especiales”, cit., pág. 354.

${ }^{115}$ Lara González, R., Echaide Izquierdo, J.M.: “Consumo y Derecho”. Ed.: ESIC Editorial, Madrid 2007, pág. 340.

${ }^{116}$ González Cano, M.I.: "La tutela colectiva de consumidores y usuarios en el proceso civil”, cit., pág. 12.
} 


\section{CAPÍTULO IV. LA SOLUCIÓN EXTRAJ UDICIAL DE LITIGIOS DE CONSUMO}

Aunque acudir a las vías alternativas de solución de conflictos en realidad es práctica habitual en derecho de consumo, tan solo vamos a dar unas pinceladas, por ser otro el motivo de este trabajo.

El impulso de las técnicas alternativas de resolución de conflictos, los ADR (mecanismos para resolver disputas al margen de los tribunales, Alternative Disputes Resolutions) ha venido propiciado desde los orígenes de la Unión Europea (ya existe referencia a ellos en el Convenio Europeo de Protección de los Derechos Humanos de Roma de 4 de noviembre de 1950), generalizándose a partir de ese momento un movimiento en defensa del acceso universal a la justicia ${ }^{117}$, y plasmándose a través del Libro Verde sobre las modalidades alternativas de resolución de conflictos en materia civil y mercantil de 19 de abril de 2002.

Son varios los sistemas de ADR, siendo la clasificación más habitual basada en la función desempeñada por el tercero neutral que interviene en la gestión del conflicto. Se trata en su mayoría de métodos autocompositivos, como la conciliación y la negociación por ser las propias partes quienes alcanzan el acuerdo, a excepción de la mediación y el arbitraje, que se califican de métodos heterocompositivos.

\section{A. LA MEDI ACIÓN}

La aparición de la mediación en el ámbito de consumo deriva de la Recomendaciones 98/257/CE, de 30 de marzo y 2001/310/CE, de 4 de abril de 2001, de la Comisión Europea, sobre los principios aplicables por los órganos responsables de la resolución consensuada de litigios en materia de consumo.

El esfuerzo de la Unión Europea por regular de forma eficaz estos sistemas, se concreta también en el denominado Libro Verde sobre las medidas alternativas de solución de conflictos en el ámbito civil y mercantil, COM/2002/0196, en la Directiva 2008/52/CE del

\footnotetext{
117 Gómez Colomer, J.L. en Montero Aroca, J, Montón Redondo, A., Gómez Colomer, J.L., Barona Vilar, S.: "Derecho Jurisdiccional II. Proceso Civil", Ed.: Tirant lo Blanch, Valencia 2015, pág. 38; Barona Vilar, S.: "Arbitraje y justicia en el S. XXI". Ed.: Thomson Civitas, Pamplona 2007, págs. 25 a 28; Blanco García, A.I.: "La tutela del cliente bancario y las ADR: la institución del Ombudsman". Ed.: Tirant Monografías, Valencia 2015, pág. 72.
} 
Parlamento Europeo y del Consejo de 21 de mayo de 2008, sobre ciertos aspectos de la mediación en asuntos civiles y mercantiles, así como en el Reglamento (UE) no 524/2013, del Parlamento Europeo y del Consejo, de 21 de mayo de 2013, sobre resolución de litigios en línea en materia de consumo.

Este Reglamento regula las vías extrajudiciales de solución a través de entidades de resolución alternativa que cumplen los requisitos de calidad mínimos exigidos que ya fueron concretados por la Directiva 2013/11/UE del Parlamento Europeo y del Consejo, de 21 de mayo de 2013, también relativa a resolución alternativa de litigios de consumo.

Las disposiciones del Reglamento, dirigidas a la creación de una plataforma "online" de la UE en la que se puedan dirimir conflictos transfronterizos y llevar a cabo la resolución de disputas en línea de consumidores y comerciantes para los asuntos relacionados con el comercio electrónico o prestación de servicios en la red, han entrado en vigor en el año 2016.

Esta plataforma ODR (Online Dispute Resolution) permite a consumidores y comerciantes presentar reclamaciones mediante un formulario electrónico disponible en todas las lenguas de la UE para todos los asuntos relacionados con el comercio electrónico o la prestación de servicios en internet.

Este instrumento precisa la garantía de los estados miembros sobre la disponibilidad a los consumidores de acceso a las entidades que hagan posible la resolución alternativa de litigios, para dar cobertura geográfica completa, nombrando además autoridades que se encarguen de recibir las solicitudes y supervisar el cumplimiento de las condiciones establecidas ${ }^{118}$.

También en España existe una regulación sobre la mediación mediante Ley 5/2012, de 26 de julio, de mediación en asuntos civiles y mercantiles (LMACM), desarrollada a través del Reglamento de Mediación, aprobado mediante Real Decreto 980/2013, de 13 de diciembre.

\footnotetext{
118 Esteban de la Rosa, F.: “Claves para la incorporación al Derecho español del nuevo Derecho europeo” en Palao Moreno (Editor): "Los instrumentos europeos en materia de conciliación, mediación y arbitraje de consumo”. Ed.: Tirant lo Blanch, Valencia 2016, pág. 100.
} 
En la Ley de mediación encontramos además la regulación de dos procedimientos simplificados de mediación; uno de ellos, desarrollado en el art. 24.1, relativo a actuaciones de mediación por medios electrónicos, donde existe un mediador, y otro procedimiento también electrónico, que se recoge en el apdo. 20 del mismo artículo, cuando la cuantía sea inferior a 600 euros, cuya labor se realiza por las mismas partes sin existencia de un mediador, donde una de ellas traslada sus propuestas a la otra ${ }^{119}$.

Este sistema se recoge también en el Real Decreto 231/2008, de 15 de febrero, por el que se regula el Sistema Arbitral de Consumo (RDAC), que por primera vez en la regulación de las vías alternativas de solución de conflictos, dedica su art. 38 expresamente a la mediación ${ }^{120}$, que se intentará antes del procedimiento arbitral en el ámbito de la Junta Arbitral de Consumo.

Los órganos de mediación, ante los que se plantea la misma, están compuestos por representantes de la Administración y de las Asociaciones de Consumidores y de Empresarios.

El proceso se inicia tras haber sido presentada por el consumidor la Hoja de Reclamaciones ante el establecimiento o la empresa. Si en el plazo de 10 días no ha obtenido respuesta o no ha sido satisfactoria a los intereses de la persona consumidora, podrá acudir a los servicios de Consumo de Consejería responsable en el ámbito de su Comunidad Autónoma, con sede en todas las provincias, donde atenderán la petición de mediación, o bien dirigirse a cualquiera de las asociaciones de consumidores existentes ${ }^{121}$.

\footnotetext{
119 Azcárraga Monzonis, C.: "Medios electrónicos en los sistemas extrajudiciales de resolución de conflictos", en Palao Moreno (Editor): "Los instrumentos europeos en materia de conciliación, mediación y arbitraje de consumo", cit. pág. 24; Daniel Franco, O.: “Mediación electrónica (e-Mediación)”. Diario La Ley no 8519 de 15 de abril de 2015, pág. 4.

120 Busto Lago, J.M., (coord.) en Álvarez Lata, N. y Peña López, J.: "Reclamaciones de consumo. Derecho de consumo desde la perspectiva del Consumidor", cit., pág. 375; Marcos Francisco, D.: "La mediación: ¿ fórmula para resolver los conflictos de consumo? en Gómez Colomer, J.L., Barona Vilar, S., Calderón Cuadrado, M.P. (coord.): "El Derecho Procesal Español del Siglo XX a golpe de tango, Juan Montero Aroca (Liber Amicorum, en homenaje y para celebrar su LXX cumpleaños)”, cit., pág. 588.

${ }^{121}$ González Pillado, E.: “Arbitraje y mediación en materia de consumo”, Ed.: Tecnos, Madrid 2012, pág. 213 a 245.
} 
Una vez el consumidor opta por la mediación, la Secretaría del órgano de mediación elegido notifica a la empresa reclamada para adherirse al proceso, la cual puede o no aceptar ${ }^{122}$.

Si la empresa no acepta la mediación, se pone fin al procedimiento y el consumidor puede iniciar el proceso judicial ordinario.

Si acepta la mediación, se da comienzo a la misma, exponiendo las partes sus argumentos y pretensiones. La finalización de la mediación puede ser con avenencia o sin ella, reflejando su resultado en un acta que firmarán ambas partes, pudiendo el consumidor acudir a los tribunales ordinarios de no haberse alcanzado el acuerdo.

El acta la firman las partes y el mediador, emitiendo una copia para cada uno de los firmantes. El acuerdo alcanzado tiene valor contractual, genera de derechos y obligaciones para ambas partes ${ }^{123}$.

Por lo que respecta al mediador, su actuación se somete a los principios de independencia, imparcialidad y neutralidad, siendo completamente distinta la función del árbitro dentro del proceso arbitral, a la del mediador, que sólo deberá emitir una propuesta de solución que las partes harán suya aceptándola o rechazándola sin ningún efecto vinculante y sin carácter ejecutivo.

Al mediador se le reconoce la posibilidad de ofrecer una propuesta de solución formal al objeto de que las partes la puedan aceptar o rechazar.

También se le reconoce como parte de sus funciones la posibilidad de abrir un expediente sancionador cuando exista una negativa u obstaculización al desarrollo de la mediación por parte del comerciante o la empresa ${ }^{124}$.

Aunque se trata de un procedimiento sencillo, rápido y práctico, por parte de las asociaciones de consumidores no se ha observado el

\footnotetext{
122 http://www.fundacionmediara.es/index.php/mediacion/mediacion-de-consumo, últ. consulta el 22 de enero de 2016.

${ }^{123}$ González Pillado, E.: “Arbitraje y mediación en materia de consumo”, cit., pág. 217.

124 Blanco Carrasco, M.: "La alternativa a la mediación en conflictos de consumo". Anuario Jurídico y Económico Escurialense no 42/2009, pág. 129 a 152; Espín Alba, I.: "Arbitraje y Mediación de consumo: a propósito de la Ley 16/2011, de 24 de junio, de contratos de crédito al consumo”. Boletín del Ministerio de Justicia no 2160, noviembre 2013, pág. 4.
} 
apoyo necesario a esta institución, cuya postura se ha tratado de justificar en una "clara desventaja" para el consumidor, aunque entendemos desacertada esta posición que evita situar a la mediación en el lugar que merece como medio alternativo de resolución de conflictos, privando a los consumidores de muchos acuerdos que se alcanzarían con éxito ${ }^{125}$.

\section{B. EL ARBI TRAJ E}

También regulado en la normativa europea anteriormente referida, es una vía que por sus características como la voluntariedad, la agilidad, rapidez, carencia de formalismos, carácter vinculante de la resolución que se adopta, su gratuidad y carácter institucional, resulta en la práctica mucho más eficaz que la judicial ${ }^{126}$.

El arbitraje de consumo, nacido en nuestro país por mandato constitucional ${ }^{127}$, es el sistema institucional de resolución de conflictos de carácter vinculante y ejecutivo que pretende ofrecer el acceso a una resolución justa mediante un mecanismo distinto, basado en la voluntariedad de las partes, puesto que sólo los consumidores o usuarios pueden instarlo ${ }^{128}$.

Dentro del concepto de arbitraje, existen dos sistemas diferenciados, dependiendo de la forma de tratar el conflicto: son el arbitraje de derecho, y el de equidad, pudiendo darse también el arbitraje internacional, cuya determinación vendrá por la propia relación comercial entre las partes ${ }^{129}$.

El arbitraje resulta atractivo para solucionar problemas de consumo por su reducido coste, al no precisar de abogado y procurador y por asumir incluso el coste de las pruebas cada una de las partes, aunque como veremos, es frecuente la solicitud de

\footnotetext{
${ }^{125}$ Barona Vilar, S.: "Integración de la mediación en el moderno concepto de "Acces To Justice": Luces y sombras en Europa, pág. 29. Editado por Indret Revista para el análisis del Derecho, nº 4, octubre 2014.

${ }^{126}$ Marcos Francisco, D.: "Consumidores, sujetos privilegiados en el nuevo paradigma de justicia civil y extraprocesales para su protección”, Revista InDret, núm. 5/2015, pág. 16.

${ }^{127}$ Maluquer de Motes Bernet, C.J.: "El acceso de los consumidores a la justicia". Art. publicado en la Revista Togas el 28 de julio de 2005, no 53.

${ }^{128}$ Busto Lago, J.M., (coord.) en Álvarez Lata, N. y Peña López, J.: "Reclamaciones de consumo. Derecho de consumo desde la perspectiva del Consumidor”, cit., págs. 383 a 400.

${ }^{129}$ De León de Arce, A. en García García, L.M. (artículo de Bujosa Vadell, L.M.): Derechos de los Consumidores y Usuarios”, cit., tomo II pág. 1799.
} 
pruebas de oficio que son costeadas por la propia junta arbitral de consumo o por la administración de que dependan.

Su regulación se encuentra en la Ley 60/2003, de 23 de diciembre, de Arbitraje (en adelante LA), y en el Real Decreto 231/2008, de 15 de febrero regulador del Sistema Arbitral de Consumo (RDAC).

Concretamente, la Disposición Adicional única de la LA extiende su ámbito de aplicación con carácter supletorio, al arbitraje de consumo a que se refiere el TRLGDCU, y el RDAC introduce en sus art. 33 su decisión en equidad, salvo, como veremos, que las partes opten de forma expresa por la decisión en derecho ${ }^{130}$.

Este RDAC desarrolla el sistema de arbitraje e introduce nuevos órganos para garantizar su funcionamiento, como son la Comisión de las Juntas Arbitrales de Consumo, y el Consejo General del Sistema Arbitral de Consumo.

El primer paso para iniciar un arbitraje de consumo depende de si existe adhesión por el empresario o profesional al sistema arbitral de consumo ${ }^{131}$.

En el supuesto de que no exista adhesión debemos distinguir si la reclamación se produce por un consumidor individual o por una pluralidad de consumidores.

Si es individual, el criterio para determinar la competencia territorial de las juntas arbitrales es el acuerdo de las partes, aquella junta donde ambas partes decidan presentar la solicitud.

Existe además la posible presentación de una pluralidad de solicitudes acumuladas, en base al art. 56 RDAC, aunque algunos

\footnotetext{
${ }^{130}$ Gimeno Sendra, V.: “Derecho Procesal Civil II. Los procesos especiales”, cit., pág. 592.

${ }^{131}$ Florensa i Tomás, C.E., Alonso Franco, F., Barreto Rocha, J.C., Carrasco Perera, A., Clavel Vila, M., Cortadas Arbat, R., Díaz Albart, S., Maluquer de Motes Bernet, C.J., Mercadé Merola, M., Padial Albás, A., Sanchidrián,R., Torres Sánchez, F. : “ El arbitraje de consumo. Una nueva dimensión del arbitraje de derecho privado”, Ed.: Tirant lo Blanch, Valencia 2004, cit., pág. 57; Barona Vilar, S.:"Solución extrajurisdiccional de conflictos: Alternative Disputes Resolution (ADR) y Derecho Procesal". Ed.: Tirant lo Blanch, Valencia 1999, pág. 309; BARONA VILAR, S. en Ruiz Jiménez, José Ángel (coord.):"ADR en materia de consumo en la Unión Europea". Temas actuales de consumo: la resolución de conflictos en materia de consumo”. Ed.: Instituto Vasco de Derecho Procesal, San Sebastián 2004, pág. 63-95;

http://www.uclm.es/actividades0708/jornadas/meeting/pdf/2.mediaci\%C3\%B3n\%20de\%20consumo.ppt, últ. consulta el 22 de enero de 2016.
} 
autores como Marín López o Marcos Francisco se muestran en contra del arbitraje colectivo ${ }^{132}$.

El requisito necesario para su presentación es la existencia de legitimación directa de los afectados por un hecho dañoso, del cual deberá conocer la Junta del territorio en que estén domiciliados los consumidores afectados. De encontrarse afectados consumidores de todo el país, seria competente la Junta Arbitral Nacional ${ }^{133}$, siendo el laudo que se dicte vinculante para todos los intervinientes.

A nuestro entender la presentación del arbitraje colectivo es tan válido y efectivo para resolver la controversia como el individual, sobre todo en el marco actual de las fórmulas alternativas de resolución de conflictos que se desarrollan "online" a partir de la plataforma europea aludida.

En estos casos, el Presidente de la Junta Arbitral a quien corresponda conocer deberá acordar el inicio de las actuaciones, bien de oficio o a petición de las asociaciones de consumidores representativas en ese territorio, requiriendo a la empresa para que manifieste si acepta la sumisión a arbitraje colectivo y proponga un acuerdo.

A continuación, si la empresa acepta la sumisión a arbitraje, quedan suspendidos los arbitrajes individuales si los hubiere, y se procede a realizar un llamamiento que contendrá el acuerdo de iniciación del arbitraje, la indicación del lugar en que los interesados puedan ver la propuesta de acuerdo, y que se publicará mediante anuncio en el Diario Oficial del territorio, al objeto de que todos los consumidores que se sientan afectados puedan personarse.

El arbitraje colectivo finalizará mediante laudo que será dictado dentro de los ocho meses siguientes a la publicación del llamamiento y que sólo afectará a quienes hayan sido parte, bien por haber

\footnotetext{
${ }^{132}$ Marín López, M.J.: “Objeto y límites del arbitraje de consumo”. Revista Jurídica de Castilla-La Mancha 2005, $\mathrm{n}^{\circ}$ 39, pág. 183; Marcos Francisco, D.: “¿Es posible la tutela de intereses colectivos y difusos en el arbitraje de consumo? Revista Boliviana de Derecho, Iuris Tantum, nº 11, pág. 184.

${ }^{133}$ González Pillado, E.: "Resolución de conflictos en materia de consumo: proceso y arbitraje". Ed.: Tecnos, Madrid 2008, pág. 201; Montesinos García, A.: "La Recomendación de la Comisión Europea sobre principios aplicables a los mecanismos de recurso colectivo (2013/396/UE) ¿Es posible el arbitraje colectivo?" en Palao Moreno (Ed.): "Los instrumentos europeos en materia de conciliación, mediación y arbitraje de consumo”, cit., pág. 189.
} 
atendido el llamamiento, bien por haber traído su solicitud individual al arbitraje colectivo ${ }^{134}$.

\section{a. Arbitraje de equidad.}

A diferencia del arbitraje ordinario, en el arbitraje de consumo se decide habitualmente "en equidad". Así, el art. 33.1 del RDAC establece que "El arbitraje de consumo se decidirá en equidad, salvo que las partes opten expresamente por la decisión en derecho".

Pese a que el propio RDAC establece la decisión en equidad, salvo que las partes opten expresamente por el arbitraje en derecho, la preferencia por este último tipo es la orientación más generalizada en defecto de acuerdo de las partes ${ }^{135}$.

En la practica el que las partes no concreten su voluntad de someterse al arbitraje sin más especificaciones no supone que la controversia se resuelva en equidad, quedando limitado este arbitraje de equidad a los casos en que las partes lo hayan pactado expresamente, ya sea a través de una remisión literal a la equidad o a términos similares como la decisión en conciencia, "ex a quo et bono", o que el árbitro actuará como amigable componedor ${ }^{136}$.

\section{b. Arbitraje de derecho}

Impulsado desde las propias administraciones públicas, al constituir juntas arbitrales en las Comunidades Autónomas, provinciales y locales, para tratar y resolver conflictos de consumo que, sin poner en peligro la competencia del Estado, han organizado un sistema arbitral que permite desarrollar el arbitraje a través de un convenio, por medio de un procedimiento dirigido por la propia administración de que depende la Junta, cumpliendo unas

\footnotetext{
${ }^{134}$ Montesinos García, A.: "La recomendación de la Comisión Europea sobre principios aplicables a los mecanismos de recurso colectivo (2013/396/UE) ¿Es posible el arbitraje colectivo? en Palao Moreno (Editor): "Los instrumentos europeos en materia de conciliación, mediación y arbitraje de consumo", cit., pág. 191.

${ }^{135}$ García Gil, F.J.: "Suma de la Protección y defensa de los derechos de los consumidores”, cit., pág. 742.

${ }^{136}$ Benavent Piera, A., Cobo Sáenz J.F., Delgado Cruces, J., Gesto Alonso, B., Goñi Urriza, N., Hualde Manso, T., Lara González, R., Riaño Brun, I., Richard González, M., Rifá Brun, A., Rifá Soler, J.M. en Richard González, M., Rifá Soler, J.M. (coord.):” Estudios sobre Arbitraje de Consumo”. Ed.: Aranzadi, S.A., Pamplona 2011, pág. 110.
} 
formalidades mínimas, siendo el requisito indispensable la sumisión voluntaria de ambas partes al arbitraje ${ }^{137}$.

Por lo que respecta a las juntas arbitrales intervienen dos tipos de órganos, uno encargado de la administración del arbitraje que son las JUNTAS ARBITRALES, y otros, Ios ÓRGANOS ARBITRALES que son quienes conocen de la controversia concreta y emiten el laudo, siendo designados para cada caso concreto.

\section{c. Las J untas Arbitrales de Consumo.}

Las Juntas arbitrales de consumo, son el órgano administrativo institucional del sistema arbitral de consumo que gestiona el servicio de arbitraje. Se distinguen la Junta de Arbitraje Nacional y las Juntas Territoriales que se constituyeron a través de un Convenio de Colaboración entre las Administraciones y el Instituto Nacional de Consumo, integradas por un Presidente y un Secretario, cargos que recaen en personal al servicio de la administración pública a que corresponde la Junta ${ }^{138}$.

Su existencia se determina por medio del Instituto Nacional de Consumo, que suscribe un acuerdo con la administración titular de cada junta, en el cual se fija el ámbito funcional y territorial que ostentará 139 .

Las funciones de las juntas arbitrales vienen desarrolladas en el art. 6 RDAC; entre ellas podemos destacar el fomento y formalización de convenios arbitrales dentro de su ámbito de actuación, la confección y actualización del censo de las empresas que hayan realizado ofertas públicas de adhesión al sistema arbitral y, en función más estricta la administración del propio arbitraje, asegurar

\footnotetext{
${ }^{137}$ Florensa i Tomás, C.E., Alonso Franco, F., Barreto Rocha, J.C., Carrasco Perera, A., Clavel Vila, M., Cortadas Arbat, R., Díaz Albart, S., Maluquer de Motes Bernet, C.J., Mercadé Merola, M., Padial Albás, A., Sanchidrián,R., Torres Sánchez, F. : “ El arbitraje de consumo. Una nueva dimensión del arbitraje de derecho privado”, cit., pág. 42.

${ }^{138}$ Blanco Carrasco, M.: “La alternativa a la mediación en conflictos de consumo”. Anuario Jurídico y Económico Escurialense n 42/2009, cit.

139 http://pendientedemigracion.ucm.es/info/contratos/wikiglo/index.php/Categor\%c3\%ada:Mediaci\%c3\% b3n_de_consumo. Ult. consulta el 23 de enero de 2016.
} 
el recurso a la mediación, dar publicidad a las empresas y profesionales adheridos ${ }^{140}$.

Actualmente existen:

La Junta Arbitral Nacional, competente sólo para conocer de las reclamaciones interpuestas por asociaciones de consumidores que excedan del ámbito territorial de una Comunidad Autónoma, aunque este criterio debe ir acompañado con el hecho de que los consumidores afectados se radiquen en varias comunidades autónomas $^{141}$.

18 Juntas arbitrales autonómicas.

10 Juntas arbitrales provinciales.

2 Juntas de mancomunidad.

40 Juntas municipales.

\section{d. Colegios arbitrales.}

Además de las juntas arbitrales existen los Colegios Arbitrales, compuestos por los árbitros que van a resolver cada controversia, los cuales se designan en cada ocasión para solucionar la concreta cuestión planteada. Estos se rigen bajo los principios de imparcialidad, independencia y confidencialidad y finalizan el proceso con la emisión de un laudo arbitral de obligado cumplimiento con el mismo valor que una sentencia judicial firme (la cuestión no se puede volver a plantear en el arbitraje ni llevarse a la vía judicial), previa la celebración de una vista ${ }^{142}$.

El árbitro puede ser único, utilizado cuando lo acuerden de este modo las partes o cuando lo establezca el presidente de la junta arbitral por ser la cuantía reclamada inferior a 300 euros y carecer el

\footnotetext{
${ }^{140}$ Benavent Piera, A., Cobo Sáenz J.F., Delgado Cruces, J., Gesto Alonso, B., Goñi Urriza, N., Hualde Manso, T., Lara González, R., Riaño Brun, I., Richard González, M., Rifá Brun, A., Rifá Soler, J.M. en Richard González, M., Rifá Soler,J.M. (coord.):” Estudios sobre Arbitraje de Consumo”, cit. pág. 158.

${ }^{141}$ González Pillado, E.: “Arbitraje y mediación en materia de consumo”, cit., pág. 28.

${ }^{142}$ Florensa i Tomás, C.E., Alonso Franco, F., Barreto Rocha, J.C., Carrasco Perera, A., Clavel Vila, M., Cortadas Arbat, R., Díaz Albart, S., Maluquer de Motes Bernet, C.J., Mercadé Merola, M., Padial Albás, A., Sanchidrián, R., Torres Sánchez, F.: "El arbitraje de consumo. Una nueva dimensión del arbitraje de derecho privado", cit., pág.103.
} 
asunto de complejidad. El árbitro único se designa entre los árbitros acreditados propuestos por la administración pública ${ }^{143}$.

También existe el colegio arbitral, integrado por tres árbitros que acreditados, actuarán de forma colegiada y serán elegidos entre los propuestos por la Administración, las asociaciones de consumidores y organizaciones empresariales o profesionales.

En casos excepcionales establecidos en el art. 20 apdo. 20 del RDAC las partes podrán solicitar que se designe al presidente del órgano arbitral de común acuerdo, cuando la especialidad de la reclamación lo requiera y cuando la reclamación sea dirigida contra una entidad pública vinculada a la Administración a la que esté adscrita la J unta Arbitral.

Estos se rigen bajo los principios de imparcialidad, independencia y confidencialidad, finalizando el proceso con la emisión de un laudo arbitral de obligado cumplimiento con el mismo valor que una sentencia judicial firme (la cuestión no se puede volver a plantear en el arbitraje ni llevarse a la vía judicial), previa la celebración de una vista ${ }^{144}$.

\section{e. Los árbitros.}

Una vez comprobado por la Junta Arbitral de Consumo que la solicitud de arbitraje es admisible y ambas partes aceptan que el conflicto se resuelva a través de este procedimiento, son los árbitros los que resolverán la reclamación siempre oyendo a ambas partes e intentando, en su caso, que estas lleguen a un acuerdo ${ }^{145}$.

Los árbitros son personas honorables que cuentan con la formación adecuada para resolver los conflictos que se someten a su consideración y que actúan con independencia, imparcialidad y confidencialidad, cuya intervención se dirige a solicitar las

\footnotetext{
${ }^{143}$ González Pillado, E.: "Resolución de conflictos en materia de consumo: proceso y arbitraje”, cit., pág. 202.

${ }^{144}$ Florensa i Tomás, C.E., Alonso Franco, F., Barreto Rocha, J.C., Carrasco Perera, A., Clavel Vila, M., Cortadas Arbat, R., Díaz Albart, S., Mluquer de Motes Bernet, C.J., Mercadé Merola, M., Padial Albás, A., Sanchidrián, R., Torres Sánchez, F.: "El arbitraje de consumo. Una nueva dimensión del arbitraje de derecho privado", cit., pág.105.

${ }^{145}$ Benavent Piera, A., Cobo Sáenz J.F., Delgado Cruces, J., Gesto Alonso, B., Goñi Urriza, N., Hualde Manso, T., Lara González, R., Riaño Brun, I., Richard González, M., Rifá Brun, A., Rifá Soler, J.M. en Richard González, M., Rifá Soler, J.M. (coord.):” Estudios sobre Arbitraje de Consumo”, cit., pág. 276.
} 
informaciones que consideren necesarias para dictar el laudo ${ }^{146}$. Su misión durante el proceso, además de dictar resolución, consistirá en intentar que las partes lleguen a un acuerdo ${ }^{147}$.

\section{f. Procedimiento.}

El procedimiento del arbitraje de consumo se regula en los arts. 58 a 62 del RDAC148, siendo el primero el que expresa la forma de inicio de las actuaciones del arbitraje de consumo, mediante acuerdo del Presidente de la Junta Arbitral de Consumo competente, bien de oficio, o a instancia de las asociaciones de consumidores que sean representativas ( definidas en el art. 24.2 del TRLGDCU) en el ámbito territorial donde se hayan visto afectados los intereses colectivos o de las juntas arbitrales de ámbito territorial inferior ${ }^{149}$.

En caso que la empresa se encontrara ya sometida a arbitraje a través de una Oferta Pública de sometimiento, el Presidente aceptará de inmediato la solicitud, pasando a continuación a resolver sobre el fondo del asunto ${ }^{150}$.

Es en ese momento cuando una parte recibe el requerimiento de la otra de someter la controversia a decisión arbitral ${ }^{151}$ y se inicia el procedimiento con la solicitud de arbitraje por escrito que incluso se podrá presentar vía electrónica (art. 34.1 RDAC).

\footnotetext{
${ }^{146}$ Benavent Piera, A., Cobo Sáenz J.F., Delgado Cruces, J., Gesto Alonso, B., Goñi Urriza, N., Hualde Manso, T., Lara González, R., Riaño Brun, I., Richard González, M., Rifá Brun, A., Rifá Soler, J.M. en Richard González, M., Rifá Soler, J.M. (coord.):” Estudios sobre Arbitraje de Consumo”, cit., pág. 109.

${ }^{147}$ Benavent Piera, A., Cobo Sáenz J.F., Delgado Cruces, J., Gesto Alonso, B., Goñi Urriza, N., Hualde Manso, T., Lara González, R., Riaño Brun, I., Richard González, M., Rifá Brun, A., Rifá Soler, J.M. en Richard González, M., Rifá Soler,J.M. (coord.):” Estudios sobre Arbitraje de Consumo”, cit., pág. 276.

148 González Pillado, E.: “Arbitraje y mediación en materia de consumo”. Ed.: Tecnos. Madrid 2012, pág. 24. Martínez García, E.: "Las medidas cautelares durante la pendencia de un arbitraje interno o internacional (a propósito de la Sentencia del Tribunal Superior de Justicia de las Comunidades Europeas de 17 de noviembre de 1998”. Ed.: Revista Vasca de derecho procesal y arbitraje. Volumen 11, $\mathrm{n}^{\circ}$ 2, 1999, pág. 301 a 314.

149 Busto Lago, J.M., (coord.) en Álvarez Lata, N. y Peña López, J.: "Reclamaciones de consumo. Derecho de consumo desde la perspectiva del Consumidor”, cit., pág. 398.

150 Vázquez Barros,S.: “Memento Práctico Francis Lefebvre, Consumo 2010-2011”, cit., pág. 293.

${ }^{151}$ Benavent Piera, A., Cobo Sáenz, J.F., Delgado Cruces, J., Gesto Alonso, B., Goñi Urriza, N., Hualde Manso, T., Lara González, R., Riaño Brun, I., Richard González, M., Rifá Brun, A., Rifá Soler, J.M. en Richard González, M., Rifá Soler, J.M. (coord.):” Estudios sobre Arbitraje de Consumo”, cit., pág. 120 y ss.
} 
El inicio del arbitraje corresponde realizarlo al Presidente de la Junta (art. 58.1 RDAC), pudiendo intervenir las partes de forma directa o por medio de representantes, y dependiendo en todo caso de las formalidades que se adopten, del tema en cuestión y de las necesidades del mismo ${ }^{152}$. Entre las funciones del Presidente se encuentra incluso la de inadmitir la solicitud de arbitraje que resulte infundada en los términos que establece el art. 35.1 (RDAC), cuando no se aprecie afectación de los derechos e intereses de los consumidores.

Una vez comprobado por la Junta Arbitral de Consumo que la solicitud de arbitraje es admisible y que ambas partes aceptan que el conflicto se resuelva a través de este procedimiento, será la empresa quien deba ejercer su derecho mediante la contestación a la solicitud, iniciándose a continuación el trámite de audiencia que establece el art. 37 RDAC, equivalente a un trámite de alegaciones.

Esta podrá acordarse de diversas formas, tanto por escrito, utilizando la firma convencional, como mediante notificación electrónica u oral, pudiendo desarrollarse de forma presencial, a través de videoconferencia o mediante el uso de otros medios técnicos que permitan la identificación y comunicación directa de los comparecientes, pero en cualquier caso es necesario que se levante acta del contenido de la misma por el secretario del órgano arbitral.

Tras los escritos iniciales de las partes, en esa fase central, las partes gozan de libertad para realizar alegaciones complementarias en cualquier momento, estando tan solo sometidas a exigencias de forma. A continuación, se iniciará la fase probatoria donde las partes podrán valerse tanto de testificales como periciales o documentales. Su aporte será escrito si se trata de documentos o informes, u oral, en caso de que se tengan que practicar interrogatorios a perito, testigos o a alguna de las partes, dando traslado de las pruebas a la otra parte para su conocimiento.

\section{g. Acumulación de procedimientos}

En la mayoría de procesos de consumo existen intereses de varios consumidores. Ello determinará la acumulación de reclamaciones en un único proceso colectivo de consumo.

\footnotetext{
152 González Pillado, E.: “Arbitraje y mediación en materia de consumo”, cit., pág. 150.
} 
Podrá hablarse de acumulación cuando las distintas demandas ya hayan sido admitidas $y$ se hayan iniciado los respectivos procedimientos. La acumulación podrá acodarse incluso sin consentimiento del reclamante, por decisión del propio Presidente de la Junta basada en razones de economía procesal, si considera que los hechos reclamados por varios consumidores son idénticos ${ }^{153}$.

\section{h. El convenio arbitral}

El convenio arbitral se constituye como una necesidad previa para la tramitación del arbitraje, bien adoptado como acuerdo independiente $o$ en una cláusula contractual incorporada a un contrato principal, debiendo expresar la voluntad de las partes de someter el conflicto a arbitraje.

El acuerdo debe haberse formalizado por escrito, aunque no existe obligación de sujeción a determinada forma, pudiendo tratarse de un documento firmado por las partes (art. 24 RDAC) o un intercambio de cartas, alguna comunicación electrónica u otro medio que permita constancia del acuerdo y sea posible su consulta en soporte electrónico ${ }^{154}$.

Además, el convenio también podrá estar contenido en un contrato de adhesión, aunque en este caso su validez está en tela de juicio al tratarse de una cláusula predispuesta por el empresario.

El convenio suscrito entre las partes les obliga a cumplir lo estipulado (art. 11 LA) ${ }^{155}$, y tiene un doble efecto, uno positivo y otro negativo, este último supone la posibilidad de que el demandado

\footnotetext{
${ }^{153}$ Es ejemplificativo el caso de las reclamaciones de telefonía por llamadas realizadas al 906, ante la Junta de Consumo de Murcia, en que se advirtió a varios consumidores de la entrega de un premio que resultó falso, y sobre cuyos hechos, varios consumidores, de forma individual, que acordó su acumulación.

${ }^{154}$ Benavent Piera, A., Cobo Sáenz J.F., Delgado Cruces, J., Gesto Alonso, B., Goñi Urriza, N., Hualde Manso, T., Lara González, R., Riaño Brun, I., Richard González, M., Rifá Brun, A., Rifá Soler, J.M. en Richard González, M., Rifá Soler, J.M. (coord.):” Estudios sobre Arbitraje de Consumo”, cit., pág. 107 Martínez García, E.:”Algunas reflexiones acerca del posible control de oficio de la existencia de convenio arbitral en la Audiencia Previa en la LEC”. Ed.: Revista de Derecho no 1 de 2002.

Martínez García, E. en Gómez Colomer, J.L., Barona Vilar, S, Calderón Cuadrado, M.P., Montero Aroca, J.:" El Derecho procesal del S. XX a golpe de tango. Las acciones colectivas de consumo en la Unión Europea”. Ed.: Tirant lo Blanch, Valencia 2012, págs. 1317 a 1336.

${ }^{155}$ Benavent Piera, A., Cobo Sáenz J.F., Delgado Cruces, J., Gesto Alonso, B., Goñi Urriza, N., Hualde Manso, T., Lara González, R., Riaño Brun, I., Richard González, M., Rifá Brun, A., Rifá Soler, J.M. en Richard González, M., Rifá Soler, J.M. (coord.):” Estudios sobre Arbitraje de Consumo”, cit., pág. 60.
} 
haga valer la declinatoria, alegando que el conflicto debe resolverse ante la jurisdicción ordinaria ${ }^{156 .}$

\section{i. El laudo arbitral}

El laudo será siempre motivado (art. 48.1 RDAC) dado que se pretende dotar al arbitraje del mismo nivel de garantía que la tutela judicial efectiva, debiendo por tanto la resolución ser fundada y razonable, y deberá dictarse por escrito transcurridos dos meses desde la publicación del llamamiento (art. 62 RDAC) a los afectados en el diario oficial ${ }^{157}$.

La resolución que adopte el laudo puede tener dependiendo de la pretensión interpuesta, el mismo contenido que la tutela judicial, pudiendo ser declarativo, constitutivo y condenatorio, siendo firme desde que se emite la decisión arbitral, debiendo dictarse, salvo que las partes hayan acordado otra cosa, dentro de los seis meses siguientes a la fecha de presentación de la contestación o del transcurso del plazo para su presentación ${ }^{158}$.

Se prevé además la posibilidad de que los árbitros dicten un laudo sobre la base del contenido de un acuerdo previo alcanzado por las partes ${ }^{159}$.

\section{j. Acciones que caben frente a los laudos}

Lo más característico del laudo arbitral es que no es recurrible, aunque cabe la acción de anulación del laudo en supuestos concretos, como la falta de consentimiento expreso para acudir al arbitraje, en caso de no constar claramente esta voluntad, cuando en el

\footnotetext{
${ }^{156}$ Benavent Piera, A., Cobo Sáenz J.F., Delgado Cruces, J., Gesto Alonso, B., Goñi Urriza, N., Hualde Manso, T., Lara González, R., Riaño Brun, I., Richard González, M., Rifá Brun, A., Rifá Soler, J.M. en Richard González, M., Rifá Soler, J.M. (coord.):” Estudios sobre Arbitraje de Consumo”, cit., pág. 126.

157 García Gil, F.J.: "Suma de la Protección y defensa de los derechos de los consumidores”, cit., pág. 726.

${ }^{158}$ Velasco Yáñez, R.: “Comentarios a la Nueva Ley de Arbitraje”. Ed.: Tirant lo Blanch, Valencia 2004, pág. 9.

159 De León de Arce, A. en García García, L.M. (art de Bujosa Vadell, L.M.): "Derechos de los Consumidores y Usuarios”, cit., tomo II pág. 1829.
} 
nombramiento de árbitros no se hayan observado las formalidades esenciales que la ley establece ${ }^{160}$.

${ }^{160}$ Benavent Piera, A., Cobo Sáenz J.F., Delgado Cruces, J., Gesto Alonso, B., Goñi Urriza, N., Hualde Manso, T., Lara González, R., Riaño Brun, I., Richard González, M., Rifá Brun, A., Rifá Soler, J.M. en Richard González, M., Rifá Soler, J.M. (coord.):” Estudios sobre Arbitraje de Consumo”, cit., pág. 99 y 115; García Gil, F.J.: "Suma de la Protección y defensa de los derechos de los consumidores”, cit., pág. 740; De León de Arce, A. en García García, L.M. (art. de Bujosa Vadell, L.M.): “Derechos de los Consumidores y Usuarios”, cit., tomo II pág. 1833. 
SEGUNDA PARTE 



\section{CAPÍ TULO V. LA PRUEBA EN GENERAL}

La prueba cumple una función esencial en todo proceso, es el fundamento de la resolución judicial, el elemento de que el juez dispone para alcanzar la realidad de las afirmaciones de las partes, esa "verdad objetiva" de que habla Montero Aroca ${ }^{161}$, entendida como la visión de la realidad del proceso extraída de la prueba desarrollada en él y que el propio juez pretende alcanzar al objeto de dictar la resolución.

La importancia de la prueba radica en que, teniendo razón, si no conseguimos demostrarla, no podremos alcanzar un resultado favorable ${ }^{162}$, teniendo en consideración que la aplicación de la norma por el juez en un proceso determinado parte de lo que se hubiera sometido a su decisión en el supuesto concreto.

Es por tanto necesaria la prueba sobre el hecho alegado sometido a decisión del órgano jurisdiccional en el proceso sobre la base de la aplicación de una norma.

A través de la prueba se pone en marcha una actividad verificadora de las afirmaciones realizadas por las partes que supone un derecho recíproco, establecido en el art. 24.2 de la CE, al mismo tiempo que implica para estas una carga procesal, puesto que toda la actividad probatoria recae sobre ellas, debiendo convencer al juez de la veracidad de los argumentos esgrimidos por la parte que la propone ${ }^{163}$.

El juez se basa en ella para valorar las afirmaciones de las partes. El criterio de valoración depende de si existe una norma

\footnotetext{
${ }^{161}$ Montero Aroca, J.: "La prueba en el proceso civil”. Ed.: Civitas-Thomson Reuters, Madrid 2012, pág. 59; De la Oliva Santos, A., en De la Oliva Santos, A, Díez Picazo, G., Vegas Torres, J.: "Curso de Derecho Procesal Civil II. Parte Especial”. Ed.: Ramón Areces, Madrid 2012, pág. 107; Gimeno Sendra, V.; "Derecho Procesal Civil. I. El proceso de declaración. Parte General". Ed.: Colex, Madrid, 2014, pág. 419; Montero Aroca, J., Gómez Colomer, J.L. Barona Vilar, S., Calderón Cuadrado, M.P.: "Derecho Jurisdiccional II", cit., pág., 227; Moreno Catena, V.: "Derecho Procesal Civil. Parte General. Ed.: Tirant lo Blanch, Valencia, 2005, pág. 191.

162 Barona Vilar (coord.), Calderón Cuadrado M.P., Sanchís Crespo, C., Jiménez Fortea, F.J., Martínez García, E., Pardo Iranzo, V., Pascual Serrats, R., Andrés Ciurana, B., García Vila, M., González Malabia, S.: "Tutela de los consumidores y usuarios en la Nueva LEC". Ed.: Tirant lo Blanch, Valencia 2002, pág. 282, Montero Aroca, J.: "Nociones generales sobre la prueba". Ed.: Cuadernos de Derecho Judicial, CGPJ, Madrid 2000, pág. 40; Montero Aroca, J., Gómez Colomer, J.L., Calderón Cuadrado, M.P.: "Derecho Jurisdiccional II. Proceso Civil”, cit., pág. 224.

${ }^{163}$ Bonet Navarro, J.: “La prueba en el proceso civil: cuestiones fundamentales”. Ed.: Difusión Jurídica, Madrid 2009, pág. 238.
} 
expresa; de no existir, el juez atiende a la "certeza subjetiva", es decir, a su propio criterio, realizando la valoración de las pruebas aportadas conforme a las reglas de la denominada "sana crítica"164, y a las normas procesales y procedimentales desarrolladas por el ordenamiento ${ }^{165}$.

En relación al desarrollo de la prueba partimos de varias premisas: la primera es su realización dentro del proceso; la segunda, su delimitación, puesto que debe versar sobre las afirmaciones contradictorias de ambas partes, es decir, sobre los hechos controvertidos fijados en el momento procesal oportuno, dependiendo de la clase de juicio ${ }^{166}$.

Una vez concretadas las premisas en las que se asienta la prueba, hemos de considerar la forma en que se realiza la aportación de las pruebas al proceso, que tiene lugar a través de los medios de prueba, siendo estos distintos de las fuentes de prueba, puesto que la fuente es lo material, mientras que los medios son la actividad instrumental que se despliega para introducir en el proceso estas fuentes, con el fin de acreditar las alegaciones efectuadas por las partes, de ahí que estas busquen las fuentes de prueba que puedan introducir en el proceso como medios para justificar sus posiciones y lo alegado por cada uno de ellos ${ }^{167}$.

Debido a ello, debemos analizar someramente la diferencia existente entre la fuente y el medio de prueba, consistente en que la fuente de prueba existe incluso antes del proceso y continúa después de que el proceso termine, mientras que el medio de prueba es el instrumento que el juez utiliza al objeto de comprobar las afirmaciones de hechos que las partes realizan, y cuyos tipos son los

\footnotetext{
${ }^{164}$ Barona Vilar, S.: “Competencia Desleal. Tomo II", cit., Epígrafe VII. II. Cap. VII. "Algunas cuestiones en torno al proceso civil sobre competencia desleal: II. Práctica de la prueba en los procesos en materia de competencia desleal”, págs. 1685 y ss.

165 Montero Aroca, J.: “Nociones generales sobre la prueba”. Ed.: Cuadernos de Derecho Judicial, CGPJ, Madrid 2000, pág. 41.

166 Respecto a los hechos no controvertidos estos no deben ser probados puesto que no existe discusión sobre ellos.

${ }^{167}$ Etxebarría Guridi, J.F.: "Las facultades judiciales en materia probatoria en la LEC”. Ed.: Tirant lo Blanch, Valencia 2003, pág. 159; Montero Aroca, J.: “La prueba en el proceso civil”, cit., pág. 121.
} 
expresados en el art. 299 de la Ley de Enjuiciamiento Civil (en adelante LEC) ${ }^{168}$.

Los medios siempre generan efectos en el proceso ${ }^{169}$, mientras que las fuentes pueden existir fuera del proceso generando efectos materiales sin más ${ }^{170 .}$

\section{A. OBJ ETO DE PRUEBA}

Por lo que respecta al objeto de la prueba en el proceso civil, lo serán los hechos alegados por las partes integradores de la causa petendi ${ }^{171}$.

La expresión "hechos" incluye tanto conductas, como sucesos influyentes en relación a las partes, cuyo conocimiento es necesario para lograr la convicción del juez ${ }^{172}$.

El objeto de la prueba se refleja en una doble dimensión: una primera dimensión objetiva, en la que se configuran los hechos que deben ser probados; y una segunda dimensión subjetiva que se corresponde con la aplicación de las reglas de la carga de la prueba, es decir, con cuál de las partes debe probar.

Tal como establece el art. 281 de la LEC, la prueba tendrá por objeto los hechos que guarden relación con la tutela judicial que se pretenda obtener en el proceso, no siendo necesaria prueba sobre los hechos en que exista plena conformidad de las partes, salvo en los casos en que la materia objeto del proceso esté fuera del poder de disposición de los litigantes.

Aunque el objeto de prueba serán como hemos indicado, fundamentalmente hechos, es posible también que el derecho, una

\footnotetext{
${ }^{168}$ Abel Lluch, X.: “Derecho Probatorio”, pág. 25. Ed.: Bosch, S.A., Barcelona 2012; Montero Aroca, J.: “La prueba en el proceso civil”, cit., pág. 69.

${ }^{169}$ Montero Aroca, J., Gómez Colomer, J.L. Barona Vilar, S., Calderón Cuadrado, M.P.: "Derecho Jurisdiccional II", cit., pág. 222.

${ }^{170}$ Barona Vilar, S.: “Competencia Desleal. Tomo II”, cit., Epígrafe VII. II. Cap. VII. Algunas cuestiones en torno al proceso civil sobre competencia desleal: II. Práctica de la prueba en los procesos en materia de competencia desleal”, págs. 1685 y ss.

${ }^{171}$ De la Oliva Santos, A.: “Objeto del proceso y cosa juzgada en el proceso civil”. Ed.: Civitas, Madrid 2005, págs. 32 y ss.

172 Bonet Navarro, J.: “La prueba en el proceso civil: cuestiones fundamentales”, cit., pág. 240; Montero Aroca, J.: “La prueba en el proceso civil”, cit., pág. 192.
} 
norma jurídica, pueda convertirse en objeto de prueba ${ }^{173}$, y así lo prevé el apdo. 20 del mismo artículo, al referirse como objeto de prueba a la costumbre y al Derecho extranjero ${ }^{174}$.

Existen cuatro categorías de hechos objeto de prueba que sintetizan los arts. 217.2 y 3 de la LEC ${ }^{175}$, son los hechos constitutivos y extintivos en relación al demandante, y los impeditivos y excluyentes en relación al demandado ${ }^{176}$.

Esta clasificación es fundamental para determinar a quién le corresponde probar lo que alega y a quién perjudica la falta de prueba, quedando supeditado el triunfo de la demanda a que el actor alegue y pruebe la efectiva existencia de los hechos constitutivos en los que funda la tutela que solicita ${ }^{177}$.

En este punto distinguimos entre el objeto de la prueba que será en lo que se base de forma abstracta y el tema de la prueba, donde se concreta el objeto de la misma, respondiendo ambos conceptos a la cuestión de qué es lo que hay que probar y su delimitación respecto a lo que puede y debe probarse ${ }^{178}$.

El objeto vendrá determinado por las aportaciones de hechos que introduzcan al proceso demandante y demandado, debiendo ser objeto de prueba los hechos que aleguen ambas partes, tanto los hechos constitutivos de la pretensión del actor, como los que impiden, extinguen o excluyen la eficacia de los hechos constitutivos alegados por el actor, siendo estos hechos los que pruebe el demandado ${ }^{179}$.

\footnotetext{
${ }^{173}$ Barona Vilar, S.: “Competencia Desleal. Tomo II”, cit., págs. 1685 y ss.

${ }^{174}$ Etxebarría Guridi, J.F.: "Las facultades judiciales en materia probatoria en la LEC. Ed.: Tirant lo Blanch, Valencia 2003, pág. 228.

${ }^{175}$ S. no 278/2006, Sec. $10^{\text {a }}$ AP Madrid de 19-04-2006 (TOL. 1.034.674).

${ }^{176}$ González Cano, M.I.: “La tutela colectiva de consumidores y usuarios en el proceso civil”, cit., pág. 86.

${ }^{177}$ Montero Aroca, J.: “La prueba en el proceso civil”, cit., pág. 79.

${ }^{178}$ Garcimartín Montero, R.: "El objeto de la prueba en el proceso civil”. Ed.: Bosch, Barcelona 1997, pág. 135 y ss.

${ }^{179}$ Así, la S. no 919/1998, TS de 13 de octubre de 1998 (TOL 439.523) entiende que el actor deberá probar los hechos normalmente constitutivos de su pretensión o necesarios para que nazca la acción ejercitada, y al demandado incumbe, en general, la prueba de los hechos impeditivos y la de los extintivos, regla general que deberá ser matizada según cada supuesto concreto por el propio Tribunal.
} 
No todos los hechos referidos deben ser probados, ni por tanto constituirán el tema de la prueba, sino sólo aquellos sobre los que exista controversia entre las partes. En consecuencia, los hechos no controvertidos, los hechos notorios y los favorecidos por una presunción legal (art. 385.1 de la LEC) ${ }^{180}$ no serán objeto de prueba.

Debemos en este punto hacer una breve mención a los distintos hechos objeto de prueba. En primer lugar existen los hechos constitutivos, son aquellos que fundamentan la petición de la demanda ${ }^{181}$.

Junto a ellos pueden existir los hechos impeditivos, extintivos o excluyentes, aquellos que, aun reconociendo que el actor tiene actualmente derecho a la tutela que solicita, otorgan al demandado determinados derechos.

Debemos además considerar que la existencia de los hechos impeditivos es compatible con los hechos constitutivos ${ }^{182}$, aunque su prueba destruye la eficacia jurídica que a los hechos constitutivos normalmente se atribuye, produce la nulidad del contrato y hace que la acción que tiene el demandante no exista183, puesto que supone que el derecho subjetivo como tal no ha llegado nunca a nacer.

Según reiterada jurisprudencia entre la que destaca la S. $n^{\circ} 660 / 2011$, Sec. $4^{\text {a }}$ de la AP de Murcia de 22 de diciembre de 2012 (JUR 2012/27774), corresponde al demandante la carga de probar "la certeza de los hechos de los que ordinariamente se desprenda, según las normas jurídicas a ellos aplicables, el efecto jurídico correspondiente a las pretensiones de la demanda".

La S. referida $n^{\circ}$ 278/2006, Sec. $10^{a}$ AP Madrid de 19-04-2006 (TOL. 1.034.674) mantiene la tesis de que lo útil procesalmente, es que el Tribunal haya podido formar elementos de juicio que comporten su convicción siendo irrelevante la procedencia subjetiva del instrumental probatorio que haya contribuido a integrar la convicción del juzgador para establecer el "factum" como sustrato del tema litigioso, por lo que el motivo ha de perecer» Cfr., T.S., Sala Primera, S. de 26 de abril de 1993 (EDJ1993/3870).

${ }^{180}$ Díaz Fuentes, A.: “La prueba en la nueva Ley de Enjuiciamiento Civil”. Ed.: Bosch, Barcelona 2002, pág. 25.

${ }^{181}$ Montero Aroca: “La prueba en el Proceso civil”, cit., pág. 34.

182 S. n ${ }^{\circ}$ 278/2006, Sec. $10^{\text {a }}$ AP Madrid de 19-04-2006, cit., considera que aun concurriendo todos los hechos constitutivos y no existiendo hechos impeditivos, es posible que, con posterioridad a unos y otros, se produzcan determinados hechos que vengan a destruir la eficacia desplegada por los hechos constitutivos. A estos hechos se llama extintivos.

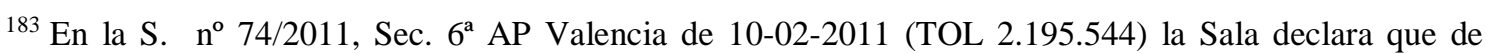
conformidad con doctrina de la carga de la prueba, el actor cumple con tal carga demostrando la existencia del contrato y el profesional debe acreditar los hechos impeditivos o extintivos que haya invocado. 
Existen además los hechos extintivos, son aquellos que ocurren con posterioridad a los constitutivos pero destruyen la eficacia desplegada por ellos y provocan la extinción del derecho subjetivo anteriormente existente ${ }^{184}$.

Los hechos excluyentes, por el contrario, son hechos jurídicos que permiten la continuación de la acción y que el derecho a la tutela efectiva exista realmente, aunque suponen el derecho de enervar (de paralizar, o de excluir) la acción que el demandante ejercita (por ejemplo, la inexistencia de los requisitos que establece el art. 1261 C.c.) ${ }^{185}$.

A los tipos de hechos aludidos debemos añadir los hechos negativos, aunque su prueba al ser difícil o imposible, es una cuestión controvertida que no ha sido resuelta por la doctrina ${ }^{186} \mathrm{ni}$ por la jurisprudencia ${ }^{187}$.

En cualquiera de los supuestos de hechos ante los que nos encontremos, los hechos alegados por las partes sobre los que exista controversia ${ }^{188}$ deberán ser probados, de modo que la jurisprudencia ha entendido que si el actor no prueba los hechos constitutivos del derecho que reclama, la pretensión será desestimada; o si el demandado no prueba la negación de esos hechos se producirá la estimación de la pretensión.

Cada parte debe por tanto asumir la prueba de su propia fundamentación, es decir, el actor los hechos constitutivos, y el demandado los hechos impeditivos, extintivos y excluyentes ${ }^{189}$.

\footnotetext{
${ }^{184}$ S. no 278/2006, Sec. 10ª AP Madrid de19-4-2006, cit.; Díaz Fuentes, A.: "La prueba en la nueva Ley de Enjuiciamiento Civil”, cit., pág. 26.

${ }^{185}$ S. $n^{\circ}$ 278/2006, Sec. $10^{\text {a }}$ AP Madrid de 19-04-2006, cit., define como excluyentes aquellos hechos que, concomitantes o posteriores a los hechos constitutivos, fundan un contra derecho a favor del demandado que le permite enervar la acción que el demandante, aun reconociendo que el actor tiene actualmente derecho a la tutela que solicita, el demandado posee un "contra derecho" (otro derecho contrario a la acción), que le permite evitar la condena.

${ }^{186}$ Díaz Fuentes, A.: “La prueba en la nueva Ley de Enjuiciamiento Civil”, cit., pág. 31.

${ }^{187}$ S. TS 29-01-1991 (TOL 1.728.361), STS n ${ }^{\circ} 748 / 2007,20-06-2007$ (TOL 1.108.629), S Sec. $12^{\text {a }}$ AP Madrid núm. 801/07, de 19-12-2008 (AC 2008/778).

${ }^{188}$ S. no 386/2010, TS 16-6-2010 (TOL 1.408.444).

${ }^{189}$ S. $n^{\circ}$ 286/2013 Sec. $1^{\text {a }}$, AP Salamanca, de 23-07-2013 (TOL 3.890.572) hace referencia al principio de aportación de parte y hace recaer sobre los litigantes la carga de alegar los hechos que la controversia contempla para su consideración por el tribunal como sustrato factico de su resolución; S. nº 386/2010, TS 16-6-2010 (TOL 1.408.444).
} 
En el supuesto de que el demandante ejercite la acción apoyándose en los hechos constitutivos faltándole los impeditivos, será él quien deba alegar y probar tales hechos.

La jurisprudencia, en sentencias como la de la Sec. 6a de la Audiencia Provincial de Valencia, de 10 de febrero de 2011, no 74/2011 (TOL 2.195.544) hace alusión a estas cuatro categorías de hechos ya referidas, cuya clasificación sirve para determinar a quién corresponde la carga de alegar los hechos y a quién perjudica la prueba o la falta de prueba de los mismos.

\section{B. OBJ ETO DE LA PRUEBA EN PROCESOS DE CONSUMO}

Los procesos de consumo, al igual que cualquier otro proceso precisan de la alegación y prueba de los hechos que cada parte argumente, aunque la forma en que acontecen los actos de consumo obstaculiza en muchas ocasiones la prueba, puesto que es frecuente que no se exija por el consumidor, por ejemplo, el justificante de compra o que no lo conservemos a posteriori.

Para que el derecho del consumidor se vea reconocido debe existir una labor previa de concienciación de los consumidores sobre sus derechos y la forma de actuar para la pre-constitución de pruebas que serán fundamentales en el proceso para justificar la verdad de las alegaciones realizadas por estos ${ }^{190}$.

Los problemas que presenta la prueba de consumo para los consumidores suponen una dificultad de acceso a la jurisdicción, tanto por la especialización que supone la diversa casuística de los procesos de consumo, como por las dificultades de prueba de los daños que en muchos procesos de consumo reclamamos.

Partimos además de la existencia de un plus de dificultad por la posición de desigualdad real de las partes en este tipo de procesos, lo cual, unido a las complicaciones de la propia prueba, hace que nos encontremos ante procesos con muchas peculiaridades, como iremos viendo a lo largo de este trabajo.

${ }^{190}$ Sanchís Crespo, C., La prueba en los procesos de consumo, en BARONA VILAR, S., (coord.), “Tutela de los consumidores y usuarios”, cit., pág. 283 y 286. 


\section{NECESI DAD DE PRUEBA}

La necesidad de prueba en el proceso está en relación tanto con los elementos de prueba como con el derecho y el deber de cada parte a la acreditación sus posiciones, jugando un papel decisivo en la convicción del juez y por tanto en la fundamentación jurídica de la sentencia ${ }^{191}$.

Además, esta necesidad es observada de dos formas distintas por el juzgador; por un lado al inadmitir determinada prueba propuesta por las partes, por entender que la cuestión ya ha quedado acreditada a través de otro medio de prueba.

A modo de ejemplo podemos referirnos al supuesto enjuiciado en la Sentencia no 435/2007 del Tribunal Supremo, de 16 de abril de 2007, (TOL 1.069.814) 192, donde se solicitó prueba de reconocimiento judicial, consistente en el desplazamiento del juzgador a la planta embotelladora de agua objeto de debate, para demostrar que el líquido que causó los daños que se reclamaban no podía ser introducido en la garrafa, ni siquiera por accidente.

El juzgador basó su argumentación en el origen del derecho al uso de los medios de prueba, implícito en el art. 24.1 de la CE, y no consideró necesario practicar este medio de prueba, al entender suficientemente ilustrados los hechos acontecidos con la testifical de un empleado, que junto a la prueba de confesión, documental y de presunciones le llevó a una resolución clara, sin necesidad de practicar ninguna otra prueba.

La segunda forma de entender la necesidad está en relación a la falta de prueba por las partes sobre el contenido de sus respectivas posiciones, existiendo supuestos en que el juez entiende que no se ha acreditado debidamente la cuestión base de la demanda. Concretamente en reclamaciones de indemnización entiende necesaria la prueba del daño, como sucede en la Sentencia $\mathrm{n}$ o 480/2012 del TS de 18 de julio de 2012 (TOL 2.593.334) de solicitud de indemnización de daños y perjuicios.

También en demandas sobre responsabilidad por culpa es necesaria la acreditación de la misma, ejemplo de lo cual es la

\footnotetext{
${ }^{191}$ S. no 189/2012, Juzgado de lo Mercantil no 3 de Madrid de 16-04-2012 (TOL 2.732.807).

${ }^{192}$ http://consumo-inc.gob.es/publicac/EC/2007/EC82/Ec82_12.pdf.
} 
Sentencia no 137/2006 de la Sec. 16a de la AP de Barcelona de 22 de marzo de 2006 (TOL 991.062)

La importancia de la prueba radica por tanto en que la aplicación de una norma por el juez ha de partir de que esta se haya probado en el pleito donde se sometió a su decisión el hecho alegado ${ }^{193}$, siendo labor del propio juzgador determinar tanto si determinado medio de prueba es necesario, como si los hechos alegados han sido finalmente probados.

\section{REFERENCIA AL ART. 299 DE LA LEC}

Los medios de prueba descritos en el art. 299 apartado 1으 de la LEC son entendidos por Montero como "actividad", puesto que en ellos se concretan cuáles son las fuentes de prueba que se necesita incorporar al proceso y de los que se podrá hacer uso en juicio.

En este artículo se contienen tanto los medios como las fuentes de prueba. Los medios vienen enumerados en el apdo. 1으, siendo numerus clausus ${ }^{194}$.

Las fuentes de prueba se concretan en los apdos. $2^{\circ}$ y $33^{\circ}$; así, el apartado 2 o del mismo artículo establece que también se admitirán, conforme a lo dispuesto en esta Ley, los medios de reproducción de la palabra, el sonido y la imagen, así como los instrumentos que permiten archivar, conocer o reproducir palabras, datos, cifras y operaciones matemáticas llevadas a cabo con fines contables o de otra clase, relevantes para el proceso ${ }^{195}$.

El punto 3 o regula el supuesto de que se pueda tener certeza de los hechos por un medio distinto de los establecidos en los apartados anteriores, en cuyo caso, el tribunal, a instancia de parte, lo admitirá como prueba, adoptando las medidas que en cada caso resulten necesarias.

\footnotetext{
${ }^{193}$ Sanchís Crespo, C.: “Tutela de los consumidores y usuarios en la nueva LEC” en Barona Vilar, S., (coord.), cit., pág. 283.

${ }^{194}$ Montero Aroca, J.: “La prueba en el proceso civil”, cit., pág. 151.

${ }^{195}$ Guasp J., Aragoneses, P.: "Derecho Procesal Civil: Tomo I”. Ed.: Thomson Civitas, Navarra 2005, pág. 468.
} 


\section{E. PROPOSICIÓN DE PRUEBA}

Existen reglas en cuanto a la proposición de los concretos medios de prueba, tanto en el juicio ordinario como en el verbal ${ }^{196}$.

La proposición en el proceso ordinario se realizará en la audiencia previa, a excepción de los documentos o dictámenes que se aportan junto a la demanda o, de no ser posible, en momento posterior siempre antes de la audiencia previa, o incluso después de esta si se tratara de hechos nuevos o de nueva noticia.

Tal como establece el art. 265 de la LEC, con la demanda o contestación deberán acompañarse los medios de prueba, a excepción de los que deben desarrollarse en el acto del juicio, como es el caso de los interrogatorios de partes, testigos o peritos.

Si durante el acto de la audiencia previa en el proceso ordinario, y al inicio del juicio en el juicio verbal, no hubiese acuerdo de las partes ni conformidad sobre los hechos, la audiencia proseguirá para la proposición y admisión de la prueba ${ }^{197}$.

Aunque la regla general es el aporte de los documentos en los momentos referidos, existe la posibilidad de que sean aportados posteriormente cuando la parte justifique no disponer de ellos en el momento de presentación de la demanda o contestación. Ello se extiende tanto a aquellos en que las partes funden su derecho, como a documentos públicos o privados que sirvan de base a su pretensión, también a los medios de reproducción de la palabra, el sonido y la imagen, así como a los instrumentos que permiten reproducirlas y a los dictámenes periciales en que apoyen sus pretensiones.

En el juicio verbal el momento de proponer prueba es el acto de la vista o en los propios escritos de demanda y contestación, aunque de forma excepcional, algún medio de prueba se podría proponer y practicar en momento distinto, como diligencias finales, siempre que se considere necesario y sea admitido por el tribunal.

\footnotetext{
196 Aragoneses Martínez, S., Cubillo López, I., Hinojosa Segovia, R., Peiteado Mariscal, P., Tomé García, J.A.: “Cien cuestiones controvertidas sobre la prueba en el proceso civil”. Ed.: Colex, Madrid 2004, pág. 23; Montero Aroca, J.: “La prueba en el proceso civil”, cit., pág. 192.

197 S. Sec. $10^{\mathrm{a}}$ AP Madrid de 19-04-2006, cit.
} 
Las pruebas serán propuestas por el actor y por el demandado, pudiendo el tribunal ${ }^{198}$, en caso de considerar que estas son insuficientes para el esclarecimiento de los hechos controvertidos, indicar el hecho o hechos que, a su juicio, podrían verse afectados por la falta de prueba, incluso señalar aquella cuya práctica considere conveniente. Esta iniciativa probatoria se reconoce en el art. 429.1 o y $435.2^{\circ}$ de la LEC, aplicables tanto al juicio ordinario como al verbal.

Las partes, a la vista de lo manifestado por el Tribunal, podrán adicionar su proposición de prueba o mantenerla invariable, continuando el curso del proceso, pues tal manifestación no resulta vinculante $^{199}$ (art. 429 LEC).

La intervención del juez en la proposición de la prueba es tenida como un deber por una parte de la jurisprudencia 200 , y por otra ${ }^{201}$, como una facultad potestativa, que se limita a poner de manifiesto a las partes los hechos controvertidos que no quedan suficientemente acreditados con la prueba propuesta por las partes.

\section{F. ADMISI ÓN DE LA PRUEBA}

Este es el acto por el que el juez determinará qué medios, de entre los que las partes han propuesto, deben ser practicados en el proceso.

La admisión se realizará en el momento siguiente a la proposición de la prueba, en el mismo acto de la audiencia previa en el juicio ordinario o de la vista en el juicio verbal ${ }^{202}$.

\footnotetext{
${ }^{198}$ Etxebarría Guridi, J.F.: “Las facultades judiciales en materia probatoria en la LEC”, cit., págs. 212, 259 y ss.

${ }^{199}$ Barona Vilar, S.: “Competencia Desleal. Tomo II”, cit. Epígrafe VII. II. Cap. VII. Algunas cuestiones en torno al proceso civil sobre competencia desleal: II. Práctica de la prueba en los procesos en materia de competencia desleal", págs. 1685 y ss; Bonet Navarro, J.: "La prueba en el proceso civil: cuestiones fundamentales", cit., pág. 183.
${ }^{200}$ Podemos hacer alusión a la S. Sec. 3a AP Tarragona de 11-06-2002 (TOL 255.268) y La S. no 24/2005, Sec. 1a, AP La Rioja de 31-01-2005 (TOL 604.106), que consideran que el juez sólo puede de intervenir en la proposición de prueba en supuestos de insuficiencia probatoria.

${ }^{201}$ Otras sentencias, de forma minoritaria, consideran que el juez debe intervenir en la proposición de prueba, poniendo de manifiesto la insuficiencia probatoria, como la S. $n^{\circ} 205 / 2002$, Sec. $1^{\text {a }}$ de la AP Ciudad Real de 28-05-2002 (TOL 200.782).

202 Etxebarría Guridi, J.F.: "Las facultades judiciales en materia probatoria en la LEC”, cit., pág. 311; Díaz Fuentes, A.: "La prueba en la nueva Ley de Enjuiciamiento Civil”, cit., pág. 57; Abel Lluch, X.: “Derecho Probatorio”, cit., pág. 280 a 286.
} 
Los criterios que rigen la decisión judicial en torno a la admisión de la prueba, sobradamente conocidos, son: su pertinencia, es decir, que se dirija a acreditar los hechos alegados (recogido en el art. 24 de la $(E)$; el de utilidad para el fin que se persigue con el proceso atendiendo a su objeto; el de necesidad y relevancia para el resultado del proceso (art. 283.2); el de legalidad (art. 283.3, referido a la inadmisión como prueba de cualquier actividad prohibida por la Ley).

El juez resolverá mediante auto la admisión o inadmisión de la prueba, condicionada a la concurrencia de los requisitos que se establecen legalmente, y deberá tratarse de un medio legalmente establecido ${ }^{203}$.

La decisión que adopte el juez puede recurrirse en reposición, tanto si se trata de admisión, como de inadmisión de prueba ${ }^{204}$. El recurso se sustanciará y resolverá en el mismo momento. Si el recurso se desestima, se puede formular protesta a los efectos de hacer valer el derecho en la segunda instancia que pudiere plantearse, tal como establece el art. 446 de la LEC.

\section{G. ANTI CI PACIÓN DE LA PRUEBA}

Supone tanto la práctica de cualquier medio de prueba en un momento anterior al establecido para cada tipo de procedimiento, como la petición de aseguramiento de la prueba, ante la posible desaparición o destrucción de la fuente probatoria, como veremos en el apartado siguiente. Si el tribunal se negare a ello, deberá resolverlo mediante auto contra el que cabe recurso de reposición y de apelación.

La anticipación puede solicitarse antes de la iniciación del proceso o una vez iniciado este ${ }^{205}$, mediante escrito motivado dirigido al tribunal que considere competente sin que sea admisible la declinatoria de jurisdicción ${ }^{206}$, acompañado de datos sobre el futuro

\footnotetext{
${ }^{203}$ Díaz Fuentes, A.: “La prueba en la nueva Ley de Enjuiciamiento Civil”, cit., pág. 60.

204 Abel Lluch, X. y Picó Junoy, J.: “Aspectos prácticos de la prueba civil”. Ed.: Bosch Procesal, Barcelona 2006, pág. 115.

205 Aragoneses Martínez, S., Cubillo López, I., Hinojosa Segovia, R., Peiteado Mariscal, P., Tomé García, J.A.: “Cien cuestiones controvertidas sobre la prueba en el proceso civil”, cit., pág. 29.

${ }^{206}$ Díaz Fuentes, A.: “La prueba en la nueva Ley de Enjuiciamiento Civil”, cit., pág. 104.
} 
demandado, con el fin de que sea debidamente citado al menos con cinco días de antelación para la práctica de la prueba.

Es requisito indispensable para que la prueba anticipada tenga valor probatorio que se presente la demanda del proceso principal en el plazo de dos meses desde que esta se practicó.

En el caso de que el tribunal que vaya a conocer del asunto no sea el mismo en el que se practicó la prueba, reclamará las actas y documentos de las actuaciones realizadas, no admitiendo la prueba anticipada de no considerar urgente su práctica ${ }^{207}$.

Si esta se planteara ya iniciado el proceso, se podrá solicitar tanto por el demandante como por el demandado, con la única condición de que se practique en un momento procesal anterior al establecido por la Ley.

Una vez llevada a cabo la misma, quedará custodiada por el Letrado de la Administración de Justicia hasta el momento oportuno del procedimiento.

\section{H. LAS MEDI DAS DE ASEGURAMI ENTO}

Las medidas de aseguramiento de la prueba establecidas en los arts. 297 y 298 de la LEC son de gran utilidad práctica en algunos procesos de consumo.

Los requisitos para la adopción de medidas de aseguramiento de la prueba se encuentran recogidos en el art. 298 de la LEC y son los siguientes:

- Que la prueba que se pretende asegurar sea posible, pertinente y útil al tiempo de proponer su aseguramiento.

- Que haya razones para temer que, de no adoptarse las medidas de aseguramiento, puede resultar imposible en el futuro la práctica de dicha prueba.

- Que la medida de aseguramiento que se propone pueda llevarse a cabo en un tiempo breve sin causar perjuicios graves a las personas implicadas o a terceros.

\footnotetext{
${ }^{207}$ En la S. no 97/2001, Sec. 1a, AP Ciudad Real de 25-10-2001 (EDJ 2001/75548) la Sala entiende que la prueba anticipada solicitada podía realizarse en el momento procesal oportuno, sin necesidad de practicarse previamente, debido a que la pretensión que daba lugar a esta sentencia ya se había intentado demostrar sin éxito en juicios anteriores, lo que suponía la ausencia de urgencia en la práctica de la prueba que se solicita.
} 
- El ofrecimiento por el solicitante de una medida de garantía para responder de los daños y perjuicios que se pudieran irrogar.

\section{REGLAS DEL PROCEDI MI ENTO PROBATORIO}

Aunque no existen reglas específicas, el discurrir de la prueba se basa en el principio de legalidad y permite obtener la certeza de las afirmaciones de hecho vertidas por las partes con la debida seguridad jurídica ${ }^{208}$.

El referido principio de legalidad se basa en que lo relevante en el proceso es que se llegue a la verificación de las afirmaciones de las partes por el camino establecido en la ley.

Las reglas a que atiende el desarrollo de la práctica de la prueba son las del respeto a los principios de contradicción (art. 289.1), publicidad (art. 138.2), documentación (art. 289), inmediación (art. 289.2) y unidad de acto (art. 290) ${ }^{209}$.

Existen dos premisas comunes a todos los medios de prueba; la primera es que la prueba no siempre es necesaria, como en el supuesto de que no existan hechos controvertidos, y la segunda, que la actividad probatoria debe estar prevista en una disposición legal ${ }^{210}$.

Los medios de prueba se practicarán bajo el principio de oralidad $^{211}$, con las mismas reglas comunes, es decir, la separación de cada medio de prueba y la determinación del momento en que deba practicarse, si es en el juicio o con anterioridad.

En el caso del interrogatorio de testigos o prueba pericial se indicará si la parte proponente se compromete a presentarlos, o si solicita intervención del juez.

\footnotetext{
${ }^{208}$ Díaz Fuentes, A.: “La prueba en la nueva Ley de Enjuiciamiento Civil”, cit., pág. 125.

${ }^{209}$ Díaz Fuentes, A.: “La prueba en la nueva Ley de Enjuiciamiento Civil”, cit., pág. 85.

${ }^{210}$ Montero Aroca, J.: “La Prueba en el proceso civil”, cit., pág., 189.

${ }^{211}$ Bonet Navarro, J.: “La prueba en el proceso civil: cuestiones fundamentales”, cit., pág. 58.
} 


\section{J. PRACTICA DE LOS MEDI OS DE PRUEBA}

Aun partiendo de los mismos principios aludidos, siempre pueden existir variantes en su desarrollo.

La regla fundamental es que todas las pruebas tengan lugar en el acto, a excepción de la prueba que deba practicarse fuera del local del tribunal, y los casos en que deban practicarse pruebas en momento distinto al del juicio ${ }^{212}$.

El orden para proceder a la práctica de la prueba lo fija el artículo 300 de la LEC, y es el siguiente:

- Interrogatorio de las partes.

- Interrogatorio de testigos.

- Declaraciones de peritos sobre sus dictámenes o presentación de éstos cuando excepcionalmente se hayan de admitir en ese momento.

- Reconocimiento judicial cuando no se haya de llevar a cabo fuera de la sede del tribunal.

- Reproducción ante el tribunal de palabras, imágenes y sonidos captados mediante instrumentos de filmación, grabación y otros semejantes.

Vamos a tratar brevemente cada medio de prueba en los aspectos que consideramos de interés para afrontar las especialidades de la prueba en el proceso de consumo, aludiendo en el orden en que se practican o aportan en el proceso.

\section{a. Prueba documental}

La prueba documental supone la materialización de la prueba a través de documentos ${ }^{213}$.

Como hemos visto, la norma general es que los documentos se aporten en los momentos iniciales del proceso, junto con la demanda o la contestación. La razón de ello se debe a la salvaguarda del

\footnotetext{
${ }^{212}$ Etxebarría Guridi, J.F.: "Las facultades judiciales en materia probatoria en la LEC”, cit., págs. 123 y 212; Bonet Navarro, J.: "La prueba en el proceso civil: cuestiones fundamentales”, cit., pág. 97.

${ }^{213}$ Díaz Fuentes, A.: “La prueba en la nueva Ley de Enjuiciamiento Civil”, cit., pág. 168; Vilaboy Lois, L.: "La prueba por medio de los modernos avances científico-tecnológicos en el proceso civil". Ed.: Tecnos, Madrid 1993, pág. 29.
} 
derecho a la igualdad de las partes, de forma que ninguna de ellas se vea sorprendida por la justificación de la razón de pedir, o de oponerse, en un momento posterior.

Desde la reforma introducida en la LEC a través de la Ley $42 / 2015$, de 5 de octubre, esos documentos deberán presentarse escaneados, puesto que la presentación de escritos y documentos se realiza de forma electrónica por parte de los profesionales intervinientes, a través del portal de la administración de justicia LEXNET, con las debidas garantías sobre su autenticidad, tal como dispone el art. 273.1 de la LEC.

Para ello deberán cumplirse los requisitos que el mismo art. 273 de la LEC establece, procediendo a su presentación utilizando la firma electrónica reconocida adaptada a las exigencias de la ley 18/2011, de 5 de julio, reguladora del uso de las tecnologías de la información y la comunicación en la administración de justicia.

En el momento de la audiencia previa también es posible aportar por el actor prueba documental, medios, instrumentos, dictámenes e informes relativos al fondo del asunto, tal como establece el art. 265.3 de la LEC, siempre que su interés o relevancia se ponga de manifiesto a consecuencia de alegaciones efectuadas por el demandado en la contestación a la demanda.

Los documentos que se presentarán al proceso por las partes deben ser originales o escaneados de los originales ${ }^{214}$, siendo lo más acertado llevar el original al acto de la vista previa para que puedan ser examinados en caso de que se cuestione su autenticidad por la parte contraria.

Si los originales no obraran en poder de la parte que los presenta, o estos estuvieran en poder de la otra parte, podrá solicitarse del Tribunal que ordene su exhibición ${ }^{215}$.

Entre los tipos de documentos que podemos aportar al proceso se encuentran también los electrónicos, entendidos por aquellos que

\footnotetext{
${ }^{214}$ Gómez Colomer, J.L. en Montero Aroca, J., Gómez Colomer, J.L., Barona Vilar, S., Calderón Cuadrado, M.P.: "Derecho Jurisdiccional II. Proceso Civil", Ed.: Tirant lo Blanch, Valencia 2015, pág. 269.

${ }^{215}$ Barona Vilar, S.: “Competencia Desleal. Tomo II”. Epígrafe VII. II. Cap. VII. Algunas cuestiones en torno al proceso civil sobre competencia desleal: II. Práctica de la prueba en los procesos en materia de competencia desleal”, cit., págs. 1685 y ss.
} 
permiten archivar, conocer o reproducir datos relevantes para el proceso, debiendo tener en cuenta la precisión hecha por el art. 11.1 de la LOPJ sobre el respeto de las reglas de la buena fe en su obtención.

En relación a los documentos electrónicos, el Real Decreto 1671/2009, de 6 de noviembre, que desarrolla parcialmente la Ley 11/2007, de acceso electrónico de los ciudadanos a los servicios públicos (vigente hasta el 2 de octubre de 2016), en su art. 41.1 establece las características que deben reunir este tipo de documentos, conservando la información en soporte electrónico con determinado formato que se pueda identificar e individualizar, aunque se incorpore a un expediente electrónico.

Al objeto de concretar lo que se entiende por la expresión prueba electrónica o documento electrónico abarca la información obtenida a partir de un dispositivo electrónico o medio digital, que sirve para conocer la certeza de un hecho.

Una fotografía, un video, una página web, un correo electrónico, una base de datos, una contabilidad en un programa de cálculo en Excel, un mensaje de teléfono móvil, un registro fonográfico, la videograbación, la fotografía digital y el fax o el contenido de cualquier soporte digital, puede constituir un documento, aunque su reproducción e impugnación sean distintos al documento tradicional ${ }^{216}$.

El documento digitalizado también se considera prueba electrónica cuando la información que contiene depende de su carácter de documento; por su parte, el correo electrónico impreso no precisa reproducción electrónica.

Los documentos electrónicos proceden de fuentes de prueba electrónicas, pudiendo encontrar varios tipos de prueba electrónica distinta; un primer tipo sería el de aquellas pruebas creadas informáticamente: se trataría de informaciones sin formato físico y que pueden ser pasadas a posteriori a tal formato, como los correos electrónicos, archivos informáticos, cookies, sitios de rastreo del

\footnotetext{
${ }^{216}$ Abel Lluch, X., Picó i Junoy, J., Richard González, M., (Dir.): “La prueba judicial. Desafíos en las jurisdicciones civil, penal, laboral y contencioso-administrativa”. Ed.: La Ley, Madrid 2011, pág. 346 y 347.
} 
historial informático, webs, comentarios vertidos en chats, foros o redes sociales como twitter, facebook.

Un segundo tipo de documentos estaría formado por aquellos que proceden de medios de reproducción o archivo electrónicos, videos o fotografía digital.

Un tercer tipo serían aquellas pruebas que se presentan a través de hardware informático como un disco duro, o cualquier dispositivo que precise USB ${ }^{217}$.

En cuanto a la validez del documento privado aportado mediante soporte electrónico, depende de si se han observado para su firma electrónica los requisitos establecidos en el arts. 3 apdo. 5 y 6 de la Ley 59/2003, de 19 de diciembre de Firma Electrónica (en adelante LFE), según la interpretación que se ha venido dando de forma generalizada por la doctrina, será admisible como prueba documental en juicio ${ }^{218}$.

En el caso de que el soporte informático sustituya a un documento tradicional, el reconocimiento del mismo por la parte a quien perjudique constituirá un supuesto de prueba tasada 219 .

De producirse su impugnación, ello no será impedimento para que se puedan presentar copias de documentos y que estos puedan ser considerados como verdadera prueba documental 220 , correspondiendo la decisión última sobre su validez y eficacia al órgano jurisdiccional.

Si la parte contraria cuestionara la exactitud o autenticidad de lo reproducido, la parte que pretenda su admisión podrá incluso justificar estos extremos a través de informe ${ }^{221}$.

\footnotetext{
${ }^{217}$ Bueno de Mata, F.: “Prueba electrónica y proceso 2.0”. Ed.: Tirant lo Blanch, Valencia 2014, pág. 115 a 135.

${ }^{218}$ Montero Aroca, J.: "La Prueba en el Proceso civil”, cit., pág. 606.

${ }^{219}$ Sanchís Crespo, C.: "La prueba por soportes informáticos”. Ed.: Tirant lo Blanch, Valencia 1999, págs. 101 y ss.

${ }^{220}$ Entre la jurisprudencia referida podemos citar sentencias del Tribunal Supremo, como la $n^{\circ}$ 50/2001 de 22-01-2001 (TOL 99.616), La no 1083/2006, la de 6-11-2006 (TOL 1.019.381), o la de la Sec. $1^{\text {a }}$ AP Asturias de 19-03-2002 (TOL 174.094).

${ }^{221}$ Illán Fernández, J.M.: "La prueba electrónica, eficacia y valoración en el proceso civil”. Ed.: Aranzadi, S.A., Pamplona 2009, pág. 403; Sanchís Crespo, C., La prueba en los procesos de consumo, en BARONA VILAR, S., (coord.), “Tutela de los consumidores y usuarios”, cit., pág. 290.
} 
En el supuesto de ser impugnados por su veracidad, se podrá acudir al cotejo pericial de letras o a cualquier otro medio que proponga el consumidor y que resulte útil y pertinente al efecto.

Cuestión distinta es la validez del documento público, que vendrá determinada por la intervención del notario al objeto de dar fe de la autenticidad del contenido de una página web o de un correo electrónico mediante acta de protocolización o de presencia ${ }^{222}$.

\section{b. Instrumentos de reproducción de palabras, imágenes y sonidos.}

Estos medios no son pruebas en sí mismas consideradas, sino que se trata de modos de expresión de la prueba reconocidos por el art. 299 de la LEC 223 .

Aunque existen problemas interpretativos sobre la condición de documentos de los medios de reproducción, a nuestro entender no ofrece ninguna duda el hecho de que estas fuentes lo que hacen es exteriorizar una prueba documental de forma distinta a la tradicional en papel, y ello debido a la evolución de la técnica ${ }^{224}$.

La LEC ha distinguido estos medios de los documentos, considerando que el documento requiere expresión escrita, mientras que los soportes informáticos precisan de un aparato específico para exteriorizar su contenido.

Existe una diferencia con relación al documento en cuanto a que, como ya hemos manifestado, en la prueba documental no existe verdadera práctica, mientras que los medios de reproducción deberán reproducirse delante del Tribunal.

Por su parte, los medios informáticos son en muchas ocasiones copia de la que se encuentra en el disco duro, considerándose como copias auténticas, tal como dispone el art. 333 en su segundo párrafo 225 .

\footnotetext{
${ }^{222}$ Abel Lluch, X., Picó i Junoy, J., Richard González, M., (Dir.): "La prueba judicial. Desafíos en las jurisdicciones civil, penal, laboral y contencioso-administrativa”, cit., págs. 356 y 357.

${ }^{223}$ Etxebarría Guridi, J.F.: “Las facultades judiciales en materia probatoria en la LEC”, cit., pág. 361.

${ }^{224}$ Sanchís Crespo, C.: “La prueba por soportes informáticos”, cit., pág. 100.

225 Aragoneses Martínez, S., Cubillo López, I., Hinojosa Segovia, R., Peiteado Mariscal, P., Tomé García, J.A.: "Cien cuestiones controvertidas sobre la prueba en el proceso civil”, cit., pág. 180.
} 
Estos instrumentos probatorios deben introducirse en el proceso en el momento inicial, al igual que los documentos, y su no presentación hace precluir el trámite.

También existen excepciones a la regla general, al igual que en la prueba documental, y de este modo, existe la posibilidad de presentación en la audiencia previa en el caso de que su interés, como en la documental, se haya puesto de manifiesto tras la contestación a la demanda.

La proposición y práctica de esta prueba puede variar dependiendo de si el medio es audiovisual o informático ${ }^{226}$. La proposición de los medios audiovisuales deberá hacerse en el tiempo y forma previstos en la LEC para los demás medios de prueba ${ }^{227}$; en la audiencia previa de forma oral, o en la vista cuando el proceso que se sigue es un juicio verbal, y su concreta realización dependerá de si se han aportado copias, y de si su contenido puede ser reproducido por el juzgador en el acto del juicio.

Incluso después de los trámites de demanda, contestación y audiencia previa, cabría admitir algunos medios de reproducción, siempre que concurran las siguientes situaciones:

- ser de fecha posterior a la presentación de la demanda o a la audiencia previa al juicio;

- tratarse de medios anteriores a la demanda o contestación, o a la audiencia previa;

- que no se dispusiera del medio siempre que fuera por causas no imputables a la parte que pretende su incorporación procesal posterior.

- Cuando se hubiesen presentado alguno de estos medios y se hubieren impugnado por su presentación extemporánea por la otra parte, el tribunal resolverá en el acto admitiéndolo o rechazándolo.

\footnotetext{
${ }^{226}$ Díaz Fuentes, A.: “La prueba en la nueva Ley de Enjuiciamiento Civil”, cit., pág. 341.

227 Aragoneses Martínez, S., Cubillo López, I., Hinojosa Segovia, R., Peiteado Mariscal, P., Tomé García, J.A.: “Cien cuestiones controvertidas sobre la prueba en el proceso civil”, cit., pág. 182.
} 
Los modos de presentar los medios pueden ser incluyendo el medio de reproducción o su impresión escrita, puesto que, por su naturaleza, difieren de los documentos.

La práctica de los medios audiovisuales se llevará a cabo en el acto del juicio, conforme a las disposiciones generales, aunque las dificultades técnicas que puede comportar este medio, puede justificar que se practique separadamente antes del juicio, siempre cumpliendo lo previsto por el art. 290 de la LEC.

Su concreta eficacia dependerá de si estos han sido impugnados, bien directamente por la parte contraria, o bien de forma indirecta con el aporte de otros medios de prueba.

\section{c. El interrogatorio de parte (art. 301 a 316).}

Este medio de prueba consiste en la declaración de una parte, siempre a petición de la contraria, sobre hechos y circunstancias de los que aquella tenga noticia y guarden relación con el objeto del proceso. La fuente en el interrogatorio de parte es la persona que se interroga y sus conocimientos sobre el tema de prueba, mientras que el interrogatorio es el medio de prueba ${ }^{228}$.

En supuestos de persona jurídica el representante legal con poderes para actuar en juicio será quien comparezca para prestar el interrogatorio, y si es persona física, el propio actor ${ }^{229}$.

El interrogatorio de las partes se lleva a cabo respondiendo a las preguntas de la parte que lo haya solicitado en primer lugar y del resto de partes y del propio tribunal a continuación. Será preguntado sobre cuestiones que se planteen en relación al objeto del proceso, entre las que se le podrían plantear la certeza y veracidad de los documentos aportados que hayan sido generados por procedimientos electrónicos e informáticos ${ }^{230}$.

Las preguntas deben formularse en sentido afirmativo, de forma clara y concreta, en aras a evitar malas interpretaciones por quien

\footnotetext{
${ }^{228}$ Planchadell Gargallo, A.: "La prueba de interrogatorio de las partes en la Nueva Ley de Enjuiciamiento Civil”. Revista de Derecho Procesal núm. 2/2000, págs. 417 a 422.

${ }^{229}$ Díaz Fuentes, A.: “La prueba en la nueva Ley de Enjuiciamiento Civil”, cit., pág. 155.

${ }^{230}$ Sanchís Crespo, C., Chaveli Donet, E.A.: "La prueba por medios audiovisuales e instrumentos de archivo en la LEC 1/2000”. Ed.: Tirant lo Blanch, Valencia 2002, pág. 155.
} 
deba responder ${ }^{231}$. Se formulan primero por la parte que ha pedido el interrogatorio, y en segundo lugar por la otra parte o partes intervinientes en el proceso, pudiendo el juez realizar preguntas en tercer lugar o solicitar aclaraciones, si lo considera oportuno tras intervención de las partes ${ }^{232}$.

Cuando el que interviene es el representante de la persona jurídica, deberá responder incluso respecto de las preguntas que se le formulen sobre hechos en los que no haya intervenido, especificando, si los conoce facilitando además los datos de quien haya intervenido en ellos en nombre de la persona jurídica.

Es posible que la persona física que debe comparecer por la persona jurídica no tenga constancia de los hechos por no haber intervenido en ellos. Por ello, según lo dispuesto en el art. 308 de la LEC, podrá proponer que conteste a las preguntas como representante, denominado por Montero Aroca 233 "representante voluntario"; se trata de un tercero que tenga conocimiento personal sobre los hechos por su relación directa con el asunto planteado.

Sobre la cuestión expuesta se dará solución en un momento distinto, dependiendo de si estamos en el juicio ordinario o verbal ${ }^{234}$, aunque en ambos casos es posible el interrogatorio de un tercero ${ }^{235}$.

Si estamos ante un juicio ordinario, tal como establece el art. 309 LEC, si el representante de la persona jurídica no tiene conocimiento directo de los hechos, podrá realizar esta alegación en el trámite de audiencia previa, haciendo referencia a la persona que

\footnotetext{
${ }^{231}$ Díaz Fuentes, A.: “La prueba en la nueva Ley de Enjuiciamiento Civil”, cit., pág. 141.

${ }^{232}$ Etxebarría Guridi, J.F.: “Las facultades judiciales en materia probatoria en la LEC”, pág. 329. Ed.: Tirant Monografías, Valencia 2003.

${ }^{233}$ Montero Aroca, J.: “La prueba en el proceso civil”, cit., pág. 252.

${ }^{234}$ Aragoneses Martínez, S., Cubillo López, I., Hinojosa Segovia, R., Peiteado Mariscal, P., Tomé García, J.A.: "Cien cuestiones controvertidas sobre la prueba en el proceso civil”, cit., pág. 56.

${ }^{235}$ Barona Vilar (coord.), Calderón Cuadrado M.P., Sanchís Crespo, C., Jiménez Fortea, F.J., Martínez García, E., Pardo Iranzo, V., Pascual Serrats, R., Andrés Ciurana, B., García Vila, M., González Malabia, S.: "Tutela de los consumidores y usuarios en la Nueva LEC”, cit., pág. 334.
} 
intervino al objeto de citarla a juicio ${ }^{236}$, y se realizará por el propio juzgado si la parte que ha propuesto la prueba así lo solicita ${ }^{237}$.

En el juicio verbal, al no existir audiencia previa hay que estar a lo dispuesto en el art. 440, debiendo constar en la citación la advertencia a la parte que sea persona jurídica, que debe comparecer en el interrogatorio a través del representante persona física que intervino en los hechos que son causa del procedimiento, disponiendo del plazo de tres días para facilitar los datos y circunstancias de quien vaya a declarar, bien como representante, bien como testigo si no forma parte de la persona jurídica.

En estos casos el propio representante, tras recibir su citación a declarar, puede manifestar mediante escrito dirigido al Juzgado, su desconocimiento de los hechos y designar a otra persona de la organización que sí es conocedor de los mismos.

Si el representante manifiesta no conocer la persona que ha intervenido, esta actitud será considerada por el tribunal como una respuesta evasiva y de resistencia a declarar, tal como establece el art. 309.3 de la LEC.

De producirse este desconocimiento de los hechos por parte del representante legal, la parte que propone la declaración podrá optar por la declaración de aquel que conozca los hechos, o por ambas declaraciones, la del representante legal, y la de quien conoce los hechos en calidad de testigo, puesto que a este sólo es posible interrogarle a cerca de los mismos, no sobre hechos que pueda conocer por causa distinta a la de su intervención en ellos.

Otra variante con la que nos encontramos en la práctica se produce cuando el representante de la sociedad es conocedor de los hechos, pero no se encuentra actualmente tal, en cuyo caso se podrá pedir su declaración en calidad de testigo.

\section{d. Interrogatorio de testigos (arts. 360 a 381).}

Este es un medio de prueba por el que las partes solicitan que declaren personas sobre hechos controvertidos del proceso por tener

\footnotetext{
${ }^{236}$ Aragoneses Martínez, S., Cubillo López, I., Hinojosa Segovia, R., Peiteado Mariscal, P., Tomé García, J.A.: "Cien cuestiones controvertidas sobre la prueba en el proceso civil", cit., pág. 56.

${ }^{237}$ Barona Vilar, S.: “Competencia Desleal. Tomo II”, cit., Epígrafe VII. II., Cap. VII. “Algunas cuestiones en torno al proceso civil sobre competencia desleal: II. Práctica de la prueba en los procesos en materia de competencia desleal”, págs. 1685 y ss.
} 
conocimiento de los mismos ${ }^{238}$. Cualquier persona puede ser testigo, aunque existen tres situaciones establecidas en el art. 361 en las que el testigo puede no ser idóneo: la permanente falta de razón, la privación de los sentidos imprescindibles para percibir ciertos hechos y la edad inferior a 14 años ${ }^{239}$. Es posible también que presten declaración las personas jurídicas, públicas y privadas.

Para practicar el testimonio de personas jurídicas y entidades públicas se requiere que lo preste una persona física, que debe tener la condición de tercero en el proceso, interviniendo para declarar sobre los hechos que tiene conocimiento.

Si se trata del procedimiento verbal, la proposición de la prueba testifical se puede efectuar en los escritos de demanda o contestación en caso de que se pretenda la citación judicial, de lo contrario, se podrán proponer de forma oral en el acto del juicio, tras el trámite de alegaciones orales, llevando consigo los testigos.

En el proceso ordinario el momento de la proposición es en el acto de la vista previa, debiendo especificar la parte que los propone si se encarga directamente de su presentación, o bien si deben ser citados por el tribunal, haciendo constar además si se solicita por medio de auxilio judicial.

En cuanto a la forma de practicar el interrogatorio, estaremos a lo establecido en el artículo 302.1 de la LEC, pudiendo incluso realizarse por videoconferencia si existe causa justificada.

La primera de las partes en preguntar al testigo es aquella que lo ha propuesto, aunque con anterioridad el juez le realizará las preguntas generales previstas en el art. 367 de la LEC. Tras su intervención, podrá realizar preguntas la parte contraria y a continuación, el propio juez le solicitará las aclaraciones que estime convenientes, igual que sucede en el interrogatorio de parte ya descrito.

\footnotetext{
${ }^{238}$ Aragoneses Martínez, S., Cubillo López, I., Hinojosa Segovia, R., Peiteado Mariscal, P., Tomé García, J.A.: "Cien cuestiones controvertidas sobre la prueba en el proceso civil", cit., pág. 75; Etxebarría Guridi, J.F.: “Las facultades judiciales en materia probatoria en la LEC”, cit., pág. 353.

${ }^{239}$ Barona Vilar, S.: “Competencia Desleal. Tomo II”, cit., Epígrafe VII. II. Cap. VII. "Algunas cuestiones en torno al proceso civil sobre competencia desleal: II. Práctica de la prueba en los procesos en materia de competencia desleal”, págs. 1685 y ss.
} 
Las preguntas se responderán oralmente y se formularán en sentido afirmativo, sin valoraciones ni calificaciones, con posible control por el juez sobre su admisibilidad, acordando realizar aquellas que sean conducentes a la averiguación de los hechos y de las circunstancias controvertidas que guarden relación con el juicio.

Si se produjera contradicción entre los testigos, el tribunal podrá acordar que se sometan a un $\operatorname{careo}^{240}$ (art. 373.1 y 2).

En la mayoría de procesos las declaraciones de los testigos suelen acompañarse de otros medios de prueba, como la documental o la pericial, aunque en casos de destrucción del producto, podría ser la única prueba existente y el juez debería justificar en ella la resolución judicial.

El interrogatorio puede prestarse incluso sobre hechos consignados en informes previamente aportados por las partes, y puede llegar a desvirtuar el contenido propio de la relación jurídica si de su práctica se deducen circunstancias distintas a las que constan hasta ese momento ${ }^{241}$.

Existe además la posibilidad, establecida en el art. 370.4 de la LEC, de que un testigo que conoce directamente o por referencia unos hechos, y que además posee conocimientos científicos o técnicos, pueda declarar como "testigo cualificado" 242 , cuya naturaleza no se encuentra definida y se encuentra entre ambos tipos de prueba, la pericial y la testifical ${ }^{243}$. Su declaración en estos casos aportará al juez, por un lado, su visión sobre los hechos de forma directa, y por otro, su valoración como experto en la materia.

\footnotetext{
${ }^{240}$ Bonet Navarro, J.: “La prueba en el proceso civil: cuestiones fundamentales”, cit., pág. 104.

${ }^{241}$ S. no 180/1998 Tribunal Supremo de 2-03-1998 (TOL 5.157.377), confirma la sentencia dictada por la Audiencia e impugnada por la sociedad codemandada-compradora, que condenó a dicha parte a otorgar escritura pública de compraventa de las viviendas litigiosas con entrega de posesión y simultáneamente, previo a tal acto de otorgamiento el importe del precio que quedaba por pagar. Siéndole imputable al recurrente la falta de práctica de la prueba de testigos propuesta y admitida, fue valorada por la Audiencia considerando que la voluntad de las partes fue distinta a la manifestada en los contratos celebrados de viviendas en el edificio en construcción que se vendía, lo que indica que a pesar que la literalidad del contrato no recogía esa asunción, que puede prevalecer frente a una probada voluntad en contrario.

${ }^{242}$ Aragoneses Martínez, S., Cubillo López, I., Hinojosa Segovia, R., Peiteado Mariscal, P., Tomé García, J.A.: "Cien cuestiones controvertidas sobre la prueba en el proceso civil”, cit., pág. 77.

${ }^{243}$ Aragoneses Martínez, S., Cubillo López, I., Hinojosa Segovia, R., Peiteado Mariscal, P., Tomé García, J.A.: "Cien cuestiones controvertidas sobre la prueba en el proceso civil", cit., pág. 80.
} 
A nuestro entender la prueba testifical tiene su importancia y es complemento de los otros medios de prueba que se puedan practicar, de forma que si las declaraciones son coincidentes con el resto de prueba se dota a la resolución judicial de mayor objetividad ${ }^{244}$.

\section{e. Prueba pericial (arts. 335 a 352 ).}

Esta prueba es de especial trascendencia ${ }^{245}$ debido a que un tercero imparcial, con conocimientos sobre la materia, expondrá su parecer acerca de la controversia ${ }^{246}$, y esta opinión, será muy importante para que el juez pueda tomar postura ${ }^{247}$.

El momento de presentación de la pericia estará relacionado con la clase de procedimiento por el que deba ventilarse la cuestión; la introducción del informe se realizará en el propio escrito de demanda o contestación, tal como establece el art. 336 de la LEC. Si la necesidad de dictamen pericial viene determinada por el contenido del escrito de contestación a la demanda, su aporte se realizará al menos con cinco días de antelación al día de celebración del juicio o de la vista, tal como establece el art. 338.2 de la LEC.

En relación a las exigencias propias que deben reunir los dictámenes, se establecen en el art. 338 apdo. $2^{\circ}$ de la LEC, donde consta que el dictamen debe formularse por escrito acompañado de los documentos, instrumentos o materiales adecuados para exponer su argumentación, conteniendo las suficientes indicaciones sobre lo narrado en el mismo.

El dictamen que emita el perito, será el que permita valorar los hechos o circunstancias relevantes del proceso, intentando que el juez a través de este medio adquiera certeza sobre los hechos ${ }^{248}$.

\footnotetext{
${ }^{244}$ Sanchís Crespo, C.: "La prueba en los procesos de consumo”, en Barona Vilar, S. (coord.), Calderón Cuadrado M.P., Sanchis Crespo, C., Jiménez Fortea F.J., Martínez García, E., Pardo Iranzo V., Pascual Serrats, R., Andrés Ciurana B., García Vila, M., González Malabia S.: "Tutela de los consumidores y usuarios en la nueva LEC: cit., pág. 311.

${ }^{245}$ Díaz Fuentes, A.: “La prueba en la nueva Ley de Enjuiciamiento Civil”, cit., pág. 239.

${ }^{246}$ Etxebarría Guridi, J.F.: “Las facultades judiciales en materia probatoria en la LEC”, cit., pág. 338.

${ }^{247}$ Barona Vilar, S.: “Competencia Desleal. Tomo II”, cit. Epígrafe VII. II. Cap. VII. “Algunas cuestiones en torno al proceso civil sobre competencia desleal: II. Práctica de la prueba en los procesos en materia de competencia desleal”, págs. 1685 y ss.

${ }^{248}$ Abel Lluch, X. y Picó Junoy, J.: “Aspectos prácticos de la prueba civil”, cit., pág. 53 y ss.
} 
Al perito, tal como establece el art. 340 de la LEC se le exige un título oficial, que se corresponda con la materia objeto del dictamen y con la naturaleza del mismo ${ }^{249}$.

También puede darse la posibilidad de que el perito sea persona jurídica, tal es el caso de una institución cultural, artística, profesional, etc. Para ello se requiere, como establece el art. 340.2 y 3, habilitación legal.

Su designación se puede realizar tanto por las partes como por el propio tribunal cuando una o ambas partes lo soliciten ${ }^{250}$. En base a ello son dos las clases de dictámenes periciales: los elaborados por peritos designados por las partes (arts. 336 a 338 LEC), y aquellos que se realizan por peritos de designación judicial, regulados en los arts. 339, 341 y 342 LEC 251 .

El juez o la parte o partes que lo hayan propuesto deberán concretar si la persona física del perito debe o no acudir al acto del juicio, al objeto de explicar su valoración del dictamen y someterse a las cuestiones que las partes y el propio juez consideren oportunas al objeto de esclarecer los hechos ${ }^{252}$.

\section{En relación a los aportados por las partes.}

Las propias partes tienen una función de vital importancia en la prueba pericial para que esta sirva de fundamento a su pretensión, debiendo alegar y probar los hechos, así como dirigir o guiar la función del perito de forma que aporte elementos a la decisión del juez o tribunal y procurando que la prueba se desarrolle sobre los hechos controvertidos ${ }^{253}$.

\footnotetext{
${ }^{249}$ Aragoneses Martínez, S., Cubillo López, I., Hinojosa Segovia, R., Peiteado Mariscal, P., Tomé García, J.A.: "Cien cuestiones controvertidas sobre la prueba en el proceso civil", cit., pág. 77.

${ }^{250}$ Aragoneses Martínez, S., Cubillo López, I., Hinojosa Segovia, R., Peiteado Mariscal, P., Tomé García, J.A.: "Cien cuestiones controvertidas sobre la prueba en el proceso civil", cit., pág. 97; Etxebarría Guridi, J.F.: “Las facultades judiciales en materia probatoria en la LEC”, cit., pág. 342.

${ }^{251}$ Díaz Fuentes, A.: “La prueba en la nueva Ley de Enjuiciamiento Civil”, cit., pág. 304.

${ }^{252}$ Barona Vilar, S.: “Competencia Desleal. Tomo II”, cit., Epígrafe VII. II. Cap. VII. Algunas cuestiones en torno al proceso civil sobre competencia desleal: II. Práctica de la prueba en los procesos en materia de competencia desleal”, págs. 1685 y ss.

253 Abel Lluch, X. y Picó Junoy, J.: “Aspectos prácticos de la prueba civil”. Ed.: Bosch Procesal, Barcelona 2006, pág. 397 y ss.
} 
En relación al momento de la presentación de la pericia en el proceso está condicionado por la naturaleza de las relaciones jurídicas en conflicto, así como por la clase de prueba pericial que deba practicarse y la clase de proceso de que se trate.

El momento de presentar los dictámenes en el juicio verbal será junto al escrito de demanda, si lo presenta el actor o tan pronto como obren en poder de la parte, siempre antes del acto del juicio, para que pueda darse traslado a la otra parte y tener constancia del mismo antes de su celebración ${ }^{254}$. Por su parte el demandado podrá solicitarlo bien en la contestación, o en el acto del juicio, lo cual obliga a que este se encuentre ya in situ, por si el juez acuerda su declaración.

En el juicio ordinario como regla general se presentarán en los escritos iniciales, igual que en el juicio verbal, y cabe, además, de forma excepcional su presentación posterior, siempre con antelación suficiente a la celebración de la vista previa. Para ello, la parte que lo aporte deberá justificar la imposibilidad de obtenerlos y presentarlos en ese momento.

La justificación de tal exigencia se encuentra en la protección del derecho de la otra parte de forma que, en el momento de proponer y admitir prueba, se pueda pedir otra prueba complementaria por la parte contraria, o bien un dictamen pericial.

Los peritos propuestos por las partes pueden ser tachados al objeto de controlar su imparcialidad. La argumentación de la tacha estará en relación a la afirmación y prueba de que concurren circunstancias que hacen que la persona nombrada para ejercer como perito pueda no ser imparcial.

La tacha no excluye que el perito pueda realizar su función ${ }^{255}$, ni priva a priori de valor al dictamen, pero su alegación puede ser tenida en cuenta por el juez al dictar la sentencia.

\footnotetext{
254 Aragoneses Martínez, S., Cubillo López, I., Hinojosa Segovia, R., Peiteado Mariscal, P., Tomé García, J.A.: “Cien cuestiones controvertidas sobre la prueba en el proceso civil”, cit., pág. 111.

${ }^{255}$ Díaz Fuentes, A.: “La prueba en la nueva Ley de Enjuiciamiento Civil”, cit., pág. 266.
} 


\section{La designación judicial del perito.}

Si las partes solicitan la designación de peritos al propio tribunal, esta se realizará por el actor en el juicio verbal en el propio escrito de demanda ${ }^{256}$ o si lo solicita el demandado, puede hacerlo dentro del plazo de cinco días que el Tribunal concede a las partes para proponer prueba en el Decreto de admisión y citación al acto de juicio.

En el proceso ordinario la petición de designación judicial del perito puede realizarse en dos momentos procesales: en la demanda o contestación y también en el acto de la vista previa.

En este caso, el dictamen se lleva a cabo sobre un proceso ya pendiente, pudiendo incluso versar sobre un acto de reconocimiento de objetos, de personas, o de comprobación en laboratorio por medios demoscópicos ${ }^{257}$.

Una vez emitido por escrito el dictamen pericial, el juez dará traslado a ambas partes, con el fin de que puedan solicitar la intervención en juicio del perito para que realice las aclaraciones oportunas. El juez podrá pronunciarse tanto a favor de su declaración en el juicio, o considerar que dicha intervención no es necesaria porque el informe es suficientemente esclarecedor.

Respecto a los peritos nombrados por el propio juzgado, su imparcialidad se garantiza por medio de la abstención y la recusación ${ }^{258}$, tal como establece el art. 105 LEC, que expresa que el perito deberá abstenerse si concurren las causas previstas; si no lo hiciera, cabe la recusación regulada en el art. 124 LEC 259.

En cuanto a la validez que dará el juez a la prueba pericial presentada por la parte, o a la designada por el juzgado, se considera que dará más crédito a la pericial solicitada a través del juzgado, por

\footnotetext{
${ }^{256}$ Aragoneses Martínez, S., Cubillo López, I., Hinojosa Segovia, R., Peiteado Mariscal, P., Tomé García, J.A.: “Cien cuestiones controvertidas sobre la prueba en el proceso civil”, cit., pág. 104.

257 Aragoneses Martínez, S., Cubillo López, I., Hinojosa Segovia, R., Peiteado Mariscal, P., Tomé García, J.A.: "Cien cuestiones controvertidas sobre la prueba en el proceso civil”, cit., pág. 108.

${ }^{258}$ S. ${ }^{0}$ 152/2003, Sec. $7^{\text {a }}$ AP Alicante de 25-3-2003 (TOL 274.977) entiende que las causas de recusación son taxativas y que por lo tanto no se puede hacer una interpretación extensiva de las mismas.

259 Aragoneses Martínez, S., Cubillo López, I., Hinojosa Segovia, R., Peiteado Mariscal, P., Tomé García, J.A.: "Cien cuestiones controvertidas sobre la prueba en el proceso civil”, cit., pág. 121.
} 
estar el perito dotado de las garantías de imparcialidad necesarias en el momento de realizar el peritaje.

\section{Breve puntualización sobre el desarrollo de la pericial informática.}

Para el desarrollo de la pericial informática, por tratarse de la adquisición de datos, es recomendable que la prueba sea obtenida a presencia de testigos y se deposite en una notaría mediante un acta de manifestaciones del perito en la que se detalle el proceso de obtención de la información digital a cuyo efecto es conveniente que el perito, amén de la elevada calificación técnica, atesore un mínimo de conocimiento de la normativa legal ${ }^{260}$.

Además, es fundamental la conservación de las copias y la constatación de las técnicas empleadas para garantizar la integridad de la información obtenida.

Es tipo de prueba va precedida de una investigación pericial para la concreción de la prueba informática a realizar, debiendo implicarse el perito desde el primer momento en la preparación de la información.

\section{a. Reconocimiento judicial.}

Este medio de prueba tiene relevancia cuando se precisa de un examen concreto de elementos fácticos de forma personal. Regulado en los arts. 353 a 359 de la LEC, es la prueba en que el tribunal examina por sí mismo el lugar, objeto o persona, con la finalidad de esclarecer hechos relevantes. Este puede ofrecer al juzgador un plus de convicción, al poder ver por sí mismo algo de extraordinaria relevancia para la resolución del proceso, pudiendo de este modo dictar la sentencia con un conocimiento directo que le confiera mayor convicción, junto a percepción exacta de la realidad ${ }^{261}$.

La prueba de reconocimiento se podrá proponer en el acto de vista previa en el juicio ordinario, o en el acto del juicio, en el verbal, siendo de interés que se precisen los extremos sobre los que deba extenderse, indicando además si al acto acudirá algún técnico en la

\footnotetext{
${ }^{260}$ Abel Lluch, X., Picó i Junoy, J., Richard González, M., (Dir.): “La prueba judicial. Desafíos en las jurisdicciones civil, penal, laboral y contencioso-administrativa”, cit., págs. 356 y 357.

${ }^{261}$ Díaz Fuentes, A.: “La prueba en la nueva Ley de Enjuiciamiento Civil”, cit., pág. 281.
} 
materia, en el caso de que se trate de reconocimiento de productos 0 maquinaria 262 .

Aunque el reconocimiento podría ser útil en los procesos de consumo, al objeto de valorar las consecuencias producidas en servicios o bienes, se utiliza en mayor medida la pericial por dotar al tribunal de conocimientos especializados ${ }^{263}$.

A su vez el reconocimiento puede ser también medio para incorporar fuentes de prueba electrónicas valiéndose de la percepción de datos de forma digital. La evidencia digital, aludiendo al art. 353 de la LEC, podrá ser utilizada como reconocimiento de un lugar y se lleva a cabo a través de la navegación por la red o ciber navegación.

El art. 353.2 LEC incluso establece la posibilidad de que sea el juez quien determine la amplitud del reconocimiento ${ }^{264}$, más allá de lo especificado por las partes.

Su práctica seguirá las reglas establecidas en el art. $354^{265}$, y se documentará en acta lo actuado, dejando constancia de ello el Letrado de la Administración de Justicia. Esta acta tiene una función distinta, dependiendo de si el juez que realiza el reconocimiento va a ser el mismo que deba dictar sentencia, o si será otro juez quien la dicte, siendo la función del acta en este último caso la de servir de convicción del resultado en ella plasmado.

\section{b. Las presunciones.}

Es necesario realizar un breve apunte sobre ellas dada la importancia y la aplicación que se realiza en los procesos de consumo.

\footnotetext{
${ }^{262}$ Bonet Navarro, J.: "La prueba en el proceso civil: cuestiones fundamentales”, cit., pág. 102. Ed.: difusión Jurídica, Madrid 2009.

${ }^{263}$ Martínez García, E.: “Tutela de los Consumidores y Usuarios en la nueva Ley de Enjuiciamiento Civil”, cit., pág. 354.

${ }^{264}$ Etxebarría Guridi, J.F.: “Las facultades judiciales en materia probatoria en la LEC”, cit., pág. 347; S. $n^{\circ}$ 435/2007 Tribunal Supremo de 16-4-2007 (TOL. 1.069.814).

${ }^{265}$ Abel Lluch, X., Picó i Junoy, J.: “La prueba de reconocimiento judicial”, cit., pág. 375; Abel Lluch, X., Picó i Junoy, J., Richard González, M., Dir.): "La prueba judicial. Desafíos en las jurisdicciones civil, penal, laboral y contencioso-administrativa”, cit., págs. 356 y 357; Aragoneses Martínez, S., Cubillo López, I., Hinojosa Segovia, R., Peiteado Mariscal, P., Tomé García, J.A.: “Cien cuestiones controvertidas sobre la prueba en el proceso civil”, cit., pág. 190.
} 
Las presunciones, que consisten en un método probatorio y no en una verdadera actividad probatoria, según Montero Aroca se basan en la posibilidad de llegar a afirmar la existencia de un hecho, partiendo de otro hecho aceptado por ambas partes (el indicio o base) o que se haya demostrado en el proceso ${ }^{266}$, y se obtienen a partir de hechos, cosas o personas relacionados con el objeto de prueba ${ }^{267}$.

En la misma línea doctrinal, Serra Domínguez entiende que las presunciones se encuentran entre la apreciación y la carga de la prueba, independientes a su vez de ambas instituciones ${ }^{268}$.

Debido a su condición de método probatorio y no de verdadero medio de prueba, tal como constan descritas incluso en la propia Exposición de Motivos de la LEC, no se encuentran recogidas entre los medios de prueba que establece el art. $299^{269}$.

Las presunciones aludidas, establecidas en el art. 386.1 de la LEC son las denominadas judiciales, que serán consideradas por el Juez ${ }^{270}$, y para llegar a ellas será necesaria una labor intelectual de análisis, tanto de los hechos como del resto de pruebas si las hubiere.

\footnotetext{
${ }^{266}$ Montero Aroca, J.: “La prueba en el proceso civil”, cit., pág. 176; Gómez Colomer, J.L. en Montero Aroca, J., Gómez Colomer, J.L., Barona Vilar, S., Calderón Cuadrado, M.P.: "Derecho Jurisdiccional II. Proceso Civil", cit., pág. 304 a 308. Serra Domínguez, M.: "Normas de presunción en el Código Civil y Ley de Arrendamientos Urbanos”. Ed.: Ediciones Nauta, S.A., Barcelona 1963, pág. 39.

${ }^{267}$ De la Oliva Santos, Díez Picazo Giménez, I.: "Derecho Procesal Civil: El proceso de declaración conforme a la Ley 1/2000, de 7 de enero de Enjuiciamiento Civil”. Ed.: Centro de Estudios Ramón Areces, S.A., Madrid 2003, pág. 375.

${ }^{268}$ Serra Domínguez, M.: "Normas de presunción en el Código Civil y Ley de Arrendamientos Urbanos". Ed.: Ediciones Nauta, S.A., Barcelona 1963, pág. 62.

${ }^{269}$ S. no 432/2003 TS de 30-04-2003 (TOL 275.461) desestima el recurso de casación deducido por la mercantil suministrada y condenada en primera y segunda instancia a pagar el precio de las mercancías despachadas por la demandante. La prueba del incumplimiento se ha deducido de la valoración del material aportado a las actuaciones, sin tener que acudir a la prueba de presunciones. La actora sí probó que la mercancía fue entregada a la demandada, de modo que no hay falta de prueba, sino completa prueba, por lo que corresponde a la recurrente asumir la carga de la prueba de los hechos impeditivos y extintivos.
}

${ }^{270}$ Así ha sido considerado en un caso de resolución de contrato de arrendamiento por la Sec. $10^{\text {a }}$ de la AP Madrid de 26-03-2002 (TOL 200.707), manifestando que a falta de otras pruebas contundentes y aun teniendo en cuenta que, en estos supuestos, por la dificultad que entrañan, adquieren especial relevancia la prueba de presunciones y las pruebas indiciarias.

Otro ejemplo de la aplicación de las presunciones lo encontramos en la S. no 432/2003 TS de 30-042003(TOL 275.461), que desestima el recurso de casación deducido por la mercantil suministrada y condenada en primera y segunda instancia a pagar el precio de las mercancías despachadas por la demandante. Entiende que la prueba del incumplimiento se ha deducido de la valoración del material 
Se caracterizan porque el nexo causal entre los hechos base y presunto lo determina la labor del juzgador en el propio procedimiento a partir de un hecho admitido o demostrado, encontrando un enlace directo entre este y otro hecho del proceso que no ha sido directamente probado ${ }^{271}$.

Una de las peculiaridades en su aplicación es que las presunciones operan siempre con carácter supletorio ante la imposibilidad de prueba por medios ordinarios de los hechos que deduciremos a través de la presunción ${ }^{272}$.

Existen también las denominadas "presunciones legales", establecidas en los arts. 1249 a 1253 del C.c. que dispensan de la prueba del hecho presunto a la parte que favorece, y sólo serán admisibles cuando la certeza del hecho-indicio del que parte la presunción haya quedado establecida mediante admisión o prueba ${ }^{273}$.

La parte que la alegue deberá fijar el hecho base invocando la norma en que basa la presunción, pudiendo ser objeto de impugnación probando su inexistencia ${ }^{274}$. De hecho, algunos autores como de la Oliva Santos 275 , consideran que la parte a quien perjudique una presunción podría proponer prueba para enervarla en la audiencia previa, porque la parte favorecida tendría una suerte de

aportado a las actuaciones, sin tener que acudir a la prueba de presunciones. La actora sí probó que la mercancía fue entregada a la demandada, de modo que no hay falta de prueba, sino prueba completa, por lo que corresponde a la recurrente asumir la carga de la prueba de los hechos impeditivos y extintivos.

271 Cordón Moreno, F., Armenta Deu, T., Muerza Esparza, J.J., Tapia Fernández, I. (coord.): “Comentarios a la Ley de Enjuiciamiento Civil”. Vol. I. Ed.: Aranzadi, Navarra 2001, pág. 1289.

272 Álvarez Sánchez de Movellán: “La prueba por presunciones. Particular referencia a su aplicación en supuestos de responsabilidad extracontractual”. Ed.: Comares, Madrid 2007, pág. 101.

273 Bonet Navarro, J.: “La prueba en el proceso civil: cuestiones fundamentales”. Ed.: Difusión Jurídica, Madrid 2009, pág. 151; Uriarte Codón, A.: “La inversión de la carga de la prueba, objeto y carga de la prueba civil”. Publicación V Lex Basic 2007, cit., págs. 103 a 107; Abel Lluch, X.: “Derecho Probatorio", cit., pág. 439; Serra Domínguez, M.: "Normas de presunción en el Código Civil y Ley de Arrendamientos Urbanos”, cit., pág. 69; Bonet Navarro, J.: "La prueba en el proceso civil: cuestiones fundamentales”, cit., pág. 151; Abel Lluch, X.: “Derecho Probatorio”, cit., pág. 439; Aragoneses Martínez, S., Cubillo López, I., Hinojosa Segovia, R., Peiteado Mariscal, P., Tomé García, J.A.: “Cien cuestiones controvertidas sobre la prueba en el proceso civil”. Ed.: Colex, Madrid 2004, pág. 48.

${ }^{274}$ Díaz Fuentes, A.: “La prueba en la nueva Ley de Enjuiciamiento Civil”. Ed.: Bosch, Barcelona 2002, pág. 362.

275 De la Oliva Santos, A., Díez- Picazo Giménez, I, Vegas Torres, J., Banacloche Palao, J.: “Comentarios a la Ley de Enjuiciamiento Civil”, Ed.: Civitas, Madrid 2001, pág. 649. 
obligación de solicitar la aplicación de la presunción en su escrito de alegaciones ${ }^{276}$.

Las presunciones introducidas al proceso por cualquiera de las partes son aplicadas, al igual que las judiciales, por el juez según su criterio en relación a las partes y al proceso 277 , y vienen a dispensar de la carga de probar hechos, extrayendo unas consecuencias jurídicas ${ }^{278}$.

Dentro del análisis de esta especialidad probatoria, hemos de hacer también alusión a la apariencia de falsas presunciones, que son aquellas que no contienen las exigencias necesarias de la presunción para que pueda considerarse tal, cual es la existencia de un hecho cierto, que es el indicio que ha sido probado, y a partir del cual se deriva otro hecho ${ }^{279}$, que en los supuestos analizados se concreta, como ya hemos aludido, en la prueba del nexo causal ${ }^{280}$.

Como último apunte de las presunciones, tan sólo hacer alusión a su posible revisión en casación, entendida por la jurisprudencia como limitada. Así la Sentencia no 931/2006 del TS, de 28 de septiembre de 2006 (TOL 1.014.554), considera que sólo se pueden desarrollar cuando las hayan utilizado los tribunales de instancia en ausencia de prueba directa y para suplir esta.

\section{K. DI LI GENCI AS FI NALES}

Se refieren a ellas los arts. 435 y 436 de la LEC, y serán autorizadas por el juez por su valor esencial en el proceso para

\footnotetext{
${ }^{276}$ S. $n^{\circ}$ 313/2003, Sec. $8^{\text {a }}$ AP Valencia de $19-05$ y n $^{\circ}$ 788/2003 de 15-12-2003 (TOL 321.716 y TOL 436.345).

277 También en la S. no 477/13 del Juzgado de Primera Instancia no 71 de Madrid de 11-04-2013 (JUR 2014/206375) relativa a la nulidad de un contrato de suscripción de participaciones preferentes, el juzgado consideró necesario acudir a las presunciones al objeto de valorar la conducta de los empleados en relación al asesoramiento al cliente sobre la adquisición del producto. Presumió este hecho, lo cual tuvo por confirmado al no ser desvirtuado por la parte demandada, y ello lo dedujo de la declaración testifical de un empleado.

${ }^{278}$ Forner Delaygua, J.J.: "La prueba de los hechos en el proceso: aspectos de ley aplicable”. Ed.: Bosch, Barcelona 2005, pág. 154.

${ }^{279}$ Bonet Navarro, J.: “La prueba en el proceso civil: cuestiones fundamentales”. Ed.: Difusión Jurídica, Madrid 2009, cit., pág. 238.

280 S. no 120/2009, TS de 19 de febrero de 2009 (TOL 1.452.539), S. n ${ }^{\circ}$ 1242/2007, TS de 4-12-2007 (TOL 1.256.811).
} 
llevarse a efecto dentro de los veinte días siguientes a la celebración del juicio ${ }^{281}$.

Suponen una facultad de las partes, y en último término, del propio juez, de practicar prueba que no pudo proponerse 0 practicarse en el momento establecido para cada tipo de proceso, siempre que se dé alguno de los supuestos que establece el art. 435.

Con la realización de esta actividad probatoria posterior se pretende completar toda la posible prueba en el proceso con el fin de que el juez cuente con todos los elementos necesarios para dictar resolución ${ }^{282}$.

Puede admitirse de forma excepcional la presentación de documentos como diligencia final, siempre que concurran las condiciones a que se refiere el art. 270 LEC:

- ser el documento de fecha posterior a la demanda o contestación, siempre que no lo hubiesen podido obtener con anterioridad a dichos momentos procesales;

- tratarse de documentos anteriores a la demanda, la contestación o la vista previa cuando la parte justifique no haber tenido antes conocimiento de su existencia;

- no haber sido posible obtener con anterioridad los documentos, medios o instrumentos, por causas que no sean imputables a la parte, siempre que haya hecho oportunamente la designación ${ }^{283}$.

\footnotetext{
${ }^{281}$ Etxebarría Guridi, J.F.: "Las facultades judiciales en materia probatoria en la LEC”, cit., pág. 371. Por su parte, lLa S. no 126/2005, Sec. $5^{\text {a }}$ AP Málaga de 25-02-2005 (TOL 659.647) manifiesta que la ley prevé la adopción de diligencias finales a criterio del juzgador y previa petición de parte, siendo el órgano judicial el que adopta la decisión en función del conjunto probatorio y de las posibilidades de dictar resolución acorde con las pretensiones de las partes.

${ }^{282}$ Barona Vilar (coord.), Calderón Cuadrado M.P., Sanchís Crespo, C., Jiménez Fortea, F.J., Martínez
García, E., Pardo Iranzo, V., Pascual Serrats, R., Andrés Ciurana, B., García Vila, M., González Malabia,
S.: “Tutela de los consumidores y usuarios en la Nueva LEC", cit., pág. 285; Gómez Colomer, J.L. en
Montero Aroca, J., Gómez Colomer, J.L., Barona Vilar, S., Calderón Cuadrado, M.P.: "Derecho
Jurisdiccional II. Proceso Civil”, Ed.: Tirant lo Blanch, Valencia 2015, pág. 309; Aragoneses Martínez,
S., Cubillo López, I., Hinojosa Segovia, R., Peiteado Mariscal, P., Tomé García, J.A.: “Cien cuestiones
controvertidas sobre la prueba en el proceso civil”, cit., pág. 34; Montero Aroca, J.: "La prueba en el
proceso civil”, cit., pág. 551-552; Díaz Fuentes, A.: "La prueba en la nueva Ley de Enjuiciamiento Civill,
cit., pág. 104.
}

${ }^{283}$ Etxebarría Guridi, J.F.: “Las facultades judiciales en materia probatoria en la LEC”, cit., pág. 333. 
Una vez finalizada la práctica, las partes podrán, dentro del quinto día, presentar escrito en que resuman y valoren el resultado de estas diligencias (art. 436.1 LEC).

\title{
L. VALORACIÓN DE LA PRUEBA
}

Como ya hemos indicado en páginas anteriores, toda la actividad probatoria se dirige a convencer al juez de la veracidad de los argumentos esgrimidos por la parte que la propone ${ }^{284}$.

La valoración consta de dos momentos, el de apreciación o interpretación, al que le sigue la valoración en sentido estricto ${ }^{285}$, por ello, el tribunal, al dictar resolución valorará la certeza que ha alcanzado en relación a determinado hecho ${ }^{286}$, así como la facilidad de acceso de cada parte al medio de prueba, y aplicará las consecuencias desfavorables de esta teniendo en cuenta la circunstancia expresada 287 .

En un primer momento el juzgador analiza de forma separada las pruebas para establecer los elementos que proporciona cada una, las características particulares de cada medio y las incidencias acaecidas durante su práctica, viendo las afirmaciones que de la prueba cabe extraer ${ }^{288}$.

\footnotetext{
${ }^{284}$ Bonet Navarro, J.: “La prueba en el proceso civil: cuestiones fundamentales”, pág. 238.

${ }^{285}$ Forner Delaygua, J.J.: "La prueba de los hechos en el proceso: aspectos de ley aplicable”. Ed.: Bosch, Barcelona 2005, pág. 112; Stein, F.: "El conocimiento privado del juez". Ed.: Centro de Estudios Ramón Areces, S.A., Madrid 1990, pág. 82 y 95; Abel LLuch, X.: "La valoración de la prueba en el proceso civil”. Ed.: La Ley, Madrid, 2014, pág.
}

\begin{abstract}
${ }^{286}$ La S. no 1243/2007, TS de 4-12-2007 (TOL1.256.811), publicada en la Revista de Estudios de Consumo núm. 84 de 2008, en un tema de responsabilidad civil por una transfusión de sangre contaminada con el virus de la hepatitis C, considera que la prueba practicada debe analizarse por el juzgador de instancia y no en casación. La misma posición se repite en otras sentencias del TS como la $\mathrm{n}^{\circ}$ 951/2006, de 4-10-2006 (TOL 1.014.503), añadiendo además que la valoración de la prueba se regirá por lo dispuesto en los arts. 316, 319, 326, 334, 348, 376 y 384 de la LEC.
\end{abstract}

${ }^{287}$ En este sentido es ilustrativa la S. $n^{\circ}$ 202/2011, Sec. $8^{a}$ de la AP Valencia, de 11-04-2011 (TOL 2.159.112), en un supuesto de producto defectuoso, donde el juzgador, al proceder a la valoración conjunta de la prueba, observó la falta de prueba de que los defectos no se produjeron dentro del periodo de garantía, considerando la carencia de una prueba técnico hubiera ilustrado al tribunal sobre la causa del defecto, demostrando que el vicio era originario y no ocasionado por un uso indebido.

${ }^{288}$ Díaz Fuentes, A.: “La prueba en la nueva Ley de Enjuiciamiento Civil”, cit., pág. 160; Abel Lluch, X.: "Derecho Probatorio", cit., pág. 32; Taruffo M.: "La prueba de los hechos”. Ed.: Trotta, Bolonia, 2002, pág. 398; Sentis Melendo, S.: "La prueba. Los grandes tratados de Derecho Probatorio". Ed.: Ediciones Jurídicas Europa-América, Buenos Aires, 1979, pág.269; Montero Aroca, J.: "La prueba en el proceso civil”, cit., pág. 610 . 
La labor de valoración se concreta en la necesidad de motivación de la sentencia impuesta por la propia CE (art. 120.3). En el sistema español se combinan para valorar la prueba la aplicación de ciertas reglas legales con criterios de la sana crítica ${ }^{289}$. Por ello, existe un sistema de valoración de la prueba que Montero Aroca, Gómez Colomer o Jiménez Conde, entre otros, denominan "mixto" 290.

El juez para formar su convicción sobre los hechos del proceso y la prueba practicada cuenta con las denominadas "máximas de la experiencia" que según Stein ${ }^{291}$, son definiciones o juicios hipotéticos de contenido general que forman parte de los principios del Derecho y son aceptadas por interpretar los hechos y resolver la situación jurídica ${ }^{292}$.

Concretamente 293 , se otorga valor legal a unos medios de prueba, como el interrogatorio de parte o la documental, aunque el juez realizará su propia valoración en el interrogatorio de hechos personales no perjudiciales para el que declara, así como en relación a los documentos privados impugnados sobre los que no se haya

\footnotetext{
${ }^{289}$ La S. $n^{\circ}$ 56/2007 del JPI $n^{\circ} 10$ de Murcia de 2-03-2007 (AC 2007/840) considera que la fuerza probatoria de los dictámenes periciales reside no en sus afirmaciones ni en la condición, categoría o número de sus autores, sino en su mayor o menor fundamentación y razón de ciencia, debiendo ser prevalentes las afirmaciones o conclusiones que vengan dotadas de una superior aplicación racional, sin olvidar los criterios auxiliares como el de la mayoría coincidente o el del alejamiento del interés de las partes. Junto a ello, no puede omitirse la transcendente relevancia probatoria de los dictámenes médicoforenses emitidos, los cuales, si bien no pueden tener por sí mismos valor decisorio en el proceso civil, sus cualidades imponen que su contenido sea inexcusable referencia para resolver la contradicción de los dictámenes periciales aportados por las partes en los que fundamenten distinta valoración de unos mismos hechos.
}

290 S. del JPI no 12de Barcelona de 27-09-2006 (TOL 1.005.510), y S. $n^{\circ}$ 345/2005 de la Sec. $3^{\text {a }}$ AP de Vizcaya, de 18-05-2005 (TOL 701.903), ambas consideran que para valorar la prueba pericial en base a la sana crítica del juzgador, deben ponderar los razonamientos que contengan los dictámenes, los que se hayan vertido en el acto del juicio o vista en el interrogatorio de peritos, pudiendo aceptar o no aceptar el dictamen, o bien, aceptar uno de los aportados por estar mejor fundamentado que otro, teniendo en cuenta además, según la S. no 84/1994 TS, de 10-02-1994 ( TOL 1.664.886), las conclusiones de los dictámenes y la motivación de su decisión, así como los medios o instrumentos empleados y los datos en que se apoyen los dictámenes como considera la S. no 8/1995 TS de 28-01-1995 (TOL 1.667.060), así como el resto de circunstancias que hagan presumir su objetividad.

${ }^{291}$ Stein, F.: “El conocimiento privado del juez”, cit., pág. 82.

${ }^{292}$ S. no 101/2000, Sec. $3^{\text {a }}$ AP Córdoba 7-04-2000 (EDJ 2000/238719) desestima el recurso de apelación contra la sentencia de primera instancia que estimó la demanda de reclamación de cantidad, indicando que la valoración y apreciación de la prueba corresponde al juzgador de instancia de manera libre y según las reglas de la sana crítica, sin que las deducciones sean ilógicas o arbitrarias, por lo que si alcanza una conclusión de tal modo y el recurrente no aporta razones que la puedan desvirtuar, debe mantenerse lo señalado por el Juez.

${ }^{293}$ Gómez Orbaneja, E.: “Derecho Procesal civil I”. Ed.: Artes Gráficas, Madrid, 1962, pág. 297. 
podido establecer su autenticidad, también en relación a las copias reprográficas cuando no se puedan cotejar, y en relación a los dictámenes periciales, la prueba testifical, los soportes informáticos así como los medios de reproducción de imagen y sonido.

a. Resulta interesante en relación al interrogatorio de parte, la apreciación de Abel Lluch en el sentido de que el juez debe evitar deducciones prematuras a partir del aspecto físico de la parte, así como otras circunstancias relativas al modo de realizar la declaración ${ }^{294}$. En el caso de que el interrogado reconozca determinados hechos en los que intervino personalmente, si no se contradicen con las demás pruebas ${ }^{295}$ y su fijación le resulta perjudicial, se considerarán ciertos (art. 316.1 de la LEC).

b. En cuanto a los documentos públicos, no existe duda sobre ellos, harán prueba plena del hecho, acto o estado de cosas que documenten ${ }^{296}$, tal como establece el art. 326.1 de la LEC, así como de su fecha e identidad del fedatario público y de las personas que intervengan ${ }^{297}$ (art. 319.1 de la LEC), aunque su valor no es absoluto y podría verse desvirtuado por las demás pruebas que se presenten.

Con respecto al documento público electrónico, presenta una especial problemática en cuanto a su autenticidad y a su conservación íntegra, salvo los realizados con firma reconocida del notario o fedatario público interviniente, que tendrán la misma consideración y validez que el documento público en papel ${ }^{298}$.

\footnotetext{
${ }^{294}$ Abel Lluch, X.: “La valoración de la prueba en el proceso civil”, cit., pág. 63.

${ }^{295}$ La S. no 821/1997, Sec. 6 ${ }^{\text {a }}$ AP Valencia de 6-10-1997 (TOL 3.624.619) considera que, como la confesión judicial, en nuestro ordenamiento jurídico no se adhiere al sistema de prueba tasada, no puede ser considerada como la reina de las pruebas, sino que ha de ser valorada conjuntamente con los demás medios probatorios.
}

\footnotetext{
${ }^{296}$ La S. nº 599/2010, Sec. $10^{\circ}$ AP Madrid de 15-12-2010 (TOL 2.055.922) en relación a la valoración probatoria efectuada por los órganos judiciales de instancia al configurar el "factum" de sus resoluciones, entiende que los documentos privados tienen su fuerza probatoria y son de libre valoración, conforme a las reglas de la sana crítica, si no ha habido impugnación.
}

297 Mora Díaz, R.: “Valoración de la prueba”. Ed.: Noticias Jurídicas, junio 2004, www.noticias.juridicas.com/articulos. Bonet Navarro, J.: "La prueba en el proceso civil: cuestiones fundamentales”, cit., pág. 241; Guerra Pérez, M., Nikolaeva Georgieva, G.: "Proceso civil, documentos y prueba pericial”. Ed.: Sepin, Madrid 2014, pág. 186.

${ }^{298}$ Mora Díaz, R.: "Valoración de la prueba”, www.noticias.juridicas.com/articulos, cit. 
c. Por su parte, la fuerza probatoria de los documentos privados y su autenticidad constituye una cuestión que debe ser objeto de valoración por el tribunal de instancia atendiendo al resto de pruebas ${ }^{299}$, y va a depender como ya hemos referido, de si han sido impugnados, en cuyo caso deberá acreditarse su autenticidad y si no pudiera determinarse, se valorará conforme a las reglas de la sana crítica ${ }^{300}$. De no haber sido impugnados, gozan de la misma eficacia probatoria que el documento público (art. 319 LEC).

Además, debemos distinguir entre aquellos que son registros originales, sobre los que existe presunción de validez, de aquellos documentos o registros informáticos que sólo se presumirán válidos si no existe prueba en contrario a cargo de la parte que los tache de inexactos, tal como establece el art. 427 de la LEC.

Cuestión distinta es la de los nuevos documentos, teniéndose por tales aquellos que se aportan tras la demanda o contestación por ser de fecha posterior o por resultar de interés para la resolución del proceso, a juicio de la parte que los propone.

En estos supuestos, si su autenticidad se cuestiona por la parte contraria o si ha mediado resistencia por la parte que lo aporta, o respuestas evasivas sobre su validez, no carecerán por ello de eficacia probatoria debiendo el juez apreciarlos de un modo u otro en relación a las circunstancias del caso y al resto de pruebas.

Es importante aludir también a la forma de valorar aquellos documentos privados que se generan de forma habitual en las transacciones comerciales actuales, puesto que su valoración tiene un matiz distinto al del documento tradicional.

A este respecto, si la parte contraria procediera a su impugnación tendrá que justificarlo mediante el aporte de prueba pericial de expertos informáticos, al objeto de valorar las

\footnotetext{
${ }^{299}$ Guerra Pérez, M., Nikolaeva Georgieva, G.: “Proceso civil, documentos y prueba pericial”, cit., pág. 189.

${ }^{300}$ Montero Aroca, J., Gómez Colomer, J.L., Barona Vilar, S., Calderón Cuadrado M.P.: "Derecho Jurisdiccional II". Ed.: Tirant lo Blanch, $22^{\mathrm{a}}$ Edición, pág. 270; Abel LLuch, X.: "La valoración de la prueba en el proceso civil", cit., pág. 128.
} 
características del sistema y los registros del documento electrónico presentados $^{301}$.

El ejemplo más común de transacción es la realización de un pedido en una tienda "online" en que se haya producido una reclamación a consecuencia de haberse servido un material defectuoso.

En estos casos, siguiendo a autores como Barriuso Ruíz ${ }^{302}$, el soporte informático que se aportará como documental donde consta tanto la transacción efectuada como la respuesta de la tienda ${ }^{303}$, tal como establece la propia LEC en su art. 384.3, se valorará libremente por el tribunal.

d. Las declaraciones de los testigos 304 deben valorarse según el propio juez, atendiendo a los criterios de la sana crítica y teniendo en cuenta las circunstancias que en ellos concurran, puesto que el testigo cuenta los hechos como los percibió (art. 376) ${ }^{305}$.

e. Por lo que respecta a la valoración del dictamen de peritos ${ }^{306}$ debe interpretarse libremente junto a los documentos,

\footnotetext{
${ }^{301}$ Lotario Vilaboy, L.: "La prueba por medio de los modernos avances científico-tecnológicos en el proceso civil”, cit., pág. 26 a 36.

302 Barriuso Ruiz “La contratación electrónica, Madrid 1998”, cit., págs. 309 a 312.

${ }^{303}$ Barona Vilar, S., Calderón Cuadrado M.P., Sanchis Crespo, C., Jimenez Fortea F.J., Martínez García, E., Pardo Iranzo V., Pascual Serrats, R., Andrés Ciurana B., García Vila, M., González Malabia S.: "Tutela de los consumidores y usuarios en la nueva LEC, artículo de Sanchís Crespo, C.: "La prueba en los procesos de consumo”, cit., pág. 298; Guasp J., Aragoneses, P.: “Derecho Procesal Civil”: Tomo I”, cit., pág. 469; Montero Aroca, J.: "La prueba en el Proceso Civil", cit., pág. 503; Mora Díaz, R.: "Valoración de la prueba", www.noticias.juridicas.com/articulos, cit.; Bonet Navarro, J.: "La prueba en el proceso civil”, cit., pág. 240.
}

${ }^{304}$ S. no 278/2006, Sec. $10^{\text {a }}$ AP Madrid de 19-04-2006, cit. Los tribunales valorarán la fuerza probatoria de las declaraciones de los testigos conforme a las reglas de la sana crítica teniendo en consideración la razón de ciencia que hubieren dado y las circunstancias que en ellos concurran, lo que, al no estar formuladas en la ley o doctrina legal estas reglas equivalen a remitir a la lógica, sensata crítica y experiencia del Juez, siendo tan sólo apreciable la valoración de la credibilidad de los testigos en función del principio de inmediación.

${ }^{305}$ S. n ${ }^{0}$ 567/1999 TS de 22-06-1999 (EDJ 1999/16806). El TS declara no haber lugar al recurso de casación que procede del incumplimiento del contrato de permuta al resultar acreditado que las dos partes contratantes han incumplido dicho contrato. Entiende que se ha tratado de partir de datos fácticos diferentes de los fijados en la resolución objeto del recurso, sin obtener previamente su modificación o integración por parte del Tribunal de Casación. Además, considera que la apreciación de la prueba de testigos es discrecional por el juzgador y no impugnable en casación, pues no se sujeta a reglas de valoración probatoria tasada.

${ }^{306}$ S. $n^{0}$ 8/2010, Sec. $2^{\text {a }}$ AP Lleida de 7-01-2010 (TOL 1.815.415) el Juzgador debe valorar dichos informes según las reglas de la sana crítica, es decir, con criterios lógico-racionales, valorando el contenido del dictamen y no únicamente su resultado, en función de los demás medios de prueba o del 
materiales 0 instrumentos complementarios que se adjunten al mismo y con las observaciones y aclaraciones ofrecidas, tal como ha manifestado la jurisprudencia ${ }^{307}$, realizando una labor de análisis del significado real de los datos y juicios de valor consignados en el informe ${ }^{308}$.

En este sentido, la labor del juez es de análisis del significado real de los datos y juicios de valor consignados en el informe ${ }^{309}$, al objeto de constatar los extremos sobre los que se ha pronunciado el perito ${ }^{310}$.

La doctrina ha considerado que, aunque el juez carezca de conocimientos para verificar la prueba pericial, se basará en conocimientos comunes o especiales, si los tuviera, repasando el dictamen en cuanto a su lógica concatenación y concreción ${ }^{311}$.

f. En lo relativo a la valoración del reconocimiento judicial, no existe en la LEC norma sobre ello, puesto que, al ser una percepción directa del juzgador, su valoración es libre y refleja en

objeto del proceso a fin de dilucidar los hechos controvertidos. En el supuesto que obren en el proceso dictámenes contradictorios, el Juez es soberano para optar por aquel o aquellos que estime más convincentes u objetivos, es decir, que ofrezcan una mayor aproximación a la realidad de los hechos; S. $\mathrm{n}^{\mathrm{o}}$ 275/2013, Sec. $11^{\text {a }}$ de la AP Madrid de 14-05-2013 (TOL 3.795.53).

307 Así se manifiesta desde antiguo en sentencias como la del TS de 15-12-1986 (TOL 1.735.599), la de 19-02-1990 (TOL 1.729.239) y la de la A.P. de Córdoba de 10 de octubre de 2002 (TOL 263.793), o la n ${ }^{\circ}$ 821/1997 de la Sec. 6 a de la A.P. de Valencia de 6-10-1997 (TOL 3.624.619).

${ }^{308}$ Aragoneses Martínez, S., Cubillo López, I., Hinojosa Segovia, R., Peiteado Mariscal, P., Tomé García, J.A.: "Cien cuestiones controvertidas sobre la prueba en el proceso civil", cit., pág. 132; Planchadell Gargallo, A.: "Valoración de la prueba pericial en la Ley 1/2000, de Enjuiciamiento Civil". Revista Española de Derecho Procesal núm. 7/2000, págs. 777 a 788.

${ }^{309}$ S. $n^{\circ}$ 1002/1994, TS de 7-11-1994 (TOL 5.127430), S. n ${ }^{\circ}$ 977/1995, TS de 13-11-1995 (TOL 1.667.764) o la S. $n^{\circ} 358 / 2001$, Sec. $2^{\text {a }}$ AP Toledo de 31-07-2001 (TOL 126.310) señala que es doctrina jurisprudencial consolidada la libre valoración de la prueba pericial por parte de los jueces y tribunales, que la apreciarán según las reglas de la sana crítica sin estar obligados a sujetarse al dictamen de los peritos, pudiendo casarse dicha valoración cuando el juzgador "a quo" extraiga conclusiones absurdas o ilógicas. Al tribunal "a quo" no le está permitido asumir el papel de perito, ni realizar un dictamen pericial paralelo carente de base científica o técnica, considerándose por el tribunal que no existen motivos que justifiquen apartarse de la conclusión a la que llegó el perito calígrafo, que dictaminó que la firma estampada en el pagaré era del demandado, admitiéndose, como ha destacado el TS, como presunción "iuris tantum", que la firma es una demostración de conformidad de quien la puso.

${ }^{310}$ En este sentido se ha pronunciado el TS en sentencias como la $\mathrm{n}^{\circ}$ 866/2010 de 16-12-2010 (TOL 2.011.314), no 196/2010 de 13-04-2010 (TOL 1.822.923), no 709/2010 12-11-2010 (TOL 1.991.461), o la S. no 91/2003, Sec. $3^{\text {a }}$ AP Vizcaya, S. 20-02-2003 (EDJ 2003/48541).

${ }^{311}$ Martínez García, E.: "Tutela de los Consumidores y Usuarios en la nueva Ley de Enjuiciamiento Civil”, cit., pág. 357; Gómez Colomer, J.L.: "Derecho Jurisdiccional II. Proceso Civil”, cit., pág. 287 y 316. 
acta lo que ha percibido, sin que ello dé lugar a ningún tipo de interpretación, sino a una concreta constancia de la realidad.

Un último apunte en relación a la posible impugnación de la sentencia basada en error en la valoración de la prueba, sobre lo cual, la jurisprudencia es reiterada en el sentido de considerar que, si la prueba practicada en el procedimiento ha sido ponderada por el Juez a quo de forma racional, sin que exista contradicción con los criterios de valoración referidos, llegando a una conclusión razonable y correcta, tal valoración debe mantenerse ${ }^{312}$.

\section{PRUEBA EN SEGUNDA I NSTANCI A}

En la LEC actual, al igual que en la anterior, se regula un recurso de apelación limitada (art. 456.1) ${ }^{313}$, aunque existen algunos supuestos en que resulta admisible la introducción de la prueba en segunda instancia con carácter limitado y excepcional ${ }^{314}$.

Los arts. 460 y 461 establecen dos modalidades de presentación de la prueba en la segunda instancia:

- $\quad$ Si se tratara de documentos, pueden aportarse junto al escrito de interposición del recurso, siempre que se encuentren en alguno de los casos previstos en el art. 270 y no hubieran podido aportarse en la primera instancia.

- Pueden también acompañarse los documentos al escrito de oposición o impugnación por quienes no hubiesen recurrido inicialmente.

Para la proposición de la prueba en segunda instancia rige la forma escrita, que deberá efectuarse en la interposición del recurso de apelación, o bien en el escrito de oposición o de impugnación de la sentencia.

\footnotetext{
${ }^{312}$ Como establece la S. no 43/2007, Sec. $1^{\text {a }}$ de la AP de Cáceres, de 1-02-2007 (JUR 2007/138827), entre otras.

${ }^{313}$ Este recurso se produce cuando la resolución impugnada se pronuncia sobre el fondo del asunto estimando o desestimando la pretensión. En este lo que persigue el apelante es que, en base a los mismos fundamentos alegados en la primera instancia, se revoque la resolución recurrida, estando limitadas las peticiones del recurso a las que realizó en primera instancia, sin que tampoco pueda alterar la causa de pedir, aunque sí puede invocar razonamientos jurídicos distintos.

${ }^{314}$ Picó y Junoy, J.: "El Derecho a la prueba en el proceso civil”, Ed.: J.M. Bosch Editor, S.A., Barcelona 1996, pág. 69; Díaz Fuentes, A.: "La prueba en la nueva Ley de Enjuiciamiento Civil”, cit., pág. 117; Abel Lluch, X.: “Derecho Probatorio”, cit., pág. 243.
} 
Los documentos que podrían acompañarse son los previstos en el art. 270 siempre que no hayan podido aportarse en primera instancia ${ }^{315}$.

Condición indispensable para la admisión de esta prueba es que se trate de pruebas solicitadas en tiempo y forma en primera instancia, que las proponga la parte a quien le fueron denegadas y que hubiere formulado recurso en la instancia, pudiendo además practicarse prueba sobre las admitidas en primera instancia no practicadas por causa no imputable a quien la propuso. A los requisitos referidos para la admisión se unen además que su práctica sea posible, que su no realización produzca indefensión a la parte ${ }^{316}$, que no se haya podido practicar como diligencia final y, por último, que sea relevante para la decisión del pleito ${ }^{317}$.

\footnotetext{
${ }^{315}$ S. AP Huesca de 7-04-1993 (AC 1993/862) estima el recurso de apelación, señalando que la petición de la práctica de prueba en la segunda instancia se funda en que la pericial, propuesta y admitida en el incidente de ejecución de sentencia seguido entre las partes, no pudo practicarse por causas ajenas a su voluntad. De acuerdo con el artículo 897 de la LEC anterior, la Sala afirma que sólo podrá otorgarse el recibimiento a prueba en las apelaciones, cuando la Ley la conceda para la primera y concurra alguno de los casos expresados en el artículo 862 LEC anterior, entre los que se enumera, en segundo lugar, "cuando, por cualquier causa no imputable al que solicitare la prueba, no hubiera podido hacerse en la primera instancia toda o parte de la que hubiere propuesto", que es lo sucedido en el presente caso en el que incluso se llegó a designar la persona del perito, debiendo desecharse las manifestaciones realizadas por el apelado acerca de la inutilidad de la prueba, ya que en la primera instancia se estimó necesaria o conveniente para la defensa de los intereses de la parte.
}

\footnotetext{
${ }^{316}$ Montero Aroca, J.: “La Prueba en el Proceso civil”, cit., pág. 226 y 227.

${ }^{317}$ Abel Lluch, X.: “Derecho Probatorio”, cit., pág. 244.
} 



\section{CAPítulo Vi. LA PRUEBA EN los PROCESOS de CONSUMO}

A lo largo de este capítulo analizaremos el objeto de la prueba en este tipo de procesos, cómo se concreta en ellos la carga de la prueba y sus reglas en algunos procesos concretos de consumo, como en la exoneración de responsabilidad en daños causados por productos defectuosos, también la prueba de la falta de conformidad del producto con el fin al que se destina, la del carácter individual de una cláusula, el uso de la firma electrónica en las transacciones de consumo y los supuestos que encontramos sobre la Ley del Contrato del Seguro. A continuación, estudiamos la inversión de la carga de la prueba y la admisión de prueba indirecta o indiciaria el desarrollo del procedimiento probatorio con los distintos medios de prueba, aunque resulta inevitable volver sobre esta cuestión, aunque de forma somera al tratar ciertas cuestiones en el Capítulo VIII.

En la práctica, la prueba en los procesos de consumo presenta una problemática específica en la que incide el coste de la prueba para el consumidor, sobre todo en las demandas de reclamación de daños ${ }^{318}$, como veremos a lo largo de este capítulo, y también por la posición de inferioridad que ocupa el consumidor en relación al empresario o fabricante demandado, a quien le es muy difícil acceder a la prueba que fundamente su pretensión.

\section{A. REGLAS SOBRE LA CARGA DE LA PRUEBA}

Como ya hemos puesto de manifiesto, aunque el art. 217.2 y 3 de la LEC establecen como regla general la carga de la prueba de los hechos constitutivos al demandante y demandado reconveniente ${ }^{319} \mathrm{y}$ la de los impeditivos y excluyentes al demandado o actor reconvenido, en los procesos de consumo, según Montero Aroca, deben tenerse en cuenta normas especiales que distribuyen la carga

\footnotetext{
${ }^{318}$ Barona Vilar, S., Calderón Cuadrado M.P., Sanchis Crespo, C., Jimenez Fortea, F.J., Martínez García, E., Pardo Iranzo V., Pascual Serrats, R., Andrés Ciurana B., García Vila, M., González Malabia, S.: "Tutela de los consumidores y usuarios en la nueva LEC, artículo de Sanchís Crespo, C.: "La prueba en los procesos de consumo", cit., pág. 286.

${ }^{319}$ La S. $n^{\circ}$ 660/2011 de la Sec. $4^{\text {a }}$ de la AP Murcia, de 22-12-2011 (JUR 2012\27774) considera que desde el punto de vista jurídico lo relevante es sobre quién pesa la carga de la prueba, como establece el artículo 217.1 LEC, "cuando, al tiempo de dictar o resolución semejante, el Tribunal considere dudosos unos hechos relevantes para su decisión, desestimará las pretensiones del actor o del reconveniente, o las del demandado o reconvenido, según corresponda a unos u otros la carga de probar los hechos que permanezcan inciertos y fundamenten las pretensiones". Manifiesta también la sentencia que "incumbe al demandado la carga de probar los hechos que, conforme a las normas que le sean aplicables, impidan, extingan o enerven la eficacia jurídica de los hechos a que se refiere el apartado anterior".
} 
de la prueba según la facilidad probatoria y la posibilidad de acceso de cada una de las partes a ella.

La propia LEC en su art. 217.60 puntualiza la regla general, expresando que las normas de los apartados precedentes se aplicarán siempre que una disposición expresa no establezca criterios especiales para probar ciertos hechos relevantes ${ }^{320}$.

En la práctica se observa además que las reglas de la carga de la prueba se adaptan a las circunstancias que en cada caso se presenten ${ }^{321}$ puestas en relación con los criterios de facilidad probatoria establecidos en el art. 217 apdo. 70, de disponibilidad de medios y de proximidad a las fuentes de prueba de cada una de las partes ${ }^{322}$.

Numerosas sentencias de las Audiencias Provinciales han considerado que las reglas de distribución de la carga de la prueba se deben flexibilizar según cada caso concreto, permitiendo al juez antes de dictar sentencia, resolver situaciones de incertidumbre sobre a cuál de las partes le corresponde probar, como en el supuesto enjuiciado por la S. no 308/2013 de la Sec. 6a de la AP de la Coruña de 25 de noviembre de 2013 (TOL 5.379.380), donde se mencionan las modernas doctrinas sobre flexibilidad y facilidad probatoria de cada parte ${ }^{323}$, o la S. ya referida no 551/2010, Sec. 10a de la AP de Madrid de 24 de noviembre de $2010^{324}$, pretendiendo con ello

\footnotetext{
${ }^{320}$ Montero Aroca, J.: “La Prueba en el Proceso Civil”, cit., pág. 134; Fraga Mandián, A., Fraga Mandián J.: "La tutela procesal civil de los consumidores en las leyes sustantivas especiales”, pág. 15. Ed.: Sepin Cuadernos Jurídicos nº 103/2011.

${ }^{321}$ Fraga Mandián, A., Fraga Mandián, J.: "La tutela procesal civil de los consumidores en las leyes sustantivas especiales”, cit., pág. 16; Díaz Fuentes, A.: "La prueba en la nueva Ley de Enjuiciamiento Civil”. Ed.: Bosch, Barcelona 2002, cit., pág. 39.

${ }^{322}$ González Cano, M.I.: "La tutela colectiva de consumidores y usuarios", cit., pág. 86; Montero Aroca, J.: "La Prueba en el Proceso Civil", cit., pág. 130; López Fragoso, T.: "La carga de la prueba según el artículo 217 de la Ley 1/2000 de Enjuiciamiento Civil”. Actualidad Civil Año XI no487 de 24 de mayo de 2001. Ed.: Aranzadi, S.A., portada y pág. 2.

${ }^{323}$ Vázquez Barros, S.: “Memento Practico de consumo 2010-2011”, cit., pág. 149; Álvarez Lata, N., Peña López, F., Busto Lago, J.M. (coord.): "Reclamaciones de consumo. Derecho de consumo desde la perspectiva del consumidor”, cit., pág. 762.

${ }^{324}$ Carretero González, C.: "Las cláusulas abusivas en las condiciones generales de los contratos relacionadas con la carga de la prueba. (Comentario a la Sentencia número 166, de 13 de mayo de 2002, de la Sección Primera de la Audiencia Provincial de Ciudad Real)". Publicación Revista de Derecho Bancario y Bursátil, núm. 90 abril-junio 2003; De León de Arce, A., en García García, L.M., (coord.): "Derechos de los consumidores y usuarios”. Tomo II, cit., pág. 1782.
} 
conocer cuál de las partes tiene a su alcance el material probatorio que de no aportarlo, repercutirá en su contra.

Entendemos que el tribunal, para poder resolver tales situaciones, atendiendo a la naturaleza de los hechos afirmados o negados y a los criterios referidos ${ }^{325}$, acudirá a las reglas expresadas ${ }^{326}$, las cuales se consideran infringidas, según el propio TS en sentencias como la no 662/2012, de 12 de noviembre de 2012 (TOL 2.706.873), la AP Guadalajara, en la S. no 169/2010 de la Sec. 1 a, 13 de octubre de 2010 (TOL 1.993.329), o la S. № 551/2010 Sec. 10a de la Audiencia Provincial de Madrid de 24 de noviembre de 2010 (TOL 2.044.657) 327 , entre otras muchas, cuando las consecuencias desfavorables de no haberse probado un hecho controvertido y relevante recaen sobre la parte a quien según las reglas generales no le correspondía probar ${ }^{328}$.

Por ello, en caso de falta de prueba de alguno de los hechos alegados por las partes, cada una debe asumir las consecuencias de esa falta, tal como ha entendido la jurisprudencia del TS que concretamente, la S. no 1000/1998, de 4 de noviembre de 1998 (TOL 5.157.175), que alude a la doctrina alemana que expresa "el problema de la carga de la prueba es el problema de la falta de prueba", en el sentido de que la carga está en relación a quien necesite probar determinado hecho en el proceso.

\section{a. En relación a la carga de la prueba del defecto de los productos}

La rigidez de la regla del art. 1214 C.c. sobre la prueba del cumplimiento de las obligaciones, contrasta con las especialidades probatorias en materia de consumo que se regulan en la normativa

\footnotetext{
${ }^{325}$ S. Sec. $13^{a}$, AP Barcelona de 26-04-01 (TOL 205.003), S. $n^{\circ} 285 / 2001$, Sec. $4^{\text {a }}$ AP Málaga, ${ }^{\circ}$ 285/2011, de 27-05- 2011 (TOL 2.240.502), S. no 105/2009 AP Guipúzcoa de 24-04-09 (TOL 1.568.818), S. n ${ }^{\circ}$ 610/2011, Sec. 11 $1^{\mathrm{a}}$ AP Madrid de 25-11-2011 (TOL 2.303.221), entre otras.

${ }^{326}$ Carretero González, C.: "Las cláusulas abusivas en las condiciones generales de los contratos relacionadas con la carga de la prueba. (Comentario a la Sentencia número 166, de 13 de mayo de 2002, de la Sección Primera de la Audiencia Provincial de Ciudad Real)", cit.

${ }^{327}$ De León de Arce, A., en García García, L.M., (coord.): "Derechos de los consumidores y usuarios”. Tomo II, cit., pág. 15.

${ }^{328}$ Marín López M.J.; “Contratos vinculados “en” y "al margen de” la ley 7/1995, de 23 de marzo, de crédito al consumo: doctrina del Tribunal Supremo", Ed.: Civitas, Cuadernos Civitas de Jurisprudencia Civil no 91, enero-abril de 2013, pág. 469 a 490.
} 
europea y en el TRLGDCU y que iremos viendo a lo largo de este capítulo y del siguiente.

Es necesario conocer en primer lugar lo que entienden por producto defectuoso tanto el TRLGDCU en su art. 137, como el art. 3 de la Ley de Responsabilidad Civil por Productos Defectuosos derogada por el TRLGDCU. Ambos artículos lo definen como aquel que no ofrezca la seguridad que cabría esperar teniendo en cuenta todas las circunstancias, su presentación y uso razonable, todo ello en relación con el momento de su puesta en circulación ${ }^{329}$.

De la lectura del precepto referido se desprende que el consumidor además de probar el defecto y el daño, también debe justificar que este está en relación con la persona contra la que se dirige la acción. Cabe además la posibilidad de que el consumidor aporte prueba al objeto de acreditar su ausencia de culpa.

Partiendo de la Directiva no 85/374 CEE, del Consejo, de 25 de julio, relativa a la aproximación de las disposiciones legales, reglamentarias y administrativas de los Estados Miembros en materia de responsabilidad por los daños causados por productos defectuosos (D.O.U.E. serie L, núm. 210, de 7 de agosto), transpuesta a nuestro ordenamiento a través del art. 139 del TRLGDCU, consagra en su artículo 4 el reparto de la carga de la prueba de forma que esta corresponde al perjudicado que solicite la reparación del daño, debiendo acreditar el daño, el defecto y la relación causal entre ambos.

El concepto de defecto que incorpora la Directiva es flexible y amplio sin que concurran en él elementos subjetivos, y se basa en la idea de seguridad del producto referida y en la prueba del defecto por parte del perjudicado ${ }^{330}$.

\footnotetext{
${ }^{329}$ La S. n ${ }^{\circ}$ 84/2003, Sec. $2^{\text {a }}$ de la AP León de 13-03-2003 (TOL 304.279) hace alusión a la S. TS de 2506-1996 (TOL 1.659.425) para realizar una interpretación del concepto de producto defectuoso, reducida a "cuando no ofrece la seguridad a la que una persona tiene derecho teniendo en consideración todas las circunstancias”, acude al art. 6.9 de la Directiva 85/374 CEE, de 25-07-1985, de Responsabilidad en Materia de Productos Defectuosos.

${ }^{330}$ La jurisprudencia acude a la definición contenida en los artículos referidos para argumentar lo que se entiende por producto defectuoso, muestra de lo cual son sentencias como la $\mathrm{n}^{\mathrm{o}} 200 / 2010$, Sec. $2^{\mathrm{a}}$ de la AP Cádiz de 22 de junio de 2010 (TOL 2.052.218) o la no 235/2011, Sec. $13^{\text {a }}$ de la AP Madrid de 4 de mayo de 2011, (TOL 2.161.355) que coinciden en considerar que el producto será defectuoso siempre que no ofrezca la seguridad de que gocen los demás ejemplares de la serie.
} 
La regulación, tanto por parte de la Directiva como del TRLGDCU supone un sistema de responsabilidad objetiva que dota al consumidor perjudicado por productos defectuosos de una mayor protección, puesto que siguiendo a autores como Solé i Feliu, Jiménez Liébana, Marín López o González Poveda, lo que no estará obligado a probar el perjudicado es la culpa del fabricante ${ }^{331}$.

EI TS ya en el año 1984 entendió que el fabricante que había lanzado un producto defectuoso al mercado incurría en una responsabilidad objetiva que comportaba una acción culposa que debía indemnizarse ex art. 1902 C.c.

La regla general establecida en el citado art. 139 del TRLGDCU no está exenta de matizaciones, y la primera de ellas la establece el art. 140 del mismo cuerpo legal, al imponer la carga probatoria al productor en relación a la exención de su responsabilidad ${ }^{332}$.

Además, el TRLGDCU introduce unas reglas especiales, como hemos manifestado, siendo destacable la regulación de una excepción en muchos procesos de consumo que supone la consideración de que corresponde al actor la carga de probar la certeza de los hechos de los que ordinariamente se desprenda el efecto jurídico correspondiente a las pretensiones de la demanda, teniendo en consideración las normas jurídicas a ellos aplicables.

Es decir, al actor le corresponderá la prueba de la existencia del daño, sin que sea necesario para que prospere su demanda acreditar el origen del mismo. Por tanto, la prueba de que el producto no es defectuoso corresponde al fabricante, dando a conocer primero las expectativas de seguridad que cabe esperar del producto, como sucede en la S. no 748/2001 del TS de 23 de julio de 2001 (TOL 4.794.600) 333 .

En estos supuestos, en aras a la protección del consumidor, el producto se entenderá defectuoso si el demandado no acredita su

\footnotetext{
${ }^{331}$ González Poveda, P.: "La responsabilidad civil por bienes o servicios defectuosos”. Ed.: Bosch, S.A., Barcelona 2008, pág.873.

${ }^{332}$ Abel Lluch, X., Picó i Junoy, J., Richard González, M.: "La prueba judicial. Desafíos en las jurisdicciones civil, penal, laboral y contencioso-administrativa”, cit., pág. 1391; León de Arce, A., García García L.M., artículo de Palacios González, D., (coord.) "Derechos de los consumidores y usuarios”, cit., pág. 1445.

333 Marín López, M.J., Martínez Espín, P.: “Código de consumo. Legislación, comentarios y jurisprudencia”. Ed.: Aranzadi, Pamplona 2004, pág. 184.
} 
estado y el cumplimiento de la normativa que le es de aplicación en todo el proceso de fabricación ${ }^{334}$, produciéndose por tanto una verdadera inversión de la que hablaremos en las páginas siguientes.

La jurisprudencia para determinar a quién corresponde la carga de la prueba en aquellos casos en que los hechos son dudosos o permanecen inciertos, ha optado por entender de aplicación genérica el art. 217 de la LEC poniéndolo en relación con el art. 1214 del C.c. y con la normativa de aplicación al supuesto concreto, suavizando de este modo la regla expresada en el sentido que la prueba debe recaer sobre la parte a la que le sea posible probar si a la contraria le fuera imposible o difícil ${ }^{335}$.

EI TS en relación a los concretos procesos de consumo ha entendido que la prueba debe fundarse en unos principios esenciales que constituyen los cimientos sobre los que se asienta la misma en cualquier proceso civil, ejemplo de ello es la Sentencia del Tribunal Supremo no 556/2002, de 10 de junio de 2002 (TOL 4.975.740) ${ }^{336}$.

\footnotetext{
${ }^{334}$ La S. no 496/2003 AP Baleares de 30-09-2003 (TOL 355.558), donde se ejercita la acción de indemnización por inundación de la vivienda contra la propietaria del piso, la aseguradora y contra el fabricante del latiguillo que causó la fuga, entiende que al ser objetiva la responsabilidad del fabricante, este deberá acreditar las causas de exoneración de responsabilidad.
}

Otro ejemplo en relación a la prueba del fabricante que pueda conducir a una exoneración de su responsabilidad, es la S. $\mathrm{n}^{0}$ 1071/2008, TS de 7-11-2008 (TOL 1.401.716), la cual considera en una acción de indemnización por responsabilidad por defectos de funcionamiento de airbag debido a falta de prueba de la incidencia del no uso del cinturón de seguridad en el accidente, que se le puede eximir de responsabilidad al fabricante en función de las circunstancias del caso, si el daño causado fuera debido a un defecto del producto y a culpa del perjudicado o de una persona de la que este deba responder civilmente.

335 S. TS 31-12-1999 (TOL 171.413) y S. nº 476/2000, TS 4-05-2000 (TOL 1.565), S. no 185/2016 TS de 18-3-2016 (TOL 5.673.509), S. n ${ }^{\mathrm{o}}$ 13/2010, Sec. $4^{\mathrm{a}}$ AP Alicante de 14-1-2010 (TOL 1.993.331).

\footnotetext{
${ }^{336}$ Esta sentencia realiza una interpretación del art. 28 de la anterior LGCU donde el criterio de imputación de la responsabilidad se localiza en el daño sufrido por el consumidor, y considera la posibilidad, como en el supuesto que enjuicia la existencia de una culpa compartida en el hecho acontecido.
}

Esta culpa es admitida por el TS en múltiples resoluciones como la S. no 524/1993 de 20-05-1993 (TOL 5.130.084), S. $n^{\circ}$ 725/1993 de 8-07-1993 (TOL 1.663.458) y S. n ${ }^{\circ} 1212 / 1993$ de 15-12-1993(TOL 5.123.193), citadas en la S. $n^{\circ}$ 64/1995 de 24-06-1995 (TOL 5.130.776), y se traduce en una compensación de las consecuencias pecuniarias derivadas de ella. La sentencia referida entiende además de aplicación el severo régimen de responsabilidad objetiva establecido para (entre otros productos) los alimentos en el art. 28 y evita tener que discutir el reproche culpabilístico.

Asienta de este modo el principio de evitar comprobar la relación entre el producto y el daño, siendo suficiente la prueba de la relación de causalidad entre la acción del producto y el resultado producido para que surja la responsabilidad. 
La jurisprudencia anterior al TRLGDCU no consideró relevante cuál de las partes aportara la prueba, siempre que el hecho estuviera probado o acreditado en autos, siendo lo realmente importante que el órgano decisor pudiera extraer, valorar y concretar el hecho proclamado y que este se encontrara suficientemente demostrado.

Al concretar los extremos relacionados con la parte que debe probar el defecto, es fundamental la postura adoptada desde antiguo por el TS en la S. de 16 de abril de 1971 (TOL 4.268.392), donde entendió que quien actúa frente al estado normal de las cosas o situaciones de hecho o de Derecho ya producidas es quien debe probar el hecho impediente de la constitución o extinción válida del derecho que reclama.

Este principio fue también recogido en sentencias como la del Tribunal Supremo de 22 de marzo de 1983 (TOL 1.738.477) y la de 30 de noviembre de 1993 (TOL 1.656.002), según la cual "el material instructorio valorable se compone de todo lo alegado y probado por las dos partes", de manera que las alegaciones de una parte o las pruebas que se practiquen en el proceso pueden aprovechar también a la contraria.

Esta postura inicial se ha ido suavizando por la dificultad ya comentada de prueba del consumidor ${ }^{337}$, e incluso ha llegado a considerarse que pueda ser la parte demandada la que aporte un informe pericial sobre el estado del producto, por ser quien tiene a su disposición los medios necesarios para verificar el correcto o incorrecto funcionamiento del mismo ${ }^{338}$.

Por ello, en sentencias posteriores a la referida, el Tribunal Supremo acude al principio de flexibilidad en la atribución de la carga de la prueba como se observa en las sentencias de 18 de mayo de 1988 (TOL 1.733.156) y 3 de abril de 1992 (TOL 1.654.968), entre otras. Se habla así de que recae sobre la demandada la prueba del hecho extintivo de la acción o bien de la resolución de la relación contractual constituida con el pretendido responsable.

Haciendo alusión a otros ejemplos de la jurisprudencia referida, el TS, en sentencias como la no 938/2007, de 21 septiembre de 2007

\footnotetext{
${ }^{337}$ Abel Lluch, X., Picó i Junoy, J., Richard González, M.: "La Prueba Judicial. Desafíos en las jurisdicciones civil, penal, laboral y contencioso-administrativo.” cit., pág. 1398.

${ }^{338}$ S. nº 73/2006, Sec. 28 , AP Madrid 25-05-2006 (TOL 1.034.761).
} 
(TOL 1.150.977), interpreta el art. 139 citado en el sentido de que debe ser el actor quien lleve a cabo la prueba del defecto, de la que sólo quedará liberado en supuestos de dificultad probatoria.

Si el actor no probara el defecto, como en el supuesto enjuiciado en la S. no 222/1999, Sec. Única de la AP de Huesca de 24 de junio de 1999, (TOL 391.524), donde no pudo probar la existencia de relación directa entre la avería del frigorífico de un restaurante, la pérdida de los productos congelados y el corte de suministro de energía, será desestimada la pretensión.

Por su parte la S. no 237/2016 TS de 12 de abril de 2016 (TOL 5.694.661) en que se condenaba a la empresa suministradora de unas placas fotovoltaicas por un defecto técnico, denunció en apelación la infracción de las normas de la carga de la prueba por no haber considerado el principio de facilidad probatoria.

En este caso, el informe sobre el defecto fue aportado por la propia parte actora, por tanto, aunque es de aplicación el criterio de facilidad probatoria, también lo es el principio fundamental de que la prueba puede ser introducida al proceso por cualquiera de las partes.

De este modo, la sala de apelación entendió ajustada a derecho la resolución y valoración de la prueba llevada a cabo por el juzgador de instancia que observó el defecto y desestimó el recurso.

Se observa de la jurisprudencia analizada que al tribunal no le importa demasiado cuál de las partes la aporte, valorando eso sí, de forma negativa como ya hemos manifestado, la falta de prueba de la parte que estaba en posibilidad de aportarla ${ }^{339}$.

Esta postura referida en relación al posible aporte de la prueba por cualquiera de los litigantes a la que alude el principio denominado de «adquisición procesal», fue consagrado por el TS en sentencias como la de 22 de marzo de 1983 (TOL 1.738.477), la S. no 482/1993 de 10 de mayo (TOL 1.662.895) y la de 30 de noviembre de 1993 (TOL 1.664.220), según el cual «...el material instructorio valorable se compone de todo lo alegado y probado por las dos partes, de manera que las alegaciones de una parte o las pruebas que practique pueden aprovechar también a la contraria».

${ }^{339}$ Vázquez Barros, S.: “Memento Práctico Francis Lefebvre, Consumo 2010-2011”, cit., pág. 487. 


\section{Carga de la prueba de la relación de causalidad entre el defecto y el daño.}

Pese al carácter objetivo manifestado sobre la prueba del defecto ${ }^{340}$, precisa igualmente una mínima actividad probatoria acerca de la relación de causalidad entre este y el daño producido que incumbe, conforme a las normas generales, al perjudicado.

Sobre la comentada prueba por parte del consumidor, donde esta presentará más dificultad será en acreditar el origen del daño; por ello, la jurisprudencia, consciente de la problemática que supone para el consumidor, hace recaer en ciertos supuestos sobre el productor o suministrador la prueba referida ${ }^{341}$, siendo ejemplo de ello la S. TS de 23 de julio de 2001 (RJ 2001/8411) donde se trata de determinar la responsabilidad de una agencia de viajes en un accidente ocurrido en una avioneta.

En consecuencia, en estos casos a la víctima no le corresponde la prueba de que el fabricante no ha cumplido con las precauciones y medidas apropiadas en su proceso productivo, ni tampoco probar que ha obrado con toda corrección en el uso y consumo, sino que será el propio fabricante quien deberá acreditar que el uso del producto fue incorrecto y que no adolecía de defecto alguno para librarse de su obligación de responder.

Este tipo de responsabilidad se concreta a su vez dependiendo de ante qué supuestos nos encontremos. Cuando estamos en procesos por daños causados por determinados productos como los alimentos, higiene, limpieza, cosméticos, productos farmacéuticos, servicios sanitarios, gas, electricidad, electrodomésticos, ascensores, medios de transporte, vehículos a motor, juguetes y productos dirigidos a los niños, se presume una responsabilidad objetiva a menos que el propio demandado pruebe que se ha realizado un uso incorrecto ${ }^{342}$.

\footnotetext{
${ }^{340}$ Así lo entendió la S. no 279/2003, Sec. 1ª AP Córdoba de 24-11-2003 (TOL 335.749).

341 Marín López, M.J., Martínez Espín, P.: “Código de consumo. Legislación, comentarios y jurisprudencia”, cit., pág. 184.

${ }^{342}$ Barona Vilar en Barona Vilar (coord.), Calderón Cuadrado M.P., Sanchís Crespo, C., Jiménez Fortea, F.J., Martínez García, E., Pardo Iranzo, V., Pascual Serrats, R., Andrés Ciurana, B., García Vila, M., González Malabia, S.: “Tutela de los consumidores y usuarios en la Nueva LEC”, cit., pág. 288.
} 
En estos casos, se produce la inversión de la carga de la prueba que trataremos en el apartado siguiente, tanto se trate de un fabricante o suministrador, quienes deberán probar la culpa del usuario, prueba complicada para este dado que en algunos casos necesitará acreditar el uso incorrecto o inadecuado respecto de cada consumidor o usuario ${ }^{343}$.

\section{Carga de la prueba de la culpa del perjudicado.}

La responsabilidad en que incurra bien el perjudicado o el propio fabricante dependerá de la acción realizada por el primero, pudiendo esta incluso ser repercutida a ambos si se debiera a la intervención de los dos. Podemos encontrarnos por tanto en supuestos de responsabilidad compartida y también en otros, de culpa exclusiva de la víctima si el fabricante ha cumplido su obligación de informar sobre las condiciones de uso y riesgos del producto ${ }^{344}$.

En relación a la prueba de la culpabilidad es requisito indispensable la determinación del nexo causal entre la conducta del agente y la producción del daño, debiendo acreditar la culpa del usuario, también complicada para el demandado, pues en algunos casos necesitará probar el uso incorrecto o inadecuado respecto de cada consumidor o usuario ${ }^{345}$.

Debe por tanto existir una acción culposa que se puede materializar de diversas formas y producirse, bien por el consumidor, bien por el fabricante o por un tercero ${ }^{346}$.

Existen casos en que existe culpa exclusiva de la víctima que quiebran el nexo causal ${ }^{347}$ y deben también ser objeto de prueba

\footnotetext{
${ }^{343}$ S. n $n^{\circ} 170 / 2012$, Sec. $28^{\text {a }}$ AP Madrid de 28-05-2012 (TOL 2.265.105) en que la Sala desestima el recurso de apelación, que interpone el consumidor contra la sentencia desestimatoria de la acción de cesación y reclamación de indemnización, formulada contra la empresa por publicidad engañosa, considera que incurrió en error el propio usuario sin que el mismo fuera inducido en ningún momento por el demandado, siendo el uso realizado culpa del propio usuario y no de la entidad bancaria demandada.

${ }^{344}$ Ejemplo de ello es la S. TS de 30 de junio de 2000 (TOL 6.610) o la S. TS de 14 de noviembre de 1984 (TOL 1.737.330), entre otras.

345 Abel Lluch, X., Picó i Junoy, J., Richard González, M.: "La Prueba Judicial. Desafíos en las jurisdicciones civil, penal, laboral y contencioso-administrativo”, cit., pág. 1410 a 1412.

${ }^{346}$ En la S. del TS de 3-12-1997 (TOL 216.433) se afirmó la responsabilidad de una empresa importadora aun cuando la máquina importada se empleó de forma indebida porque no se pusieron en conocimiento del actor las medidas de seguridad para su correcto uso.

${ }^{347}$ Para atribuir culpa a la víctima debemos demostrar la relación entre la consecuencia dañosa y la conducta de esta, valorando si ha sido causa exclusiva del daño o parte del mismo, entendiendo que existe
} 
rigurosa para demostrar que fue el propio consumidor quien causó los daños relacionados con el correcto uso y consumo del producto, prueba que en todos los casos debe acreditar el demandado ${ }^{348}$.

Existen además supuestos en que la responsabilidad resulta compartida por ser el daño debido tanto a un defecto del producto como a la culpa del perjudicado o de una persona de la que este deba responder civilmente, en los cuales, la responsabilidad del fabricante o del importador podrá, en función de las circunstancias del caso, minorarse o suprimirse.

Así lo establece el art. 145 del TRLGDCU, y el art. 1103 C.c., que faculta a los tribunales a moderar la responsabilidad procedente de la culpa 349 , aunque para ello, la culpa del perjudicado deberá ser probada, no bastando su simple alegación, lo cual se llevará a cabo mediante la práctica de la prueba pericial, valorando la existencia del defecto en el producto, la relación con el daño y la culpa de la víctima ${ }^{350}$.

En el caso de que exista duda sobre la culpabilidad del fabricante, vendedor o presunto responsable, esta duda debe perjudicar al propio demandado y no al consumidor que ejercita la acción ${ }^{351}$.

culpa de la víctima si se ha producido su participación, como lo ha entendido la jurisprudencia en multitud de sentencias, como la S. TS de 7-11-2008 (LA LEY 169531/08), o la S. no 1054/1996 TS, de 11-12-1996 (TOL 1.658.583), en relación a defectos observados en productos pirotécnicos, que el fabricante no ha incurrido ni se le puede imputar conducta culposa, imprudente o negligente por haberse limitado a fabricar y distribuir entre los minoristas un producto, debiendo concretarse la conexión entre la conducta del agente y la producción del daño. En la misma línea podemos mencionar también la $\mathrm{S}$. $\mathrm{n}^{\mathrm{o}}$ 623/1993 TS, de 23-06-1993 (RJ 199315380), y la S. nº 71/2003 de la Sec. 13ª de la AP Madrid de 23-102003 (TOL 200.199), entre otras.

Son muchos los ejemplos de sentencias que se pueden citar en relación a esta cuestión, de la que es buena muestra la S. no 649/2014 TS de 13-01-2015 (TOL 4.706.623) donde se reclamaba la indemnización por daños causados a los pasajeros de un avión que colisionó con otro, como han puesto de manifiesto sentencias como la de la Sec. $1^{\text {a }}$ AP Barcelona de 17 de noviembre de 2003 (TOL 333.199).

348 Álvarez Lata, N., Peña López, F., Busto Lago, J.M (coord.): “Reclamaciones de consumo. Derecho de consumo desde la perspectiva del consumidor”, cit., pág. 1300.

${ }^{349}$ la S. $\mathrm{n}^{\circ} 1087 / 2008$, TS 21-11-08 (TOL 1.408.444), considera que no puede ser responsable la propia víctima por falta de lectura del etiquetado, o la S. no 477/2009 Sec. 13 $3^{\text {a }}$ AP Barcelona, de 15-09-2009 (TOL 1.642.179) en relación a la concurrencia de causas.

350 Álvarez Lata, N., Peña López, F., Busto Lago, J.M (coord.): “Reclamaciones de consumo. Derecho de consumo desde la perspectiva del consumidor”, cit., pág. 767.

${ }^{351}$ J. B. Acosta Estévez: “Tutela procesal de los consumidores”, cit., pág. 96. 
En el supuesto enjuiciado en la S. no 613/2007 del TS, de 6 de junio de 2007 (TOL 1.106.774), en relación a las quemaduras sufridas al tocar con la mano un horno en funcionamiento, se llegó a una atenuación de la responsabilidad al considerar que no se trataba de culpa exclusiva de la víctima, puesto que aunque existió una conducta negligente del actor y el horno cumplía las normas administrativas vigentes, la puerta de vidrio del aparato llegaba a superar la temperatura máxima prevista al homologarse el modelo 352 .

Sentado el criterio general de la carga de la prueba de la culpa en el demandado, existen supuestos como el de las prótesis mamarias, cuya responsabilidad ha sido considerada por algunas sentencias como "quasi objetiva" en base al art. 6 de la derogada LPD; muestra de ello es la S. del Juzgado de Primera Instancia no 24 de Barcelona, de 18 de marzo 2010 (TOL 1.796.157) la cual, siguiendo la posición mantenida por otras sentencias como la no 497/2009, Sec. 13a AP Barcelona de 23 de septiembre de 2009 (TOL 1.651.000), o la no 938/2007 del TS de 21 de septiembre de 2007 (TOL 1.150.977), obliga al perjudicado a probar la relación entre el uso de determinado producto y el daño, correspondiendo al fabricante la prueba de la idoneidad del producto o su uso incorrecto para que puedan concurrir las causas de exoneración ${ }^{353}$.

\section{b. Carga de la prueba de la exoneración de la responsabilidad por daños ocasionados por productos defectuosos.}

La referida Ley 22/1994, de 6 de julio, de responsabilidad por daños causados por productos defectuosos, establecía que el perjudicado que pretendiera obtener la reparación de un daño tendría que probar tanto el defecto como el daño y la relación de causalidad ${ }^{354}$.

\footnotetext{
352 Abel Lluch, X., Picó i Junoy, J., Richard González, M.: "La Prueba Judicial. Desafíos en las jurisdicciones civil, penal, laboral y contencioso-administrativo”, cit., pág. 1412.

${ }^{353}$ La S. no 477/2009, Sec. 13 ${ }^{\text {a }}$ AP Barcelona, de 15-09-2009 (TOL 1.642.179) entiende que para que el productor quede liberado de su responsabilidad, tiene que acreditarse que la causa del daño se encuentra en relación exclusivamente a la conducta de la víctima y no a un defecto del producto.

${ }^{354}$ García Cuerva García, S., Abel Lluch, X., Picó i Junoy, J. (Dir.): “Objeto y carga de la prueba civil”, cit., pág. 68.
} 
En la actualidad, el art. 140 del TRLDCU establece la carga para el demandado de la prueba de los hechos constitutivos de la acción reparadora, al exigir que sea el empresario o fabricante quien pruebe los hechos impeditivos frente a la imputación de la responsabilidad ${ }^{355}$.

Por ello, a efectos de la exoneración de la responsabilidad por el fabricante es fundamental la prueba de la culpa del perjudicado en la producción del daño, puesto que, según reiteradas sentencias tanto de las audiencias provinciales como del propio TS, debe ser el fabricante quien la acredite ${ }^{356}$.

\section{c. Sobre la carga de la prueba de la falta de conformidad del producto con el contrato.}

Por lo que respecta a la prueba de la falta de conformidad del producto con el contrato son dos las cuestiones que debemos analizar: por un lado, la acreditación de que el producto es defectuoso, y por otro, el momento en que el consumidor pone de manifiesto esa falta de conformidad.

La función de la prueba en estos supuestos se basa en la existencia de la falta de conformidad y la acreditación de que esta ya existía en el momento de la entrega ${ }^{357}$.

Pese a que se observe alguno de los requisitos para que pueda considerarse la existencia de una falta de conformidad, no habrá

\footnotetext{
355 “Memento Práctico Francis Lefebvre, Consumo 2010-2011”, cit., pág. 163.

356 Ejemplo de ello son las sentencias $n^{0}$ 347/1998, Sec. $3^{\text {a }}$, AP de Tarragona de 18-07-1998 (EDJ1998/29625) y S. Sec. 17ª AP Barcelona de 17-12- 2001 (EDJ2001/74345).
}

Otros ejemplos los encontramos en la jurisprudencia del propio TS, en sentencias como la de 25-031991(EDJ1991/3213) la no 530/1993 de 29-05-1993 (TOL 1.663.045), S. no 793/1994 TS, 22-07-1994, (TOL 1.665.478), la de 8-02-1995, (EDJ1995/170), la no 778/1996, de 4-10-1996, (EDJ1996/6966), la nº 981/1996, de 22-11-1996 (TOL 1.658.763), la no 394/1998, de 6-05-1998 (TOL 5.119.892), la de 30-071998, (EDJ1998/17344) y S. n ${ }^{\circ}$ 1207/1998, TS de 28-12-1998, (TOL 171.002), en las que el TS, siguiendo la línea aludida, consideró que el fabricante o prestador del servicio, para liberarse de la obligación de responder debe probar que el uso que le dio el consumidor al producto no fue correcto.

357 Bermúdez Ballesteros, M. S.: “Alcance de la responsabilidad del vendedor por la falta de conformidad en un bien de consumo, detectada en el plazo de garantía y manifestada durante y tras la expiración de dicho plazo". Revista CESCO de Derecho de Consumo no 7/2013, págs. 56 a 63. http://www.revista.uclm.es/index.php/cesco. 
lugar a responsabilidad por el vendedor cuando el consumidor conociera el defecto que alega ${ }^{358}$.

Al objeto de que pueda operar la exención de responsabilidad, es necesario que exista el defecto o problema en el momento de la entrega del bien, debiendo para ello quedar probada que esta falta de conformidad ya existía cuando se entregó. Para justificar esta cuestión es de vital importancia que la denuncia de la falta de conformidad por parte del consumidor se lleve a cabo en el plazo legal establecido.

El plazo para que el consumidor pueda denunciar su falta de conformidad con el producto se concreta en el art. 123 del TRLGDCU, que establece un límite de dos meses desde que se realizó la entrega. Si cumple esta exigencia se presume que existe falta de conformidad debiendo acreditar el vendedor que la comunicación se llevó a cabo fuera del plazo legal.

Existe además otra presunción establecida en este artículo en el supuesto de que la falta de conformidad se manifieste en los seis meses posteriores a la entrega del producto (tanto para productos nuevos como de segunda mano), basada en considerar que el defecto del producto ya existía en el momento de su adquisición, excepto cuando esta presunción sea incompatible con la naturaleza del producto o la índole de la falta de conformidad.

Por tanto, ante esta presunción será el vendedor quien deba probar que el defecto no existía en el momento de la entrega.

A las cuestiones tratadas sobre la conformidad del producto con el contrato hemos de añadir la del plazo al cual se extiende la responsabilidad del vendedor, de dos años desde la entrega, pudiendo en productos de segunda mano pactarse un plazo menor no inferior a un año desde la entrega.

También se regula en este mismo artículo, en su apartado 4o, el supuesto de que el consumidor comunique la falta de conformidad al fabricante fuera del plazo de dos meses. En estos casos, el propio consumidor responderá de los daños y perjuicios que el retraso en la

\footnotetext{
${ }^{358}$ Avilés García, J.: "Los contratos de compraventa de bienes de consumo. Problemas, propuestas y perspectivas de la venta y garantías en la Directiva 1999/447/CE y la Ley 23/2003”. Ed.: Comares, Granada 2007, pág. 322.
} 
comunicación ocasione en el empresario, pero no perderá el derecho de saneamiento ${ }^{359}$ por el defecto del producto.

\section{d. Carga de la prueba del carácter individual de una cláusula}

Pese a que, en cualquier contrato privado, las cláusulas deberían ser pactadas de común acuerdo entre las partes, y así se desprende del art. 1255 C.c., existen ciertos contratos, como los de adhesión, que imponen las cláusulas contractuales a la otra parte.

Al hilo de la referencia al art. 1255 C.c., el libre pacto de condiciones contractuales que establece se ve limitado por la existencia de otras normas en el mismo C.c. y en otros textos legales de carácter imperativo, que reducen la libertad contractual, como la el art. 1583 C.c. sobre la nulidad del arrendamiento si se pacta sin límite temporal.

En relación a este tipo de contratación, el concepto de libertad de los pactos incluidos en ciertos contratos, como aquellos que recogen condiciones generales o los llamados contratos de adhesión, se vio afectado por el fenómeno de contratación masiva por la predisposición del contenido contractual por una de las partes que lleva a resultados injustos, debido a que pueden implicar renuncias a las facultades o posibilidades que la ley dispone a favor de una de las partes y en contra de la otra.

En este sentido la S. no 274/2003 TS de 21 de marzo de 2003 (TOL 353.849) entiende que en estos casos las cláusulas han sido predispuestas por una parte e impuestas a la otra sin posibilidad de negociación ni contraoferta, y que la prueba en contrario recae el profesional demandado, tal como establece el art. 80.1 b) del TRLGDCU ${ }^{360}$.

\footnotetext{
${ }^{359}$ Fraga Mandián, A., Fraga Mandián, J.: "La tutela procesal civil de los consumidores en las leyes sustantivas especiales”, cit., pág. 17.

${ }^{360}$ García Cuerva García,S., Abel Lluch,X., Picó i Junoy, J.( Dir.): “Objeto y carga de la prueba civil”. Ed.: Bosch Procesal, Barcelona 2007, pág. 68.
} 


\section{e. Carga de la prueba en la ley 15/2003, de 20 de noviembre, de firma electrónica.}

Es también destacable lo dispuesto sobre la prueba la Ley 15/2003, de 20 de noviembre, de firma electrónica (LFE) por el uso que se le pueda dar en transacciones de consumo y en el comercio electrónico, debido a la cada vez más creciente demanda de productos a través de internet y generación de documentos electrónicos mediante firma reconocida.

Tan solo hacer alusión a lo dispuesto en su art. 3 en su apartado 7 en cuanto a la validez jurídica que otorga a la firma, la cual tiene en juicio el mismo valor que la firma manuscrita en relación a los datos consignados en papel, siendo admisible como prueba en juicio y se valorará según los criterios de la LEC ${ }^{361}$.

A pesar de la evolución hacia el comercio electrónico cada vez mayor, parece más seguro para el consumidor acreditar sus compras de forma tradicional que confiando en la fuerza probatoria de los soportes informáticos ${ }^{362}$.

En estos procesos al demandado le corresponderá probar la veracidad de lo argumentado por el actor en su demanda o, en el caso de la publicidad, la exactitud de los datos materiales que exprese la publicidad objeto de demanda y que alega el actor.

No por ello la parte actora queda exonerada de probar los hechos, aunque el verdadero peso de la prueba, recaerá sobre la parte demandada.

\section{f. Carga de la prueba en otros supuestos}

La regulación de la prueba en la Ley 50/1980, de 8 de octubre, de contrato de seguro (en adelante LCS), según lo dispuesto en el

\footnotetext{
${ }^{361}$ Barona Vilar, S., Calderón Cuadrado M.P., Sanchis Crespo, C., Jimenez Fortea F.J., Martínez García, E., Pardo Iranzo V., Pascual Serrats, R., Andrés Ciurana B., García Vila, M., González Malabia S.: "Tutela de los consumidores y usuarios en la nueva LEC, artículo de Sanchís Crespo, C.: "La prueba en los procesos de consumo", cit., pág. 300.

${ }^{362}$ Sanchís Crespo C., en Barona Vilar, S., Calderón Cuadrado, M.P., Sanchis Crespo, C., Jimenez Fortea, F.J., Martínez García, E., Pardo Iranzo, V., Pascual Serrats, R., Andrés Ciurana, B., García Vila, M., González Malabia, S.: "Tutela de los consumidores y usuarios en la nueva LEC.: "La prueba en los procesos de consumo”, cit., pág. 300; García Cuerva García, S., Abel Lluch, X., Picó i Junoy, J. (Dir.): "Objeto y carga de la prueba civil”, cit., pág. 68.
} 
art. 38.2 de la LCS $^{363}$, el contenido de la póliza constituye una presunción a favor del asegurado cuando no existan pruebas concretas.

\section{B. I NVERSI ON DE LA CARGA DE LA PRUEBA}

Como ya hemos adelantado en el apartado anterior, el diseño de los procesos de consumo comporta especialidades en materia probatoria, tanto en el uso de los diferentes medios de prueba, como de la prueba a practicar en los diferentes procesos, tales como los procesos por daños y perjuicios en relación a faltas de conformidad, los productos defectuosos, etc., como veremos al tratar diferentes supuestos en los capítulos siguientes ${ }^{364}$.

Debido a la variedad de conflictos que pueden surgir en materia de consumo y a la dificultad que encuentra el consumidor para acceder a los medios de prueba, resulta indiferente, como ya hemos indicado, cuál de los litigantes logre la justificación de un hecho dado, según el principio denominado "de adquisición procesal", regulando además la inversión de la carga de la prueba por los perjuicios que le ocasionaría la falta de disposición y acceso a ella, modificando de este modo el supuesto de hecho de la norma, de forma que el demandante tiene que probar los hechos impeditivos, extintivos o excluyentes de la pretensión, y al demandado le incumbe acreditar los hechos constitutivos de la misma ${ }^{365}$.

Concretamente existen reglas especiales sobre inversión de la carga de la prueba ${ }^{366}$ en normas europeas, como la Directiva ya aludida 85/374 CEE, del Consejo, de 25 de julio, relativa a la aproximación de disposiciones legales, reglamentarias y administrativas de los Estados miembros en materia de responsabilidad por los daños causados por productos defectuosos, y también en la normativa estatal, tanto en el TRLGDCU, en supuestos de responsabilidad del fabricante en relación a un producto

\footnotetext{
${ }^{363}$ García Cuerva García, S., Abel Lluch, X., Picó i Junoy, J. (Dir.): “Objeto y carga de la prueba civil”, cit., pág. 68.

${ }^{364}$ González Cano, M.I.: “La tutela colectiva de consumidores y usuarios”, cit., pág. 85.

${ }^{365}$ Abel Lluch, X., Picó i Junoy, J. Dir.: "El objeto y carga de la prueba civil”. Ed.: Bosch Procesal, Barcelona 2007, pág. 107.

${ }^{366}$ S. no 91/2003, Sec. $3^{\text {a }}$ AP Vizcaya de 20-02-2003 (EDJ2003/48541), manifiesta respecto a la carga de la prueba, que corresponde a la parte actora la prueba de los hechos constitutivos de la demanda, y los obstativos e impeditivos a la parte demandada.
} 
defectuoso, bien sea en relación a la prueba del defecto o a su exoneración, así como a la prueba de la falta de conformidad del producto o la prueba sobre el carácter individual de una cláusula.

Por ello, la anterior Ley General de Consumidores y Usuarios de 1984 en sus arts. 24 y 25 concretó el principio de inversión de la carga de la prueba en el productor o suministrador, debiendo probar para quedar exonerados de responsabilidad, que la causa del daño es debida a la conducta culposa del usuario o de las personas por las que este debe responder.

En su art. 26 trasladaba la prueba sobre el cumplimiento de las exigencias debidas a los productores, importadores y suministradores ${ }^{367}$.

En la actualidad, tanto el TRLGDCU en los artículos 69, 80, 82, 109, 140 y 147, así como la Ley 7/1998, de 13 de abril, sobre Condiciones Generales de Contratación en su art. 10 bis 1 y la D.A. 1a. 19a , la LFE y la LCS prevén la posible inversión de la carga de la prueba considerando, además como cláusula abusiva la imposición de la carga de la prueba en perjuicio del consumidor en los casos en que debería corresponder a la otra parte contratante.

En base a los artículos citados, se responsabiliza a quienes produzcan, importen, suministren o faciliten productos a consumidores, de los daños que les causen, a no ser que acrediten haber cumplido las exigencias o cuidados necesarios ${ }^{368}$.

En todos ellos se establece la inversión de la carga de la prueba a favor del consumidor, debiendo ser el demandado quien acredite bien que informó al actor sobre la posibilidad de desistir del contrato, como contempla el art. 69 del TRLGDCU, bien del conocimiento y entrega del contrato, en los supuestos que establece el art. 80 del mismo cuerpo legal, sobre las cláusulas no negociadas individualmente que han sido contratadas de forma telefónica o

\footnotetext{
${ }^{367}$ Llamas Pombo. E. (coord.) "Ley General para la Defensa de los Consumidores y Usuarios. Comentarios y jurisprudencia de la Ley veinte años después”. Ed.: La Ley, Madrid 2005 pág. 722; Reyes López, M.J., Puertes Martí, A., Estruch Estruch, J. y Montés Rodríguez, P.: "Jurisprudencia en materia de Protección de Consumidores y usuarios”. Ed.: Practica del Derecho, S.L., Valencia 1995, pág. 51.

${ }^{368}$ Barona Vilar, S., Calderón Cuadrado M.P., Sanchis Crespo, C., Jimenez Fortea F.J., Martínez García, E., Pardo Iranzo V., Pascual Serrats, R., Andrés Ciurana B., García Vila, M., González Malabia S.: "Tutela de los consumidores y usuarios en la nueva LEC, artículo de Sanchís Crespo, C.: "La prueba en los procesos de consumo", cit., pág. 288.
} 
electrónica, o en relación a la negociación de forma individual de las cláusulas abusivas previstas en el art. 82 del TRLGDCU. Por su parte el art. 109 hace recaer también en el demandado la carga de probar que los contratos celebrados fuera del establecimiento mercantil no se encuentran sometidos al TRLGDCU, pues de lo contrario se presumen sometidos al mismo.

Corresponde también al empresario la prueba de la exoneración de su responsabilidad, cuya relación de supuestos concretos establece el art. 140 del mismo.

El art. 147 también del TRLGDCU, al tratar del régimen de responsabilidad de los prestadores de servicios, hace recaer la carga de la prueba en el demandado que deberá acreditar haber cumplido las exigencias y requisitos reglamentariamente establecidos y los demás cuidados y diligencias que exige la naturaleza del servicio, debido a que se presume su responsabilidad por los daños y perjuicios causados a los consumidores y usuarios ${ }^{369}$, y el demandante deberá probar el correcto uso o consumo y el daño causado ${ }^{370}$.

Otro ejemplo de regulación legal de la inversión de la carga de la prueba se encontraba también en la Ley 22/1994, de 6 de julio, de responsabilidad por daños causados por productos defectuosos, refundida dentro del TRLGDCU, que determinaba que el perjudicado que pretendiera obtener la reparación de un daño tenía que probar tanto el defecto, como el daño y la relación de causalidad, cuestión de gran dificultad para el consumidor que no controla el proceso de producción ${ }^{371}$.

\footnotetext{
${ }^{369}$ García-Cuerva García, S., Abel Lluch, X., Picó i Junoy, J. (Dir.): “Objeto y carga de la prueba civil”. Ed.: Bosch Procesal, Barcelona 2007, pág. 68.
${ }^{370}$ Barona Vilar, S., Calderón Cuadrado, M.P., Sanchis Crespo, C., Jimenez Fortea F.J., Martínez García, E., Pardo Iranzo V., Pascual Serrats, R., Andrés Ciurana, B., García Vila, M., González Malabia S.: "Tutela de los consumidores y usuarios en la nueva LEC, artículo de Sanchís Crespo, C.: "La prueba en los procesos de consumo", cit., pág. 288.

${ }^{371}$ El TS en la línea manifestada, en sentencias como la no 793/1994 de 22-07-1994 (EDJ 1994/6155) de la que se ha hecho eco la jurisprudencia de las audiencias provinciales en multitud de sentencias como la $n^{\circ}$ 814/2001, Sec. $1^{\text {a }}$ de la AP de Santa Cruz de Tenerife de 5-11-2001 (TOL 139.860), ha entendido que en los procesos de consumo prima el principio de inversión de la carga de la prueba debido a la mayor facilidad de acceso a la prueba por la parte demandada. En la referida sentencia, donde se valora el defecto de un vehículo, considera que tenían que ser las entidades demandadas las que probaran el defecto.
} 
Por ello, la inversión de la carga de la prueba exige que el fabricante o vendedor demuestre que el producto era defectuoso o que se le facilitó al consumidor toda la información necesaria para el manejo del mismo ${ }^{372}$.

Como hemos indicado, también la LCGC, concretamente en el art. 10 bis apdo. 1 de la LCGC, en relación a las cláusulas abusivas, establece que el profesional que afirme que una determinada cláusula no ha sido negociada, asumirá su prueba ${ }^{373}$.

Otras leyes como la Ley de firma electrónica y la Ley del contrato de seguro también regulan la posible inversión.

En la LCS se regula la inversión de la carga de la prueba en el art. 38.2, diciendo que incumbe al asegurado probar la preexistencia de los objetos, constituyendo el contenido de la póliza una presunción a favor del asegurado cuando no existan pruebas concretas.

Concretando la apreciación jurisprudencial en relación a la aplicación de alguno de estos artículos, en supuestos de productos defectuosos supone atribuir al fabricante, sobre el que recae la referida responsabilidad objetiva, la prueba del origen del daño, pero no sobre materias excluidas del TRLGDCU, como el caso enjuiciado en la S. no 200/2007 de la AP de Castellón, de 10 de octubre de 2007 (TOL 1.258.301), al entender el tribunal que se encontraba ante una clara responsabilidad extracontractual donde la prueba corresponde al perjudicado.

Otro ejemplo de inversión en productos defectuosos lo encontramos en cuestiones en que existe una responsabilidad "quasi objetiva", en los cuales la jurisprudencia entiende que se produce la inversión de la carga de la prueba en un segundo momento, tras la prueba del defecto por el actor, que de mediar culpa de la víctima y del fabricante, la indemnización se reducirá proporcionalmente en atención a la gravedad de la culpa de la víctima puesta en relación a

\footnotetext{
En igual sentido se pronunció la Sentencia del TS de 23 de mayo de 1991 (TOL1.728.948), también sobre defectos en un vehículo.

${ }^{372}$ Llamas Pombo, E. (coord.) "Ley General para la Defensa de los Consumidores y Usuarios. Comentarios y jurisprudencia de la Ley veinte años después”, cit., pág. 721; De León de Arce, A., en García García, L.M., (coord.): “Derechos de los consumidores y usuarios”. Tomo II, cit., pág. 1778.

${ }^{373}$ García-Cuerva García, S., Abel Lluch, X., Picó i Junoy, J. (Dir.): “Objeto y carga de la prueba civil”, cit., pág. 68.
} 
la incidencia de su comportamiento sobre las consecuencias del siniestro ${ }^{374}$.

En el supuesto enjuiciado por la Sentencia de 13 de mayo de 2002, de la Sec. $1^{\underline{a}}$ de la Audiencia Provincial de Ciudad Real (TOL 200.258), ante el uso de una tarjeta de crédito en una transacción, donde la parte actora aporta como única prueba la liquidación que emite la entidad, entendió que esa misma parte debió aportar la prueba necesaria por su cercanía y posible disponibilidad de la misma ${ }^{375}$.

El hecho de que la prueba obrara en este caso en poder de la actora, unido al hecho de que pudiera haber aportado más acerbo probatorio del que aportó, lleva a que la sentencia concluya considerando que no basta la existencia de un contrato y la presentación de una liquidación por la parte demandante para probar la realización de unas compras.

En la transacción llevada a cabo, existe un pago que constituye una apariencia de cumplimiento por el vendedor que justifica que deba ser el comprador el que pruebe su disconformidad.

Debemos realizar un último apunte sobre la inversión de la carga de la prueba en procesos sobre tutela de los intereses difusos, como analizaremos con mayor detalle en el apartado siguiente, donde la doctrina no es pacífica, puesto que existe un sector que defiende la inversión de la carga de la prueba y otro que se muestra contrario a ella en determinados casos como veremos al analizar los productos defectuosos, considerando que debería ser la propia parte demandada la que probara el daño a ella imputable, dado que estima que de este modo se vulnera el derecho a la presunción de inocencia del art. $24 \mathrm{CE}$, y la inversión supondría una alteración de la garantía de equilibrio en el procedimiento judicial ${ }^{376}$.

${ }^{374}$ S. no 617/2011, Sec. $7^{\text {a }}$ AP Barcelona de 19-12-2011 (TOL 2.471.673), S. $n^{\circ}$ 300/2007, Sec. 19, AP Barcelona de 6-06-2007 (TOL 1.176.665), S. no 278/2015, Sec. 17 AP Barcelona de 19-06-2015 (TOL 5.491.696), entre otras.

375 A modo de ejemplo podemos aludir también a la S. de la Sec. $2^{\text {a }}$ de la AP Valencia de, de 8-012001(TOL 75.725) en una demanda por impago de factura telefónica, donde debe probarlo argumentado por el actor la propia Compañía demandada, o en la S. no 120/2009, de 19-02-2009 (TOL 1.452.539) sobre la prueba de los daños producidos por la explosión de una bombona de butano, que corren a cargo de la suministradora demandada.

${ }^{376}$ J. B. Acosta Estévez: “Tutela procesal de los consumidores”. Ed.: J.M. Bosch Editor, S.A., Barcelona 1995, pág. 94. 


\section{LA ADMI SI ÓN DE LA PRUEBA I NDI RECTA O I NDI CI ARIA}

Debido a la complejidad manifestada en el apartado anterior ${ }^{377}$, ya desde el año 1990 se observa por parte de la jurisprudencia del TS la aplicación de presunciones en cuestiones de responsabilidad del fabricante, lo cual introdujo cambios en la forma de valorar y llegar a la prueba ${ }^{378}$.

Vamos ahora a analizar la utilización de las presunciones en varios supuestos distintos:

a) Iniciando el estudio del uso de las presunciones sobre cuestiones contractuales, podemos hacer alusión entre otras a la Sentencia no 432/2003, del TS de 30 de abril de 2003 (TOL 275.461), en la que se admite la eficacia de la prueba de presunciones en procesos de consumo en ausencia de pruebas directas y cuando el actor pruebe la parte esencial de la relación contractual.

b) En cuestiones sobre defectos del producto, son de vital importancia para concretar la preexistencia de defectos en el producto. En relación ello, Avilés García, al analizar la Directiva 1999/44/CE, del Parlamento Europeo y del Consejo, de 25 de mayo de 1999 sobre determinados aspectos de la venta de bienes de consumo, llega a la conclusión de que sólo podrá considerarse que el defecto es de origen mediante meros indicios obtenidos a través de informes periciales realizados por profesionales que determinen la disconformidad del producto ${ }^{379}$.

En este tipo de procesos sobre productos defectuosos, son reiteradas las sentencias que presumen la existencia del defecto a partir de la prueba de la relación de causalidad entre el correcto uso y

\footnotetext{
${ }^{377}$ De León de Arce, A., en García García, L.M., y Bujosa Badell, L.M. (coord.): "Derechos de los consumidores y usuarios”. Epígrafe 64. Editorial Tirant lo Blanch 2007, cit., pág. 8; Álvarez Sánchez de Movellán: "La prueba por presunciones. Particular referencia a su aplicación en supuestos de responsabilidad extracontractual”. Ed.: Comares, Madrid 2007, pág. 101; De León de Arce, A., en García García, L.M., y Bujosa Badell, L.M. (coord.): "Derechos de los consumidores y usuarios". Epígrafe 64. Editorial Tirant lo Blanch 2007, cit., pág. 8.

${ }^{378}$ S. no 374/1990, TS 18-06-1990 (TOL 1.730.393).

${ }^{379}$ Avilés García, J.: "Los contratos de compraventa de bienes de consumo. Problemas, propuestas y perspectivas de la venta y garantías en la Directiva 1999/447/CE y la Ley 23/2003", cit., pág. 326; Álvarez Sánchez de Movellán: "La prueba por presunciones. Particular referencia a su aplicación en supuestos de responsabilidad extracontractual”, cit., pág. 109; Busto Lago, J.M. (coord.), Álvarez lata, N., Peña López F.: "Reclamaciones de consumo. Derecho de consumo desde la perspectiva del consumidor”, cit., pág. 762.
} 
consumo del producto con el daño ${ }^{380}$. Tal como ha declarado el Tribunal Supremo, cabrá acudir a esta prueba de indicios o presunciones judiciales al objeto de demostrar, a través de un procedimiento lógico y racional, que el daño se ha producido porque el producto adolecía de un defecto ${ }^{381}$.

Ejemplo de ello es la Sentencia no 144/2009 de Sec. 10ạ de la AP Madrid de 10 de febrero de 2009 (TOL 1.554.150), o la Sentencia no 931/2006 del TS 28 de septiembre de 2006 (TOL 1.014.554), siendo además de una importancia decisiva la emisión de dictámenes periciales ${ }^{382}$.

c) Concretamente, en las reclamaciones de responsabilidad civil donde se solicita una indemnización, se presume la culpabilidad del fabricante si no justifica que fue debida al propio comprador, por encontrarse sometido al régimen de la responsabilidad general.

En estos casos, solo podrá librarse del pago de la indemnización probando que el consumidor o quien deba responder por el daño causado haya realizado un uso indebido o negligente del producto, o bien justificando que se han cumplido todas las garantías y exigencias según la naturaleza del producto ${ }^{383}$.

Por su parte, la Sentencia del TS de 23 de junio de 1993 (EDJ 1993/6177), en el caso del estallido de una botella, presumió que ni la víctima debía probar que el fabricante no había cumplido con las

\footnotetext{
380 Álvarez Lata, N., Peña López, F., Busto Lago, J.M (coord.): “Reclamaciones de consumo. Derecho de consumo desde la perspectiva del consumidor”, cit., pág. 764

${ }^{381}$ No es necesario acreditar el defecto de que adolecía, pero sí que este es el que ha originado el daño, como reza la S. $n^{\circ}$ 144/2009, Sec. 10a , AP Madrid de 10-02-2009 (TOL 1.554.150), siendo de importancia decisiva para poder basarse en las presunciones, el informe pericial que determine la causa del perjuicio, o esta otra S. TS 21-03-2006, n 258/2006 (TOL 866.065).
}

Con ocasión de un accidente pirotécnico, la S. del TS de 25-03-1991 (TOL 1.728.182), consideró que no se puede olvidar que la prueba de presunciones exigía al actor la prueba de que el daño fue debido solo a la fabricación o mal funcionamiento del cohete.
${ }^{382}$ La S. $n^{\circ}$ 332/2008, de 30 de abril de 2008 (TOL 1.311.962) recurre a la prueba de presunciones para probar el defecto cuando afirma que, ubicado el origen del mismo en el motor y sin influencia de causas externas, se produce un resultado que no se hubiera esperado en un vehículo nuevo, y al estar además aparcado, no se puede considerar mala utilización.

En relación a esta misma cuestión existen muchas otras sentencias del TS, como la nº 659/2005 de 27 de julio de 2005 (RJ 2005/510), la no 938/2007 de 21 de septiembre de 2007 (RJ 2007/5495) o la no 346/2007 de 16 de marzo de 2007 (RJ 12007/1859).

${ }^{383}$ López Fragoso, T.: “La carga de la prueba según el artículo 217 de la Ley 1/2000 de Enjuiciamiento Civil”. Actualidad Civil Año XI nº487 de 24 de mayo de 2001, cit., pág. 2. 
precauciones necesarias, ni que la propia víctima había actuado con corrección, pero consideró que el fabricante tampoco podía liberarse de su responsabilidad probándolo.

d) También en el ámbito de la responsabilidad por culpa en muchos casos se ha acudido a la prueba de presunciones, como en la Sentencia no 648/1998 del TS de 3 de julio de 1998 (TOL 5.156.886) ${ }^{384}$, según la cual, en actividades empresariales que suponen un beneficio para quien causa un peligro, se exige prueba de la ausencia de culpa.

En el caso de actividades peligrosas, la Sentencia del TS $\mathrm{n}$ 1012/2008, de 29 de octubre de 2008 (TOL 1.393.360) describe los criterios de la responsabilidad civil y presume que el autor del daño incurre en culpa, debiendo ser él mismo quien desvirtúe tal presunción, mediante la prueba de haber obrado con la diligencia debida, no bastando el cumplimiento de los reglamentos y demás disposiciones legales que obligan a la adopción de garantías para prevenir y evitar daños.

e) En casos especiales, como ocurre con la Sentencia del TS de 10 de junio de 2000 (TOL 7.290), se han decretado los daños sin prueba directa, justificando la propia sentencia su decisión basándose en que ello es posible en los supuestos en los que de los hechos demostrados y reconocidos por las partes se deduzca necesaria y fatalmente la existencia del daño real y efectivo, y la relación de causalidad entre este y el incumplimiento.

f) También existen pronunciamientos sobre los condicionantes necesarios para desvirtuar los efectos de una presunción alegada, de este modo, según la Sentencia no 22/2014 de la Sec. 3a de la AP de Baleares de 24 de enero de 2014 (TOL 4.103.864), la presunción que se cree puede quedar desvirtuada en el proceso mediante la oportuna prueba.

\section{MEDI OS DE PRUEBA}

De entre los medios de prueba ya referidos que enumera el art. 299.2 de la LEC, algunos de ellos resultan más idóneos y habituales

\footnotetext{
384 Álvarez Sánchez de Movellán: "La prueba por presunciones. Particular referencia a su aplicación en supuestos de responsabilidad extracontractual”, cit., pág. 108.
} 
en procesos de consumo, como veremos en las páginas siguientes, pero todos ellos son utilizados.

Algunos medios como la documental, los medios de reproducción de la palabra, el sonido y la imagen, así como los instrumentos que permiten archivar y conocer o reproducir palabras, datos, cifras y operaciones matemáticas llevadas a cabo con fines contables o de otra clase y la prueba pericial se utilizan con mayor frecuencia, como analizaremos a continuación, sin entrar en detalles puesto que será objeto de estudio en los capítulos siguientes.

Respecto a la forma de llevar al proceso las pruebas no existen diferencias con respecto al resto de procesos civiles, siguiendo el orden establecido en el art. 300 de la LEC para todo proceso civil:

\section{a. Documental}

Los documentos cumplen la función de verdaderas fuentes de prueba que se van a introducir en el proceso a través de la prueba documental y que permiten verificar las alegaciones realizadas por las partes en el proceso ${ }^{385}$.

Haciendo referencia en primer lugar a los documentos tradicionales, este medio de prueba es fundamental para hacer constar la existencia de determinadas relaciones de consumo, como en el caso de la documentación de un crédito, puesto que no prosperará su petición si reclama su existencia y no aporta el documento justificativo del mismo. Por otro lado, es particularmente utilizado el documento en soporte electrónico, especialmente en la prueba de la contratación electrónica.

Para su presentación las partes tendrán en consideración lo establecido en los arts. 265.2 de la LEC (para el supuesto de que el documento no pueda aportarse junto a la demanda o contestación, pudiendo hacer referencia al archivo, protocolo o lugar donde se encuentre), y 270 de la LEC en relación a los condicionantes de la

\footnotetext{
${ }^{385}$ S. no 44/2007 Sec. $28^{\text {a }}$ AP Madrid de 22-02-2007 (TOL 1.155.821). Respecto de las pruebas periciales considera reiterada jurisprudencia que se trata de pruebas de libre valoración por los órganos judiciales. En cuanto a la pericial económica, para que exista la consideración como desleal, no basta con la concurrencia de una situación de dependencia económica de la actora respecto de la demandada, de poder relativo de mercado, sino que es preciso que la demandada abuse de tal situación, es decir, explote deslealmente la situación de dependencia económica que respecto de ella tiene la actora como empresa suministradora.
} 
admisión de documentos presentados en un momento posterior no inicial del proceso.

Si la prueba documental se hubiera aportado ya en el escrito de demanda, como en el caso ejemplificativo de que el consumidor haya aportado una factura, si esta resulta impugnada por el demandado alegando que la mención de pagado ha sido añadida, el juzgador valorará el documento según el artículo referido.

En este caso, el consumidor podría solicitar el cotejo pericial de letras aludido o proponer cualquier otro medio de prueba útil para ello ${ }^{386}$.

Este tipo de prueba, pese a su uso frecuente e importancia, en la mayoría de casos, debe acompañarse de otros medios de prueba para que el juzgador pueda alcanzar su convicción.

En relación a la prueba documental aportada mediante registros de una transacción electrónica, el Juez la admitirá y actuará en función del carácter público o privado del registro electrónico, aunque las partes podrán argumentar sobre su falsedad, en cuyo caso, debido a la dificultad de acreditar su manipulación o alteración, que sólo se podrá realizar mediante la pericia de un experto, esta alegación no será tenida en consideración por parte del Juez ${ }^{387}$.

\section{b. Los medios audiovisuales y soportes informáticos}

En relación a los medios de reproducción de la palabra, el sonido y la imagen de los arts. 382 a 384 de la LEC $^{388}$, es relevante la prueba practicada a través de cintas o grabaciones de vídeo o de audio, por ejemplo, en procesos sobre publicidad ilícita y también tiene gran trascendencia como prueba la utilización de soportes informáticos (diskettes, cd-roms, discos duros, etc.). Este medio es interesante en la determinación de los consumidores y usuarios

\footnotetext{
${ }^{386}$ Barona Vilar (coord.), Calderón Cuadrado M.P., Sanchís Crespo, C., Jiménez Fortea, F.J., Martínez García,E., Pardo Iranzo, V., Pascual Serrats, R., Andrés Ciurana, B., García Vila, M., González Malabia, S.: "Tutela de los consumidores y usuarios en la Nueva LEC”, cit., pág. 298.

${ }^{387}$ Sabah Gomez Soares, F.: "La Prueba en la contratación electrónica”. Revista Internacional de Estudios de Derecho Procesal y Arbitraje no 3/2009: pág. 21, disponible en www.riedpa.com.

388 Barona Vilar, S., Calderón Cuadrado M.P., Sanchis Crespo, C., Jimenez Fortea F.J., Martínez García, E., Pardo Iranzo V., Pascual Serrats, R., Andrés Ciurana B., García Vila, M., González Malabia, S.: "Tutela de los consumidores y usuarios en la nueva LEC, artículo de Sanchís Crespo, C.: "La prueba en los procesos de consumo”. Ed. Tirant lo Blanch, Valencia 2013, pág. 294.
} 
perjudicados a consecuencia del consumo o uso de un producto 0 servicio, si existiera algún tipo de registro o archivo ${ }^{389}$.

En muchos casos se trata de documentos privados, aportados a través de este medio al proceso, sustituyendo de esta forma al documento tradicional.

La prueba de soportes informáticos viene utilizándose cada vez más por ser una forma cómoda y segura de aportar al proceso una cantidad importante de información.

El soporte en que se hallen los datos firmados electrónicamente será admisible como prueba documental en juicio, según el art. 3.8 de la LFE, puesto que el consentimiento prestado por vía electrónica, en soporte informático o electrónico, se equipara con el plasmado en soporte de papel, tal como establece el art. 24.2 de la LFE.

Este medio de prueba es imprescindible en todo proceso de consumo, donde de entrada, debe aportarse de forma documental el justificante de la relación comercial o de la petición que se inicia (bien mediante contrato si lo hubiere, factura, ticket, listado de movimientos de la tarjeta, si la compra se ha realizado utilizando este medio, etc.).

Se trata por tanto de mecanismos de prueba de las transacciones electrónicas, de pedidos de material "online" servido de forma defectuosa.

Esta, en ocasiones en este tipo de procesos, tendrá que realizarse fuera de la sede del órgano jurisdiccional, como en el supuesto de que tenga que examinarse un ordenador central de una entidad bancaria o acceder a un intranet empresarial ${ }^{390}$.

\footnotetext{
${ }^{389}$ Del Olmo Del Olmo, J.A.: "Especialidades de la fase declarativa en los procesos para la tutela de los consumidores y usuarios (ley de enjuiciamiento civil 1/2000) (y II), artículo publicado por el Ministerio de Justicia en su boletín núm. 1968, pág. 24 y ss, http://www.mjusticia.gob.es/cs/Satellite/Portal/1292344079564?blobheader=application\%2Fpdf\&blobhea dername1=Content-

Disposition\&blobheadername2=EstudioDoctrinal\&blobheadervalue1=attachment\%3B+filename\%3D200 4_1969.pdf\&blobheadervalue2=1288778656924.

${ }^{390}$ Barona Vilar (coord.), Calderón Cuadrado M.P., Sanchís Crespo, C., Jiménez Fortea, F.J., Martínez García,E., Pardo Iranzo, V., Pascual Serrats, R., Andrés Ciurana, B., García Vila, M., González Malabia, S.: “Tutela de los consumidores y usuarios en la Nueva LEC”, cit., pág. 298.
} 


\section{c. El interrogatorio de parte.}

En este punto encontramos la primera peculiaridad que ofrecen los procesos de consumo en la práctica del interrogatorio, que supone que las reglas establecidas en los arts. 301 y ss. deberán suavizarse debido a las dudas y problemas que pueden surgir a la hora de responder las preguntas, pues en su mayoría puede tratarse de cuestiones técnicas.

Aunque las cuestiones aludidas van a dificultar la formulación de las preguntas, pese a ello, el interrogatorio de parte se suele practicar en la mayoría de supuestos de consumo, siendo de importancia en cuestiones sobre resolución y anulación de contratos, sobre todo contratos financieros o de compraventa, donde es importante aclarar el juego de voluntades de las partes.

Especial carácter reviste también el interrogatorio en cualquier proceso cuando una parte es una Administración pública, a las que se les concede un privilegio especial consistente en la posible decisión del interrogado de "no comparecer" o "no contestar de forma oral", emitiendo un escrito que se envía al juzgado atendiendo la petición de prueba.

Otra cuestión que se suscita en el interrogatorio es la determinación de a quién corresponde declarar en calidad de parte cuando la demanda ha sido interpuesta por una asociación de consumidores y usuarios ${ }^{391}$. En estos casos resulta de aplicación el art. 301.2 de la LEC que faculta a declarar como interrogado al titular del derecho, es decir, al propio consumidor ${ }^{392}$.

\section{d. Interrogatorio de testigos}

La prueba testifical es también importante en los procesos de consumo, puesto que en algunos supuestos puede ser determinante, por carecer de la documental necesaria. El ejemplo más significativo

\footnotetext{
${ }^{391}$ Del Olmo Del Olmo, J.A.: "Especialidades de la fase declarativa en los procesos para la tutela de los consumidores y usuarios (ley de enjuiciamiento civil 1/2000) (y II), cit., pág. 24 y ss; Sanchís Crespo, C.: "La prueba en los procesos de consumo", en Barona Vilar, S. (coord.), Calderón Cuadrado M.P., Sanchis Crespo, C., Jimenez Fortea F.J., Martínez García, E., Pardo Iranzo V., Pascual Serrats, R., Andrés Ciurana B., García Vila, M., González Malabia S.: "Tutela de los consumidores y usuarios en la nueva LEC", cit., pág. 294.

392 Ejemplo de ello son los supuestos resueltos en las sentencias n ${ }^{0}$ 197/2016, TS de 30-03-2016 (TOL 5.682.215) y en la S. $n^{\circ} 125 / 2016$, Sec. $1^{\text {a }}$ AP Orense, de 8 de marzo de 2016 (TOL 5.701.201).
} 
sería en los casos en que ha intervenido un empleado en la relación comercial.

Este medio de prueba, junto al interrogatorio de parte supone aportar al proceso alegaciones personales que coexisten con otros medios de prueba más objetivos dado que lo decisivo en algunos procesos de consumo, como los referidos a productos defectuosos, se basa en la prueba de la relación de causalidad entre el defecto del producto y el daño causado, así como la evaluación del mismo.

\section{e. La prueba pericial}

Además de la especialización exigida en este tipo de procesos, a los dictámenes que habitualmente se aportan en cualquier proceso civil, se unen otros de gran importancia que trataremos en el capítulo siguiente ${ }^{393}$.

A través de los informes periciales se introduce en el proceso información relevante que sirve para llevar a cabo la verificación de las alegaciones realizadas por las partes. En supuestos de reclamaciones por productos defectuosos, por ejemplo, es fundamental el dictamen pericial al objeto de establecer la relación de causalidad y probar los daños.

Puede incluso proponerse en el mismo proceso tanto la prueba pericial de parte como la judicial, aunque el juez no puede solicitar la ampliación de oficio del dictamen, sólo se basará en la facultad que le concede el art. 429.1 de la LEC de considerar que existe insuficiencia probatoria.

La primera cuestión a analizar es la eficacia probatoria concreta de la prueba pericial, existiendo procesos en que esta es de vital importancia, como en temas de daños de los consumidores donde se pretenda su reparación y son necesarios conocimientos especiales.

Merece ser mencionado el aporte de informes técnicos confeccionados por empresas externas, consideradas como

\footnotetext{
393 S. no 44/2007, Sec. $28^{\text {a }}$ AP Madrid de 22-02-2007 (TOL 1.155.821), respecto de las pruebas periciales considera reiterada la jurisprudencia que determina que se trata de pruebas de libre valoración por los órganos judiciales. También hace alusión al supuesto concreto de la pericial en materia de competencia desleal, entendiendo que para que exista la conducta desleal no basta con la concurrencia de una situación de dependencia económica de la actora respecto de la demandada, de poder relativo de mercado, sino que es preciso que la demandada abuse de tal situación, es decir, explote deslealmente la situación de dependencia económica que respecto de ella tiene la actora como empresa suministradora.
} 
interesadas de forma indirecta en la resolución del conflicto, sobre todo por la existencia de una relación continuada entre esta y el servicio técnico que podría incluso llegar a ser motivo de tacha ${ }^{394}$.

Los informes aludidos en muchas ocasiones no identifican al técnico redactor del mismo, ni hacen constar su cualificación profesional, no entran a analizar los posibles fallos o estado técnico del bien, ni realizan explicación técnica alguna que los determine, no constan las fechas, ni se menciona el servicio técnico que ha intervenido. Además de lo dicho, carecen de justificación o argumento sobre la opinión en él manifestada y sobre las razones que conducen a tal argumentación, no identificando tampoco al emisor del mismo con su firma ni con sello alguno.

Este tipo de informe podría ser tachado por parte del demandado, pudiendo incluso impugnar su validez como verdadero medio de prueba.

Debido a ello el usuario se ve en la necesidad de acudir a un proceso judicial o arbitral donde deberá presentar una prueba pericial que desvirtúe el informe escueto y falto de justificación del servicio técnico. Pese a ser esta la única solución que tiene el usuario, es poco frecuente que sea utilizada por el elevado coste que supone, incluso mayor que el del bien cuyo daño o defecto plantea, encontrándose de este modo en una situación de total desprotección.

Cabe la posibilidad de que el tribunal, una vez aportado este con las carencias indicadas, lo admita y solicite su ampliación al objeto de que se concreten los extremos que considere necesarios. También es posible que pese a carecer de la necesaria justificación y documentación por falta de aporte de fotos, ensayos, objetos, etc., sean considerados por el tribunal como verdaderos informes y sean tenidos como verdadera prueba pericial, acordando incluso la comparecencia del perito al acto del juicio ${ }^{395}$.

Para poder considerar el dictamen pericial como verdadera prueba deben constar los datos y cualificación del perito así como el nombre del profesional que lo suscribe, identificando claramente el

\footnotetext{
${ }^{394}$ Mendoza Losana, A.I.: "Cómo probar que los desperfectos de los bienes no están cubiertos por la garantía en la venta de bienes muebles”, cit., págs. 35 a 49.

395 Así lo entendieron las STS de 15 de diciembre de 1986 (TOL 1.734.522), la de 19 de febrero de 1990 (TOL 1.729.260), y de la AP Córdoba de 10 de octubre de 2002 (TOL 263.793).
} 
objeto de la pericia, describiendo el defecto observado y el estado técnico en que se encuentre el bien en el momento de su realización, ofreciendo una explicación de la técnica utilizada para su averiguación, la mención a las fechas de garantía, la fecha de solicitud del informe y la firma del técnico con el sello del servicio técnico que lo realiza, en su caso ${ }^{396}$.

De presentarse varios dictámenes periciales, el juez, para decidirse por uno u otro informe, tendrá en consideración su razonamiento y justificación, siempre que aquel cumpla su función y responda a una lógica que pueda ser comprobable ${ }^{397}$, sobre todo en casos de indemnizaciones.

Si entre los informes presentados se encuentra un informe pericial judicial, el órgano jurisdiccional otorgará a este mayor credibilidad, por estar dotado de la garantía de imparcialidad necesaria en el momento de realizar el peritaje ${ }^{398}$.

Debido al importante coste del dictamen pericial, la Ley de Asistencia Jurídica Gratuita posibilita el nombramiento de perito a través de funcionarios, organismos o servicios técnicos públicos o privados designados por insaculación ${ }^{399}$.

\section{f. El reconocimiento judicial ante las especialidades de los procesos de consumo.}

Esta prueba, de gran importancia en los procesos de consumo, donde se exigen evaluaciones sobre las consecuencias del uso o consumo de bienes o servicios en personas lugares u objetos, difícilmente llega a admitirse.

\footnotetext{
${ }^{396}$ Mendoza Losana, A.I.: "Cómo probar que los desperfectos de los bienes no están cubiertos por la garantía en la venta de bienes muebles”, cit., pág. 35 a 49.

${ }^{397}$ Barona Vilar, S., Calderón Cuadrado M.P., Sanchis Crespo, C., Jimenez Fortea F.J., Martínez García, E., Pardo Iranzo V., Pascual Serrats, R., Andrés Ciurana, B., García Vila, M., González Malabia, S.: "Tutela de los consumidores y usuarios en la nueva LEC, artículo de Sanchís Crespo, C.: "La prueba en los procesos de consumo", cit., pág. 303.

${ }^{398}$ Barona Vilar, S., Calderón Cuadrado, M.P., Sanchis Crespo, C., Jimenez Fortea, F.J., Martínez García, E., Pardo Iranzo, V., Pascual Serrats, R., Andrés Ciurana B., García Vila, M., González Malabia S.: "Tutela de los consumidores y usuarios en la nueva LEC, artículo de Sanchís Crespo, C.: "La prueba en los procesos de consumo", cit., pág. 302.

${ }^{399}$ De León de Arce, A., en García García, L.M., (coord.): “Derechos de los consumidores y usuarios”. Tomo II, cit., pág. 1778.
} 
El reconocimiento, de practicarse, se realizará junto a otros medios, como es el dictamen de peritos que será el que valore los hechos controvertidos. En procesos de consumo la práctica del reconocimiento judicial exigirá, debido a la naturaleza de las pretensiones, evaluaciones a cerca de las consecuencias del uso o consumo de bienes y servicios, y por tanto, que se desarrolle a través de la prueba pericial por los conocimientos especializados ${ }^{400}$.

Aunque existe una gran reticencia por parte de los jueces a acordar esta prueba, si se considerara conveniente su práctica por el tribunal, dictará providencia admitiéndolo y ordenando su práctica junto a la prueba pericial y la de reconocimiento judicial.

De llevarse a cabo el reconocimiento judicial de algún contrato relacionado con una operación realizada electrónicamente, serán además objeto de examen las instalaciones de donde proceda, ya sea un ordenador o un sitio web ${ }^{401}$.

Este tipo de prueba tampoco es frecuente en los procesos de competencia desleal, pero sí que podría ser utilizada en determinados casos, como en el reconocimiento de una maquinaria que se ha utilizado para fabricar una serie de productos.

\footnotetext{
${ }^{400}$ Barona Vilar, S., Calderón Cuadrado M.P., Sanchis Crespo, C., Jimenez Fortea, F.J., Martínez García, E., Pardo Iranzo, V., Pascual Serrats, R., Andrés Ciurana, B., García Vila, M., González Malabia, S.: "Tutela de los consumidores y usuarios en la nueva LEC, artículo de Sanchís Crespo, C.: "La prueba en los procesos de consumo", cit., pág. 308.

${ }^{401}$ Aragoneses Martínez, S., Cubillo López, I., Hinojosa Segovia, R., Peiteado Mariscal, P., Tomé García, J.A.: “Cien cuestiones controvertidas sobre la prueba en el proceso civil”. Ed.: Colex, Madrid 2004, pág. 188.
} 


\section{CAPÍTULO VII. ESPECIALIDADES DE LA PRUEBA EN EL PROCESO DE CONSUMO ( 1 ).}

Analizaremos a lo largo de este capítulo la importancia de la prueba pericial haciendo especial mención a una prueba que se puede considerar muy útil en los procesos de consumo, como es la de los sondeos demoscópicos.

Nos adentraremos además en cuestiones específicas en materia de prueba, en varios aspectos de especial relevancia como la prueba en las prácticas comerciales desleales, en los procesos sobre publicidad ilícita, en la ley de marcas, sobre cláusulas abusivas de los contratos con consumidores, así como en los productos defectuosos.

En relación a estos últimos, y aunque han sido motivo de tratamiento en el capítulo anterior al analizar la carga de la prueba, existen cuestiones concretas que surgen en relación al objeto de la prueba que puntualizaremos, tanto del defecto, de la relación de causalidad, de la responsabilidad del propio perjudicado, tratando ciertos temas concretos sobre daños causados por productos defectuosos a modo ejemplificativo.

\section{A. IMPORTANCIA DE LA PRUEBA PERICIAL EN LOS PROCESOS DE CONSUMO.}

Aunque en todos los tipos de procedimientos de consumo es importantísimo el dictamen pericial, vamos a referirnos a algún supuesto de forma ejemplificativa, considerando algunas cuestiones de interés en relación a los mismos.

En los procesos donde se ejercitan reclamaciones de daños, se hace necesaria la prueba pericial ${ }^{402}$, bien para concretar la relación de causalidad o para determinar la propia existencia de los mismos.

Lo mismo sucede en los supuestos de productos defectuosos, donde en muchas ocasiones la prueba pericial se antepone a cualquier otra, como ocurrió en el caso enjuiciado en la S. no 352/2011, Sec. 11 a de la AP de Barcelona, de 30 de junio de 2011 (TOL 2.222.025), al conceder mayor credibilidad a lo informado por

\footnotetext{
${ }^{402}$ Barona Vilar, S., Calderón Cuadrado, M.P., Sanchis Crespo, C., Jimenez Fortea F.J., Martínez García, E., Pardo Iranzo, V., Pascual Serrats, R., Andrés Ciurana B., García Vila, M., González Malabia S.: "Tutela de los consumidores y usuarios en la nueva LEC, artículo de Sanchís Crespo, C.: "La prueba en los procesos de consumo", cit., pág. 301.
} 
el perito de la actora sobre los defectos observados en la adquisición de un vehículo, que a un documento que acreditaba la puesta a punto del mismo aportado por el vendedor.

El objeto de la pericia será distinto dependiendo del tipo de producto y del defecto que se pretenda probar, tal como analizaremos en este capítulo.

Mediante la prueba pericial se acreditará la existencia del defecto y la relación de causalidad entre el defecto y el daño, siendo sus condicionantes básicos la claridad y la fundamentación sobre datos concluyentes siendo en ocasiones incluso necesario que se presenten varias pruebas periciales sobre extremos distintos que han llegado a producir el defecto ${ }^{403}$.

También en los procesos en que se ejercitan pretensiones sobre competencia desleal puede ser de especial interés la presentación de informes periciales o dictámenes específicos del propio sector de actividad ${ }^{404}$ en aras a la acreditación del conocimiento de la marca y su incidencia en el mercado.

El objeto de la prueba pericial en estos supuestos dependerá del tipo de acción que se interponga, bien sea la declarativa de deslealtad, la de cesación de la conducta desleal o de prohibición de su reiteración futura, la de remoción, rectificación, resarcimiento o enriquecimiento injusto.

En relación a estos, el dictamen pericial constituye una prueba esencial, como ya manifestamos en el capítulo anterior, sobre todo, cuando la competencia desleal se haya producido a través de anuncios publicitarios donde se solicita la declaración de deslealtad y la cesación de la publicidad desleal en el supuesto de que para determinar la deslealtad sean necesarios conocimientos técnicos ${ }^{405}$.

\footnotetext{
${ }^{403}$ S. no 183/2007, TS de 19-05-2007 (TOL 1.038.326), S. nº 84/2003 A.P. León de 13-03-2003 (TOL 04.279).

404 De hecho, la S. de la Sec. $8^{a}$ de la AP de Alicante de 6-02-2014 (TOL 4.177.568) considera fundamental para la resolución de la cuestión planteada que el carácter distintivo de una marca hubiera sido introducida al proceso mediante un sondeo demoscópico aportado como prueba pericial, por ser esta la única forma que permitiría determinar si la marca era o no conocida, al tratarse de un análisis de mercado, no quedando probado tal conocimiento sin la práctica de la misma.

405 Podemos hacer alusión a sentencias como la no 208/2011 de la Sec. 28 a de la AP de Madrid de 17-062011 (TOL 2.207.510), o la S. no 274/2010, de la AP de la Coruña de 11-06-2010 (TOL 1.948.979).
} 
Incluso en supuestos de actos de engaño, de denigración de un tercero o de comparación inadecuada, el juez podrá requerir de oficio al demandado para que aporte informe relativo a la exactitud y veracidad de las indicaciones o manifestaciones realizadas pudiendo alcanzar su convicción basándose en la presunción de que las afirmaciones realizadas en el anuncio son inexactas o falsas cuando dicha prueba no fuere aportada.

También es relevante la prueba pericial en los contratos celebrados por vía electrónica para que el consumidor pruebe que la conducta negligente del prestador del servicio de certificación le ha ocasionado un daño, dado que la propia LFE en su art. 23.1 regula una serie de limitaciones del emisor de la certificación.

En relación a la exoneración de la responsabilidad por parte del prestador del servicio, el informe pericial resultará trascedente para acreditar que el servicio se haya prestado reuniendo todos los requisitos necesarios para su validez, es decir, teniendo en cuenta toda la normativa que le es de aplicación, tanto lo dispuesto en el C.c., como en el Código de Comercio, en las normas de protección a los consumidores y en las normas concretas que regulan la actividad comercial de que se trata.

Merece una última mención la importancia de la prueba pericial en temas de responsabilidad civil de seguro de vehículos para probar que los daños del objeto asegurado son consecuencia de su mal uso, para de este modo no recurrir a la presunción de que el consumidor ha actuado de forma diligente, siendo la aseguradora la que deberá probar estos extremos. En caso de que el asegurador se niegue a asumir los daños, debe probar que éstos se deben a un mal uso.

Dada la importancia de la prueba pericial en la mayoría de temas de consumo y al objeto de proteger la situación del consumidor afectado ante la posición de superioridad de la empresa, desde el Ministerio de Sanidad, Servicios Sociales e Igualdad, se ha puesto a disposición del consumidor la Comisión de Cooperación de Consumo integrada en la Conferencia Sectorial de Consumo, con la finalidad de fomentar la cooperación, comunicación e información entre la Administración General del Estado y las Comunidades Autónomas en las materias que afectan a la defensa de los derechos de los 
consumidores ${ }^{406}$, y que a su vez se integra en grupos de trabajo de todas las Comunidades Autónomas existiendo una Comisión.

En muchos casos se acude al informe de este organismo y no es de extrañar que el informe que emita sea contrario al realizado por el servicio técnico, de ahí la necesidad de acudir a un órgano imparcial que realice un verdadero informe, que elabore un estudio en profundidad sobre las normas de calidad de aplicación al producto en cuestión, al objeto de valorar si cumple o no tal normativa.

\section{B. REFERENCIA A LOS SONDEOS DEMOSCÓPICOS}

Especial mención merecen los sondeos de opinión como prueba pericial, los cuales ayudan a determinar el impacto de los productos en el mercado.

El sondeo demoscópico es una encuesta de opinión que realiza una medición estadística a partir de preguntas efectuadas a la opinión pública. Estos suponen interesantes aportaciones en la búsqueda de la opinión común, media y general, que permite la intervención de expertos en demoscopia, en sociología, en estadística, etc., para conseguir una opinión media del hombre de la calle, jugando un papel importante en el ámbito del derecho del consumo ${ }^{407}$.

A través de ellos es posible indagar sobre el impacto u opinión de los ciudadanos en relación con determinados aspectos que sucedan en el desarrollo de una actividad económica del mercado.

Como tal aportación de datos se entienden incluidos dentro de las máximas de la experiencia ${ }^{408}$ ya aludidas, desligados de los hechos concretos que se han de juzgar en el proceso, procedentes de la experiencia, pero independientes de los casos particulares de cuya

\footnotetext{
${ }^{406}$ Mendoza Losana, A.I.: "Cómo probar que los desperfectos de los bienes no están cubiertos por la garantía en la venta de bienes muebles”, cit., págs. 35 a 49.

407 Álvarez García, F.J., Iglesias Rio, M.A., Martínez Guerra, A., Manjón-Cabeza Olmeda, A., Cobos Gómez de Linares, M.A., Gómez Pavón, P.: "Libro Homenaje al profesor Luis Rodríguez Ramos", Epígrafe 25: "Estudios de Derecho Penal. Parte. Parte Especial. Imagen del consumidor y delito de publicidad engañosa. Necesidad y merecimiento de protección. Una aproximación a partir de la reciente interpretación alemana". Ed.: Tirant lo Blanch, Valencia 2013, págs. 1 a 3.

${ }^{408}$ Barona Vilar, S.: “Competencia Desleal. Tomo II”, cit., págs. 1685 y ss.

${ }^{408}$ Barona Vilar, S.: “Competencia desleal. Tutela jurisdiccional -especialmente proceso civil- y extra jurisdiccional. TOMO II. Sujetos, actividades previas, medidas cautelares y proceso civil. Doctrina, legislación y jurisprudencia”, cit., págs. 1685 a 1805.
} 
observación se han inducido y que, por encima de esos casos, pretenden tener validez para otros nuevos".

El papel de los sondeos como prueba dentro del proceso es relevante en aquellos en que se ejercitan acciones de consumo en las que se ven afectados un número importante de consumidores, en que se defienden intereses colectivos, también en los procesos en que se ejercitan pretensiones contra la deslealtad competencial y en derecho de marcas, viniendo su utilización en este ámbito fomentada desde la propia Unión Europea, pudiendo incluso utilizarse antes del inicio del proceso, como diligencia preliminar para conseguir determinar a los afectados por un concreto problema de consumo, al objeto de formalizar la demanda.

La realización de estos sondeos o informes ofrece respuestas para la posible valoración de determinados productos, también hace posible aclarar determinados puntos relevantes sobre las afirmaciones de hecho referidas a conductas desleales en el mercado, aunque su coste es muy elevado, debido a que para llevarlas a cabo y conseguir fiabilidad en el resultado, se requiere trabajar con un determinado porcentaje de consumidores para valorar si pueden resultar inducidos a un comportamiento concreto.

Entendemos para que el sondeo pueda tener validez dentro del proceso, que debe reunir necesariamente además de los condicionantes referidos, unos requisitos tales como la designación del instituto que lo realice, el ámbito sobre el que debe extenderse y la determinación de las preguntas que quieran ser probadas.

La cuestión fundamental en relación a los sondeos es a través de qué medio de prueba serán incorporados al proceso, dado que no son medio sino fuente de prueba, pudiéndose llevar a cabo, dependiendo de cómo se aporte y de quién lo realice, bien como prueba documental, mediante la declaración en el acto del juicio de quien lo ha confeccionado; bien a través de la prueba pericial, con la declaración de un perito redactor del informe o realizador del sondeo, o también, mediante la prueba testifical, como testigo de la opinión que del sondeo se deriva y de la elaboración del mismo.

La forma más aconsejable de introducirlo al proceso es como prueba pericial, mediante informe de parte en el trámite de alegaciones o en un momento posterior, antes de la audiencia previa o de la celebración de la vista en el juicio verbal, o incluso en la 
propia vista con la posibilidad de suspensión de la misma, siempre que las partes así lo hubieren solicitado, con el fin de poder formularle cuestiones al respecto.

Para que tenga la consideración de verdadero dictamen pericial será de vital importancia el alcance del sondeo en el resultado del proceso y dependerá de los medios empleados en su elaboración, debiendo haberse realizado por un especialista y dirigido por un profesional ${ }^{409}$. Además, para responder a la finalidad perseguida de considerarse una verdadera prueba pericial, deberá también valorarse la proporcionalidad entre el resultado obtenido por el dictamen y el coste que este supone ${ }^{410}$.

Asimismo, si existiera desacuerdo entre las partes sobre el perito a realizar el sondeo, se podría solicitarse la pericial judicial ${ }^{411}$, o incluso ser acordado por el propio juez en el trámite de audiencia previa, en base a una interpretación amplia de lo dispuesto en el art. 429.1 II de la LEC, tras ponerlo de manifiesto a las partes, ciñéndose a los elementos probatorios cuya existencia resulte de los autos ${ }^{412}$.

El Tribunal de Justicia de la Unión Europea, en diversas sentencias sobre marcas comunitarias ha considerado de especial importancia el aporte del sondeo demoscópico al proceso ${ }^{413}$ por transmitir la percepción de los consumidores, siendo de vital importancia para alcanzar su resolución.

La jurisprudencia, en sentencias como la no 51/2008 del J uzgado de lo Mercantil no 2 de Alicante, de 5 de febrero de 2008 (TOL

\footnotetext{
${ }^{409}$ De León de Arce, A., en García García, L.M., (coord.): "Derechos de los consumidores y usuarios”. Tomo II. Ed.: Tirant lo Blanch, Valencia 2007, pág. 1776.

${ }^{410}$ Barona Vilar, S.: “Competencia Desleal. Tomo II”. Ed.: Tirant lo Blanch, Valencia 2008. Epígrafe VII. II. Cap. VII. "Algunas cuestiones en torno al proceso civil sobre competencia desleal: II. Práctica de la prueba en los procesos en materia de competencia desleal”, págs. 1685 y ss.

${ }^{411}$ La propia S. ${ }^{\circ}$ 51/2008 del JM no 2 de Alicante 5-02-2008 (TOL 1.319.277) admite el sondeo como prueba pericial y considera relevante a efectos de una resolución estimatoria la realización de un sondeo demoscópico que, en el caso concreto hubiera permitido probar la realidad del conocimiento de la marca por el público interesado, y hubiera quedado acreditada su notoriedad.

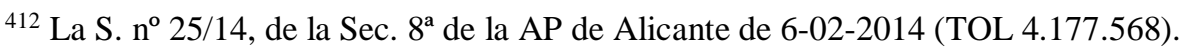

${ }^{413}$ S. no ECLI:C:1998:369 del TJUE de 16-07-1998,Asunto C-210/96 (TOL 103.647), la S. ${ }^{\circ}$ ECLI:EU:C:2002:380, de 18-06- 2002, Asunto C-299/99, (TOL 159.803), la S. nº ECLI:EU:C:2003:206 de 8-04-2003, asuntos acumulados C-53/01 a C-55/01, 29-4-2004, (TOL 260.206), la S. $\mathrm{n}^{\circ}$ ECLI:EU:T:2012:424, del Tribunal General de 13-09-2012, asunto C-72/11 (TOL 3.297.761) o la $n^{\circ}$ ECLI:EU:T:2006:397 de 14-12-2006 (TOL 4.629.048).
} 
1.319.277) otorga validez al sondeo, es más, en la acción de cesación de la Ley de Marcas lo encuentra necesario, siempre que se realice de forma que a través del mismo se ofrezca el análisis de mercado que lleve al tribunal a considerar que la marca era conocida por el público interesado ${ }^{414}$.

Concretamente la Sentencia del Juzgado de lo Mercantil № 1 de Madrid de 23 de marzo de 2006 (TOL 951.678) recaída en un tema de marca, consideró necesario, para dictar resolución, que la parte hubiera aportado un sondeo demoscópico sobre la percepción que los consumidores de esta clase de productos tienen en relación con la procedencia del producto, y sobre cómo afectan a su consumo los signos distintivos de esta.

\section{PRUEBA EN los CONCRETOS PROCESOS DE CONSUMO}

Tras el análisis de los principales medios de prueba en distintos procesos de consumo, vamos a tratar la prueba en los procesos sobre competencia desleal, publicidad ilícita y Ley de Marcas, para a continuación comentar ciertas cuestiones sobre la prueba en relación a las cláusulas abusivas y algunos supuestos concretos de productos defectuosos.

\section{a. En relación a las prácticas comerciales desleales}

Este tipo de cuestiones han sido objeto de regulación por la Unión Europea mediante la Directiva 2005/29/CE del Parlamento Europeo y del Consejo, de 11 de mayo de 2005, sobre prácticas comerciales desleales de las empresas en sus relaciones con los consumidores en el mercado interior, e introducida al derecho español a través de la LCD.

De hecho, su considerando 7 establece que para apreciar el engaño que da lugar a la práctica desleal, es necesario que el consumidor tome una decisión sobre una transacción que de otro modo no hubiera tomado.

A su vez, la Directiva regula también la prueba en su considerando 21 , entendiendo que los estados deben conferir a los

${ }^{414}$ S. no 25/2014, Sec. $8^{\text {a }}$ AP Alicante de 6-02-2014 (TOL 4.177.568), S. no 248/2014, JM no 2 Palma de Mallorca de 10-10-2014 (TOL 5.577.564). 
tribunales y órganos administrativos facultades ${ }^{415}$ para exigir a los comerciantes la carga de la prueba de la veracidad de las afirmaciones vertidas en el acto de competencia desleal ${ }^{416}$.

Esta recomendación se ve plasmada en el art. 217 apdo. 4 de la LEC donde se regula la inversión de la carga de la prueba en materia de competencia desleal y publicidad ilícita ${ }^{417}$.

Se trata de una regla especial cuya falta de prueba afecta negativamente al demandado la falta de prueba ${ }^{418}$. Esta será de aplicación cuando no exista una disposición legal que distribuya con criterios especiales la carga de probar los hechos relevantes, tal como especifica el apdo. 60 del mismo artículo ${ }^{419}$.

De este modo, sobre el demandado recaerá la carga de la prueba de la exactitud y veracidad de las indicaciones y manifestaciones realizadas y de los datos materiales que la publicidad exprese, debiendo el consumidor acreditar el uso o consumo, el daño que ha producido, la relación de causalidad entre el producto y el daño, además de una actuación diligente por su parte ${ }^{420}$.

En igual sentido, el actor que considere que la prueba se encuentra en poder del demandado, deberá requerirlo a través del juzgado en el propio proceso para que la aporte.

\footnotetext{
${ }^{415}$ Lázaro Sánchez Emilio J. (coord.): “Comentario a la Ley General de Publicidad”. Alonso Espinosa, F., De la Vega García, F., García Pérez, C., Iniesta Delgado, J.J., Lázaro Sánchez, E.J., López Pellicer, J.A., Martínez Martínez, D.F., Martínez Martínez, I., Navarro Castro, M., Pardo López, M.M., Pérez Morales, M.G., Sánchez Ruiz, M., Verdú Cañete, M.J. Ed.: Civitas-Aranzadi, S.A. Pamplona 2009, Pág. 123.

${ }^{416}$ Massaguer, J.: "El nuevo derecho contra la competencia desleal. La Directiva 2005/209/CE sobre las Prácticas Comerciales Desleales”, pág. 148. Ed.: Aranzadi, S.A. Pamplona 2006.

${ }^{417}$ Barona Vilar, S.: “Competencia Desleal. Tomo II”. Epígrafe VII. II. Cap. VII. Algunas cuestiones en torno al proceso civil sobre competencia desleal: II. Práctica de la prueba en los procesos en materia de competencia desleal”, cit., págs. 1685 y ss.

${ }^{418}$ Montero Aroca, J.: "Nociones Generales sobre la prueba". Ed.: Cuadernos de Derecho Judicial 7/2000, pág. 21; García-Cuerva García,S., Abel Lluch, X. y Picó i Junoy, J., Dir.: "Las reglas generales del onus probandi”. Ed.: Bosch Procesal, Barcelona 2007, pág. 65; Fernández López, M.: “La carga de la prueba en la práctica judicial civil”. Ed.: La Ley, Madrid 2006, pág. 146.

${ }^{419}$ S. no 436/06 Sec.15 AP Barcelona de 29-09-2006 (TOL 1.026.971).

${ }^{420}$ Aragoneses Martínez, S., Cubillo López, I., Hinojosa Segovia, R., Peiteado Mariscal, P., Tomé García, J.A.: “Cien cuestiones controvertidas sobre la prueba en el proceso civil”. Ed.: Colex, Madrid 2004, pág. 19.
} 
A nuestro juicio la regla establecida en el artículo referido no es interpretable, es una regla clara que traslada la carga de la prueba al demandado, aunque la jurisprudencia, la ha ido matizando y determinando casos concretos en que procede la prueba al propio actor, de modo que numerosas resoluciones analizadas del TS y de las Audiencias Provinciales ${ }^{421}$ optan por distribuir la carga de la prueba atendiendo a criterios prácticos de proximidad a la propia fuente $\mathrm{H}^{422}$ y de facilidad probatoria ya aludidos.

Si a la demanda por el acto de deslealtad se hubiere acumulado también la acción de resarcimiento, su prueba recaerá sobre el actor, quien deberá probar, además del acto desleal, el daño concreto y efectivo producido a algún participe del mercado, junto a la relación de causalidad entre ambos ${ }^{423}$, siendo posible incluso presumir la existencia del daño sin prueba directa del mismo en supuestos muy concretos en que el propio juez observa con claridad el daño producido mediante la conducta del demandado, como ocurre en la S. no 113/2002, Sec. 1a a AP Murcia de 20 de marzo de 2002 (TOL $174.111)^{424}$.

En relación a la prueba de todos los extremos necesarios para que prospere la imputación de responsabilidad al demandado, la jurisprudencia, de forma unánime en sentencias como la no 200/2015 de la AP de Murcia de 16 de abril de 2015, (TOL 5.003.267), o la S.

\footnotetext{
${ }^{421}$ Ejemplo de ello es la S. $\mathrm{n}^{\circ}$ 445/2014 del TS de 4-09-2014 (TOL 4.516.765), que ofrece una interpretación del art. 217.4 de la LEC en el sentido que este no concreta imperativamente cuál de las partes debe probar, sino que establece las consecuencias de la falta de prueba suficiente sobre los hechos relevantes a la parte que dispone de ella.
}

En el mismo sentido encontramos la posición de las Audiencias Provinciales, muestra de lo cual es la S. de la AP de Madrid de 22-02-2007 (EDJ 2007/171335), que entienden que la regla del referido artículo solo es aplicable a los supuestos en los que la conducta desleal consista en indicaciones inexactas o inciertas. En esos casos, si las manifestaciones pueden inducir a error, es el demandado quien debe probar la veracidad de las mismas y de no probarse la existencia de un hecho constitutivo de conducta desleal, la falta de prueba perjudicará al demandado, no al demandante.

Otras resoluciones a las que podemos referirnos son la S. $\mathrm{n}^{\circ}$ 346/2010, TS de 14-06-2010 (TOL 1.881.674), S. $\mathrm{n}^{\circ}$ 81/2007, de 2-02-2007 (TOL 1.044.132), S. $\mathrm{n}^{\circ}$ 747/2003, TS de 18-07-2003 (TOL 4.924.603), S. $n^{\circ}$ 223/2015, TS de 29-04-2015 (TOL 5.00.589), S. no 1011/1999, TS de 30-11-1999 (5.120.671), entre otras.

${ }^{422}$ Montero Aroca, J.: “Nociones Generales sobre la prueba". Ed.: Cuadernos de Derecho Judicial 7/2000, pág. 103 y ss.

${ }^{423}$ García Cruces, J.A.: "Tratado de Derecho de la Competencia y de la Publicidad”, Tomo II. Ed.: Tirant lo Blanch, Valencia 2014, pág. 1865.

${ }^{424}$ S. no 512/2005 TS de 24-06-2005 (TOL 674.252); S. no 279/2002, TS 1-04-2002 (TOL 161.870) o S. TS 16-06-2009 (TOL 1.554.277), entre otras. 
no 512/2005, TS de 24 de junio de 2005 (TOL 674.252) ${ }^{425}$ considera, en base al art. 1214 del C.c., que se impone al demandante la acreditación de los hechos cuya indemnización solicita.

Para su reclamación el actor deberá exponer todos los conceptos que reclama, incluido el descrédito sufrido por la actora y los daños derivados del desánimo ocasionado en su actividad empresarial, gozando el juez, según ha mantenido el TS de total discrecionalidad para su valoración ${ }^{426}$.

En este sentido, para que prospere la acción de resarcimiento, el actor deberá acreditar que los daños que reclama son subsumibles en la conducta de deslealtad, además de los hechos que justifican el nexo causal existente ${ }^{427}$.

Hay sin embargo excepciones en supuestos concretos de daños que no exigen prueba, como los daños "ex re ipsa", donde "el hecho habla por sí mismo", cuya prueba resulta evidenciada como consecuencia lógica del comportamiento enjuiciado, o cuando la propia norma establece la indemnización por la sola situación antijurídica ${ }^{428}$. En estos casos puntuales se presume que el incumplimiento causa el daño, de modo que no hace falta prueba porque la realidad actúa incuestionablemente sobre ella.

En la práctica, la jurisprudencia referida ha entendido que habrá lugar a la indemnización cuando la producción del daño sea real y

\footnotetext{
${ }^{425}$ En la misma línea que las señaladas se encuentran otras muchas sentencias como la S. $n^{\circ} 187 / 97$, Sec. $3^{a}$ A.P. Córdoba, de 14-07-1997 (AC1997/1560), S. no 91/2002, Sec. $1^{\text {a }}$ A.P. Cáceres de 18-04-2002 (TOL 174.091), o la S. no 200/2015, Sec. $4^{\mathrm{a}}$ de la AP de Murcia de 16-04-2015 (TOL 5.003.267).

${ }^{426}$ Así lo entiende la S. TS no 170/2014 de 8-04-2014 (TOL 4.280.441), S. no 412/2014 TS de 10-07-2014 (TOL 4.478.976).

${ }^{427}$ S. ${ }^{\circ}$ 00050/2009 JM. $\mathrm{n}^{\circ} 1$ de Palma de Mallorca, de 11-02-2009 (TOL 1.475.636) corresponde al demandado la carga de la prueba de la exactitud y veracidad de las manifestaciones realizadas y de los datos que la publicidad exprese, debiendo probar el actor los hechos constitutivos de su derecho y si el demandado alega otros, tendrá que probarlos. Las consecuencias de la falta de prueba de un hecho alegado no probado son que se tendrá este hecho por inexistente en el proceso.
}

En cuanto a la petición de resarcimiento debe acreditarse que el acto de competencia desleal ocasionó una lesión patrimonial efectiva, incluyendo el daño emergente y el lucro cesante, mediando dolo por parte del autor, de ahí que no se puede afirmar que la comisión de un acto de competencia desleal determine de forma necesaria la realización de un daño, y por ello se exige la prueba de su efectividad y cuantía.

${ }^{428}$ Como ejemplo de ello podemos aludir a la S. no 692/2008 TS de 17-07-2008 (TOL 1.353.188) y a la S. $\mathrm{n}^{0}$ 541/2012 TS de 24-10-2012 (TOL 2.706.112), que haciendo uso de la doctrina aludida estima correcta la presunción de existencia del daño cuando se produce una situación en que los daños y perjuicios se revelan reales y efectivos, considerando que en tales casos no será necesaria la prueba. 
origine una contraposición de intereses, extremos que serán valorados atendiendo a las circunstancias de cada caso en particular ${ }^{429}$.

Otra cuestión importante en relación a la indemnización de daños y perjuicios es la forma de cuantificarla, que debe estar en relación con la fecha en que recaiga la condena efectiva, por lo que cuando se pide la indemnización debe establecerse la cuantía exacta de los daños o las bases que se proponen para su cálculo, y de no estar concretadas en la demanda, deberán estarlo en el momento de instar la ejecución de la sentencia ${ }^{430}$.

Mayor dificultad presenta la prueba del lucro cesante por su alto grado de indeterminación, debiendo especificar y acreditar todos los extremos que componen la cuantificación del mismo ${ }^{431}$.

Cuestión distinta es la prueba de la indemnización por daños morales sobre los cuales, la doctrina general sentada por el TS en S. como la S. no 366/2010 de 15 de junio de 2010 (TOL 1.947.394) sostiene que no es imprescindible acreditarlos por tratarse de daños "in re ipsa" cuya prueba se obtiene a través de presunciones, dado que no pueden ser probados de otra forma, debiendo derivar necesariamente del propio acto de deslealtad. Por su parte será el demandado quien deberá probar que la causa alegada no ha sido producida por su conducta ${ }^{432}$.

En relación a la prueba concreta en temas de competencia desleal, la que deba practicar el demandado dependerá de la propuesta o practicada por el actor y de la acción concreta de competencia desleal que haya interpuesto.

Consideramos que resultará más útil tanto para el demandado como para el propio juez poder llegar a la certeza sobre los hechos, la presentación de un informe pericial realizado por un técnico especializado que puede ser aportado para el análisis de cualquier

\footnotetext{
${ }^{429}$ S. n ${ }^{\circ} 454 / 2009$, Sec. $5^{\text {a }}$ de la AP Zaragoza de 16-09-2009 (TOL 1.654.081).

${ }^{430}$ S. no 714/2003 de 14-07-2003 (TOL 295.892), S. no 1348/2006 de 29-12-2006 (TOL 1.036.542).

${ }^{431}$ En el supuesto enjuiciado por la S. ${ }^{\circ}$ 6/2015, Sec. $8^{\text {a }}$ de la AP de Madrid de 2-01-2015 (TOL 4.746.186) se condena al pago del lucro cesante por encontrarse debidamente acreditadas sus partidas y su justificación mediante informe pericial.

${ }^{432}$ Barona Vilar, S.: "Objeto del proceso civil por actuaciones de competencia desleal (II)". Petitum o Petición. “Tutela de condena al resarcimiento de daños y perjuicios.”, cit., pág. 799 a 876.
} 
expresión publicitaria o bien para esclarecer el alcance de las alegaciones de las partes, siendo imprescindible su aporte cuando la complejidad de las alegaciones publicitarias comporte una interpretación técnica.

\section{b. Prueba en el proceso sobre publicidad ilícita.}

La Directiva 2006/114/CE del Parlamento Europeo y del Consejo, de 12 de diciembre de 2006, sobre publicidad engañosa y publicidad comparativa, cuyo objeto es proteger a los comerciantes frente a la publicidad engañosa, así como establecer las consecuencias injustas y las condiciones en las que estará permitida la publicidad comparativa, en art. 3 especifica cuáles son los condicionantes de una publicidad engañosa entre las que destacan:

a) las características propias de los bienes o servicios, tales como su disponibilidad, su naturaleza, su ejecución, su composición, el procedimiento y la fecha de fabricación o de prestación, su carácter apropiado, sus utilizaciones, su cantidad, etc...

b) el precio o su criterio de determinación y las condiciones de suministro de bienes o de prestación de servicios;

c) la naturaleza, caracteres y derechos del anunciante, tales como su identidad y su patrimonio, sus cualificaciones y sus derechos de propiedad industrial, comercial o intelectual, o los premios que haya recibido o sus distinciones.

En cuanto a la actividad probatoria en estos procesos, la Directiva referida también establece directrices e impone a los estados la obligación de conferir a los tribunales facultades para exigir al anunciante que presente pruebas sobre la exactitud de las afirmaciones de hecho que contiene la publicidad.

En relación a la prueba, el art. ya referido 217.4 de la LEC dispone la obligación del demandado de probar la exactitud de los datos materiales que expresa la publicidad.

Concretamente, en los asuntos en que se ejercita la acción de cesación de la publicidad ilícita, la prueba tiene escasa relevancia debido a que la justificación que se debe aportar se basa en la publicidad que se pretende cesar. Bastará para que pueda prosperar la acción con justificar la referida publicidad y hacer alusión a la normativa que vulnera. 
En los supuestos en que se ejercita una acción de publicidad ilícita por ser una publicidad excluyente, la prueba se hace necesaria, debiendo el actor justificar que el demandado es su competidor en el sector demostrando la exactitud de la posición de primacía en el mercado ${ }^{433}$, aunque si el actor no aporta prueba alguna, el resultado del proceso dependerá de la actitud del demandado.

$\mathrm{Si}$ el demandado presentara prueba de la veracidad de las manifestaciones publicitarias que realiza podría el actor ver desestimada su demanda 434 ; en cambio, si la actitud del demandado fuera pasiva y no acreditara la veracidad de sus manifestaciones publicitarias o si las pruebas no fueren suficientes, la publicidad difundida se considerará engañosa ${ }^{435}$.

Por su parte el juzgador, para determinar si la publicidad se ajusta o no a la legalidad, deberá considerar el hecho de que los mensajes publicitarios induzcan a error o engaño en los destinatarios de forma que sea susceptible de alterar su comportamiento económico ${ }^{436}$ en relación al consumidor medio, que es el que se define por la propia Ley como normalmente informado $y$ razonablemente atento y perspicaz (definición que viene realizada por la jurisprudencia del Tribunal Europeo en sentencias como la del TJCE de 16 de julio de 1998 C44/01 y de 19 de septiembre de 2006, C356/04).

Se entiende incluso que si el mensaje publicitario tiene capacidad potencial para influir en el comportamiento económico de sus destinatarios, simplemente con que induzca a error, se considerará que es ilícito, y será engañoso si además silencia datos fundamentales de los bienes, actividades o servicios publicitarios, siempre que tal omisión pueda generar error o confusión en el consumidor ${ }^{437}$.

Como prueba tipo en estos procesos es frecuente aportar un informe realizado por técnico especializado para el análisis de

\footnotetext{
${ }^{433}$ Patiño Alves, B.: “La autorregulación publicitaria”. Ed.: Bosch, Barcelona 2007, págs. 336 a 352.

${ }^{434}$ Patiño Alves, B.: “La autorregulación publicitaria”, cit., págs. 336 a 352.

435 S. no 202/2010, Sec. 4 $4^{\text {a }}$ AP Alicante de 27-05-2010 (TOL 1.991.654).

${ }^{436}$ S. no 284/2009, del JM n 5 de Barcelona de 16-11-2010, (TOL 4.368.976).

${ }^{437}$ S. del JM Alicante $\mathrm{n}^{\circ} 1$ de 18-07-2013 (TOL 4.472.669).
} 
cualquier expresión publicitaria al objeto de esclarecer el alcance de las alegaciones realizadas por las partes. Su aporte será imprescindible cuando la complejidad de las alegaciones publicitarias lo requiera.

Entrando a citar supuestos concretos, existen multitud de resoluciones judiciales en relación a anuncios de tabaco o bebidas alcohólicas donde se ejercitaban acciones de cesación de la publicidad ilícita. A modo de ejemplo aludimos a los anuncios de bebidas alcohólicas situados en la vía pública, prohibidos en la Comunidad de Madrid por la ley 5/2002 sobre drogodependencias y otros trastornos adictivos, en los que existen multitud de sentencias que admiten las acciones de cesación de la publicidad ilícita debido a la prohibición establecida en esta Ley ${ }^{438}$.

Todas las sentencias analizadas estiman las acciones de cesación de la publicidad ilícita planteadas por ser contrarias a la Ley referida y entienden que la prohibición de anuncios de alcohol en la vía pública responden a una preocupación por la salud, y, por tanto, siendo la justificación de la existencia de la publicidad ilícita, la única prueba necesaria para que la acción pueda prosperar, por ejemplo, mediante una valla publicitaria.

Refiriéndonos a otros supuestos de publicidad ilícita, el Juzgado de lo Mercantil no de 6 de Madrid, en S. de 21 de febrero de 2011, (TOL 2.096.925) enjuicia un supuesto de póliza dental, aplicando el art. 4 de la LGP. La sentencia es esclarecedora en el sentido que analiza los condicionantes que debe contener la publicidad para

\footnotetext{
${ }^{438}$ S. del JPI no 49 Madrid de 12-05-99 (TOL 198.300), en cuya demanda se ejercitaba una acción de publicidad ilícita presentada por AUC contra TABACALERA, S.A. por un anuncio publicitario emitido en las televisiones donde se anuncia el "compact disc" denominado "Carácter latino", con la mención en letras amarillas y negras de "Duca-2 music", y que posteriormente apareció en vallas exteriores, en prensa y televisión. La demandada anunció la marca de cigarrillos Ducados con la misma imagen gráfica y visual del "Duca 2" y un slogan similar, considerando la sentencia, que además de ejercer una práctica publicitaria indirecta de tabaco prohibida en la LGP, inducía a confusión por realizar una publicidad desleal.
}

Podemos hacer mención, entre otras a las Sentencias de la Sala Civil del Tribunal Supremo n ${ }^{\circ}$ 891/2010, de 3-01-2011 (TOL 2.039.124) y a la sentencia $\mathrm{n}^{\circ}$ 797/2011, de 18-11-2011 (TOL 2.289.671) está en relación a publicidad encubierta de tabaco (ambas extraídas de la web de la Asociación de Usuarios de la Comunicación).

Otras sentencias en que era parte actora la misma asociación, AUC, también en relación a los anuncios de bebidas alcohólicas en la Comunidad de Madrid son la S. de 15-02-2013 y la de 3-06-2013, ambas del Juzgado de lo Mercantil no 11; la del Juzgado de lo Mercantil no 10 de Madrid de 16-04-2012, y la del Juzgado de lo Mercantil no 8 de Madrid de 25-07- 2013, todas ellas publicadas en la web www.auc.com 
considerarse ilícita, siendo su principal punto de apoyo la influencia que esta cause en la decisión económica tomada por el destinatario.

Por tanto, lo que deberá probarse en estos casos será la titularidad de la marca, extremo que se acreditará a través de la prueba documental, mediante el aporte de su inscripción y signos distintivos, consistiendo la labor del tribunal en valorar la semejanza de ambas marcas.

Lo habitual es que la labor del tribunal se vea apoyada también en una prueba pericial, que puede ser aportada por cualquiera de las partes, al objeto de que acredite o bien las similitudes de ambas marcas o productos, en caso de que la prueba pericial sea aportada por el actor, o bien, el informe que acredite las diferencias existentes entre una y otra, en el supuesto de que sea el demandado el que aporte el informe.

Con resoluciones como las referidas se protege el objetivo fundamental de la LGP que es la protección de la libertad de elección del consumidor. El simple hecho de que la publicidad pueda afectar al comportamiento económico de los destinatarios, perjudicar o ser capaz de llegar a afectar a un competidor, es suficiente para considerar que se ha producido el perjuicio, sin necesidad de prueba de ello 439 .

Hemos de hacer alusión también a la posible resolución de cuestiones de publicidad a través de la Asociación para la Autorregulación de la Comunicación Comercial (AUTOCONTROL), organismo perteneciente a la Red Europea de órganos de Resolución extrajudicial de litigios con los consumidores, gestionado por la Dirección General de Justicia y Consumidores de la Comisión Europea.

En la resolución de los conflictos a través de este organismo interviene el Jurado de la Publicidad, como órgano independiente que resuelve las reclamaciones aplicando el Código de Conducta Publicitaria y la LGP y al Código de Conducta Publicitaria aprobado en Asamblea General Extraordinaria de 19 de diciembre de 1996, con

439 Tirado Suárez, F.J.: “La aplicación de la Ley General de Protección de los consumidores y usuarios al Contrato de Seguro”. BIB/2013/16047. Ed.: Estudios y Comentarios Legislativos (Civitas), Madrid 2013. 
revisiones y modificaciones posteriores aprobadas por la Asamblea General Ordinaria, el día 26 de abril de 2011) ${ }^{440 .}$

Para la resolución de las reclamaciones, la Asociación para la Autorregulación de la Comunicación Comercial regula un procedimiento donde también resulta necesaria la prueba del perjuicio que la publicidad ocasiona.

Nos encontramos en este ámbito con la falta de atribución de la carga de la prueba, puesto que en el Código de Conducta no se prevé la inversión de la carga de la prueba, y la doctrina del Jurado tampoco se ha manifestado de forma unánime sobre ella, debido a que existen varias posturas.

Una de las posturas al respecto, puesta de manifiesto a través de resoluciones como la de 7 de julio de 1997, recaída en el caso CEPSA-GAS NATURAL, donde el Jurado consideró que el anunciante debía acreditar las afirmaciones de su publicidad, al igual que en la Resolución del Jurado de 13 de noviembre de 1998, Caso AUC-Aula Activa, S.A, no $24^{441}$ o en la no 80 de 8 de agosto de 2003, afirmando además que la inversión de la carga de la prueba no siempre exige idéntica actividad probatoria por parte del anunciante, y ante su inoperancia para demostrarla, se podría declarar engañosa una campaña y obligar a las partes al aporte de nuevas pruebas.

Esta posición, avalada por lo dispuesto en la Norma 23 del Código referido, entiende que el anunciante siempre debe demostrar la veracidad de las alegaciones publicitarias, y ante la ausencia de prueba al respecto, estas pueden ser consideradas engañosas.

Una segunda postura es la que se manifiesta en otras muchas ocasiones por el Jurado, cuando no obliga al anunciante a demostrar la veracidad de sus alegaciones, produciéndose en estos casos la inversión. Nos referimos a casos como el de la Resolución del Jurado no 32 de 22 de abril de 1999 "Licor del Polo más vitaminas", o a la Resolución también del Jurado no 56 de 2 de julio de 2001 del caso "Corazón Solano", donde entienden que el alcance de la regla sobre la prueba no es el mismo dependiendo de la intensidad y actividad probatoria que se realiza en cada procedimiento.

\footnotetext{
440 www.autocontrol.es/reclamaciones_quien2.shtml. Últ. consulta 8-05-2016.

441 Patiño Alvés, B.: “La autorregulación publicitaria en el Código de Conducta Publicitaria”. Ed.: Bosch, Barcelona 2007, págs. 433 a 439.
} 
En estos últimos supuestos el Jurado entendió suficientes las pruebas aportadas por la reclamante, pese a que en ocasiones pudieran favorecer a la parte contraria.

También en resoluciones como la no 42, de 25 de abril de 2000, el Jurado entendió que rige una regla de inversión de la carga de la prueba en cuanto a la veracidad publicitaria ${ }^{442}$.

Debido a que no existe una regla específica, no siempre se aplica igual por parte del Jurado la regla de la carga de la prueba de la veracidad de las manifestaciones; de hecho, en la Resolución del Jurado no 56, de 2 de abril de 2004, en el caso Chupa-Chups Cremoso, el jurado declaró que la campaña publicitaria era engañosa en base a las pruebas que aportó la reclamante.

Lo que observamos es que el Jurado no tiene un criterio uniforme de atribución de la carga de la prueba y está a las circunstancias del caso concreto para determinar a quién corresponde esta, viéndose condicionado en su determinación por la propia actividad probatoria que realiza cada una de las partes.

Autores como Barona Vilar han analizado la dualidad de posiciones del Jurado y han considerado que la variedad de actitudes de este no puede calificarse como verdadera inversión de la carga de la prueba, sino simplemente una alteración dependiendo del caso concreto ${ }^{443}$.

Entendemos siguiendo la posición de Silvia Barona que se trata de un sistema mixto, donde se admite que la prueba la aporte cualquiera de las partes sin que exista obligación concreta y específica de prueba de cada parte; de hecho, cuando el reclamante haya aportado pruebas o indicios que permitan dudar de la credibilidad de las alegaciones publicitarias, el anunciante deberá desarrollar una actividad probatoria intensa, encaminada a acreditar la veracidad de sus afirmaciones ${ }^{444}$. Será en estos casos donde el anunciante deberá probar al menos la credibilidad de sus afirmaciones.

\footnotetext{
442 Todas las resoluciones del Jurado de Autocontrol publicitaria se encuentran publicadas en www.autocontrol.es.

443 Barona Vilar: “Competencia Desleal”, cit., pág. 286 y ss.

${ }^{444}$ Patiño Alvés, B.: “La autorregulación publicitaria en el Código de Conducta Publicitaria”, cit., págs. 433 a 439.
} 


\section{c. Prueba en la ley de marcas}

Sobre el derecho de marca se puede ejercitar tanto la acción de cesación del art. 41 LM, como la acción de reclamación de daños y perjuicios, regulada en el art 42 de la misma, y también es posible ejercer la acción sobre una marca comunitaria.

En relación a la primera, la acción de cesación, la jurisprudencia del TS en sentencias como la recaída en el caso de la marca NIKE de 22 de septiembre de 1999 (TOL 344.973), considera que para apreciar la semejanza de las marcas deberán ser puestas en relación y ver su parecido visual en su conjunto con una visión unitaria de cada una.

La jurisprudencia del TS ha formado un cuerpo consolidado de doctrina ${ }^{445}$ muestra de la cual es la S. № 139/2005 de 3 de marzo de 2005 (TOL 603.848) donde en un caso en que "Chanel, S.A." demanda a "Undiscal, S.L." y "Creaciones Co. Design, S.L." solicitando la condena de las demandadas a cesar en la comercialización y exposición en sus escaparates de zapatos y pañuelos distinguidos con signos idénticos y similares a unas marcas propiedad de la actora ${ }^{446}$.

La Sentencia establece los requisitos concretos que son necesarios para que prospere la acción de cesación que son: la violación del derecho de marca, el registro de la primera en la Oficina de Patentes y Marcas, el acto de imitación y que el parecido sea tal que lleve a confusión al consumidor.

Merecen especial mención, por ser de actualidad, las cuestiones surgidas en torno al uso de palabras clave en publicidad a través de internet. Nos detenemos en un supuesto concreto que ha sido polémico; se trata de la utilización de una marca de un tercero simplemente mediante una palabra clave en un contrato de

\footnotetext{
${ }^{445}$ En cuanto al parecido necesario para que se prohíban sus signos, la S. $n^{\circ}$ 871/2003 del TS de 29-092003 (TOL 316.464) especifica que éstos deben tener la suficiente entidad para inducir a errores en el consumidor que le lleven a confundir una marca con otra.

En la misma línea que la anterior podemos aludir a modo ejemplificativo a otras sentencias del TS como las de 8-02-99 (RJ 1999/644), 18-02-99 (RJ 1999/886), 3-11-00 (TOL 52.526), 17-10-02 (TOL 4.975.089), o la más reciente, la S. no 98/2016, TS de 19-02-2016 (TOL 5.699.140).

${ }^{446}$ Podemos además aludir a otras muchas sentencias del TS como la S. $\mathrm{n}^{\circ} 1026 / 2008$, TS 12-11-2008 (TOL 1.408.429), la S. no 241/2013, de 9-05-2013 (TOL 3.671.048) o la S. $n^{\circ} 188 / 2005$, de 28-03-2005 (TOL 646.341).
} 
ADWORDS (desde donde se realiza la publicidad en GOOGLE). Esta fue utilizada por parte del empresario no titular del signo distintivo, con la finalidad exclusivamente de posicionarse en la red. Se trata de la S. del TJUE de 23 de marzo de 2010 ${ }^{447}$, (caso GOOGLE FRANCE y GOOGLE), en el que fue examinada la legalidad de la venta de marcas en ADWORDS a terceros para posicionar su anuncio en GOOGLE por encima incluso del verdadero titular marcario.

El Tribunal Europeo de Justicia exculpa a GOOGLE porque simplemente utiliza los signos distintivos como palabras clave en un contrato de ADWORDS. En este sentido, la STJUE de 23 de marzo de 2010 (caso GOOGLE FRANCE y GOOGLE), afirma que el uso de un signo idéntico o similar a una marca por un tercero implica, como mínimo, que este utilice el signo en el marco de su propia comunicación comercial.

Esta sentencia, al igual que las que vamos a citar a continuación, (estas dentro del ámbito nacional), consideró que este tipo de procesos relacionados con el efecto de determinada marca a través de la publicidad mediante internet era una actuación no perseguible a través de la Ley de Marcas.

Es destacable la resolución de la AP Alicante Sec. 8ā, S. no 105/2013 de 7 de marzo 2013 (TOL 4.505.149) en la que se valora el uso de las marcas de la competencia en los anuncios de GOOGLE caso MAHERLO IBÉRICA S.L. contra C. S.A.M., entendiendo que el criterio jurisprudencial aplicable al uso de marcas de la competencia en anuncios de GOOGLE es que la utilización de marcas ajenas exclusivamente como palabras clave en el marco de un contrato en ADWORDS no podrá ser calificada como infracción de marca ajena si no existe uso en el tráfico mercantil y riesgo de confusión.

El Juzgado de lo Mercantil no 1 de Alicante 31 de octubre de 2013, no 169/2013 (TOL 4.034.733) en un asunto relativo a la utilización de la marca ORONA como palabra clave en el buscador GOOGLE, considera que cuando aparezca en internet la marca a partir de una palabra clave correspondiente a una marca de renombre y esta proponga una alternativa a los productos o a los servicios del titular de dicha marca, sin ofrecer una simple imitación de los productos o de los servicios de su titular, no causando

${ }^{447}$ Disponible en www.curia.eu. 
difuminación y sin menoscabar las funciones de la marca, se trata de un acto de competencia sana y leal en el sector de los productos o servicios de que se trate.

Todas las sentencias citadas entienden que para que pueda declararse indebido el uso de las marcas ajenas para anunciarse en el marco de un servicio de referencias en Internet como ADWORDS, debe aportarse por el que se considera perjudicado, prueba del riesgo de confusión entre los productos distinguidos con dichas marcas y los que publicita el anunciante, riesgo que engloba el de asociación respecto al origen empresarial de dichos productos o confusión, que deberá producirse en la mente del usuario del motor de búsquedas de GOOGLE.

En tanto en cuanto no se pruebe ese riesgo de confusión, el derecho de marca no puede declararse vulnerado aun cuando sea cierto que se adquieran marcas ajenas para anunciar productos 0 servicios propios.

Así pues, la utilización de algún signo distintivo coincidente con otra marca ajena como palabra clave en un contrato de ADWORDS, con la única finalidad de posicionarse, no supone una vulneración de los derechos de marca establecidos en la LM y concretados en su 34.2, puesto que la protección recogida en este artículo se refiere a la concreta publicidad del producto que implique confusión con otra marca de la competencia.

Por lo tanto, la prueba del riesgo de confusión debe ser suficiente para demostrar que el anuncio no permite al internauta medio determinar si los productos o servicios incluidos en el anuncio proceden del titular de la marca o de una empresa económicamente vinculada a este $\mathrm{o}$ si, por el contrario, proceden de un tercero ${ }^{448}$.

Otra cuestión que se puede plantear es la del número de visitas que se produzca al anuncio del competidor. El hecho de que sean muchas las visitas que reciba el competidor no implica que esa publicidad genere riesgo de confusión en el consumidor, porque esas visitas pueden haberse producido después de reconocer en primer lugar al verdadero titular de la marca, y deberse al interés del

\footnotetext{
${ }^{448}$ Así lo declaran las S. TJUE de 23-03-2010 (TOL 2.638.631), caso GOOGLE FRANCE y GOOGLE, de 25-03-2010 (TOL 2.157.332),caso BERGSPECHTE, o de 8-07-2010 (TOL 4.630.982), caso PORTAKABIN, accesibles en www.curia.eu.
} 
consumidor en buscar otras alternativas que se ajusten más a sus necesidades ${ }^{449}$.

La S. del TJUE de 23 de marzo de 2010 (caso GOOGLE FRANCE y GOOGLE), considera que el mero uso por parte del consumidor de las marcas de su competidor por la concreta palabra clave para anunciarse, no supone un uso comercial ilícito y el titular de una marca no dispone de acción de marca a invocar contra Google como consecuencia del alojamiento de marcas registradas para su venta en Adwords.

Por lo tanto, si las marcas ajenas no se usan comercialmente en el anuncio no existe riesgo de confusión y de poco sirve que se examinen otros factores complementarios como si se trata de empresas competidoras o de sus canales de venta.

Las sentencias analizadas exculpan a GOOGLE y suponen un gran avance en lo que atañe al conflicto de titulares que no disponen de acción de la Ley de Marcas contra la venta de marcas en el marco del servicio publicitario que GOOGLE ofrece a través de ADWORDS.

En relación a la segunda de las acciones referidas de la LM, la de indemnización exige que pruebe el daño el titular de la marca infringida, gozando del derecho a percibir la indemnización por daños y perjuicios sin necesidad de que éstos sean probados ${ }^{450}$.

La prueba de los daños por el actor en las reclamaciones sobre marcas y patentes que se plantean ante los tribunales es una exigencia necesaria para que pueda existir la condena a indemnizar, siendo desestimada en el supuesto de no conseguir probar el perjuicio sufrido ${ }^{451}$.

De hecho, sentencias como no 1032/1996 de TS de 9 de diciembre de 1996 (TOL 1.658.572) consideran que no existe en la LM ninguna presunción legal sobre la existencia de daños y perjuicios por la mera lesión al derecho de marca, por lo que la producción o

\footnotetext{
${ }^{449}$ S. TJUE de 22-09-2011 (TOL 2.258.308), caso INTERFLORA y OTROS en www.curia.eu.

${ }^{450}$ Bercovitz Rodríguez Cano, Dir., García Cruces, J.A., Dir. Adjunto: “Comentarios a la Ley de Marcas”, Tomo I. Ed.: Thomson Aranzadi, Pamplona 2008, pág. 692.

${ }^{451}$ Bercovitz Rodríguez Cano, Dir., García Cruces, J.A., Dir. Adjunto: “Comentarios a la Ley de Marcas”, Tomo I, cit. pág. 710.
} 
existencia de los daños corre a cargo del titular de la marca afectada 452 .

Dada la dificultad de prueba en determinados supuestos sobre la realidad de los perjuicios, la jurisprudencia ha entendido que el éxito de la acción no debe quedar frustrado por la ausencia de prueba de la realidad de los perjuicios ${ }^{453}$, debiendo ser reconocido el derecho del titular de una marca que se ha visto afectada por la competencia desleal de otra. Para ello, se aplica por la jurisprudencia lo que se ha venido a llamar "licencia hipotética", cuya aplicación responde a la necesidad de que la marca no quede sin protección por las dificultades de probar los beneficios obtenidos por el infractor.

En estos casos deberá ser el propio infractor quien acredite la cuantía de los daños al objeto de evitar una condena de cuantía mayor. Concretamente la S. № 592/1995 del TS de 7 de junio de 1995 (RJ 1995/4635) ha entendido que para pedir el resarcimiento de daños basta con aportar un principio de prueba del quebranto padecido.

Otra cuestión no exenta de complejidad es la determinación del alcance del daño, para lo cual el actor deberá aportar una apreciación global de todos los factores que pueden contribuir a su comparación y apreciación, de los daños que puede causar o los cambios que el quebranto puede suponer al consumidor. Cuanto más renombre tenga la marca mayor perjuicio supondrá su uso.

En otras ocasiones al tratar de infracciones del derecho de patente $o$ en procesos sobre marcas o de competencia desleal, tras reconocer la doctrina de la Sala la necesidad de prueba de los daños para condenar al infractor, establece que en ciertos supuestos los daños pueden presumirse producidos sin necesidad de razonar su evidencia, S. no 136/1998 TS de 23 de febrero de 1998 (TOL 5.114.945), S. no 962/1999 de 17 de noviembre de 1999 (TOL 5.120 .654 ) y 10 de octubre de 2001 (RJ 2001/8794). Incluso la STS de 27 de julio de 1998 (TOL 389.851) admite el derecho de

\footnotetext{
${ }^{452}$ En la misma línea se encuentran las S. no 336/2000, TS de 5-4-00 (TOL 4.926.862), S. no 31/2007 de 25-1-07 (RJ 2007/2778).

${ }^{453}$ S. no 40/2008, TS de 5-02-2008 (TOL 1.333.420) y S. no 95/2009 TS de 2-03-2009, no 113/2009 de 403-2009 y n ${ }^{\circ}$ 114/2009 de 9-03-2009 (TOL 1.466.720, 1.466.714, 1.485.194), entre otras.
} 
resarcimiento probando sólo la infracción, sin necesidad de probar la existencia y alcance del daño ${ }^{454}$.

Debemos también hacer mención en tercer lugar a los procesos sobre acciones de marcas comunitarias de lo cual es ejemplificativa la S. no 20/2014 del JM no 1 de Alicante de 28 de enero de 2014 (TOL 4.093.493) que entiende que para que prospere la acción de cesación de una marca comunitaria, el actor deberá justificar que con el uso de la marca posterior se puede causar un perjuicio al distintivo de la marca anterior, que produce o puede producir un cambio en el comportamiento económico del consumidor medio de los productos o servicios para los que se registró la marca primera, o un riesgo de que esta modificación se produzca en el futuro.

Para el éxito de la acción será importante la prueba documental sobre la inscripción y registro de la marca, así como un informe pericial que acredite el daño o posible daño que podría causar al condicionar el comportamiento del consumidor. Se trataría por tanto de reconocer un perjuicio para el titular de la marca y un beneficio para el infractor que mediante la práctica de una prueba pericial se podría evidenciar, tal como han entendido sentencias entre las que destacan las del TS no 413/1992 (TOL 1.659.761) de 21 de abril de 1992 (TOL 60.949), de 23 de febrero de 1998, 28 de septiembre (TOL 66.555), y S. no 910/2001 de 10 de octubre de 2001 (TOL 66.398) y la no 401/2005 de 1 de junio de 2005 (TOL 667.469).

\section{d. Prueba sobre cláusulas abusivas.}

Existen cláusulas abusivas en diversidad de contratos de consumo, aunque tan solo analizaremos la prueba en relación a las cláusulas abusivas en dos tipos de procesos que han tenido una gran importancia y repercusión en los últimos años: en los de préstamos hipotecarios que han generado multitud de resoluciones judiciales en el sentido de declarar nulas determinadas cláusulas, y en los contratos de transporte aéreo de pasajeros.

En relación a los primeros, nos referimos a las "famosas" cláusulas suelo de los préstamos hipotecarios y a su generalidad, es decir a su aplicación y utilización por parte de la entidad bancaria de

${ }^{454}$ Bercovitz Rodríguez Cano, Dir., García Cruces, J.A., Dir. Adjunto: “Comentarios a la Ley de Marcas”, Tomo I, cit., pág. 710 
forma generalizada y a la falta de negociación de las mismas con el consumidor individual.

Antes de entrar a analizar algunas cuestiones relativas a la prueba en los procesos sobre cláusulas abusivas debemos referirnos brevemente a su regulación y al tipo de cláusulas que se consideran como tales.

Según Diez Picazo, la definición de "cláusulas abusivas" se refiere al contenido contractual, sin incluir las prestaciones esenciales de las partes, estando en relación con los bienes y servicios que deban proporcionarse y la contraprestación que deba pagar por ellos, así como a su equilibrio económico ${ }^{455}$.

La normativa básica en esta materia se encuentra en la Directiva 93/13/CE del Consejo, de 5 de abril de 1993, sobre cláusulas abusivas en los contratos celebrados con consumidores, traspuesta al derecho interno a través de la LCGC.

Esta consideración también la mantiene el TRLGDCU que entiende en su art. 82 que son abusivas todas aquellas cláusulas no negociadas entre las partes e impuestas individualmente ${ }^{456}$ en las que el consumidor no haya podido influir en su contenido y tampoco en su supresión ${ }^{457}$.

La jurisprudencia al valorar la abusividad de las cláusulas se cuestiona si estas pueden considerarse abusivas tanto en relación al TRLGDCU como a la LCGC, puesto que el primer cuerpo legal es de aplicación a los procesos de consumidores y usuarios y la LCGC se aplica a todo tipo de contratos, intervengan consumidores o no. Para ello primero será importante considerar si el actor tiene la condición de consumidor y una vez concretado este extremo, se procede a la interpretación de lo dispuesto sobre cláusulas abusivas en ambos textos normativos.

Para iniciar su estudio debemos aludir a la relación de las concretas cláusulas de los contratos que se consideran como

\footnotetext{
${ }^{455}$ Diez Picazo, L.: "Las condiciones generales de la contratación y las cláusulas abusivas", Ed.: Civitas, Madrid 2002, pág. 41.

${ }^{456}$ De León de Arce A., en García García, L. M. (coord.), "Derechos de los Consumidores y Usuarios”,cit., Epígrafe 13:”Las cláusulas abusivas”.

${ }^{457}$ S. no 155/1998, TS 25-02-1998 (TOL 170.694).
} 
abusivas, establecidas en los artículos 85 a 90 del TRLGDCU, donde se enumeran como tales las siguientes cláusulas ${ }^{458}$ :

i. aquellas que vinculen el contrato a la voluntad del empresario;

ii. que limiten los derechos del consumidor y usuario;

iii. determinen la falta de reciprocidad en el contrato;

iv. impongan al consumidor y usuario garantías desproporcionadas o le impongan indebidamente la carga de la prueba;

v. resulten desproporcionadas en relación con el perfeccionamiento y ejecución del contrato;

vi. y que contravengan las reglas sobre competencia y derecho aplicable.

Si bien los artículos citados concretan además los condicionantes que debe reunir cualquier cláusula para ser considerada como abusiva, es la jurisprudencia la que interpreta si se ajustan a lo establecido en estos artículos para tener la condición de tales, tal como establece el art. 3.1 de la Directiva 93/13/CE ${ }^{459}$.

El art. 8.2 LCGC en relación a los artículos 80 y ss del TRLGDCU, dispone que serán nulas las condiciones generales que sean abusivas, entendiéndose por tales aquellas que contengan estipulaciones no negociadas, también las que causen un perjuicio al consumidor en contra de las exigencias de la buena fe, o un desequilibrio importante de los derechos y obligaciones de las partes que se deriven del contrato.

Igualmente son abusivas determinadas cláusulas que por su propia naturaleza limitan los medios de prueba del consumidor o facilitan al profesional los suyos, causando un desequilibrio entre las partes, como el caso de las cláusulas que conceden al profesional la facultad de concretar si el bien o servicio objeto de contrato se ajusta a lo en él estipulado, o las que obligan al consumidor a realizar declaraciones de recepción o conformidad sobre hechos ficticios.

\footnotetext{
${ }^{458}$ Fraga Mandián, A., Fraga Mandián, J.: "La tutela procesal civil de los consumidores en las leyes sustantivas especiales”, cit., pág. 15.

459 S. no C:2015:14 del TJUE de 15-01-2015 (TOL 4.631.850), S. T-319/05 REC del TJUE 7-03-2012 (TOL 2.516.894), S. no C-602/13 del TJUE 11-06-2015 (TOL 5.170.613).
} 
Otro ejemplo de desequilibrio sería la existencia de una cláusula tendente a suprimir u obstaculizar el ejercicio de acciones judiciales o de recursos por parte del consumidor, correspondiendo al juzgador determinar si la cláusula concreta reúne los requisitos exigidos y puede calificarse como abusiva en el sentido que establece el art. 3.1 de la Directiva 93/13/CE ${ }^{460}$.

Debido al ánimo de reemplazar el equilibrio formal que el contrato establece entre los derechos y obligaciones de las partes por un equilibrio real, el art. 6 apdo. 1 de la Directiva establece que los estados miembros deben velar porque las condiciones de los contratos que se entiendan abusivas no vinculen al consumidor, disposición que ha sido tenida como imperativa por la jurisprudencia del TJUE ${ }^{461}$, concediendo amplio poder de intervención a los órganos judiciales en el control de las cláusulas para evitar posiciones de inferioridad.

El punto de partida de la doctrina jurisprudencial, impulsado por las propias resoluciones del Tribunal de Justicia de la Unión Europea, y este a su vez tratando de hacer cumplir en sus estrictos términos la Directiva aludida, es la protección del consumidor que se halla en una posición de inferioridad en la relación contractual respecto del profesional, situación que le lleva a adherirse a las condiciones redactadas de antemano por el profesional sin poder influir en el contenido de estas ${ }^{462}$.

Muestra de ello es el caso contemplado en la S. no 265/2015 del TS de 22 de abril de 2015 (TOL 4.952.038) en relación a la condición general que establece el interés de demora en los contratos de préstamo sin garantía hipotecaria, donde se hace eco de la postura mantenida por la Sala ${ }^{463}$ que ha considerado, para que se puedan

\footnotetext{
${ }^{460}$ S. TJUE 26-10-2006, C-168/05 y S. TJUE 3-6-2010, C484/08, www.curia.eu.

${ }^{461}$ S. TJUE de 27-06-2000, C-240/98 a C-244/98, de 26-10-2006, C-168/05, 4-06-2009, C-243/08, 6-102009, C40/08, 3-6-2010, C-484/08, 9-11-2010, C-137/08, 15-03-2012, C-453/10, 26-04-2012, C-472/10, 14-06-2012, C-618/10, 21-02-2013, C-472/11, 14-03-2013, C-415/11 y 21-03-2013 ( todas ellas en www.curia.eu).

${ }^{462}$ La consideración de abusividad de las cláusulas viene concretamente definida en la S. nº 168/2006 de la Sec. 9a de la AP Valencia de 26-04-2006 (TOL 1.009.419).

463 Como la $\mathrm{n}^{\mathrm{o}}$ 406/2012, de 18-06-2012 (TOL 2.652.597), la $\mathrm{n}^{\circ}$ 241/2013, de 9-05-2013 (TOL 3.671.048), la $\mathrm{n}^{\mathrm{0}}$ 166/2014 de -04-2014 (TOL 4.264.715), la $\mathrm{n}^{\mathrm{0}}$ 246/2014 de 28-05-2014 (TOL 4.437.949), la no 464/2014 de 8-09- 2014 (TOL 4.529.142), o la no 677/2014 de 2-12-2014 (TOL 4.748.715).
} 
entender eficaces tales cláusulas aunque exista consentimiento del adherente y estén redactadas de modo claro, comprensible y transparente, que estas además deben respetar las exigencias de buena fe y justo equilibrio entre los derechos y obligaciones de las partes.

Entiende la sentencia, basándose además en la doctrina mantenida por la propia Sala, que el hecho de que las cláusulas sean claras no es obstáculo para que puedan declararse nulas "cuando, pese a las exigencias de la buena fe, causan en detrimento del consumidor un desequilibrio importante entre los derechos y obligaciones de las partes que se derivan del contrato".

La mayoría de sentencias analizadas en que se considera la existencia de cláusulas abusivas se basan en la falta de negociación individual, por falta de transparencia y claridad de lo en ellas establecido o en la imposición de condiciones desproporcionadas al consumidor.

Citando algunos ejemplos de nulidad de cláusulas por abusivas, por los defectos manifestados, la S. del TS de 9 de mayo de 2013 (TOL 3.671.048) cuyo proceso fue instado mediante demanda donde se solicitaba la declaración de nulidad por abusivas de las cláusulas de un contrato de préstamo hipotecario a interés variable, celebrado entre un profesional y un consumidor, fijó un tipo mínimo de interés o un tipo mínimo de referencia, entendiendo que una cláusula general debía considerarse abusiva cuando hubiera falta de transparencia.

En su argumentación partió del criterio mantenido por el TJUE en sentencias como la de 27 de junio de 2000 (C-240/98) o la de 21 de marzo de 2013, entre otras, tomando en consideración la posición de inferioridad del consumidor en relación al profesional.

En el supuesto contemplado en la S. no 265/15 TS de 22 de abril de 2015 (TOL 4.952.038) declara abusiva la cláusula del interés de demora aplicable a un préstamo personal por superar en más de dos puntos el interés remuneratorio y se elimina la cláusula por considerarla abusiva y no haber sido negociada.

Como ejemplo de que siendo una cláusula clara y determinada puede igualmente declararse abusiva podemos citar la STS de 4 de marzo de 2015 (TOL 4.766.879), en cuyo supuesto la cláusula se 
estimó abusiva por dejar al arbitrio de una de las partes la entrega de la vivienda.

En igual sentido, basándose en la decisión unilateral de la introducción de una de las cláusulas contractuales, además de tratarse de una cláusula general, la S. № 6/2015 de 24 de febrero de 2015 (TOL 4.765.338) entiende abusiva la cláusula que establece la sumisión a arbitraje habiendo sido redactada con la finalidad de incluirla en multitud de contratos, privando al adherente de intervención en el proceso de negociación, considerando por tanto nula la cláusula al infringir el principio de igualdad.

La jurisprudencia del TS en sentencias como la ya aludida de 9 de mayo de 2013 (TOL 3.671.048) parte del criterio de protección sostenido por la jurisprudencia del TJUE, basado en la posición de inferioridad del consumidor respecto del profesional, tanto en relación a la capacidad de negociación como al nivel de información facilitado, siendo este el motivo principal que le lleva a adherirse a las condiciones redactadas por el profesional sin influir en ellas.

Cuestión distinta es la relativa a la consideración de abusivas de las condiciones generales de los contratos según la LCGC, en cuyos supuestos la jurisprudencia ha entendido que será abusiva toda cláusula o estipulación general contenida en un contrato si no cumple los requisitos de buena fe y justo equilibrio de las contraprestaciones ${ }^{464}$.

Si la cláusula resultare desconocida para el adherente porque no ha tenido conocimiento o porque al leerla se le antoja incomprensible o ambigua, el efecto legal es que dicha cláusula deberá tenerse por no puesta, deviniendo inexigible tal como establece el art. 7 de la Ley 7/1998, de 13 de abril, sobre Condiciones Generales de la Contratación (en adelante LCGC).

Esta situación es distinta a la de su nulidad donde lo que se cuestiona jurídicamente es la ineficacia, que no la inexistencia de la cláusula de condición general, nulidad que podrá desembocar en la de todo el contrato, o en la de la cláusula ilícita si es posible salvar el resto de las estipulaciones atendiendo al criterio de integración previsto por los arts. 9.2 y 10 de la LCGC.

\footnotetext{
${ }^{464}$ S. no 886/2011 TS 12-12-2011 (TOL 2.367.453), S. n ${ }^{\circ}$ 168/2016, Sec. $1^{\circ}$ AP Pontevedra de 31-032016 (TOL 5.701.328), S. $n^{\circ}$ 34/2016 de JM no 1 de Valladolid de 21-02-2016 (TOL 5.702.793), S. $\mathrm{n}^{\circ}$ 59/2016 JM n 1 de Donostia de 19/02/2016 (TOL 5.702.455).
} 
Tanto según la LCGC, como en los supuestos incluidos en la regulación del TRLDGCU, y según establece la propia LEC en su art. 552.1, el carácter abusivo de la cláusula se apreciará de oficio por el tribunal, quien decidirá teniendo en cuenta la naturaleza de los bienes o servicios objeto del contrato puestos en relación con todas las circunstancias concurrentes en el momento de su celebración, así como con las demás cláusulas del contrato, dado que este no dimana exclusivamente de la falta de negociación individual, aunque ello constituya su contenido esencial.

Es necesario para que se entienda una cláusula abusiva que cause un detrimento importante en los derechos y obligaciones del consumidor, además deberá ser la propia entidad financiera quien pruebe el conocimiento del clausulado por el consumidor, tal como entiende la S. № 139/2015 TS de 25 de marzo de 2015 (TOL 4.828.169).

Entrando en el concreto análisis de la prueba de las cláusulas abusivas, la jurisprudencia analizada en este apartado considera que para que una cláusula sea abusiva debe reunir alguno de los requisitos aludidos en el momento de la firma del contrato, teniendo en cuenta todas las circunstancias concurrentes en el caso concreto 465 , sin que el consumidor deba aportar prueba en cuanto a la abusividad, debiendo ser el juez en cada proceso concreto quien valore si la cláusula cuya nulidad se pretende tiene esta consideración, dependiendo de las circunstancias concurrentes.

En relación a la carga de la prueba, hemos de distinguir dos tipos de asuntos, aunque en ambos la carga de la prueba corresponde al demandado:

a) aquellas demandas que se basan en la vulneración del art. 5.1 de la LCGC, donde, al no haber mostrado el consumidor su conformidad con la condición general impuesta, sea del tipo de que

\footnotetext{
${ }^{465}$ Son muchos los ejemplos a que podemos hacer alusión sobre nulidad de cláusulas por abusivas, concretamente la S. no 886/2011 TS de 12-12-2011 (TOL 2.367.453), al tratar el cargo por la emisión de un billete de avión de forma electrónica, entiende abusiva esta cláusula por incrementar el precio del servicio y por tratarse de una cláusula incorporada a una pluralidad de contratos, debiendo ser probadas por el actor ambas afirmaciones.
} 
sea, corresponde a la empresa predisponente ${ }^{466}$ la prueba en contrario.

Ello implica que el demandado debe probar el conocimiento y aceptación del clausulado por parte del consumidor, debiendo acreditar la existencia y contenido de la información previa de las cláusulas del contrato, la entrega de las condiciones generales, la justificación documental de la contratación una vez efectuada, la renuncia expresa al derecho de resolución, y la correspondencia entre la información, entrega, justificación documental y el momento de sus respectivos envíos.

Concretamente la S. no 621/1996 TS 12 de julio de 1996 (TOL 1.659.032), en su Fundamento de Derecho segundo establece: “...El profesional que afirme que una cláusula tipo se ha negociado individualmente, asumirá plenamente la carga de la prueba..." ${ }^{467}$.

b) El segundo tipo de asuntos sobre cláusulas abusivas se plantean por infracción de lo dispuesto en los artículos referidos del TRLGDCU, donde la prueba de la no abusividad de las cláusulas también corresponde al demandado, bastando que el actor aporte el clausulado al objeto de acreditar sus afirmaciones y de que sea valorado por el juez, siendo la prueba de lo contrario a cargo del demandado ${ }^{468}$.

1. Entrando en el análisis del primero de los dos supuestos concretos que anunciábamos al inicio de este apartado, el de las cláusulas suelo en las escrituras de hipoteca, el TS considera que las condiciones generales pueden ser objeto de control por tener que ajustarse a las condiciones de transparencia, claridad, concreción y sencillez, tal como dispone el art. 5.5 LCGC $^{469}$.

\footnotetext{
${ }^{466}$ En igual sentido se pronuncian otras sentencias de TS como la $\mathrm{n}^{\circ}$ 740/1996 de 14-09-1996 (TOL 1.659.0878), $\mathrm{n}^{\circ}$ 1070/1996 de 4-12-1996 (TOL 1.658.552), la S. $\mathrm{n}^{\circ}$ 75/1997, TS de 1-02-1997 (TOL 215.950), la S. no 846/1999, TS de 13-10-1999 (TOL 169.315), la de 14-4-2000 (TOL 1.554) y la S. ${ }^{\circ}$ 508/2000, TS de 12-05-2000 (TOL 1.799).

${ }^{467}$ Este es el caso de la S. $n^{\circ}$ 199/2002, Sec. $7^{\text {a }}$ AP Asturias de 30-03-2002 (TOL 212.546) donde afirma que debe ser la demandada quien acredite que la cláusula ha sido negociada de forma individual, o el de la S. n ${ }^{\circ}$ 265/2015 del TS de 22-04-2015 (TOL 4.952.038) donde se presume que las cláusulas de contratos bancarios concertados por consumidores son generales, es decir, sujetos a la LCGC y susceptibles de control de abusividad salvo que se pruebe por la entidad bancaria que en ella el consumidor obtuvo contrapartida.

${ }^{468}$ S. Sec. $1^{\text {a }}$ AP Ciudad Real de 13-05-2002 (TOL 200.258).

${ }^{469}$ S. no 464/2014, TS de 8-09-2014 (TOL 4.529.142), S. nº 197/2016 de 30-03-2016 (TOL 5.689.011).
} 
Aunque en principio dada la normativa existente sobre control y transparencia de las cláusulas de los préstamos hipotecarios, podíamos considerar que el consumidor gozaba de una especial protección y control, resoluciones como las mencionadas del Tribunal de Justicia de la Comunidad Europea nos han demostrado que la legislación española no es conforme a los principios establecidos por la propia Unión Europea en la Directiva referida y que la legislación española debía sufrir un profundo cambio tanto para adecuarse a la legislación comunitaria, como para poner en funcionamiento efectivo ese sistema de protección.

Observamos por tanto que las disposiciones recogidas en normas como la Ley $2 / 1994$, de 30 de marzo de subrogación y modificación de préstamos hipotecarios, la Ley 44/2002, de 22 de noviembre, de Medidas de Reforma del Sistema Financiero, la Orden ECO/734/2004, de 11 de marzo, sobre los departamentos y servicios de atención al cliente y el defensor del cliente de las entidades financieras, así como en la Ley 22/2007, de 11 de julio, sobre comercialización a distancia de servicios financieros destinados a los consumidores, no son lo suficientemente protectoras del consumidor.

En estos casos, debe realizarse el control sobre la inclusión de las cláusulas abusivas según la regulación de la Orden EHA/2899/11, de 28 de octubre, de transparencia y protección del cliente de servicios bancarios en relación con los créditos de préstamos bancarios y la Circular 5/12, de 27 de junio, del Banco de España, dirigida a las entidades de crédito y proveedores de servicios de pago, sobre transparencia de los servicios bancarios y responsabilidad en la concesión de préstamos.

Aunque no existe norma específica de prueba sobre la negociación individual, resulta necesario que el empresario demandado pruebe la negociación de las cláusulas entre las partes, como señala la Directiva del Parlamento Europeo y del Consejo 2011/83/UE, de 25 de octubre de 2011, sobre derechos de los consumidores, ya que pretender repercutir la prueba de la negociación individual del clausulado en el consumidor sería una prueba imposible o diabólica que vulneraría el derecho de tutela judicial efectiva.

Lo que aún llama más la atención es que haya tenido que ser un juez de primera instancia, a petición de un afectado, el que diera la voz de alarma ante tal situación. 
Es imprescindible aludir en este punto a la importantísima jurisprudencia del TJUE que ha establecido el criterio sobre el que los tribunales españoles dictan sus resoluciones, siempre considerando la posición de inferioridad que ocupa el consumidor respecto al profesional.

El Tribunal Europeo ha dictado sentencias de gran interés, como la del TJUE de 14 de junio de 2012, C 618/10 (Banesto), a raíz de una cuestión prejudicial planteada por la AP de Barcelona con motivo de la resolución de un recurso de apelación contra una Sentencia el Juzgado de Primera Instancia no 2 de Sabadell donde el banco había interpuesto una demanda en proceso monitorio contra un consumidor por impago de siete cuotas mensuales de amortización.

El juez de instancia dictó auto constatando que el contrato controvertido era un contrato de adhesión, por haberse celebrado sin posibilidades reales de negociación, tampoco se distinguía la aceptación del interés de demora del $29 \%$ por parte del consumidor.

Debido a ello, declaró nula la cláusula que establecía el interés de demora por estimarla abusiva, remitiéndose a reiterada jurisprudencia del Tribunal de Justicia de las Comunidades Europeas en la materia que incluso fijó el interés de demora en el $19 \%$ basándose en el establecido en las Leyes de Presupuestos de 1990 a 2008, y requiriendo al Banco para que realizara de nuevo el cálculo de intereses.

Banesto apeló y la Audiencia, aunque consideró que el juez en un proceso monitorio no está facultado para declarar de oficio la nulidad de la cláusula relativa a los intereses de demora, tuvo dudas al interpretar el derecho de la Unión Europea y planteó la cuestión prejudicial.

Por su parte el TJUE entendió que la legislación española es contraria a la Directiva 93/13, al no permitir el examen de oficio de las cláusulas, y declaró que el juez no solo puede, sino que debe apreciar de oficio el carácter abusivo de una cláusula, subsanando de ese modo el equilibrio entre el profesional y el consumidor.

En estos supuestos de abusividad por aplicación de un tipo de interés excesivo, la prueba se limitará al contrato o escritura de hipoteca firmada y a la comparación entre el interés que consta en el contrato con el tipo de interés vigente. 
Mayor importancia todavía reviste la Sentencia TJUE, de 14 de marzo de 2013, recaída en el C415/11 que motivó la reforma de la ejecución hipotecaria operada en la LEC a través de la ley $1 / 13$, de 14 de mayo, incluyendo una 4a causa de oposición a la ejecución hipotecaria por la existencia de cláusulas abusivas, y del art. 114 de la Ley Hipotecaria, añadiendo un tercer párrafo en relación a los intereses de demora por la adquisición de vivienda habitual garantizados con hipoteca sobre la misma vivienda, estableciendo que estos no podrán ser superiores a tres veces el interés legal del dinero y sólo podrán devengarse sobre el principal pendiente de pago ${ }^{470}$. Desde su inclusión, los jueces realizan el control de oficio de las referidas cláusulas, comparando el tipo de interés pactado con el tipo de interés vigente.

La sentencia aludida fue dictada por el TJUE tras someter el JPI no 5 de Martorell competente cuestión prejudicial en el caso "Aziz", al considerar que el art. 698 de la LEC impedía al juez competente declarar abusiva una cláusula de un contrato de préstamo hipotecario y poder suspender por ello el procedimiento de ejecución. Entendía que este artículo resultaba contrario al principio de efectividad y hacía imposible aplicar la protección que la Directiva concede a los consumidores.

Pero el Tribunal aún fue más allá, estableciendo incluso los términos del concepto de cláusula abusiva, apreciando este teniendo en cuenta las normas aplicables del Derecho nacional cuando no exista acuerdo entre las partes y examinando la situación jurídica del consumidor, debiendo para ello comprobar si el profesional podía haber concretado esta cláusula de acuerdo con el consumidor y de ser así, si este la hubiera aceptado.

En el clausulado de la escritura de hipoteca del Sr. Aziz existían tres cláusulas que el tribunal consideró abusivas: la de fijación de los intereses de demora, la del vencimiento anticipado y la de liquidación unilateral por el prestamista del importe de la deuda pagada. La única prueba en que el Tribunal basó su decisión fue la comparación del clausulado de la escritura de hipoteca con la Directiva de aplicación.

\footnotetext{
${ }^{470}$ Ruiz de Lara, M.: "Condiciones Generales de la contratación, cláusulas abusivas y protección del consumidor a la luz de la jurisprudencia comunitaria y nacional”. Ed.: Fe d'erratas, Madrid 2014, pág. 82.
} 
La sentencia supuso una denuncia de la normativa española en materia de ejecuciones hipotecarias por hallarla incompatible con el necesario control jurisdiccional de la relación jurídica subyacente en el proceso de ejecución.

Tras este cambio legislativo sí que podemos presumir que en la contratación de los préstamos hipotecarios se garantizan los requisitos que establece el artículo referido, realizando los propios jueces la labor de control de la transparencia.

Por tanto, el juez con el objetivo de valorar si las cláusulas reúnen los requisitos de buena fe y justo equilibrio entre las contraprestaciones de las partes, y de si la carga económica que el contrato supone para el consumidor reúne todos los requisitos de legalidad, revisará y declarará nulas las cláusulas suelo cuando haya falta de transparencia en los contratos de préstamo hipotecario a interés variable celebrados entre profesionales y consumidores o cuando exista una cláusula abusiva que se proyecte sobre elementos esenciales del contrato.

Sobre la carga de la prueba de que las cláusulas no fueron impuestas, no existe norma específica en la LCGC, siendo la jurisprudencia la que aclara este particular.

Ejemplo de ello es la S. no 241/13 del Pleno del TS de 9 de mayo de 2013 (TOL 3.671.048) en que la Asociación de Consumidores Ausbanc demandaba a varias entidades de crédito ejercitando la acción colectiva en solicitud de nulidad de cláusulas de limitación de la revisión del tipo de interés. EI TS reitera la jurisprudencia del TJUE en cuanto a la consideración de que el consumidor ocupa una posición de inferioridad en las cláusulas de los préstamos hipotecarias debido a su imposición sin ningún tipo de conocimiento ni negociación previa.

Esta sentencia ha creado una línea jurisprudencial sobre la validez y la posibilidad de control judicial del carácter abusivo de las cláusulas suelo incorporadas a los contratos bancarios de préstamo a consumidores con garantía hipotecaria y a interés variable celebrados con consumidores y usuarios. El Tribunal admite la validez de tales cláusulas cuando cumplen los requisitos de especial transparencia exigible en los contratos celebrados con consumidores. 
Mantiene qué cláusulas suelo tienen la consideración de condición general de la contratación, siendo siempre impuestas por las entidades de crédito aun cuando hacen referencia a intereses y constituyen un elemento esencial del contrato.

Considera además que es función del juez el restablecimiento del equilibrio mediante la declaración de nulidad de la cláusula, cuya apreciación se puede realizar de oficio, aludiendo como precedente la S. no 401/10 del Tribunal Supremo de 1 de julio (TOL 2.006.750).

En la misma línea que la anterior podemos aludir a la S. no 88/2013 del Juzgado de lo Mercantil no 5 de Barcelona, de 17 de junio de 2013 (TOL 3.796.760) que entiende que tanto las cláusulas suelo como el clausulado pre redactado debe someterse a un control de su contenido, dado que el establecimiento de cláusulas suelo y su falta de negociación son condiciones fundamentales que afectan a la validez del vínculo contractual que deben ser probadas por el empresario.

De este modo, la labor probatoria corresponderá a la entidad bancaria y se basará, tanto en acreditar la información facilitada previa a la aceptación y firma de las condiciones de la póliza, puesto que el consumidor debe ser informado de que con la cláusula suelo que consta en el documento sólo se verá alterado el tipo de interés aplicable si el índice de referencia es modificado al alza, como en que el clausulado de la póliza no era de aplicación general y fue redactado de forma negociada por las partes e individualizada.

En relación a la prueba del conocimiento de la cláusula suelo incorporada a la escritura, la labor probatoria de la entidad bancaria tratará de acreditar que informó al consumidor de forma clara y destacada de las referidas cláusulas, sin que estas puedan pasar inadvertidas. Para ello, incluso pedirá, aunque no conocemos de ningún proceso en que la misma haya sido admitida, la declaración del propio notario autorizante al objeto de que confirme que informó al cliente sobre el contenido de la referida cláusula.

Por parte del consumidor también se deberá realizar una importante, aunque sencilla labor probatoria que consistirá en acreditar el desconocimiento sobre el contenido del clausulado, extremo que bastará acreditar con la declaración del propio actor, debiendo ser la entidad bancaria, como ya hemos referido, la que aporte prueba en sentido contrario. 
En este sentido, la Sentencia no 464/2014, de 8 de septiembre de 2014 (TOL 4.529.142) en relación a la prueba aportada por la entidad bancaria en un recurso donde se anularon ocho cláusulas suelo de Caja Segovia, hoy integrada en Bankia, sobre la valoración de la prueba aportada por la entidad bancaria de la advertencia realizada por el notario a los firmantes de la hipoteca en relación a la cláusula suelo por parte del notario en el momento de la firma, entendió que no era suficiente para que se pudiera afirmar el total conocimiento del significado y contenido de las mismas por el firmante.

La jurisprudencia analizada considera que las cláusulas suelo son lícitas si su transparencia permite identificarlas como definidoras del objeto principal del contrato y conocer el real reparto de riesgos de la variabilidad de los tipos sin que sea preciso que exista equilibrio económico o equidistancia entre el tipo inicial fijado y los topes señalados como suelo y techo.

EI TS fija incluso las bases para realizar el control mediante indicios o hechos que de concurrir permitan apreciar la comprensión real del consumidor, basados en averiguar si el consumidor es consciente de la contratación realizada de un préstamo con un interés mínimo fijo que comportará la imposibilidad de beneficio en un futuro de las bajadas del tipo de referencia.

Es fundamental además que la cláusula suelo sea transparente, es decir, esté clara y no dé lugar a confusión, esté visible y bien redactada de forma que no induzca a error.

Así, la S. no 241/2013 del TS de 19 de marzo de 2013 (CENDOJ 28079119912013100009) en que AUSBANC demanda al BBVA, Caja Mar, Cajas Rurales Unidas, S.C.C., NCG Banco S.A.U. por abusividad de las cláusulas suelo de préstamos hipotecarios, considera que el deber de su acreditación está cumplido cuando se demuestra de forma clara y contundente la validez de la cláusula, pudiendo incluso el juez nacional acordar de oficio diligencias de prueba para determinar si una cláusula está comprendida en el ámbito de aplicación de la Directiva (así lo ha entendido también el TSJUE en sentencias como las ya citadas).

Más importante todavía resulta la Sentencia del Juzgado de lo Mercantil no 11 de Madrid, de 7 de abril de 2016 (CENDOJ: $28079470112016100001)$ en resolución de una macro demanda de 
unos cuarenta bancos y un total de quince mil afectados, presentada por la Asociación de Consumidores ADICAE, entiende que el consumidor debe tener un conocimiento completo del precio y del objeto del contrato de préstamo hipotecario antes de prestar su consentimiento, debiendo tratar de evitar que las cláusulas de limitación de la variabilidad de tipos se oculten en las condiciones generales.

El motivo por el que la sentencia entiende que debe declararse nula determinada cláusula suelo no es la cláusula en sí misma, sino la contradicción que supone para las legítimas expectativas del consumidor, puesto que existe una falta de transparencia en su existencia y ha sido tratada como condición general, de alcance secundario cuando es una condición importante que afecta directamente al precio del contrato, y su conocimiento hubiera sido determinante para decidir sobre su contratación.

Considera que los clientes entendieron que firmaban un contrato de préstamo hipotecario a interés variable de forma que los intereses oscilarían en función de la evolución del índice de referencia pactado, y ante la bajada del tipo de referencia, se iba a producir una bajada de la cuota del préstamo hipotecario.

Llega a tal conclusión al observar que a las cláusulas suelo introducidas en los contratos de hipoteca se les dio un tratamiento secundario, quedando introducidas entre otros datos que las enmascaran, cuando deberían haber sido objeto de un tratamiento especial.

A raíz de la referida sentencia, tanto las entidades intervinientes en el proceso como aquellas que no intervinieron, han adecuado su clausulado y comunicado a sus clientes las modificaciones precisas en su cumplimiento.

La resolución definitiva sobre esta cuestión que tantas sentencias ha generado en favor del consumidor, se ha producido a través de la Sentencia no 980/2016 del TJUE, en fecha de 21 de diciembre de 2016 (TOL 5.912.453) al resolver tres asuntos prejudiciales acumulados (asuntos C-154/15, C-307/15 y C-308/15) en relación a la retroactividad de las cláusulas suelo en España y a la interpretación que debe darse a la Directiva 93/13/CEE, considerando que deben devolverse a todos los afectados las cantidades ingresadas por estos conceptos desde el inicio de la relación contractual, contradiciendo lo 
que resolvió el TS en la S. № 241/2013, de 9 de mayo de 2013 (TOL 3.671.048) al limitar los efectos propios de su resolución a situaciones posteriores a la misma.

En los supuestos analizados, la falta de prueba no puede perjudicar al consumidor, por tanto, el obligado a practicar la prueba es la entidad bancaria, no sólo sobre el conocimiento del consumidor y la individualización del clausulado, sino también en relación a la negociación de las cláusulas o que pese a tratarse de una cláusula pre redactada, esta no estaba destinada a una pluralidad de ofertas $^{471}$.

Debido a lo manifestado, la prueba versará sobre el conocimiento del consumidor de la realidad de lo pactado que se llevará a cabo, como hemos aludido mediante la confección de un cuestionario respondido por el propio consumidor, así como la justificación por la entidad bancaria de que el clausulado fue redactado de forma individual.

La regla sobre la que determinar a quién corresponderá la prueba se basa en la máxima ya aludida de concretar a quién perjudicará la falta de prueba de determinados hechos.

2. Entrando en las demandas sobre cláusulas abusivas en contratación de transporte aéreo, la Sentencia no 113/2013, de 30 de septiembre de 2013 del Juzgado de lo Mercantil no 5 de Madrid, en que la Organización de Consumidores y Usuarios demanda a "Ryanair Limited" (CENDOJ 28079470052013100001), en solicitud de nulidad de varias cláusulas objeto del contrato de transporte analiza una a una cada cláusula cuya nulidad se pretende y las pone en relación a la normativa europea, entendiendo que para interpretar una disposición del Derecho de la Unión Europea debe tenerse en cuenta además de su tenor literal, su contexto y los objetivos perseguidos por la normativa de la que forma parte.

Pese a que en este procedimiento se aplica la ley irlandesa y la jurisdicción competente es la irlandesa, entiende que alguna de las cláusulas causa un desequilibrio al consumidor. En el supuesto de la cláusula de sumisión a la ley y a la jurisdicción irlandesa se concreta

\footnotetext{
${ }^{471}$ En la misma línea se encuentran las S. no 86/2014 TS de 26-05-2014 (TOL 4.388.014), S. no 149/2014 TS de 10-03-2014, (TOL 4.142.469), S. no 152/2014 de 11-03-2014, (TOL 4.143.010), S. no 166/2014, de 7-04-2014 (TOL 4.264.715).
} 
en que le obliga a litigar en un país cuya normativa y funcionamiento desconoce, limitando a su vez el acceso a la jurisdicción y ocasionándole un sobrecoste por el desplazamiento a Irlanda.

En este tipo de procesos, la prueba es muy precisa, basada en la documentación contractual de las partes, debiendo ser la parte que afirme que una determinada condición general ha sido negociada, quien aporte prueba de ello.

Ejemplo de ello es la Sentencia no 254/2012, de 11 de septiembre de 2012 del Juzgado de lo Mercantil no 12 de Madrid donde la OCU demanda a IBERIA, Línea Aérea de España, S.A. en solicitud de nulidad de determinadas cláusulas por su carácter abusivo al tratarse de condiciones generales ${ }^{472}$.

La sentencia analiza cada una de las cláusulas cuya nulidad se pretende, afirmando que la carga de la prueba recae en quien alegue que la cláusula ha sido negociada individualmente, y la Sentencia no 363/2013, Sec. 15a de la AP de Barcelona de 21 de octubre de 2013 de OCU contra VUELING AIRLINES, S.A. (TOL 3.990.943) en la que la propia compañía aérea afirma que se trata de un contrato de adhesión puesto que es imposible realizar un contrato por cada cliente; analiza cada una de las cláusulas objeto de nulidad y estima parcialmente la demanda anulando las cláusulas que considera abusivas.

\section{e. Prueba en los procesos sobre productos defectuosos.}

En relación a los concretos defectos de los productos ya hemos analizado en el capítulo anterior las cuestiones en relación a la carga de la prueba, pero existen otros condicionantes que trataremos en este apartado, sobre lo que debe probarse para obtener una resolución favorable al consumidor.

La prueba guarda estrecha relación con el tipo de producto y con los defectos que presente, que pueden ser variados y afectar a fases distintas del proceso productivo, pudiendo englobar tanto el diseño, como la fabricación del producto, la información que se ofrece del mismo, o la seguridad aludida, manifestándose estos últimos en la propia presentación del producto.

472 Disponible en https://www.ocu.org/organizacion/prensa/notas-de-prensa/2012/iberia-clausulasabusivas. 
Partimos de una idea general como desarrollaremos, de que basta que la parte demandante consiga convencer al juzgador de la inseguridad del producto, debiendo en estos casos el fabricante acreditar la idoneidad del mismo y la concurrencia de causas que pudieran exonerarle de la responsabilidad.

Aunque siempre suele resultar difícil acreditar la falta de diligencia del que causa el daño, debe probarse, como veremos, el nexo causal a la vez que la negligencia producida.

Debido a que la prueba de los productos defectuosos tiene un triple componente ya aludido, vamos a analizar por separado cada uno de ellos, en primer lugar trataremos la prueba del defecto, a continuación, la relación de causalidad, la prueba de la responsabilidad del productor y por último, la prueba de la responsabilidad del perjudicado y su exoneración.

El punto de partida del proceso por productos defectuosos es la prueba del defecto ${ }^{473}$ y la relación de causalidad. La prueba de ambas cuestiones al igual que la concreción de la responsabilidad incumben al demandante y las causas de exoneración de responsabilidad debe probarlas el fabricante ${ }^{474}$, aunque todo ello lo iremos matizando a lo largo de este apartado.

\section{En relación a la prueba del defecto.}

Los puntos en común de estos procesos son la prueba por parte del consumidor de la existencia del defecto, del daño y de su origen, y en relación a la exoneración de responsabilidad del fabricante, la prueba por parte de este de la culpa del consumidor.

Son varios los artículos a que alude el TRLGDCU sobre la prueba de los productos defectuosos; concretamente el art. 118 del TRLGDCU, en relación a la responsabilidad del vendedor por los defectos del producto, establece que el consumidor sólo tiene que probar el uso o consumo, el daño y la relación de causalidad. La culpa del fabricante, importador o suministrador se presume, como

\footnotetext{
${ }^{473}$ La S. de la Sec. $4^{\text {a }}$ de la AP Santander de 10-05-2001 (TOL 106.901), considera que la responsabilidad civil por producto defectuoso está regulada por las normas de la Ley 22/1994, incluidas con la refundición en el actual TRLGDCU, que establece un régimen de responsabilidad objetiva permitiendo al fabricante exonerarse de ella en los supuestos que establece el art. 6 de la misma.

${ }^{474}$ León de Arce, A., García García, L.M., artículo de Palacios González, D., (coord.) "Derechos de los consumidores y usuarios”, cit., pág. 1445.
} 
veremos en las páginas siguientes, debiendo ser este el que acredite el cumplimiento de las exigencias reglamentarias y demás cuidados y diligencias que exige la naturaleza del producto o servicio.

Debido a la desigualdad ya comentada existente entre las partes y a la dificultad de prueba del defecto por parte del consumidor, dado que la jurisprudencia tiene en consideración estos hechos, no existe un criterio claro y único en cuanto a la prueba en los procesos por daños ocasionados por productos defectuosos optando los tribunales por la solución más prudente, estar a cada caso en concreto para valorar la necesidad de prueba por parte del perjudicado o del causante del daño ${ }^{475}$.

En cualquiera de los casos, la prueba del defecto es necesaria, puesto que, si no se puede probar la causa de los daños, no resultará imputable la responsabilidad al fabricante, perjudicando al actor la falta de prueba o la incerteza de la misma, según reiterada jurisprudencia de la que podemos citar a modo ejemplificativo la $\mathrm{S}$. no 659/2005 del TS de 27 de julio de 2005 (TOL 674.295) ${ }^{476 .}$

Sobre la necesidad de prueba del defecto el criterio jurisprudencial ha sido unánime, apreciando en muchos casos que no existe la responsabilidad del demandado no por la falta de prueba del nexo causal, sino por la duda sobre la existencia del defecto, como ocurre en las sentencias del TS de 28 de septiembre de 2006, no $966 / 2006$ (TOL 1.014.549) y no 1290/2002 de 27 de diciembre de 2002 (TOL 4.927.466).

Son innumerables las sentencias existentes en este sentido, y claro ejemplo de ello es la S. no 183/2007 del TS de 19 de febrero de 2007 (TOL 1.038.326) ${ }^{477}$, donde se manifiesta esta necesidad de prueba del defecto por el perjudicado, aunque se está al caso concreto para determinar si existe posibilidad de prueba, como en el supuesto enjuiciado en la sentencia citada, que no alcanza a probar la

\footnotetext{
475 Álvarez Lata, N., Peña López, F., Busto Lago, J.M (coord.): “Reclamaciones de consumo. Derecho de consumo desde la perspectiva del consumidor”, cit., pág. 1313.

${ }^{476}$ Es también relevante, a los efectos estudiados la STS n ${ }^{\circ}$ 332/2008 de 30-04-2008 (TOL 1.311.962), que se pronuncia en los mismos términos que la anterior en relación a la carga de la prueba del defecto y a su justificación.

477 Otras sentencias a que podemos hacer alusión a modo ejemplificativo son la S. n ${ }^{\circ}$ 931/2006, de TS de

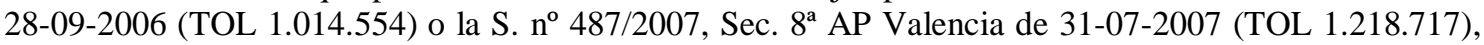
S. $n^{\circ}$ 551/2010, Sec. $10^{\text {a }}$ A.P. Madrid de 24-11-2010 (TOL 2.044.657).
} 
causa del defecto, tan solo a concretar el fallo del producto (un cohete) por falta de seguridad.

Una de las cuestiones más importantes en relación al defecto del producto es la de su seguridad, tal como establece la Directiva aludida, siendo un derecho del consumidor que el producto pueda ser utilizado sin riesgos para la integridad física o patrimonial, uniéndose así los dos elementos: la seguridad y el defecto.

Por tanto, uno de los puntos básicos para determinar la existencia del defecto, además de la valoración de su seguridad, es la condición del mismo, dado que puede ser de distinta procedencia dependiendo de si lo son de fabricación del producto, de diseño o de información.

Sobre el concreto defecto de que adolezca el producto puesto en relación con los de su clase, debemos en primer lugar conocer la seguridad necesaria y estar informados de las expectativas que cabe esperar del producto ${ }^{478}$.

Llegados a este punto nos planteamos las grandes dificultades con que se encontrará el actor, un usuario, un ciudadano en muchos casos con pocos medios para probar la existencia del defecto.

A la complejidad de prueba de los productos defectuosos, sobre todo por el origen del defecto, se une la dificultad todavía mayor cuando debemos realizar la comparación del producto con los de su gama. La prueba del defecto supone una identificación del producto y de las circunstancias en que se produjo el resultado, teniendo en consideración el uso dispensado y debiendo este ser probado.

La dificultad probatoria aludida se acrecienta en los casos de destrucción del objeto a consecuencia del defecto, lo que impide que podamos conocer su origen. En tales casos se opta por no cargar al perjudicado con la prueba de un hecho imposible y se exige a la parte actora la acreditación del daño y que este se produjo cuando se estaba utilizando el producto, debiendo por su parte la demandada probar la buena calidad del mismo ${ }^{479}$.

\footnotetext{
${ }^{478}$ Como ocurre en el supuesto enjuiciado por la S. $n^{\circ}$ 286/2008, Sec. $3^{\text {a }}$ AP Islas Baleares de 18-09-2008 (TOL 1.443.815) o la S. $n^{\circ}$ 174/2013, Sec.1 $1^{a}$ AP Jaén de 25-11-2013 (TOL 4.126.291) donde se causan lesiones al presentar defectos de seguridad un juguete.

${ }^{479}$ En la década de los 90 el TS resolvió varios supuestos de daños por estallidos de botellas debidas (S.
} 
Además, resulta muy difícil separar las distintas cuestiones sobre los concretos defectos del producto que se plantean en las sentencias, puesto que en la mayoría de supuestos, el defecto observado por el producto comporta a su vez, varios defectos en el mismo, de forma que el defecto de diseño del producto comporta a su vez un defecto de fabricación y de seguridad. Por ello, el estudio debe contemplar los defectos en su conjunto.

En los casos en que no exista prueba cierta sobre la causa de los daños no puede apreciarse la específica responsabilidad por productos defectuosos. Así lo han entendido Sentencias del TS como la de 27 de julio de 2005 (TOL 674.295) que exime de responsabilidad a los demandados por no haber acreditado la causa directa del reventón de la rueda de un vehículo y que este fuera debido a un defecto de fabricación, y la no 938/2007, TS, de 21 de septiembre de 2007 (TOL 1.150.977) ${ }^{480}$.

\section{La Prueba de la relación de causalidad.}

Una vez probada la existencia del defecto, que generalmente corresponderá al actor, la prueba se centrará en justificar la relación entre la causa y el efecto, es decir, en el nexo causal entre el defecto y el daño, sin cuya prueba no podrá estimarse la responsabilidad del fabricante por productos defectuosos.

La relación de causalidad es por tanto el primer y más importante eslabón de la prueba del defecto del producto; establecido en el art. 139 del TRLGDCU, ha sido entendido como veremos por el TS como de prueba obligatoria.

Es el art. 119 el que establece como ya hemos aludido este sistema de responsabilidad objetiva, al igual que realiza el art. 139, ambos del TRLGDCU al afirmar que el productor responde por los daños ocasionados en el correcto consumo o uso de bienes y servicios, dando lugar a la exoneración de responsabilidad cuando tal consumo sea incorrecto, de forma que la culpa del perjudicado sirve para exonerar la responsabilidad del demandado ${ }^{481}$.

no 661/2000, TS 23-06-1993 (TOL 6.610), S. 8-02-1995 (TOL 1.658.301), S. no 778/1996, de 4-10-1996 (TOL 1.659.077).

${ }^{480}$ De León de Arce, A., en García García, L.M., (coord.): "Derechos de los consumidores y usuarios”. Tomo II, cit., pág. 1779.

${ }^{481}$ S. no 876/2006 TS de 20-9-2006 (TOL 995.559) en la que el TS desestima el recurso de casación 
Es también de aplicación lo dispuesto en el art. 1902 del C.c. en relación a la culpa en la producción del daño y a la relación de causalidad.

De los preceptos citados deducimos que el productor responde de los daños que cause la puesta en circulación de sus productos, aunque no exista conducta concreta que le sea imputable ${ }^{482}$; es decir, la existencia del defecto y la relación de causalidad serán motivo suficiente para considerar al fabricante responsable de los daños, salvo que este justifique que medió culpa del usuario o de un tercero.

Entendemos por tanto que la prueba de la relación de causalidad está en relación con el concreto defecto, y con la forma en que se haya producido. Esta idea se ve claramente en el caso de defecto por utilización inadecuada del producto por falta de información al consumidor sobre su uso, pues por el simple hecho de existir esa falta de información se dará la causalidad suficiente, que deberá también ser objeto de prueba ${ }^{483}$.

Aunque la prueba del defecto es el punto fundamental y previo a concretar, no basta sólo con probar el defecto, sino que debe acreditarse que este constituye la causa del daño, independientemente de que exista o no la culpa ${ }^{484}$. Esta prueba puede resultar compleja, dado que se exige que sea clara y basada en medios de prueba concluyentes, debiendo ser el actor quien aporte indicios sobre la falta de seguridad del producto y que esta falta conlleva un defecto en el mismo ${ }^{485}$.

dirigido contra la sentencia que confirmó la responsabilidad de la empresa demandada, suministradora de las prótesis implantadas a la demandante, por los daños causados a esta última. Considera la Sala que el sistema legal actual no requiere la plasmación de una diligencia exorbitante, fuera de lo común y próxima a la imposibilidad de ponerse en práctica, que constituye el límite del deber de responder, sino la de procurar las correspondientes a la propia esencia y a las características del producto. Añade que, en estos casos, la responsabilidad surge cuando se han desatendido las medidas de seguridad y los controles técnicos que garanticen las condiciones en que, en ese orden preventivo, los productos han de llegar al usuario.

\footnotetext{
482 Abel Lluch, X., Picó i Junoy, J., Richard González, M.: “La Prueba Judicial. Desafíos en las jurisdicciones civil, penal, laboral y contencioso-administrativo.” Ed.: La Ley, Madrid 2011, pág. 1371.

483 S. TS 3-12-1997 (TOL 216.433).

${ }^{484}$ La S. $n^{\circ}$ 1381/2008, TS de 7-11-2008 (TOL 1.401.716) en un caso de defectos de airbag considera que la acreditación de la deficiencia sólo exonera de responsabilidad en caso de que la anomalía de funcionamiento se debiese a la intervención del sujeto dañado.

${ }^{485}$ En este sentido son relevantes la S. $n^{\text {o } 393 / 2005, ~ S e c . ~} 1^{\text {a }}$ de la AP Córdoba de 19-10-2005 (TOL 924.463), y la de la misma AP, S. $n^{\circ}$ 48/2010, Sec. $3^{\text {a }}$ de 23-3-2010 (TOL 1.952.448), y la S. $n^{\circ} 279 / 2003$,
} 
La jurisprudencia, de forma reiterada ha sido rigurosa en relación a la prueba del nexo causal entre la conducta del agente y el daño producido ${ }^{486}$, exigiendo necesariamente que tal prueba se practique, entendiendo además que debe probar quien disponga de mayor facilidad probatoria 487 , pese a que debería ser el actor quien acreditara la existencia del nexo causal ${ }^{488}$.

En relación a los elementos que deben ser probados para acreditar la existencia del nexo causal, es imprescindible que exista una certeza probatoria basada en una prueba determinante sin que sean suficientes meras conjeturas, deducciones o probabilidades constituyendo "el cómo" y "por qué" de lo acontecido elementos indispensables en el examen de la causa del evento dañoso.

Los tribunales han adoptado distintas posturas dependiendo del caso particular. Así encontramos una posición más estricta, la subjetiva, que entiende que debe probarse la correlación entre la autoría de la conducta dañosa y la producción del daño ${ }^{489}$, exigiendo por tanto la prueba de todo el proceso de desenlace del daño desde su origen hasta su efectiva producción, así como el origen y la causa del mismo.

Esta postura se aplica en supuestos en que no resulta evidente la relación de causalidad, siendo en estos casos necesaria la prueba de todos los elementos del nexo causal ${ }^{490}$.

Así lo ha entendido la jurisprudencia en sentencias como la del TS de 13 de febrero de 1991 (RJ 1991\1200), que enjuició la responsabilidad de un fabricante de piensos por haber producido la muerte del ganado al ingerir pienso en mal estado, considerando responsable al vendedor no sin antes quedar suficientemente acreditado mediante dictamen pericial que el motivo de la muerte fue

Sec. 1a también de la AP Córdoba de 24-11-2003 (TOL 335.749) en relación a que la prueba del defecto y de su relación con el daño, debe basarse en indicios, deben estar plenamente acreditados.

${ }^{486}$ S. TS de 10-05-2001 (TOL 106.901), S. n 1071/2008 TS de 7-11-2008 (TOL 1.401.716).

487 Abel Lluch, X., Picó i Junoy, J., Richard González, M.: "La prueba judicial. Desafíos en las jurisdicciones civil, penal, laboral y contencioso-administrativa”. Ed.: La Ley, Madrid 2011, pág. 1391.

${ }^{488}$ S. no $258 / 2006$ TS de 21-03-2006 (TOL 866.065).

${ }^{489}$ S. $n^{\circ}$ 36/2006, Sec. 3a A.P. Almería de 7-03-2006, TOL 961.540, S. no 184/2014, Sec. 2a A.P. Almería de 3-7-2014 (TOL 4.563.424), S. no 2/2009, Sec. $3^{\text {a }}$ A.P. Guipúzcoa de 9-01-2009 (TOL 1.521.269), etc.

490 Abel Lluch, X., Picó i Junoy, J., Richard González, M.: "La prueba judicial. Desafíos en las jurisdicciones civil, penal, laboral y contencioso-administrativa”, cit., pág. 1395. 
la ingesta del pienso, o la no 132/2015, de la Sec. 1a AP Pontevedra de 13 de abril de 2015 (TOL 4.899.489), al considerar necesario para que se produzca la imputación de responsabilidad, que el actor acredite la producción de un hecho causado por el demandado ${ }^{491}$.

Otra postura en relación a la acreditación del nexo causal opta por un criterio de imputación objetivo de la responsabilidad y exige al amparo de los arts. 137 y 139 del TRLGDCU que se pruebe el defecto, aunque no considera necesario identificar la causa para que su reclamación sea estimada, debiendo ser el actor quien pruebe que el producto presentaba una anomalía en relación al resto de productos de su misma serie ${ }^{492}$.

Esta última postura es la adoptada por el TS tras la Sentencia no 151/2003 de 21 de febrero de 2003 (TOL 265.196), donde se abordaba la prueba del defecto de una botella de gaseosa de cristal que estalló al cogerla el consumidor causándole lesiones. En este caso, el actor no tuvo que probar el defecto del producto ni su uso inadecuado puesto que se entiende que el producto no presentaba la seguridad que cabía esperar invirtiendo la carga de la prueba por corresponder al fabricante acreditar la idoneidad del mismo o la concurrencia de causas de exoneración.

La adopción de una u otra postura depende de cada caso en particular, así como de la existencia del producto o del daño que cause, puesto que encontramos supuestos de destrucción del producto, como el contemplado por la S. № 332/2008 del TS de 30 de abril de 2008 (TOL 1.311.962).

Ambas posturas tienen en común la exigencia de la prueba del defecto, siendo la primera más exigente al pretender que el actor pruebe además la intervención del demandado en la producción del daño.

La adopción de una u otra postura depende del tipo de daño y del producto que lo causa, puesto que, por ejemplo, en los daños por incendio, no es posible probar el nexo causal por haberse destruido el

\footnotetext{
${ }^{491}$ Otras sentencias en relación a pienso en mal estado S. TS 11-04-2002 (TOL 155.142), consideran de vital importancia la existencia y prueba de los daños y perjuicios junto a la relación causa-efecto entre el estado del pienso y la muerte, en este caso, de conejos.

492 Abel Lluch, X., Picó i Junoy, J., Richard González, M.: "La prueba judicial. Desafíos en las jurisdicciones civil, penal, laboral y contencioso-administrativa”, cit., pág. 1395.
} 
producto, no pudiéndose determinar la causa concreta que lo ocasionó ${ }^{493}$.

Concretamente, la S. TS no 305/2006, de 21 de marzo de 2006 (TOL 871.859) entiende que a la prueba del nexo causal no le alcanza la presunción de existencia sin prueba alguna, por lo que incumbe al actor probar por qué se imputa al demandado la responsabilidad por los daños o cómo y porqué se produjo el accidente, siendo estos elementos indispensables en el examen de la causalidad eficiente del evento dañoso.

Así, su Fundamento de Derecho Tercero expresa: “...para que surja el régimen de responsabilidad objetivo u objetivado a que se refiere el recurrente, es absolutamente necesario acreditar un daño o perjuicio causado al consumidor o destinatario final incluido en el ámbito de aplicación de la Ley, en directa relación de causalidad a la conducta que se imputa al agente, sobre la que construir el régimen de las acciones que prevé la Ley General para la Defensa de los Consumidores y Usuarios de 1984, fundadas con carácter predominante en un sistema objetivado de responsabilidad".

Hemos de considerar además que la prueba de la relación de causalidad se complica en las reclamaciones conjuntas realizadas por un grupo de afectados, donde la prueba deberá ser única para todo el grupo.

Así sucede en el supuesto enjuiciado por la S. no 292/14, Sec. 4ạ AP Baleares de 23 de junio de 2014 (TOL 4.484.029), confirmatoria de la dictada por el Juzgado de Primera Instancia no 1 de Palma de Mallorca que desestimó la demanda de 53 afectadas por prótesis mamarias defectuosas que presentaron contra la clínica que les practicó el aumento de pecho, si bien el juez en su sentencia considera que se trata de un "claro supuesto de producto defectuoso", entendió que no había quedado acreditado que el establecimiento del demandado y la empresa que lo explotaba fuesen los que vendiesen los implantes, no observando tampoco relación de causalidad entre las prótesis y el desarrollo de tumores, practicándose la prueba conjunta sobre el producto y sobre su

\footnotetext{
${ }^{493}$ S. no 943/2007 de 25-09-2007 (TOL 1.644.795), S. de 31-01-00 (TOL 1.780), la S. no 210/2003 TS de 27-02-2003 (TOL 265.208), la n ${ }^{\circ}$ 654/2003 de 26-06-2003 (TOL 305.379), S. no 440/2004 2-06-2004 (TOL 499.264), S. no 463/2005 de 9-06-2005 (TOL 667.458), S. 5-03-2007 (TOL 1.44.147), todas ellas del TS.
} 
comercialización e información, sin que se admitiera la prueba testifical de cada afectada.

O en el supuesto enjuiciado en la S. del Juzgado de Primera Instancia no 90 de Madrid de 19 de noviembre de 2013 (TOL 4.009.866) donde se presentó demanda por la asociación de Víctimas de la Talidomida (AVITE) en nombre de los afectados de un medicamento, denominado "talidomida", un fármaco que se empezó a vender masivamente en 1957 para paliar los efectos de las náuseas de las embarazadas y que causó graves malformaciones en los niños, entendiendo el juzgado que debía concurrir la culpa.

Esta sentencia fue recurrida y resuelta por la de Sec. 14a $\mathrm{aP}$ Madrid de 13 de octubre de 2014 (TOL 4.529.928), en el sentido de entender prescritas las acciones ejercitadas por el actor, revocando en su integridad la resolución adoptada.

La posición mantenida por AVITE, tanto en fase de apelación como en el posterior recurso interpuesto contra la misma ante el TS, se basó en la continuidad de los daños, en su progresión e incerteza, en la producción de minusvalías reconocidas, así como en la posible alteración genética de los afectados que podría ser heredada por sus descendientes.

Ni la AP ni el propio TS en su pronunciamiento mediante la S. no $544 / 2015$, de 20 de octubre de 2015 (TOL 5.511.240), reconocieron el "dies a quo" para el inicio del cómputo de los daños, apreciando prescripción al entender que los efectos se produjeron por la ingestión de la madre y pudieron detectarse en el momento del nacimiento y reclamarse por cada afectado al cumplir la mayoría de edad.

Pese a la posición generalizada tanto de las Audiencias Provinciales como del TS en relación a la necesaria acreditación de la certeza del nexo causal productor del daño, existe unanimidad al entender que no siempre es necesario que se dé una certeza absoluta ${ }^{494}$.

\footnotetext{
${ }^{494}$ Claro ejemplo de ello son la STS 31-01-2000 (TOL 1780), la $\mathrm{n}^{\text {o }}$ 210/2003 de 27-02-2003 (TOL 4.927.712), la $n^{\circ}$ 651/2003 de 26-06-2003 (TOL 305.397), la no 440/2004 de 2-06- 2004 (TOL 449.264), la $\mathrm{n}^{\circ}$ 215/2005 de 9-06-2005 (TOL 673.230) y la de 5-03-2007 (TOL 1.044.147), entre otras, que observan suficiente un juicio de probabilidad cualificada para entender que existe el nexo causal.
} 
En otros casos como el contemplado en la S. Sec. 17a AP de Barcelona de 17 de diciembre de 2001 (TOL 163.431), consideró responsable a la comercializadora solidariamente junto al fabricante de un líquido desatascador cuya etiqueta no advertía de la peligrosidad del mismo, y recogía una deficiente información sobre su correcto uso causando daños por inhalación de la actora que fueron probados mediante pericial del médico forense consistente en el análisis del producto y de las lesiones.

En muchas ocasiones la sentencia es desestimatoria del defecto más por falta de prueba del mismo que por la falta de prueba del nexo causal.

Podemos citar como ejemplo de ello, la Sentencia no 426/2006 del Tribunal Supremo, de 28 de junio de 2006 aludida (TOL 1.027.427), donde se demandaba por defectos constructivos a la promotora de unas viviendas aunque no se consiguió acreditar la concreta causa de los defectos dado que los dos dictámenes periciales que se realizaron no coincidieron en el origen de la patología existente, y la Sentencia no 1290/2002 TS de 27 de diciembre de 2002 (TOL 4.927.466), donde la falta de acreditación del nexo causal impidió que se dictara sentencia condenatoria a la indemnización por los perjuicios reclamados como consecuencia de los daños sufridos por inhalación de monóxido de carbono que se había acumulado en el apartamento que ocupaba debido a la defectuosa instalación del calentador de gas butano.

\section{Prueba de la responsabilidad de productor.}

Debemos realizar una última mención a la responsabilidad del fabricante por los daños sufridos por el consumidor, partiendo como veremos, de la presunción de responsabilidad del productor, a menos que conste o se acredite que se han cumplido las exigencias y requisitos reglamentariamente establecidos, y los demás cuidados y diligencias que exige la naturaleza del producto, servicio o actividad $^{495}$.

La responsabilidad del productor viene establecida en el art. 135 del TRLGDCU ${ }^{496}$ en el sentido de que los fabricantes e importadores

\footnotetext{
${ }^{495}$ Abel Lluch, X., Picó i Junoy, J. (Dir.): “El objeto y carga de la prueba civil”. Ed.: Bosch Procesal, Barcelona 2007, pág. 68. Cap. IX.

${ }^{496}$ De León de Arce, A., en García García, L.M., y Bujosa Badell, L.M. (coord.): "Derechos de los consumidores y usuarios”. Epígrafe 64. Editorial Tirant lo Blanch 2007, cit., pág. 10.
} 
son responsables de los daños causados por los defectos de los productos que fabriquen o importen, debiendo limitarse el perjudicado a probar el defecto, el daño y la relación de causalidad entre ambos.

En base a ello, para que el fabricante quede liberado de su responsabilidad, según establece el art. 140 del TRLGDCU deberá acreditar que su producto no fue el causante del daño reclamado ${ }^{497}$, justificando además los detalles concretos al objeto de valorar la exoneración de la responsabilidad. Pese a ello, el productor responderá de los daños que cause la puesta en circulación de sus productos, aunque no exista conducta que le sea imputable ${ }^{498}$.

También en relación a los servicios prestados defectuosamente se establece regulación en el art. 147 del TRLGDCU, en el sentido que los prestadores de servicios serán responsables de los daños y perjuicios causados a los consumidores y usuarios, salvo que prueben que han cumplido las exigencias reglamentariamente establecidas y los cuidados que exige la naturaleza del servicio ${ }^{499}$.

\section{Prueba de la responsabilidad del perjudicado y su exoneración.}

En los supuestos de responsabilidad objetiva establecidos como ya hemos mencionado 500 , en el TRLGDCU, la única causa de exoneración de responsabilidad del fabricante es la culpa de la víctima y es a este a quien corresponde la prueba de tal culpabilidad ${ }^{501}$, por tanto, la única prueba posible que libere al fabricante de cualquier responsabilidad es el uso indebido del producto por parte del consumidor.

En estos supuestos, la víctima no tiene que probar que el fabricante no ha cumplido las normas relativas a su actividad

\footnotetext{
${ }^{497}$ S. del JPI n ${ }^{\circ} 13$ de Barcelona de 11-06-2007 (TOL 1.380.025).

498 Abel Lluch, X., Picó i Junoy, J., Richard González, M.: "La Prueba Judicial. Desafíos en las jurisdicciones civil, penal, laboral y contencioso-administrativo”. Ed.: La Ley, Madrid 2011, pág. 1371.

${ }^{499}$ S. no 712/2010, Sec. $1^{\text {a }}$ AP Castellón de 23-09-2010 (TOL 1.997.720), S. no 675/2006, Sec. $8^{\text {a }}$ AP Valencia de 25-06-2008 (TOL 1.373.209).

${ }^{500}$ Calvo Mejide, A. A.: "Responsabilidad civil por riesgo y protección de los derechos del consumidor" Editorial: El Derecho Editores / Diario de Jurisprudencia El Derecho, nº 390, pg. 110 de junio de 1996.

${ }^{501}$ Ejemplo de lo cual es la S. TS de 23-07-1993 (TOL 1.655.564).
} 
mercantil o comercial, como tampoco le corresponde probar que ha obrado con corrección en el uso y consumo.

Se exceptúan de este supuesto los medicamentos, los alimentos y otros productos alimenticios destinados al consumo humano ${ }^{502}$, que se regulan específicamente en diversas leyes como, la Ley 29/2006, de 26 de julio, de garantías y uso racional de medicamentos, y por el Real Decreto 1334/1999, de 31 de julio, por el que se aprueba la Norma General de Etiquetado, Presentación y Publicidad de los Productos Alimenticios, (BOE 24.08.1999 modificado por el Real Decreto 238/2000, de 18 de febrero), el Real Decreto 1324/2002, de 13 de diciembre, por el que se modifica la norma general de etiquetado y publicidad de los productos alimenticios, el Real Decreto 2220/2004, de 26 de noviembre, por el que se modifica la norma general de etiquetado, el Real Decreto 892/2005, de 22 de julio, que modifica el Real Decreto 1334/1999, o el Real Decreto 1164/2005, de 30 de septiembre.

Concretamente el art. 140503 contempla las causas de exoneración de responsabilidad del fabricante de forma taxativa ${ }^{504}$, haciendo depender su exoneración de la prueba ${ }^{505}$ de la ausencia de culpa, considerando que este no será responsable si prueba que no puso el producto en circulación o bien que el producto no fue fabricado para la venta, que se elaboró conforme a las normas imperativas vigentes ${ }^{506}$, que el estado de conocimientos científicos existentes en ese momento no permitía apreciar la existencia del

\footnotetext{
${ }^{502}$ S. $n^{\circ}$ 363/2012, TS de 10-07-2014 (TOL 4.478.976) en relación a un medicamente defectuoso por deficiente información, reitera los criterios ya mantenidos por otras sentencias como la S. no 442/2011 de 17-06- 2011(TOL 2.161.152), la n $n^{\circ} 350 / 2012$ de 28-05- 2012 (TOL 2.549.935), la n ${ }^{\circ} 362 / 2012$ de 6-062012 (TOL 2.559.074) y la no 403/2013 de 18-06-2013 (TOL 3.790.821), todas ellas del TS, en relación al medicamento denominado "Agreal" consumido de forma masiva para el alivio de los sofocos y los trastornos asociados con la menopausia, el TS lo ha considerado defectuoso no por sus efectos secundarios sino por la falta de suficiente y clara información de estos efectos secundarios.
503 Álvarez Lata, N., Peña López, F., Busto Lago, J.M (coord.): “Reclamaciones de consumo. Derecho de consumo desde la perspectiva del consumidor”, cit., pág.765.
${ }^{504}$ Abel Lluch, X., Picó i Junoy, J., Richard González, M.: "La Prueba Judicial. Desafíos en las jurisdicciones civil, penal, laboral y contencioso-administrativo”, cit., pág. 1407.

${ }^{505}$ S. no 237/2001, AP Ávila de 26-07-2001 (AC 2001/325448).

${ }^{506}$ S. TJUE 10 mayo 2001, Asunto 203/99 y de 9 de febrero de 2006 TJUE 9 febrero de C-127/2004).
} 
defecto ${ }^{507}$, o bien si prueba que el defecto es imputable al proceso de elaboración del producto y no intervino en este ${ }^{508}$.

Por tanto, no se reconocerá al productor como responsable si demuestra las circunstancias aludidas $u$ otras como que no se distribuyó en el ámbito de su actividad profesional, que el defecto se debe a que el producto se ajusta a las normas imperativas dictadas por los poderes públicos, o bien que en el momento de su puesta en circulación el estado de los conocimientos científicos y técnicos no permitían identificar la existencia del defecto, y por último, que el defecto se causó durante la fabricación de un producto final ${ }^{509}$.

Una vez probado el defecto, el responsable no puede exonerarse de responsabilidad mediante acreditación de que actuó con la diligencia debida, puesto que la imputación de responsabilidad deviene de la fabricación o puesta en circulación de un producto defectuoso o la venta del mismo ${ }^{510}$.

En resumen, para que el productor quede exonerado de su responsabilidad en la causación del daño tiene que existir una ruptura del nexo causal, en los supuestos en que el daño se cause por la propia conducta de la víctima y no por el defecto ${ }^{511}$, ello según lo dispuesto en el art. 145 del TRLGDCU 512.

\footnotetext{
${ }^{507}$ S. AP Cáceres de 18-04-2002 (TOL 174.091) define la responsabilidad cuasi-objetiva a que hace alusión la LPD considerando que es una responsabilidad objetiva no absoluta permitiendo que el fabricante pueda exonerarse de responsabilidad en determinados supuestos establecidos por la propia ley.

508 Abel Lluch, X., Picó i Junoy, J., Richard González, M.: “La Prueba Judicial. Desafíos en las jurisdicciones civil, penal, laboral y contencioso-administrativo”, cit., pág. 1407.

${ }^{509}$ En esa misma línea, la S. $n^{0}$ 35/2012, Sec. $1^{\text {a }}$ de la AP Zamora, de 8-03-2012 (TOL 2.506.446) manifiesta que el comprador no está obligado a probar que el defecto en el producto ya existía en el momento de la entrega, es suficiente que pruebe la aparición del defecto dentro del periodo de garantía, siendo el vendedor, al objeto de exonerarse de responsabilidad, quien deba probar la mala utilización del bien por el comprador y que ha sido el mal uso el causante del defecto.
}

510 S. $n^{\circ}$ 276/2002, Sec. $3^{\text {a }}$, AP Santa Cruz de Tenerife de 19-04-2002 (TOL 212.303) en un asunto de daños de lesiones causados por un corte con un cristal que se encontraba dentro de una botella de cerveza, fabricada y envasada por el demandado, el actor acreditó el daño y la forma de producción de este aunque de la prueba practicada no se observa ninguna de las causas de exoneración de la responsabilidad recogidas en el art. 6 de la LRCPD, considerando que el fabricante responde cuando existe algún grado de culpa en el daño producido.

511 Abel Lluch, X., Picó i Junoy, J., Richard González, M.: “La prueba judicial. Desafíos en las jurisdicciones civil, penal, laboral y contencioso-administrativa”, cit., pág. 1410.

512 Ejemplo de ello son la STS de 21-11-2008 (LA LEY 184737/2008), la S. de la Sec. 2a AP Santander 16-02-2001 (TOL 112.811), la n 284/2015, Sec. $7^{\text {a }}$ AP Asturias de 3-09-2015 (TOL 761.814). 


\section{Prueba de daños causados en el uso de tecnologías.}

Estas cuestiones suponen un mundo nuevo y totalmente distinto al comentado hasta ahora, pero no podemos dejar de hacer alusión a ciertos daños producidos por el uso de las tecnologías, aunque sea brevemente, puesto que se producen daños muy concretos que también afectan a los consumidores.

Mencionar en primer lugar que la normativa europea de aplicación es la Directiva 2000/31/CE del Parlamento y del Consejo, de 8 de junio de 2000, relativa a determinados aspectos jurídicos del comercio Electrónico que, con el fin de aumentar la confianza de los internautas, establece un marco jurídico en que los servicios se ajustan a los principios del mercado interior y se instauran una serie de medidas armonizadoras.

En relación a la responsabilidad de los intermediarios, la Directiva establece que pueden ser responsables de contenidos ilegales y nocivos publicados en su red o en su servidor, aunque exime de responsabilidad a los intermediarios que desempeñan un papel pasivo encargándose del simple transporte de información procedente de terceros.

La concreción de lo dispuesto en la Directiva se realiza a nivel estatal a través de la Ley 34/2002, de 11 de julio, de Servicios de la Sociedad de Información (en adelante LSSI), concretamente su art. 13.1 considera responsables a los proveedores del servicio de los daños que se causen a terceros siempre que estos se encuentren comprendidos dentro del sistema general de imputación de responsabilidad que se aplica a las tecnologías de internet, exigiéndose además, tal como establece el art. 13.2 del mismo texto legal, la retirada de los contenidos.

Los arts. 14 a 17 de la misma regulan los supuestos imputables a estos proveedores, donde intervenga una especial y directa relación con los mismos, participando en su comisión o bien, teniendo la diligencia debida en la retirada de contenidos lesivos.

En el caso concreto de que presentemos demanda contra el prestador de servicios de internet, corresponde al propio prestador 
del servicio acreditar su falta de responsabilidad mediante la prueba de conductas negativas ${ }^{513}$.

Concretamente el TJUE en Sentencias como la de 16 de febrero de 2012, C-360-10, (TOL 2.517.026) consolida criterios sobre el alcance de la responsabilidad de los proveedores de servicios de la sociedad de información en respuesta a las cuestiones prejudiciales relativas a responsabilidad y deber de colaboración de un prestador de servicios de alojamiento de datos y un proveedor de acceso a internet, entendiendo que un juez nacional no puede ordenar a esos intermediarios que establezcan un sistema filtrado de la información que se aplique, con carácter preventivo, indistintamente con respecto a toda su clientela.

Por ello el tribunal se cuestiona la forma de protección sobre los contenidos, aunque parece haber sido resuelto por otras sentencias, como la recaída en el caso Scarlet Extended-Sabam, de 24 de noviembre de 2011 Asunto C-70/10 (TOL 2.436.388), en que Sabam solicitaba la condena a la Compañía Scarlet Extended, cuyos servicios se limitaban a ofrecer a sus clientes acceso a internet, impidiendo cualquier envío y recepción de archivos de obras musicales sin autorización de sus titulares, fuera condenada por infringir sus derechos de autor sobre obras musicales pertenecientes a su repertorio.

En este caso se practicó prueba pericial consistente en determinar si existen esos posibles filtros para llevar a cabo intercambios ilícitos de archivos electrónicos y si existen dispositivos que permitan controlar el uso de esos programas, en aras a averiguar si realmente el prestador del servicio era o no responsable y a su vez determinar a quién corresponde la utilización de los medios aludidos.

\section{Las presunciones.}

Las presunciones han sido utilizadas tanto para probar el defecto como la relación de causalidad; sobre el primero se ha recurrido a su aplicación en temas indemnizatorios de daños causados por incendios o explosiones y en supuestos en que el accidente era de tal magnitud que no existía ninguna posibilidad de prueba ${ }^{514}$, como ocurre en la

\footnotetext{
513 Cotino Hueso, L. (coord.): “Consumidores y usuarios ante las nuevas tecnologías”. Ed.: Tirant lo Blanch, Valencia 2008, pág. 611.

514 Álvarez Lata, N., Peña López, F., Busto Lago, J.M (coord.): “Reclamaciones de consumo. Derecho de consumo desde la perspectiva del consumidor”, cit., pág. 1444.
} 
S.no 19/2013, Sec. 1a AP Palencia de 24 de enero de 2013 (TOL 3.055.940), cuya presunción sobre el origen del daño se alcanzó tras el análisis de la prueba pericial practicada, que por la observancia de los hechos, entendió cuál podía ser su origen, pese a ser imposible su comprobación por haber ocurrido un incendio.

Su aplicación en relación al nexo causal puede producirse 515 siempre que provenga de hechos demostrables de haber causado daño en el uso del producto.

Podemos concretar siete tipos presunciones relacionadas todas ellas con la falta de conformidad del producto:

i. Una primera presunción, relativa al uso correcto del producto efectuada por el consumidor.

ii. Una segunda presunción en relación a la conformidad del producto en origen.

iii. Una tercera, que opera una vez acreditado el defecto, y se basa en el origen del mismo, entendiendo que es de fabricación si se observa dentro de los primeros seis meses contados desde la fecha de la compra, aunque en casos específicos, como veremos, su inicio se contará desde que empiece realmente a ser utilizado el producto.

iv. Una cuarta presunción en aquellos supuestos en que se presume la culpa del fabricante y en consecuencia la existencia de un defecto de fabricación sin que precise prueba del concreto defecto ni de la relación de causalidad. Nos referimos a aquellos supuestos en que se produce una lesión al consumidor.

v. Existe una quinta presunción que considera suficiente la existencia de juicio de probabilidad cualificada para entender que existe el nexo causal entre el defecto observado y el daño producido. En estos casos debe ser el fabricante quien acredite lo contrario para verse exonerado de responsabilidad.

vi. A los supuestos anteriores hemos de añadir además una sexta presunción sobre la falta de conformidad prevista en el

${ }^{515}$ León de Arce, A., García García L.M., artículo de Palacios González, D., (coord.): “Derechos de los consumidores y usuarios”, cit., pág. 1358. 
art.123.1 TRLGDCU, consistente en la observancia del momento en que se ha producido la falta de conformidad, puesto que si llega a manifestarse dentro de los seis meses del periodo de garantía, sea este incluso de segunda mano, entiende que es procedente la resolución del contrato por encontrarnos ante un caso de incumplimiento contractual por adolecer el producto de la calidad exigible ${ }^{516}$.

vii. Por último, además de las presunciones dichas, se admiten en determinados casos otras presunciones en relación a la existencia del defecto sin que exista prueba, sobre todo en supuestos de falta de seguridad evidente del producto, o debido a que no es posible proceder a su comprobación por haberse destruido, que llega a producir en muchos supuestos lesiones físicas en el consumidor.

Para que esta presunción entre en juego, deberán ser probados todos los extremos referidos, tanto el defecto como su aparición dentro del referido periodo, aunque todas las cuestiones relativas a la referida presunción no serán tratadas en este punto, sino que hablaremos más ampliamente de ella en el capítulo siguiente al tratar las faltas de conformidad del producto.

Vamos a adentrarnos ahora en los requisitos que deben probarse para desvirtuar cada una de las presunciones aludidas.

i. La primera de las presunciones manifestadas, la de la actuación correcta del consumidor en el uso del producto, es aplicada por la jurisprudencia de forma unánime, incluso es estricta al valorar la prueba aportada por el demandado sobre la culpa del consumidor para desvirtuar la presunción.

Ejemplo de ello lo encontramos en el supuesto enjuiciado por la S. 460/2012, Sec. 4a AP Santander de 17-10-2012 (TOL 2.703.026), donde se reclamaba una indemnización por los perjuicios causados por la reparación de un vehículo, y pese a que se había practicado un dictamen pericial en relación a una segunda reparación, el juzgador no la consideró como prueba segura y respetuosa al no haber sido practicada en presencia del consumidor.

${ }^{516}$ S. no 53/2014, Sec. $8^{\text {a }}$ AP Alicante de 6-03-2014 (TOL 4.231.509). 
Lo que se pretendía probar era que una abrazadera había sido manipulada después de haberle entregado el vehículo, motivo que según las demandadas causó la avería, pero el juzgador entendió que el dictamen se había realizado sin dar aviso al consumidor y por tanto este informe no podía desvirtuar un hecho tan relevante como la culpa exclusiva del consumidor, lo que le llevó a la estimación íntegra de la demanda ${ }^{517}$.

El consumidor, como ya hemos adelantado, lo que deberá probar es que la disconformidad que presenta el producto no es consecuencia de su uso, así como que no hay indicios de que haya usado el bien de forma irregular, contraria a las instrucciones, ni se ha producido ningún impacto o agresión externa posterior a la entrega ${ }^{518}$. En estos supuestos la garantía quedará excluida, y también cuando el consumidor conociera la falta de conformidad en el momento de celebrar el contrato o si fuera debida a los materiales que él mismo suministró 519 .

ii. La segunda presunción, basada en conformidad del producto con el contrato 520 , deberá desvirtuarse por el actor acreditando los siguientes extremos según establece el TRLGDCU:

- Defectos materiales, como los que son tratados en la S. no 364/2014, Sec. 5a AP Málaga de 28 de julio de 2014 (TOL 4.710.431), en que el vehículo vendido presentaba una falta de conformidad de la que debe responder la empresa vendedora dada la existencia de defectos que se acreditan mediante dictamen pericial, que se manifestaron dentro del plazo legal y que hacen presumible que el defecto ya existía en el momento de la entrega del vehículo.

- Defectos funcionales, como los observados en la S. no 19/2016, Sec. 5 AP Palma de Mallorca de 1 de febrero de

\footnotetext{
${ }^{517}$ S. no 506/1996 del TS, de 21-06-1996 (TOL 1.659.434) y S. no 103/2006, Sec. $4^{\text {a }}$ de la AP de Tenerife, de 15-03-2006 (TOL 950.533), entre otras.

${ }^{518}$ Avilés García, J.: "Los contratos de compraventa de bienes de consumo. Problemas, propuestas y perspectivas de la venta y garantías en la Directiva 1999/447/CE y la Ley 23/2003”, cit., pág. 323.

${ }^{519}$ Vattier Fuenzalida, C.: "Sobre la garantía legal en las ventas de consumo". Ed.: La Ley, Actualidad Civil no 5, Sección A. Fondo del 1 al 15 de marzo de 2008, pág. 449, Tomo 1. S. no 431/2013, Sec. $17^{\mathrm{a}}$ AP Barcelona de 26-09-2013 (TOL 4.049.497).

${ }^{520}$ S. $n^{\circ}$ 431/2013, Sec. 17ª AP Barcelona de 26-09-2013 (TOL 4.049.497).
} 
2016 (TOL 5.649.637), donde se enjuician los defectos encontrados en las viviendas de un edificio que comportan vicios ocultos recogidos en los informes periciales y que suponen una clara ruina funcional y por tanto, una imposibilidad de destino del bien al fin del contrato.

- Defectos de instalación, como en el caso de una instalación de gas con defectos en su acabado, que comportaron incluso que tuviera que ser sustituida, y que se enjuician en la S. no 255/2010, Sec. 8a AP Madrid de 31 de mayo de 2010 (TOL 1.925.926), cuyas deficiencias que se desprenden de los informes técnicos aportados.

- Ajuste a la publicidad, como el supuesto resuelto en la S. no 315/2006, Sec. 9a AP Valencia de 14 de septiembre de 2006 (TOL 1.033.829), en la promoción de una serie de viviendas que ejercitaron la acción de publicidad engañosa, al ocultar la superficie de la vivienda, acreditada dentro del proceso mediante informe pericial al contratar la inexistencia de identidad entre los planos a escala facilitados y los folletos informativos.

iii. La tercera presunción se encuentra en relación al defecto y al origen del mismo.

Así lo entendieron además otras sentencias como la no 725/2010 del TS de 22 de abril de 2009 (TOL 2.002.214) en la que se consideró existente el defecto tras haberse acreditado el daño (la producción de un incendio) mediante la práctica de la prueba pericial, presumiendo como causa del mismo un defecto de fabricación existente en la bombona de gas, considerando que fue una fuga de gas la causante de la explosión y el incendio.

En estos casos, se presume la existencia del defecto sin necesidad de que el actor desarrolle prueba alguna en relación al mismo, como tampoco se precisará prueba del nexo causal ni de la culpabilidad del fabricante ${ }^{521}$ en relación a los productos que causan

\footnotetext{
${ }^{521}$ Son supuestos de diverso tipo, como los enjuiciados en la S. no 623/1993 de 23-6-1993 (TOL 6.610), la de 8-2-1995 (TOL 1.658.301), o la S. 4-10-1996 (TOL 1.659.077), todas ellas del TS en las que se resuelven unos daños causados a un consumidor por la explosión de una botella, de gaseosa, de cerveza o de alguna otra bebida en el momento de cogerla, o también los hay sobre juguetes como el supuesto enjuiciado en la S. $n^{\circ}$ 286, Sec. $3^{\mathrm{a}}$ AP Mallorca de 18 de septiembre de 2008 (TOL 1.443.815).
} 
una lesión evidente al consumidor, entendida por tal aquella que se aprecia a simple vista, como una herida, una rotura de un miembro, etc.... siendo lo único necesitado de prueba en estos casos la lesión sufrida.

Nos referimos a supuestos como el enjuiciado por la S. del TS de 4 de octubre de 1996 (TOL 1.659.077): “Ni a la víctima le corresponde la prueba de que el fabricante ha cumplido con las precauciones y medidas apropiadas en su proceso productivo, ni este puede liberarse de su responsabilidad probándolo, ni por último, a la víctima le corresponde probar que ha obrado con toda corrección en el uso, sino al fabricante la prueba de que fue incorrecto, para liberarse de su obligación de responder".

iv. Una cuarta presunción sobre la responsabilidad o culpa del fabricante, que debe desvirtuar el demandado con su actividad probatoria, consistente en acreditar o bien que ha existido fuerza mayor o caso fortuito, o bien culpa del actor, tal como disponen los arts. 128 a 131 del TRLGDCU; tanto una como otra deberán desvirtuarse en el periodo probatorio por cada una de las partes ${ }^{522}$.

En la práctica observamos que los tribunales no exigen al demandante ni la prueba del defecto del producto ni la de la culpa del demandado, presumen que existe un defecto y atribuyen la responsabilidad al fabricante, que sólo podrá exonerarse de su responsabilidad si acredita el mal uso del producto por quien ha sufrido el daño ${ }^{523}$.

Las audiencias provinciales se pronuncian en idénticos términos, reflejo de lo cual son las S. n $151 / 2013$, Sec. $1^{\text {a }}$ de AP Burgos de 20-05-2013 (TOL 3.778.199), la S. $n^{0}$ 551/2004, Sec. 9a AP Valencia de 17-092004 (TOL 1.620.738), la S. no 327/2010 de la misma AP Valencia, Sec. 11 a de 29-06-2010 (TOL 1.958.813), entre otras.

522 S. Sec. $3^{\text {a }}$ AP Tenerife de 19-04-2002 (TOL 212.303) considera que del elemento probatorio no es posible determinar la concurrencia de ninguna causa de exoneración prevista en el art. 6 de la LRCPD, concretamente la establecida en el $n^{\circ} 1$ b) que recoge la presunción de que el defecto no existía en el momento en que se puso en circulación el producto.

La culpa del actor puede llevar a exonerar la responsabilidad del productor, siempre que no haya existido defecto en el producto, exigiendo que sea el fabricante demandado quien pruebe la culpa, S. $\mathrm{n}^{\circ} 71 / 2003$, Sec. $13^{\mathrm{a}}$ AP Madrid de 23-10-2003 (TOL 497.244).

S. $n^{\circ}$ 431/2011, Sec. 16 ${ }^{\text {a }}$, de 8-07-2011 (TOL 2.232.003) de la AP Barcelona afirma que no se puede presumir que el producto era defectuoso, cuando estaba ahí para ser examinado y cuando el único técnico que lo examinó informó que el material no presentaba ninguna evidencia de ser defectuoso.

${ }^{523}$ S. n ${ }^{\circ}$ 907/2006, TS 19-09-2006 (TOL 3.423.475). 
v. Por lo que respecta a la quinta presunción, a los supuestos en los cuales la prueba del defecto no es necesaria que se realice por el actor, bien por su evidencia o bien porque el defecto se presume, estas presunciones serán admitidas atendiendo a las circunstancias del caso, cuando del concreto hecho enjuiciado se desprende que el defecto existía desde que se puso en circulación, siendo evidente que el defecto es de fabricación y por tanto, existía cuando se puso en circulación el producto ${ }^{524}$.

Concretamente la S. no $1266 / 2007$ del TS de 23 de noviembre de 2007 (TOL 1.213.848) declara que la convicción y demostración de que un producto es defectuoso se puede alcanzar en ausencia de pruebas directas, a través de la prueba de presunciones debido a que en ocasiones el producto ha desaparecido, como en los casos en que el defecto es tan grave que se puede presumir que existió falta de seguridad ${ }^{525}$.

En relación a este tipo de supuestos, existen sentencias del TS como la de 25 de marzo de 1991 (TOL 1.728.182) y la no 1266/2007 del TS de 23 de noviembre de 2007 (TOL 1.213.848), donde se presume defectuoso un cohete debido a la causación de un daño, al desaparecer tras su explosión.

En la misma línea que las anteriores, la S. no 132/2015, Sec. 1aㅡ de la AP Pontevedra de 13 de abril de 2015 (TOL 4.899.489), en que la empresa demandada, prestadora del servicio de instalación de un cuadro eléctrico de automáticos que ocasionó un incendio en una vivienda provocando el fallecimiento de la esposa, también se dedujo por el juzgador la prueba del nexo causal del análisis de la pericial obrante en autos.

\footnotetext{
524 “Memento Práctico Francis Lefebvre, Consumo 2010-2011", cit., pág. 163; S. no 58/2006 Sec. 1a, AP Barcelona de 3-02-2006 (TOL 990.991) presume vigente el periodo de garantía del producto, en este caso se trataba de un reloj; S. $\mathrm{n}^{\circ}$ 931/2006 TS de 28-09-2006 (TOL 1.014.554), argumenta el art. 5 de la LRCPD imponiendo al demandante la carga de probar, acudiendo además a las presunciones para justificar el carácter defectuoso del artificio pirotécnico cuya explosión ocasionó daños.

S. n 298/2006 TS 21-03-2006 (TOL 866.066) argumenta que a la prueba del nexo causal no le alcanza la presunción ínsita en la doctrina de la carga de la prueba, por lo que incumbe al actor probar por qué se imputa al demandado la responsabilidad por los daños o cómo y porqué se produjo el accidente constituyen elementos indispensables en el examen de la causalidad eficiente del evento dañoso.

${ }^{525}$ León de Arce, A., García García, L.M., artículo de Palacios González, D., (coord.): “Derechos de los consumidores y usuarios”, cit., págs. 1446 a 1450; Abel Lluch, X., Picó i Junoy, J., Richard González, M.: "La Prueba Judicial. Desafíos en las jurisdicciones civil, penal, laboral y contenciosoadministrativo.” cit., pág. 1390; Álvarez Lata, N., Peña López, F., Busto Lago, J.M (coord.): "Reclamaciones de consumo. Derecho de consumo desde la perspectiva del consumidor”, cit., pág. 1445.
} 
Encontramos ejemplos de presunción entre el defecto y el daño en sentencias como las ya citadas al tratar la certeza del nexo causal en el apartado relativo a la prueba en la relación de causalidad, sentencias del TS como la no 651/2003, de 26 de junio de 2003 (TOL 305.397), la no 215/2005 de 9 de junio de 2005 (TOL 673.230) o la de 5 de marzo de 2007 (TOL 1.044.147), entre otras, que observan suficiente la probabilidad de que el daño haya sido causado por el defecto observado en el producto.

vi. En relación a la sexta presunción aludida sobre la falta de conformidad, será objeto de análisis en el capítulo siguiente.

vii. Por lo que respecta a la séptima de las presunciones sobre la falta de seguridad del producto, la concreta prueba coincide con la manifestada respecto a la presunción del defecto y del daño aludidos en quinto lugar.

A nuestro juicio la postura de los tribunales de aplicar la presunción del defecto es la única opción posible, debido a que ni se puede someter el producto a examen para valorar a qué fue debido el estallido, ni tampoco se puede cuestionar en modo alguno la existencia de culpa del perjudicado, de forma que, mientras no sea acreditado por el fabricante que fue culpa de la víctima, o que medió un tercero en el proceso de comercialización que pudo producir el defecto, la única posibilidad es presumir la responsabilidad del fabricante.

Las presunciones expresadas operan salvo prueba en contrario de la parte a quien no favorezca; en el caso de la primera, deberá ser el demandado quien la desvirtúe; en la relativa a la conformidad del producto expuesta en segundo lugar, deberá ser el actor quien la pruebe; y la tercera sobre el defecto y su origen, que opera también a favor del consumidor, será también el demandado quien deba desvirtuarla.

Aunque exista una especialidad probatoria en cuanto a la carga de la prueba, esta se regirá por las reglas del art. 217 de la LEC y por los arts. 281 y ss en relación a su práctica, a los medios de prueba y a su valoración ${ }^{526}$.

\footnotetext{
${ }^{526}$ Mendoza Losana, A.I.: “Cómo probar que los desperfectos de los bienes no están cubiertos por la garantía en la venta de bienes muebles”, cit., págs. 35 a 49.
} 
Por el contrario, cuando se trata de supuestos cuya responsabilidad puede haberse producido por una variedad de factores, resoluciones como la S. no 486/2001, Sec. 4a AP de Las Palmas de 6 de junio de 2001 (TOL 124.944), donde se trató de determinar la responsabilidad del fabricante por el reventón del neumático de un camión, han entendido que la prueba de la imputación de responsabilidad no puede alcanzar a la prueba del nexo causal, cuya concreción es necesaria, no pudiendo aplicar las presunciones a la conducta del agente. Considera además que al conocimiento de la producción del daño no se puede llegar mediante la aplicación de las presunciones ${ }^{527}$.

\section{Reclamación de daños y perjuicios y su cuantificación.}

La reclamación de daños por parte del consumidor surge cuando este sufre daños dentro de una transacción de consumo, bien por defecto producido, una entrega fuera de plazo, o cualquier otro incumplimiento contractual o legal que le ocasione un perjuicio.

En el caso de la prestación de un servicio al consumidor, este dispone del derecho a la reparación del bien establecido en el art. 118 del TRLGDCU. El derecho referido no supone la posible reparación y posterior reclamación, puesto que la avería o el defecto de funcionamiento debe comunicarse previamente al vendedor y es en ese momento cuando nace la obligación de reparar el bien.

El art. 120 d) del TRLGDCU expresa que si una vez concluida la reparación y entregado el producto, este sigue siendo no conforme con el contrato, el consumidor podrá exigir la sustitución del producto, salvo que esta opción resulte desproporcionada, en cuyo caso podrá optar por la rebaja del precio o la resolución del contrato, salvo que se trate de productos no fungibles o de segunda mano, en los que no se podrá exigir la sustitución.

La prueba necesaria para obtener el resarcimiento del daño se basa en la acreditación de la relación de causalidad entre el daño y el incumplimiento que debe probar el consumidor ${ }^{528}$, aunque la

\footnotetext{
${ }^{527}$ En la misma línea que la anterior, también en un supuesto de rotura de neumáticos podemos referirnos a la S. ${ }^{\circ}$ 251/2003, Sec. $1^{\text {a }}$ AP Pontevedra de 30-06-2003 (TOL 350.499). S. $n^{\circ} 355 / 2013$, Sec. $3^{\text {a }}$ AP Guipúzcoa de 28-11-2013 (TOL 4.359.512), S. n 259/2012, Sec. 2 ${ }^{\text {a }}$ AP Albacete de 10-12-2012 (TOL 2.716.422).

528 Álvarez Lata, N., Peña López, F., Busto Lago, J.M (coord.): “Reclamaciones de consumo. Derecho de consumo desde la perspectiva del consumidor”, cit., pág. 1275.
} 
jurisprudencia ha suavizado esta exigencia en supuestos de dificultad probatoria, invirtiendo la carga de la prueba y haciendo que sea el vendedor quien pruebe su no culpabilidad o la interrupción del nexo causal por culpa exclusiva del comprador, debiendo probar además las circunstancias que le exoneran de responsabilidad, como la culpa de la víctima, el caso fortuito o la fuerza mayor ${ }^{529}$, ello en base a los arts. 1214,1183 y 1105 del C.C.

Para poder ver reconocido el derecho a la indemnización deberá acreditarse la relación entre la efectiva reclamación y los daños producidos limitándose la indemnización a los daños causados por el propio producto ${ }^{530}$. Así lo entiende la S. no 1071/2008 del TS de 7 de noviembre de 2008 (TOL 1.401.723), sobre reclamación de cantidad en concepto de indemnización de daños como consecuencia de la puesta en circulación de un producto defectuoso que condenó a una cantidad inferior a la solicitada, puesto que la entidad demandada sólo fue responsable parcialmente de las lesiones sufridas.

En este sentido, merece especial mención la S. no 739/2003 del TS, de 10 de julio de 2003 (TOL 295.857) por hacer a su vez alusión a reiterada jurisprudencia de esa misma Sala, según la cual no basta el incumplimiento de la obligación para reclamar la indemnización de daños y perjuicios; los daños han de ser probados y derivados del incumplimiento ocasionado, correspondiendo dicha prueba al actor.

Resulta por tanto imprescindible para obtener una sentencia condenatoria a indemnizar por la existencia de un defecto en el producto, la prueba del referido defecto generado durante el proceso de fabricación.

Dentro del ámbito del seguro obligatorio por daños en vehículos causados por accidentes de circulación, el criterio jurisprudencial, cuyo ejemplo lo encontramos en sentencias como la S. no 278/2009, de 8 de mayo 2009 (TOL 1.567.099), la S. no 618/2009, de 9 de diciembre de 2009 (TOL 1.770.598) o la no 327/2011, de 1 de julio de 2011 (TOL 2.198.311) todas ellas de la Sec. 7ạ de la AP Asturias, es que se produzca la inversión de la carga de la prueba y que esta recaiga en el causante del daño, no en el perjudicado, debiendo

\footnotetext{
${ }^{529}$ Álvarez Lata, N., Peña López, F., Busto Lago, J.M (coord.): "Reclamaciones de consumo. Derecho de consumo desde la perspectiva del consumidor”, cit., pág. 1277.

${ }^{530}$ S. no 476/2005, Sec. $4^{\text {a }}$ AP Zaragoza de 14-09-2005 (TOL 765.495).
} 
acreditar su falta de culpa, porque hubo negligencia por acción u omisión, y que esta se debió únicamente a la actuación del perjudicado, motivo por el cual queda interrumpida la relación de causalidad.

Entre los conceptos incluidos en la indemnización se encuentra además el lucro cesante, cuya determinación y límites resultan complejos puesto que se exige que exista concreción y total relación con el daño, siendo la postura adoptada por la jurisprudencia prudente y restrictiva en cuanto a su estimación, debiendo probarse de forma clara, real, precisa y concreta las ganancias dejadas de obtener. Es significativa en este sentido la S. no 219/2010 de la AP de Ciudad Real de 28 de septiembre de 2010 (TOL 1.992.751).

Además el lucro cesante precisa la concreción de la relación de causalidad entre el evento y las consecuencias económicas derivadas del mismo y que los conceptos indemnizables sean valorados por un experto en base a estimaciones técnicas, lo cual se obtendrá mediante la prueba pericial.

Cuando se trate de indemnizar lesiones personales ${ }^{531}$, existen dos sectores jurisprudenciales en relación a la cuantificación de la indemnización: la línea mayoritaria entiende de aplicación para el cálculo de los daños el baremo establecido en la Ley de Ordenación del Seguro532; y la postura minoritaria, se aparta de la aplicación del baremo, muestra de la cual es la S. TS no 280/1997, de 26 de marzo de 1997 (TOL 215.800), o la S. AP de Cáceres de 18 de abril de 2002 (TOL 174.091), que consideran que la cuantía de la indemnización es función de la propia jurisprudencia, sin que se halle sujeta a ninguna previsión normativa ${ }^{533}$.

\footnotetext{
${ }^{531}$ Auto TS de 25-2-2015 (TOL 4.753.926).

${ }^{532}$ Ejemplo de ello son muchísimas sentencias como la S. de la Sec. $4^{\text {a }}$ de la AP de Asturias de 21 de marzo de 2001 (TOL49.554), la S. no 118/2008 y también la n ${ }^{\circ} 636 / 2011$, ambas de la Sec. $7^{\text {a }}$ de la AP de Valencia, de 29-02-2008 (TOL 1.304.633) y de 28-11- 2011 (TOL2.411.220), respectivamente.

${ }^{533}$ No podemos dejar de hacer mención en supuestos de lesiones personales, al caso más importante que ha acontecido sobre lesiones a los 30.000 afectados del Aceite de Colza, cuya S., la nº 895/1997 de 26-091997 (TOL 5.136.824), asunto calificado por el propio TS como de "catástrofe nacional", donde la indemnización establecida para las víctimas no se basó en los criterios del baremo, como tampoco lo hizo la S. n ${ }^{\circ}$ 649/2014 TS de 13-01-2015 (TOL 4.706.623) mantiene las indemnizaciones establecidas por la S. de la AP Barcelona que se recurre, de entre 1,5 y 5,5 millones de dólares por cada familia de los fallecidos (en su mayoría jóvenes y niños) a las dos empresas norteamericanas fabricantes de los sistemas anticolisión de que iban dotados los dos aviones que chocaron provocando un accidente aéreo ocurrido cerca del lago Constanza en Alemania el 1 de julio de 2002.
} 
En ambos casos, el art. 141 b) del TRLGDCU establece un límite a la indemnización causada por productos defectuosos para lesiones personales o muerte de 63.106.270.96 €.

\section{La concreción del daño moral.}

La prueba que debe practicarse para obtener el resarcimiento del daño moral se encuentra en relación con los daños y el incumplimiento producido.

Son escasos los ejemplos de resoluciones favorables al daño moral en temas de consumo, aunque la S. no 105/2014 de la Sec. 1aㅡ AP Barcelona de 11 de marzo de 2014 (TOL 4.184.888), que enjuició una reclamación de daño moral por producto defectuoso contra CARREFOUR, estimó, pese a considerar no incluido el daño moral en la normativa de productos defectuosos, que este daño debía ser indemnizado.

El juzgador adopta tal decisión basándose sobre todo en la importancia de lo ocurrido, puesto que se trataba de la compra de un producto alimenticio.

Entiende que el daño moral en este supuesto debe ser reparado puesto que la presencia de un tornillo oxidado en el interior de la pizza que adquirió el actor le colocó en una situación de riesgo para su salud.

Para adoptar su decisión indemnizatoria se apoya en el marco contractual del art. 1101 C.c., que establece el deber genérico de reparar el daño causado.

Otros supuestos en que se acuerda indemnizar el daño moral en temas de consumo ha sido en casos de víctima fallecida, como en el supuesto de la S. no 132/2015 AP Pontevedra de 13 de abril de 2015 (TOL 4.899.489), donde la deficiente instalación de un cuadro eléctrico por una empresa dedicada a tal clase de actividad causó un incendio y el fallecimiento una persona, o el enjuiciado por la S. no 139/2001 del TS de 22 de febrero de 2001 (TOL 99.620), sobre las lesiones sufridas por un turista al caer de un quinto piso de un hotel quedando parapléjico debido al mal estado de conservación de la barandilla y que llevó a la indemnización de 30 millones de euros en concepto de daño moral. 
En todos los supuestos relacionados, a excepción de los daños por electrocución en los que sólo es necesario probar el daño, por la evidencia del nexo causal, en el resto, debe probarse tanto el daño como el nexo causal.

\section{Prueba en supuestos concretos de daños por productos defectuosos.}

Después de haber analizado cuestiones sobre productos en relación a la carga de la prueba en el capítulo anterior, y en este mismo capítulo las cuestiones que deben ser objeto de prueba, vamos a analizar en este apartado de forma breve algún supuesto específico donde se observa buena parte de las cuestiones tratadas en los puntos anteriores.

En este tipo de procesos especialmente debemos estar al caso concreto para determinar lo que sea objeto de prueba y a cuál de las partes corresponderá su práctica.

Partiendo del estudio de los productos defectuosos y de la prueba del defecto, esta dependerá sobre todo de cuestiones ya tratadas como si el producto existe o se ha destruido y del concreto defecto o daño denunciado, pero también de otros factores como la intervención del propio actor en la producción del daño o en la manipulación del producto.

Dependiendo de a cuál de las partes corresponda probar el defecto podemos hacer una división en cuatro apartados:

Salvo los casos que se pueden considerar excepciones a que hemos aludido al analizar las presunciones, la prueba del defecto es necesaria que se lleve a cabo.

1. Entre los referidos en primer lugar y que conforman un primer apartado, se encuentran dos tipos de productos:

i. Los que no precisan prueba por el actor, por presumirse el defecto, ya analizados en el apartado relativo a las presunciones.

ii. Aquellos en que no ha podido mediar manipulación del consumidor, por estar envasados y etiquetados por el 
fabricante, siendo este último quien deberá acreditar lo contrario para quedar exonerado de responsabilidad ${ }^{534}$.

En estos casos debe acreditar el daño el propio demandante; son supuestos en que pese a causar lesión, esta puede haberse producido por efecto de otro producto, es el caso de reacciones físicas a determinados productos, donde para resultar condenado a indemnizar el demandado, el actor deberá acreditar la relación de causalidad entre el daño producido y la ingesta u utilización de determinado producto ${ }^{535}$ mediante un informe pericial.

2. Un segundo apartado, compuesto por los casos de desaparición del producto, donde el defecto se presume sin necesidad de acreditarlo, tan sólo cabe la opción de que el fabricante acredite culpa de la víctima como causa de exoneración de la responsabilidad ${ }^{536}$.

En estos supuestos el actor no necesita probar el defecto pero sí la culpa del fabricante en la producción del daño, debiendo justificar cómo se ha originado el daño y por qué motivo, además de los elementos necesarios para que vea prosperar su demanda. Por su parte el fabricante deberá probar el uso incorrecto por parte del consumidor si quiere verse exonerado de su responsabilidad ${ }^{537}$.

3. Un tercer apartado donde se podrían ubicar los daños causados por productos en los que existe un uso por el consumidor, bien se trate de maquinaria, electrodomésticos, vehículos, productos cosméticos, utensilios de uso personal o profesional, etc., donde

\footnotetext{
${ }^{534}$ Ejemplo de ello es la S. TS de 8-2-1995 (TOL 1.658.301), la S. $n^{\circ}$ 200/1999, Sec. $1^{\circ}$ AP Asturias de 24-03-1999 (AC 1999/428), o la S. nº 337/2002, Sec. Única, AP La Rioja de 31-07-2002 (TOL 225.189).

${ }^{535}$ Son supuestos como el contemplado en la S. $n^{\circ}$ 44/2008, Sec. $6^{\text {a }}$ AP de la Coruña de 13-02-2008 (TOL 1.376.370) por daños en cabello producidos por un tinte de una peluquería, S. Sec. $16^{\circ}$ AP Barcelona de 13-01-2003 (TOL 278.432) en intoxicación alimentaria, la $n^{0} 147 / 2010$, Sec. $3^{\text {a }}$ AP Santa Cruz de Tenerife de 26-03-2010 (TOL 2.012.749) en intoxicación por pescado en mal estado, o la S. TS de 13-021991 (RJ1991/1200) en que se produjo la muerte de ganado por ingerir pienso en mal estado.
}

Otro grupo numeroso de sentencias sobre daños por defecto del producto son las relativas a defectos de airbag de vehículo donde al igual que en los supuestos referidos, se precisa prueba del defecto por el actor para poder repercutir la responsabilidad al fabricante, S. $n^{\circ}$ 144/2014, Sec. 11 ${ }^{\text {a }}$ AP Barcelona 27-03-2014 (TOL 4.206.143), S. no 390/2005, Sec. $2^{\text {a }}$ AP Badajoz de 27-10-2005 (TOL 777.821).

${ }^{536}$ Son supuestos como los de explosiones de gas visto en la S. no 117/1997 de la AP de Córdoba de 1405-1997 (AC 1997/1045), el de la S. no 99/2007(TOL 1.895.219) y S. no 98/2007, ambas de la Sec. $3^{\text {a }}$ AP Burgos de 28-02-2007 (JUR 2007/138085), o la S. Sec. 14ª AP Madrid de 28-02-2001 (TOL 49.807).

${ }^{537}$ S. no 117/1997 de la AP Córdoba de 14-05-1997 (AC 1997/1045), S. TS 306-2000 (TOL 6.610), S. Sec. 14 ${ }^{\mathrm{a}}$ AP Madrid de 28-02-2001 (TOL 49.807), S. Sec. $3^{\mathrm{a}}$ AP Burgos de 28-02-2007 (TOL 1.895.219) 
puede haber mediado culpa del usuario, por tanto, deberá determinarse en primer lugar la existencia del defecto, en segundo lugar, la intervención del usuario en la producción del daño, y por último, la causa concreta que provocó el daño ${ }^{538}$.

En este tipo de daños, en los que también podemos incluir los debidos a reparaciones por averías ${ }^{539}$, la jurisprudencia ha ido evolucionando en el mismo sentido comentado en el punto anterior estando a las circunstancias del caso concreto y a la diligencia requerida según las circunstancias de cada uno, extremando la prudencia para evitar el daño sin erigir riesgo y sin excluir el principio de la responsabilidad culposa, correspondiendo al demandante probar la existencia de defectos del bien adquirido ${ }^{540}$.

En estos supuestos 541 , cuyas demandas pueden también presentarse a través de la acción de responsabilidad extracontractual, lo verdaderamente importante para el demandado será la determinación de si medió culpa del usuario, hecho que deberá ser probado por este, fundamentalmente mediante prueba pericial, al partir de la presunción ya analizada de que el uso del producto fue el adecuado ${ }^{542}$.

En estos procesos se tratará por tanto de acreditar por la parte actora la existencia del defecto y por la parte demandada que el defecto no existe, que no es de fabricación, que ha surgido a posteriori, se fabricó cumpliendo la normativa vigente en ese momento, o simplemente que el producto era adecuado y el defecto observado se debe a la culpa del consumidor.

\footnotetext{
538 Abel Lluch, X., Picó i Junoy, J., Richard González, M.: “La prueba judicial. Desafíos en las jurisdicciones civil, penal, laboral y contencioso-administrativa”, cit., pág. 1402.

${ }^{539}$ S. ${ }^{\circ}$ 39/2012, Sec. $3^{\text {a }}$ AP Almería de 25-02-2012 (TOL 2.498.315), S. no 276/2004, Sec. $1^{\text {a }}$ AP Jaén de 3-12-2004 (TOL 582.286), S. $n^{\circ}$ 217/2011, Sec. $7^{\text {a }}$ AP Asturias de 13-05-2011 (TOL 2.137.129).

${ }^{540}$ En este supuesto se trataba de una máquina excavadora, pero ocurre de la misma forma en cualquier caso de avería o defecto, ya sea un ordenador, como en la S. no 285/2011, Sec. $4^{\text {a }}$ AP Málaga de 27-052011 (TOL 2.240.502), o en un reloj, S. nº 58/2006, Sec. 17ª AP Barcelona de 3-02-2006 (TOL 990.991).

${ }^{541}$ En el supuesto contemplado en la S. no 1266/2007 del TS 23-11-2007 (TOL 1.213.848), donde un cohete causó daño por ser defectuoso, entiende que se trata de una responsabilidad extracontractual y en relación a la inversión de la carga de la prueba obliga a la demandada para eximirse de responsabilidad, a acreditar que no hubo por su parte en la fabricación del producto actuación imprudente.

${ }^{542}$ Nos referimos a daños ocasionados por bombonas de gas, supuestos en los que han recaído sentencias como la $\mathrm{n}^{0}$ 117/1997 de la AP Córdoba de 14-05-1997 (AC1997/1045) en que se solicita la indemnización de daños y perjuicios, donde no medió la necesaria prueba del uso incorrecto por parte del consumidor, que debió acreditar el fabricante, por lo que se le repercutió a este la responsabilidad por la explosión y tuvo que indemnizar al actor por los perjuicios sufridos.
} 
En principio debe ser el actor quien acredite mediante prueba pericial la realidad del hecho imputable al demandado del que se hace surgir la obligación de reparar el daño causado ${ }^{543}$.

En estos casos el cómo y por qué se produjo el daño constituyen elementos indispensables en el examen de la causa del evento dañoso. Estos extremos que permiten conocer el origen del daño, deberán ser probados por la parte actora para que su demanda pueda prosperar, siendo la parte demandada la que deberá acreditar, al objeto de quedar exonerada de su responsabilidad, que medió culpa del usuario ${ }^{544}$.

Concretamente, en los procesos por daños debidos a falta de seguridad de productos fabricados en cadena, se deberá acreditar esta falta comparándolo con los demás productos fabricados, siendo la serie a la que los productos defectuosos pertenezcan la referencia para valorar la seguridad del mismo ${ }^{545}$.

La prueba en cuestiones de falta de seguridad corresponde al actor, debiendo acreditar que el producto es defectuoso o bien que no responde a la "seguridad que cabría legítimamente esperar", atendiendo a todas las circunstancias concurrentes, aunque en ocasiones será suficiente acreditar tan solo la existencia del defecto sin que tenga que determinarse la clase del mismo ${ }^{546}$.

4. Un cuarto apartado que es objeto de análisis en el capítulo siguiente, incluye aquellos productos en los que entra en juego la garantía.

${ }^{543}$ S. no 23/1998, TS 23 enero 2004 (TOL 348.808), S. Sec. 14 AP Madrid de 28-02-2001 (TOL 49.807), S. Sec. $3^{\mathrm{a}}$ AP Burgos de 28-02-2007 (TOL 1.895.219).

${ }^{544}$ En este tipo de daños el TS ha considerado la concurrencia de culpas, dado que los demandantes corren un riesgo y son conscientes del potencial peligro existente, aunque deberá acreditarse que la empresa adoptó todas las medidas de seguridad. S. TS 30-07-98 (TOL 2.602), S. nº 959/2000, TS 25-102000 (TOL 1.841).

A modo de ejemplo podemos aludir a varios supuestos en los que se ha precisado la acreditación del uso incorrecto: en el contemplado en La S. no 117/1997 de la AP de Córdoba de 14-05-1997 (AC1997/1045), en que se solicitaba la indemnización de daños y perjuicios sin mediar la prueba del uso incorrecto por parte del consumidor que debió practicar el fabricante y al no realizarlo, repercutió sobre él la responsabilidad y tuvo que indemnizar por los perjuicios sufridos, o en el enjuiciado en la S. TS 7-112008 (TOL 1.401.716), o en defectos de vehículos de segunda mano, S. n ${ }^{\circ} 49 / 2015$, Sec. $3^{\text {a }}$, AP Vizcaya de 11-03-2015 (TOL 4.893.522).

${ }^{545}$ S. n ${ }^{\circ}$ 545/2010 TS de 9-12-2010 (TOL 2.201.482).

${ }^{546}$ S. $\mathrm{n}^{\circ}$ 931/2006 del TS de 28-09-2006 (TOL 1.014.554) y S. $\mathrm{n}^{\circ}$ 1290, TS de 27-12-02 (LA LEY 10949/2003). 
Lo que tienen en común todos los diferentes supuestos comentados hasta ahora y los contenidos en el capítulo siguiente, es la necesidad de prueba de culpa del consumidor por parte del fabricante, condición indispensable para que este quede exonerado de responsabilidad ${ }^{547}$.

${ }^{547}$ S. TS 10-03-1987 (TOL 1.736.246) y S. no 755/1997, TS 2-09-1997 (TOL 216.209). 


\section{CAPÍtUlO VIII. ESPECIALIDADES DE LA PRUEBA EN EL PROCESO DE CONSUMO (II)}

En este capítulo se estudian otros supuestos específicos de prueba en otros procesos de consumo como son de falta de conformidad del producto con el contrato, el derecho de desistimiento, los contratos vinculados, la falta de prestación efectiva del servicio o de la entrega, la prueba en cuestiones sobre protección de los consumidores en la contratación de bienes con oferta de restitución de precio.

También analizaremos la prueba en varios supuestos de consumo que tienen regulación específica además de peculiaridades en la prueba. Nos referimos a las reclamaciones de telefonía, contratos fuera de establecimiento, contratación electrónica, la responsabilidad del suministrador, la incidencia en viajes y por último a la responsabilidad médica y sanitaria, los daños producidos por medicamentos o productos sanitarios defectuosos.

\section{A. PRUEBA De LA falta de CONFORMI DAD DEL PRODUCTO CON EL CONTRATO}

Aunque también hemos tratado las faltas de conformidad en el Capítulo VI, lo era tan solo en relación a la carga de la prueba, siendo ahora objeto de estudio la forma de probar la falta de conformidad.

La regulación sobre las garantías de los bienes de consumo se encuentra en la Directiva 1999/44/CE del Parlamento Europeo y del Consejo de 25 de mayo de 1999, sobre determinados aspectos de la venta y las garantías de bienes de consumo, modificada por la Directiva 2011/83/UE del Parlamento Europeo y del Consejo de 25 de octubre de 2011.

La primera de ellas fue transpuesta al Derecho Español a través de la LGVBC, integrada dentro del actual TRLGDCU, cuyo art. 3 establecía la presunción de conformidad del producto con el contrato siempre que se ajuste a la descripción pactada, sean aptos para el uso al que ordinariamente se destinen y para cualquier uso especial requerido por el consumidor, puesto en conocimiento del vendedor en el momento de la contratación si reúne además los requisitos de calidad y prestaciones habituales de cualquier otro bien del mismo tipo. 
Esta misma presunción hoy incardinada literalmente en el art. 116.1 del TRLGDCU, protege al consumidor de las faltas de conformidad del bien, estableciendo que la sola acreditación por el comprador de una falta de conformidad, es decir, presumiendo esa falta, se traslada al vendedor la carga de probar que la exigencia está cumplida, y en caso de no estarlo se presumirá la existencia de la falta de conformidad referida, ya sea por la naturaleza propia del bien o por su contenido.

En los supuestos que se pretenda reclamar la garantía por un producto defectuoso, el consumidor puede hacer valer su derecho mediante la acción de saneamiento del art. 1484 del C.c. o bien mediante la acción establecida en el art. 116.1 del TRLGDCU citado que le ofrece la posibilidad de alegar falta de conformidad, debiendo optar por el ejercicio de una u otra.

En estos casos, lo que deberá probar el consumidor será el concreto defecto del producto y el momento de su aparición, alegando que el producto no funciona correctamente, sin necesidad de demostrar el defecto de que adolece ${ }^{548}$, puesto que se produce la inversión de la carga de la prueba, debiendo ser el empresario demandado el que pruebe la exoneración de su responsabilidad o bien que el consumidor no dio un uso correcto al producto.

En estos casos debemos prestar especial atención al momento en que se produce el defecto, debido a que este debe haberse producido dentro del periodo de garantía, y es precisamente ese momento, junto a la existencia del defecto, lo que se deberá acreditar.

En este sentido, el TRLGDCU establece además en su art. 123 un plazo máximo en que opera la responsabilidad del vendedor, que será de dos años desde la entrega, un año para los de segunda mano, presumiendo la existencia de las faltas de conformidad al entender que estas ya existían en el momento de la entrega si se han puesto de manifiesto en los seis meses posteriores a la puesta en disposición del producto.

Cuestión también importante es la determinación del inicio del cómputo del plazo que será desde el día que conste en el tique de compra o albarán de entrega, excepto cuando esta presunción sea

${ }^{548}$ Llamas Pombo. E. (coord.) "Ley General para la Defensa de los Consumidores y Usuarios. Comentarios y jurisprudencia de la Ley veinte años después”, cit., pág. 413 y 414. 
incompatible con la naturaleza del producto o la índole de la falta de conformidad ${ }^{549}$.

En relación al referido plazo es importante destacar que este no será interrumpido salvo que haya habido alguna reparación o sustitución del producto, correspondiendo al propio consumidor probar tanto la disconformidad ${ }^{550}$, como el momento en que esta se puso en conocimiento del vendedor, puesto que para que pueda operar la garantía, debe haberse comunicado en el plazo máximo de dos meses.

De cumplir este aviso dentro de plazo, entrará en juego una nueva presunción a favor del consumidor, en este caso consistente en que puso los hechos en conocimiento del vendedor dentro de plazo, debiendo ser el propio vendedor quien acredite lo contrario. Si llegara a probarse la comunicación extemporánea afectaría al consumidor, quien deberá indemnizar al vendedor por los daños y perjuicios que el retraso en la comunicación de la falta de conformidad le hubiera ocasionado, aunque no por ello perderá el derecho de saneamiento ${ }^{551}$.

Adentrándonos en las peculiaridades de la prueba, es unánime la postura jurisprudencial en el sentido de que es el empresario demandado quien debe probar que el producto no reúne las condiciones para que opere la garantía o bien que los defectos han sido causados por el propio consumidor o mediando fuerza mayor.

De hecho, la jurisprudencia, como ya hemos indicado, tratando de salvar las dificultades probatorias, ha considerado que no se precisa la prueba del concreto defecto, debiendo sólo probarse por el actor la existencia de "un defecto" 552, teniendo en consideración todas las circunstancias del caso, su presentación, el uso razonable que debe darse al producto, el momento de su puesta en circulación, en qué consiste la falta de seguridad y el momento en que esta se produce.

\footnotetext{
${ }^{549}$ Llamas Pombo. E. (coord.) "Ley General para la Defensa de los Consumidores y Usuarios. Comentarios y jurisprudencia de la Ley veinte años después”, cit., pág. 414.

${ }^{550}$ Avilés García, J.: "Los contratos de compraventa de bienes de consumo. Problemas, propuestas y perspectivas de la venta y garantías en la Directiva 1999/447/CE y la Ley 23/2003”, cit., pág. 323.

${ }^{551}$ Fraga Mandián, A., Fraga Mandián, J.: "La tutela procesal civil de los consumidores en las leyes sustantivas especiales”, cit., pág. 17.

552 Álvarez Lata, N., Peña López, F., Busto Lago, J.M (coord.): "Reclamaciones de consumo. Derecho de consumo desde la perspectiva del consumidor”, cit., pág. 765.
} 
Pese a la dificultad de prueba directa sobre la falta de conformidad, sobre todo por el momento en que se practica (posterior al de la aparición del defecto o producción del daño) ${ }^{553}$ la función probatoria debería recaer sobre la existencia de la falta de conformidad y su preexistencia en el momento de la entrega ${ }^{554}$.

La referida prueba, de aportarla el vendedor 555 mediante prueba pericial, tratará de justificar que no existe tal falta de conformidad556, pudiendo incluso acudir a la prueba video-gráfica ${ }^{557}$, cuya admisión también es posible por la dificultad aludida 558 .

Si la alegación del consumidor se basa en la diferencia de características en relación a la publicidad del producto ${ }^{559}$, el vendedor deberá probar que existe tal correspondencia, o que no han sido bien entendidas por el consumidor ${ }^{560}$, o bien que este dio preferencia en su adquisición a características no referidas en las declaraciones públicas.

\footnotetext{
${ }^{553}$ Avilés García, J.: "Los contratos de compraventa de bienes de consumo. Problemas, propuestas y perspectivas de la venta y garantías en la Directiva 1999/447/CE y la Ley 23/2003”, cit., pág. 322.

${ }^{554}$ Bermúdez Ballesteros, M. S.: "Alcance de la responsabilidad del vendedor por la falta de conformidad en un bien de consumo, detectada en el plazo de garantía y manifestada durante y tras la expiración de dicho plazo". Revista CESCO de Derecho de Consumo nº 7/2013, pág. 56 a 63, http://www.revista.uclm.es/index.php/cesco.

${ }^{555}$ La S. $\mathrm{n}^{\circ}$ 571/2006 de la Sec. $10^{\text {a }}$ de la AP Madrid de 5-10-2006 (TOL 1.034.712) en que la actora compró un vehículo instando la resolución del contrato por vicios de origen, la Sala considera incuestionable que el vicio sea originario puesto que entiende que se presume que todo defecto acaecido durante el lapso temporal dispuesto para la garantía del bien adquirido tiene carácter originario, salvo prueba en contrario del transmitente o productor del bien.
}

${ }^{556}$ La S. $n^{\circ}$ 383/2012, Sec. $1^{\text {a }}$ AP La Rioja de 20-11-2012 (TOL 2.712.548) , tras la práctica de las pruebas testifical y pericial concluyó que el vehículo vendido presentaba manchas de aceite en los asientos plegados de tercera fila, entendiendo que tal defecto se encontraba incluido dentro de la garantía convencional pactada debiendo coincidir el producto con lo ofertado en la publicidad y el perfecto estado del vehículo en el momento de la venta, cubriendo la garantía las averías o disconformidades surgidas en el plazo de dos años siguientes a la entrega.

${ }^{557}$ En el supuesto enjuiciado en la S. $n^{\circ}$ 221/2011 de la Sec. $7^{\text {a }}$ de la AP de Asturias de 13-05-2011 (TOL 2.142.642), en el caso de la compra de unos pantalones que quedaron para arreglar el bajo sin que la medida se ajustara a lo concretado, no fue necesario la prueba pericial ni la de presunciones, puesto que la única prueba que se practicó y que fue concluyente para el juzgador de instancia y posteriormente para el tribunal fue la prueba video-gráfica donde aparecía el defecto referido, además del interrogatorio de las partes.

${ }^{558}$ Avilés García, J.: "Los contratos de compraventa de bienes de consumo. Problemas, propuestas y perspectivas de la venta y garantías en la Directiva 1999/447/CE y la Ley 23/2003”, cit., pág. 322.

${ }^{559}$ Por su parte la S. no 480/2012, Sec. $10^{\text {a }}$ de la AP Madrid de 21-09-2012 (TOL 2.661.271), en relación a la correspondencia del producto con su publicidad, entiende que esta forma parte de un contrato, no siendo necesario ni siquiera que sea inexacta o inveraz, basta con que aun siendo veraz, induzca a error.

${ }^{560}$ Vattier Fuenzalida, C.: “Sobre la garantía en las ventas de consumo”. Ed.: La Ley, Actualidad Civil nº 5 Sección A. Fondo del 1 al 15 de marzo de 2008, Tomo I, pág. 449. 
En cualquiera de los casos referidos, el fabricante o vendedor no será responsable ${ }^{561}$.

En relación a esta cuestión, es ejemplificativa la S. no 35/15 del Juzgado de Primera Instancia no 8 de Castellón de 16 de febrero de 2015, recaída en el juicio verbal no 1395/14 en la compra de un "Ipad" Apple 3 Wifi 4G en un establecimiento y al contratar los servicios $4 \mathrm{G}$ con su operador móvil, el I pad no funcionaba en esta red 4G, dando el actor aviso al servicio técnico oficial de Apple donde le informaron de que este aparato no estaba preparado para operar con las redes $4 \mathrm{G}$ en España ni en el resto de Europa.

La sentencia, aplicando la LGVBC y el TRLGDCU entendió que el vendedor no cumplió con la obligación de información precontractual que le exige la normativa de consumo, debiendo la vendedora haber advertido al cliente de que este servicio todavía no estaba implantado en España y de que una vez instalada, su compatibilidad dependería del operador de telefonía móvil.

En todos los casos es necesario que el defecto aparezca en el momento de la entrega y que ello se pueda acreditar, tratando de evitar que se hagan valer defectos originados con posterioridad a su adquisición, como deterioro por su uso, averías no debidas a defectos de fabricación, uso incorrecto, etc. ${ }^{562}$.

De hecho, la determinación del momento ${ }^{563}$ en que apareció el defecto resulta de vital importancia tanto para valorar si es de origen

\footnotetext{
${ }^{561}$ Martín Aresti, P.: "Las Garantías de los Productos de Consumo". Ed.: Thomson Reuters-Aranzadi, S.A., Pamplona 2010, pág. 75.

${ }^{562}$ León de Arce, A., García García, L.M., artículo de Palacios González, D., (coord.): "Derechos de los consumidores y usuarios”, cit. pág. 1095.

${ }^{563}$ En relación a la presunción sobre el momento de aparición del defecto, en la jurisprudencia existen posturas uniformes; concretamente la S. $n^{0}$ 53/2014, Sec. $8^{\text {a }}$ AP Alicante de 6-03-2014 (TOL 4.231.509) en que un vehículo, desde fechas inmediatamente posteriores a su entrega y durante más de un año sufrió continuas averías, entendió que debía resolverse el contrato por flagrante incumplimiento contractual al considerar el defecto encontrado como originario del producto.
}

En el mismo sentido, la S. $n^{\circ}$ 8/2015, Sec. $1^{\text {a }}$ AP Zaragoza de 22-01-2015 (TOL 4.738.032) presume, en un supuesto en que hubo sucesivas averías en un vehículo, que el defecto era originario, al haber acaecido dentro del periodo de garantía, considerando que al consumidor sólo le compete acreditar el vicio y que su aparición se produjo dentro de un uso normal del mismo. 
y se ha manifestado dentro del período de garantía ${ }^{564}$, como en relación al inicio del cómputo.

La regla general en la determinación del momento de inicio es el de la compra, aunque de forma excepcional se permite su cómputo desde que esté en funcionamiento, en el supuesto de que precise instalación o unos trabajos previos. Así lo dispone la S. no 221/03 de la AP de Jaén de 9 de septiembre de 2003 (TOL 318.101), donde se tienen en consideración las fechas de las averías acontecidas en el producto, un transformador eléctrico entendiendo que el plazo deberá iniciarse desde el efectivo uso del transformador.

Ya en la demanda, el consumidor acreditará la existencia del motivo de disconformidad o el defecto que observa en el producto, y el vendedor deberá probar que esa exigencia fue cumplida o si no lo estuviera, que ello es debido a que esta no es aplicable al contrato, bien por la naturaleza del bien o por el propio contenido del mismo, pudiendo quedar desvirtuada la presunción de conformidad.

Una vez analizada la posible existencia del defecto, la carga de la prueba de cada una de las partes, y las presunciones operan de varios modos, tanto sobre su aparición como en relación a su conformidad.

La cuestión que se nos plantea es la de qué prueba practicar, que sin duda será la pericial, dado que el conocimiento sobre el estado del bien sólo se puede alcanzar mediante ella o mediante el uso de alguna presunción en los supuestos de imposibilidad de prueba directa, como ya comentamos en el capítulo anterior al referirnos a los productos defectuosos ${ }^{565}$.

Transcurrido el periodo desde los seis primeros meses y hasta los dos años, al comprador no se le puede exigir prueba de que la disconformidad ya existía en el momento de la entrega, aunque sí deberá probar que esta no es consecuencia del uso y que no existen indicios de uso anormal, ni de daño causado por este.

\footnotetext{
${ }^{564}$ Fraga Mandián, A., Fraga Mandián J.: "La tutela procesal civil de los consumidores en las leyes sustantivas especiales”, cit., pág. 16.

${ }^{565}$ León de Arce, A., García García, L.M., artículo de Palacios González, D., (coord.): "Derechos de los consumidores y usuarios”, cit., pág. 1096.
} 
Si el defecto aparece tras los seis primeros meses ${ }^{566}$ se está a la regla general ${ }^{567}$ de la carga de la prueba contenida en el art 217. $2^{568}$ y corresponderá al consumidor ${ }^{569}$ acreditar el incumplimiento por el vendedor y que este le ha entregado un bien defectuoso, justificando además el origen de la falta, como entendió la S. no 300/2008, Sec. 8a AP Valencia de 20 de mayo de 2008 (TOL 1.358.691) en el supuesto de una cámara fotográfica averiada 570 .

Por tanto, lo que debe ser objeto de prueba son los defectos descubiertos después de la entrega, acreditando además el momento de su aparición.

Es aquí donde se observa la distinción de plazos así como los efectos que produce para las partes el momento en que se descubre el defecto, tanto en relación a la responsabilidad que se imputa al fabricante, como a la prueba del defecto, siendo su prueba a cargo del vendedor si el defecto es observado dentro de los seis primeros meses, y a partir del séptimo mes la prueba pesa sobre el comprador.

Es de gran importancia el hecho al que ya hemos aludido, pero que consideramos necesario reiterar, de que, aunque la carga de la prueba de la falta de conformidad recae en el actor y se realizará mediante informe pericial.

Aunque como norma general, este es aportado por el fabricante ${ }^{571}$ por su cercanía a la fuente de prueba, se cumple de este

\footnotetext{
${ }^{566}$ León de Arce, A., García García, L.M., artículo de Palacios González, D., (coord.): “Derechos de los consumidores y usuarios”, cit., pág. 1095.

${ }^{567}$ En la S. no 300/2008 Sec. $8^{\text {a }}$ AP Valencia de 20-05-2008 (TOL 1.358.691) se acreditó una supuesta avería y la causa de la misma, y aunque no se hiciera referencia expresa a la garantía en el escrito de demanda, entendió que esta existía en base a la previsión del art. 11 de la Ley 23/2003, como acreditó la documental obrante autos. Considera también que en los casos de garantía comercial complementaria a la legalmente prevista, el beneficiado por la misma sólo tiene que acreditar que el bien objeto de venta no funciona correctamente sin que tenga que probar cuál es la causa de ese anómalo funcionamiento, debiendo limitarse la reclamación del comprador al contenido de la propia garantía comercial.

${ }^{568}$ Fraga Mandián, A., Fraga Mandián J.: "La tutela procesal civil de los consumidores en las leyes sustantivas especiales”, cit., pág. 16.

${ }^{569}$ Tal como aprecia la S. no 8/2015, Sec. $1^{\text {a }}$ de la AP de Zaragoza de 22-01-2015 (TOL 4.738.032) al aplicar la presunción iuris tantum de que todo defecto acaecido durante el tiempo de garantía es originario, salvo prueba en contrario, y considerar que al consumidor sólo le compete acreditar la existencia del vicio.

${ }^{570}$ Mendoza Losana, A.I.: "Cómo probar que los desperfectos de los bienes no están cubiertos por la garantía en la venta de bienes muebles”, cit., pág. 35 a 49.

${ }^{571}$ Mendoza Losana, A.I.: "Cómo probar que los desperfectos de los bienes no están cubiertos por la garantía en la venta de bienes muebles”, cit., pág. 35 a 49.
} 
modo la especificación contemplada en el art. 217 apdo. 7 de la LEC, sin que este hecho sea razón para entender que el informe no reúne los requisitos necesarios de veracidad e imparcialidad ${ }^{572}$.

Existen una serie de supuestos en que se excepciona al actor de la prueba del defecto, como son aquellos en que este fuera conocido en el momento de celebrar el contrato o fuera debido a materiales 573 por él suministrados.

Además de los supuestos de responsabilidad del demandado referidos, existen los casos de responsabilidad solidaria derivada del art. 124 en relación al art 132 del TRLGDCU, cuando sean varios los responsables del defecto, como pueden serlo los fabricantes, importadores y distribuidores, debiendo ser ellos mismos quienes deberán acreditar su exoneración de toda responsabilidad, como ocurre en la falta de conformidad enjuiciada por la S. no 103/2015, Sec. 20a AP Madrid de 18 de marzo de 2015 (TOL 4.834.843), donde se condenó solidariamente a dos empresas, fabricante e instaladora por el defecto que presentaron una tuberías instaladas en una vivienda.

En relación a los bienes de segunda mano el régimen de aplicación de las presunciones no se efectúa del mismo modo puesto que la jurisprudencia entiende que no es posible presumir que el defecto esté incardinado dentro de la falta de conformidad, debiendo ser probado este extremo por el propio consumidor ${ }^{574}$, de forma que quede acreditado que no medió un mal uso y que el defecto aparecido procedía de un momento anterior al de su puesta a disposición.

Por último, nos queda analizar de forma breve las causas de exoneración de responsabilidad establecidas en el art. 116.3 del TRLGDCU, donde se regulan varios supuestos en que el vendedor puede quedar exonerado de responsabilidad por faltas de conformidad del producto con el contrato si llegan a acreditarse los siguientes extremos:

\footnotetext{
${ }^{572}$ León de Arce, A., García García, L.M., artículo de Palacios González, D., (coord.): "Derechos de los consumidores y usuarios”, cit., pág. 1095.

${ }^{573}$ Vattier Fuenzalida, C.: “Sobre la garantía legal en las ventas de consumo”, cit., pág. 449.

${ }^{574}$ S. $n^{\circ} 184 / 2013$ de la Sec. $1^{\text {a }}$ AP Ciudad Real de 14-06-2013 (TOL 3.849.695), S. no $678 / 2012$, Sec. $1^{\text {a }}$ AP Lugo de 19-12-2012 (TOL 3.013.289), S. n 264/2012, Sec. 1ª AP Cáceres de 14-05-2012 (TOL 2.565.236).
} 
- El conocimiento del consumidor, en los casos en que advirtiera la existencia de la falta y no hubiera podido fundadamente ignorarla en el momento de la celebración del contrato o que esta tenga su origen en materiales suministrados por el propio consumidor ${ }^{575}$.

-Cuando el consumidor no acredite los hechos sobre los que se basa y el fabricante o empresario justifiquen que éstos reúnen los requisitos de calidad exigidos ${ }^{576}$. En estos casos, si lo que hubiera que acreditar fueran los materiales empleados en la fabricación del producto, la prueba resultaría sencilla ${ }^{577}$.

- Si el propio fabricante acredita la conformidad del producto en el momento de la entrega, justificando que el defecto es posterior y puede ser debido a un mal uso, un caso fortuito o a su normal deterioro ${ }^{578}$.

- Cuando lo que argumenta el consumidor sin prueba alguna es que existe una diferencia entre la publicidad del producto y las características que este presentaba, siendo determinantes de su inaptitud para el uso que debía darle el consumidor ${ }^{579}$.

- Por último, cuando el consumidor dio preferencia en su adquisición a características no referidas en las declaraciones públicas ${ }^{580}$.

De resultar acreditada la falta de conformidad, esta podrá comportar una rebaja del precio, una indemnización o incluso la suspensión del pago hasta que se subsane el defecto si aún no hubiera sido abonado ${ }^{581}$.

\footnotetext{
575 S. TS 30-03-2000 (TOL 1.519) y S. TS 9-12-2010 (TOL 2.021.482).

${ }^{576}$ S. no 117/2015, Sec. 14 AP Barcelona de 16-04- 2015 (TOL 5.170.375).

577 S. Sec. $5^{\mathrm{a}}$ AP Asturias de 29-06-2011 (TOL 2.292.983), S. nº 421/2012 Sec. $17^{\mathrm{a}}$ AP Barcelona de 609-2012 (TOL 2.669.539).

${ }^{578}$ S. no 1071/2008, TS 7-11-2008(TOL 1.401.716), S. no 931/2006, TS de 28-09-2006 (TOL 1.014.554).

${ }^{579}$ S. no 506/1996 TS de 21-06-1996 (TOL 5.153.370).

${ }^{580}$ Martín Aresti, P: “Las Garantías de los Productos de Consumo”. Ed.: Thomson Reuters-Aranzadi, cit., pág. 75.

${ }^{581}$ Martín Aresti, P: "Las Garantías de los Productos de Consumo". Ed.: Thomson Reuters-Aranzadi, S.A., Pamplona 2010, cit., pág. 260 y ss.
} 


\section{B. PRUEBA DEL DERECHO DE DESI STI MI ENTO.}

El derecho de desistimiento, regulado en el artículo 71 del TRLGDCU, el cual sufrió una modificación a través de la Ley 3/2014, de 27 de marzo, (en adelante LCU), debe haberse ejercido en tiempo y forma y acreditarse tal extremo.

En relación a ello, hemos de tener en consideración el plazo dentro del cual se puede ejercer este derecho, es de 14 días desde la adquisición del bien o el producto.

Por tanto, el objeto de prueba versará sobre el ejercicio de este derecho en tiempo y forma, debiendo acreditar tal extremo el consumidor 582, según lo dispuesto en el art. 72 del TRLGDCU, pudiendo ser justificado por cualquier medio, tanto a través del interrogatorio, la documental o la testifical. Su ejercicio no comporta ningún formalismo, pudiendo ser manifestado de forma verbal o escrita ${ }^{583}$.

Hay cinco cuestiones básicas que deben ser motivo de prueba en cualquier proceso en que se cuestione el derecho de desistimiento y que vamos a analizar, son las siguientes: La prueba de la advertencia que el empresario debe haber realizado al consumidor; la justificación del incumplimiento por parte del empresario; la prueba de que el desistimiento se ha ejercido por el consumidor dentro del plazo establecido; la justificación de la devolución del producto dentro del plazo, y, la imposibilidad de cumplimiento del contrato por parte del consumidor.

1) Sobre la prueba de la advertencia que el empresario debe haber realizado al consumidor mediante la entrega del documento donde conste el derecho a desistir, la carga de la prueba de la entrega del documento de desistimiento corresponde al empresario, de forma que si este no probara que realizó la advertencia al consumidor sobre su posible desistimiento, se alargaría el plazo para poderlo ejercitar ampliándose a los doce meses siguientes a la fecha de expiración del periodo inicial, a contar desde que se entregó el

\footnotetext{
${ }^{582}$ Fraga Mandián, A., Fraga Mandián J.: "La tutela procesal civil de los consumidores en las leyes sustantivas especiales”, cit., pág. 13.

${ }^{583}$ Fraga Mandián, A., Fraga Mandián, J.: "La tutela procesal civil de los consumidores en las leyes sustantivas especiales”, cit., pág. 14.
} 
bien contratado, o se hubiera celebrado el contrato si su objeto fuera la prestación de un servicio, tal como establece el art. 71.3 de la LCU.

2) La S. no 62/2012, Sec. 4a de la AP Santa Cruz de Tenerife de 15 de febrero de 2012 (TOL 2.550.685), en aplicación de la anterior regulación sobre el derecho de desistimiento del TRLGDCU entendió de forma literal su art. 71.3, y considerando que el derecho de desistimiento debía ejercitarse en el plazo de 7 días desde la recepción del bien o desde la celebración del contrato siempre que el empresario hubiera cumplido con el deber de información y documentación y si no lo hizo, en el plazo de tres meses a contar desde que se celebró el contrato.

3) La segunda cuestión sobre la justificación del incumplimiento por parte del empresario del deber de información sobre el ejercicio del derecho, la prueba corresponderá al consumidor ${ }^{584}$.

A modo ejemplificativo podemos aludir a la Sentencia $\mathrm{n}$ 318/2008 de la Sec. 6a de la Audiencia Provincial de Valencia de 14 de mayo de 2008 (TOL 1.341.142) en que se desestima la demanda de un empresario por entender que este incumplió el deber de información sobre el derecho de desistimiento.

El consumidor así lo acreditó al aportar el detalle de la llamada telefónica que le realizó la empresa, al objeto de informarle sobre la posibilidad de desistir después de que el consumidor le hubiera manifestado su voluntad de devolver la mercancía, cuya afirmación también logró acreditar mediante el aporte del documento de entrega de la misma al transportista.

4) La tercera de las cuestiones que deben necesariamente ser objeto de prueba para que prospere el ejercicio de una acción de desistimiento es el ejercicio de tal derecho dentro del plazo legalmente establecido, tal como establece el art. 72 ya aludido del

\footnotetext{
${ }^{584}$ La S. $n^{\text {o }}$ 491/2011 de la Sec. $1^{\text {a }}$ de la AP de Albacete de 25-03-2011 (TOL 2.178.299) no entendió probada la procedencia de la resolución del contrato por incumplimiento de la demandante, al no probar ninguna de las manifestaciones realizadas en su demanda: no demostró que el material remitido no se correspondiera con el curso contratado, ni tampoco que la actora rehusara prestarle los servicios complementarios pactados.
} 
TRLGDCU, correspondiendo al consumidor, como hemos avanzado al inicio de este epígrafe tal acreditación ${ }^{585}$.

5) En relación a la cuarta cuestión, sobre la prueba de la devolución del producto dentro del plazo legal ${ }^{586}$, el art. 76 último párrafo del mismo cuerpo legal establece que la carga probatoria recae en el empresario ${ }^{587}$, lo cual está justificado dado que es el empresario quien controla los tiempos aludidos al estar obligado a realizar la devolución de las cantidades que haya recibido del consumidor en el plazo máximo de 30 días desde que este se haya hecho efectivo.

Si en este plazo no se le ha devuelto el importe, el consumidor podrá reclamar el doble y además deberá compensarle por los perjuicios sufridos por la falta de devolución dentro de plazo en lo que exceda de esta cantidad, según establece el art. 76 TRLGDCU ${ }^{588}$.

6) $Y$, en último lugar, la imposibilidad de cumplimiento del contrato por parte del consumidor, en cuyos supuestos corresponde al consumidor su prueba, como por ejemplo, cuando ejerce el derecho de desistimiento de un vuelo, para lo cual deberá mediar causa justificada, al objeto de verse indemnizado por ello con la devolución del precio del billete.

La prueba que deberá presentar está en relación a su imposibilidad para viajar por alguna razón, como una enfermedad espontánea, como sucedió en el supuesto enjuiciado en la S. no 182/2009 del Juzgado de Primera Instancia no 12 de Bilbao, de 16 de julio de 2009 (TOL 1.588.815) ${ }^{589}$.

\footnotetext{
${ }^{585}$ Así lo ha entendido reiterada jurisprudencia ejemplo de la cual son sentencias como la $n^{\circ}$ 491/2011 de 25 de marzo, de la Sec. $1^{\text {a }}$ de la AP de Albacete (TOL 2.178.299), la S. $n^{\circ} 1 / 2016$, Sec. $1^{\text {a }}$ de la AP de León de 11de enero de 2016 (TOL 5.642.295), o la S. no 62/2012, Sec. 4a, AP Tenerife de 15 de febrero de 2012 (TOL 2.550.685).

${ }^{586}$ Fraga Mandián, A., Fraga Mandián J.: "La tutela procesal civil de los consumidores en las leyes sustantivas especiales”, cit., pág. 14.

${ }^{587}$ Larrosa Amante, M.A: "Derecho de consumo. Protección Legal del Consumidor”. Ed.: El Derecho, Madrid 2011.

${ }^{588}$ Fraga Mandián, A., Fraga Mandián, J.: "La tutela procesal civil de los consumidores en las leyes sustantivas especiales”, cit., pág. 14.

${ }^{589}$ La Sentencia del Juzgado de lo Mercantil $\mathrm{n}^{\circ} 1$ de Vizcaya de 7 de julio de 2008, estimatoria de una demanda contra una compañía aérea en la compra de un billete de ida y vuelta con tarifa reducida, no llegando a utilizar el primer trayecto cancelando la demandada el trayecto de vuelta probando que se debió a problemas de salud.
} 


\section{ESPECI AL REFERENCI A A LOS CONTRATOS VI NCULADOS}

Cuestión distinta, y que merece especial atención, es el análisis del derecho de desistimiento en los contratos vinculados.

La regulación de los contratos vinculados se encuentra en la Directiva 90/88/CEE de 22 de febrero de 1990, en la Directiva 2008/48 del Parlamento Europeo y del Consejo de 23 de abril de 2008 y en la Ley 16/2011, de 24 de junio de contratos de crédito al consumo (en adelante LCC).

El art. 29 de la LCC los define como aquellos que sirven para financiar un contrato principal, constituyendo ambos una unidad comercial. Ejemplo de ello sería la formalización de un préstamo para pagar a plazos el importe de un servicio o la compra de un producto 590 .

En la actual regulación mediante la Ley 16/2011, de 24 de junio, (en adelante LCC) la casuística ha cambiado como veremos a lo largo de este apartado.

\section{a. En relación a la prueba del derecho de desistimiento}

Centraremos este apartado en los efectos que produce el derecho de desistimiento del contrato principal sobre el contrato vinculado y que se encuentran regulados tanto en el art. 28 de la LCC como en el art. 76 bis de la LCU, estableciendo este último la carga de la prueba sobre el empresario, en relación al cumplimiento del plazo.

La regulación ya existente en el TRLGDCU se complementa con la LCU, cuyo art. 28 incorpora el derecho de desistimiento del contrato vinculado, debiendo pagar el capital y el interés acumulado entre la fecha de disposición del crédito y la fecha del reembolso del capital.

Argumentó que no estaba previsto en la cláusula contractual, que esta condición general no fue ni informada ni aceptada por el demandante dado que no existía ninguna referencia a ella en el billete remitido por correo electrónico, ni tampoco hubo remisión a las condiciones generales de la web. El juez entendió que esta cláusula era abusiva puesto que la Compañía aérea no aportó prueba alguna que desvirtuara el contenido del billete recibido.

\footnotetext{
${ }^{590}$ Marín López, M.J. en su estudio: “Acuerdo Previo, concertado en exclusiva entre prestamista y proveedor”, (disponible en http://www.uclm.es/centro/cesco/pdf/trabajos/6/2008/6-2008-2.pdf), realiza un estudio de la doctrina jurisprudencial de las audiencias provinciales en la materia, considera que es el prestamista quien tiene que acreditar que no existe la exclusividad.
} 
La gran peculiaridad de la vinculación de los contratos radica en los efectos que se producirán en el supuesto de que el consumidor ejercite su derecho de desistimiento respecto al contrato principal, puesto que el contrato de crédito vinculado dejará de obligarle sin penalización alguna para el consumidor.

En estos casos podrá ejercitar los derechos que le correspondan frente al proveedor de los bienes o servicios adquiridos, siempre que no sean conformes con lo pactado o no hayan sido entregados y que el consumidor haya instado reclamación judicial o extrajudicial contra el proveedor sin que haya obtenido la satisfacción a la que tiene derecho.

En la práctica el consumidor ejercita el derecho de desistimiento contra el propio prestador del servicio y contra la entidad financiadora del crédito vinculado. Para ello se basa en la falta de prestación o en la prestación defectuosa del bien o servicio.

Lo que el consumidor alcanza, en caso de obtener una sentencia condenatoria es la resolución del contrato principal y consecuentemente, la del contrato vinculado ${ }^{591}$, para lo cual deberá acreditar el defecto o la falta de prestación del servicio.

Es habitual que por parte del consumidor se solicite como documental que la entidad bancaria aporte la certificación de los pagos realizados, intereses generados y gastos cobrados con la finalidad de acreditar que la cantidad que se reclama es un $40 \%$ superior a la que en principio se concedió.

A los profesionales les es difícil conseguir que el banco emita el referido certificado en la fase anterior a la demanda; de hecho el cliente en la mayoría de ocasiones lo ha solicitado a petición de su abogado pero no se le ha facilitado, de ahí que se tenga que acudir a la vía judicial, mediante el trámite de las Diligencias Preliminares que regulan los arts. 256 y ss, al objeto de que el órgano jurisdiccional requiera su aporte a la entidad bancaria.

Además del defecto o la falta de prestación del servicio, el consumidor debe acreditar que la empresa demandada tenía un acuerdo previo con la entidad bancaria al objeto de que ofreciera el crédito para la venta del producto o para la prestación del servicio,

${ }^{591}$ Jesús Marín, M.: “Contratos vinculados y cierre de negocio”. Revista Cesco de Derecho de Consumo, no 4 2012, págs. 160 a 184. 
cuya concreta prueba reviste especial complejidad cuando la demanda se ejercita de forma individual, siendo sencilla cuando existen varios afectados.

A la prueba documental propuesta por el letrado del consumidor en relación al montante de la deuda y acreditativa del destino del crédito sobre el concreto contrato ${ }^{592}$, es posible que se sumen varias testificales, en relación al defecto o a la falta de prestación del servicio siendo el órgano jurisdiccional quien en última instancia decidirá el número de testificales a practicar, tras asegurarse preguntando al letrado solicitante sobre el conocimiento que cada uno de los testimonios puede aportar en relación a los hechos objeto del interrogatorio.

En situaciones como la relatada, el letrado del consumidor puede incluso mostrarle al juez su duda sobre los hechos que pueda aportar cada testigo, proponiendo incluso el inicio del interrogatorio y su finalización prematura en caso de reiteración de declaraciones o falta de aporte de nueva información.

Existen variedad de sentencias sobre contratos vinculados, existiendo también diferencias en relación a la carga de la prueba dependiendo de la causa de afectación del contrato vinculado o del contrato principal ante la que nos encontremos, bien sea en relación a la defectuosa prestación del servicio por parte de la suministradora, a la falta de prestación del servicio, a su falta de adaptación o a la finalidad a que se destina ${ }^{593}$.

Además de los supuestos referidos, con la anterior regulación la cuestión más importante es la de acreditar uno de los requisitos a los que antes aludíamos, el de la exclusividad.

\footnotetext{
${ }^{592}$ Marín López, J.J.: Almoguera Gómez, A., Azparren Lucas, A., Bonet Sánchez, J.I., Duque Domínguez, J.F., Fernández López, J.M., Giménez Villanueva, T., Marín López, J.J., Marín López, M.J., Martí Sánchez, J.N., Muñoz Cervera, M., Nieto Carol, U., Roca Guillamón, J., Rubio Vilar, J., Sarazá Jimena, R., Toledano Barrero, V.: "Crédito al consumo y transparencia bancaria". Ed.: Civitas, Madrid 1998, pág. 90.

${ }^{593}$ Como en el supuesto enjuiciado en la S. $\mathrm{n}^{\circ}$ 204/2012, Sec. $10^{\mathrm{a}}$ AP Madrid de 21-03-2012 (TOL 2.506.844), en un contrato de préstamo vinculado a un contrato de aprovechamiento por turno, donde se observa vicio del consentimiento en el otorgamiento del préstamo, debido a que sólo ha sido posible practicar prueba testifical y documental privada, siendo el objeto principal de prueba la intimidación en la contratación efectuada, donde la falta de prueba efectiva sobre el particular por parte de la empresa lleva a presumir el vicio aludido. O la S. no 24/2012, Sec. $4^{\text {a }}$ AP Asturias de 25-01-2012 (TOL 2.440.551), en una reclamación de cantidad por cantidades prestadas a través de un contrato de crédito al consumo, donde la actora aportó certificación del saldo pagado del préstamo, reconociendo tan solo el tribunal las cantidades que allí constaban.
} 


\section{b. Sobre la prueba de la exclusividad de los contratos vinculados}

La anterior regulación mediante la Ley 7/1995, de 23 de marzo, de Crédito al Consumo exigía la prueba del carácter de la exclusividad, aunque, tras la modificación legislativa operada en el crédito al consumo por la Ley 16/2011, de 24 de junio, no se considera requisito básico del contrato.

Pese a ello, consideramos de especial importancia hacer una breve mención a ellos, por la gran cantidad de supuestos que sobre este particular se resolvieron a principios de los años 2000 con la anterior regulación, siendo los más característicos los que se dieron en relación a demandas presentadas contra academias de inglés que tuvieron que cerrar por encontrarse con graves dificultades económicas trayendo como consecuencia el impago de los préstamos que se habían suscrito con las entidades bancarias para costear el curso.

Este tipo de demandas se planteaba en grupo, siendo imprescindible la descripción sobre el vínculo de unión de los afectados que consistía en la contratación del mismo servicio en un contrato idéntico ${ }^{594}$. Ejemplo de ello es el cierre de la academia de inglés «Opening» 595 que generó una multitud de afectados y demandas en diversos puntos de la geografía española.

La doctrina de las Audiencias Provinciales en aquel momento consideró fundamental la prueba de la exclusividad del contrato vinculado que debía acreditar el prestamista, no pudiendo trasladarse al consumidor ${ }^{596}$ por resultarle totalmente desconocidos los acuerdos suscritos entre el proveedor y el financiador ${ }^{597}$.

\footnotetext{
${ }^{594}$ Álvarez Martínez, G.I.: "Los grupos de contratos en el crédito al consumo”. Ed.: La Ley, Madrid 2009, pág. 183.

${ }^{595}$ La S. ${ }^{o}$ 66/2003, Sec. $5^{\text {a }}$ AP Zaragoza de 7-02-2003 (TOL 425.396), S. $n^{\circ} 123 / 2003$, Sec. $7^{\text {a }}$ AP Valencia de 27-02-2003, (PROV 2003/135897); S. n ${ }^{0}$ 297/2004, Sec. $1^{\text {a }}$ AP Castellón de 27-09-2004 (TOL 526.916) y por la S. n ${ }^{\circ}$ 541/2004 Sec. $9^{a}$ AP Valencia de 16-09-2004 (TOL 569.271), S. nº 11/2006 Sec. $1^{\text {a }}$ AP Huesca de 17-01-2006 (TOL 809.023).

${ }^{596}$ La S. n ${ }^{\circ}$ 23/2007, Sec. $14^{\text {a }}$ AP Madrid de 23-01-2007 (TOL 1.091.077), se hace eco de la postura
generalizada de las Audiencias Provinciales, que liberan al consumidor de la carga de justificar la
exclusividad que previamente pactara la suministradora con la entidad bancaria, en aplicación de los
principios de facilidad y disponibilidad probatoria que proclama el art. 217.6 LEC, pues es claro que
aquel carece de acceso a los medios de prueba acreditativos tanto de la exclusividad como de su ausencia,
y desplazan ese deber probatorio sobre las entidades afectadas, que sí tienen acceso a la documentación u
} 
Si se tratara de probar la exclusividad ${ }^{598}$, la prueba en estos supuestos corría a cargo del empresario, por la dificultad que encontraba el consumidor, tal como ha entendido la jurisprudencia de forma unánime ${ }^{599}$.

Para llevar a cabo esta prueba se servían en la mayoría de supuestos de indicios de que el acuerdo existía de forma verbal y que en él se entendió la exclusividad del vendedor que colaboraba con determinado prestamista ${ }^{600}$. Ello suponía la prueba de un hecho negativo, dado que lo que se trataba de probar era que la empresa no tenía vinculación con ninguna otra entidad financiadora ${ }^{601}$.

Otra cuestión importante de cuya prueba también se eximió al consumidor fue de los pactos previos entre financiador y proveedor,

otros medios acreditativos de la diversidad de entidades de financiación con las que los clientes de la misma proveedora conciertan sus préstamos para adquisición de bienes o servicios.

En el mismo sentido, la S. $n^{0}$ 108/2009, Sec. 3ª AP de Guipúzcoa de 24-04-2009 (TOL 1.568.825) entiende que la prueba de la inexistencia del acuerdo corresponderá en virtud del principio de facilidad probatoria, ex art. 217 de la L.E.C a la prestamista y no al prestatario, pues para él mismo se convertiría en una auténtica "probatio diabólica”, bastando con que este justifique la remisión a una determinada entidad financiera por parte de la vendedora para estimar la existencia de algún tipo de convenio o acuerdo y que surja el desplazamiento de la carga probatoria, sin que deba acreditar otra circunstancia reveladora de "acuerdo" expreso con tal finalidad.

597 S. ${ }^{\circ}$ 62/2006 Sec. $14^{\text {a }}$ AP Madrid de 8-02-2006 (TOL 851.593), S. $n^{\circ}$ 23/2007, Sec. $14^{\text {a }}$ AP Madrid de 23-01-2007 (TOL 1.091.077).

${ }^{598}$ Ejemplo de ello lo encontramos en sentencias como la $n^{\circ}$ 278/2006, Sec. 9a AP de Murcia de 21-112006 (TOL 1.310.576) que desestima la demanda de una entidad de crédito contra un particular, correspondiendo a la actora (la entidad de crédito) la prueba de la inexistencia de exclusividad mediante hechos positivos.

${ }^{599}$ S. n ${ }^{\circ}$ 617/2003, Sec. $5^{\text {a }}$ de la AP Málaga de 28-7- 2003 (TOL 315.144), la S. nº 62/2005, Sec. $12^{\text {a }}$ de la AP Madrid, de 15-11-2005 (TOL 822.035), S. $n^{\circ}$ 90/2006, Sec. $3^{\text {a }}$ de la AP Baleares de 27-02- 2006 (TOL 861.285), S. $n^{\circ}$ 2039/2007, Sec. $3^{\text {a }}$ de la AP Guipúzcoa, de 5-02- 2007 (TOL 1.077.088), S. $n^{\circ}$ 301/2006, Sec. $10^{a}$ de la AP Madrid (TOL 1.034.670) de 27-04- 2006, S. n ${ }^{\circ}$ 246/2005, Sec. $10^{\text {a }}$ AP Madrid de 1-04-2005 (TOL 624.847), así como las Sentencias de los JPI no 3 de Ferrol, de 30-09-2004 (JUR 2005/36499), del JPI n ${ }^{\circ}$ 8, de Madrid de 30-7-2004 y del JPI n 17 de Madrid, de 15-12-2006 (TOL 1.051.511), S. $n^{\circ}$ 214/2004 de la Sec. $1^{\text {a }}$ de la AP Castellón de 27-9-2004 (TOL 519.993), la S. $n^{\circ}$ 548/2004 de la Sec. $9^{\text {a }}$ de la AP Valencia de 16-09-2004 (TOL 569.272), entre otras, todas ellas referidas por Marín López, M.J.: “Interpretación y prueba del acuerdo previo, concertado en exclusiva, entre prestamista y proveedor (art. 15.1.b). de la Ley de Crédito al Consumo): doctrina de las Audiencias Provinciales”. BIB2008/2872. Ed.: Aranzadi, S.A., Pamplona 2008.

${ }^{600}$ Cuñat Edo, V.: “Protección de particulares frente a las malas prácticas bancarias II”. Ed.: Consejo General del Poder Judicial, Madrid 2006.

601 S. $n^{\circ}$ 13/2004, Sec. $5^{\text {a }}$ AP Asturias de 21-01-2004 y S. $n^{\circ}$ 189/2004, Sec. $7^{\text {a }}$ AP Asturias 2-04-2004 (TOL 498.796). 
dado que se entendió que no podía conocerlos ${ }^{602}$, y la demostración sobre la forma concreta y exacta en que se le ofreció la posibilidad de financiación sólo podía lograrse mediante la aportación de su propia experiencia personal o de otros clientes ${ }^{603}$.

\section{c. Prueba de la defectuosa prestación del servicio en los contratos vinculados.}

La segunda causa de afectación del contrato vinculado que también existe tras la reforma, es la prestación defectuosa del servicio, aunque la Ley 16/2011 no establece un criterio específico sobre cuál de las partes debe concretar la prueba, sino que entiende que cualquiera de ellas lo podrá acreditar, como en el supuesto enjuiciado en la S. oㅡ 278/2006 Sec. 10a de la Audiencia Provincial de Madrid, de 19 de abril de 2006 (TOL 1.034.674) ${ }^{604}$, que atiende al criterio de facilidad probatoria, estando a los concretos medios de prueba a practicar en relación a la forma de materializarse la operación y al servicio a prestar ${ }^{605}$.

\section{d. Falta de prestación efectiva del servicio o de entrega del producto adquirido.}

En relación a la tercera causa de afectación del contrato vinculado, relativa a la falta de prestación efectiva del servicio o entrega del producto adquirido, la jurisprudencia ha entendido que es

\footnotetext{
${ }^{602}$ Marín López, M.J.: "Interpretación y prueba del $<<$ acuerdo previo, concertado en exclusiva >>, entre prestamista y proveedor (art. 15.1 b) de la Ley de Crédito al Consumo): doctrina de las Audiencias Provinciales”. Ed.: Aranzadi, Pamplona. 2008.

${ }^{603}$ S. ${ }^{\circ}$ 152/2004, Sec. $8^{\text {a }}$ AP Valencia, de 22-03- 2004 (TOL 445.521), S. $n^{\circ} 730 / 2003$, Sec. $6^{\text {a }}$ AP Valencia de 28-10-2003 (TOL 353.475), la S. no 54/2009, Sec. $6^{\text {a }}$ de la AP de La Coruña de 11-02-2009 (TOL 1.958.205), S. $n^{\circ}$ 89/2002, AP Huesca de 22-03-2002 (TOL 200.576), S. $n^{\circ} 714 / 2003$, S. $n^{\circ}$ 714/2003, Sec. $5^{\text {a }}$ AP Málaga de 17-09-2003 (TOL 325.757), S. Sec. 3a AP Castellón de 17-12-2.003 (TOL 337.211), S. $n^{\circ}$ 623/2004, S. $n^{\circ}$ 623/2004, Sec. $7^{\text {a }}$ AP Valencia, 10-11-2004 (TOL 547.598), S. $n^{\circ}$ 314/2005 de la Sec. 19a AP Madrid de 24-06-2005 (TOL 699.600).

${ }^{604}$ Este principio ha sido consagrado por la Jurisprudencia en sentencias como la S. $n^{\circ} 66 / 2003$, Sec. $5^{\text {a }}$, AP Zaragoza de 7-02-2003 (AC 2003/823), S. Sec. $7^{\text {a }}$ AP Valencia 27-02-2003 (PROV 2003/135897), S. $\mathrm{n}^{\mathrm{o}}$ 297/2004, Sec. $1^{\text {a }}$ AP Castellón de 27-09-2004 (TOL 526.916) y por la S. $\mathrm{n}^{0} 541 / 2004$, Sec. $9^{\text {a }}$, AP Valencia de 16-09-2004 (TOL 569.271), S. $\mathrm{n}^{0}$ 11/2006, Sec. $1^{\text {a }}$ AP Huesca de 17-01-2006 (TOL 809.023).

${ }^{605}$ Como en la S. no 237/2016, TS de 12-04-2016 (TOL 5.694.661), donde se suministraron unos módulos fotovoltaicos defectuosos, siendo el vendedor quien debía probar la validez del producto para el uso a que estaba destinado.
} 
el empresario demandado quien deberá acreditar el cumplimiento de las obligaciones ${ }^{606}$.

Así sucede en supuestos como el de compra de vehículo sin que llegue a producirse su entrega, tratado por la S. no 539/2012, Sec. 4a AP Illes Balears de 4 de diciembre de 2012 (TOL 2.716.289) ${ }^{607 .}$

La consecuencia de la sentencia estimatoria de las causas de afectación aludidas sobre el contrato de crédito vinculado era su ineficacia automática, puesto que corría la misma suerte que el contrato principal y por tanto las circunstancias que podían concurrir en el desarrollo del contrato accesorio no podían hacer revivir una consecuencia como sería la validez del contrato que ha sido declarada como viciada en el contrato principal, debiendo por tanto anularse el contrato vinculado y restituirse recíprocamente las prestaciones que hubieran recibido en virtud del mismo ${ }^{608}$.

\section{LEY 43/ 2007, DE 13 DE DI CIEMBRE, DE PROTECCIÓN DE LOS CONSUMI DORES EN LA CONTRATACIÓN DE BIENES CON OFERTA DE RESTITUCIÓN DE PRECIO.}

La prueba en estos casos se basará en la existencia de la información precontractual obligatoria al consumidor que según lo dispuesto en el art. 3 debe ser relevante, veraz y suficientemente detallada; especificando el art. 7 que la prueba del cumplimiento del deber de información corresponde a la empresa o profesional. No es el consumidor quien deba probar el cumplimiento de las obligaciones que impone la norma, sino la propia empresa ${ }^{609}$.

\footnotetext{
${ }^{606}$ Como en los casos del cierre de los centros de estudios de inglés "Cambridge”, donde la postura del TS en la S. no 494/2012, de 20-07-2012 (TOL 3.022.392) fue de resolución del contrato vinculado junto al contrato principal, puesto que no se prestó el servicio contratado, condenando a las entidades bancarias a la restitución de las cantidades en pago de la financiación abonada con posterioridad al cierre de las academias.

${ }^{607}$ También sucede en otros supuestos, como es el caso de la S. $n^{\circ}$ 488/2011, Sec. $3^{\text {a }}$ AP Tarragona de 712-2011 (TOL 2.499.442), como en tratamientos dentales, o, en el suministro de productos, como el caso enjuiciado en la S. no 977/1995, TS de 13 de noviembre de 1995 (TOL 1.667.764), sobre una centralita telefónica. También en los procesos de multipropiedad, ejemplo de lo cual es la S. no 610/2011, Sec. $11^{\text {a }}$ de la AP Madrid de 25-11-2011 (TOL 2.303.221), o la no 2/2015, de la misma Audiencia y Sec. de 15-012015 (TOL 4.750.181).

${ }^{608}$ S. no 456/2012, Sec. $13^{\mathrm{a}}$ AP Madrid de 24-09-2012 (TOL 2.706.528).

${ }^{609}$ Fraga Mandián, A., Franga Mandián J.: "La tutela procesal civil de los consumidores en las leyes sustantivas especiales”, cit., pág. 18.
} 
Así lo considera la S. no 67/2010, Sec. 28a de la AP de Madrid, de 12 de marzo de 2010 (TOL 1.875.679) donde se enjuiciaba el famoso caso de "Forum Filatélico, S.A.", que entendió que debía ser la entidad financiera la que acreditara la información facilitada.

En la misma línea que la anterior se encuentra también la S. $\mathrm{n}$ o 360/2013, Sec. 28 de la AP de Madrid, de 16 de diciembre de 2013 (TOL 4.113.976) en relación a unos contratos de mandato de venta de diversas obras de arte.

En relación a la prueba sobre las concretas circunstancias pactadas, el Auto no 155/2011, Sec. 16a , AP Barcelona de 30 de junio de 2011 (TOL 5.329.942) donde se debatía la validez de las cláusulas de sumisión a arbitraje pactadas en los convenios de prestación de servicios financieros pactados, entiende pese a que considera que tales cláusulas fueron impuestas por la entidad financiera, que existía conformidad de los consumidores intervinientes.

\section{E. PRUEBA EN LOS PROCESOS SObRe ReCLAMACIONES DE TELEFONÍ A.}

Las reclamaciones de telefonía suponen más de la mitad del total de reclamaciones de consumo y su tramitación se realiza, en su mayoría a través del procedimiento arbitral de consumo ${ }^{610}$, siendo objeto de breve tratamiento en un apartado específico al tratar la prueba en el arbitraje de consumo. De ellas, la mayoría se refieren a facturación de llamadas que el usuario no las reconoce como propias.

El servicio de telefonía posee regulación especial mediante el RD 1736/1998, de 31 de julio, por el que se aprueba el Reglamento de la Ley General de Telecomunicaciones y el RD 1912/97, de 19 de diciembre, que aprueba el Reglamento Técnico y de Prestación de servicio final telefónico básico y de los servicios portadores. Concretamente sus arts. 40 a 44 establecen las relaciones entre el prestador del servicio y sus abonados.

En estos casos existe la peculiaridad de que es el empresario de telefonía quien controla el servicio, debiendo ser de calidad y

\footnotetext{
610 Cabañas García, J.C.: "Los procesos civiles sobre consumidores y usuarios y de control de las cláusulas generales de los contratos”. Ed.: Tecnos, Madrid, pág. 70.
} 
funcionar correctamente, correspondiendo como veremos en todos los casos la carga de la prueba al empresario ${ }^{611}$.

Las demandas que se tramitan en relación al servicio telefónico son muy variadas, van desde la defectuosa prestación del servicio o mal funcionamiento del mismo, una facturación inadecuada o cantidades impagadas, pasando por cuestiones sobre contratos de servicios especiales, el contenido propio del contrato o de sus cláusulas generales, en relación a la contratación efectuada o a la información facilitada.

En todos los supuestos referidos es la compañía la que ostenta la carga de la prueba, aunque el objeto de la prueba variará dependiendo del caso concreto; en el supuesto de que la demanda verse sobre el mal funcionamiento del servicio, la prueba de la compañía tratará de argumentar la idoneidad técnica de todos los elementos relacionados con la línea que puedan haber influido en su defectuoso funcionamiento o en su uso ilegítimo, con la justificación además de la información facilitada al cliente sobre las inspecciones técnicas realizadas ${ }^{612}$.

En demandas sobre condiciones generales del servicio de telefonía la compañía deberá acreditar la contratación efectuada en cuanto a información previa, entrega de condiciones generales, documentación del contrato, renuncia al derecho de resolución, correspondencia entre la oferta y el cumplimiento del contrato así como la aceptación del adherente ${ }^{613}$ y cualquier otra cuestión que surja en relación a la contratación telefónica ${ }^{614}$.

\footnotetext{
${ }^{611}$ Florensa i Tomás, C.E., Alonso Franco, F., Barreto Rocha, J.C., Carrasco Perera, A., Clavel Vila, M., Cortadas Arbat, R., Díaz Albart, S., Maluquer de Motes Bernet, C.J., Mercadé Merola, M., Padial Albás, A., Sanchidrián, R., Torres Sánchez, F.: "El arbitraje de consumo. Una nueva dimensión del arbitraje de derecho privado", cit., pág. 173.

${ }^{612}$ S. $n^{\circ} 326 / 2000$, TS 4-05-2000 (TOL 1.565) y la S. no $118 / 2002$, Sec. $7^{\text {a }}$ AP Alicante de 4-03-2002 (TOL 160.602) donde se realiza una interpretación del art. 1214 C.c. en una demanda del consumidor por la utilización ilícita de la línea, y en la S. Sec. 2ª AP Valencia 8-01-2001 (TOL 75.725).

${ }^{613}$ Martín Aresti, P: “Las Garantías de los Productos de Consumo”, cit., pág. 63 y 64. Ed.: Thomson Reuters-Aranzadi, S.A. Pamplona 2010.

${ }^{614}$ La S. AP de Alicante de 4-03-2002 (TOL 160.602), razona que es la compañía la que dispone de importantes medios técnicos y de la posibilidad de acceso a los registros debiendo ser esta la que verifique todos los elementos relacionados con la línea telefónica que puedan influir en un defectuoso funcionamiento o en un uso ilegítimo e informar de su resultado al cliente, acompañando copia de todas las inspecciones técnicas realizadas. Otras sentencias que podemos citar a modo de ejemplo sobre facturación telefónica son la S. $\mathrm{n}^{\circ}$ 89/2008, Sec. $5^{\mathrm{a}}$ AP Zaragoza 18-02-2008 (TOL 1.314.796), S. ${ }^{\circ}$ 642/2008, Sec. 5a , AP Zaragoza de 20-11-2008 (TOL 1.477.576) y S. no 316/2004, Sec. 2a 25-05-2004
} 
Cuando la demanda tenga por objeto la excesiva facturación, lo que la compañía deberá acreditar será que las llamadas realizadas se corresponden con las facturadas ${ }^{615}$; en cuestiones sobre impagos ${ }^{616}$, la compañía deberá justificar la deuda, las llamadas y números de destino ${ }^{617}$. En relación a estas últimas, también cabría acreditar la oferta publicitaria anterior a la contratación, al objeto de mostrar que la tarifación realizada coincide con lo posteriormente contratado, como ocurrió en la S. no 534/2010, Sec. 5a AP Zaragoza de 16 de septiembre de 2010 (TOL 1.952.047).

En servicios especiales que pueden ser los prestados mediante líneas 803, 806 y 807, o aquellos servicios ofrecidos en el extranjero, como el acceso a internet fuera de España, la compañía deberá probar si surge cualquier cuestión sobre el servicio, tanto de facturación como de cualquier otra índole, la entrega de las condiciones generales y particulares donde conste la forma de prestación del servicio y la tarifa que le será de aplicación.

En relación a la contratación del servicio ${ }^{618}$, la prueba de la compañía versará sobre el contenido de la información previa facilitada ${ }^{619}$, la entrega de las condiciones generales, así como del

(TOL 466.320), S. no 1043/2006 TS 27-10-2006 (TOL 1.006.926) y S. no 236/2004 de 7-04-2004 (TOL 633.070).

${ }^{615}$ S. $n^{\circ}$ 16/2012, Sec. $7^{\text {a }}$ AP Asturias de 20-01-2012 (TOL 2.433.851), S. Sec. $2^{\text {a }}$ AP Valencia de 8-012001 (TOL 75.725), S. Sec. 6 ${ }^{\text {a }}$ AP La Coruña de 23-05-2000 (TOL 192.766).

${ }^{616}$ Las Sentencias de la Sec. $2^{\text {a }}$ de la AP de Valencia de 8-01-2001 (75.725) y la de la Sec. 6 a AP La Coruña de 23-05-2000 (TOL 192.766), en demandas presentadas por la Cía. telefónica por falta de pago de alguna factura, se han decantado por imponer la carga de la prueba a la suministradora del servicio, tanto por tratarse de la prueba del hecho en que funda su pretensión, como por tener a su favor la disponibilidad y facilidad probatoria, teniendo además especialmente en cuenta el carácter de consumidor de quien reclama.

${ }^{617}$ S. $n^{\circ}$ 405/2011, Sec. $3^{\text {a }}$ AP Valladolid de 8-01-2001 (TOL 2.304.473), S. ${ }^{0} 354 / 2010$, Sec. $5^{\text {a }}$ AP Vizcaya de 15-07-2010 (TOL 1.996.128), S. $\mathrm{n}^{\circ}$ 271/2003, Sec. $3^{\mathrm{a}}$ AP Navarra de 12-11-2003 (TOL 367.112); S. no 726/2010, Sec. $6^{\text {a }}$ AP Valencia de 28-12-2010 (TOL 2.085.266); S. la AP de Valencia de 8-01-2001 (TOL 75.725).

${ }^{618}$ En relación a la prueba de la contratación, la S. no 271/2003 Sec. $3^{\text {a }}$ de la Audiencia Provincial de Navarra de 12-11-2003 (TOL 367.112) asigna al operador el riesgo sobre la forma de contratación elegida, siendo la propia empresa operadora la que debe probar que el contrato se celebró con la parte demandada, debiendo acreditar que se le entregó el contrato por escrito o en cualquier otro soporte, sin que pueda alegar tampoco que lo envió, pero no lo cumplimentó. Debe asegurarse de recibirlo firmado antes de emitir pago alguno.

${ }^{619}$ Gomes Soares, S.F.: "La prueba en la contratación electrónica de consumo". Núm. 3 del 2009 de la Revista Internacional de Estudios sobre Derecho Procesal y Arbitraje (Riedpa) www.riedpa.com; Mendoza Losana, A.I.: "Particularidades de la contratación de servicios de telecomunicaciones por vía telefónica", cit., pág. 10; Mendoza Losana, A.I.: "Particularidades de la contratación de servicios de telecomunicaciones por vía telefónica”, cit., pág. 11. 
completo documento suscrito y la justificación documental de todo ello. Si la contratación se ha realizado verbalmente, lo justificará aportando la grabación realizada garantizando su autenticidad, identificando a los intervinientes sin que sufra alteración alguna su contenido.

\section{F. LA PRUEBA EN LOS CONTRATOS CELEBRADOS FUERA DE LOS ESTABLECI MI ENTOS.}

La regulación europea de los contratos celebrados fuera de establecimiento se recoge en la Directiva 97/7/CEE del Parlamento Europeo y del Consejo, de 20 de mayo de 1997, relativa a la protección de los consumidores en materia de contratos a distancia.

Regulados en el art. 92 del TRLGDCU y establecido su ámbito de aplicación en el art. 92 de la LCU, son aquellos que se realizan sin la presencia física simultánea de los contratantes, siempre que la oferta y aceptación se realicen de forma exclusiva a través de una técnica cualquiera de comunicación a distancia y dentro de un sistema de contratación a distancia organizado por el empresario ${ }^{620}$.

Las cuestiones más comunes en este tipo de procesos se basan en la contratación, el derecho de revocación, errores en la entrega y el cumplimiento resolución del contrato ${ }^{621}$. La carga de la prueba dependerá del caso ante el que nos encontremos, correspondiendo al consumidor cuando la demanda verse sobre la contratación y sobre el ejercicio del derecho de revocación y resolución ${ }^{622}$, y al empresario cuando se base en errores en la entrega o en el cumplimiento del contrato, producto defectuoso o falta de cumplimiento de las obligaciones de documentación de la transacción.

En relación a las cuestiones referidas en primer lugar, sobre la contratación de la operación, el consumidor podrá aportar como documental el propio contrato o factura, incluso el ticket de caja que registró la transacción con ese producto o servicio. En defecto de la prueba referida podrá acudir a medios de prueba personales, tales

\footnotetext{
${ }^{620}$ Fraga Mandián, A., Franga Mandián J.: “La tutela procesal civil de los consumidores en las leyes sustantivas especiales”, cit., pág. 16.

${ }^{621}$ S. $n^{\circ}$ 379/2010, Sec. $4^{\text {a }}$ AP Vizcaya de 18-05-2010 (TOL 1.997.506).

${ }^{622}$ S. Sala $4^{\mathrm{a}}$ TJUE de 15-04-2010 (TOL 1.820.703).
} 
como el interrogatorio de parte $\mathrm{o}$ de testigos tendentes a la corroboración de los hechos.

Sobre la prueba del cumplimiento de las obligaciones de documentación y de entrega al consumidor, corresponde su justificación al empresario, pudiendo llevarse a cabo mediante cualquier clase de prueba admitida en derecho, como la confesión, la testifical e incluso la documental consistente en la aportación de una copia de dicho documento donde conste el recibí firmado por el consumidor, o también se podría aportar un duplicado del pedido.

Por último, la del derecho de revocación por parte del consumidor se basará en el ejercicio del mismo respecto a los contratos referidos ${ }^{623}$. Para el supuesto en que el consumidor decida ejercer este derecho, no deberá indemnizar por los daños ${ }^{624} \mathrm{O}$ deméritos sufridos por el bien o servicio, salvo cuando quede constancia de que el envío se debió a un error y lo ponga de manifiesto el empresario al consumidor, correspondiendo al primero la carga de la prueba ${ }^{625}$.

\section{G. CONTRATACIÓN ELECTRÓNI CA}

Centrados en el supuesto más común de contratación a distancia, la realizada electrónicamente, esta se regirá por lo dispuesto en la Ley 34/2002, de 11 de julio, de servicios de la Sociedad de la Información y el Comercio Electrónico (en adelante LSSICE), que establece las reglas en materia de prueba y al régimen específico de la LFE, considerando en relación a la prueba lo dispuesto en los arts. 299 a 384 de la LEC 626.

\footnotetext{
${ }^{623}$ Concretamente, la S. Sec. $7^{\text {a }}$ AP Valencia 21-02-2003 (TOL 254.779) en relación al derecho de revocación del consumidor de un curso de inglés, hace alusión a los requisitos especificados a la necesidad de que el derecho de revocación conste en el documento contractual, debiendo plasmarse por escrito al igual que la oferta, mencionando que corresponde al consumidor probar que ha ejercitado su derecho de revocación y considera además que de la copia del contrato aportada al procedimiento no consta que antes de la firma aparezca de forma clara y concreta el posible ejercicio del derecho de revocación sin que la actora haya probado que se le entregara por el empresario el documento de revocación.

${ }^{624}$ S. Sala $1^{\text {a }}$ TJUE de 3-09-2009 (TOL 120.602).

${ }^{625}$ Reyes López M.J: “Manual de Derecho Privado de Consumo”. Ed.: La Ley, Las Rozas 2009 pág. 268.

${ }^{626}$ Vilaboy Lois L. en Tato Plaza, A. (coord.): "Reflexiones a la luz de la ley 1/2000, de 7 de enero, de Enjuiciamiento Civil. El Comercio electrónico en internet”. Ed.: Marcial Pons, Barcelona 2001, págs. 477 a 495.
} 
En este tipo de demandas lo más común es que se planteen cuestiones sobre la contratación efectuada o la validez y autenticidad de la firma utilizada en la transacción, correspondiendo en cualquier caso la carga de la prueba al empresario.

Sobre la concreta prueba a practicar y su normativa de aplicación, el art. 24 de la LSSICE expresa que en los contratos electrónicos se sujetará a las reglas generales del ordenamiento jurídico y a la legislación sobre firma electrónica siendo lo más habitual el aporte del contrato como prueba documental, y también admisible en juicio como tal el soporte en que conste la celebración del contrato ${ }^{627}$.

La prueba en estos supuestos, según establece el art. 24 de la LSSICE se sujeta a las reglas generales del ordenamiento y a la legislación sobre firma electrónica, de ahí que se deduzca que el soporte electrónico tendrá la categoría de prueba documental, equivalente en papel, siendo lo que constituye la prueba documental el propio soporte puesto en relación con su contenido o con la información que él mismo suministra a través de la firma electrónica ${ }^{628}$.

Lo más habitual es que la prueba de la contratación quede en soporte electrónico ${ }^{629}$ (regulado en los arts. 265 y ss. de la LEC), sin que su eficacia probatoria se vea alterada cuando no se pudiera determinar su autoría o autenticidad ${ }^{630}$. Su presentación se podría realizar incluso si no estuviera firmado, aunque su valor probatorio en

\footnotetext{
${ }^{627}$ Yzquierdo Tolsada, M., Navarro Mendizábal I.A., Acosta Mérida, M.P.: "Manual básico de derecho de consumo" Ed.: Cálamo Mataró 2005, pág. 188.

${ }^{628}$ Gomes Soares, S.F.: “La prueba en la contratación electrónica de consumo”, núm. 3 del 2009 de la Revista Internacional de Estudios sobre Derecho Procesal y Arbitraje” (Riedpa) www.riedpa.com; Miranda Serrano, L.M., Pagador López, J: "La formación y ejecución del contrato electrónico: aproximación a una realidad negocial emergente”. Estudios sobre Consumo núm. 85 del año 2008.

${ }^{629}$ Gómez- Ferrer Sapiña, R.: “Contrato electrónico y documento público electrónico” (TOL 227.026). Ed.: Tirant on line, Valencia 2003; Gomes Soares, S.F.: "La prueba en la contratación electrónica de consumo". Núm. 3 del 2009 de la Revista Internacional de Estudios sobre Derecho Procesal y Arbitraje”, Riedpa.com. wwww.riedpa.com; León de Arce, A., García García, L.M., artículo de Palacios González, D., (coord.): “Derechos de los consumidores y usuarios”, cit., pág. 1021.

${ }^{630}$ La S. no 404/2012, Sec. 3a AP Granada de 28-09-2012 (TOL 3.022.914) sostiene que la prueba de la celebración de un contrato por vía electrónica será admisible mediante aporte del soporte como prueba documental.
} 
ese caso será muy limitado ${ }^{631}$ al no reunir los requisitos exigidos por la LFE para que sea considerado documento válido.

Las cuestiones más comunes que surgen en relación a la prueba vienen dadas por los problemas de inseguridad que genera el medio utilizado, la contratación e identidad de los contratantes, la autenticidad, integridad y validez de la operación y el no repudio.

1. En relación a la primera cuestión de prueba más común, los problemas de inseguridad por el medio utilizado, el empresario aportará prueba de la contratación, mediante la justificación de la aceptación por parte del consumidor y su envío mediante soporte donde consten los términos de la contratación según dispone el art. 80 TRLGDCU 632 .

De esta forma quedó perfeccionado el contrato, sirviendo de prueba de la recepción por el consumidor y de la identidad de ambos, acreditando además que las declaraciones de voluntad no han sido alteradas, es decir, que no ha habido una renuncia posterior por el consumidor.

2. La segunda de las cuestiones, la prueba de la autenticidad, integridad o validez de la operación realizada, deberá ser acreditada por el empresario analizando y comprobando todos los requisitos que debe reunir el prestador del servicio de firma electrónica según el art. 3.8 LFE, así como las obligaciones necesarias para garantizar su confidencialidad ${ }^{633}$. La forma de proceder a probar este extremo sería mediante la pericial informática regulada en el art. 326.2 de la LEC.

Esta prueba en ocasiones puede incluso ser preconstituída debido a la existencia del archivo de la contratación de las partes en una entidad de certificación, como la CERES, Entidad Pública de Certificación Española. Las operaciones realizadas a través de este medio quedarán archivadas telemáticamente durante 5 años, tal como establece el art. 25 LSSICE.

\footnotetext{
${ }^{631}$ León de Arce, A., García García, L.M., artículo de Palacios González, D., (coord.): “Derechos de los consumidores y usuarios”. Ed.: Tirant lo Blanch, Valencia 2006, pág. 930.

${ }^{632}$ Fraga Mandián, A., Franga Mandián, J.: "La tutela procesal civil de los consumidores en las leyes sustantivas especiales”, cit., pág. 15.

${ }^{633}$ Yzquierdo Tolsada, M., Navarro Mendizábal I.A., Acosta Mérida, M.P.: "Manual básico de derecho de consumo", cit., pág. 344.
} 
3. La prueba de la tercera cuestión aludida, sobre la validez de la operación y su no repudio, tratará de acreditar que el contrato fue emitido por el empresario y recibido por el consumidor de forma que queda acreditada la identidad de ambos, la vigencia de poderes cuando actúen mediante representación de otro, que las declaraciones de voluntad no han sido alteradas al formular el contrato y que las partes no nieguen el medio utilizado ${ }^{634}$.

\section{H. RESPONSABI LI DAD DEL SUMI NI STRADOR}

El contrato de suministro es aquel en que las partes se obligan a mantener una compra continuada con una entrega repetida y diferida. Las obligaciones que nacen del mismo se contemplan en los arts. 1089, 1091 y 1258 C.c.

Analizando la responsabilidad del suministrador en relación al suministro de gas butano, en lo que este tiene de servicio de comprobación y vigilancia de la seguridad de las instalaciones, no se encuentra comprendido dentro del TRLGDCU, estando reguladas las obligaciones impuestas al suministrador en el Real Decreto 1085/1992, por el que se aprueba el Reglamento de la actividad de distribución de gases licuados del petróleo.

En base a la regulación referida, el demandado sólo puede librarse de su responsabilidad probando que cumplió con la reglamentación administrativa reguladora del servicio en cuestión, con todas las medidas exigibles, probando además que el daño se ha producido por el uso incorrecto del mismo por parte de la víctima ${ }^{635} \mathrm{o}$ por una falta de adopción por el usuario de las precauciones necesarias.

En relación al suministro de energía eléctrica, regulado por la Ley 24/2013, de 26 de diciembre, del Sector Eléctrico, la prueba la desarrollará el suministrador sólo en lo relativo a la exoneración de su responsabilidad y se basará en acreditar que no existe responsabilidad por su parte, aunque en estos casos existen algunas matizaciones, como en el supuesto de defectuoso suministro de

\footnotetext{
${ }^{634}$ Sanchís Crespo, C.: “La prueba por soportes informáticos”, cit., págs. 101 y ss.

${ }^{635}$ Art 17 TRLGDCU: "Los poderes públicos, en el ámbito de sus respectivas competencias, fomentarán la formación y educación de los consumidores y usuarios, asegurarán que estos dispongan de la información precisa para el eficaz ejercicio de sus derechos y velarán para que les preste la información comprensible sobre el adecuado uso y consumo de los bienes y servicios puestos a su disposición en el mercado".
} 
energía eléctrica, en el que la prueba corresponderá a la empresa suministradora.

En el resto de casos será el perjudicado quien deberá probar todos los demás extremos, el hecho acontecido, la relación entre el hecho y el producto y el defecto de este, si bien para ello basta con que el mismo no alcance los niveles de seguridad que cabe legítimamente esperar.

La regla anterior es de aplicación salvo que de la práctica de la prueba se deduzca que existió un daño que puede deberse a la conducta de la empresa, donde operará la presunción a favor del consumidor y la necesaria prueba de la empresa en relación a la culpa del usuario o a la prestación del servicio por esta con las debidas garantías ${ }^{636}$, siendo en ambos casos el medio de prueba utilizado para acreditar el daño y la relación de causalidad, el informe pericial ${ }^{637}$.

\section{PRUEBA DE I NCI DENCI AS EN VI AJES}

Aunque las incidencias en viajes pueden ser muy variadas, tan solo vamos a analizar de forma breve cuestiones tales como los retrasos de la compañía aérea, los supuestos de indemnización por pérdida de maleta, los casos de desistimiento de todo o de parte del viaje y aquellas cuestiones que pueden dañar al consumidor y ser objeto de indemnización por la agencia de viajes contratada.

En estos supuestos la carga de la prueba depende del caso en que nos encontremos: si se trata de retrasos de compañías aéreas, la carga de la prueba ${ }^{638}$ de que este no se ha producido recae sobre la compañía aérea, según establece el propio Convenio de Varsovia de 12 de octubre de 1929, ratificado por España el 31 de enero de 1931, para unificación de reglas acerca del transporte aéreo internacional.

\footnotetext{
${ }^{636}$ S. $\mathrm{n}^{\mathrm{o}} 330 / 2005$, Sec. $4^{\text {a }}$ de la AP de Las Palmas de 4-07-2005 (TOL 714.280), S. $\mathrm{n}^{\mathrm{o}}$ 104/1996 TS de 15-02-1996 (TOL 1.669.195), S. no 537/2000, TS de 26-05-2000 (TOL 4.927.074) y S. no 435/1996 de 28-05-1996 (TOL 1.659.506), S. AP Huelva nº1 70/2011 de 18-03-2011 (TOL 2.151.221).

${ }^{637}$ La S. $n^{\circ}$ 98/2010, Sec. 5 a de la AP de Las Palmas de 8-03-2010 (TOL 5.306.802) en una avería eléctrica de una puerta automática de garaje causada por una sobretensión se considera acreditada la responsabilidad de la demandada, que no justifica circunstancias que le exoneren de ella, tal y como indica el artículo 217.3 de la LEC, sin que ello suponga acudir a una inversión de la carga de la prueba, sino a su correcta distribución con arreglo al citado precepto.

${ }^{638}$ S. no 340/2012, Sec. 4 a AP Las Palmas de 26-07-2012 (TOL 2.670.482) entiende que la carga de la prueba de las circunstancias concretas que pudiera eximir a la Cía. aérea de tener que indemnizar a los pasajeros por el retraso sufrido recae en la propia Cía.
} 
En estos casos, la compañía aérea deberá acreditar que adoptó las medidas necesarias para evitar el daño, o bien que le fue imposible adoptarlas, sin que pueda considerarse prueba de exoneración de responsabilidad alegar fallos mecánicos, pues es deber de la compañía disponer de los medios de transporte, en este caso aviones, en perfecto estado de mantenimiento y revisión. La Compañía queda liberada de responsabilidad cuando los retrasos se deban a razones meteorológicas o por fuerza mayor que afecten a la seguridad 639 .

En relación a la prueba concreta para acreditar el retraso dependerá de la circunstancia que lo hubiera generado, pero en cualquier caso, si fue por motivos ajenos a su voluntad, deberá acreditarlo mediante prueba documental, al igual que si se trató de alguna circunstancia extraordinaria como la existencia de condiciones meteorológicas adversas en el momento y lugar del despegue.

Se ha admitido la indemnización de daños morales en el retraso de vuelos, siempre que el consumidor acredite que este es imputable a la Compañía y que las circunstancias concurrentes permitan valorar la afectación del retraso en la propia esfera psíquica del pasajero ${ }^{640}$, como establece la S. no 413/2005 de la Sec. 2a AP Lleida de 8 de noviembre de 2005 (TOL 839.017).

Cuestión distinta supone el extravío del equipaje, donde una vez concretada la culpa de la compañía aérea por el propio consumidor, lo que deberá ser objeto de prueba es el valor de su contenido para proceder al cálculo de la indemnización, teniendo en cuenta que existe un Convenio de aplicación, el de Montreal de 1999 que fija el límite de la indemnización en 900 euros. Por tanto, el importe reclamado y el valor de los enseres contenidos en la maleta deberá ser probado por el propio consumidor, correspondiendo a la compañía aérea la prueba sobre la ausencia de responsabilidad ${ }^{641}$.

\footnotetext{
639 Álvarez Lata, N., Peña López, F., Busto Lago, J.M (coord.): “Reclamaciones de consumo. Derecho de consumo desde la perspectiva del consumidor”, cit., pág. 1466.

640 Álvarez Lata, N., Peña López, F., Busto Lago, J.M (coord.): “Reclamaciones de consumo. Derecho de consumo desde la perspectiva del consumidor”, cit., pág. 1469.

${ }^{641}$ La S. $n^{\text {o }}$ 174/2011 Sec. 15a, AP Barcelona de 14-04-2011 (TOL2.173.423) enjuicia un extravío de maleta y en relación a la valoración del contenido de la misma pese a que el actor aportó justificantes de compra donde constaba el valor de todos los objetos que contenía, entiende que no puede acogerse a ellos, dado que resulta anómalo que el pasajero conservara todas las facturas de adquisición de cada uno de los efectos contenidos en su equipaje no pudiendo por tanto ser tenidos como medios directos de
} 
La prueba en estos supuestos por parte del actor se basará en la acreditación de los vuelos realizados y en el contenido y valor de los objetos que reclama mediante el aporte de las facturas de compra.

Si se tratara de un viaje combinado que se desarrolló en varios trayectos e intervinieron varias compañías, corresponde a las compañías demandadas probar en qué trayecto se perdió el equipaje ${ }^{642}$.

Otro caso en que es el propio consumidor quien asumirá la carga de la prueba, en este caso del perjuicio sufrido y de la relación de causalidad, es cuando reclame una indemnización a la agencia de viajes por un daño sufrido, debiendo acreditar tanto el daño concreto causado como su cuantificación y responsabilidad ${ }^{643}$.

\section{J. ADQUISICION DE VIVIENDAS}

En relación a la compraventa de viviendas por consumidores, existe regulación específica en el Real Decreto 515/1989, de 21 de abril, sobre protección de los consumidores en cuanto a la información suministrada en la compraventa y arrendamiento de viviendas.

Las cuestiones que se pueden plantear en este tipo de contratación pueden ser varias, analizando en este apartado alguna de ellas.

En relación a la carga de la prueba, es de destacar que no existe una regla única sobre la carga de la prueba en todos los supuestos, por ejemplo, si el proceso se inicia por incumplimiento contractual derivado de la falta de entrega ${ }^{644}$ del inmueble, se entenderá sin

prueba del contenido de la misma, y por tanto, será indemnizado según el convenio al que hemos hecho alusión.

${ }^{642}$ S. no 13/2006, Sec. 4a , AP de Baleares de 23-01-2006 (TOL 932.865).

${ }^{643}$ La S. no 221/2011, Sec. 2a, AP de Ciudad Real de 7-07-2011 (TOL 2.227.634), donde ser reclama por daños sufridos en una maleta, entiende que con los medios probatorios empleados el recurrente no ha conseguido acreditar la realidad del daño que reclama a la agencia de viajes, debido a que nadie ha visto la maleta dañada y el informe pericial parte de que esta no se ha comprobado por estar en Inglaterra. Tampoco aportó ninguna otra prueba que pudiera acreditar el daño ocasionado, como por ejemplo unas fotografías que hubieran acreditado el daño.

${ }^{644}$ Así lo entendieron también otras sentencias como la S. no 235/2007 de Sec. $10^{\text {a }}$ de la AP Madrid de 22-05-2007 (JUR 2007/199964), publicada en el núm. 83 del año 2008 de la revista Estudios sobre Consumo, y la S. $\mathrm{n}^{\circ}$ 59/2014, Sec. $3^{\text {a }}$ AP Valladolid de 11-03-2014 (TOL 4.150.741), S. ${ }^{\circ}$ 778/2014 TS de 20-01-2015 (TOL 4.733.341). 
necesidad de prueba que produce un daño calculado según el valor en uso que obliga a su indemnización con la única justificación de la mora del promotor mediante el aporte del propio contrato de compraventa ${ }^{645}$.

Si la demanda se plantea por vicios en el consentimiento, su carga corresponderá a quien alega el error o el dolo para invalidar el contrato, recayendo las consecuencias negativas en el caso de no estimarse que exista error sobre quien lo alegue ${ }^{646}$, siendo la prueba que suele aportarse la documental.

La demanda por incumplimiento de la obligación de informar sobre alguno de los extremos importantes del contrato comportará la carga de la prueba sobre el particular a cargo del demandado647. La jurisprudencia del Tribunal Supremo, desde la S. no 933/1998 de 16 de octubre de 1998 (TOL 5.157.080) ha entendido que la carga de la prueba de que esta información se ha suministrado corresponde al profesional en base a la mayor facilidad probatoria ${ }^{648}$, al igual que la prueba del carácter con que se contrata ${ }^{649}$.

\section{K. RESPONSABI LI DAD MÉDI CA Y SANI TARI A}

En materia de responsabilidad sanitaria existen también varios ámbitos de exigencia de la responsabilidad, aunque sólo tiene relación con la materia de consumidores el de la responsabilidad

\footnotetext{
${ }^{645}$ León de Arce, A., García García, L.M., artículo de Palacios González, D., (coord.): "Derechos de los consumidores y usuarios”, cit., pág. 2157.

${ }^{646}$ S. no 297/2002, Sec. 3ª AP León de 9-10-2002 (JUR 2003/80374) aunque referido a la adquisición; S. $\mathrm{n}^{\mathrm{o}}$ 148/2004, Sec. 5a , AP Vizcaya de 15-03-2004 (TOL 505.908); S. Sec. 21 a, AP Madrid de 3-04-2001 (AC 2001/1997).
}
${ }^{647}$ La S. $n^{\circ}$ 193/2009, Sec. $6^{\text {a }}$ AP de Valencia de 2-04-2009 (TOL 1.553.399) hace recaer sobre los demandados la carga de demostrar haber informado a los actores de la existencia de una hipoteca que gravaba la vivienda.

${ }^{648}$ S. $n^{\circ}$ 3/2001, TS 12-01-2001 (TOL 99.652), la S. ${ }^{\circ}$ 828/2003 TS de 8-09-2003 (TOL 307.998), S. ${ }^{\circ}$ 481/2006 de 18-05-2006 (TOL 952.802).

${ }^{649}$ La S. $\mathrm{n}^{\circ}$ 431/2010, Sec. $1^{\text {a }}$ de la AP de Santa Cruz de Tenerife de 11-10-2010 (TOL 2.142.811) entiende que debe ser la parte empresarial o profesional la que debe cargar con la prueba de que la otra parte contratante no debe beneficiarse de ser tratada como consumidor, demostrando al efecto que esa persona ha actuado dentro de su ámbito de actividad empresarial.

En el caso concreto de la sentencia referida se considera consumidor al contratante ya que no se ha desplegado la actividad probatoria que acredite su condición de empresario al no aportar prueba de la que quepa concluir que la actividad de compraventa de inmuebles constituye el objeto de la actividad empresarial del actor y no se justifica que exista mención alguna en sus comunicaciones escritas que ponga de manifiesto una actuación empresarial o profesional. 
extracontractual de centros sanitarios por daños causados a los consumidores del servicio.

Concretamente, en relación a la responsabilidad médica se considera una obligación de medios, no de resultados, siempre que se hayan tenido en consideración las reglas de la lex artis del supuesto en cuestión, a excepción de los casos de medicina satisfactoria o voluntaria, como es el de la estética o la odontología.

En procedimientos como los referidos, es de vital importancia la acreditación del consentimiento informado por el paciente sobre los riesgos y consecuencias de la intervención, lo cual resulta también esencial para valorar la existencia o no de responsabilidad ${ }^{650}$.

En relación a cuál de las partes debe probar, la jurisprudencia desde antiguo ha entendido que debe ser el centro médico o el profesional causante de los daños quien acredite que actuó con la diligencia exigible ${ }^{651}$.

En cuanto a la concreta prueba a practicar se reduce a la prueba del resultado y a la acreditación del consentimiento informado, pudiendo quedar el profesional exonerado de responsabilidad si acredita que el resultado pudo ser debido acaso fortuito o fuerza mayor ${ }^{652}$.

La S. TS de 29 de noviembre de 2002 (TOL 229.646) citada, en relación al deber de probar, entiende que recae sobre los facultativos demandados, que por sus propios conocimientos técnicos en la materia litigiosa y por los medios de que disponen tienen mayor acceso al material probatorio.

En la línea referida hay cientos de sentencias; a modo de ejemplo podemos hacer alusión a la S. no 1155/2007 del TS de 19 de octubre de 2007 (TOL 1.177.288), publicada en el núm. 83 del año 2008 de la revista Estudios sobre Consumo ${ }^{653}$.

\footnotetext{
${ }^{650}$ García Cuerva García, S., Abel Lluch, X., Picó i Junoy, J. (Dir.): “Objeto y carga de la prueba civil”, cit., pág. 213.

${ }^{651}$ Podemos hacer alusión entre otras a la S. no 604/1997 TS 1-07-1997 (TOL 215.680), S. nº 688/1997, TS 21-07-1997 (TOL 215.308), S. no 1146/1998, TS de 9-12-98 (TOL 8.732) y S. no 1152/2002, TS de 29-11-2002 (TOL 229.646).

${ }^{652}$ García Cuerva García, S., Abel Lluch, X., Picó i Junoy, J. (Dir.): “Objeto y carga de la prueba civil”, cit., pág. 210 a 214.

653 S. no 125/1992 TS de 20-02-1992 (TOL 5.156.347), STS de 14-04-1999 (TOL 1.467), S. no 504/2003 TS de 27-05-2003 (TOL 274.494), S. no 527/2007 TS de 9-05-2007 (TOL 1.075.942), STS 17-05-2002 (TOL 161.927), S. $n^{0}$ 306/2014, Sec. $8^{a}$ AP Valencia de 24-07-2014 (TOL 4.573.980), entre otras muchas.
} 
Esta sentencia enjuiciaba un supuesto de responsabilidad extracontractual de un centro sanitario por la infección producida en una intervención quirúrgica, donde no se probó uno de los hechos controvertidos fundamentales al alcance del centro médico que es quien debe acreditar que actuó con la diligencia debida, siendo quien dispone de los medios para acreditarlo según el criterio de facilidad probatoria establecido en el art. 217.6 de la LEC.

Cuestión distinta es la atribución de la concreta responsabilidad entre el centro sanitario y su personal. En relación a ello la $S$. no 25/1997 TS de 27 de enero de 1997 (5.153.465), entiende que el centro sanitario tiene responsabilidad directa en base al art. 1903.4 C.c. así como los titulares de hospitales, cuando se advierten deficiencias imputables a la asistencia masificada que dispensan con imposibilidad de ejercer un absoluto control de la actuación profesional y administrativa del personal que presta sus servicios en los mismos, haciéndose preciso acudir a una interpretación de la responsabilidad.

En relación a la infección de un paciente en la UCI de centro hospitalario, la S. del TS no 29/2015 de 2 de febrero de 2015 (TOL 4.709.012) resuelve un recurso iniciado por una demanda en solicitud de indemnización de daños y perjuicios por sufrir infección de VIH y SIDA en la UCI de un hospital al realizarle unas transfusiones de plasma y una de concentrado de hematíes, a raíz de las cuales sufrió episodios febriles y varias infecciones tras lo cual se le detectó la infección referida. La sentencia resuelve sin ninguna duda la responsabilidad del centro sanitario dado que la relación de causalidad estaba acreditada.

Otra sentencia de especial relevancia sobre estos casos es la de

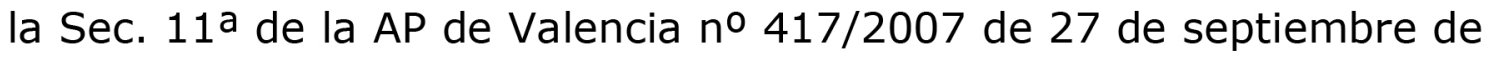
2012 (TOL 2.709.620) en la que no se consideró imputable ninguna responsabilidad al centro sanitario por una infección, dado que no quedó acreditado de forma indubitada el lugar y momento en que esta se originó a la vista de los períodos de incubación habituales de la bacteria detectada en la actora, y según los protocolos exigibles en relación a la conservación de las instalaciones y del instrumental quirúrgico en las condiciones que impone la legislación vigente, sin que haya habido tampoco infección en otros pacientes ${ }^{654}$.

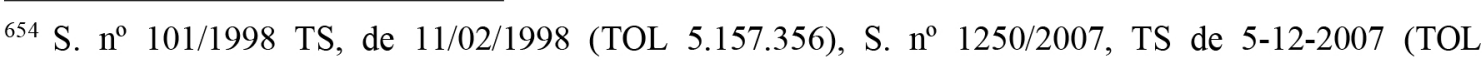
1.235.320), o la S. $n^{0} 583 / 2010$ TS de 27-09-2010 (TOL 1.958.896), esta última entiende que la distinción 
En los casos de responsabilidad por actuaciones médicas se puede constatar el recurso a las presunciones, en sentencias como la no 115/1998 de la Sec. 4a de la AP la Coruña de 20 de marzo de 1998 (AC 1998/370), donde se considera que existe responsabilidad medica por contagio de SIDA, presuponiendo al no existir prueba directa de ello que el médico causó el contagio.

En supuestos de contagios por transfusiones, la Sentencia del T. Supremo de 18 de febrero de 1997 (TOL 5.114.407), y siguiendo esta postura, muchas otras resoluciones, como la del Juzgado de Primera Instancia no 7 de Palma de Mallorca de 20 de junio de 2007 (TOL 1.156.086), han utilizado la prueba de presunciones para constatar la existencia del nexo causal entre la transfusión y el contagio, considerando existente la relación de causalidad cuando el demandante demuestra que con anterioridad a la transfusión o tratamiento con hemoderivados no estaba infectado por el virus y sí lo estaba después de la transfusión o tratamiento

\section{MEDICAMENTOS O PRODUCTOS SANITARIOS DEFECTUOSOS}

En cuestiones sobre defectos en material o productos sanitarios defectuosos rige la misma regla de la carga de la prueba que hemos comentado en relación a los productos defectuosos, correspondiendo la prueba al actor ${ }^{655}$, tanto sobre el daño, como sobre el defecto y la relación de causalidad, independientemente del tipo de producto, bien sean prótesis mamarias que no responden a la seguridad que pudiera esperarse, o a cualquier otro tipo de prótesis, incluso un marcapasos ${ }^{656}$. Por tanto, el perjudicado que pretenda la reparación el daño causado le corresponde probar la realidad y alcance del daño, así como el defecto, y que fue precisamente ese defecto el que produjo el daño.

Pese a la necesidad de prueba aludida, esta tiene una matización en relación al concreto defecto que presenta el producto, puesto que

entre obligación del médico y resultados no es posible mantenerla en el ejercicio de la actividad médica, salvo que el resultado se pacte o se garantice.

655 Pipaón Pulido, J.G.: “Derechos de los consumidores y usuarios”, cit., pág. 218. Ed.: Lex Nova, S.A., Valladolid, 2009.

656 La S. del TJUE de 5-03-2015 (www.curia.eu) sobre defecto por falta de seguridad de un marcapasos o las sentencias $n^{\circ} 390 / 2007$, en relación a prótesis mamarias, la de la Sec. $2^{\text {a }}$ de la AP de Guipúzcoa de 2606-2006 (TOL 991.962), o la S. nº 85/2014, Sec. 14 a AP Madrid de 13-10-2014 (TOL 4.529.928) recaída con motivo de la demanda de las afectadas por el fármaco de la talidomida. 
no se exige su concreción, sólo es necesario acreditar que este existe, debiendo ser el productor el que pruebe su exoneración, y si ha resultado o no perjudicado.

Por tanto, lo mismo cabrá decir sobre la exoneración de responsabilidad por parte del fabricante que comentamos en el capítulo anterior, en el sentido que la inversión de la carga de la prueba sólo alcanza al elemento de la culpabilidad que este no será considerado responsable si prueba que no existía defecto, o que para su elaboración se siguieron las normas establecidas ${ }^{657}$; que el producto no se había fabricado para la venta; que los conocimientos científicos y técnicos existentes al poner el producto en circulación no permitían apreciar la existencia del defecto; que el defecto es imputable a la forma de concebir el producto al que se ha incorporado, o bien, a las instrucciones que presenta el fabricante de ese producto ${ }^{658}$.

Y en cuanto al medio de prueba por excelencia que permitirá valorar la falta de seguridad del producto y el daño causado por este motivo al consumidor será la prueba pericial que determine la existencia del defecto concreto ${ }^{659}$.

\footnotetext{
${ }^{657}$ Busto Lago, J.M. (coord.), Álvarez lata, N., Peña López F.: "Reclamaciones de consumo. Derecho de consumo desde la perspectiva del consumidor”, cit., pág. 770.

${ }^{658}$ La S. $n^{\circ}$ 80/2007 (TOL 1.957.280), Sec. 6ª AP La Coruña de 16-03-2007, S. nº 80/2007, Sec. $6^{\text {a }}$ de la AP La Coruña de 16-03-2007 (TOL 1.957.280).

${ }^{659}$ Sentencia del JPI no 13 de Barcelona de 11-06-2007 (TOL 1.380.025).
} 



\section{CAPÍTULO IX. PRUEBA EN LA CONTRATACI ÓN BANCARI A}

Trataremos en este capítulo varios tipos de contratos de servicios financieros, como los incluidos en la ley 2/2009, de 31 de marzo, de contratación de préstamos y servicios de intermediación y en la Ley 22/2007, de 11 de julio, sobre Comercialización a distancia de Servicios Financieros; haremos mención a algún supuesto de errores administrativos y de gestión, a cuestiones surgidas en la prestación de servicios de contratación de préstamos hipotecarios, o en la prestación de servicios de intermediación para la celebración de préstamos o créditos, a la reclamación de cuotas impagadas de préstamos, también a ciertas cuestiones surgidas por el uso de las tarjetas de crédito, a demandas sobre arrendamiento financiero o en relación al uso de la banca electrónica.

También son objeto de estudio en este capítulo las demandas presentadas por consumidores contra entidades bancarias como Bankia, Caixa Galicia, Catalunya Bank y otras muchas.

Se trata de un tema de actualidad durante varios años, sobre el que se han presentado miles de demandas que incluso ha llevado a la designación de jueces específicos mediante comisiones de servicio para atender la frenética actividad judicial que se ha producido en los últimos años.

Nos referimos a demandas donde se insta la nulidad de contratos relativos a acciones y a otros productos financieros complejos por vicio en el consentimiento.

Haciendo en primer lugar una breve referencia a la regulación de la contratación bancaria esta se contiene a nivel europeo en la Directiva 2005/29/CE del Parlamento Europeo y del Consejo, de 1 de mayo de 2005, relativa a las prácticas comerciales desleales, modifica el régimen legal de la competencia desleal para la mejora de la protección de los consumidores y usuarios.

La transposición de esta Directiva al Derecho español se realizó mediante la Ley 2/2009, de 31 de marzo, Reguladora de la Contratación con los Consumidores los Consumidores de Préstamos o Créditos Hipotecarios y de servicios de intermediación para la celebración de contratos de préstamo o crédito, siendo esta la regulación normativa de la contratación bancaria. 
Además de esta Ley, los productos y servicios ofrecidos por las entidades de crédito en sus relaciones con los consumidores y usuarios se regulan específicamente por las normas de ordenación y disciplina supervisadas por el Banco de España.

Por otra parte, existe un numeroso conjunto de normas que responde al tipo de «regulación por producto» que busca unificar los requisitos que han de cumplir ciertos productos financieros, de forma que éstos sean similares independientemente de la entidad que los presta, ya se trate de una entidad de crédito o de cualquier otra empresa.

Lo mismo sucede con la prestación de servicios financieros a distancia, regulados por la Ley 22/2007, de 11 de julio, sobre Comercialización a Distancia de Servicios Financieros destinados a los Consumidores, la cual transpone la Directiva 2002/65/CE del Parlamento Europeo y del Consejo, de 23 de septiembre de 2002, que contiene el régimen jurídico específico de la protección de los consumidores en los servicios financieros que se comercializan a distancia.

\section{A. CUESTI ONES EN RELACIÓN A CONTRATOS DE SERVICIOS BANCARIOS}

Analizando ahora los supuestos mencionados, iniciamos nuestro estudio sobre las diversas cuestiones anunciadas, en las cuales la prueba que se aporta en la generalidad de los casos es la documental que acredite los distintos extremos objeto de la controversia.

a) Ante la observancia de la comisión de errores administrativos o de gestión, la propia entidad debe acreditar de la correcta prestación del servicio ${ }^{660}$, y el consumidor probar la existencia de errores en el desarrollo de la gestión a través documentos que justifiquen la existencia de tales errores.

b) En relación a la prestación de servicios financieros a distancia, de la normativa referida, al igual que en el supuesto anterior, se desprende que corresponde al proveedor del servicio, la entidad financiera, la carga de probar el cumplimiento de las obligaciones que le incumben así como el consentimiento favorable

${ }^{660}$ S. $n^{\text {o }} 82 / 2007$, Sec. $7^{\text {a }}$ AP Valencia de 12 de febrero de 2007 (TOL 1.129.556). 
del consumidor en la celebración del contrato y la transmisión de la información necesaria al cliente para efectuar la contratación ${ }^{661}$.

Por tanto, el empresario proveedor a distancia de servicios financieros debe probar el cumplimiento de sus obligaciones siendo nula por abusiva ${ }^{662}$ cualquier cláusula en la que se pacte lo contrario ${ }^{663}$.

c) Por lo que respecta a los servicios de contratación de préstamos hipotecarios y servicios de intermediación para la celebración de contratos de préstamo o crédito, la Ley 2/2009, de 31 de marzo, aludida, hace recaer también en la entidad demandada la prueba, habitualmente mediante documental, del consentimiento prestado por el consumidor ${ }^{664}$, así como sobre cualquier cuestión que surja en relación a estos contratos ${ }^{665}$, tal como establece su art. 8.

La cuestión en relación a la prueba a practicar en los procesos concretos sobre hipotecas es más compleja, dado que el material probatorio que se puede aportar se encuentra reducido a la propia escritura de hipoteca. En la práctica, los letrados de la entidad bancaria llegan a solicitar incluso el interrogatorio del Notario interviniente en la formalización del préstamo hipotecario, al objeto de que acredite que informó al comprador del clausulado que constaba en la escritura, y de este modo, justificar que no puede alegar desconocimiento.

Pese a que podría ser esclarecedora esta prueba, no es admitida en la mayoría de juzgados por entender que la afirmación del notario de que informó sobre la operación no implica que el consumidor entendiera exactamente los términos y condiciones de la operación.

\footnotetext{
${ }^{661}$ Fraga Mandián, A., Fraga Mandián, J.: "La tutela procesal civil de los consumidores en las leyes sustantivas especiales", cit., pág. 17; Lafuente Sánchez, R.: "Los servicios financieros bancarios electrónicos”. Ed.: Tirant lo Blanch, Valencia 2005, págs. 153 a 191.

${ }^{662}$ El Anexo de la Directiva 93/13/CEE incluye la lista indicativa de cláusulas que pueden considerarse abusivas.

${ }^{663}$ Fraga Mandián, A., Fraga Mandián J.: "La tutela procesal civil de los consumidores en las leyes sustantivas especiales”, cit., pág. 15.

${ }^{664}$ Memento Práctico de consumo 2010-2011 Ed.: Francis Lefebvre.

${ }^{665}$ Criterio mantenido de forma unánime por la jurisprudencia, muestra de ello son las sentencias $\mathrm{n}^{\circ}$ 71/2006, (TOL 949.772) de 21-02-2006, $\mathrm{n}^{\circ}$ 55/2006 ambas de la Sec. 11 ${ }^{\text {a }}$ de AP Madrid de 8-3-2006, (TOL 949.786), S. Sec. $1^{\text {a }}$ AP Barcelona de 27-07- 2006 (TOL 1.035.793), S. $n^{\circ} 34 / 2015$, Sec. $1^{\text {a }}$ AP León de 20-02-2015 (TOL 4.800.381).
} 
d) Si lo que se trata de enjuiciar es el impago de cuotas de préstamo, por la propia naturaleza del hecho corresponde también la prueba a la entidad bancaria ${ }^{666}$, dado que de lo contrario recaería sobre el consumidor la carga de la prueba de un hecho negativo ${ }^{667}$.

En este tipo de supuestos no resulta fácil la prueba directa de la falta de pago, de ahí que se haya admitido tanto la prueba de indicios, como la prueba de un hecho positivo contrapuesto al hecho negativo objeto de litigio, para de esta forma alcanzar la prueba del segundo ${ }^{668}$.

La misma línea manifestada en relación a la carga de la prueba se aplica en supuestos como el descuento bancario ${ }^{669}$ o las demandas sobre las cláusulas de redondeo de las pólizas de préstamo, cuya prueba corresponde a la entidad financiera 670 , así como en reclamaciones de saldo deudor de cuenta corriente ${ }^{671}$.

e) En cuestiones sobre tarjetas de crédito existen variedad de supuestos planteados, como los pagos y cargos realizados

\footnotetext{
${ }^{666}$ Hemos encontrado una Sentencia que de forma excepcional por su peculiaridad, atribuye la carga de la prueba al consumidor, se trata de la S. $n^{0}$ 168/2008, Sec. $1^{\text {a }}$ de la AP de Guadalajara de 7-10-2008 (TOL 1.480.172), en demanda de oposición a juicio cambiario por un préstamo garantizado mediante un pagaré en blanco en una contratación de crédito al consumo, entiende que la cláusula del pagaré en blanco comporta la imposición de la carga de la prueba en perjuicio del consumidor en los casos en que debería corresponder a la otra parte contratante, en tanto será el consumidor quien tenga que probar que la cantidad consignada en el pagaré es cierta, líquida y exigible.

${ }^{667}$ Podemos aludir a la S. de la AP de Barcelona de 26-04-2001 (TOL 205.003), la cual considera, en un caso de relación contractual entre una entidad financiera y un particular, que la carga de la prueba incumbe a la parte demandada.

${ }^{668}$ Aludiendo a varias sentencias significativas sobre lo comentado, la S. $n^{\circ} 81 / 2006$, Sec. $14^{\text {a }}$ AP Madrid de 30-03-2006 (TOL 1.608.4281) entiende tras examinar las actuaciones y siguiendo la corriente mayoritaria de las audiencias provinciales en supuestos semejantes al que nos encontramos, que debe darse trámite a la petición del Banco que ofrece prueba sobre la existencia de la relación jurídica que liga a las partes, al aportar el original de la póliza de préstamo firmada por ambas partes y una prueba indiciaria del crédito del actor, ya que se detallan los vencimientos impagados con aplicación concreta de los intereses ordinarios y moratorios aplicados según las estipulaciones de la póliza de préstamo.

${ }^{669}$ Por su parte la S. $n^{\circ}$ 492/1996 del TS de 13-06-1996 (TOL 1.659.511) en un tema de descuento bancario en que un banco presenta demanda contra un cliente impagado, el Tribunal considera difícil para el actor la prueba de un hecho negativo como es la falta de pago, pero pese a ello es al propio actor a quien corresponde llevar a cabo tal prueba por ser el hecho básico que constituye su pretensión.

${ }^{670}$ S. no 70/2015 TS 11-02-2015 (TOL 4.719.668), S. no 861/2010 TS de 29-10-2010 (TOL 2.031.067).

${ }^{671}$ La S. no 99/2006, Sec. 21 de 11-01-2006 (TOL 822.299), donde la entidad bancaria tuvo que practicar prueba acreditativa del descubierto reclamado mediante los extractos de movimientos, el aporte del contrato de apertura de la cuenta y el contrato de tarjeta del crédito vinculado a la cuenta.
} 
mediante tarjeta, los saldos en descubierto ${ }^{672}$, las reclamaciones de pago por un uso indebido o cualquier otra incidencia, así como la contratación efectuada ${ }^{673}$, la custodia del número secreto o la firma del contrato de la tarjeta. En todos los casos descritos, la prueba corre a cargo de la entidad bancaria ${ }^{674}$.

En supuestos de reclamaciones de pago de cantidades pendientes, sólo deberán ser probados por el consumidor si realizara oposición, al igual que sucede en el uso indebido de la tarjeta por un tercero 675 , que aunque en general la carga de la prueba corresponderá al consumidor, la jurisprudencia ha sido flexible al considerar que la prueba en relación a este particular puede ser aportada por cualquiera de las partes ${ }^{676}$.

Lo mismo sucede en relación a la justificación de la realidad de la deuda generada mediante el uso de la tarjeta de crédito, donde la jurisprudencia de forma unánime ha entendido que debe ser la entidad bancaria la que presente prueba fehaciente de la liquidación de la deuda, bastando con aportar los documentos acreditativos del uso de la tarjeta en los que quede estampada la firma del cliente ${ }^{677}$.

\footnotetext{
${ }^{672}$ En relación al saldo deudor, la S. no 56/2012, Sec. $2^{\text {a }}$ AP Huelva de 20-03-2012 (TOL 2.593.429) entiende que es el banco quien debe acreditarlo. La misma regla sigue la S. de la AP Santa Cruz de Tenerife 630/1999, de 3-07-1999 (AC 1999/1860) en demanda contra la entidad bancaria sobre el incorrecto funcionamiento de la tarjeta, al considerar que la prueba de su funcionamiento corresponde al actor y la de los hechos que reclama el consumidor, al propio consumidor.
}

${ }^{673}$ S. no 413/2014 de la AP de Jaén de 26-06-2014 (TOL 4.486.438) en que se reclama el pago de una tarjeta de crédito, pero no se acredita la relación contractual entre las partes al aportarse como prueba un solo contrato en el que no figura el $\mathrm{n}^{\circ}$ de tarjeta, considera que la entidad emisora tiene la carga de aportar los documentos emitidos por los establecimientos adheridos a su sistema de tarjetas.

${ }^{674}$ Concretamente, la S. $\mathrm{n}^{\circ}$ 277/2014 de AP Jaén de 26-06-2014 (TOL 4.486.438) considera que la entidad emisora debe aportar necesariamente con su demanda aquellos documentos emitidos por los establecimientos prestadores de servicios adheridos a su sistema de tarjetas como soporte de sus propias liquidaciones y en este caso no ha resultado acreditada la certeza y exigibilidad de la deuda reclamada.

O esta otra S. $n^{\circ}$ 273/2010 Sec. $1^{\text {a }}$ AP Álava de 1-06-2010 (TOL 1.996.342), establece que la carga de probar la existencia del crédito de la tarjeta reclamado incumbe a la entidad bancaria pues de no aportar prueba los hechos permanecerán inciertos en perjuicio de la actora.

${ }^{675}$ S. no 56/2012, Sec. $2^{\text {a }}$ AP Huelva de 20-03-2012 (TOL 2.593.429).

${ }^{676}$ S. $n^{\circ}$ 21/2015, Sec. $3^{\text {a }}$ AP Barcelona de 22-01-2015 (TOL 4.755.603), la S. ${ }^{0} 587 / 2008$, Sec. $6^{\text {a }}$ AP Valencia de 29-09-2008 (TOL 1.421.279), S. $n^{\circ}$ 2/2012 de 16-02-2012 de la Sec. $1^{\text {a }}$ del Tribunal Superior de Justicia de Navarra de 16-02-2012 (TOL 3.005.690).

677 S. $n^{\circ}$ 387/2008, Sec. $19^{\mathrm{a}}$ AP Madrid 10-9-08 (TOL 1.462.658), S. no 164/2006 Sec. 9a AP Madrid 243-06 (TOL 937.230), S. n ${ }^{\circ}$ 258/2003, Sec. $1^{\text {a }}$ AP Cuenca 13-11-03 (TOL 354.978), S. no 242/2002, Sec. $6^{\text {a }}$ AP Valencia 27-04-02 (TOL 160.638), S. $n^{\circ}$ 68/2001, Sec. $1^{\text {a }}$ AP Albacete 31-03-01 (TOL 70.484), la S. $\mathrm{n}^{0}$ 111/2007, Sec. 9a AP Alicante de 30-03-2007 (TOL 1.090.594) y la S. Sec. $4^{\mathrm{a}}$ AP Baleares de 17-072002 (TOL 229.005). 
En relación a demandas sobre problemas en la custodia del número secreto, la prueba de la negligencia del consumidor en el uso o en la custodia del número secreto corresponderá a la entidad bancaria, aunque en estos casos el consumidor deberá con su demanda aportar los justificantes de las transacciones realizadas con la tarjeta ${ }^{678}$.

También han existido varias cuestiones en relación a la firma del consumidor en el contrato de la tarjeta, entendiendo la jurisprudencia que la alegación de este hecho no es obstáculo para considerar válido el contrato y el documento aportado por la entidad bancaria, puesto que para considerarse "no válido" debería haberse solicitado el cotejo pericial de letras, único medio de prueba apto para acreditar si la firma del documento es auténtica, y crucial para determinar la validez del mismo. Así lo entendió la reciente sentencia ya citada no 21/2015 de la Sec. 3o de la AP de Barcelona de 22 de enero de 2015.

Otra cuestión que ha sido tratada por la jurisprudencia es la relacionada con los documentos que debe aportar la entidad bancaria como prueba de las operaciones realizadas mediante tarjeta, como es la S. no 17/2015 Sec. 19ạ AP Madrid de 21 enero 2015 (TOL 4.770.575), que considera que las certificaciones de deuda y extractos bancarios, aunque son unilaterales, son prueba suficiente de la acreditación de la deuda, puesto que estos son documentos bancarios habituales en este tipo de operativa, no habiendo aportado el consumidor ninguna liquidación alternativa.

En estos procesos existe problemática en relación a la dificultad de obtener justificación documental sobre determinado cargo efectuado a la tarjeta, aunque ello ha servido de amparo al consumidor al objeto de eludir la prueba cuando a este le corresponde acreditar determinado cargo ${ }^{679}$.

f) Sobre demandas de arrendamiento financiero ("leasing"), debido a su vinculación a la compra de un bien mueble, nos remitimos a lo comentado sobre la carga de la prueba en los productos defectuosos y a lo comentado en supuestos de falta de

\footnotetext{
${ }^{678}$ Como entienden la S. no 642/2004 Sec. $10^{a}$ AP Madrid 6-10-2010 (TOL 545.801) o la S. $n^{\circ}$ 497/2002, Sec. 6 ${ }^{\text {a }}$ AP Málaga de 23-07-2002 (TOL 1.190.811) pudiendo incluso, ante la insuficiencia probatoria alcanzar la prueba mediante presunciones sobre el negligente cuidado en su custodia.

${ }^{679}$ Rivero Alemán, S.: “Crédito, consumo y Comercio Electrónico. Aspectos jurídicos bancarios”, cit., pág. 560.
} 
conformidad del producto con el contrato en el sentido de que el consumidor acreditar la existencia del daño y la intervención del demandado en su producción ${ }^{680}$.

g) En cuestiones derivadas del uso de la banca electrónica, la prueba recae al igual que en los supuestos anteriores, en la entidad bancaria que tratará de ver exonerada su responsabilidad, acreditando para ello que su dirección web es segura, debiendo el cliente probar que el equipo desde el que ha accedido también lo es 681 .

En relación a ello, la S. no 126/2008 del Juzgado de Primera Instancia no 2 de Castellón de 25 de junio de 2008 (TOL 1.378.694) reconoció que la banca electrónica se desarrolla por medio del comercio electrónico y de la firma electrónica reconocida, siendo el principal problema probatorio el de la existencia de las declaraciones de voluntad que dan lugar al contrato cuando se llevan a cabo con un medio intangible como el electrónico.

Existe alguna excepción en que la prueba recae sobre la persona física demandada en los casos en que el uso del medio telemático de pago sea utilizado con fines distintos a los de mero consumidor; así, la S. no 218/2010 de la Sec. 9a de la AP Valencia de 19 de julio de 2010 (TOL 1.962.016) en el supuesto de una transferencia realizada a través de la banca electrónica entendió, puesto que la transferencia se realizó dentro de su actividad y no como consumidor, que no era de aplicación el TRLGDCU y por tanto, no existía inversión de la carga de la prueba.

\section{B. PARTI CI PACIONES PREFERENTES, SWAPS, OBLIGACIONES, DEUDA SUBORDINADA Y ACCIONES DE BANKI A}

Es conveniente realizar una breve referencia a la normativa básica de aplicación a los diferentes productos que han generado el aluvión de sentencias de estos últimos años en temas financieros, a

\footnotetext{
${ }^{680}$ Ejemplo de ello es la S. $n^{o}$ 8/2015, Sec. $1^{\text {a }}$ AP Zamora de 22-01-2015 (TOL 4.738.032) en la compra de un vehículo mediante leasing, considera que al consumidor le corresponde únicamente acreditar la producción del vicio pudiendo presumirse que todo defecto acaecido durante el tiempo de garantía es originario, salvo prueba en contrario. Entiende además que al comprador le basta con probar la existencia de la avería y es el vendedor quien debe acreditar que la misma no es debida a defectos del vehículo.

${ }^{681}$ Álvarez Vega, M.I. "La protección jurídica del consumidor sobre endeudado e insolvente”, cit., Ed.: Aranzadi, S.A., Pamplona 2010, pág. 404.
} 
la regulación legal tanto de los tipos de clientes como de las obligaciones impuestas a la entidad bancaria, para después analizar las cuestiones que deben ser probadas en el proceso y a quién corresponde su prueba.

La Ley 19/2003, de 4 de julio, de régimen jurídico de los movimientos de capitales de las transacciones económicas con el exterior y sobre determinadas medidas de prevención del blanqueo de capitales, introdujo la Disposición Adicional Segunda y recoge por primera vez una regulación específica de las participaciones preferentes como recursos propios.

Esta ley es modificada por el art. 1.10 de la Ley 6/2011, de 11 de abril, que transpone a nuestro Derecho la Directiva 2009/111/CE, del Parlamento Europeo y del Consejo, de 16 de septiembre de 2009, regulando las participaciones preferentes, consideradas como valores negociables de naturaleza imprecisa, que más bien parecen responder a un valor de deuda.

Por su parte, la Ley 9/2012, de 14 de noviembre, de estructuración y resolución de entidades de crédito, establece mecanismos voluntarios y obligatorios de gestión de instrumentos híbridos de capital que afectarán tanto a las participaciones preferentes como a la deuda subordinada.

Además de la normativa referida, hemos de hacer alusión a la Directiva 2004/39/CE y a la Directiva 2006/73/CE que junto al Reglamento 1287/2006CE componen las normas conocidas coloquialmente como "MiFID" (Directiva sobre mercados de instrumentos financieros), a través de las cuales se crea un marco jurídico único armonizado en toda la Unión Europea para todos los instrumentos financieros y la prestación de servicios de inversión.

Su transposición al Derecho español se realiza a través de la Ley 47/2007 que modifica la Ley 24/1988, de 28 de julio, del Mercado de Valores (en adelante LMV), y establece en su art. 78 bis la clasificación de los clientes de estos productos en dos categorías: el cliente minorista y el cliente profesional, al objeto de determinar el producto adecuado según sus conocimientos.

Finalmente, la Orden ECC/2316/2015, de 4 de noviembre, relativa a las obligaciones de información y clasificación de productos financieros, que entró en vigor el 5 de febrero de 2016 tiene como 
objetivo garantizar un nivel adecuado de protección al cliente de productos financieros, implantando un sistema normalizado de información y clasificación del riesgo, de forma que cese el aluvión de reclamaciones que la comercialización de estos productos ha generado.

Tal ha sido la avalancha de reclamaciones judiciales generadas que incluso el Ministerio de Justicia se vio obligado a crear plazas de jueces en comisiones de servicio en algunas provincias al objeto de enjuiciar exclusivamente estos asuntos que en su mayoría relativas al error o el vicio en el consentimiento, de modo que, si se acredita su existencia, el contrato queda anulado ${ }^{682}$.

La Comunidad Valenciana ha sido una zona especialmente castigada por la venta de estos productos hasta el punto de que los juzgados de Valencia, según manifestó el 7 de abril de 2016 en rueda de prensa el Juez Decano de Valencia, han tramitado un total de 18000 demandas entre el año 2013 a 2015. Durante el primer año se tramitaron 2000 demandas; durante el 2015 fueron 9700 las demandas tramitadas y en el primer trimestre de 2016 se recibieron más de 4000, con un porcentaje de éxito para el consumidor del $98 \%$.

Los costes que suponen para la entidad bancaria por tener que asumir las costas de estos procesos hacen que incluso los propios jueces se cuestionen el motivo de la continuidad de los procesos por las entidades bancarias.

Además, el gran número de afectados por la compra de estos productos financieros ha generado alarma social entre las asociaciones de consumidores que se han movilizado, al igual que ocurre en cualquier cuestión de consumo que afecte a multitud de consumidores.

Ello motivó el inicio de un protocolo de actuación consensuado entre el gabinete de información de la asociación y el departamento jurídico, de forma que el gabinete iba preparando material probatorio a instancias del jurídico, que servirá de soporte para el desarrollo del posterior proceso, pudiendo llegar a concretarse incluso inspecciones

\footnotetext{
${ }^{682}$ En relación al vicio del consentimiento, la S. nº 683/2012 TS de 21-11-2012 (TOL 2.708.761) y la S. $n^{\circ}$ 660/2012, de 15-11-2012 (TOL 2.698.226) resuelve sobre la anulabilidad de varios contratos de permuta financiera (swaps), entendiendo que existe error del consentimiento cuando la voluntad del contratante para la realización del contrato se forma a partir de una creencia inexacta.
} 
de consumo a las entidades objeto de litigio, levantando el acta de inspección correspondiente.

Por su parte, las asociaciones de consumidores cuentan con profesionales del derecho con una larga experiencia y un sentido claro del objetivo de la concreta prueba a aportar no solo en este tipo de asuntos, sino en todos los supuestos de consumo.

Esta capacidad y experiencia de los profesionales, junto a los medios de que disponen, hace que consigan preparar y documentar el proceso antes de que este se inicie, logrando unos resultados altamente satisfactorios.

El conocimiento previo de qué son cada uno de estos productos supone un paso inicial al objeto de explicar las obligaciones de la entidad bancaria en su comercialización, analizar los tipos de acciones que se pueden interponer y finalmente ver la prueba a presentar y la carga de la misma:

1) Definiendo en primer lugar las participaciones preferentes, se trata de productos complejos, variables, con remuneración periódica alta, que se encuentran a mitad camino entre los valores de renta fija y de renta variable; en definitiva, son fondos captados por terceros con carácter perpetuo cuya remuneración está condicionada a la existencia de beneficios o reservas distribuibles a la entidad de crédito emisora sujeta a condicionantes como la cancelación de pago que pudiera acordar el Banco de España debido a la situación financiera de la entidad y a su solvencia ${ }^{683}$.

2) Las obligaciones subordinadas son productos de renta fija a largo plazo que suelen llevar aparejada una alta rentabilidad pero también un alto riesgo y una baja liquidez. Se trata de un producto complejo, según manifiesta la propia jurisprudencia en sentencias como la no 184/2013 Juzgado de Primera Instancia no 7 de Córdoba de 12 de septiembre de 2013 (TOL 4.124.548) con riesgos superiores a los de una cuenta tradicional, por lo que el perfil del inversor debería ser de cliente especializado con conocimientos financieros.

3) De la misma familia es la deuda subordinada, al tratarse también de títulos valores de renta fija con rendimiento explícito emitidos habitualmente por entidades de crédito y grandes

${ }^{683}$ S. no 163/2013 AP Pontevedra de 4-04-2013 (TOL 3.660.220). 
sociedades en los que el cobro de intereses puede estar condicionado a la existencia de un determinado nivel de beneficios.

4) Por lo que respecta a los contratos de permuta financiera (swaps) ${ }^{684}$, son aquellos contratos bilaterales en los que cada parte se obliga a entregar a la otra según lo pactado, cantidades de dinero determinadas en función de unos parámetros objetivos calculados sobre un capital de referencia invariable ${ }^{685}$ y cuyo valor deriva del precio de una actividad financiera ya existente.

5) Por último, hemos de hacer mención a las demandas por vicio en el consentimiento en la compra de acciones de Bankia, puesto que también han sido objeto de numerosos procesos cuyo origen se encuentra en el incumplimiento de las obligaciones de la entidad emisora para con el cliente establecidas en la LMV 686.

A la necesidad de informar y a los modos de llevar a cabo la información que hemos expresado, en el caso concreto de la venta de las acciones de BANKIA, se facilitó además al cliente un tríptico publicitario de la oferta pública de suscripción y admisión a negociación de las acciones, donde la entidad hacía públicos sus datos financieros y ello, como veremos, fue el motivo para que todas las sentencias dictadas hasta el momento, fueran condenatorias, por vicio en el consentimiento, a la restitución de la cantidad invertida por el consumidor, más los intereses legales y las costas causadas.

Todas las sentencias basaban su decisión en que las afirmaciones vertidas en el propio folleto, donde se publicaba la información sobre el estado contable correspondiente al trimestre cerrado a 31 de marzo de 2011, reconocía un beneficio contable de 309 millones de euros correspondientes al ejercicio 2011, desmentido

\footnotetext{
${ }^{684}$ La jurisprudencia los califica de contratos complejos en sentencias como la de la $\mathrm{n}^{\mathrm{o}} 416 / 2011$, Sec. $7^{\mathrm{a}}$ AP de Asturias de 16-09-2011 (TOL 2.248.031), S. n 274/2011, Sec. $2^{\text {a }}$ AP León de 1-09-2011 (TOL 2.239.999), S. n ${ }^{\circ} 440 / 2010$, Sec. $6^{\text {a }}$ AP La Coruña de 4-11-2010 (TOL 2.037.514), S. $n^{\circ}$ 68/2011, S. $n^{\circ}$ 68/2011, Sec. $1^{\text {a }}$ AP Girona de 18-02-2011 (TOL 2.087.634) o la S. no 178/2011, Sec. $2^{\text {a }}$ AP Badajoz de 17-05-2011 (TOL 2.148.473), entre otras muchas.

${ }^{685}$ Juan Sanjosé, R.J.: “Los contratos de permuta financiera (swaps)”. Revista Jurídica Tirant on line, ${ }^{\circ}$ 4/2013 (TOL 3.536.567).

${ }^{686}$ Podemos hacer alusión a multitud de sentencias, de entre las que destacamos la S. ${ }^{\circ}$ 20/2014, JM n ${ }^{\circ} 1$ Bilbao de 27-01-2014 (TOL 4.078.531), S. n ${ }^{\circ}$ 67/2013 JPI Terrassa de 7-05-2013 (JUR2014/203063), S. $n^{\circ}$ 115/2013, JPI ${ }^{\circ} 25$ de Valencia de 10-06-2013 (TOL 3.795.319), S. ${ }^{\circ} 60 / 2014$, JPI $n^{\circ} 84$ de Madrid de 5-06-2013 (TOL 3.792.322), S. $\mathrm{n}^{\circ}$ 148/2012, JPI n 11 Bilbao de 22-04-2013 (TOL 3.659.615) y la S $\mathrm{n}^{\circ}$ 241/2015 JPI $\mathrm{n}^{\circ} 18$ de Madrid de 16-10-2015 (TOL 5.564.083) en las que se establece el deber de información y las consecuencias de su incumplimiento.
} 
a posteriori por la propia entidad, al solicitar una inyección de capital de 19.000 millones de euros.

Ello llevó a la presentación de un nuevo estado contable y a una reformulación de las cuentas del referido ejercicio ya auditadas, que reflejaban una pérdida de 2979 millones de euros, junto a la petición de intervención el 21 de noviembre de 2011, pasando desde ese momento a ser un banco nacionalizado.

La argumentación sobre la falta de conocimiento real del resultado contable provocó que la jurisprudencia de forma unánime, tanto en sede de primera instancia como de apelación, reconociera la existencia de vicio en el consentimiento y procediera a la anulación de la operación, con el efecto de condenar a la entidad al pago de la cantidad invertida en acciones más los intereses legales y la condena a las costas procesales ${ }^{687}$.

La actuación negligente de BANKIA en su salida a bolsa llevó incluso a que por parte de Sec. 3a de la Sala de lo Penal de la Audiencia Nacional se entendiera que podía existir delito en ella, aunque formalmente cumpliera los requisitos legales establecidos.

Nos referimos al deber de diligencia, transparencia e información, que en el supuesto de las acciones precisa de mayor concreción y documentación, al ser necesaria la entrega de un folleto informativo al objeto de poder evaluar la situación económica de la sociedad anónima que le oferta pasar a ser accionista, contenido que la jurisprudencia ha entendido como determinante para realizar o no la inversión ${ }^{688}$, tal como establece el art. 27 de la LMV y el art. 16 del RD 2010/2005, de 4 de noviembre de 2005, por el que se desarrolla parcialmente la LMV.

Este tipo de operaciones goza además de una garantía jurídica añadida, debido a la función de supervisión y el control de los valores que lleva a cabo la Comisión Nacional del Mercado de Valores. Este sistema de protección incorpora medidas de vigilancia sobre el

\footnotetext{
${ }^{687}$ La S. no 36/2015 JPI no 4 de Tarragona de 5-03-2015 (TOL 4.769.172).

${ }^{688}$ Como ejemplo de ello son muchas las sentencias existentes, fallando la nulidad del contrato de compraventa de acciones por vicio en el consentimiento. Podemos referirnos a la S. no 381/2014, Sec. $9^{a}$ AP Valencia de 29-12-2014 (TOL 4.617.754), la S. no 234/2015 Sec. 3ª AP Castellón 4-09-2015 (TOL 5.560.446).
} 
inversor al objeto de velar por la transparencia del mercado y la correcta formación de los precios.

La falta de cumplimiento de las obligaciones impuestas a la entidad emisora en relación al deber de transparencia que vienen establecidas en el art. 28 de la LMV, comporta la responsabilidad de esta por la información manifestada en el folleto, obligando además al autor del mismo a declarar que los datos son conformes con la realidad sin omitir hechos que por su naturaleza puedan alterar su alcance.

Además de las acciones que a continuación analizaremos, basadas en los vicios o el error del consentimiento, ante el perjuicio causado por la compra de un producto "engañoso" como ha resultado ser el de las acciones de BANKIA, cabe también el ejercicio de forma colectiva de las acciones reguladas en el art. 32 de la LCD, tanto la declarativa de deslealtad como accesoriamente, la de remoción e indemnización ${ }^{689}$.

La cuestión que generó multitud de procesos judiciales en toda España y la movilización de las asociaciones de consumidores se cerró definitivamente tras dos sentencias consecutivas del Pleno de la Sala de lo Civil del Tribunal Supremo dictadas el 3 de febrero de 2016, Sentencias no 23 y 24 (TOL 5.630 .372 y TOL 5.630.373), puesto que aunque su postura mantenía el error en el consentimiento que todas las anteriores habían apreciado, sirvieron para que la propia entidad diera un giro en su posición y admitiera su fracaso, haciendo pública el 17 de febrero de 2016 su decisión de devolver a todos los accionistas el importe de su inversión con el uno por ciento de interés anual.

Entre las obligaciones anunciadas que esta ley impone a las entidades de crédito en relación a todos estos productos, las de diligencia y transparencia ${ }^{690}$ se encuentran recogidas en su art. 79 y 79 bis, debiendo ofrecer una información que además deberá reunir los requisitos de claridad ${ }^{691}$, imparcialidad y veracidad, junto a otros

\footnotetext{
${ }^{689}$ Marimón Durá, R. (Dir.): "La oferta pública de suscripción de acciones desde la perspectiva judicial. Análisis de la OPS de BANKIA 2011”. Ed.: Aranzadi, S.A., Navarra 2016.

${ }^{690}$ S. no $244 / 2013$, TS 18-04-2013 (TOL 3.743.970).

${ }^{691}$ S. $n^{\circ}$ 91/2011, Sec. $5^{\text {a }}$ AP Illes Balears de 21-03-2011 (TOL 2.127.093), S. $n^{\circ}$ 38/14 del JPI $n^{\circ} 4$ de Donostia de 20-02-2014 (JUR2014/218141), S. no 82/2012, Sec. $3^{\text {a }}$ AP Illes Balears de 16-02-2012 (TOL 2.490.158), S. $\mathrm{n}^{\circ}$ 105/2011, Sec. $5^{\mathrm{a}}$ AP Murcia de 1-04-2011 (TOL 2.121.494).
} 
condicionantes como el asesoramiento y gestión de las carteras previa evaluación de la idoneidad y conveniencia del instrumento financiero ${ }^{692}$ que se pretende contratar, debiendo actuar como un ordenado empresario y representante leal de los intereses del cliente ${ }^{693}$.

Sobre la forma en que la entidad bancaria debe ejercer su función de asesoramiento e información al cliente en relación a todos estos productos complejos, ha tenido gran repercusión en la jurisprudencia posterior la S. no 82/2012 de la AP de Baleares de 16 de febrero de 2012 (TOL 2.490.158).

Esta sentencia, siguiendo la Sentencia no 28/2003 TS de 20 de enero de 2003 (TOL 239.735), sobre la obligación de actuar en la transmisión de la información por parte de la entidad bancaria, entiende que esta debe ejercer su profesión como un ordenado empresario y representante leal de los intereses del cliente; por ello, lo fundamental es que la propia entidad se asegure de que el consentimiento se preste de forma válida, sin errores, sin violencia, intimidación o dolo, debiendo procurar que la información exista ya

${ }^{692}$ Añón Calvete, J.: “Participaciones preferentes, vicios del consentimiento”. Revista Jurídica no 10/2013 (TOL 3.982.019).

${ }^{693}$ S. $\mathrm{n}^{\circ}$ 220/2015 del JPI $\mathrm{n}^{\circ} 5$ de Torrent de 13-10-2015 (ECLI:ES:JPI:2015:174) valora todas las circunstancias concurrentes en relación a las características del cliente y del producto, puestas en relación con todas las obligaciones que la legislación sobre productos financieros y las garantías que deben otorgarse al cliente minorista.

Por tanto, la juzgadora basa su decisión en la prueba sobre la correcta información que debe justificar la entidad bancaria, teniendo en cuenta la diligencia que debe presidir el asesoramiento al cliente que según jurisprudencia reiterada entre la que destaca la más antigua del TS de 14-11-2005, debe mostrar la diligencia del ordenado empresario y representante leal en defensa de los intereses de los clientes debiéndose acoger el clausulado a los dispuesto en el art. 8 de la LCGC sobre claridad, sencillez, buena fe $\mathrm{y}$ justo equilibrio de las prestaciones.

Al haber transcurrido tantos años se desconoce por el testigo la información facilitada a la cliente por tanto, la juzgadora desconoce la información que a esta se le facilitó puesto que solo consta como documental al recompra de las obligaciones y su canje por acciones entiende que es nula la operación porque falta el consentimiento de la actora, que difícilmente sabe escribir, nunca ha efectuado operaciones financieras y pese a que la parte demandada alegó caducidad de la acción por tratarse de una operación formalizada en el año 1991, la juzgadora entiende que el ejercicio de esta acción es imprescriptible.

Pese a que según alega la demandada, se produjo un canje de las obligaciones subordinadas por acciones de BANKIA en marzo de 2012 y ello supondría confirmación del primer contrato, no lo ha entendido de este modo la juzgadora puesto que puesto que el canje que se le ofreció era obligatorio y su aceptación no fue un acto libre debiendo exigirse además como requisito de validez que el vicio que originó la invalidez del primer contrato haya cesado, por tanto, entiende que la nulidad de la compra conlleva la nulidad del canje posterior por acciones de Bankia. 
en fase precontractual para que despliegue su eficacia en las distintas fases del mismo ${ }^{694}$.

Por tanto, la entidad comercializadora del producto debe actuar en el asesoramiento que presta con la referida diligencia exigible a un ordenado empresario y representante leal en defensa de los intereses de sus clientes. Ya en la fase pre contractual debe procurarse al contratante una información clara y precisa para que entienda el producto o servicio que pueda contratar ${ }^{695}$, debiendo ser la propia entidad la que acredite el cumplimiento de tal extremo.

También en relación a la información facilitada por la entidad, el Real Decreto 217/2008 establece la necesidad de que el asesoramiento al cliente previo a la adquisición de un producto financiero sea personalizado, anteponiendo el interés del cliente al suyo propio ${ }^{696}$

Esta información contendrá todos los aspectos necesarios para que pueda adoptar la decisión sobre la adquisición del producto, debiendo ser facilitada además con suficiente antelación a la celebración del contrato, entregándose una copia del mismo ${ }^{697}$.

A su vez, la información a facilitar por la entidad bancaria al cliente dependerá de la consideración del mismo, ya que la Directiva realiza una clasificación en tres tipos: el cliente minorista, que es el que se ha visto afectado por la venta masiva de los productos que estamos analizando, al cual la Directiva le dispensa un nivel máximo de protección, o un cliente profesional, entendido por tal aquel que se dedique de forma profesional a actividades de inversión, como instituciones de inversión, grandes empresas, cuyo balance sea de 20

\footnotetext{
${ }^{694} \mathrm{El}$ deber de información está en relación al perfil del inversor y al conocimiento de la operación que este posea, tal como ha manifestado la S. no 458/2014 de 8-09-2014 del Pleno TS (TOL 4.522.848) desestimó el recurso por considerar a la demandante inversora de riesgo, conocedora del producto y por tanto en este caso concreto, carece de relevancia si se le informó dado que era conocedora de las condiciones.

${ }^{695}$ S. $n^{\circ}$ 278/2011, Sec. $5^{\text {a }}$ AP Illes Balears de 2-09-2011 (TOL 2.236.929), S. no 289/2011 JPI $n^{\circ} 13$ Barcelona 4-04-2012 (TOL 2.516.336), S. Sec. $4^{\text {a }}$ AP Zaragoza 10-05-2013 (TOL 3.864.365), S. $n^{\circ}$ 428/2011, Sec. $7^{\mathrm{a}}$ AP Asturias 26-09-2011 (TOL 2.268.094), S. $n^{\circ}$ 278/2011, Sec. $5^{\mathrm{a}}$ AP Palma de Mallorca de 2-09-2011 (TOL 2.236.929).

${ }^{696}$ S. JPI no 13 de Barcelona de 4-04-2012 (TOL 2.516.336).

${ }^{697}$ S. $n^{\circ}$ 30/13 Sec. $1^{\text {a }}$ AP Santa Cruz de Tenerife de 24-1-2013 (TOL 3.710.673), S. $n^{\circ} 163 / 2013$, Sec. $1^{\text {a }}$ AP Pontevedra de 4-04-13 (TOL 3.660.221), S. TS 244/2013 de 18-04-2013 (TOL 3.745.892) entiende esta última que no se suministra una información completa y clara al inversor ni se actúa de buena fe si no se ofrece una información completa y veraz del producto.
} 
millones de euros y su volumen de negocio de 40 millones de euros, estando en último lugar una categoría denominada "Contraparte Elegible", que se refiere a aquellos clientes que tienen los máximos conocimientos, experiencia y capacidad financiera.

Centrando nuestra atención en el cliente minorista, el deber de información exigible en todos los productos referidos se fundamenta en la necesidad de acreditación, que pasa además por la realización de la dos tipos de tests que deben llevarse a cabo según las normas de la Directiva MiFID: el de conveniencia y el de idoneidad de los que hablaremos a continuación; en cambio, del cliente profesional se presume su experiencia, conocimientos y cualificación necesaria para tomar sus propias decisiones de inversión ${ }^{698}$.

El contenido de los referidos tests se encuentra regulado en los arts. 72 y 73 del Real Decreto 217/2008, de 15 de febrero, sobre régimen jurídico de las empresas de servicios de inversión y de las demás entidades que prestan servicios de inversión y por el que se modifica parcialmente el Reglamento de la Ley 35/2003, de 4 de noviembre, de Instituciones de Inversión Colectiva, aprobado por Real Decreto 1309/2005, de 4 de noviembre que valora los conocimientos, estudios, profesión y experiencia en cuanto a frecuencia y volumen de operaciones del cliente con la finalidad de conocer sus competencias en materia financiera.

También se encuentran precisiones sobre su contenido en el Real Decreto Ley 6/2013, de 22 de marzo, de protección a los titulares de determinados productos de ahorro e inversión y otras medidas de carácter financiero; aludiendo concretamente, a la valoración de conocimientos que se llevan a cabo del cliente por medio del test de idoneidad (estudios y profesión) y experiencia (frecuencia y volumen de operaciones del cliente), con la finalidad de que la entidad pueda hacerse una idea de sus competencias en materia financiera ${ }^{699}$.

Las exigencias del denominado test de conveniencia son menores que las del test de idoneidad, el cual opera cuando además

\footnotetext{
${ }^{698}$ Entre las sentencias que podemos mencionar como ejemplo de la necesidad de realización del test de conveniencia se encuentra la no 840/2013 TS de 20-01-2014 (TOL 4.103.965).

${ }^{699}$ La función de ambos tests fue referida por el TS en la S. n 840/2013, ya aludida, de 20-01-2014, donde se distingue la finalidad de ambos tests: el test de conveniencia trata de evaluar si al cliente le interesa o no la contratación, mientras que el de idoneidad trata de determinar la capacidad del cliente de conocer el producto que adquiere.
} 
se ha prestado por la entidad financiera un servicio de asesoramiento en materia de inversiones o de gestión de carteras. En estos casos el banco debe realizar un examen completo del cliente, sumando al test de idoneidad el de conveniencia, mediante la realización de una recomendación personalizada.

La jurisprudencia se muestra unánime, al resolver demandas sobre cualquiera de los productos financieros aludidos, en la necesidad de realizar un examen completo al cliente minorista que sume ambos tests, por tanto, lo primero que valorará el juez de instancia es que estos se hayan realizado, al objeto de conocer de qué tipo de cliente se trata y si estaba en condiciones de entender el producto que adquiría, pues esta valoración es esencial para poder determinar si existía o no vicio del consentimiento ${ }^{700}$.

A través de las propias sentencias se ha ido matizando y concretando la forma adecuada de informar al consumidor, como realiza la S. no 263/2012, Sec. 3ạ AP Guipúzcoa de 19 septiembre de 2012 (TOL 4.342.527), al exigir que la entidad bancaria informe al cliente con claridad, imparcialidad y carencia de engaño, de forma que el cliente alcance a conocer y comprender el contenido de la operación y el riesgo que asume ${ }^{701}$, debiendo además, informar al cliente de los riesgos de la operación antes de la contratación, tal como establece la S. TS no 385/2014, de 7 de julio de 2014 (TOL 4.430.489).

Lo que finalmente llevará al juez a adoptar su decisión será tanto la evaluación del test de conveniencia como el conocimiento del producto, que el cliente no haya padecido error al contratar y tuviera conocimiento de los riesgos asociados al producto.

Dentro de la obligación de informar y junto a la obligatoriedad de los tests referidos, debe ponerse en conocimiento del cliente un informe de situación financiera del producto y de la comercializadora

\footnotetext{
${ }^{700}$ S. no 33/2014 de 6-02-2014 AP Ciudad Real de 6-02-2014 (TOL 4.121.529), S. nº 47/2015 AP Soria de 21-05-2015 (TOL 5.162.720).

${ }^{701}$ En la misma línea podemos también aludir a la S. nº 839/2013 del TS de 2-01-2014 (TOL 4.103.965) que ofrece una interpretación del art. 79 bis apdo. 3 en el sentido de imponer a la entidad bancaria que comercializa productos financieros un deber de información al cliente minorista de forma comprensible y adecuada de tales productos que debe incluir orientaciones y advertencias sobre los riesgos asociados a tales instrumentos, información que es necesaria para que el cliente preste válidamente el consentimiento.
} 
del mismo (ingresos, gastos y patrimonio) así como sus objetivos de inversión (duración prevista, perfil de riesgo y finalidad) ${ }^{702}$.

Este deber de información sobre el informe de situación financiera y la acreditación de haberse llevado a cabo por parte de la entidad bancaria alcanza a todo tipo de clientes, incluidos aquellos con perfil inversor, dado que la entidad bancaria debe prestar además labor de asesoramiento ${ }^{703}$.

La información facilitada ha sido puesta por la jurisprudencia en relación con la declaración de conocimiento firmada por el cliente, aunque este hecho no hace presumir en modo alguno que se ha cumplido con la obligación de informar ni que efectivamente el inversor conozca los riesgos de la operación, tal como establece también el art. 89.1 TRLGDCU.

Como ya hemos manifestado, las demandas sobre estos productos financieros complejos se tramitan mediante el ejercicio de alguna de las acciones contempladas en el C.c. que dan lugar a declarar la nulidad por error o vicio en el consentimiento.

Habitualmente la sentencia que se dicta no se apoya en el TRLGDCU, como tampoco la propia demanda, que se interpone en base a uno de los fundamentos del C.c., salvo que se ejercite la acción del art. 89.1 del mismo. La opción del ejercicio de las acciones contempladas en el C.c. permite al actor disponer de un mayor campo de actuación.

Centrándonos en las consecuencias del incumplimiento de las especificaciones comentadas, estas comportan la posible consideración de la existencia de vicio o error en el consentimiento (el art. 1261 C.c. establece los requisitos esenciales del contrato), cuyos efectos pueden comportar incluso su nulidad (art. 1265 C.c.).

La forma habitual de proceder por los consumidores afectados por este tipo de productos es mediante el ejercicio de varios tipos de

\footnotetext{
${ }^{702}$ Ejemplo de ello es la S. no 381/2014, Sec. $9^{\text {a }}$ AP Valencia de 29-12-2014 (TOL 4.617.754), tomada como referencia por la multitud de resoluciones judiciales posteriores, como la S. no 41/2016, Sec. $5^{\text {a }}$ AP Las Palmas de 5-02-2016 (TOL 5.678.283) o la S. $n^{\circ}$ 109/2016, AP Santander de 22-02-2016 (TOL 5.707.316), que destacan la relevancia de facilitar la suficiente información al consumidor, con especial referencia a los riesgos, a la situación financiera, a los beneficios y pérdidas que se pueden obtener, etc..., con el fin de que el inversor evalúe la situación económica de la sociedad que le oferta pasar a ser accionista.
}

${ }^{703}$ S. no 318/2013, Sec. 4 a AP Granada de 4-10-2013 (TOL 4.037.101). 
acciones, que en muchos de los casos se plantean de forma acumulada y que son siempre iniciadas de forma individual por el consumidor 704 , puesto que en el proceso deben valorarse las circunstancias personales de cada consumidor.

Hemos de detenernos en cada una de las posibles acciones a plantear debido a que la prueba concreta versará sobre los hechos planteados a través de ellas.

\section{a. La acción de nulidad contemplada en el art. 1261 C.c., basada en error del consentimiento.}

Se interpondrá cuando se alegue la falta de alguno de los requisitos necesarios para que se pueda entender formalizado el contrato; nos referimos al consentimiento, al objeto cierto y a la causa de la obligación que se establezca, debiendo determinar si existe error, tal como establece el art. 1265 C.c. y si este es invalidante del consentimiento por no reunir los requisitos establecidos en el art. 1266 C.c.

Esta acción se utiliza en todos los productos financieros definidos, incluidos aquellos en que se pretende la nulidad de los contratos de permuta de tipos de interés que tienen como fundamento el error del consentimiento, debido a una falta de información o incluso por información suministrada erróneamente por las entidades financieras ${ }^{705}$.

Los requisitos de prosperabilidad de la acción se basan en la falta de información al cliente, bien por no haber cumplimentado el test de idoneidad, por haber ofrecido una información genérica cuya nulidad contiene el art. 89.1 del TRLGDCU, por haber facilitado una información ficticia o defectuosa ${ }^{706}$, debiendo tratarse de un error esencial que invalide el consentimiento prestado en la contratación.

\footnotetext{
${ }^{704}$ En relación a la acción individual de nulidad, la S. n n $^{\text {259/2013 JM n }} 3$ de Valencia de 2-12-2013 (TOL 5.493.222) determina que la nulidad de los contratos sobre preferentes solo puede solicitarse en un procedimiento en que se analice cada contrato y las circunstancias propias de la contratación que pueden ser variables debiendo pedirse de forma individual y no a través de una acción colectiva de cesación.

${ }^{705}$ Ejemplo de lo cual es la S. no 1090/2004 TS 12-11-2004 (TOL 513.427).

${ }^{706}$ La S. no 840/2013 TS 20-01-2014 (TOL 4.103.965) analiza la contratación de un swap en relación al error del consentimiento, considerando que la falta de conocimiento del producto contratado y de los riesgos asociados al mismo determina en el cliente minorista que lo contrata una representación mental equivocada sobre el objeto del contrato, además la no realización permite presumir el error del consentimiento.
} 
La existencia del incumplimiento del deber de información no comporta necesariamente el error como vicio del consentimiento, aunque puede incidir en la apreciación del mismo. Para que se considere nulo el contrato, el error debe ser sustancial y recaer sobre el objeto del contrato ${ }^{707}$.

En estos supuestos el tribunal realiza su valoración dependiendo del tipo de error de que se trate: si lo que alega el actor es la falta de información prestada por la entidad bancaria debido a la no realización del test de idoneidad; deberá probar estos extremos para acreditar el incumplimiento del deber de información y por tanto, puede existir el error del consentimiento ${ }^{708}$.

Si la demanda se basa en la información de unos hechos ficticios, una vez acreditado este extremo, serán considerados nulos por el juzgador aquellos contratos de productos en los que se haya facilitado al cliente un formulario tipo, debido a que la información debe ser personalizada y concreta ${ }^{709}$.

La primera sentencia que se dictó en relación a este tipo de acción entendió que debía declararse nulo el contrato de adquisición de participaciones preferentes por inadecuada, falta e insuficiente información por parte de la entidad financiera que provocó error en el contratante, habiendo quedado acreditado que el test no fue veraz ${ }^{710}$.

Un caso especial lo enjuició la S. № 516/2012, Sec. 3a de la AP de Castellón de 26 de octubre de 2012 (TOL 2.675.427), confirmatoria de la S. del Juzgado de Primera Instancia no 4 de Castellón, al declarar la nulidad del contrato de participaciones preferentes concertado con BANKINTER, y decimos especial porque quien contrató el producto fue el hijo del actor, que ya había contratado el mismo en un momento anterior, pero la Sala entendió, pese a tratarse de una persona más joven y con una contratación anterior, que el consentimiento incurría igualmente en un error

\footnotetext{
${ }^{707}$ Debiendo ser la entidad bancaria, según considera la S. no 840/2013 del TS de 20-01-2014 (TOL 4.103.965), la que acredite la realización de los referidos test en los supuestos de productos en que éstos son obligatorios.

${ }^{708}$ S. JPI no 10 Valencia 3-05-2013 (TOL 3.724.808), S. no 61/2014, Sec. $8^{\text {a }}$ AP Valencia de 24-02-2014 (TOL 4.294.231).

${ }^{709}$ En este sentido se han pronunciado sentencias como la n ${ }^{0}$ 72/2014 de la Sec. $1^{\text {a }}$ de la AP Ciudad Real de 21-03-2014 (TOL 4.184.815).

710 La $n^{\circ}$ 83/2012 del JPI $n^{\circ} 1$ de Cambados de 10 de julio de 2012 (disponible en www.icafi.com/docs/noticias/sentencia_preferentes.pdf).
} 
invalidante del negocio jurídico al desconocer el rendimiento del producto, el plazo de duración y la posibilidad de rescate, no habiendo facilitado al cliente toda la información necesaria.

En relación a la última de las posibles causas de nulidad referida, la de deficiente información, esta es razón suficiente para determinar la existencia del error en el consentimiento, como considera entre otras la S. no 20/2014 del Juzgado de lo Mercantil no 1 de Bilbao (AC2014/21) en el llamado "Caso Eroski".

Sobre el error del consentimiento basado en la incorrecta información facilitada en un contrato de permuta financiera (swap), la S. no 840/2014 del Pleno TS de 20 de enero de 2014 (TOL 4.103.965) ${ }^{711}$ analiza el alcance de los deberes de información y asesoramiento desde la perspectiva de la normativa establecida en la Directiva 2004/39/CEE sobre instrumentos financieros, transpuesta al ordenamiento español por la Ley 47/2007, de 19 de diciembre, siendo seguida por la jurisprudencia posterior.

Todas las razones referidas llevan a la determinación del error en el consentimiento que recae sobre las características principales del producto, pudiendo incluso agrupar en una misma demanda más de un motivo de error.

Cuestión también importante es la de las consecuencias que la jurisprudencia concreta al declarar la nulidad del contrato, basándose en varias posturas: la de aquellas sentencias que se orientan a la restitución de la situación anterior, unas apoyándose en el art. 1303 C.c. ${ }^{712}$; otras sin hacer alusión directa al precepto referido determinando la misma consecuencia ${ }^{713}$; y una tercera posición que

\footnotetext{
${ }^{711}$ Esta Sentencia entendió probado que el producto fue ofrecido aprovechando la relación de confianza entre los representantes de la entidad financiera demandada y la sociedad demandante, sin conocimientos financieros específicos y careciendo de los requisitos legales para considerar a la sociedad mercantil como inversor profesional, sin que tampoco se hubiera practicado prueba de la realización del test de conveniencia e idoneidad. La única información precontractual existente eran dos emails cruzados en los que no se informaba del riesgo de la operación, sino que se hablaba del producto como si se tratara de un seguro financiero.

${ }^{712}$ Como la S. no 20/2014, del JM nº 1 de Bilbao de 27 de enero de 2014 (TOL 4.078.531).

${ }^{713}$ Ejemplo de ello es la S. no 105/2011, Sec. 5a de la AP de Murcia de 1 de abril de 2011 (TOL 2.121.494), la S. ${ }^{\circ}$ 428/2012, Sec. $10^{\text {a }}$ AP Madrid de 26 de junio de 2012 (TOL 2.602.632), S. JM n 1 Bilbao de 27-01-2014, S. $n^{\circ}$ 474/14 JPI ${ }^{0} 7$ de Valladolid de 5-02-2014, S. $n^{\circ} 105 / 2011$, Sec. $5^{\text {a }}$ AP Murcia de 1-4-2011 (TOL 2.121.494), S. no 428/2012, Sec. 10 ${ }^{\text {a }}$ AP Madrid 26-06-2012 (TOL 2.602.632), S. Sec. $4^{\text {a }}$ AP Zaragoza 10-05-2013 (TOL 3.864.365), las cuales son ejemplo de que la jurisprudencia todavía no es unánime en relación a la determinación de las consecuencias de la mala praxis.
} 
invoca directamente la necesidad de concretar una indemnización por daños y perjuicios idéntica a la cantidad invertida por el consumidor ${ }^{714}$.

\section{b. Nulidad por dolo civil del art. 1269 C.c.}

Para su apreciación será suficiente acreditar la causa de nulidad basada en el engaño al cliente, abusando de su confianza para venderle un producto perjudicial o con alto riesgo siendo consciente de lo que se ocultaba ${ }^{715}$.

El dolo según lo dispuesto en el art. 1269 C.c., se basa en palabras o maquinaciones insidiosas al objeto de manipular la voluntad de la otra parte, inducida por error provocado. Tales palabras pueden ser de carácter positivo o negativo, cuando manifiestan el dolo además de la insidia o la inducción a una conducta errónea por el otro contratante, así como la reticencia dolosa del que calla u oculta omitiendo hechos o circunstancias influyentes determinantes para la conclusión del contrato ${ }^{716}$.

\section{c. Anulabilidad por defecto de capacidad.}

Se encuentra relacionada con la acción anterior y es posible su interposición cuando se alega falta de capacidad de uno de los contratantes, o cuando concurran vicios del consentimiento como error, dolo o violencia e intimidación del art. 1265 C.c. ${ }^{717}$.

\footnotetext{
${ }^{714}$ Podemos aludir a la S. no 82/2012, Sec. $3^{\text {a }}$ AP Palma Mallorca de 16 de febrero de 2012 (TOL 2.490.158), la no 209/2013 de la Sec. $4^{\text {a }}$ de la AP de Zaragoza de 10 de mayo de 2013 (TOL 3.864.365).

${ }^{715}$ La S. JPI $n^{0} 1$ Mataró de 5-02-2013 (TOL 3.056.293) enjuició un supuesto de dolo civil en participaciones preferentes entendiendo que la conducta pasa de ser no honesta ni transparente a incurrir en responsabilidad cuasi delictual ya que ante un producto complejo dentro del dolo civil incardina la maquinación fraudulenta o la emisión de expresiones insidiosas sin que el cliente hubiera suscrito el contrato cuya anulabilidad se insta.

${ }^{716}$ La S. $n^{\circ}$ 158/2012, Sec. $10^{\text {a }}$ AP Madrid de 26-06- 2012 (TOL 2.602.632), entiende que el hecho de que el actor hubiera adquirido con anterioridad acciones no supone que tenga un manejo y un conocimiento suficiente del mercado financiero como para llegar a la conclusión de que estaba adquiriendo participaciones preferentes ni ser consciente del tipo de riesgo que ello conllevaba.

${ }^{717}$ La S. no 27/2015, Sec. 6a AP Valencia de 5-02-2015 (TOL 4.984.921) declara nula la orden de compra de unas obligaciones subordinadas tras haberse ejercitado la acción de anulabilidad y haber sido declarada en la sentencia dictada en primera instancia al considerar que existe error en el consentimiento debido a que el legal representante de la entidad no tuvo cabal conocimiento del contenido de los contratos.
} 


\section{d. Nulidad por incumplimiento de normativa MI FI D.}

La Directiva 2004/39/CE junto a la Directiva 2006/73/CE y al Reglamento 1287/2006 CE ya aludidos conforman el marco de protección europea de los instrumentos financieros. El incumplimiento de los preceptos que regulan los textos legales referidos podría llegar a producir la nulidad del contrato, basándose a su vez en la Ley 47/2007, de 19 de diciembre, a través de la cual se transpone la Directiva referida y se modifica la LMV ${ }^{718}$.

Aunque la acción se puede plantear por el consumidor en base a esta normativa, en todos los casos, independientemente del tipo de acción elegido, se ha visto vulnerada la misma y todas las resoluciones judiciales analizadas en que el actor es un "cliente minorista", consideran incumplida esta normativa, entienden que existe error en el consentimiento y declaran nulo el negocio jurídico ${ }^{719}$.

\section{e. Nulidad por incumplimiento de la legislación sobre consumo.}

Esta acción se basa en la alegación de que la comercialización del producto supone un engaño al consumidor al vulnerar el art. 8 del TRLGDCU en base al derecho a una información correcta por parte del consumidor sobre el producto que adquiere.

El engaño encuentra su fundamento en la protección del derecho básico del consumidor reconocido constitucionalmente que se concreta en el conocimiento exacto de lo que está adquiriendo y la manifestación de su voluntad indubitada de la contratación realizada, tras la recepción de la información detallada y el cumplimiento de

\footnotetext{
${ }^{718}$ En la línea referida encontramos sentencias como la n ${ }^{\circ}$ 65/2015 de la Sec. $11^{\text {a }}$ AP Madrid de 27-022015 (TOL 4.792.079), la S. $\mathrm{n}^{\circ}$ 177/2014 JPI $\mathrm{n}^{\circ} 23$ Baleares de 30-12-2014 (TOL 4.608.026), S. $\mathrm{n}^{\mathrm{o}}$ 430/2014, Sec. 11 ${ }^{\text {a }}$ AP Valencia de 26-12-2014 (TOL 4.807.254), S. AP León Sec. $1^{\text {a }} n^{0}$ 256/2014 de 9.12- 2014 (TOL 4.710.185).

${ }^{719}$ En relación a este incumplimiento, la S. no 30/2014 de la Sec. 1a AP León de 6-03-2014 (TOL 4.145.923) alude a la S. TJUE de $30-05-2013^{719}$ que interpreta la obligación de la entidad bancaria de evaluar al cliente al prestar un servicio de inversión a un cliente, indicando que el asesoramiento en materia de inversión consiste en la prestación de recomendaciones personalizadas al cliente. Además, la relación se constituye con una parte más débil, que es el consumidor sobre el que van a recaer todos los efectos del servicio.
} 
todos los requisitos, tanto en cuanto a la información, como a la capacidad de comprender la misma ${ }^{720}$.

Además de las acciones referidas, todas ellas encauzadas a obtener la nulidad del contrato, se interponen otro tipo de acciones también acumuladamente, entre las que podemos enumerar las siguientes:

\section{f. Acción subsidiaria por negligencia en el cumplimiento de las obligaciones contractuales.}

Esta acción regulada en el art. 1101 C.c., basada, al contrario de las ya analizadas, en el cumplimiento de su deber de información, pero a consecuencia de la operación se ocasionó un perjuicio al consumidor en el comportamiento manifestado en el desarrollo de la operación ${ }^{721}$.

Para que la acción referida pueda prosperar debe acreditarse que la entidad bancaria cumplió con el deber de información, averiguando a su vez el comportamiento de las partes relativo a la gestación y desarrollo de la "orden de compra" que configura y constituye el germen de lo que se reclama ${ }^{722}$.

La mayoría de estos procesos se ventilan por el juicio ordinario, y en éstos tiene vital importancia el acto de la vista previa, siendo a diferencia de en otro tipo de procesos, primordial la labor que realiza el juzgador en este acto en el sentido de fijar los hechos, dado que la mayoría de demandas no concretan cuestiones importantes y datos relevantes, como las fechas de compra o de venta de los productos financieros.

Por tanto, el acto de la vista previa, si se tramitara por el cauce del juicio ordinario, se aprovecha para concretar información relevante sobre los hechos, además de todas las cuestiones que deben ser tratadas en este acto, como la resolución de la excepción

\footnotetext{
720 Sanjuán y Muñoz, E. (Dir.-coord.), López Jiménez, J.M. (Dir.): "Reclamaciones frente a la comercialización de las participaciones preferentes”. Ed.: Bosch, Barcelona 2013, pág. 143.

721 S. $\mathrm{n}^{\circ}$ 93/2014 del JPI $\mathrm{n}^{\circ} 3$ de Valencia de 2-05-2014 (disponible en www.avacu.es/images/blanca/SentenciaPreferentes02052014\%20.pdf), S. no 46/2014 del JPI $n^{\circ} 46$ de Barcelona de 3-3-2014 (AC 2014/1366).

${ }^{722}$ La S. Sec. 4a AP Zaragoza de 10-05-2013 (TOL 3.864.365) para que el incumplimiento genere la resolución del contrato, debe ser de tal entidad que frustre el contrato en el sentido de la no satisfacción del interés del acreedor.
} 
de caducidad de la acción, que en muchas ocasiones es alegada por la entidad financiera aunque difícilmente prospera.

La fase de proposición culmina con los posibles recursos de las partes y la resolución de los mismos que en la mayoría de casos se resuelven de forma desestimatoria dada la certeza del juzgador al adoptar la decisión de inadmitirlos, sobre todo, por la reiteración de los supuestos que se enjuician.

Es importante también conocer la postura que adoptan los jueces en relación a la falta de prueba, puesto que en muchos procesos la parte actora solicita a la demandada el aporte de ciertos documentos contractuales y esta no los aporta.

Debido a ello, la actora muestra en reiteradas ocasiones su necesidad de aporte, aunque ello no parece relevante para el juzgador, dado que la falta de aporte de la prueba tan sólo fortalecerá la posición del actor y perjudicará a la propia entidad bancaria.

Por ello, el juzgador entiende que o bien no dispone de esa prueba, o le es difícil o imposible encontrarla, sobre todo por los procesos de fusión llevados a cabo en los últimos años, cierre de oficinas, salida de una parte importante de su personal, etc.

La prueba solicitada por la entidad bancaria es muy reducida, sobre todo porque su postura no cuenta con demasiados medios para poder sustentarse, contando con grandes limitaciones que determinan que los letrados de las entidades bancarias se vean con verdaderos problemas en la defensa del cliente.

Sobre a quién corresponde la carga de la prueba ${ }^{723}$, la jurisprudencia es unánime en todos los productos comentados ${ }^{724}$, al entender que la carga de la prueba la ostenta la entidad bancaria ${ }^{725}$,

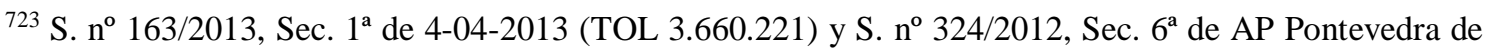
25-04-2012 (TOL 2.540.924).

${ }^{724}$ S. no 1025/2004 TS 27-10-2004 (TOL 514.262) la parte que dispone de la fuente deberá probar. No se trata de una relación de la parte con el hecho sino de la disponibilidad de la fuente de prueba como ya mantuvo la S. TS de 15-11-1991.

${ }^{725}$ Así lo ha entendido la jurisprudencia de forma reiterada y es muestra de ello la S. no 244/2013 dictada por el Pleno del TS, de 18-04-2013 (TOL 3.743.970) al indicar que la carga de la prueba sobre la información facilitada al cliente corre a cargo de la entidad bancaria, ya que de lo contrario estaríamos
} 
puesto que no puede obligarse al cliente a acreditar un hecho negativo ${ }^{726}$; siendo por tanto la entidad bancaria la que debe probar la información facilitada al cliente, tanto sobre estas cuestiones, como en relación al cumplimiento de la obligación de informar al cliente como un ordenado empresario 727 de todas las obligaciones en relación a los productos financieros que comercializa.

En igual sentido deberá ser acreditada por la entidad bancaria la falta, deficiencia, inexactitud, no veracidad de la información, falta de asesoramiento o falta de realización de los tests de conveniencia e idoneidad $^{728}$.

La obligación de prueba de la entidad sobre el cumplimiento del deber de información se extiende también a su contenido, es decir, deberá acreditar que la información facilitada al cliente se corresponde con la real y veraz del producto contratado ${ }^{729}$.

No sólo la jurisprudencia ha establecido la obligación de prueba por parte de la entidad bancaria, sino que el propio Banco de España establece que las entidades financieras deben acreditar las condiciones en las que se realiza la contratación según establece en

provocando que el cliente probara un hecho negativo; también la S. no 16/2013, Sec. 9a AP Valencia de 17-01-2013 (TOL 3.661.340), considerando además fundamental conocer el grado de información que se ha facilitado al cliente para que este proceda a la contratación ${ }^{725}$.

Un ejemplo cercano lo encontramos en la S. $n^{0}$ 61/2015 del JPI no 8 de Castellón de 07-04-2015 (TOL 4.818.332) recaída en una demanda de nulidad por deuda subordinada y participaciones preferentes, que posteriormente fueron canjeadas entiende que la carga de la prueba sobre el deber de informar suficientemente al cliente corresponde a la entidad bancaria, debiendo ser probados todos los requisitos para que proceda su anulación. (www.reclamacionesaccionesbankia.com).

${ }^{726}$ S. no 394/2012, Sec. $1^{\text {a }}$ AP La Rioja de 30-11-2012 (TOL 2.722.917), S. Sec. $1^{\text {a }}$ AP Madrid de 17-012014 (TOL 4.085.258), S. $n^{0}$ 185/2013 del JPI n ${ }^{\circ} 12$ La Coruña de 5-12-2013 (TOL 4.050.019), S. $n^{\circ}$ 65/2014, Sec. $5^{\mathrm{a}}$ AP Asturias 4-03-2014 (TOL 4.186.902), S. nº 82/2014, Sec. $2^{\text {a }}$ AP León de 28-03-2014 (TOL 4.265.569), S. n ${ }^{\circ}$ 98/2014 del JPI no 1 de A Coruña de 14-05-2014 (TOL 4.320.280).

${ }^{727}$ S. $n^{\circ}$ 56/2012, Sec. $5^{\text {a }}$ AP Zaragoza de 3-02-2012 (TOL 2.452.809), S. $n^{\circ} 377 / 2012$, Sec. $4^{\text {a }}$ AP Alicante de 27-09-2012 (TOL 2.650.890).

${ }^{728}$ S. $n^{\circ}$ 190/2014, Sec. $1^{\text {a }}$ AP Cáceres de 15-1-2014 (TOL 4.516.291), S. $n^{\circ} 173 / 2013$, Sec. $2^{\text {a }}$ AP Albacete de 21-10-2013 (TOL 4.010.735), S. JPI Santander de 27-11-2013 (TOL 4.020.964), S. $\mathrm{n}^{\circ}$ 350/2013, Sec. $3^{\text {a }}$ AP San Sebastián de 25-11-2013 (Id Cendoj: 20069370032013100055).

${ }^{729}$ Así lo vemos en la S. no 8/2014, Sec. $1^{\text {a }}$ de la AP de Cáceres de 2-01- 2014 (TOL 4.104.552), en la S. $n^{\circ}$ 531/2011, Sec. $7^{\circ}$ AP Asturias de 21-11- 2011 (TOL 2.298.465), o en la S. $n^{\circ}$ 278/2011, Sec. $5^{\text {a }}$ de la AP de Baleares de 2-09-2011 (TOL 2.236.929) considera que la entidad de crédito por ser el profesional financiero es quien debe probar que facilitó la información previa al consumidor de forma correcta y veraz. En la misma línea se encuentra la S. no 91/2011 de la misma Sec. y Sala de 21-03-2011 (TOL 2.127.093) y la S. $n^{\circ}$ 89/2012, Sec. $5^{\text {a }}$ AP Asturias de 7-03-2012 (TOL 2.501.175), la S. Sec. $3^{\text {a }}$ AP Baleares de 16-02-2012 (TOL 2.490.158), S. no 237/2006, Sec. $6^{\text {a }}$ de la AP Valencia de 26-04-2006 (TOL 1.437.686), S. $n^{\circ}$ 378/2015, Sec. $16^{\mathrm{a}}$ AP Barcelona de 31-07-2015 (TOL 5.505.839). 
su Informe Anual del año 2008, así como justificar que con anterioridad a formalizar la operación se ha facilitado al cliente el documento informativo sobre la cobertura que ofrece con la debida claridad y transparencia que deben ser las inspiradoras de las buenas prácticas bancarias.

Existe además la Circular no 6/2016, de 30 de junio del Banco de España, que aprueba el modelo estandarizado de evaluación del riesgo que a su vez explica la metodología para realizar su evaluación.

Aunque no existe duda alguna sobre la prueba que debe llevar a cabo la entidad bancaria, si el actor alega error en el consentimiento, será válido el mismo si la entidad bancaria acredita que cumplió con el deber de información y asesoramiento correcto ${ }^{730}$. El error debe quedar cumplidamente acreditado junto a las circunstancias que fueron determinantes para considerarlo como tal.

Adentrándonos en la cuestión de qué debe probarse para acreditar la nulidad, será el motivo de la misma, independientemente de la acción que se ejercite. En los procesos en que se alegue falta de información, la jurisprudencia coincide en que deben quedar acreditadas una serie de cuestiones, dependiendo del fundamento de la propia demanda:

1) O bien que la información facilitada por la entidad bancaria a la parte contratante fue deficiente e incompleta y afecta a elementos esenciales del objeto del contrato, como el riesgo asumido y la ocultación de un error del consentimiento ${ }^{731}$.

2) Que la información prestada al cliente es engañosa o falsa y recae sobre aspectos esenciales del contrato que han sido determinantes para su suscripción ${ }^{732}$.

3) Y por último, que la información que recibe genera dudas y oscuridad en el objeto del contrato ${ }^{733}$.

\footnotetext{
${ }^{730}$ La S. no 443/2012, Sec. $6^{\text {a }}$ AP Valencia de 12-07-2012 (TOL 2.679.609), S. $n^{\circ} 61 / 2015$ del JPI ${ }^{\circ} 8$ Castellón de 7 de abril de 2015 (Id Cendoj: 12040420082015100001).

${ }^{731}$ S. no 377/2012, Sec. 4 AP Alicante de 27-09-2012 (TOL 2.650.890).

${ }^{732}$ S. JPI n 1 Cambados de 10-07-2012 (TOL 2.585.052).

${ }^{733}$ S. no 73/2012, JPI no 4 de Castellón, de 4-04- 2012 (TOL 2.603.271).
} 
Los concretos medios de prueba aportados se concretan en las diversas posiciones del actor: si lo que pretende probar el actor es 0 bien el desconocimiento del producto por el cliente pese a haberlo contratado, o la falta de capacidad para poder conocer el producto, o finalmente, su perfil de ahorrador minorista, lo acreditará, bien basándose en el argumento de la confianza con el empleado para realizar la contratación, bien en la falta de información, o en la falta de capacidad para entender el tipo de producto que contrataba ${ }^{734}$.

La parte demandada por su parte basa su posición en el consentimiento prestado por el actor, en la información facilitada, así como en la capacidad de entender y querer del cliente sobre la contratación efectuada.

En ocasiones, debido a la falta de documentación con que cuenta la parte actora, se solicitan unas Diligencias Preliminares al objeto de reunir la prueba mediante requerimiento a la entidad para que aporte la documentación, aunque en ocasiones ni la propia entidad dispone de documentación, tan solo la orden de compra.

Aunque la prueba de la información facilitada recae sobre la entidad bancaria, dado que tiene este deber legal como profesional, cuando la parte actora pretende probar que existió falta de información, aunque le resultará difícil de acreditar al tratarse de un hecho negativo ${ }^{735}$, podrá intentar llevarla cabo de forma indirecta ${ }^{736}$.

Otra cuestión importante en relación a la prueba del deber de información la encontramos cuando el demandado alega que esta no era veraz, en cuyo caso, su acreditación también corresponderá al propio demandado ${ }^{737}$.

\footnotetext{
${ }^{734}$ S. no 363/13 del Juzgado de Primera Instancia de Ponferrada de 29-11-2013 (TOL 4.029.700) entiende que debe probarse si se realizó la clasificación previa de cliente minorista tal como dispone la LMV. En este supuesto no se llevó a cabo, por tanto de ahí entiende la juzgadora que desconocía totalmente el tipo de producto que iba a contratar al igual que la información que recibió sobre el producto contratado, sin que tampoco se le advirtiera del riesgo del producto ni se le mostraran los diferentes escenarios que se pudieran producir, todo ello obtenido de la testifical del empleado de la entidad, del director de la oficina, de la testifical del padre que le acompañó en la contratación y del interrogatorio del propio cliente.

${ }^{735}$ S. no 168/2006, Sec. 9a AP Valencia 26-4-2006 (TOL 1.009.419), S. TS no 769/2014 de 12 de enero de 2015 (TOL 4.712.377).

736 Juan Sanjosé, R.J.: “Los contratos de permuta financiera (swaps)”. Revista Jurídica Tirant on line, Valencia 2013, n ${ }^{\circ}$ 4/2013 (TOL 3.536.567).

${ }^{737}$ Marimón Durá, R. (Dir.): “La oferta pública de suscripción de acciones desde la perspectiva judicial”, cit., pág. 59 y 85.
} 
El juzgador valora en cada caso en particular la información facilitada y el consentimiento prestado, así como el alcance de la declaración de voluntad prestada.

En relación a lo que debe probarse como ya hemos adelantado, dependerá de los fundamentos de las posiciones que ocupe cada parte, siendo los medios de prueba a través de los cuales se apoyan estas posiciones y que se solicitan de forma habitual, la pericial y la documental, junto a los demás medios de prueba, como el interrogatorio de parte, al que en ocasiones se renuncia en el momento anterior a su prestación, y la testifical, bien del empleado de la entidad, o de alguien que acompañó al cliente en la contratación.

Sobre los medios concretos de prueba que son admitidos en la práctica por el juzgador, se encuentran en relación con cada supuesto, aunque tanto para el juzgador como para los profesionales intervinientes son de vital importancia la práctica de las tres pruebas aludidas.

Entre las pruebas mayormente solicitadas destacan los siguientes:

\section{Interrogatorio del actor:}

Se suele solicitar en la mayoría de casos, siendo dirigido a la comprobación de la certeza sobre el desconocimiento que alega en relación a lo que firmaba ${ }^{738}$.

\section{Documental, consistente en:}

a. La orden de compra, que puede ser aportada tanto por el propio actor si obra en su poder, como por la propia entidad bancaria a requerimiento del juzgador en los casos en que esta no haya sido entregada a petición del actor y siempre que haya quedado acreditado que el propio cliente no ha tenido acceso a la prueba que solicita ${ }^{739}$.

b. La certificación de la entidad bancaria acreditativa de una serie de extremos como la clase de producto, el tipo de interés,

\footnotetext{
${ }^{738}$ S.n ${ }^{\circ}$ 144/2013 Sec. $2^{\mathrm{a}}$ AP Navarra de 9-07-2013 (TOL 3.915.178), cit.

${ }^{739}$ S. no 39/2014 JPI no 7 Cáceres de 12-02-2014 (TOL 4.113.561), S. no 68/2012, Sec. 9a AP Valencia de 20-02-2013 (TOL 3.762.847) o la S. no 141/2015 del JPI no 4 de Oviedo de 20-10-2015 (TOL 5.544.083).
} 
la fecha de la contratación y los intereses generados hasta el momento para valorar su evolución ${ }^{740}$.

\section{c. Certificación de la entidad bancaria al objeto de que} aporte los tests de idoneidad y conveniencia practicados al cliente, ello con el objetivo de valorar si se cumplimentaron correctamente, o bien su redacción responde a un patrón genérico ${ }^{741}$.

La admisión de estos medios de prueba dependerá de la justificación por el actor de su petición anterior sin resultado satisfactorio, y de su relación con la compra del producto; por ello entendemos que lo más conveniente sea solicitar la información precisada mediante escrito dirigido a la entidad, acreditando su recepción para poder aportar el documento al proceso.

d. Certificación de los estudios del cliente, que suele aportarse cuando carece de ellos, al objeto de acreditar que no tenía conocimiento real de lo que contrataba ${ }^{742}$.

e. Certificación del estado de salud del cliente en los casos en que este haya podido influir en la contratación, como en supuestos en que se encuentran mermadas sus facultades intelectivas o mentales ${ }^{743}$.

f. Certificación acreditativa del representante de la entidad que realizó la operación con el cliente.

Esta prueba de resultar positiva, puede incluso ser complementada por un informe pericial que aclare el tipo de productos que tenía contratados que incluso se puede ratificar por el propio perito en el acto del juicio.

Pese a ello, no siempre resulta beneficiosa para el consumidor puesto que, de emitirse el certificado por parte de la entidad, no se

\footnotetext{
${ }^{740}$ S. Sec. $1^{\text {a }}$ AP Huelva de 25-04-2012 (TOL 2.540.404), S. no 407/2013 AP Castellón 21-10-2003 (TOL 4.062.014), S. n ${ }^{\circ}$ 363/2013 JPI Ponferrada de 29-11-2013 (TOL 4.029.700), entre otras.

${ }^{741}$ S. $n^{\circ} 7 / 2014$, Sec. $6^{a}$ AP Sevilla de 22-01-2014 (TOL 4.177.218), S. $n^{\circ} 145 / 2012$, Sec. $5^{a}$ AP Las Palmas de 27-03-2012 (TOL 2.564.666) o la S. TS no 563/2015, de 15-10-2015 (TOL 5.533.074).

${ }^{742}$ S. no 595/2015 TS 30-10-2015 (TOL 5.550.327) o S. TS no 742/2015 de 18-12-2015 (TOL 5.596.103).

${ }^{743}$ S. no 633/2015 TS de 13-11-2015 (TOL 5.558.055), S. no 94/2015, Sec. 6 a AP Valencia de 14-04-2015 (TOL 5.214.712).
} 
admitirá además la declaración testifical del propio empleado como testigo donde podría conseguir mayor información ${ }^{744}$.

\section{g. Aportación del tríptico de información entregado al cliente.}

Se trata de una prueba habitual en estos procesos, que ofrece tanto una información relevante al juzgador sobre el tipo de cliente de que se trata, si es un cliente minorista, propietario de plazos fijos, o es un inversor en acciones o en productos similares de otras entidades, como en aras a la acreditación de los productos financieros de que dispone, al objeto de valorar sus características ${ }^{745}$.

h. I nforme elaborado por el Defensor del Pueblo sobre participaciones preferentes en marzo de 2013, accesible a través de la web www.defensordelpueblo.es, donde se realizan recomendaciones ante la situación de miles de pequeños ahorradores.

i. Además de los documentos aludidos, que suelen aportarse en papel, ambas partes, pero sobre todo la entidad bancaria, aportan documentos mediante soporte electrónico como CDs, USBs, cuando se trata de documentos extensos, que pueden ser también sustituidos o acompañados por un escrito del letrado que con el resumen del contenido que incluye ${ }^{746}$.

La admisión de estos medios supone la visualización en el acto del juicio de su contenido a través de un medio de reproducción (ipad, libro electrónico, ordenador portátil, etc.).

En cuanto a las formas de aportar la información, la más habitual es su solicitud a través de Oficio al Registro Central de Entidades y a la Agencia tributaria.

Entendemos que la solicitud de esta información debe realizarse mediante oficio, solicitando que se oficie directamente a la AEAT, y, subsidiariamente de no admitirse, se solicite a través del Punto

\footnotetext{
${ }^{744}$ S. no 563/2015 TS 15-10-2015 (TOL 5.533.074).

${ }^{745}$ En este sentido es relevante la S. no 188/2014, Sec. 9a de la AP de Valencia de 23-06-2014 (TOL 4.523.097).

${ }^{746}$ S. no 491/2015 Pleno TS de 22-07-2015 (TOL 5.438.433).
} 
Neutro del juzgado, debiendo argumentarse la importancia del mismo al objeto de concretar si existe o no error en el consentimiento.

Este oficio no siempre es admitido por el juzgador debido a que el art. 94 de la LGT sólo permite solicitarlo de oficio a la AEAT en ejecuciones específicas.

A pesar de lo manifestado, la solicitud de información sobre el propio cliente a la AEAT es tan frecuente y determinante que la pide el propio juzgado sin necesidad de que deba solicitarla ninguna de las partes.

De practicarse la referida prueba y resultar que el consumidor tenía más productos de las mismas características, se entenderá que no existe el error.

Si esta información no se obtiene a través de los organismos referidos, cabe también su solicitud a través del Punto Neutro del juzgado, pudiendo ser o no admitido por el juzgador.

Las certificaciones que se soliciten a través del juzgado, si se trata de juicio verbal, se recogerán en un escrito anterior al acto de la vista y en el juicio ordinario, en la vista previa.

\section{Testifical, consistente en:}

a) Declaración de los testigos con conocimiento directo en el acto de la contratación, en ningún caso se admite la de testigos que no hayan tenido conocimiento directo ${ }^{747}$.

En relación a esta cuestión incluso se ha dado el caso de que el juez admita la declaración de un testigo que estuvo presente en la compra de parte del producto, pudiendo tan sólo declarar y causar efectos su declaración sobre la parte del producto cuya adquisición presenció.

b) Testifical del empleado de la entidad que comercializó el producto, prueba fundamental para lograr una resolución declarando la nulidad por vicio del consentimiento. Es una prueba de importancia que se admite de forma generalizada, aunque en la práctica se cuenta con escasos detalles sobre la compra y la persona interviniente, pudiendo incluso solicitarse como prueba documental la

${ }^{747}$ S. no 300/2015 Sec. $3^{\text {a }}$ AP Guipúzcoa de 25-11-2015 (TOL 5.602.333). 
acreditación de la persona que comercializó el producto mediante su identificación ${ }^{748}$.

Esta testifical del empleado de la entidad, de poderse realizar y si el testigo afirmara que se facilitó la información al actor en su totalidad y transparencia, no será motivo para considerar suficientemente acreditado este extremo, sobre todo porque en la mayoría de supuestos el propio testigo no recuerda exactamente si contrató con el cliente directamente o lo hizo otro empleado de la oficina.

Si el empleado continúa en activo, la citación para declarar en el acto del juicio se pide que la realice directamente por la propia entidad, salvo en los casos de jubilación, que el juzgador solicita a la entidad bancaria el aporte los datos completos del empleado para ser citado por el propio juzgado.

\section{Pericial, consistente en los siguientes informes:}

a) Informe del Defensor del Pueblo a que hemos aludido en la documental, y que también puede ser aportado como pericial, que es genérico, válido para todos los procesos.

En muchas ocasiones se inadmite por no considerarlo relevante para la resolución del proceso al ser de sobra conocido. Pese a que puede no considerarse necesario por el juzgador, el letrado del consumidor plantea en ocasiones la opción de aportarlo como instructa ${ }^{749}$.

b) Informe de los peritos del Banco de España, en el caso de compra de acciones de BANKIA, aportado habitualmente en CD por ser voluminoso, donde se analizan las irregularidades cometidas en su salida a bolsa, los perjuicios generados a los clientes, el estado contable real y las consideraciones que sobre el particular realiza el propio Banco de España ${ }^{750 .}$

c) El aporte de un Informe Pericial sobre el producto que se adquiere, al objeto de acreditar si medió error o vicio en el

\footnotetext{
${ }^{748}$ S. no 128/2014, Sec. $8^{\text {a }}$ AP Sevilla de 20-05-2014 (TOL 4.483.106).

${ }^{749}$ S. $n^{\circ} 136 / 2013$, Sec. $17^{\text {a }}$ AP Barcelona de 4-05-2015 (TOL 5.22.074), S. $n^{\circ}$ 261/2015, Sec. $4^{\text {a }}$ AP Las Palmas de 14-07-2015 (TOL 5.537.301).

${ }^{750}$ S. no 300/2015, AP Guipúzcoa de 25-11-2015 (TOL5.602.333).
} 
consentimiento del cliente. El informe será ratificado en el acto del juicio sólo en los supuestos en que este sea impugnado ${ }^{751}$.

\section{Reconocimiento judicial, consistente en:}

La solicitud a instancia del demandante de que el juzgador reconozca al propio demandante, al objeto de que pueda realizar una valoración del perfil de cliente de que se trata y las condiciones del mismo para conocer y perfeccionar el contrato objeto de la demanda.

En muchos de estos casos, no ha sido admitido por el juzgador puesto que supone un "interrogatorio encubierto" 752, y en ningún caso se ha practicado a instancias del demandado.

También es posible que el reconocimiento venga solicitado a instancia de la parte demandada, sustentado en el conocimiento preciso por parte del demandante del contenido del contrato y de las características del producto, de modo que no ha lugar a dudas sobre su aceptación y sobre el conocimiento del mismo, para lo cual intenta acreditar la firma en la contratación del producto, su actuación diligente y el perfecto conocimiento del cliente.

Esta prueba, se suele solicitar en la práctica junto a otros medios de prueba, sirviéndose de:

a) El Interrogatorio del actor, solicitado sólo en los casos en que permita acreditar que era consciente de lo que contrataba, lo cual dependerá de su edad, estado de salud y madurez ${ }^{753}$.

b) También acompañado de documental, bien de documentos contractuales firmados por el cliente y los relativos a la información facilitada, o de la certificación sobre los productos financieros que tiene contratados el actor.

Esta prueba es admitida por algunos juzgados, aunque otros consideran, como hemos adelantado, que se trata de un interrogatorio encubierto, argumentando que debió haberse solicitado el informe de parte, pudiendo solicitarlo en ese momento y aportar su acreditación documental.

\footnotetext{
${ }^{751}$ S. no 60/2014, Sec. $3^{\text {a }}$ AP Palma de Mallorca de 17-2-2014 (TOL 4.121.928).

${ }^{752}$ S. JPI n ${ }^{\circ} 1$ de Mataró de 5-02-2012 (TOL 3.024.772).

${ }^{753}$ S. no 144/2013 Sec. $2^{\text {a }}$ AP Navarra de 9-07-2013 (TOL 3.915.178).
} 
La jurisprudencia dictada en estas cuestiones no ha estimado relevante para la resolución de la cuestión la prueba pericial al entender que carece de eficacia para concretar la adecuación de la información facilitada al cliente según las exigencias de la normativa aplicable ${ }^{754}$.

En síntesis, se observa en todos estos procesos una extensa actividad probatoria, tanto la documental como la pericial, la testifical y el reconocimiento judicial cuando este es admitido, sirven para formar la convicción del juzgador sobre la existencia del error en el consentimiento del cliente al realizar la contratación.

La prueba que consideramos más relevante es la declaración testifical, donde podremos obtener respuesta concreta a todas las cuestiones sobre la contratación y la relación directa con el cliente.

${ }^{754}$ S. no 769/2014 TS de 12-01-2015 (TOL 4.712.377), S. n $^{\circ}$ 563/2015 TS de 15-10-2015 (TOL 5.533.074), S. $n^{\circ}$ 306/2013, Sec. $1^{\mathrm{a}}$ AP Lugo de 30-07-2013 (TOL 3.913.360), S. $n^{\circ} 313 / 2016$, Sec. $5^{\mathrm{a}}$ AP Las Palmas 12-07-2016 (TOL 5.845.200). 



\section{Capítulo $X$. PRUeba en el arbitraje de consumo: ESPECIAL REFERENCIA A LA PRUEBA EN EL ARBITRAJE DE TELEFONI A}

El objeto de este capítulo es realizar un breve análisis sobre las formalidades existentes en el sistema arbitral de consumo en relación a la prueba, la forma en que esta se incorpora al proceso y su incidencia en el posterior laudo arbitral.

Es importante destacar en primer lugar que en la práctica los arbitrajes de consumo se dictan en equidad y se fundamentan jurídicamente con preceptos del C.C., el TRLGDCU, y la LEC en lo relativo a las cuestiones procesales.

Tanto el art. 41 del RDAC, como el art. 24 de la LA, establecen los principios de igualdad, audiencia y contradicción que deben regir en las actuaciones arbitrales ${ }^{755}$, así como las reglas del procedimiento probatorio, reguladas en el art. 45 RDAC.

Otros conceptos relacionados con el procedimiento probatorio como son la admisión, pertinencia, utilidad, valoración, práctica de la prueba, se regulan en el art. 25.2 LA y el art. 45 del RD, de forma que todos ellos son propios tanto del arbitraje general como del arbitraje de consumo ${ }^{756}$.

El sistema que vamos a desarrollar en este apartado, de solución extrajudicial de conflictos de consumo, se verá modificado en breve con la aprobación de la Ley sobre solución alternativa de conflictos de consumo, de la que actualmente sólo disponemos de su Anteproyecto.

Esta ley supondrá la transposición al derecho español de la Directiva 2013/11/UE del Parlamento Europeo y del Consejo, de 21 de mayo de 2013, relativa a la resolución alternativa de litigios en materia de consumo y por la que se modifica el Reglamento (CE) № 2006/2004, del Parlamento Europeo y del Consejo, de 27 de octubre de 2004, y la Directiva 2009/22/CE (Directiva sobre resolución alternativa de litigios en materia de consumo).

\footnotetext{
755 González Pillado, E.: “Arbitraje y mediación en materia de consumo”, cit., pág. 49.

${ }^{756}$ González Pillado, E.: “Arbitraje y mediación en materia de consumo”, cit., pág. 53.
} 
El objetivo de este anteproyecto de ley, elaborado por la Subdirección General de Arbitraje y Derechos del Consumidor de la Agencia Española de Consumo, Seguridad Alimentaria y Nutrición (AECOSAN), es garantizar a los consumidores la posible presentación de reclamaciones de consumo ante las entidades de resolución alternativa de conflictos, publicadas específicamente por la Comisión Europea mediante una lista consolidada.

Entendemos que el referido texto normativo no supondrá modificaciones significativas en relación al sistema de resolución extrajudicial de conflictos actualmente vigente, puesto que el objetivo que persigue esta norma es asegurar los procedimientos y garantizar la imparcialidad y transparencia que se consiguen con el sistema actual, salvo la introducción del posible tratamiento de los conflictos transfronterizos por los organismos referidos, que podrán conocer los contratos celebrados a través de internet y también será de aplicación a los servicios financieros.

Las entidades cuya acreditación se llevará a cabo a nivel europeo serán las actuales Juntas Arbitrales de Consumo a las que hemos hecho alusión.

Existen algunas materias que presentan un arbitraje peculiar, como las de competencia desleal y publicidad ilícita que son objeto de resoluciones por parte de la Asociación para la Autorregulación de la Comunicación Comercial ya referida y que acuden en cuanto a la prueba a lo dispuesto en el art. 217.4 LEC, siendo el demandado quien debe probar la licitud de su conducta ${ }^{757}$.

El procedimiento arbitral ${ }^{758}$, desarrollado en tres fases, viene regulado en los arts. 33 y ss del RDAC y en LA tiene como finalidad la resolución con carácter vinculante y ejecutivo de los conflictos que afectan a los derechos legalmente reconocidos de los consumidores 759 .

\footnotetext{
${ }^{757}$ Resoluciones Asociación Autocontrol Comercial de 4-12-2012 y de 10-01-2013, entre otras, accesibles a través de www.confianzaonline.es/consumidores/publicaciones.

${ }^{758}$ Marcos Francisco, D.: “El arbitraje de consumo y sus nuevos retos”. Ed.: Tirant lo Blanch, Valencia 2010, págs. 255 a 284.

${ }^{759}$ San Cristóbal Reales, S.: "El arbitraje de consumo”. Anuario jurídico y económico escurialense, XL (2007), pág. 104.
} 
Tanto si se trata de un arbitraje colectivo, como si se presenta de forma individual, la proposición, admisión y práctica de la prueba sigue los mismos criterios, aunque en el procedimiento colectivo existe la necesidad de realizar el llamamiento previo a los afectados que establece el art. 59.2을 $\operatorname{RDAC}^{760}$.

Su inicio tiene lugar mediante la solicitud de arbitraje, tal como establece el art. 37. 3 a) RDAC, de la que se da traslado a la parte contraria para que formule alegaciones, haciendo alusión a los hechos y aportando la justificación de los mismos, con mención expresa a las pruebas que se proponen. Se procede a continuación en una segunda fase con la admisión y práctica de la prueba, y una última fase de conclusiones y decisión mediante el laudo arbitral ${ }^{761}$.

Aunque en los escritos iniciales de solicitud y oposición, las partes deben concretar sus peticiones, es posible, tal y como establece el art. 43 del RDAC, que estas, en cualquier momento antes de finalizar el trámite de audiencia, puedan modificar o ampliar la solicitud de arbitraje o la contestación de la demanda, pudiendo incluso plantearse reconvención frente a la parte reclamante ${ }^{762}$.

Comparando el procedimiento arbitral con el judicial, vemos que pese a tener puntos en común y remitirse a la LEC en ciertas cuestiones de prueba, difiere del mismo en aspectos puntuales, como en los efectos que produce la falta de contestación, inactividad o incomparecencia injustificada de cualquiera de las partes en alguna fase del procedimiento, puesto que este hecho no impedirá la continuación del proceso y que se dicte el laudo, independientemente de cuál de las partes sea la que no haya comparecido.

Por ello, el silencio, la falta de actividad o la incomparecencia de las partes no se considerará como allanamiento o admisión de los hechos alegados por la otra parte, llegando el procedimiento hasta la resolución.

En el supuesto de que una de las partes no presente prueba y no alegue causa suficiente a juicio de los árbitros, estos podrán

\footnotetext{
${ }^{760}$ Marcos Francisco, D.: “El arbitraje de consumo y sus nuevos retos”, cit., págs. 255 a 284.

${ }^{761}$ González Pillado, E.: “Arbitraje y Mediación en materia de consumo”. Ed.: Tecnos, Madrid 2012, pág. 52.

${ }^{762}$ Florensa i Tomás, C.E., Carrasco Perera, A.: "El arbitraje de consumo. Una nueva dimensión del arbitraje de derecho privado”. Ed.: Tirant lo Blanch, Valencia 2004, epígrafe 4.
} 
continuar el procedimiento y dictar el laudo conforme a las pruebas de que dispongan, tal como establece el art. 31 c) de la LA.

También en materia de prueba tiene gran importancia la naturaleza jurídica del arbitraje, por la diferencia de tratamiento del "modus probandi" con el proceso judicial regulado en el artículo 217.1 de la LEC, en el que los árbitros pueden prescindir de la actividad probatoria de ambas partes, estando en este caso sólo a las alegaciones que estas realicen ${ }^{763}$.

El órgano arbitral goza de mayores facultades que el órgano jurisdiccional en cuanto a las pruebas, aunque no tiene la capacidad coercitiva para que se personen los testigos, los cuales tendrán que acudir voluntariamente.

En cuanto al desarrollo del procedimiento probatorio se regula en el art. 45 del RDAC estableciendo algunas normas específicas como la posible proposición de prueba de oficio por parte del órgano arbitral o la determinación de cuál de las partes tiene que asumir el coste de la prueba ${ }^{764}$.

En la práctica el procedimiento es mucho más sencillo que el judicial y las pruebas que se practican, aunque como veremos, se pueden proponer las mismas que en el proceso judicial, son sobre todo las declaraciones de las partes y la documental.

\section{A. REGLAS DE LA CARGA DE LA PRUEBA.}

En relación a las reglas de la carga de la prueba, se siguen los mismos criterios que en el proceso judicial, todas las resoluciones y laudos analizados ofrecen una postura única, remitiéndose de ser necesario a las reglas $1^{\underline{a}}$ y $2^{\underline{a}}$ del art. 217 de la LEC, considerando fundamental que cada parte pruebe los hechos en que funde su pretensión ${ }^{765}$.

En relación a las consecuencias de los extremos faltos de prueba, las reglas son las mismas que en el proceso judicial, y las

\footnotetext{
763 Velasco Yáñez, R.: “Comentarios a la Nueva Ley de Arbitraje”. Ed.: Tirant lo Blanch, Valencia 2004, pág. 27.

${ }^{764}$ González Pillado, E.: “Arbitraje y Mediación en materia de consumo”, cit., pág. 57.

${ }^{765}$ Laudos Junta Nacional de Arbitraje $\mathrm{n}^{\circ}$ exp.1027/2014, de 9-02-2015, $\mathrm{n}^{\circ}$ exp. 2055/2013, exp. 2042/2013, exp. 2047/2013, de la misma fecha, 17-7-2013, disponible en www.confianzaonline.es/consumidores/publicaciones.
} 
consecuencias negativas de la falta de prueba serán repercutidas a la parte que pudo aportarla y no lo realizó, en base al principio establecido en el art. 1214 C.C., al art. 217 de la LEC y a la doctrina jurisprudencial analizada en anteriores capítulos.

\section{B. EL RECURSO A LAS PRESUNCI ONES.}

Las presunciones ya aludidas en el capítulo anterior son aplicables también en el arbitraje, incluso en los arbitrajes sobre garantías de bienes y servicios de consumo ${ }^{766}$, donde se aplican en relación a las faltas de conformidad, salvo cuando esa presunción sea incompatible con la naturaleza de los bienes o la índole de la falta de conformidad, debiendo ser el actor quien documente la existencia del defecto y su aparición dentro del periodo de garantía ${ }^{767}$.

\section{PROPOSICIÓN.}

Del art. 45.1 RDAC, se deduce que el momento de realizar la proposición de prueba es el de los escritos iniciales, y rige el principio de adquisición procesal, de forma que independientemente de la parte que las aporte, se adquieren para el proceso de forma irrevocable, aunque también cabe, como ya hemos indicado, la proposición de prueba de oficio por el órgano arbitral ${ }^{768}$, debiendo ser llevada a cabo como una facultad complementaria de la actividad probatoria de las partes ${ }^{769}$.

En la práctica, al igual que en el proceso civil, la prueba queda reducida a los extremos que sean contradichos por una de las partes, es decir, a todo aquello sobre lo que exista desacuerdo ente ellas 770.

\footnotetext{
${ }^{766}$ Busto Lago, J.M. (coord.), Álvarez lata, N., Peña López F.: “Reclamaciones de consumo. Derecho de consumo desde la perspectiva del consumidor”, cit., pág. 403.

${ }^{767}$ Laudo recaído en el expediente 1027/2014 de la Junta Nacional de Arbitraje de 9 de febrero de 2015, disponible en www.confianzaonline.es/consumidores/publicaciones, y el Laudo de la Junta Arbitral Nacional de Consumo de 17 de julio de 2013, exp. n 2014/13 (disponible en www.confianzaonline.es).

768 El Sistema Arbitral de Consumo. Tramitación del arbitraje: árbitros, audiencia y pruebas. http://www.facua.org/es/guía.php?Id=118\&capitulo=1071.

${ }^{769}$ San Cristóbal Reales, S.: "El arbitraje de consumo”. Anuario jurídico y económico escurialense, XL (2007), pág. 131.

${ }^{770}$ Gete-Alonso y Calera, M.C.: "Valoración y carga de la prueba en el procedimiento arbitral de consumo (Reclamaciones en el ámbito de la telefonía”. Artículo publicado en www.consumo-inc.gob.es, pág. 41.
} 
El órgano arbitral posee incluso mayor libertad que el Juez para proponer de oficio la práctica de pruebas complementarias que se consideren indispensables para la solución de la controversia ${ }^{771}$, apreciando las circunstancias que concurren en relación a las partes y a la naturaleza de los hechos ${ }^{772}$, pudiendo admitirse otros medios distintos si con ellos pudiera obtenerse la certeza o negativa de los hechos relevantes ${ }^{773}$.

Una vez propuestas las pruebas, para proceder a su admisión los árbitros deberán comprobar su licitud, que se ajustan al objeto del proceso y que su práctica conduce al esclarecimiento de la pretensión.

\section{ADMI SIÓN.}

La admisión dependerá del propio órgano arbitral, como en los procesos judiciales, estando en relación a las alegaciones de hecho discutidos o controvertidos, de forma que la finalidad de la prueba es la ya manifestada de proporcionar al órgano arbitral los elementos necesarios para resolver el asunto, y aportar los medios de prueba en que sustenten sus alegaciones ${ }^{774}$, correspondiendo su admisión al órgano arbitral.

Entrando en los criterios de admisibilidad de la prueba en el arbitraje son los mismos ${ }^{775}$ que en los procedimientos judiciales (pertinencia, utilidad, licitud y aportación potestativa) ${ }^{776}$.

\footnotetext{
${ }^{771}$ Richard González, M., Riaño Brun, I., Rifá Soler, J.M. (coord.): "Estudios sobre Arbitraje de Consumo", cit., pág. 354.

772 Busto Lago, J.M. (coord.), Álvarez lata, N., Peña López F.: "Reclamaciones de consumo. Derecho de consumo desde la perspectiva del consumidor”, cit., pág. 354.

773 Gete-Alonso y Calera, M.C.: "Valoración y carga de la prueba en el procedimiento arbitral de consumo. Reclamaciones en el ámbito de la telefonía”. Artículo publicado en www.consumo-inc.gob.es, pág. 42.

${ }^{774}$ Gete-Alonso y Calera, M.C.: "Valoración y carga de la prueba en el procedimiento arbitral de consumo" (Reclamaciones en el ámbito de la telefonía)". Artículo publicado en www.consumoinc.gob.es, pág. 46.

775 Richard González, M., Riaño Brun, I., Rifá Soler, J.M. (coord.): "Estudios sobre Arbitraje de Consumo”. Ed.: Aranzadi, Pamplona 2011, pág. 282; Richard González, M., Riaño Brun, I., Rifá Soler, J.M. (coord.): “Estudios sobre Arbitraje de Consumo”. Ed.: Aranzadi, Pamplona 2011, pág. 282.

${ }^{776}$ La S. no 192/2003, Sec. 9a AP Valencia de 25-03-2003 (TOL 277.982) entiende que los árbitros no tienen la obligación de admitir y practicar toda la prueba que interesen las partes, pues están facultados legalmente a rechazar las pruebas que no sean pertinentes y admisibles en derecho.
} 
La decisión del órgano arbitral sobre estimación o desestimación de la prueba puede ser impugnada mediante la acción de anulación del laudo ${ }^{777}$.

\section{E. MEDI OS DE PRUEBA.}

Los medios de prueba que pueden aportarse son los mismos que en el proceso judicial, pudiendo admitirse tanto los documentos, como el interrogatorio de parte, la testifical, la pericial, al igual que los medios de reproducción de la palabra, el sonido, la imagen y los demás instrumentos que permitan archivar, reproducir y conocer palabras, datos, cifras y demás operaciones matemáticas relevantes para el procedimiento, incluido el reconocimiento por parte del Colegio Arbitral 778 , siendo los más habituales la documental, tanto electrónica como en forma tradicional, y la pericial.

\section{F. PRÁCTICA DE LA PRUEBA.}

El acuerdo del órgano arbitral sobre la práctica de la prueba será notificado por escrito a las partes con expresión de la fecha, hora y lugar de celebración convocándolas a la práctica de aquellas en las que sea posible su presencia, tal como establece el art. 45.2 RDAC.

En el mismo escrito las convocará para su práctica, con expresión del día, hora y lugar en que deban practicarse, siguiendo los principios de oralidad, inmediación, concentración y publicidad ${ }^{779}$, y se realizará según las reglas establecidas en el RDAC y en lo no dispuesto expresamente por este, por la LEC, sin que esté previsto que se documente el resultado de la prueba practicada ${ }^{780}$.

\footnotetext{
777 González Pillado, E.: “Arbitraje y mediación en materia de consumo”, cit., pág. 62.

778 El Sistema Arbitral de Consumo. Tramitación del arbitraje: árbitros, audiencia y pruebas. http://www.facua.org/es/guía.php?Id=118\&capitulo=1071; Vázquez Barros, S.: "Memento Práctico Francis Lefebvre, Consumo 2010-2011”, cit., pág. 296.

${ }^{779}$ González Pillado, E.: “Arbitraje y Mediación en materia de consumo”, cit., pág. 63; Ormazábal Sánchez, G.: “La iniciativa probatoria del árbitro”, en Gómez Colomer, J.L., Barona Vilar, S., Calderón Cuadrado, M.P. (coord.): "El Derecho Procesal Español del Siglo XX a golpe de tango, Juan Montero Aroca (Liber Amicorum, en homenaje y para celebrar su LXX cumpleaños)”, cit., pág. 680.

${ }^{780}$ Tal extremo no se considera una vulneración de los principios rectores del procedimiento como manifiesta la S. de la Sec. 14ª de la AP de Madrid, de 9 de mayo de 2000 (AC 2000/1989), al entender que el carácter convencional del proceso arbitral permite que el mismo se celebre en su totalidad de forma oral, con o sin documentación de todas o de alguna de sus fases, y si no hay acuerdo, no se entienden infringidos los principios de audiencia, contradicción o defensa.
} 
Habrá casos en que incluso se acudirá al auxilio judicial para llevarla a cabo, como establece el art. 33 de la LA, que podrá consistir en su práctica ante el tribunal, bajo su exclusiva dirección, o bien mediante la adopción por el tribunal de las medidas necesarias para que la prueba se pueda desarrollar ante los árbitros, acordando en este caso las medidas pertinentes para ello ${ }^{781}$, aunque no está claro si estos valorarán la prueba en relación a los criterios de la LEC aplicando las reglas de la prueba tasada.

La forma de practicarla dependerá de cada medio de prueba: concretamente, la documental, tal como establece el art. 37.3 b) RDAC, se debe aportar junto con la propia solicitud ${ }^{782}$; la prueba pericial se solicitará y recabará como informe previo al acto de la comparecencia, y, por lo que respecta a la testifical, se practicará en el acto de la comparecencia.

En el arbitraje electrónico el desarrollo de la prueba se realiza por videoconferencia o cualquier medio técnico que permita identificar y comunicarse directamente con los comparecientes, debiendo estar todas las partes interconectadas a la hora de practicar las pruebas (art. 45.4 RDAC) ${ }^{783}$.

\section{G. ESPECI AL REFERENCI A A LA PRUEBA PERI CI AL.}

Esta prueba será aportada por las propias partes si fue solicitada por ellas, incluso se podrá proponer por ambas de común acuerdo ${ }^{784}$, o solicitarla al órgano arbitral, dependiendo su realización de que el árbitro lo considere admisible.

Lo habitual en la mayoría de supuestos es optar por esta segunda opción y que sea el propio árbitro quien designe el perito, dado que goza de poderes amplios para ello, tal como establece el art. 32.1 a) LA, aunque una parte de la doctrina, como Cubillo López no ha acogido favorablemente el otorgamiento de tan amplios poderes; por el contrario, otros autores como Picó y Junoy o Abel

\footnotetext{
${ }^{781}$ González Pillado, E.: “Arbitraje y mediación en materia de consumo”, cit., pág. 53.

${ }^{782}$ González Pillado, E.: “Arbitraje y mediación en materia de consumo”, cit., pág. 58.

${ }^{783}$ Busto Lago, J.M. (coord.), Álvarez lata, N., Peña López F.: “Reclamaciones de consumo. Derecho de consumo desde la perspectiva del consumidor”. Ed.: Aranzadi, S.A., Pamplona 2010, pág. 400.

${ }^{784}$ González Pillado, E.: “Arbitraje y Mediación en materia de consumo”, cit., pág. 71.
} 
LLuch entienden positivamente tan amplias facultades, sin que por ello se haga peligrar su imparcialidad.

El nombramiento del perito se realiza de forma sencilla y directa respetando los principios de inmediación, audiencia y contradicción, y se le facilitarán todos los elementos necesarios, documentos u objetos para poder realizar la pericia.

En la práctica también es posible encontrarnos con informes de ambas partes, en cuyo caso, lo habitual es que sean contradictorios, y el árbitro decidirá sobre la conveniencia de solicitar un tercer informe ${ }^{785}$.

Lo más adecuado si se pretende acudir al perito de parte, para evitar alargar el proceso y generar costes, sería que las propias partes nombraran un perito común, atendiendo al tipo de pericia y al caso concreto, satisfaciendo los honorarios ambas por mitad ${ }^{786}$.

También es habitual que la junta arbitral, los árbitros o las partes insten la emisión de un informe, dictamen o recomendación de la Comisión de las Juntas Arbitrales de Consumo que sirva de apoyo a los árbitros en el ejercicio de sus funciones, que puede ser utilizado como medio de prueba o como consulta ante cualquier cuestión que se plantee dentro del proceso ${ }^{787}$.

Su variante más utilizada en la actualidad es la pericial tecnológica 788 , fundamental en el arbitraje, sobre todo en el internacional, que deberá practicarse cuando sean necesarios conocimientos especializados ${ }^{789}$.

Una vez aportado el dictamen, o incluso tras la declaración del perito en la audiencia prevista para la práctica de las pruebas, se analizará, interpretará y valorará por el órgano arbitral, aunque

\footnotetext{
${ }^{785}$ González Pillado, E.: “Arbitraje y mediación en materia de consumo”, cit., pág. 79.

${ }^{786}$ González Pillado, E.: “Arbitraje y Mediación en materia de consumo”, cit., pág. 71.

${ }^{787}$ Marín López, M.J.: “Análisis del Real Decreto 231/2008, de 15 de febrero que regula el sistema arbitral de consumo". Revista del Centro de Estudios de Consumo de la Universidad de Castilla-La Mancha, disponible en www.uclm.es/cesco, pág. 3.

${ }^{788}$ González Pillado, E.: “Arbitraje y Mediación en materia de consumo”, cit., pág. 79.

${ }^{789}$ González Pillado, E.: “Arbitraje y mediación en materia de consumo”, cit., pág. 78.
} 
también puede suceder que sin realizar valoración alguna, se limite a dictar el laudo en los términos expuestos en el informe pericial ${ }^{790}$.

\section{H. COSTE DE LA ACTI VI DAD PROBATORIA.}

En cuanto a los gastos ocasionados por la práctica de las pruebas solicitadas por las partes, salvo que el órgano arbitral acuerde un reparto distinto, corren a cargo de la parte que las haya propuesto.

Existe una excepción a esta regla general para el supuesto que el órgano arbitral entienda que ha existido mala fe o temeridad por alguna de las partes, pudiendo en estos casos a través del laudo arbitral, realizarse la distribución del coste de las pruebas de otro modo, a criterio del propio órgano.

De haberse acordado de oficio la práctica de la prueba pericial, será costeada por la Junta Arbitral de Consumo o por la administración de quien dependa y debe limitarse a los hechos discutidos ${ }^{791}$, tal como establece el art. 45.3 RDAC, debido a la existencia de conciertos con entidades públicas como universidades, organismos dependientes de la administración autonómica ${ }^{792}$.

\section{VALORACIÓN DE LA PRUEBA EN EL ARBITRAJE.}

En cuanto a la valoración de la prueba en el arbitraje es libre ${ }^{793}$ no existe obligatoriedad de ajustar la resolución a lo probado dado que no existe ninguna norma específica que lo regule, deberá estar contenida en el laudo para motivarlo pero no existe norma que la oriente, se realizará empleando criterios racionales así como las

\footnotetext{
${ }^{790}$ González Pillado, E.: “Arbitraje y Mediación en materia de consumo”, cit., pág. 80.

791 Ormazábal Sánchez, G.: “La iniciativa probatoria del árbitro”, en Gómez Colomer, J.L., Barona Vilar, S., Calderón Cuadrado, M.P. (coords.): "El Derecho Procesal Español del Siglo XX a golpe de tango, Juan Montero Aroca (Liber Amicorum, en homenaje y para celebrar su LXX cumpleaños)”, cit., pág. 683.

${ }^{792}$ Marín López, M.J.: “Análisis del Real Decreto 231/2008, de 15 de febrero que regula el sistema arbitral de consumo". Revista del Centro de Estudios de Consumo de la Universidad de Castilla-La Mancha, disponible en www.uclm.es/cesco, pág. 3.

${ }^{793}$ Bujosa Badell: “Derecho de los consumidores y usuarios”, cit., pág. 1828.
} 
máximas de la experiencia ${ }^{794}$, no pudiendo revisarse posteriormente por la jurisdicción mediante el procedimiento de anulación ${ }^{795}$.

Es posible incluso que pese a que quede probado un hecho alegado por una de las partes, si la consecuencia del hecho no parece justa al colegio arbitral, como resuelve en equidad, puede no tenerla en cuenta ${ }^{796}$.

\section{J. ESPECIAL RefERENCIA A LA PRUEBA EN EL ARBITRAJe DE TELEFONÍ A.}

Son muy frecuentes, en el ámbito de los consumidores, los conflictos que surgen con las compañías telefónicas. Las reclamaciones que se generan se tramitan ante las Juntas Arbitrales de Consumo, si el uso del servicio es profesional (aunque únicamente están legitimados los autónomos), o ante la Secretaría de Estado de Telecomunicaciones, si el uso es privado.

La forma a través de la cual se iniciará será mediante escrito adjuntando el contrato, si obra en poder del consumidor, y las facturas.

Aunque los afectados en cuestiones de telefonía, deberían basar su reclamación en hechos probados o en indicios que permitan confirmar las alegaciones de las partes, suelen acudir a un arbitraje de equidad, presentando simplemente la factura, sobre todo en reclamaciones por excesos de facturación, que es el documento que impugna el usuario, sin aportar el contrato, careciendo de asesoramiento y desconociendo la labor probatoria que deben practicar, limitándose en la fase de alegaciones a volver a hacer mención a lo narrado en la propia reclamación.

Lo lógico desde el punto de vista procedimental sería que la parte reclamante aportara alguna prueba que justificara su reclamación. Por ejemplo, en el supuesto de facturación de llamadas no realizadas o de facturación de cualquier tipo de servicio telefónico,

\footnotetext{
${ }^{794}$ González Pillado, E.: “Arbitraje y Mediación en materia de consumo”, cit., pág. 53; Gete-Alonso y Calera, M.C.: "Valoración y carga de la prueba en el procedimiento arbitral de consumo" (Reclamaciones en el ámbito de la telefonía”. Artículo publicado en www.consumo-inc.gob.es, pág. 45.

795 Busto Lago, J.M. (coord.), Álvarez lata, N., Peña López F.: "Reclamaciones de consumo. Derecho de consumo desde la perspectiva del consumidor”, cit., pág. 540; S. n 1 14/2012, Sec. $13^{\text {a }}$ A.P. Madrid de 2701-2012 (TOL 2.490.466).

${ }^{796}$ San Cristóbal Reales, S.: "El arbitraje de consumo”. Anuario jurídico y económico escurialense, XL (2007), pág. 132.
} 
el certificado de empadronamiento con el que acreditar las personas que habitan en la vivienda y tienen acceso a la línea. Ello sería una prueba importante en caso de tratarse de línea fija, o bien la prueba de la ausencia del domicilio en esas fechas, mediante facturas de hotel, justificantes de horarios de trabajo, etc.

Pese a la facilidad que supondría para el consumidor el aporte de los documentos aludidos, en la práctica no se aporta prueba alguna, limitándose a expresar los motivos sin su acreditación.

Otros documentos que pueden ser presentados en estas reclamaciones de telefonía pueden ser las certificaciones donde consten las llamadas y horas junto a algún documento que acredite que estaba en otro lugar en ese momento, como recibos de autopista o de pagos mediante tarjetas de crédito.

La prueba concreta que deberá aportar la demandada, al igual que sucedería si la vía de reclamación fuera la judicial, se funda en los documentos o registros que posee o que conoce que se encuentran recogidos en grabaciones. Por lo general los datos de las declaraciones con la información facilitada de la compañía no se aportan al proceso, sólo los datos de las manifestaciones orales y raramente se acude a documentos elaborados por terceros.

En las cuestiones más reclamadas, como la aludida sobre facturación de servicios telefónicos, la S. AP Alicante de 4 de marzo de 2002 (TOL 160.602) considera que la prueba que deberá aportar la Compañía telefónica versará sobre la acreditación de la realidad de los cargos efectuados al usuario, pudiendo a su vez el usuario presentar prueba en contrario.

Lo que no será objeto de prueba en este tipo de reclamaciones por facturación de servicios telefónicos es la existencia o no del contrato o del terminal o el derecho de la empresa a exigir el pago de los servicios, debiendo acreditarse únicamente si se han realizado o no las llamadas y si su realización se conoce o admite ${ }^{797}$.

En los casos en que se trate de reclamación relacionada con la propia contratación, los extremos que deben probarse son los relativos a la contratación realizada, a la información previa facilitada

\footnotetext{
797 Gete-Alonso y Calera, M.C.: "Valoración y carga de la prueba en el procedimiento arbitral de consumo" (Reclamaciones en el ámbito de la telefonía". Artículo publicado en www.consumo-inc.gob.es, pág. 41.
} 
sobre el clausulado del contrato, a la entrega al consumidor de las condiciones generales, así como la correspondencia entre la información, entrega y justificación documental realizada en el momento de los envíos ${ }^{798}$, debiendo estos ser acreditados por el operador, donde el demandante sólo deberá justificar su posición ${ }^{799}$.

Si nos encontramos en supuestos de dificultad de prueba, se podrá invertir su carga al objeto de que recaiga sobre la parte que tenga mayor facilidad para llevarla a cabo, debiendo el demandado demostrar extremos tales como que no ha tenido lugar la llamada o que el servicio no ha sido regular.

Pese a que la prueba que resulta más apropiada es la pericial, esta no suele practicarse, limitándose al interrogatorio de las partes, no suele tampoco acudirse a la prueba de reconocimiento o a la testifical.

Concretamente, la testifical no se practica en la mayor parte de los casos por la dificultad o imposibilidad de existencia, ya que no se concede credibilidad tanto por parte del órgano arbitral, como en el proceso judicial, a las manifestaciones que puedan efectuar las personas que acompañan al demandante en el acto de la contratación o tengan constancia de ella.

En cambio, sí que resultaría admitida la certificación de un tercero que permitiera valorar la imposibilidad de que el reclamante en el momento de realizarse las llamadas hubiera tenido acceso a la línea telefónica, aunque esta prueba solo alcanzaría al reclamante y no a los demás miembros de su familia.

La carga de la prueba recae sobre la compañía debido a que esta dispone de importantes medios técnicos y posibilidad de acceso a los registros correspondientes, a diferencia del consumidor.

Por su parte, a la compañía le corresponde la verificación de todos los elementos relacionados con la línea telefónica que puedan comportar un defectuoso funcionamiento o un uso ilegitimo e informar de su resultado al cliente acompañando la oportuna copia de

\footnotetext{
798 Mendoza Losana, A.I.: "Particularidades de la contratación de servicios de telecomunicaciones por vía telefónica”, cit., pág. 10.

${ }^{799}$ Gete-Alonso y Calera, M.C.: "Valoración y carga de la prueba en el procedimiento arbitral de consumo" (Reclamaciones en el ámbito de la telefonía)". Artículo publicado en www.consumoinc.gob.es, pág. 47.
} 
las inspecciones técnicas realizadas, documento que por su grado de detalle permitirá al órgano arbitral ponderar todas las posibilidades que puedan dar lugar a un defectuoso funcionamiento o a un uso ilícito por terceros explicando las razones técnicas por las que se trata ${ }^{800}$.

Cuestión distinta es la consideración de la referida factura por el propio órgano arbitral, que la valora como un documento unilateral del demandado en el que no ha intervenido el reclamante, y que ni siquiera le merece la calificación jurídica de documento ${ }^{801}$, otorgándole tan solo valor como indicio de prueba por escrito.

\footnotetext{
${ }^{800}$ Florensa i Tomás, C.E., Alonso Franco, F., Barreto Rocha, J.C., Carrasco Perera, A., Clavel Vila, M., Cortadas Arbat, R., Díaz Albart, S., Maluquer de Motes Bernet, C.J., Mercadé Merola, M., Padial Albás, A., Sanchidrián,R., torres Sánchez, F. : “El arbitraje de consumo. Una nueva dimensión del arbitraje de derecho privado", cit., pág. 177.

${ }^{801}$ Gete-Alonso y Calera, M.C.: "Valoración y carga de la prueba en el procedimiento arbitral de consumo" (Reclamaciones en el ámbito de la telefonía”. Artículo publicado en www.consumo-inc.gob.es, pág. 42.
} 
CONCLUSI ONES 

PRI MERA. El Derecho de consumo, fundamentado en la idea del reconocimiento de los derechos y de la protección de los consumidores, encuentra su origen en el Tratado de Roma.

A nivel nacional, el texto constitucional junto a las diversas Directivas, Resoluciones, Reglamentos y Decisiones en el ámbito de la Unión Europea ha sido el motor fundamental para el desarrollo de la legislación interna en materia de protección y garantía de los derechos de los consumidores.

Entre la legislación interna destaca el Texto Refundido de la Ley General para Defensa de los Consumidores y Usuarios que regula los derechos básicos de los consumidores, principalmente respecto a la seguridad de los mismos y prevención de daños y al derecho de asociación.

I gualmente, esta norma se refiere a la necesaria creación de un sistema de información, así como al control de los precios, la promoción de ventas, la publicidad o el derecho de desistimiento, además de las obligaciones de los empresarios o fabricantes.

SEGUNDA. La importancia de la protección del consumidor y su desarrollo normativo ha ido creciendo de forma sorprendente, cuyo ejemplo reciente lo encontramos en la promulgación de regulación sectorial y las modificaciones llevadas a cabo en el Texto Refundido de la Ley General para la Defensa de los Consumidores y Usuarios, que han supuesto esfuerzos por regular, concretar y aclarar cuestiones en relación a los derechos de los consumidores en sus diversos ámbitos.

La reciente labor jurisprudencial de la Unión Europea ha resultado fundamental para consolidar muchos de estos derechos tal como se encuentran reconocidos actualmente.

TERCERA. De especial importancia resulta además la regulación que el Texto Refundido de la Ley General para la Defensa de los Consumidores y Usuarios realiza sobre el derecho a la tutela en aras a la protección del consumidor, así como la Ley de Enjuiciamiento Civil, cuyo artículo 11, concreta como legitimados tanto a los perjudicados de forma individual, como la legitimación de las asociaciones de consumidores, de los grupos de afectados, de las entidades habilitadas e incluso del Ministerio Fiscal en defensa de los intereses de los consumidores y usuarios. 
En este aspecto se observa una conciencia clara del Estado sobre la necesidad de proteger los intereses de los consumidores a través de mecanismos concretos de tutela, mediante la vía judicial o acudiendo a otros cauces alternativos de solución de conflictos de consumo, como la mediación y el arbitraje.

Si bien la mediación se encuentra todavía carente de estímulos ciudadanos que propicien su práctica y resulta muy difícil su implantación efectiva; no sucede lo mismo en relación al arbitraje de consumo, el cual se encuentra organizado a nivel institucional y cuenta con las juntas arbitrales como organismos especialmente preparados y eficaces para la resolución de conflictos de consumo.

CUARTA. Independientemente de cuál sea la opción de tutela elegida por el consumidor, es clave en cualquiera de ellas la actividad probatoria, la cual resulta compleja en muchas ocasiones.

Las razones de la dificultad que presenta la prueba se deben a varios factores, entre ellos sus peculiaridades, la forma en que se lleva a cabo la concreta relación de consumo, junto a la posición de inferioridad del consumidor respecto del empresario sobre la prueba, también a la especialización que se requiere para su realización, así como la variada casuística que ofrecen los procesos de consumo.

Los motivos aludidos hacen que la propia ley haya optado por posibilitar la variación de la regla general sobre la carga de la prueba, regulando especialidades y dotando de cierta flexibilidad el aporte de la misma al proceso.

La jurisprudencia, incluso en supuestos en que no se prevé legalmente, también ha tratado de suavizar las reglas generales sobre la carga de la prueba cuando esta resulta compleja para el consumidor por su dificultad de obtención, debido sobre todo a la complejidad existente en la acreditación de los hechos objeto de reclamación y a su elevado coste.

QUI NTA. En aras a la prueba de los hechos alegados por el consumidor, en muchos de estos procesos se precisa la realización de dictámenes periciales como prueba fundamental, sobre todo cuando se trata de determinar la existencia de defectos o concretar las condiciones en que se encuentra el producto, así como para justificar la causa del daño. 
Ello, no obstante, son también aportados como prueba los documentos, tanto en su forma tradicional como a través de medios de reproducción electrónicos.

Especial mención merecen los denominados "sondeos demoscópicos" que se pueden aportar bien como documental o como pericial en procesos en que se encuentran afectados un importante número de consumidores, siendo estos de especial relevancia para valorar cuestiones de impacto o trascendencia en el consumo y en relación al uso de determinada marca.

SEXTA. Al hilo de la especialidad de estos procesos, se observa también la flexibilidad de la jurisprudencia en otros aspectos concretos relacionados con la prueba, admitiendo el recurso a la prueba indiciaria o de presunciones en aras a facilitar la resolución de las cuestiones planteadas.

La aplicación de las presunciones facilita una solución en aquellos procesos en los que es imposible alcanzar prueba directa, sobre todo en cuestiones sobre productos defectuosos, donde hemos encontrado hasta siete tipos de presunciones diferentes.

Nos referimos a las que se aplican en los procesos sobre responsabilidad del productor o prestador del servicio, en el ámbito de la responsabilidad por culpa, incluso si el producto ha desaparecido, tanto para probar el defecto como la relación de causalidad, lo cual también se observa en cuestiones sobre la responsabilidad del fabricante, esta última basada en acreditar si ha existido fuerza mayor, caso fortuito, o culpa del actor, y en supuestos de responsabilidad por actuaciones médicas.

SEPTIMA. Observamos además un matiz de gran importancia que se tiene en consideración en casi todos los supuestos de consumo, que supone la adaptación de las reglas sobre la carga de la prueba según la facilidad y disponibilidad de cada una de las partes.

De este modo, la jurisprudencia entiende que debe ser el consumidor en ciertos casos quien acredite las afirmaciones que realiza, mientras que en otros casos, considera que debe ser el empresario demandado quien debe aportar prueba.

OCTAVA. Junto a los recursos aludidos utilizados tanto por el legislador como por los propios jueces para salvar los obstáculos con 
los que se encuentra el consumidor para probar los concretos hechos, es frecuente recurrir a la inversión de la carga de la prueba, la cual se encuentra recogida en varios preceptos.

Observamos que la inversión de la carga de la prueba se produce en materia de telefonía, en contratos vinculados, cuando se reclama por la defectuosa prestación de un servicio, en cuestiones relativas a contratos celebrados fuera de establecimiento.

También se produce la inversión de la carga de la prueba en la contratación electrónica, donde al demandado le corresponderá probar la veracidad de lo argumentado por el actor en su demanda, así como en cuestiones sobre vicios del consentimiento en la compraventa de viviendas si se alegare incumplimiento del deber de información.

NOVENA. Los casos concretos en los que la prueba corresponde al consumidor se encuentran en aquellos procesos en los que se tramitan cuestiones sobre faltas de conformidad de un producto, o en supuestos en que este pretenda ver reconocido su derecho a una garantía, incluidos aquellos procesos sobre ventas de bienes de segunda mano, en los que debe ser el consumidor quien pruebe el defecto y que este no se ha producido por su uso.

En estos casos la prueba que deberá realizar el demandado estará en relación a que el producto no reúne las condiciones para que la garantía opere o que los defectos fueron causados por el propio consumidor mediando fuerza mayor.

Recaerá también la prueba en el actor cuando se trate sobre condiciones generales de contratación no negociadas, en reclamaciones sobre indemnización, donde el consumidor debe acreditar la relación existente entre los daños producidos y su cuantía, mientras que el vendedor debe acreditar la culpa de la víctima o la interrupción del nexo causal, probando además las circunstancias que le exoneren de la responsabilidad.

En relación a cuestiones sobre indemnización del daño moral, será el consumidor quien deba acreditar su existencia, aunque son escasas las resoluciones favorables, tan solo se observa reconocida en algunos supuestos específicos de daños personales sufridos por algún producto alimenticio y en actos de competencia desleal y propiedad intelectual. 
DÉCI MA. Por su parte, será el demandado quien deba probar en aquellos casos en que se enjuicie el carácter abusivo de una cláusula, así como cuando deba acreditarse el conocimiento del clausulado por parte del consumidor.

También será el demandado en supuestos de responsabilidad médica quien deba acreditar el consentimiento informado, el conocimiento del consumidor de los riesgos y consecuencias de la intervención, así como la actuación diligente del facultativo.

En la mayoría de cuestiones sobre contratación bancaria, la prueba también recae en la entidad demandada. El fundamento de esta obligación se encuentra en este caso, además de en la facilidad de acceso, en la imposibilidad de prueba por el consumidor de un hecho negativo, admitiendo también en estos casos, incluso el recurso a las presunciones.

Por otro lado, existen reclamaciones sobre la existencia de pagos pendientes, las cuales, con carácter excepcional, deberán ser probadas por el consumidor si planteara oposición.

UNDÉCI MA. En relación a los recientes temas surgidos sobre productos financieros, es necesaria la prueba sobre la información facilitada al cliente, debiendo el actor probar el desconocimiento del producto, pese a haberlo contratado, así como su falta de capacidad para conocer el mismo.

En estos procesos, la prueba más importante que se practicará será la documental basada en diversas certificaciones del banco, acreditativas de las condiciones de contratación y clase de producto, el tipo de interés, la fecha de contratación, la realización de los necesarios tests al cliente, la información facilitada y certificados concretos sobre el cliente, que serán aportadas por el mismo en relación a sus estudios o su estado de salud.

DUODÉCIMA. Existen supuestos en los que la prueba puede corresponder a una $u$ otra parte del proceso, como en supuestos sobre el derecho de desistimiento, donde existen cuatro cuestiones objeto de prueba y según ante cuál de ella nos encontremos, la prueba corresponderá al consumidor o al empresario: 
- la primera, la acreditación de la advertencia del empresario sobre el derecho a desistir, cuya carga corresponde al empresario;

- la segunda, la justificación del incumplimiento por el empresario, cuya prueba corresponde al consumidor;

- la tercera, la prueba del ejercicio del desistimiento dentro de plazo, correspondiendo su prueba al consumidor;

- y la cuarta relativa a la justificación de la devolución del producto dentro de plazo, que debe probar el empresario.

DÉCI MOTERCERA. Cuando se producen incidencias en viajes, dependiendo del asunto de que se trate, la prueba puede corresponder al consumidor o al empresario:

- Si se trata de retrasos de las compañías aéreas, la carga de la prueba recae sobre la propia compañía; si se trata de pérdida de maletas, una vez concretada la culpa de la compañía, será el consumidor quien deberá acreditar la valoración de los enseres contenidos en su equipaje.

- Si por el contrario existe extravío del equipaje, pero se trata de un viaje combinado, la carga de la prueba de la pérdida del equipaje corresponderá a la compañía en caso de desconocimiento del trayecto en que se perdió el mismo.

- En otro tipo de cuestiones como el derecho de desistimiento de un vuelo, la carga de la prueba sobre el motivo que le imposibilita a viajar, corresponde al consumidor.

- En otras cuestiones sobre daños indemnizables será el propio consumidor quien deberá acreditar tanto el daño como su cuantificación y responsabilidad.

- Respecto a determinadas cláusulas existentes en contratos de transporte aéreo, la prueba se basará en la documentación contractual de las partes, y será la parte que firme determinada condición general la que aporte prueba de ello.

DÉCIMOCUARTA. En otro tipo de procesos como los de competencia desleal, publicidad ilícita y cuestiones sobre uso indebido 
de una marca en una campaña publicitaria de google por internet, también se ha matizado la regla sobre la carga de la prueba establecida en la Ley de Enjuiciamiento Civil atendiendo al caso concreto, siendo el objeto de prueba la veracidad de las afirmaciones realizadas y la similitud de ambas marcas, pudiéndose declarar engañosa la publicidad por el simple hecho de que no se aporte prueba acreditativa de lo contrario.

Si además el perjudicado reclama los daños causados por la publicidad ilícita, el demandado podrá aportar prueba en relación a la cuantía de los daños para no verse condenado al pago de una cantidad mayor.

Resulta relevante en estos casos el hecho de que en ciertos supuestos, como en el tratamiento de infracciones del derecho de patente o en procesos sobre marcas o de competencia desleal, se admite la presunción de que los daños han sido producidos sin necesidad de razonar su evidencia, no exigiendo la prueba de su existencia y alcance.

En el último de los supuestos referidos, el de campañas publicitarias a través de google, será el perjudicado quien acredite el uso indebido y el riesgo de confusión entre dos marcas. 

TESIS 

La labor de resolución de los conflictos de consumo ha sido problemática, aunque resuelta satisfactoriamente por el propio juzgador acudiendo a las especialidades probatorias aludidas, tanto a la variación de las reglas de la carga de la prueba según las circunstancias del caso, considerando además la disponibilidad y facilidad probatoria de cada una de las partes, así como el recurso a la inversión de la carga de la prueba. Además, la aplicación de las presunciones ha permitido enjuiciar y resolver cuestiones de difícil o imposible prueba directa.

Del análisis de las peculiaridades que encontramos en estos procesos, consideramos que resulta necesaria la regulación de un procedimiento especial y exclusivo para tratar todas las cuestiones sobre consumidores, basado precisamente en sus especialidades y en las reglas específicas sobre la prueba, de forma que ofrezcan solución a los problemas que se plantean en la práctica. 



\section{BI BLI OGRAFí A}



Abel Lluch, X. y Picó Junoy, J.: “Aspectos prácticos de la prueba civil”. Ed.: Bosch Procesal, Barcelona 2006.

Abel Lluch, X., Picó i Junoy, J. Dir.: "El objeto y carga de la prueba civil". Ed.: Bosch Procesal, Barcelona 2007.

Abel Lluch, X., Picó i Junoy, J., Richard González, M.: “La Prueba Judicial. Desafíos en las jurisdicciones civil, penal, laboral y contencioso-administrativo." Ed.: La Ley, Madrid 2011.

Abel Lluch, X.: “Derecho Probatorio". Ed.: Bosch, S.A., Barcelona 2012.

Abel LLuch, X.: "La valoración de la prueba en el proceso civil". Ed.: La Ley, Madrid, 2014.

Acosta Estévez, J.B.: "Tutela procesal de los consumidores". Ed.: J.M. Bosch Editor, S.A., Barcelona 1995.

Álvarez García, F.J., I glesias Rio, M.A., Martínez Guerra, A., ManjónCabeza Olmeda, A., Cobos Gómez de Linares, M.A., Gómez Pavón, P.: "Libro Homenaje al profesor Luis Rodríguez Ramos". Ed.: Tirant lo Blanch, Valencia 2013.

Álvarez Lata, N.: “Invalidez e Ineficacia en el Derecho Contractual de Consumo Español. Análisis de los supuestos típicos de ineficacia en los contratos con consumidores". Ed.: Aranzadi, S.A., Pamplona 2004.

Álvarez Martínez, G.I.: “Los grupos de contratos en el crédito al consumo". Ed.: La Ley, Madrid 2009.

Álvarez Sánchez de Movellán: “La prueba por presunciones. Particular referencia a su aplicación en supuestos de responsabilidad extracontractual". Ed.: Comares, Granada 2007.

Añón Calvete, J.: "Participaciones preferentes, vicios del consentimiento". Revista Jurídica o 10/2013 (TOL 3.982.019).

Aragoneses Martínez, S., Cubillo López, I., Hinojosa Segovia, R., Peiteado Mariscal, P., Tomé García, J.A.: "Cien cuestiones controvertidas sobre la prueba en el proceso civil". Ed.: Colex, Madrid 2004. 
Ariza Colmenarejo, M.J.: "La intervención procesal en el ámbito de los consumidores". El Derecho, 2 de octubre de 2016.

Avilés García, J.: "Los contratos de compraventa de bienes de consumo. Problemas, propuestas y perspectivas de la venta y garantías en la Directiva 1999/447/CE y la Ley 23/2003". Ed.: Comares, Granada 2006.

Azcárraga Monzonís, C.: "Los instrumentos europeos en materia de conciliación, mediación y arbitraje de consumo". Ed.: Tirant lo Blanch, Valencia 2016.

Barona Vilar, S.: "Solución extrajurisdiccional de conflictos: Alternative Disputes Resolution (ADR) y Derecho Procesal". Ed.: Tirant lo Blanch, Valencia 1999.

Barona Vilar, S., Calderón Cuadrado, M.P., Sanchís Crespo, C., Jiménez Forte, J., Martínez García, E., Pardo Iranzo, V., Pascual Serrats, R., Andrés Ciurana, B., García Vila, M., González Malabia, S.: "Tutela de los consumidores y usuarios en la nueva Ley de Enjuiciamiento Civil", Ed.: Tirant lo Blanch, Valencia 2002.

Barona Vilar, S. en Ruiz Jiménez, José Ángel (coord.):"ADR en materia de consumo en la Unión Europea". Temas actuales de consumo: la resolución de conflictos en materia de consumo". Ed.: Instituto Vasco de Derecho Procesal, San Sebastián 2004.

Barona Vilar, S.: "Arbitraje y justicia en el S. XXI". Ed.: Thomson Civitas, Pamplona 2007.

Barona Vilar, S.: "Competencia Desleal. Tutela jurisdiccional (especialmente proceso civil) y extra jurisdiccional. Doctrina legislación y jurisprudencia". Tomo I y II. Consideraciones generales y objeto del proceso civil. Ed.: Tirant lo Blanch, Valencia 2008.

Barona Vilar, S.: "Integración de la mediación en el moderno concepto de "Acces To Justice": Luces y sombras en Europa. Editado por Indret Revista para el análisis del Derecho, no 4, octubre 2014.

Barriuso Ruiz: "La contratación electrónica, Madrid 1998". Ed.: Dykinson, Madrid 1998. 
Benavent Piera, A., Cobo Sáenz J.F., Delgado Cruces, J., Gesto Alonso, B., Goñi Urriza, N., Hualde Manso, T., Lara González, R., Riaño Brun, I., Richard González, M., Rifá Brun, A., Rifá Soler, J.M. en Richard González, M., Rifá Soler, J.M. coord.: "Estudios sobre Arbitraje de Consumo". Ed.: Aranzadi,S.A., Pamplona 2011.

Bercovitz Rodríguez Cano, Dirs., García Cruces, J.A., Dir. Adjunto: "Comentarios a la Ley de Marcas", Tomo I. Ed.: Thomson Aranzadi, Pamplona 2008.

Bermúdez Ballesteros, M. S.: "Alcance de la responsabilidad del vendedor por la falta de conformidad en un bien de consumo, detectada en el plazo de garantía y manifestada durante y tras la expiración de dicho plazo". Revista CESCO de Derecho de Consumo no 7/2013. http://www. revista.uclm.es/index.php/cesco.

Blanco Carrasco, M.: "La alternativa a la mediación en conflictos de consumo". Anuario Jurídico y Económico Escurialense no 42/2009, pág. 129 a 152.

Blanco García, A.I.: "La tutela del cliente bancario y las ADR: la institución del Ombudsman". Ed.: Tirant Monografías, Valencia 2015.

Bonet Navarro, J.: "La prueba en el proceso civil: cuestiones fundamentales". Ed.: Difusión Jurídica, Madrid 2009.

Bujosa Badell, L.M.: “La protección jurisdiccional de los intereses de grupo", Ed.: J.M. Bosch Editor, Barcelona, 1995.

Busto Lago, J.M., Álvarez lata, N., Peña López F.: "Reclamaciones de consumo. Derecho de consumo desde la perspectiva del consumidor". Ed.: Aranzadi, S.A., Pamplona 2010.

Cabañas García, J.C.: "Los procesos civiles sobre consumidores y usuarios y de control de las cláusulas generales de los contratos", Ed.: Tecnos, Madrid, 2005.

Calvo Mejide, A.A.: "Responsabilidad civil por riesgo y protección de los derechos del consumidor" Editorial: El Derecho Editores / Diario de Jurisprudencia El Derecho, no 390, junio de 1996.

Camacho Pereira, C.: "La Protección del Consumidor frente al mensaje publicitario. Integración de la publicidad en el contrato". Ed.: Aranzadi, S.A., Pamplona 2012. 
Carreras Maraña, M.A.: "La intervención adhesiva en el proceso civil: Ed.: El Derecho Editores, Madrid, 2006.

Carretero González, C.: "Las cláusulas abusivas en las condiciones generales de los contratos relacionadas con la carga de la prueba. (Comentario a la Sentencia número 166, de 13 de mayo de 2002, de la Sección Primera de la Audiencia Provincial de Ciudad Real)". Publicación Revista de Derecho Bancario y Bursátil, núm. 90 abriljunio 2003.

Cordón Moreno, F.: "El acceso a la justicia de los derechos de los consumidores". Estudios Sobre Consumo, no 16/1989.

Cordón Moreno, F., Armenta Deu, T., Muerza Esparza, J.J., Tapia Fernández, I. (Coord.): "Comentarios a la Ley de Enjuiciamiento Civil". Vol. I. Ed.: Aranzadi, Navarra 2001.

Cotino Hueso, L. (coord.): “Consumidores y usuarios ante las nuevas tecnologías". Ed.: Tirant lo Blanch, Valencia 2008.

Cuñat Edo, V. Escuela Judicial: "Protección de particulares frente a las malas prácticas bancarias II". Ed.: Consejo General del Poder Judicial, Madrid 2006.

Daniel Franco, O.: “Mediación electrónica (e-Mediación)". Diario La Ley no 8519 de 15 de abril de 2015.

De la Oliva Santos, A.: "Sobre la protección jurisdiccional a los consumidores y usuarios". Revista sobre Consumo, no 16/1989.

De la Oliva Santos, A., Díez- Picazo Giménez, I, Vegas Torres, J., Banacho Palao, J.: "Comentarios a la Ley de Enjuiciamiento Civil", Ed.: Civitas, Madrid 2001.

De la Oliva Santos, A. Díez Picazo Giménez, I.: “Derecho Procesal Civil: El proceso de declaración conforme a la Ley 1/2000, de 7 de enero de Enjuiciamiento Civil". Ed.: Centro de Estudios Ramón Areces, S.A., Madrid 2003.

De la Oliva Santos, A.: "Objeto del proceso y cosa juzgada en el proceso civil". Ed.: Civitas, Madrid 2005. 
De la Oliva Santos, A., Díez Picazo, I., Vegas Torres, J.: Curso de Derecho Procesal Civil I. Parte General: De la Oliva Santos, A.: "La acción y los Derechos Básicos de los justiciables". Ed.: Universitaria Ramón Areces, Madrid 2012.

De la Oliva Santos, A, Díez Picazo, G., Vegas Torres, J.: "Curso de Derecho Procesal Civil II. Parte Especial". Ed.: Ramón Areces, Madrid 2012.

De la Oliva Santos, A., Peiteado Mariscal, P.: "Sistema de tutela judicial efectiva", Ed.: CEF Ediciones, Madrid, 2014.

De León de Arce, A., en García, L.M., coord.: "Derechos de los consumidores y usuarios". Tomo II. Ed.: Tirant lo Blanch, Valencia 2006.

Del Olmo Del Olmo, J.A.: "Especialidades de la fase declarativa en los procesos para la tutela de los consumidores y usuarios (ley de enjuiciamiento civil 1/2000) (y II), artículo publicado por el Ministerio de Justicia en su boletín núm. 1968.

Díaz Fuentes, A.: "La prueba en la nueva Ley de Enjuiciamiento Civil". Ed.: Bosch, Barcelona 2002.

Díez Picazo, L y Guillón A.:" Sistema de Derecho Civil", Vol. I. Ed.: Tecnos, Madrid 1990.

Diez Picazo, L.: “Las condiciones generales de la contratación y las cláusulas abusivas". Ed.: Civitas, Madrid 2002.

El Sistema Arbitral de Consumo. Tramitación del arbitraje: árbitros, audiencia $y$ pruebas. http: //www. facua.org/es/guía. php?l d=118\&capitulo=1071.

El Sistema Arbitral de Consumo. Tramitación del arbitraje: árbitros, audiencia y pruebas.

http://www. facua.org/es/guía. php?! d=118\&capitulo=1071.

Espín Alba, I.: “Arbitraje y Mediación de consumo: a propósito de la Ley 16/2011, de 24 de junio, de contratos de crédito al consumo". Boletín del Ministerio de Justicia no 2160, noviembre 2013.

Etxebarría Guridi, J.F.: "Las facultades judiciales en materia probatoria en la LEC". Ed.: Tirant lo Blanch, Valencia 2003. 
Fernández López, M.: “La carga de la prueba en la práctica judicial civil”. Ed.: La Ley, Madrid 2006.

Florensa i Tomás, C.E., Alonso Franco, F., Barreto Rocha, J.C., Carrasco Perera, A., Clavel Vila, M., Cortadas Arbat, R., Díaz Albart, S., Maluquer de Motes Bernet, C.J., Mercadé Merola, M., Padial Albás, A., Sanchidrián,R., Torres Sánchez, F. : “El arbitraje de consumo. Una nueva dimensión del arbitraje de derecho privado", Ed.: Tirant lo Blanch, Valencia 2004.

Forner Delaygua, J.J.: "La prueba de los hechos en el proceso: aspectos de ley aplicable". Ed.: Bosch, Barcelona 2005.

Fraga Mandián, A., Fraga Mandián J.: "La tutela procesal civil de los consumidores en las leyes sustantivas especiales". Ed.: Sepin, Cuadernos J urídicos no 103/2011.

García Cruces, J.A.: "Tratado de Derecho de la Competencia y de la Publicidad", Tomo II. Ed.: Tirant lo Blanch, Valencia 2014.

García Cuerva García, S., Abel Lluch,X., Picó i Junoy, J.( Dir.): "Objeto y carga de la prueba civil". Ed.: Bosch Procesal, Barcelona 2007.

García Gil, F.J.: "Suma de la Protección y defensa de los derechos de los consumidores", Ed.: Bosch, S.A., Barcelona 2009.

García Vila, M: "Las condiciones generales de la contratación: aspectos procesales". Ed.: práctica de derecho, Valencia 2006.

García-Cuerva García,S., Abel Lluch, X. y Picó i Junoy, J., Dir.: “Las reglas generales del onus probandi". Ed.: Bosch Procesal, Barcelona 2007.

Garcimartín Montero, R.: "El objeto de la prueba en el proceso civil". Ed.: Bosch, Barcelona 1997.

Gascón Inchausti, F., cit.: "Acción colectiva de los usuarios frente a la entidad concesionaria de una autopista como consecuencia de las retenciones provocadas por una nevada (algunas consideraciones a la luz de la Sentencia de 15 de julio de 2010)" (B 2011/295). Publicación Aranzadi Civil y Mercantil. Ed.: Aranzadi, S.A. 
Gete-Alonso y Calera, M.C.: "Valoración y carga de la prueba en el procedimiento arbitral de consumo" (Reclamaciones en el ámbito de la telefonía)". Artículo publicado en www.consumo-inc.gob.es.

Gimeno Sendra, V.: "Derecho Procesal Civil. I. El proceso de declaración. Parte General”. Ed.: Colex, Madrid, 2014.

Gimeno Sendra, V.: “Derecho Procesal Civil. II. "Los procesos especiales". Ed.: Colex, Madrid 2014.

Gomes Soares, S.F.: “La prueba en la contratación electrónica de consumo". Núm. 3 del 2009 de la Revista Internacional de Estudios sobre Derecho Procesal y Arbitraje (Riedpa) www.riedpa.com.

Gómez Colomer, J.L. en Montero Aroca, J., Gómez Colomer, J.L., Barona Vilar, S., Calderón Cuadrado, M.P.: "Derecho J urisdiccional II. Proceso Civil", Ed.: Tirant lo Blanch, Valencia 2015.

Gómez-Ferrer Sapiña, R.: "Contrato electrónico y documento público electrónico" (TOL 227.026). Ed.: Tirant on line, Valencia 2003.

Gómez Orbaneja, E.: "Derecho Procesal civil I". Ed.: Artes Gráficas, Madrid, 1962.

González Cano, M.I.: "La tutela colectiva de consumidores y usuarios en el proceso civil". Ed.: Tirant on line.

González Pillado, E.: "Arbitraje y mediación en materia de consumo". Ed.: Tecnos. Madrid 2012.

González Pillado, E.: "Resolución de conflictos en materia de consumo: proceso y arbitraje". Ed.: Tecnos, Madrid 2008.

González Poveda, P.: “La responsabilidad civil por bienes o servicios defectuosos". Ed.: Bosch, S.A., Barcelona 2008.

Guasp J., Aragoneses, P.: "Derecho Procesal Civil: Tomo I". Ed.: Thomson Civitas, Navarra 2005.

Guerra Pérez, M., Nikolaeva Georgieva, G.: "Proceso civil, documentos y prueba pericial". Ed.: Sepin, Madrid 2014.

I boleón Salmerón, B., García-Villanova Zurita, G.: “Una aproximación jurídica al estudio del principio "in dubio pro consumidor". Revista de estudios jurídicos no 14/2014, Ed.: Universidad de J aén. 
Illán Fernández,J.M.: "La prueba electrónica, eficacia y valoración en el proceso civil”. Ed.: Aranzadi, S.A., Pamplona 2009.

Jesús Marín, M.: "Contratos vinculados y cierre de negocio". Revista Cesco de Derecho de Consumo, no 42012.

Juan Sanjosé, R.J.: "Los contratos de permuta financiera (swaps)". Revista Jurídica Tirant on line, no 4/2013 (TOL 3.536.567).

Lafuente Sánchez, R.: "Los servicios financieros bancarios electrónicos". Ed.: Tirant lo Blanch, Valencia 2005.

Lara González, R., Echaide Izquierdo, J.M.: "Consumo y Derecho". Ed.: ESIC Editorial, Madrid 2007.

Larrosa Amante, M.A.: "Es necesario un nuevo proceso específico para la protección de los intereses individuales de los consumidores?". Revista de Jurisprudencia el Derecho no 5, marzo 2006.

Larrosa Amante, M.A: "Derecho de consumo. Protección Legal del Consumidor". Ed.: El Derecho, Madrid 2011.

Lasarte Álvarez, C.: "Manual Sobre Protección de los Consumidores y Usuarios" pág. 293, Ed.: Dykinson, Madrid 2010.

Lázaro Sánchez Emilio J. coord.: "Comentario a la Ley General de Publicidad". Alonso Espinosa, F., De la Vega García, F., García Pérez, C., Iniesta Delgado, J.J., Lázaro Sánchez, E.J., López Pellicer, J.A., Martínez Martínez, D.F., Martínez Martínez I., Navarro Castro, M., Pardo López, M.M., Pérez Morales, M.G., Sánchez Ruiz, M., Verdú Cañete, M.J. Ed.: Civitas-Aranzadi, S.A. Pamplona 2009.

León de Arce, A., García García, L.M., artículo de Palacios González, D., Coord. "Derechos de los consumidores y usuarios".

Llamas Pombo, E. (coord.) "Ley General para la Defensa de los Consumidores y Usuarios. Comentarios y jurisprudencia de la Ley veinte años después". Ed.: La Ley, Madrid 2005.

Llobet i Aguado, J.: “El Derecho de información en la formación de los contratos". Ed.: Marcial Pons, Madrid 1996.

Lotario Vilaboy, L.: "La prueba por medio de los modernos avances científico-tecnológicos en el proceso civil”. Ed.: Tecnos, Madrid, 1993. 
López Fragoso, T.: “La carga de la prueba según el artículo 217 de la Ley $1 / 2000$ de Enjuiciamiento Civil". Actualidad Civil Año XI no487 de 24 de mayo de 2001. Ed.: Aranzadi, S.A.

López Hernández, C.V.: "La protección frente a los gravámenes ocultos" Epígrafe I. Ed.: Tirant lo Blanch, Valencia 2006.

Maluquer de Motes Bernet, C.J.: "El acceso de los consumidores a la justicia". Art. publicado en la Revista Togas el 28 de julio de 2005, no 53.

Marcos Francisco, D.: "El arbitraje de consumo y sus nuevos retos". Ed.: Tirant lo Blanch, Valencia 2010.

Marcos Francisco, D.: “ ¿Es posible la tutela de intereses colectivos y difusos en el arbitraje de consumo? Revista Boliviana de Derecho, I uris Tantum, no 11.

Marcos Francisco, D.: "Consumidores, sujetos privilegiados en el nuevo paradigma de justicia civil y extraprocesales para su protección". Revista InDret, núm. 5/2015.

Marimón Durá, R. (Dir.): "La oferta pública de suscripción de acciones desde la perspectiva judicial. Análisis de la OPS de BANKIA 2011". Ed.: Aranzadi, S.A., Navarra 2016.

Marín López, M.J.: "Objeto y límites del arbitraje de consumo". Revista Jurídica de Castilla-La Mancha 2005, no 39.

Marín López, M.J.: “Acuerdo Previo, concertado en exclusiva entre prestamista y proveedor", disponible en http://www. uclm.es/centro/cesco/pdf/trabajos/6/2008/6-2008-2.pdf.

Marín López, M.J .: “Contratos vinculados "en" y " al margen de" la ley 7/1995, de 23 de marzo, de crédito al consumo: doctrina del Tribunal Supremo", Ed.: Civitas, Cuadernos Civitas de Jurisprudencia Civil no 91, enero-abril de 2013.

Marín López, J.J.: Almoguera Gómez, A., Azparren Lucas, A., Bonet Sánchez, J.I., Duque Domínguez, J.F., Fernández López, J.M., Giménez Villanueva, T., Marín López, J.J., Marín López, M.J., Martí Sánchez, J.N., Muñoz Cervera, M., Nieto Carol, U., Roca Guillamón, J., Rubio Vilar, J., Sarazá Jimena, R., Toledano Barrero, V.: "Crédito al consumo y transparencia bancaria". Ed.: Civitas, Madrid 1998. 
Marín López, M.J., Martínez Espín, P.: "Código de consumo. Legislación, comentarios y jurisprudencia". Ed.: Aranzadi, Pamplona 2004.

Marín López, M.J.: “Interpretación y prueba del $<<$ acuerdo previo, concertado en exclusiva $>>$, entre prestamista y proveedor (art. 15.1 b) de la Ley de Crédito al Consumo): doctrina de las Audiencias Provinciales". Ed.: Aranzadi, Pamplona. 2008.

Marín López, M.J.: “Análisis del Real Decreto 231/2008, de 15 de febrero que regula el sistema arbitral de consumo". Revista del Centro de Estudios de Consumo de la Universidad de Castilla-La Mancha, disponible en www.uclm.es/cesco.

Martín Aresti, P.: "Las Garantías de los Productos de Consumo". Ed.: Thomson Reuters-Aranzadi, S.A., Pamplona 2010.

Martínez García, E.: “Algunas reflexiones sobre la legitimación en el proceso civil". Ed.: La Ley Revista Jurídica no 2 de 1996.

Martínez García, E.: “Las medidas cautelares durante la pendencia de un arbitraje interno o internacional (a propósito de la Sentencia del Tribunal Superior de Justicia de las Comunidades Europeas de 17 de noviembre de 1998". Ed.: Revista Vasca de derecho procesal y arbitraje. Volumen 11, № 2, 1999.

Martínez García, E.:" Algunas reflexiones acerca del posible control de oficio de la existencia de convenio arbitral en la Audiencia Previa en la LEC". Ed.: Revista de Derecho oo 1 de 2002.

Martínez García, E. en Gómez Colomer, J.L., Barona Vilar, S, Calderón Cuadrado, M.P., Montero Aroca, J.:" El Derecho procesal del S. XX a golpe de tango. Las acciones colectivas de consumo en la Unión Europea". Ed.: Tirant lo Blanch, Valencia 2012.

Massaguer Fuentes, J.: "El nuevo derecho contra la competencia desleal. La Directiva 2005/209/CE sobre las Prácticas Comerciales Desleales", pág. 148. Ed.: Aranzadi, S.A. Pamplona 2006.

Mendoza Losana, A.I.: “Cómo probar que los desperfectos de los bienes no están cubiertos por la garantía en la venta de bienes muebles". Revista CESCO de Derecho de Consumo no 7/2013. http://www. revista.uclm.es/index.php/cesco. 
Mendoza Losana, A.I.: "Particularidades de la contratación de servicios de telecomunicaciones por vía telefónica". BIB 2011/711. Ed.: Aranzadi, Pamplona 2011.

Miranda Serrano, L.M., Pagador López, J: “La formación y ejecución del contrato electrónico: aproximación a una realidad negocial emergente". Estudios sobre Consumo núm. 85 del año 2008.

Monsalve del Castillo, R.: "Legitimación activa de las asociaciones de consumidores y usuarios para el ejercicio de las acciones colectivas en defensa del interés general". Revista Aranzadi Doctrinal núm. 9/2011 (comentario). Editorial Aranzadi, S.A., Pamplona 2011.

Montero Aroca, J., en Montero Aroca, J, Montón Redondo, A., Gómez Colomer, J.L., Barona Vilar, S.: “Derecho Jurisdiccional II. Proceso Civil", Ed.: Tirant lo Blanch, Valencia 2010.

Montero Aroca, J., Gómez Colomer, J.L., Barona Vilar, S., Calderón Cuadrado, M.P.: "Derecho Jurisdiccional II". Ed.: Tirant lo Blanch, Valencia 2015.

Montero Aroca, J.: "De la legitimación en el proceso civil", Ed.: Bosch, S.A., Barcelona 2006.

Mora Díaz, R.: "Valoración de la prueba". Ed.: Noticias Jurídicas, Junio 2004, www.noticias.juridicas.com/articulos.

Moreno Catena, V.: “Derecho Procesal Civil. Parte General. Ed.: Tirant lo Blanch, Valencia, 2005.

Parra Lucán, M.A.: "La Protección del Consumidor frente a los daños. Responsabilidad del fabricante y del prestador de servicios". Colección Derecho del Consumo, Universidad de Zaragoza, Madrid 2011. Ed.: Reus, S.A.

Patiño Alvés, B.: "La autorregulación publicitaria en el Código de Conducta Publicitaria". Ed.: Bosch, Barcelona 2007.

Pérez Mosteiro, A.M. en Boyano Adánez, U.C. coord.: "La reforma de la Ley de Competencia Desleal", Ed.: Difusión Jurídica y Temas de Actualidad, S.A. Madrid 2011.

Picó y Junoy, J.: "El Derecho a la prueba en el proceso civil", Ed.: J.M. Bosch Editor, S.A., Barcelona 1996. 
Pipaón Pulido, J.G.: "Derechos de los consumidores y usuarios". Ed.: Lex Nova, Madrid 2010.

Pipaón Pulido, J.G.: Acciones en materia de prácticas desleales y códigos de conducta en relación con los consumidores y usuarios". Actualidad Jurídica Aranzadi no 799/2010 (Comentario). Editorial Aranzadi, S.A., Pamplona 2010.

Planchadell Gargallo, A.: "La prueba de interrogatorio de las partes en la Nueva Ley de Enjuiciamiento Civil". Revista Española de Derecho Procesal, núm. 2/2000.

Planchadell Gargallo, A.: "Valoración de la prueba pericial en la Ley 1/2000, de Enjuiciamiento Civil". Revista Española de Derecho Procesal, núm. 7/2000.

Planchadell Gargallo, A.: "La intervención de los consumidores afectados en los procesos colectivos", en Gómez Colomer, J.L., Barona Vilar, S., Calderón Cuadrado, M.P. (coords.): “El Derecho Procesal Español del Siglo XX a golpe de tango, Juan Montero Aroca (Liber Amicorum, en homenaje y para celebrar su LXX cumpleaños)". Ed.: Tirant lo Blanch, Valencia 2013.

Planchadell Gargallo, A.: "Las acciones colectivas en el ordenamiento jurídico español", Ed.: Tirant lo Blanch, Valencia 2013.

Planchadell Gargallo, A.: "La consecución de la tutela judicial efectiva en la litigación colectiva". Revista InDret, núm. 4/2015.

Puche Ramos, A.: "La Acción por incumplimiento contractual en reclamación de vicios o defectos en la construcción". El Derecho Editores, Revista de Jurisprudencia.

Rebolledo Varela, A.L.: “Legitimación pasiva”. Publicación Grandes Tratados, Ed.: Aranzadi, S.A., Pamplona 2000.

Revista Española de Derecho Procesal núm. 7, 2000.

Reyes López M.J: "Manual de Derecho Privado de Consumo". Ed.: La Ley, Las Rozas 2009.

Reyes López, M.J., Puertes Martí, A., Estruch Estruch, J. y Montés Rodríguez, P.: "Jurisprudencia en materia de Protección de Consumidores y usuarios". Ed.: Practica del Derecho, S.L., Valencia 1995. 
Richard González, M., Riaño Brun, I., Rifá Soler, J.M. (coord.): "Estudios sobre Arbitraje de Consumo". Ed.: Aranzadi, Pamplona 2011, pág. 282.

Richard González, M., Riaño Brun, I., Rifá Soler, J.M. (coord.): "Estudios sobre Arbitraje de Consumo". Ed.: Aranzadi, Pamplona 2011, pág. 282.

Rivero Alemán, S.: “Crédito, consumo y Comercio Electrónico. Aspectos jurídicos bancarios".

Ruiz de Lara, M.: “Condiciones Generales de la contratación, cláusulas abusivas y protección del consumidor a la luz de la jurisprudencia comunitaria y nacional". Ed.: Fe d'erratas, Madrid 2014.

Ruiz González, J.G.: "Las asociaciones de consumidores. Configuración y Régimen jurídico". Ed.: Tirant lo Blanch, Valencia 2010.

Sabah Gomez Soares, F.: "La Prueba en la contratación electrónica". Revista Internacional de Estudios de Derecho Procesal y Arbitraje no 3/2009: pág. 21, disponible en www.riedpa.com.

San Cristóbal Reales, S.: "El arbitraje de consumo". Anuario jurídico y económico escurialense, XL (2007).

Sanchís Crespo,C.: “ La prueba por soportes informáticos". Ed.: Tirant lo Blanch, Valencia 1999.

Sanchís Crespo, C., Chaveli Donet, E.A.: "La prueba por medios audiovisuales e instrumentos de archivo en la LEC 1/2000". Ed.: Tirant lo Blanch, Valencia 2002.

Sanjuán y Muñoz, E. (Dir.-Coord.), López Jiménez, J.M. (Dir.): "Reclamaciones frente a la comercialización de las participaciones preferentes". Ed.: Bosch, Barcelona 2013.

Sarazá Jimena, R.: "La protección jurisdiccional de los derechos fundamentales en las relaciones entre particulares". Ed.: Tirant lo Blanch, Valencia 2011.

Sentis Melendo, S.: "La prueba. Los grandes tratados de Derecho Probatorio". Ed.: Ediciones Jurídicas Europa-América, Buenos Aires, 1979. 
Serra Domínguez: "Estudios de Derecho Procesal". Ed.: Ariel, Barcelona 1969.

Serra Domínguez, M.: "La intervención de terceros en el proceso". Ed.: La Ley, Madrid 2000.

Serra Domínguez, M.: "Normas de presunción en el Código Civil y Ley de Arrendamientos Urbanos". Ed.: Ediciones Nauta, S.A., Barcelona 1963.

Stein Friedrich: "El conocimiento privado del juez". Traducción al castellano de la Oliva Santos, A. Ed.: Centro de Estudios Ramón Areces, S.A., Madrid 1990.

Taruffo Michele: "La prueba de los hechos". Ed.: Trotta, Bolonia, 2002.

Tirado Suárez, F.J .: "La aplicación de la Ley General de Protección de los consumidores y usuarios al Contrato de Seguro". BIB/2013/16047. Ed.: Estudios y Comentarios Legislativos (Civitas), Madrid 2013.

Vattier Fuenzalida, C.: "Sobre la garantía legal en las ventas de consumo". Ed.: La Ley, Actualidad Civil no 5, Sección A. Fondo del 1 al 15 de marzo de 2008.

Vázquez Barros, S.: “Memento Practico de consumo 2010-2011”.

Velasco Yáñez, R.: “Comentarios a la Nueva Ley de Arbitraje". Ed.: Tirant lo Blanch, Valencia 2004.

Vilaboy Lois L.: "La prueba por medio de los modernos avances científico-tecnológicos en el proceso civil". Ed.: Tecnos, Madrid 1993.

Vilaboy Lois L. en Tato Plaza, A. (coord.): “Reflexiones a la luz de la ley $1 / 2000$, de 7 de enero, de Enjuiciamiento Civil. El Comercio electrónico en internet". Ed.: Marcial Pons, Barcelona 2001.

Vilata Menadas, S. en Ruiz Peris, J.I. (Dir.): "La nueva ley de competencia desleal. Modificaciones en materia de legitimación y procedimiento". Ed.: Tirant lo Blanch, Valencia 2010.

Yzquierdo Tolsada, M., Navarro Mendizábal I.A., Acosta Mérida, M.P.: “Manual básico de derecho de consumo" Ed.: Cálamo Mataró 2005. 


\section{Í NDI CE J URI SPRUDENCI AL}




\section{TRI BUNAL GENERAL UNI ÓN EUROPEA}

S. no ECLI : EU: C: 2006: 678 de 14-12-2006 (TOL 4.629.048).

S. de 22-09-2011 (TOL 2.258.308)

S. no ECLI:EU:T:2012:424, del Tribunal General de 13-09-2012 asunto C-72/11 (TOL 3.297.761)

\section{TRI BUNAL DE JUSITI CI A DE LA UNIÓN EUROPEA}

S. no ECLI: C: 1998:369 del TJUE de 16-07-1998 (TOL 103.647)

S. no ECLI:EU:C: 2000: 346, TJUE de 27-06-2000 (TOL 105.647)

S. no ECLI:EU:C:2001:258 de 10 mayo 2001 (TOL 105.937)

S. no ECLI:EU:C: 2002: 380, de 18-06- 2002 (TOL 159.803)

S. no ECLI:EU: C: 2003: 206 de 29-4-2004 (TOL 260.206)

S. no ECLI:EU: C: 2006: 93 de 9-02-2006 C-127/2004 (TOL 4.628.019)

S. no ECLI : EU:C:2006: 585 de 19-09-2006 (TOL 4.627.909)

S. no ECLI:EU: C: 2006: 678, TJUE 26-10-2006 (TOL 4.627.683)

S. no ECLI:EU:T:2006: 397 de 14-12-2006 (TOL 4.629.048)

S. de 4-06-2009 (TOL 2.164.065)

S. de 3-09-2009 (TOL 120.602)

S. no ECLI:EU: C: 2009:615 de 6-10-2009 (TOL 2.156.958)

S. de 23-03-2010 (TOL 2.638.361)

S. de 25-03-2010 (TOL 2.157.332)

S. no ECLI: EU: C: 2010: 309 de 3-6-2010 (TOL 2.164.226)

S. de 3-6-2010 (TOL 1.537.161)

S. de 8-07-2010 (TOL 4.630.982)

S. no ECLI:EU: C: 2010: 659 de 9-11-2010 (TOL 2.163.388) 
S. no ECLI:EU:C:2011: 771 de 24-11-2011 (TOL 2.283.368)

S. no ECLI : EU:C:2012: 85 de 16-02-2012 (TOL 2.517.026)

S. 7-03-2012 (TOL 2.516.894)

S. no ECLI:EU: C: 2012: 144 de 15-03-2012 (TOL 2.517.081)

S. de 26-04-2012 (TOL 2.517.058)

S. no ECLI : EU: C: 2012: 349 de 14-06-2012 (TOL 2.558.453)

S. no ECLI :EU:C:2013: 88 de 21-02-2013 (TOL 3.061.430)

S. no ECLI:EU:C: 2013: 164 de 14-03-2013 (TOL 3.297.918)

S. № ECLI:EU:C:2013: 180 de 21-03-2013 (TOL 3.297.938)

S. no ECLI:EU:C: 2013: 180 de 21-03-2013 (TOL 3.297.993)

S. de 15-01-2015 (TOL 4.631.850)

S. de 5-03-2015 (TOL 4.745.394)

S. 11-06-2015 (TOL 5.170.613)

S. no 980/2016 de 21-12-2016 (TOL 5.912.453)

\section{TRI BUNAL SUPREMO}

S. de 16-04-1971 (TOL 4.268.392)

S. 22-03-1983 (TOL 1.738.477)

S. de 14-11-1984 (TOL 1.737.331)

S de 15-12-1986 (TOL 1.734.522)

S. 10-03-1987 (TOL 1.736.246)

S. de 18-05-1988 (TOL 1.733.156)

S. de 19-02-1990 (TOL 1.729.260)

S. no 374/1990 18-06-1990 (TOL 1.730.393)

S. 29-01-1991 (TOL 1.728.361) 
S. de 13-02-1991 (RJ 1991/1200)

S. de 25-03-1991 (TOL 1.728.182)

S. de 23-05-1991 (TOL1.728.948)

S. de 11-02-1992 (TOL 1.661.471)

S. no $125 / 1992$ de 20-02-1992 (TOL 5.156.347)

S. № 316/1992 de 3-04-1992 (TOL 1.654.968)

S. no 413/1992 21-04-1992 (TOL 1.659.761)

S. № 482/1993 de 10-05-1993 (TOL 1.662.895)

S. no 524/1993 de 20-05-1993 (TOL 5.130.084)

S. № 530/1993 de 29-05-1993 (TOL 1.663.045)

S. № 623/1993 TS 23-06-1993 (TOL 6.610)

S. $n$ ㅇ 725/1993 de 8-07-1993 (TOL 1.663.458)

S. № 772/1993 de 23-07-1993 (TOL 1.655.564)

S. 30-11-1993 (TOL 1.656.002)

S. no $1212 / 1993$ de 15-12-1993 (TOL 5.123.193)

S. № 84/1994 de 10-02-1994 (TOL 1.664.886)

S. no 793/1994 de 22-07-1994 (TOL 1.665.478)

S. no 1002/1994 de 7-11-1994 (TOL 5.127.430)

S. no 8/1995 de 28-01-1995 (TOL 1.667.060)

S. de 8-02-1995 (TOL 1.658.301)

S. no 592/1995 de 7-06-1995 (TOL 1.667.549)

S. no 64/1995 de 24-06-1995 (TOL 1.667.198)

S. no 614/1995 de 24-06-1995 (TOL 5.130.776)

S. no 977/1995 de 13-11-1995 (TOL 1.667.764) 
S. no 104/1996 de 15-02-1996 (TOL 1.669.195)

S. no 435/1996 de 28-05-1996 (TOL 1.659.506)

S. no 492/1996 de 13-06-1996 (TOL 1.659.511)

S. no 506/1996 de 21-06-1996 (TOL 1.659.434)

S. no 540/1996 de 25-06-1996 (TOL 1.659.425)

S. no $621 / 1996$ de 12-07-1996 (TOL 1.659.032)

S. no 687/1996 de 30-07-1996 (TOL 1.659.031)

S. № 740/1996 de 14-09-1996 (TOL 1.659.0878)

S. $\mathrm{n}$ o $778 / 1996$ de 4-10-1996 (TOL 1.659.077)

S. no 981/1996 de 22-11-1996 (TOL 1.658.763)

S. o 1070/1996 de 4-12-1996 (TOL 1.658.552)

S. no $1032 / 1996$ de 9-12-1996 (1.658.572)

S. no 1054/1996 de 11-12-96 (TOL 1.658.583)

S. no 25/1997 de 27-01-1997 (TOL 5.153.465)

S. no 75/1997 1-02-1997 (TOL 215.950)

S. 18-02-1997 (TOL 5.114.407)

S. no 280/1997 de 26-03-1997 (TOL 215.800)

S. no 604/1997 de 1-07-1997 (TOL 215.680)

S. no 688/1997, 21-07-1997 (TOL 215.308)

S. no 755/1997 de 2-09-1997 (TOL 216.209)

S. no 895/1997 de 26-09-1997 (TOL 5.136.824)

S. № 1081/1997 de 3-12-1997 (TOL 216.433)

S. no 101/1998 de 11-02-1998 (TOL 5.157.356)

S. no 136/1998 de 23-02-1998 (TOL 5.114.945) 
S. no $155 / 1998$ de 25-02- 1998 (TOL 170.694)

S. no $180 / 1998$ de 2-03-1998 (TOL 5.157.377)

S. no 394/1998 de 6-05-1998 (TOL 5.119.892)

S. no 648/1998 de 3-07-1998 (TOL 5.156.886)

S. $30-07-98$ (TOL 2.602)

S. № 1146/1998 9-12-98 (TOL 8.732)

S. no 919/1998 de 13-10-1998 (TOL 439.523)

S. № 933/1998 de 16-10-1998 (TOL 5.157.080)

S. № $1207 / 1998$ de $28-10-1998$ (TOL 171.002)

S. № 1000/1998 de 4-11-1998 (TOL 5.157.175)

S. no 101/1998 de 11-02.1998 (TOL 5.157.356)

S. no 74/1999 de 8-02-1999 (TOL 5.120.246)

S. de 14-04-1999 (TOL 1.467)

S. 22-09-1999 (TOL 344.973)

S. no 846/1999 de 13-10-1999 (TOL 169.315)

S. no 962/1999 de 17-11-1999 (TOL 5.120.654)

S. no 1011/1999 de 30-11-1999 (5.120.671)

S. no $1186 / 1999$ de 31-12-1999 (TOL 171.413)

S. de 31-01-00 (TOL 1.780)

S. $\mathrm{n}$ - 336/2000 de 5-4-00 (TOL 4.926.862)

S. de 14-4-2000 (TOL 1.554)

S. no 326/2000 de 4-05-2000 (TOL 1.565)

S. no 508/2000 de 12-05-2000 (TOL 1.799).

S. no 537/2000 26-05-2000 (TOL 4.927.074) 
S. № 661/2000 30-6-2000 (TOL 6.610)

S. no 959/2000 de 25-10-2000 (TOL 1.841)

S. de 3-11-00 (TOL 52.526)

S. no 3/2001 de 12-01-2001 (TOL 99.652)

S no 50/2001 de 22-01-2001 (TOL 99.616)

S. no 139/2001 de 22-02-2001 (TOL 99.620)

S. no 454/2001 de 10-05-2001 (TOL 106.901)

S. no 748/2001 de 23-07-2001 (4.794.600)

S. de 28-09-2001 (TOL 66.555)

S. no 910/2001 de 10-10-2001 (TOL 66.398)

S. no 279/2002 de 1-04-2002 (TOL 161.870)

S. no 346/2002 de 11-04-2002 (TOL 155.142)

S. 17-05-2002 (TOL 161.927)

S. no 556/2002 de 10-06-2002 (TOL 4.975.740)

S. de 17-10-02 (TOL 4.975.089)

S. no 1152/2002 29-11-2002 (TOL 229.646)

S. no 1290/2002 de 27-12-2002 (TOL 4.927.466)

S. no 28/2003 de 20-01-2003 (TOL 239.735)

S. no 151/2003 de 21-02-2003 (TOL 265.196)

S. de 27-02-2003 (TOL 265.208)

S. № 210/2003 de 27-02-2003 (TOL 4.927.712)

S. no 274/2003 de 21-03-2003 (TOL 353.849)

S. 30-03-2000 (TOL 1.519)

S. no 432/2003 de 30-04-2003 (TOL 275.461) 
S. no $514 / 2003$ de 23-05-2003 (TOL 274.498)

S. no 504/2003 de 27-05-2003 (TOL 274.494)

S. no $654 / 2003$ de $26-06-2003$ (TOL 305.379)

S. no 651/2003 de 26-06-2003 (TOL 305.397)

S. no 739/2003 de 10-07-2003 (TOL 295.857)

S. no 714/2003 de 14-07-2003 (TOL 295.892)

S. no 747/2003 de 18-07-2003 (TOL 4.924.603)

S. no 828/2003 de 8-09-2003 (TOL 307.998)

S. no 871/2003 de 29-09-2003 (TOL 316.464)

S. no 23/2004 de 23-01-2004 (TOL 348.808)

S. no 236/2004 de 7-04-2004 (TOL 633.070)

S. no 440/2004 de 2-06-2004 (TOL 499.264)

S. no $1025 / 2004$ de 27-10-2004 (TOL 514.262)

S. no 139/2005 de 3-03-2005 (TOL 603.848)

S. no 188/2005 de 28-03-2005 (TOL 646.341)

S. no 401/2005 de 1-06-2005 (TOL 667.469)

S. no 215/2005 de 9-06-2005 (TOL 673.230)

S. no 463/2005 de 9-06-2005 (TOL 667.458)

S. no 512/2005 de 24-06-2005 (TOL 674.252)

S. no 659/2005 de 27-07-2005 (TOL 674.295)

S. no 851/2005 de 14-11-2005 (TOL 759.116)

S. no 298/2006 21-03-2006 (TOL 866.066)

S. no 258/2006 de 21-03-2006 (TOL 866.065)

S. no 305/2006 de 21-03-2006 (TOL 871.859) 
S. no $481 / 2006$ de 18-05-2006 (TOL 952.802)

S. no 413/2006 de 25-04-2006 (TOL 948.871)

S. no 426/2006 de 28-06-2006 (TOL 1.027.427)

S. no 907/2006 de 19-09-2006 (TOL 3.423.475)

S. no 876/2006 de 20-9-2006 (TOL 995.559)

S. no 931/2006 de 28-09-2006 (TOL 1.014.554)

S. no 966/2006 de 28-09-2006 (TOL 1.014.549)

S no 951/2006 4-10-2006 (TOL 1.014.503)

S. no 1043/2006 27-10-2006 (TOL 1.006.926)

S. № $1083 / 2006$ de 6-11-2006 (TOL 1.019.381)

S. no $1348 / 2006$ de 29-12-2006 (TOL 1.036.542)

S. S. no 31/2007 de 25-1-2007 (TOL 1.033.418)

S. no 81/2007 de 2-02-2007 (TOL 1.044.132)

S. no 527/2007 de 9-05-2007 (TOL 1.075.942)

S. no 183/2007 de 19-02-2007 (TOL 1.038.326)

S. de 5-03-2007 (TOL 1.44.147)

S. no 346/2007 de 16-03-2007 (TOL 1.050.526)

S. no 435/2007 de 16-4-2007 (TOL. 1.069.814)

S. no 183/2007 de 19-05-2007 (TOL 1.038.326)

S. № 613/2007 de 6-06-2007 (TOL 1.106.774)

S. no 748/2007 de 20-06-2007 (TOL 1.108.629)

S. no 938/2007 de 21-09-2007 (TOL 1.150.977)

S. no 943/2007 de 25-09-2007 (TOL 1.644.795)

S. no $1155 / 2007$ de 19-10-2007 (TOL 1.177.288) 
S. № $1266 / 2007$ de $23-11-2007$ (TOL 1.213.848)

S. № $1242 / 2007$ de 4-12-2007 (TOL1.256.811)

S. no $1250 / 2007$ de 15-12-2007 (TOL 1.235.320)

S. no 938/2007 de 21-12-2007 (TOL 1.150.977)

S. no 40/2008 de 5-02-2008 (TOL 1.333.420)

S. № 332/2008 de 30-04-2008 (TOL 1.311.962)

S. no 692/2008 de 17-07-2008 (TOL 1.353.188)

S. no 1012/2008 de 29-10-2008 (TOL 1.393.360)

S. o $1071 / 2008$ de 7-11-2008 (TOL 1.401.716)

S. no $1026 / 2008$ de 12-11-2008 (TOL 1.408.429)

S. no $1087 / 2008$ de $21-11-2008$ (TOL 1.408.444)

S. no 120/2009 de 19-02-2009 (TOL 1.452.539)

S. no 95/2009 de 2-03-2009 (TOL 1.466.720)

S. no $113 / 2009$ de 4-03-2009 (TOL 1.466.714)

S. no $114 / 2009$ de 9-03-2009 (TOL 1.485.194)

S. no 408/2009 16-06-2009 (TOL 1.554.277)

S. no 725/2010 22-04-2009 (TOL 2.002.214)

S. no $196 / 2010$ de 13-04-2010 (TOL 1.822.923)

S. no 346/2010 de 14-06-2010 (TOL 1.881.674)

S. no 366/2010 de 15-06-2010 (TOL 1.947.394)

S. no 386/2010 16-06-2010 (TOL 1.408.444)

S. no 401/10 de 1-07-2010 (TOL 2.006.750)

S. no 583/2010 de 27-09-2010 (TOL 1.958.896)

S. № $861 / 2010$ de $29-10-2010$ (TOL 2.031.067) 
S. ํo 709/2010 12-11-2010 (TOL 1.991.461)

S. no 545/2010 9-12-2010 (TOL 2.201.482)

S. № $866 / 2010$ de $16-12-2010$ (TOL 2.011.314)

S. no $891 / 2010$ de 3-01-2011 (TOL 2.039.124)

S. no 442/2011 de 17-06-2011(TOL 2.161.152)

S. no 797/2011 de 18-11-2011 (TOL 2.289.671)

S. no $886 / 2011$ de 12-12-2011 (TOL 2.367.453)

S. no 350/2012 de 28-05- 2012 (TOL 2.549.935)

S. no 362/2012 de 6-06-2012 (TOL 2.559.074)

S. no $406 / 2012$ de 18-06-2012 (TOL 2.652.597)

S. no 480/2012 de 18-07-2012 (TOL 2.593.334)

S. no 494/2012 de 20-07-2012 (TOL 3.022.392)

S. no 541/2012 de 24-10-2012 (TOL 2.706.112)

S. no 660/2012 de 15-11-2012 (TOL 2.698.226)

S. no 662/2012 de 12-11-2012 (TOL 2.706.873)

S. o $683 / 2012$ de 21-11-2012 (TOL 2.708.761)

S. no $241 / 2013$ de 9-05-2013 (TOL 3.671.048)

S. no $244 / 2013$ de 18-04-2013 (TOL 3.745.892)

S. no $241 / 13$ de 9-05-2013 (TOL 3.671.048)

S. no $275 / 2013$ de 14-05-2013 (TOL 3.795.53)

S. no 403/2013 de 18-06-2013 (TOL 3.790.821)

S. № $839 / 2013$ de 2-01-2014 (TOL 4.103.965)

S. no 840/2013 20-01-2014 (TOL 4.103.965)

S. no 149/2014 de 10-03-2014, (TOL 4.142.469) 
S. o 152/2014 de 11-03-2014 (TOL 4.143.010)

S. o 166/2014, de 7-04-2014 (TOL 4.264.715)

S. no $170 / 2014$ de 8-04-2014 (TOL 4.280.441)

S. no $86 / 2014$ de 26-05-2014 (TOL 4.388.014)

S. no 246/2014 de 28-05-2014 (TOL 4.437.949)

S. no 385/2014 de 7-07-2014 (TOL 4.430.489)

S. no 412/2014 de 10-07-2014 (TOL 4.478.976)

S. no 445/2014 de 4-09-2014 (TOL 4.516.765)

S. no 464/2014 de 8-09-2014 (TOL 4.529.142)

S. no 458/2014 de 8-09-2014 TS (TOL 4.522.848)

S. no $677 / 2014$ de 2-12-2014 (TOL 4.748.715)

S. № 769/2014 de 12-01-2015 (TOL 4.712.377)

S. no 649/2014 de 13-01-2015 (TOL 4.706.623)

S. no 778/2014 de 20-01-2015 (TOL 4.733.341)

S. № $29 / 2015$ de 2-02-2015 (TOL 4.709.012)

S. no 70/2015 de 11-02-2015 (TOL 4.719.668)

S. no 6/2015 de 24-02-2015 (TOL 4.765.338)

AUTO de 25-2-2015 (TOL 4.753.926)

AUTO de 4-03-2015 (TOL 4.766.879)

S. no 139/2015 de 25-03-2015 (TOL 4.828.169)

S. no $265 / 15$ de 22-04-2015 (TOL 4.952.038)

S. no $223 / 2015$ de 29-04-2015 (TOL 5.00.589)

S. no 491/2015 de 22-07-2015 (TOL 5.438.433)

S. № 563/2015 15-10-2015 (TOL 5.533.074) 
S. o $544 / 2015$ de 20-10-2015 (TOL 5.511.240)

S. № 595/2015 30-10-2015 (TOL 5.550.327)

S. no 633/2015 de 13-11-2015 (TOL 5.558.055)

S. o $742 / 2015$ de 18-12-2015 (TOL 5.596.103)

S. no 23 de 3-02-2016 (TOL 5.630.372)

S. $\mathrm{n}$ - 24 de 3-02-2016 (TOL 5.630.373)

S. no 98/2016 de 19-02-2016 (TOL 5.699.140)

S. no $185 / 2016$ de 18-3-2016 (TOL 5.673.509)

S no 197/2016 de 30-03-2016 (TOL 5.682.215)

S. no 237/2016 de 12-04-2016 (TOL 5.694.661)

\section{AUDI ENCI A PROVI NCI AL DE ALAVA}

S. no 273/2010 Sec. 1a AP Álava de 1-06-2010 (TOL 1.996.342)

\section{AUDI ENCI A PROVI NCI AL DE ALBACETE}

S. o $68 / 2001$ Sec. 1a 31-3-01 (TOL 70.484)

S. no 491/2011 Sec. 1a de 25-03-2011 (TOL 2.178.299)

S. no 259/2012 Sec. 2a de 10-12-2012 (TOL 2.716.422)

S. no $173 / 2013$ Sec. 2a de 21-10-2013 (TOL 4.010.735)

\section{AUDI ENCI A PROVI NCI AL DE ALI CANTE}

S. no 118/2002 Sec. 7ạ de 4-03-2002 (TOL 160.602)

S. no 152/2003 Sec. 7a de 25-3-2003 (TOL 274.977)

S. no 111/2007 Sec. 9a de 30-03-2007 (TOL 1.090.594)

S. no 13/2010 Sec. 4a de 14-1-2010 (TOL 1.993.331)

S. no 202/2010 Sec. 4a de 27-05-2010 (TOL 1.991.654)

S. no 44/2012 Sec. 8a de 2-02-2012 (TOL 2.526.728) 
S. no 377/2012 Sec. 4a de 27-09-2012 (TOL 2.650.890)

S. № 105/2013 Sec. 8a de 7-03-2013 (TOL 4.505.149)

S. no 25/2014 Sec. 8a de 6-02-2014 (TOL 4.177.568)

S. no 53/2014 Sec. 8a de 6-03-2014 (TOL 4.231.509)

\section{AUDI ENCI A PROVI NCI AL DE ALMERÍ A}

S. no 36/2006 Sec. 3a de 7-03-2006 (TOL 961.540)

S. № 16/2012 Sec. 4a de 20-01-2012 (TOL 2.433.851)

S. no 39/2012 Sec. 3a de 25-02-2012 (TOL 2.498.315)

S. № 184/2014, Sec. 2a de 3-07-2014 (TOL 4.563.424)

\section{AUDI ENCI A PROVI NCI AL DE ASTURIAS}

S. no 200/1999 Sec. 1으 de 24-03-1999 (AC 1999/428)

S. Sec. $1^{\text {a }}$ de 19-03-2002 (TOL 174.094)

S. № 199/2002 Sec. 7a de 30-03-2002 (TOL 212.546)

S. no $117 / 2003$ Sec. 5a de 28-02-2003 (AC2003/724)

S. no 13/2004 Sec. 5a de 21-01-2004 (TOL 356.045)

S. no 189/2004 Sec. 7ạ 2-04-2004 (TOL 498.796).

S. № 118/2008 Sec. 4a de 21-03-2001 (TOL49.554)

S. no 278/2009 Sec. 7ạ de 8-05-2009 (TOL 1.567.099)

S. no $618 / 2009$ Sec. 7ạ de 9-12-2009 (TOL 1.770.598)

S. no $217 / 2011$ Sec. 7ạ de 13-05-2011 (TOL 2.137.129)

S. no $221 / 2011$ Sec. 7a de 13-05-2011 (TOL 2.142.642)

S. no $280 / 2011$ Sec. 5a de 29-06-2011 (TOL 2.292.983)

S. no 327/2011 Sec. 7ạ de 1-07-2011 (TOL 2.198.311)

S. no 416/2011 Sec. 7ạ de 16-09-2011 (TOL 2.248.031) 
S. no 428/2011 Sec. 7ạ de 26-09-2011 (TOL 2.268.094)

S. no 531/2011 Sec. 70 de 21-11-2011 (TOL 2.298.465)

S. no 24/2012 Sec. 4a de 25-01-2012 (TOL 2.440.551)

S. no 89/2012 Sec. 5a de 7-03-2012 (TOL 2.501.175)

S. no 65/2014 Sec. 5a de 4-03-2014 (TOL 4.186.902)

S. no $284 / 2015$ Sec. 7ạ de 3-09-2015 (TOL 761.814)

\section{AUDI ENCI A PROVI NCI AL DE ÁVI LA}

S. no 237/2001 de 26-07-2001 (AC 2001/325448)

\section{AUDI ENCI A PROVI NCI AL DE BADAJ OZ}

S. no 390/2005, Sec. 2a de 27-10-2005 (TOL 777.821)

S. no 178/2011, Sec. 2a de 17-05-2011 (TOL 2.148.473)

\section{AUDI ENCI A PROVI NCI AL DE BARCELONA}

S. Sec. 13a de 26-04-01 (TOL 205.003)

S. Sec. 17ạ de 17-12-2001 (TOL 163.431)

S. Sec. 160 de 13-01-2003 (TOL 278.432)

S. Sec. 1a de 17-11-2003 (TOL 333.199)

S. no 58/2006 Sec. 1a de 3-02-2006 (TOL 990.991)

S. № 137/2006 Sec. 16a de 22-03-2006 (TOL 991.062)

S. Sec. 1a de 27-07- 2006 (TOL 1.035.793)

S. no 436/06 Sec.15a de 29-09-2006 (TOL 1.026.971)

S. no 300/2007 Sec. 19 de 6-06-2007 (TOL 1.176.665)

S. no 477/2009 Sec. 13a de 15-09-2009 (TOL 1.642.179)

S. no 497/2009 Sec. 13aㅡ de 23-09-2009 (TOL 1.651.000)

S. no 174/2011 Sec. 15a de 14-04-2011 (TOL 2.173.423) 
Auto no 155/2011, Sec. 16a , de 30-06-2011 (TOL 5.329.942)

S. no 352/2011 Sec. 11a de 30-06-2011 (TOL 2.222.025)

S. no 431/2011 Sec. 16a de 8-07-2011 (TOL 2.232.003)

S. no 617/2011, Sec. 7a de 19-12-2011 (TOL 2.471.673)

Auto № 211/2011 Sec. 15a de 23-12-2011 (TOL 5.350.137)

A. o 421/2012 Sec. 17a de 6-09-2012 (TOL 2.669.539)

S. no 431/2013 Sec. 17ạ de 26-09-2013 (TOL 4.049.497)

S. no 363/2013 Sec. 15a de 21-10-2013 (TOL 3.990.943)

S. № 105/2014 Sec. 1a de 11-03-2014 (TOL 4.184.888)

S. no $144 / 2014$ Sec. 11a de 27-03-2014 (TOL 4.206.143)

S. no 21/2015 Sec. 3ạ de 22-01-2015 (TOL 4.755.603)

S. no $117 / 2015$ Sec. 14a de 16-04-2015 (TOL 5.170.375)

S. no 136/2013, Sec. 17ạ de 4-05-2015 (TOL 5.22.074)

S. no 278/2015, Sec. 17 de 19-06-2015 (TOL 5.491.696)

S. no 378/2015 Sec. 16a de 31-07-2015 (TOL 5.505.839)

\section{AUDI ENCI A PROVI NCI AL DE BURGOS}

S. no 98/2007 Sec. 3a de 28-02-2007 (JUR 2007/138085)

S. no 99/2007 Sec. 3ạ de 28-02-2007 (TOL 1.895.219)

S. no 151/2013, Sec. 1a de 20-05-2013 (TOL 3.778.199)

\section{AUDI ENCIA PROVI NCI AL DE CÁCERES}

S. no 91/2002, Sec. 1a 18-04-2002 (TOL 174.091)

S. 43/2007 Sec.1a de 1-02-2007 (JUR 2007/138827)

S. no 264/2012 Sec. 1a de 14-05-2012 (TOL 2.565.236)

S. $n$ o $8 / 2014$ Sec. 1 a de 2-01-2014 (TOL 4.104.552) 
S. № 190/2014 Sec. 1a de 15-01-2014 (TOL 4.516.291)

\section{AUDI ENCI A PROVI NCI AL DE CÁDI Z}

S. no 200/2010 Sec. 2a de la AP Cádiz de 22-06-2010 (TOL 2.052.218)

\section{AUDI ENCI A PROVI NCI AL DE CASTELLÓN}

S. no 623/2004, Sec. 3a de 17-12-2003 (TOL 337.211)

S. № 214/2004 de la Sec. 1 a de 27-09-2004 (TOL 519.993)

S. no 297/2004 de la Sec. 1a de 27-09-2004 (TOL 526.916)

S. no 200/2007 de 10-10-2007 (TOL 1.258.301)

S. no 712/2010, Sec. 1a de 23-09-2010 (TOL 1.997.720)

S. no 516/2012, Sec. 3ạ de 26-10-2012 (TOL 2.675.427)

S. no 407/2013 de 21-10-2013 (TOL 4.062.014)

S. no 234/2015 Sec. 3a de 4-09-2015 (TOL 5.560.446)

\section{AUDI ENCI A PROVI NCI AL DE CI UDAD REAL}

S. Sec. 1a de 13-05-2002 (TOL 200.258)

S. no 205/2002 Sec. 1a de 28-05-2002 (TOL 200.782)

S. no 219/2010 de 28-09-2010 (TOL 1.992.751)

S. no 184/2013 de 14-06-2013 (TOL 3.849.695)

S. no 33/2014 de 6-02-2014 (TOL 4.121.529),

S. la no 72/2014 de la Sec. $1^{\text {a }}$ de 21-03-2014 (TOL 4.184.815)

\section{AUDI ENCI A PROVI NCI AL DE CÓRDOBA}

S. no $187 / 97$ Sec. 3ạ de 14-07-1997 (AC/1997/1560)

S. no 101/2000 Sec. 3a de 7-04-2000 (EDJ 2000/238719)

S. no 255/2002 Sec. 2a de 10-10-2002 (TOL 263.793) 
S. no $279 / 2003$ Sec. 1 a de 24-11-2003 (TOL 335.749)

S. no 393/2005 Sec. 1a de 19-10-2005 (TOL 924.463)

S. no 48/2010 Sec. 3으 de 23-3-2010 (TOL 1.952.448)

\section{AUDI ENCI A PROVI NCI AL DE CUENCA}

S. № 258/2003, Sec. 1a de 13-11-03 (TOL 354.978)

\section{AUDI ENCI A PROVI NCI AL DE GI RONA}

S. no 68/2011 Sec. 1a de 18-02-2011 (TOL 2.087.634)

\section{AUDI ENCI A PROVI NCI AL DE GRANADA}

S. no 404/2012 Sec. 3a de 28-09-2012 (TOL 3.022.914)

S. no 318/2013 Sec. 4a de 4-10-2013 (TOL 4.037.101).

\section{AUDI ENCI A PROVI NCI AL DE GUADALAJ ARA}

S. no $168 / 2008$ Sec. 1 a de 7-10-2008 (TOL 1.480.172)

S. Sec. 1a no 169/2010 de 13-10-2010 (TOL 1.993.329)

\section{AUDI ENCI A PROVI NCI AL DE GUI PÚZCOA}

S. Sec. 2a de 26-06-2006 (TOL 991.962)

S. no 2039/2007 Sec. 3a de 5-02- 2007 (TOL 1.077.088)

S. № 2/2009 Sec. 3a de 9-01-2009 (TOL 1.521.269)

S. no 108/2009 Sec. 3ạ de 24-04-2009 (TOL 809.023)

S. no 263/2012 Sec. 3a de 19-09-2012 (TOL 4.342.527)

S. no 355/2013 Sec. 3a de 28-11-2013 (TOL 4.359.512)

S. № 300/2015 Sec. 3a de 25-11-2015 (TOL 5.602.333) 


\section{AUDI ENCI A PROVI NCI AL DE HUELVA}

S. no 70/2011 Sec. 1a AP Huelva de 18-03-2011 (TOL 2.151.221).

S. no 56/2012 Sec. 2a de 20-03-2012 (TOL 2.593.429)

S. Sec. 1a de 25-04-2012 (TOL 2.540.404)

\section{AUDI ENCI A PROVI NCI AL DE HUESCA}

S. de 7-04-1993 (AC 1993/862)

S. no 222/1999 Sec. Única de 24-06-1999 (TOL 391.524)

S. no $89 / 2002$ de 22-03-2002 (TOL 200.576)

S. no 11/2006 Sec. 1a de 17-01-2006 (TOL 809.023)

\section{AUDI ENCI A PROVI NCI AL DE J AÉN}

S. no $221 / 2003$ de 9-09-2003 (TOL 318.101)

S. no 276/2004 Sec. 1a de 3-12-2004 (TOL 582.286)

S. no $174 / 2013$ Sec. 1 ạ de 25-11-2013 (TOL 4.126.291)

S. no $277 / 2014$ de 26-06-2014 (TOL 4.486.438)

\section{AUDI ENCIA PROVI NCI AL DE LA CORUÑA}

S. no 115/1998 Sec. 4ạ de 20-03-1998 (AC 1998/370)

S. Sec. 6ạ AP La Coruña de 23-05-2000 (TOL 192.766)

S. no 80/2007 Sec. 6ạ de 16-03-2007 (TOL 1.958.205)

S. no 44/2008 Sec. 6a de 13-02-2008 (TOL 1.376.370)

S. no 54/2009 Sec. 6ạ de 11-02-2009 (PROV 2009/191043)

S. no 274/2010 Sec. 4a de 11-06-2010 (TOL 1.948.979)

S. no 440/2010 Sec. 6a de 4-11-2010 (TOL 2.037.514)

S. no 308/2013 Sec. 6a de 25-11-2013 (TOL 5.379.380) 


\section{AUDI ENCIA PROVI NCI AL DE LAS PALMAS DE GRAN CANARIA}

S. no 486/2001 Sec. 4a de 6-06-2001 (TOL 124.944)

S. no 330/2005 Sec. 4a de 4-07-2005 (TOL 714.280)

S. no 98/2010 Sec. 5a de 8-03-2010 (TOL 5.306.802)

S. no 340/2012 Sec. 4a de 26-07-2012 (TOL 2.670.482)

S. № 145/2012 Sec. 5a de 27-03-2012 (TOL 2.564.666)

S. no 261/2015 Sec. 4ạ de 14-07-2015 (TOL 5.537.301)

S. no 41/2016 Sec. 5a de 5-02-2016 (TOL 5.678.283)

S. № 313/2016 Sec. 5a de 12-07-2016 (TOL 5.845.200)

\section{AUDI ENCI A PROVI NCI AL DE LA RI OJ A}

S. no 337/2002 Sec. Única de 31-07-2002 (TOL 225.189)

S. no 24/2005 Sec. 1a de 31-01-2005 (TOL 604.106)

S. no 383/2012 Sec. 1a de 20-11-2012 (TOL 2.712.548)

S. no 394/2012 Sec. 1a de 30-11-2012 (TOL 2.722.917)

\section{AUDI ENCI A PROVI NCI AL DE LES I LLES BALEARS}

S. Sec. 4a de 17-07-2002 (TOL 229.005)

S. no 496/2003 de 30-09-2003 (TOL 355.558)

S. no 13/2006 Sec. 4a de 23-01-2006 (TOL 932.865)

S. no 90/2006 Sec. 3a de 27-02-2006 (TOL 861.285)

S. № 286/2008 Sec. 3a de 18-09-2008 (TOL 1.443.815)

S. no 91/2011 Sec. 5a de 21-03-2011 (TOL 2.127.093)

S. no 278/2011 Sec. 5a de 2-09-2011 (TOL 2.236.929)

S. no 82/2012 Sec. 3a de 16-02-2012 (TOL 2.490.158)

S. no 539/2012 Sec. 4a de 4-12-2012 (TOL 2.716.289 
S. № 22/2014 Sec. 3a de 24-01-2014 (TOL 4.103.864)

S. no 292/14 Sec. 4a de 23-06-2014 (TOL 4.484.029)

\section{AUDI ENCIA PROVI NCI AL DE LEÓN}

S. no $297 / 2002$ Sec. 3a de 9-10-2002 (JUR 2003/80374)

S. no 84/2003 Sec. 2a de 13-03-2003 (TOL 304.279)

S. № 274/2011, Sec. 2a de 1-09-2011 (TOL 2.239.999)

S. no 88/2012 Sec. 1a de 2-03-2012 (TOL 2.491.861)

S. no 30/2014 Sec. 1a de 6-03-2014 (TOL 4.145.923)

S. no 82/2014 Sec. 2ạ AP León de 28-03-2014 (TOL 4.265.569)

S. no $256 / 2014$ Sec. 1a de 9-12-2014 (TOL 4.710.185)

S. no 34/2015, Sec. 1a de 20-02-2015 (TOL 4.800.381)

S. no 1/2016, Sec. 1a de León de 11-01-2016 (TOL 5.642.295)

\section{AUDI ENCI A PROVI NCI AL DE LLEI DA}

la S. no 413/2005 de la Sec. 2a de 8-11-2005 (TOL 839.017)

S. no 8/2010 Sec. 2a de 7-01-2010 (TOL 1.815.415)

\section{AUDI ENCI A PROVI NCI AL DE LUGO}

S. no 678/2012 Sec. 1a de 19-12-2012 (TOL 3.013.289)

S. no 306/2013 Sec. 1a de 30-07-2013 (TOL 3.913.360)

\section{AUDI ENCI A PROVI NCI AL DE MADRI D}

S. Sec. 14a de 28-02-2001 (TOL 49.807)

S. Sec. 21a de 3-04-2001 (TOL 2.732.188)

S. Sec. 14a de 29-01-2002 (AC 2002\860)

S. Sec. 10a 26-03-2002 (TOL 200.707) 
S. no $71 / 2003$ Sec. 13a de 23-10-2003 (TOL 497.244)

S. no 246/2005 Sec. 10a de 1-04-2005 (TOL 624.847)

S. no 314/2005 Sec. 19a de 24-06-2005 (TOL 699.600).

S. no 441/2005 Sec. 9a de 15-09-2005 (TOL 1.034.661)

S. no 62/2005 Sec. 12a de 15-11-2005 (TOL 822.035)

S. no 99/2006 Sec. 21 de 11-01-2006 (TOL 822.299)

S. no 71/2006 Sec. 11a de 21-02-2006 (TOL 949.772)

S. no 164/2006 Sec. 9a 24-03-06 (TOL 937.230)

S. no 278/2006 Sec. 10a de 19-04-2006 (TOL 1.034.674)

S. no 62/2006 Sec. 14a de 8-02-2006 (TOL 851.593)

S. no 55/2006 Sec. 11a de 8-03-2006 (TOL 949.786)

S. no 81/2006 Sec. 14a de 30-03-2006 (TOL 1.608.4281)

S. № 301/2006 Sec. 10a de 27-04-2006 (TOL 1.034.670)

S. no 73/2006, Sec. 28a de 25-05-2006 (TOL 1.034.761)

S. № 571/2006 Sec. 10a de 5-10-2006 (TOL 1.034.712)

S. no 23/2007 Sec. 14a de 23-01-2007 (TOL 1.091.077)

S. no 44/2007 Sec. 28a de 22-02-2007 (TOL 1.155.821)

S. no $235 / 2007$ Sec. 10 a de 22-05-2007 (JUR 2007/199964)

S. no 387/2008 Sec. 19a de 10-09-2008 (TOL 1.462.658)

S. № 801/2007 Sec. 12a de 19-12-2008 (AC 2008/778)

S. no $144 / 2009$ Sec. 10a de 10-02-2009 (TOL 1.554.150)

S. no 67/2010, Sec. 28a de 12-03-2010 (TOL 1.875.679)

S. no $255 / 2010$ Sec. 8a de 31-05-2010 (TOL 1.925.926)

S. no 642/2010 Sec. 10a de 6-10-2010 (TOL 545.801) 
S. no 551/2010 Sec. 10a de 24-11-2010 (TOL 2.044.657)

S. № 599/2010 Sec. 10 de 15-12-2010 (TOL 2.055.922) Auto no 13/2011 Sec. 28a de 4-02-2011 (TOL 5.316.564)

S. № 235/2011 Sec. 13a de 4-05-2011 (TOL 2.161.355)

S. no $208 / 2011$ Sec. 28a de 17-06-2011 (TOL 2.207.510)

S. no 610/2011 Sec. 11a de 25-11-2011 (TOL 2.303.221)

S. № 14/2012 Sec. 13a de 27-01-2012 (TOL 2.490.466)

S. no 204/2012 Sec. 10a de 21-03-2012 (TOL 2.506.844)

S. no $170 / 2012$ Sec. 28a de 28-05-2012 (TOL 2.265.105)

S. no $428 / 2012$ Sec. 10a de 26-06-2012 (TOL 2.602.632)

S. no 480/2012 Sec. 10aㅡ de 21-09-2012 (TOL 2.661.271)

S. no 456/2012 Sec. 13a de 24-09-2012 (TOL 2.706.528)

S. № 65/2012 Sec. 12a BIS de 20-12-2012 (TOL 5.360.202)

S. no 360/2013, Sec. 28 de 16-12-2013 (TOL 4.113.976)

S. Sec. 11a de 17-01-2014 (TOL 4.085.258)

S. Sec. 14a de 13-10-2014 (TOL 4.529.928)

S. no 6/2015, Sec. 8a de 2-01-2015 (TOL 4.746.186)

S. no 2/2015 Sec. 11a de 15-01- 2015 (TOL 4.750.181)

S. no 17/2015 Sec. 19a de 21-01-2015 (TOL 4.770.575)

S. no 65/2015 Sec. 11a de 27-02-2015 (TOL 4.792.079)

S. no $103 / 2015$ Sec. 20a de 18-03-2015 (TOL 4.834.843)

\section{AUDI ENCI A PROVI NCI AL DE MÁLAGA}

S. no 497/2002 Sec. 6a 23-07-2002 (TOL 1.190.811)

S. no 617/2003 Sec. 5a de 28-7- 2003 (TOL 315.144) 
S. № 714/2003 Sec. 5a de 17-09-2003 (TOL 325.757)

S. no 126/2005 Sec. 5a de 25-02-2005 (TOL 659.647)

S. no $285 / 2011$ Sec. 4a de 27-05-2011 (TOL 2.240.502)

S. no 364/2014 Sec. 5a de 28-07-2014 (TOL 4.710.431)

\section{AUDI ENCI A PROVI NCI AL DE MURCI A}

S. no 113/2002 Sec. 1a de 20-03-2002 (TOL 174.111)

S. no 278/2006 Sec. 9a de 21-11-2006 (TOL 1.310.576)

S. no 105/2011 Sec. 5a de 1-4-2011 (TOL 2.121.494)

S. no 660/2011 Sec. 4a de 22-12-2012 (JUR 2012/27774)

S. no 200/2015 Sec. 4a de 16-04-2015 (TOL 5.003.267)

\section{AUDI ENCI A PROVI NCI AL DE NAVARRA}

S. no 271/2003 Sec. 3a de 12-11-2003 (TOL 367.112)

S. no $144 / 2013$ Sec. 2a de 9-07-2013 (TOL 3.915.178)

\section{AUDI ENCI A PROVI NCI AL DE ORENSE}

S. № 125/2016 Sec. 1a de 8-03-2016 (TOL 5.701.201).

\section{AUDI ENCI A PROVI NCI AL DE PALENCI A}

S. no 19/2013 Sec. 1a AP Palencia de 24-01-2013 (TOL 3.055.940)

AUDIENCIA PROVINCIAL DE PALMA DE MALLORCA

S. no 286 Sec. 3a de 18-09-2008 (TOL 1.443.815)

S. no 278/2011 Sec. 5a de 2-09-2011 (TOL 2.236.929).

S. no 82/2012 Sec. 3a de 16-02-2012 (TOL 2.490.158).

S. no 60/2014 Sec. 3a de 17-2-2014 (TOL 4.121.928).

S. no 19/2016 Sec. 5 de 1-02-2016 (TOL 5.649.637) 


\section{AUDI ENCI A PROVI NCI AL DE PONTEVEDRA}

S. no 251/2003 Sec. 1a de 30-06-2003 (TOL 350.499)

S. № 324/2012 Sec. 6a de 25-04-2012 (TOL 2.540.924)

S. no 163/2013 Sec. 1a de 4-04-2013 (TOL 3.660.221)

S. no 132/2015 Sec. 1a de 13-04-2015 (TOL 4.899.489)

S. no 168/2016 Sec. 1a de 31-03-2016 (TOL 5.701.328)

\section{AUDI ENCI A PROVI NCI AL DE SALAMANCA}

S. no 286/2013 Sec. 1a de 23-07-2013 (TOL 3.890.572)

\section{AUDI ENCI A PROVI NCI AL DE SANTA CRUZ DE TENERI FE}

S. no 630/1999 de 3-07-1999 (AC 1999/1860)

S. no 814/2001 Sec. 1a de 5-11-2001 (TOL 139.860)

S. no 276/2002 Sec. 3a de 19-04-2002 (TOL 212.303)

S. no 103/2006 Sec. 4a de 15-03-2006 (TOL 950.533)

S. no $147 / 2010$ Sec. 3a de 26-03-2010 (TOL 2.012.749)

S. ํo 431/2010 Sec. 1a de 11-10-2010 (TOL 2.142.811)

S. no 62/2012 Sec. 4a de 15-02-2012 (TOL2.550.685)

S. no 30/13 Sec. 1a de 24-1-2013 (TOL 3.710.673)

\section{AUDI ENCI A PROVI NCI AL DE SANTANDER}

S. Sec. 2a de 16-02-2001 (TOL 112.811)

S. Sec. 4a de 10-05-2001 (TOL 106.901)

S. 460/2012, Sec. 4a de 17-10-2012 (TOL 2.703.026)

S. № 109/2016 de 22-02-2016 (TOL 5.707.316) 


\section{AUDI ENCIA PROVI NCI AL DE SAN SEBASTIÁN}

S. no 350/2013, Sec. 3a de 25-11-2013 (Id Cendoj: 20069370032013100055).

\section{AUDI ENCI A PROVI NCI AL DE SEVI LLA}

S. no 33/2004 Sec. 5a de 22-01-2004 (TOL 351.596)

S. no 7/2014 Sec. 6a de 22-01-2014 (TOL 4.177.218)

S. № $128 / 2014$ Sec. 8a de 20-05-2014 (TOL 4.483.106)

\section{AUDI ENCI A PROVI NCI AL DE TARRAGONA}

S. no 347/1998 Sec. 3a de 18-07-1998 (EDJ 1998/29625)

S. Sec. 3a de 11-06-2002 (TOL 255.268)

S. no 488/2011 Sec. 3a de 7-12-2011 (TOL 2.499.442)

\section{AUDI ENCI A PROVI NCI AL DE SORI A}

S. № 47/2015 AP Soria de 21-05-2015 (TOL 5.162.720)

\section{AUDI ENCI A PROVI NCI AL DE TOLEDO}

S. $n$ o 358/2001 Sec. 2a AP Toledo de 31-07-2001 (TOL 126.310)

\section{AUDI ENCI A PROVI NCI AL DE VALENCI A}

S. no 821/1997 Sec. 6a de 6-10-1997 (TOL 3.624.619)

S. Sec. 2a de 8-01-2001 (TOL 75.725)

S. № 242/2002 Sec. 6a de 27-4-2002 (TOL 160.638)

S. no 123/2003 Sec. 7ạ de 27-02-2003 (PROV 2003/135897)

S. Sec. 7a de 21-02-2003 (TOL 254.779)

S. no 192/2003 Sec. 9a de 25-03-2003 (TOL 277.982)

S. no 313/2003 Sec. 8a de 19-05-2003 (TOL 321.716) 
S. no $730 / 2003$ Sec. 6a de 28-10-2003 (TOL 353.475)

S. no 788/2003 Sec. 8a de 15-12-2003 (TOL 436.345)

S. no 152/2004 Sec. 8a de 22-03-2004 (TOL 445.521)

S. no $237 / 2006$ Sec. 6a de 26-04-2006 (TOL 1.437.686)

S. no 541/2004 Sec. 9a de 16-09- 2004 (TOL 569.271)

S. no 548/2004 Sec. 9a de 16-09-2004 (TOL 569.272)

S. № 551/2004 Sec. 9a de 17-09-2004 (TOL 1.620.738)

S. no 623/2004 Sec. 7a de 10-11-2004 (TOL 547.598)

S. № 168/2006 Sec. 9a de 26-04-2006 (TOL 1.009.419)

S. no 315/2006 Sec. 9a de 14-09-2006 (TOL 1.033.829)

S. no 82/2007 Sec. 7ạ de 12-02-2007 (TOL 1.129.556)

S. no $487 / 2007$ Sec. 8a de 31-07-2007 (TOL 1.218.717)

S. no $118 / 2008$ Sec. 7a de 29-02-2008 (TOL 1.304.633)

S. № 318/2008 Sec. 6a de 14-05-2008 (TOL 1.341.142)

S. no $300 / 2008$ Sec. 8a de 20-05-2008 (TOL 1.358.691)

S. no 675/2006 Sec. 8a de 25-06-2008 (TOL 1.373.209)

S. № 587/2008 Sec. 6a de 29-09-2008 (TOL 1.421.279)

S. no 193/2009 Sec. 6a de 2-04-2009 (TOL 1.553.399)

S. no 327/2010 Sec. 11a de 29-06-2010 (TOL 1.958.813)

S. o 218/2010 Sec. 9a de 19-07-2010 (TOL 1.962.016)

S. no 726/2010 Sec. 6a de 28-12-2010 (TOL 2.085.266)

S. no 74/2011 Sec. 6a de 10-02-2011 (TOL 2.195.544)

S. no 202/2011 Sec. 8a de 11-04-2011 (TOL 2.159.112)

S. no 636/2011 Sec. 7a de 28-11-2011 (TOL2.411.220) 
S. no 443/2012 Sec. 6a de 12-07-2012 (TOL 2.679.609)

S. no 417/2007 Sec. 11a de 27-09-2012 (TOL 2.709.620)

S. no 16/2013 Sec. 9ạ de 17-01-2013 (TOL 3.661.340)

S. no 68/2012 Sec. 9a de 20-02-2013 (TOL 3.762.847)

S. no 61/2014 Sec. 8a de 24-02-2014 (TOL 4.294.231)

S. no 188/2014 Sec. 9a de 23-06-2014 (TOL 4.523.097)

S. no 306/2014, Sec. 8a de 24-07-2014 (TOL 4.573.980)

S. no 430/2014 Sec. 11a de 26-12-2014 (TOL 4.807.254)

S. № 381/2014 Sec. 9a de 29-12-2014 (TOL 4.617.754)

S. no 94/2015 Sec. 6a de 14-04-2015 (TOL 5.214.712)

S. no 27/2015 Sec. 6a de 5-02-2015 (TOL 4.984.921)

S. no 22/2016 Sec. 8a de 27-01-2016 (TOL 5.647.105)

\section{AUDI ENCI A PROVI NCI AL DE VALLADOLI D}

S. no 405/2011 Sec. 3a de 8-01-2001 (TOL 2.304.473)

S. no 405/2011 Sec. 3a de 8-01-2001 (TOL 2.304.473)

S. no 59/2011 Sec. 3a de 11-03-2014 (TOL 4.150.741)

\section{AUDI ENCIA PROVI NCI AL DE VIZCAYA}

S. no 91/2003 Sec. 20-02-2003 (EDJ 2003/48541)

S. no $148 / 2004$ Sec. 5a de 15-03-2004 (TOL 505.908)

S. no 345/2005 Sec. 3a de 18-05-2005 (TOL 701.903)

S. № 354/2010 Sec. 5a de 15-07-2010 (TOL 1.996.128)

S. no 49/2015 Sec. 3a de 11-03-2015 (TOL 4.893.522)

\section{AUDI ENCIA PROVI NCI AL DE ZAMORA}

S. no 476/2005 Sec. 4ạ de 14-09-2005 (TOL 765.495) 
S. o 35/2012 Sec. 1a de 8-03-2012 (TOL 2.506.446)

S. no 8/2015 Sec. 1a de 22-01-2015 (TOL 4.738.032)

\section{AUDI ENCI A PROVI NCI AL DE ZARAGOZA}

S. Sec. 2a de 27-07-1998 (TOL 389.851)

S. no 66/2003 Sec. 5a de 7-02-2003 (TOL 425.396)

S. no 316/2004 Sec. 2a de 25-05-2004 (TOL 466.320)

S. no 89/2008 Sec. 5a de 18-02-2008 (TOL 1.314.796)

S. o $642 / 2008$ Sec. 5a de 20-11-2008 (TOL 1.477.576)

S. № 454/2009 Sec. 5a de 16-09-2009 (TOL 1.654.081)

S. no 534/2010 Sec. 5a de 16-09-2010 (TOL 1.952.047)

S. no 56/2012 Sec. 5a de 3-02-2012 (TOL 2.452.809)

S. no 209/2013 de la Sec. 4ạ de 10-05-2013 (TOL 3.864.365)

S. no 8/2015 Sec. 1a de 22-01-2015 (TOL 4.738.032)

\section{TRI BUNAL SUPERI OR DE J USTI CI A DE NAVARRA}

S. no 2/2012 de la Sec. 1a del Tribunal Superior de Justicia de Navarra de 16-02-2012 (TOL 3.005.690).

\section{J UZGADOS DE LO MERCANTI L}

S. no 4/2005 del JM no 1 de Oviedo de 1-02-2005 (AC 2005/1195)

S. del J M no 1 de Madrid de 23-03-2006 (TOL 951.678)

S. no 51/2008 del JM no 2 de Alicante de 5-02-2008 (TOL

1.319.277)

S. no 384/2008 del JM no 1 de Vizcaya de 7-07-2008 (AC 2009/306)

S. no 50/2009 JM no 1 de Palma de Mallorca de 11-02-2009 (TOL $1.475 .636)$ 
S. № 284/2009 del JM no 5 de Barcelona de 16-11-2010 (TOL

4.368.976)

S. JM no de 6 de Madrid en S. de 21-02-2011 (TOL 2.096.925)

S. no 189/2012 JM no 3 de Madrid de 16-04-2012 (TOL 2.732.807)

S. no 254/2012 de 11-09-2012 del J M no 12 de Madrid OCU-IBERIA blog.uclm.es/cesco/files/2014/03/El-presente-y-el-futuro-de-lacláusula-no-show-en-los-billetes-de-avion.pdf

S. JM no 11 de Madrid de 15-02-2013 (CENDOJ : 28079470112016100001)

S. no 88/2013 del J M no 5 de Barcelona de 17-06-2013 (TOL

3.796.760)

S. del J M Alicante no 1 de 18-07-2013 (TOL 4.472.669)

S. o 113/2013 J M no 5 Madrid de 30-09-2013

(CENDOJ : 28079470052013100001 ).

S. no 169/2013 JM № 1 de Alicante 31-10-2013 (TOL 4.034.733)

S. no 259/2013 JM no 3 de Valencia de 2-12-2013 (TOL 5.493.222)

S. no 20/2014 del JM no 1 de Bilbao de 27-01-2014 (TOL 4.078.531)

S. no 20/2014 JM no 1 de Alicante de 28-01-2014 (TOL 4.093.493)

S. no 248/2014 J M no 2 Palma de Mallorca de 10-10-2014 (TOL

$5.577 .564)$

S. no 59/2016 J M no 1 de Donostia de 19-02-2016 (TOL 5.702.455)

S. $\mathrm{n}$ - 34/2016 de JM no 1 de Valladolid de 21-02-2016 (TOL

$5.702 .793)$

\section{J UZGADOS DE PRI MERA I NSTANCI A}

S. del JPI no 49 Madrid de 12-05-99 (TOL 198.300)

S. del JPI no 8 de Madrid de 30-7-2004 (blog.adicae.net/reclama-tusderechos/files/2014/12/sentenciacomisiones. pdf)

S. JPI no 3 de Ferrol, de 30-09-2004 (JUR 2005/36499) 
S. del JPI no 12 de Barcelona de 27-09-2006 (TOL 1.005.510)

S. del JPI no 17 de Madrid de 15-12-2006 (TOL 1.051.511)

S. no 56/2007 del JPI no 10 de Murcia de 2-03-2007 (AC 2007/840)

S. JPI no 13 de Barcelona de 11-06-2007 (TOL 1.380.025)

S. JPI no 7 de Palma de Mallorca de 20-06-2007 (TOL 1.156.086)

S. no 126/2008 del JPI no 2 de Castellón de 25-06-2008 (TOL

$1.378 .694)$

S. № 182/2009 del JPI № 12 Bilbao de 16-07-2009 (TOL 1.588.815)

S. JPI № 24 de Barcelona de 18-03-2010 (TOL 1.796.157)

S. JPI no 1 de Mataró de 5-02-2012 (TOL 3.024.772)

S. JPI no 13 de Barcelona de 4-04-2012 (TOL 2.516.336)

S. no 73/2012, JPI no 4 de Castellón de 4-04-2012 (TOL 2.603.271)

S. no 83/2012 del JPI no 1 de Cambados de 10-07-2012 (TOL $2.585 .052)$

S. JPI no 1 Mataró de 5-02-2013 (TOL 3.056.293)

S. no 477/13 del JPI no 71 de Madrid de 11-04-2013 (JUR 2014/206375)

S. no 148/2012 JPI no 11 Bilbao de 22-04-2013 (TOL 3.659.615)

S. JPI no 10 Valencia 3-05-2013 (TOL 3.724.808)

S. № 67/2013 JPI Terrassa de 7-05-2013 (JUR2014/203063)

S. no 60/2014, JPI no 84 de Madrid de 5-06-2013 (TOL 3.792.322)

S. no 115/2013 JPI no 25 de Valencia de 10-06-2013 (TOL

3.795.319)

S. № 184/2013 JPI no 7 de Córdoba de 12-09-2013 (TOL 4.124.548)

S. del JPI no 90 de Madrid de 19-11-2013 (TOL 4.009.866)

S. JPI Santander de 27-11-2013 (TOL4.020.964) 
S. no 363/13 del JPI Ponferrada de 29-11-2013 (TOL 4.029.700)

S. no 185/2013 del JPI no 12 La Coruña de 5-12-2013 (TOL 4.050.019)

S. no 474/14 JPI no 7 de Valladolid de 5-02-2014 blog. adicae. net/reclamatusderechos/2014/01/09/sentencia-47414del-juzgado-de-primera-instancia-de-valladolid-de-5-de-febrero/

S. № 39/2014 JPI no 7 Cáceres de 12-02-2014 (TOL 4.113.561)

S. $\mathrm{n}$ - 38/14 del JPI no 4 de Donostia de 20-02-2014 (JUR2014/218141)

S. $\mathrm{n}$ - 46/2014 del JPI no 46 de Barcelona de 3-03-2014 (AC 2014/1366)

S. no 93/2014 del JPI no 3 de Valencia de 2-05-2014 (www.avacu.es/images/blanca/SentenciaPreferentes02052014\% 20.p df)

S. no 98/2014 del JPI no 1 de A Coruña de 14-05-2014 (TOL $4.320 .280)$

S. no 177/2014 JPI no 23 Baleares de 30-12-2014 (TOL 4.608.026)

S. no 36/2015 JPI no 4 de Tarragona de 5-03-2015 (TOL 4.769.172)

S. no 61/15 del JPI no 8 de Castellón de 07-04-2015 (TOL 4.818.332)

S. no 220/2015 del JPI no 5 de Torrent de 13-10-2015 (ECLI : ES:J PI : 2015: 174)

S no 241/2015 JPI no 18 de Madrid de 16-10-2015 (TOL 5.564.083)

S. no 141/2015 del JPI no 4 de Oviedo de 20-10-2015 (TOL

$5.544 .083)$ 
